\author{
UNIVERSITY OF ORADEA \\ FACULTY OF ECONOMIC SCIENCES
}

\title{
THE ANNALS OF THE UNIVERSITY OF ORADEA. ECONOMIC SCIENCES
}
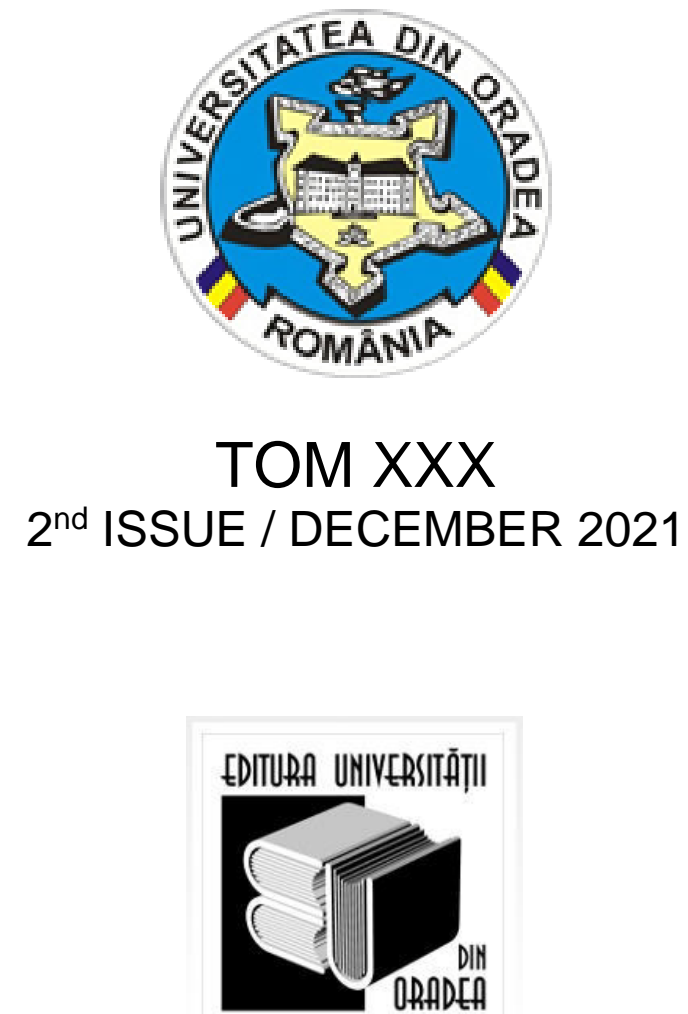

University of Oradea Publishing

ISSN 1582 - 5450 (electronic)

ISSN 1222-569X (print) 
The publication of the papers in the Journal "The Annals of the University of Oradea. Economic Sciences"- Tom XXX, 2021, ISSN 1582-5450 (in the electronic format on CD-ROM), ISSN 1222-569X (in printed format), a journal listed $\mathrm{CNCIS}$ category $\mathrm{B}+$ and indexed in RePec, DOAJ, EBSCO, CABELLS Publishing Services, and ERIH PLUS international data bases and respectively on the site of the journal http://anale.steconomiceuoradea.ro/en/, in electronic format with free and open access to full text. The Annals of the University of Oradea. Economic Sciences is an open access and peer-reviewed journal. The Journal is published in English, two issues per year, in July and December.

\title{
The papers published in this volume are exclusively engaging the authors.
}

\author{
Editor-in-Chief: \\ Claudia Diana SABĂU-POPA, Ph.D.
}

\section{Associate editors:}

Alina BĂDULESCU, PhD.

Mirabela MATEI, Ph.D.

\section{Sections' Heads:}

Dorin Paul BÂC, Ph.D.- Section Head Economics, Business Administration, Tourism and Statistics

loan Gheorghe TARA, Ph.D. -Section Head Finance, Banking, Accounting and Audit

Liana-Eugenia MEŞTER, Ph.D.- Section Head International Business, European Integration, Foreign Languages and Business Environment

Maria-Madela ABRUDAN, Ph.D.- Section Head Management, Marketing, Economic Informatics and Cybernetics

\section{Members:}

Valeriu IOAN-FRANC, Ph.D., Correspondent Member of the Romanian Academy, Romania;

Ahmet AKTAS, University of Akdeniz, Ph.D., Alanya, Turkey;

Ismet ATES, Ph.D., Adnan Menderes University, Turkey;

Mihaela BELU, Ph.D., The Bucharest University of Economic Studies,Romania;

Luminita CHIVU, Ph.D., The Romanian Academy, Romania;

Jose CIFUENTES, Ph.D., Honrubia, University of Alicante, Spain;

Dezhi LIU, Ph.D., Shijiazhuang University of Economics, China;

Marin DINU, Ph.D., The Bucharest University of Economic Studies, Romania; Anca-Otilia DODESCU, Ph.D., University of Oradea, Romania;
Sergei F. FEOSTIKOV, Ph.D., Moscow Academy of Business, Blagoveschensk Branch, Russia;

Veronika FENYVES, Ph.D., University of Debrecen, Hungary;

Xavier GALIEGUE, Ph.D., University of Orleans, France;

Adriana GIURGIU, Ph.D, University of Oradea;

Dongheng HAO, Ph.D., Shijiazhuang University of Economics, China;

Gheorghe HURDUZEU, Ph.D., The Bucharest University of Economic Studies, Romania;

Nicolae ISTUDOR, Ph.D., The Bucharest University of Economic Studies,Romania; Zoran IVANOVIC, Ph.D., University of Rijeka, Croatia;

Goran KARANOVIC, Ph.D., University of Rijeka, Croatia; 
Eugeniusz KWIATKOWSKI, Ph.D., University of Lodz, Poland;

Rajesh KUMAR, Ph.D., Osmania University, India;

Eszter LANG, Ph.D., Hitelintézeti Szemle (Financial and Economic Review), Central Bank of Hungary, Hungary;

Nicola MATTOSCIO, Ph.D., "G. D'Annunzio" University of Chieti Pescara, Italy;

Piero MELLA, Ph.D., University of Pavia, Italy; Guido MONTANI, Ph.D., University of Pavia, Italy;

Andras NABRADI, Ph.D., University of Debrecen, Hungary;

Carmen NĂSTASE, Ph.D., "Ștefan Cel Mare" University of Suceava, Romania;

Ovidiu NICOLESCU, Ph.D., The Bucharest University of Economic Studies, Romania; Giuseppe PAOLONE, Ph.D., "G. D'Annunzio" University of Chieti, Pescara, Italy;

Dorel Mihai PARASCHIV, Ph.D., The Bucharest University of Economic Studies, Romania;

Ryszard PIASECKI, Ph.D., University of Lodz, Poland;

Marilen PIRTEA, Ph.D., West University of Timisoara, Romania;

Nicolae Al. POP, Ph.D., The Bucharest University of Economic Studies,Romania, H.C of the University of Oradea;

Marilen PIRTEA, Ph.D., West University of Timisoara, Romania

Ion POPA, The Bucharest University of

Economic Studies, Romania;

Michael STOICA, Ph.D., Washburn University,USA;

Gabriela TIGU, Ph.D., The Bucharest University of Economic Studies,Romania;

Jean-Emmanuel TYVAERT, Ph.D., University of Reims Champagne-Ardenne, France;

Ada Mirela TOMESCU, Ph.D, University of Oradea;

Valentina VASILE, Ph.D., The Romanian Academy, Romania.

\section{Scientific Committee:}

Maria ALB, Ph.D., Dr. West University, Timisoara, Romania;

Carmen BĂBĂIȚĂ, Ph.D., West University, Timisoara, Romania;

Ioan BĂTRÂNCEA, Ph.D., "Babes-Bolyai" University, Cluj-Napoca, Romania;

Liviu BEGU, Ph.D., The Bucharest University of Economic Studies, Romania;

Nicolae BIBU, Ph.D., West University, Timisoara,Romania;

Sorin BRICIU, Ph.D., "1 Decembrie 1918" University, Alba lulia, Romania;

Alexandru CHIȘ, Ph.D., University BabesBolyai,Cluj Napoca, Romania;

Gheorghe CIOBANU, Ph.D., University Babes-Bolyai, Cluj Napoca, Romania;

Smaranda Adina COSMA, Ph.D., University Babes-Bolyai, Cluj Napoca, Romania;

Margit CSIPKÉS, Ph.D., University of Debrecen,Hungary;

Emilian M. DOBRESCU, Ph.D., Romanian Academy, Bucharest, Romania;

Cosmin DOBRIN, Ph.D., The Bucharest University of Economic Studies, Romania; Nicoleta FARCANE, Ph.D., West University, Timisoara, Romania;

Liliana FELEAGA, Ph.D., The Bucharest University of Economic Studies, Romania; Veronika FENYVES, Ph.D., University of Debrecen, Hungary;

Xavier GALIEGUE, Ph.D., University of Orleans, France;

Patrizia GAZZOLA, Ph.D., Insubria University, Italy; George GEORGESCU, Ph.D., The Romanian Academy, Romania; Zizi GOSCHIN, Ph.D., The Bucharest University of Economic Studies, Romania; Călin GURĂU, Ph.D., Montpellier Business School,Montpellier, France;

Nicolae ISTUDOR, Ph.D., The Bucharest University of Economic Studies, Romania; Marie-Noelle JUBENOT, University of Reims Champagne-Ardenne, France;

Androniki KAVOURA, Ph.D., Technological Educational Institute of Athens, Greece,

Goran KARANOVIC, Ph.D., University of Rijeka, Croatia;

Ramona LACUREZEANU, Ph.D., University Babes-Bolyai, Cluj Napoca, Romania; 
Domicián MÁTÉ, Ph.D., University of Debrecen, Hungary;

Ovidiu MEGAN, Ph.D., West University, Timisoara, Romania;

Tatiana MOSTEANU, Ph.D., The Bucharest University of Economic Studies, Romania - H.C of the University of Oradea;

Valentin MUNTEANU, Ph.D., West University, Timisoara, Romania;

Doina MUREȘANU, Ph.D., Université of Québec in Abitibi-Témiscamingue, Québec, Canada;

Carmen NĂSTASE, Ph.D., "Ștefan Cel Mare" University of Suceava, Romania;

Răzvan Liviu NISTOR, Ph.D., "BabeșBolyai" University, Cluj Napoca, Romania;

Nicolae PETRIA, Ph.D., "Lucian Blaga" University of Sibiu, Sibiu, Romania;

Mariana PREDIȘCAN, Ph.D., West University, Timisoara, Romania;

Gabriela PRELIPCEAN, Ph.D., "Stefan cel Mare" University of Suceava, Romania;

Cristina Teodora ROMAN, Ph.D.,"Alexandru loan Cuza" University of lași, lași, Romania;

Ovidiu RUJAN, Ph.D., The Bucharest University of Economic Studies, Romania; Steliana SANDU, Ph.D., The Romanian Academy, Romania;

Klaus-Bruno SCHEBESCH, "Vasile Goldiș" Western University, Arad, Romania;

Nicoleta SîRGHI, Ph.D., West University,

Timisoara, Romania;

Cristi SPULBĂR, Ph.D., University of Craiova, Romania;

Gabriela STĂNCIULESCU, Ph.D., The Bucharest University of Economic Studies, Romania;

Orhan ȘANLI, Ph.D., Adnan Menderes University, Turkey;

Hüseyin ŞENKAYAS, Ph.D., Adnan Menderes University, Turkey;

Ioan TALPOȘ, Ph.D., West University, Timisoara, Romania;

Carmen TODERAȘCU, Ph.D., Alexandru Ioan Cuza University, lasi, Romania;

Adriana TIRON TUDOR, Ph.D., Babes Bolyai University, Cluj Napoca, Romania Ioan TRENCA, Ph.D., "Babes-Bolyai" University, Cluj-Napoca, Romania;

Constantin TULAI, Ph.D., "Babes-Bolyai"

University, Cluj-Napoca, Romania;
Jean-Emmanuel TYVAERT, University of Reims Champagne-Ardenne, France;

Gabriela ȚIGU, Ph.D., The Bucharest University of Economic Studies, Romania; Leonard Călin ABRUDAN, Ph.D., University of Oradea, Romania;

Maria-Madela ABRUDAN, Ph.D., University of Oradea, Romania;

Olimpia-Iuliana BAN, Ph.D., University of Oradea, Romania;

Daniel Laurențiu BĂDULESCU, Ph.D., University of Oradea, Romania;

Dorin-Paul BÂC, Ph.D., University of Oradea, Romania;

Mihai BERINDE, Ph.D., University of Oradea, Romania;

Simona-Aurelia BODOG, University of Oradea,Romania;

Victoria BOGDAN, Ph.D., University of Oradea, Romania;

Marcel-loan BOLOȘ, Ph.D., University of Oradea, Romania;

Elena-Aurelia BOTEZAT, Ph.D., University of Oradea, Romania;

Nicoleta-Georgeta BUGNAR, Ph.D., University of Oradea, Romania;

Dorin Cristian COITA, Ph.D., University of Oradea, Romania;

Laurențiu DROJ, Ph.D., University of Oradea, Romania;

Adrian-Gheorghe FLOREA, Ph.D., University of Oradea, Romania;

Adriana GIURGIU, Ph.D., University of Oradea, Romania;

loana-Claudia HOREA, Ph.D., University of Oradea, Romania;

loana-Teodora MEȘTER, Ph.D., University of Oradea, Romania;

Liana-Eugenia MEȘTER, Ph.D., University of Oradea, Romania;

Ioan Dan MORAR, Ph.D., University of Oradea, Romania;

Adrian NEGREA, Ph.D., University of Oradea, Romania;

Anamaria-Mirabela POP, Ph.D., University of Oradea, Romania;

Dorina Nicoleta POPA, Ph.D., University of Oradea, Romania;

Andra-Teodora PORUMB, Ph.D., University of Oradea, Romania; loana-Crina POP-COHUT, Ph.D., University of Oradea, Romania;

Claudia-Diana SABĂU-POPA, Ph.D., University of Oradea, Romania; 
Monica-Ariana SIM, Ph.D., University of Oradea, Romania;

Ioan Gheorghe ȚARĂ, Ph.D., University of Oradea, Romania;

Naiana-Nicoleta ȚARCĂ, Ph.D., University of Oradea, Romania;

Daniela-Marioara ZĂPODEANU, Ph.D., University of Oradea, Romania;

Egidio RANGONE, "G. D'Annunzio" University of Chieti, Pescara, Italy.

\section{Editorial Review Board}

Leonard-Călin ABRUDAN, Ph.D. (University of Oradea, Faculty of Economic Sciences, Romania), MariaMadela ABRUDAN, Ph.D. (University of Oradea, Faculty of Economic Sciences, Romania), Cristina-Laura ABRUDAN, Ph.D. (University of Oradea, Faculty of Economic Sciences, Romania), Carmen ACATRINEI, Ph.D. (Bucharest University of Economic Studies, Faculty of Marketing, Bucharest, Romania), Bulent ACMA, Ph.D. (Anadolu University, Eskisehir, Turkey), Viorica CHIRILĂ, PhD (Alexandru loan Cuza" University of lași, Faculty of Economics and Business Administration),

Daniela-Tatiana AGHEORGHIESEI, (CORODEANU), Ph.D., ("Alexandru loan Cuza" University of lași, Faculty of Economics and Business Administration, Department of Management, Marketing and Business Administration, Romania), Alina Georgeta AILINCĂ, Ph.D. (Centre for Financial and Monetary Research, National Institute of Economic Research, Romanian Academy), Emre Ozan AKSOZ, Ph.D. (Anadolu University, Turkey), Nicoleta ANDREESCU, Ph.D. (Faculty of Faculty of Energy Engineering and Industrial Management, University of Oradea, Oradea, Romania), Alina ALMĂȘAN,

Ph.D. (West University of Timișoara, Faculty of Economics and Business Administration, Department of Accounting and Audit, Romania), Sorin Gabriel ANTON, Ph.D. ("Alexandru Ioan Cuza"

University of lași, Faculty of Economics and Business Administration, Department of Finance, Money and Public Administration, Romania), Laura ASANDULUI, Ph.D. ("Alexandru loan
Cuza" University of lași, Faculty of Economics and Business Administration, Department of Accounting, Economic Informatics and Statistics, Romania), Emine Turkan AYVAZ GUVEN, Ph.D. (Manisa Celal Bayar University, Turkey), Leontina Emilia BACIU, Ph.D. ("BabeșBolyai" University, Cluj-Napoca, Romania), Lia Alexandra BALTADOR, Ph.D. ("Lucian Blaga" University of Sibiu, Romania), Olimpia BAN, Ph.D. (University of Oradea, Faculty of Economic Sciences, Department of Economics and Business Romania), lonel BARBU, Ph.D. ("Aurel Vlaicu" University of Arad, Romania), Daniel-Laurențiu BĂDULESCU, Ph.D. (University of Oradea, Faculty of Economic Sciences, Department of Economics and Business Romania), IonuțCosmin BĂLOI, Ph.D. (Craiova University, Faculty of Economics and Business Administration, Department of Management, Marketing and Business Administration, Craiova, Romania), Dorin BÂC, Ph.D. (University of Oradea, Faculty of Economic Sciences, Romania), Liviu-

Stelian BEGU, Ph.D. (The Bucharest University of Economic Studies, Department of Statistics and Econometrics, Bucharest, Romania), Ciprian Beniamin BENEA, Ph.D. (University of Oradea, Faculty of Economic Sciences, Department of International Business, Romania), Corneliu-Cristian BENȚE, Ph.D. (University of Oradea, Faculty of Economic Sciences, Department of Finance- Accounting, Romania), AnaMaria BERCU, Ph.D. ("Alexandru Ioan Cuza" University of lași, Faculty of Economics and Business Administration, Romania), Irina Iuliana BILAN, Ph.D. ("Alexandru Ioan Cuza" University of Iași, Faculty of Economics and Business Administration, Romania), Jovanka BILJAN, Ph.D. (University St. Kliment Ohridski, Bitola, The Republic of Macedonia) Ioana Teodora BIȚOIU, Ph.D. (National University of Political Studies and Public Administration, Bucharest, Romania), Gratiela Dana BOCA, Ph.D. (Technical University Cluj Napoca, North Center Baia Mare, Romania), SimonaAurelia BODOG, Ph.D. (University of 
Oradea, Faculty of Economic Sciences, Romania), Victoria BOGDAN, Ph.D. (University of Oradea, Faculty of Economic Sciences, Romania), Carmen BOGHEAN, Ph.D. ("Ștefan Cel Mare" University of Suceava, Faculty of Economic Sciences and Business Administration, Department of Economics, Business Administration and Tourism, Suceava, Romania), Florin BOGHEAN, Ph.D. ("Ștefan Cel Mare" University of Suceava, Faculty of Economic Sciences and Business Administration, Department of Accounting, Finance and Business Informatics, Suceava, Romania), MarcelIoan BOLOȘ, Ph.D. (University of Oradea, Faculty of Economic Sciences, Department of Finance-Accounting, Romania), Afrodita BORMA, Ph.D. (University of Oradea, Faculty of Economic Sciences, Romania), Elena BOTEZAT, Ph.D. (University of Oradea, Faculty of Economic Sciences, Romania), Alina BOTEZAT, Ph.D. (Romanian Academy - Iasi Branch, lași, Romania), loana-Alexandra BRADEA, Ph.D. (Bucharest University of Economic Studies, Romania), Laura BRANCU, Ph.D. (West University of Timișoara, Faculty of Economics and Business Administration, Romania), Constantin BRĂTIANU, Ph.D. (Faculty of Business Administration, The Bucharest University of Economic Studies, Romania), Grațiela BRÂNZĂ, Ph.D. (Constanta Maritime University, Romania), Mirela BUCUREAN, Ph.D. (University of Oradea, Faculty of Economic Sciences, Romania), Nicoleta BUGNAR, Ph.D. (University of Oradea, Faculty of Economic Sciences, Department of International Business,Romania), Adrijana BULEVSKA ZARIKJ, Ph.D. (Integrated Business Faculty, Skopje, North Macedonia), Esra Burcu BULGURCU GÜREL, Ph.D. (Muğla Sıtkı Koçman University, Turkey), Ștefan BUNEA, Ph.D. (Buchrest University of Economic Studies, Faculty of Accounting and Management Information Systems, Department of Accounting and Economic and Financial Analysis, Bucharest, Romania), Simona BUTA, Ph.D. ("Ștefan Cel Mare" University of Suceava, Faculty of Economics and Public Administration, Romania), Eduard
Gabriel CEPTUREANU, Ph.D. (Bucharest University of Economic Studies, Faculty of Management, Romania), Sebastian CEPTUREANU, Ph.D. (Bucharest University of Economic Studies, Faculty of Management, Romania), Carmen CHASOVSCHI, Ph.D. ("Ștefan Cel Mare" University of Suceava, Faculty of Economic Sciences and Business Administration, Suceava, Romania), Viorica CHIRILĂ, Ph.D. ("Alexandru loan Cuza" University of lași, Faculty of Economics and Business Administration, Romania), Ana Maria CHISEGANEGRILA, Ph.D. ("Carol I" National Defense University, Romania), Alexandru CHIȘ, Ph.D. ("Babeș-Bolyai" University, FSEGA, Cluj-Napoca, Romania), Denisa ČIDEROVÁ, Ph.D. (University of Economics in Bratislava, Faculty of Commerce / Fakulta obchodu Vysoké školyekonomickej v Bratislave, Slovakia), Elena CIORTESCU, PhD. (Faculty of Economics and Business Administration, "Alexandru Ioan Cuza" University), Laura Mariana CISMAȘ, Ph.D. (West University of Timișoara, Faculty of Economics and

Business Administration, Romania), Maria CIUREA, Ph.D. (University of Petroșani, Romania), Ioana Florina COITA (Ph.D. (University of Oradea, Faculty of Economic Sciences, Department of Finance-Accounting, Romania), Cristinel CONSTANTIN, Ph.D. ("Transilvania" University of Brașov, Brașov, Romania), Anca CONSTANTINESCU-DOBRA, Ph.D. (Technical University of Cluj-Napoca, Romania), Smaranda Adina COSMA, Ph.D. ("Babeș-Bolyai" University, ClujNapoca, Romania), Lavinia Denisa CUC, Ph.D. ("Aurel Vlaicu" University of Arad, Romania), Serkan CURA, Ph.D. (Celal Bayar University, Manisa, Turkey), Alina Beattrice CUZDRIOREAN VLADU, Ph.D. ("Babeș-Bolyai" University, FSEGA, ClujNapoca, Romania), Dan-Cristian DABIJA, Ph.D. ("Babeș-Bolyai" University, FSEGA, Department of Marketing, Cluj-Napoca, Romania), Marius DEAC, Ph.D. (Christian University "Dimitrie Cantemir" Bucharest, Romania), Suzana DEMYEN, Ph.D. (University "Eftimie Murgu" of Resița, Faculty of Economic Sciences, Romania), Laura DIACONU, Ph.D. (MAXIM), Ph.D. 
("Alexandru Ioan Cuza" University of Iași, Faculty of Economics and Business Administration, Romania), Anca Otilia DODESCU Ph.D. (University of Oradea, Faculty of Economic Sciences, Romania), Adina DORNEAN, Ph.D. ("Alexandru loan Cuza" University of lași, Faculty of Economics and Business Administration, Romania), Larisa- Loredana DRAGOLEA, Ph.D. ("1 Decembrie 1918" University of Alba Iulia, Alba lulia, Romania), Cristina DRAGOMIR, Ph.D. (Constanța Maritime University,Romania), Laurențiu DROJ, Ph.D. (University of Oradea, Faculty of Economic Sciences, Department of Finance-Accounting, Romania), Dorel Mihai DUȘMĂNESCU, Ph.D. (Petroleum \& Gas University of Ploiești, Faculty for Economic Sciences, Romania), Mihaela ENACHI, Ph.D. (Faculty of Economics, "Vasile Alecsandri" University of Bacău, Bacău, Romania), Laura ENDRES, Ph.D.

(Preclinical Disciplines Department, University of Oradea, Faculty of Medicine and Pharmacy, Oradea, Romania), Pinar ERYIGIT, Ph.D. (Celal Bayar University, Manisa, Turkey), Hariandja EVO SAMPETUA, Ph.D. (Universitas Pelita Harapan, Tangerang, Indonesia), Teodora Viorica FARCAȘ, Ph.D. ("Babeș-Bolyai" University, FSEGA, Cluj-Napoca, Romania), Emőke-Szidónia FEDER, Ph.D. (West University of Timișoara, Romania), Sergei Vladimirovich FEOKTISTOV, Ph.D. (Moscow Academy of Business, Blagoveschensk Branch, Russia), Bogdan Florin FILIP, Ph.D. ("Alexandru Ioan Cuza" University of lași, Faculty of Economics and Business Administration, Romania), Constantin FILOTE, Ph.D. ("Ștefan Cel Mare" University of Suceava, Suceava, Romania), Bogdan Narcis FIRTESCU, Ph.D. ("Alexandru loan Cuza" University of lași, Romania), Radu FLOREA, Ph.D. ("George Bacovia" University, Bacău, Romania), Ramona FLOREA, Ph.D. ("George Bacovia" University, Bacău, Romania), Florin Sabin FOLTEAN, Ph.D. (West University of Timișoara, Faculty of Economics and Business Administration, Romania), Andreea-Florina FORA, Ph.D. (University of Oradea, Faculty of Economic Sciences, Department of
International Business, Romania), DanaSimona GHERAI, Ph.D. (University of Oradea, Faculty of Economic Sciences, Department of Finance-Accounting, Romania), Eugenia GRECU, Ph.D. (Politehnica University of Timisoara, Faculty of Management in Production and Transports, Department of Management, Timișoara, Romania), Harun GUMUS, Ph.D. (Celal Bayar University, Manisa, Turkey), Stefán GUNNLAUGSSON, Ph.D. (University of Akureyri, Akureyri, Iceland), Raluca GUSE, Ph.D. (Bucharest University of Economic Studies, Romania), Andrea HAMBURG, Ph.D. (University of Oradea, Faculty of Economic Sciences, Department of International Business, Romania), Daniela HARANGUS, Ph.D. (Economic Department, Faculty of Economic Sciences, "Aurel Vlaicu" University of Arad, Arad, Romania), Mariana HATMANU, Ph.D. ("Alexandru Ioan Cuza" University of lași, Romania), Camelia Daniela HAȚEGAN, Ph.D. (West University of Timișoara, Romania), Emilia HERMAN, Ph.D. (University of Medicine, Pharmacy, Sciences and Technology of Tîrgu Mureș, Romania), loana-Claudia HOREA, Ph.D. (University of Oradea, Faculty of Economic Sciences, Department of International Business, Romania), Tao HUANG, Ph.D. (Jiangxi University of Finance and Economics, Nanchang, China), Andreea-Oana IACOBUTA, Ph.D. ("Alexandru Ioan Cuza" University of lași, Faculty of Economics and Business Administration, Department of Economics and International Relations, Romania), Liviu ILIEȘ, Ph.D. (BabeșBolyai University, Faculty of Economics and Business Administration, ClujNapoca, Romania), Roxana IOAN, Ph.D. (West University of Timișoara, Romania), Florin Lucian ISAC, Ph.D. (Aurel Vlaicu University of Arad, Romania), Oana Raluca IVAN, Ph.D. ("1 Decembrie 1918" University of Alba lulia, Romania), Mihaela KARDOS, Ph.D. ("Petru Maior" University of Târgu Mureș, Faculty of Economic, Juridical and Administrative Sciences, Romania), Androniki KAVOURA, Ph.D. (Technological Educational Institute of Athens, Greece), Rozalia Iuliana KICSI, 
Ph.D. ("Ștefan cel Mare" University of Suceava, Romania), Mustafa KIRLI, Ph.D. (Manisa Celal Bayar University, Turkey), Gábor Dávid KISS, Ph.D. (University of Szeged, Faculty of Economics and Business Administration, Hungary), Balazs KOTOSZ, Ph.D. (Faculty of Economics and Business Administration, University of Szeged, Hungary), Tekmez KULU, Ph.D. (Accounting Department, Celal Bayar University, Manisa, Turkey), Ramona LACUREZEAN, Ph.D. (Babeș-

Bolyai University, Faculty of Economics and Business Administration, ClujNapoca, Romania), Maria-Isadora LAZĂR, Ph.D. (Bucharest University of Economic Studies, Romania), Ramona LILE, Ph.D. ("Aurel Vlaicu" University of Arad, Faculty of Economic Sciences, Department fo Economic Disciplines, Romania), MariaAntoaneta LORENTZ, Ph.D. (The Bucharest University of Economic Studies, Bucharest, Romania), Mariana LUPAN, Ph.D. ("Ștefan Cel Mare" University of Suceava, Faculty of Economic Sciences and Business Administration, Department of Economics, Business Administration and Tourism, Romania), Ondřej MACHEK, Ph.D. (University of Economics Prague, Faculty of Business Administration, Department of Business Economics, Czech Republic), Maria MACRIS, Ph.D. (University of Petroșani, Romania), Gabriela MARCHIȘ, Ph.D. (Danubius University of Galați, Galați, Romania), Codruța MARE, Ph.D. ("Babeș-Bolyai" University, Faculty of Economics and Business Administration, Department of Statistics-Forecasting-Mathematics, ClujNapoca, Romania), Camelia Loredana MARGEA, Ph.D. (West University of Timișoara, Romania), Diana MATICA, Ph.D. (University of Oradea, Faculty of Economic Sciences, Department of Finance- Accounting, Romania), Valentin Petru MAZAREANU, Ph.D. ("Alexandru Ioan Cuza" University of lași, Faculty of Economics and Business Administration, Romania), Georgeta- Madalina MEGHISAN-TOMA, Ph.D. (The Bucharest University of Economic Studies, Romania), Oznur MERT, Ph.D. (Celal Bayar University, Manisa, Turkey), IoanaTeodora MEȘTER, Ph.D. (University of
Oradea, Faculty of Economic Sciences, Department of Economics and Business, Romania), Liana MEȘTER, Ph.D. (University of Oradea, Faculty of Economic Sciences, Department of International Business, Romania), Costică MIHAl, Ph.D. ("Alexandru Ioan Cuza" University of lași, Faculty of Economics and Business Administration, Romania), Gabriela MIRCEA, Ph.D. (West University of Timișoara, Romania), Claudia Olimpia MOISĂ, Ph.D. ("1 Decembrie 1918" University of Alba lulia, Romania), Snezana MOJSOVSKA SALAMOVSKA, Ph.D. (University "St.Kliment Ohridski", Faculty of Economics, Department of Management, Marketing and Business, Bitola, Macedonia), Navid MOLLAEE, Ph.D. (Tehran Institute of Technology, Business Management Department, Iran), Maria Cristina MORARIU, Ph.D. (Bucharest University of Economic Studies, Romania), Andreea Cipriana MUNTEAN, Ph.D. ("1 Decembrie 1918" University of Alba lulia, Romania), Pablo José MOYA FERNÁNDEZ, Ph.D. (Universidad de Granada, Spain), Carmen NĂSTASE, Ph.D. ("Ștefan Cel Mare" University of Suceava, Romania), Adrian NEGREA, Ph.D. (University of Oradea, Faculty of Economic Sciences, Department of International Business, Romania), Mariya NEYCHEVA, Ph.D. (Burgas Free University, Burgas, Bulgaria), Liana Cristina NICOLAU, Ph.D. ("Transilvania" University of Brașov, Brașov, Romania), lulia Monica OEHLERSINCAI, Ph.D. (Institute for World Economy of the Romanian Academy, INCE, Romanian Academy, Bucharest, Romania), Ahmet OKUR, Ph.D. (Manisa Celal Bayar University, Manisa, Turkey), Murat ORTANCA, Ph.D. (Celal Bayar University, Manisa, Turkey), Aslihan OZEL, Ph.D. (Celal Bayar University, Manisa, Turkey), Mirela PANAIT, Ph.D. (Petroleum \& Gas University of Ploiești, Faculty for Economic Sciences, Romania), Iulia PARA, Ph.D. (West University of Timișoara, Romania), Jasanta PERANGINANGIN, Ph.D. (Institut Agama Islam Negeri Surakarta, Indonesia), Ioan Radu PETRARIU, Ph.D. (Bucharest University of Economic Studies, Faculty of 
International Economic Relations, Romania), Aleksandra Zofia PIELOCHBABIARZ, Ph.D. (University of Lodz, Faculty of Economics and Sociology, Department of International Finance and Investments, Lodz, Poland), Mariana PITAR, Ph.D. (West University of Timișoara,, Romania), Toma PLEȘANU, Ph.D. ("Carol I" National Defense University, Romania), Cătălin PLOAE, Ph.D. (Bucharest University of Economic Studies, Faculty of International Economic Relations, Romania), Eva PODOVŠOVNIK, Ph.D. (University of Primorska, Faculty for Tourism Studies, Portorož, Slovenia), loana POP-COHUȚ Ph.D. (University of Oradea, Faculty of Economic Sciences, Romania), Anamaria Mirabela POP, Ph.D. (University of Oradea, Faculty of Economic Sciences, Department of International Business, Romania), Adela-Laura POPA, Ph.D. (University of Oradea, Faculty of Economic Sciences, Department of Management- Marketing, Romania), Adriana Florina POPA, Ph.D.(Bucharest University of Economic Studies, Faculty of Accounting and Management Information Systems, Department of Accounting, Audit and Economic and Financial Analysis, Romania), Carmen Teodora POPA, Ph.D. (University of Oradea, Faculty of Law, Oradea, Romania), Mirela POPA, Ph.D. ("Babeș-Bolyai" University, Faculty of Economics and Business Administration, Department of Management, Cluj-Napoca, Romania), Doina POPESCU, Ph.D. (Bucharest University of Economic Studies, Faculty of Management, Department of Management, Romania), Felix Angel POPESCU, Ph.D. (Nationallnstitute of Administration, Bucharest, Romania), Andra PORUMB, Ph.D. (University of Oradea, Faculty of Economic Sciences), Cătălina RADU, Ph.D. (Bucharest University of Economic Studies, Romania), Valentin RADU, Ph.D. (Valahia University of Targoviste, Romania), Angela ROMAN, Ph.D. ("Alexandru Ioan Cuza" University of lași, Faculty of Economics and Business Administration, Romania), Remus-Dorel ROȘCA, Ph.D. (University of Oradea,
Faculty of Economic Sciences, Department of Management-Marketing, Romania), Ilie ROTARIU, Ph.D. ("Lucian Blaga" University of Sibiu, Sibiu, Romania), Luminița RUS, Ph.D. (University of Oradea, Faculty of Economic Sciences, Department of Finance-Accounting, Romania), Corina RUSU, Ph.D. (Christian University "Dimitrie Cantemir" Bucharest, Faculty of Economic Sciences Cluj- Napoca, Romania), Sergiu RUSU, Ph.D. ("Aurel Vlaicu" University of Arad, Romania), Valentina Diana RUSU, Ph.D. ("Alexandru Ioan Cuza" University of Iași, Institute of Interdisciplinary Research Social Sciences and Humanities Research Department, lași, Romania), Claudia-Diana SABĂUPOPA, Ph.D. (University of Oradea, Faculty of Economic Sciences, Department of Finance-Accounting, Romania), Luminița RUS, Ph.D. (University of Oradea, Faculty of Economic Sciences, Department of Finance-Accounting, Romania), Sinan SARACLI, Ph.D. (Afyon Kocatepe University, Afyon, Turkey), Dinu-Vlad SASU, Ph.D. (University of Oradea, Faculty of Economic Sciences, Department of Management-Marketing, Romania), Diana Cristina SAVA, Ph.D. (University of Oradea, Faculty of Economic Sciences, Oradea, Romania), Tomina SĂVEANU, Ph.D. (University of Oradea, Faculty of Economic Sciences, CCCDD, Romania), Carmen SCORȚE, PhD. (University of Oradea, Faculty of Economic Sciences, Department of Finance and Accounting) Oana SECARĂ, Ph.D. (University of Oradea, Faculty of Economic Sciences, Department of Management-Marketing, Romania), Ioana Cristina SECHEL, Ph.D. ("Babeș-Bolyai" University, Faculty of Economics and Business Administration, Cluj-Napoca, Romania), Mariana SEHLEANU, Ph.D. (University of Oradea, Faculty of Economic Sciences, Department of Economics and Business, Romania), Monica SIM, Ph.D. (University of Oradea, Faculty of Economic Sciences, Department of International Business, Romania), Ovidiu Laurian SIMINA, Ph.D. (Center for Migration and Mobility Studies- 
SISEC, West University of Timișoara, Romania), Ramona-Marinela SIMUT, Ph.D. (University of Oradea, Faculty of Economic Sciences and Business, Department of Economics, Romania), Nicoleta SîRGHI, Ph.D. (West University of Timișoara, Romania), Aurelia STĂNESCU, Ph.D. (Bucharest University of Economic Studies, Faculty of Management, Department of Management Romania), Cosmina Adela STANILA, Ph.D. (West University of Timișoara, Romania), Georgiana Oana STĂNILĂ, Ph.D. (Bucharest University of Economic Studies, Romania), Maria Gabriela STERIAN, Ph.D. (Romanian-American University, Bucharest, Romania), Iuliana Claudia STOIAN, Ph.D. (BOBÂLCĂ), Ph.D. ("Alexandru loan Cuza" University of lași, Faculty of Economics and Business Administration, Romania), Ilija STOJANOVIC, Ph.D. (RIT Dubai University, Dubai, United Arab Emirates), Eduard Alexandru STOICA, Ph.D. ("Lucian Blaga" University of Sibiu, Romania), Ovidiu STOICA, Ph.D. ("Alexandru loan Cuza" University of Iași, Romania), Ilija STOJANOVIC, Ph.D. (RIT Dubai University, Dubai, United Arab Emirates), Marta-Christina SUCIU, Ph.D.

(Bucharest University of Economic Studies, Romania), Andrea SZÉKELY, Ph.D. (University of Szeged, Hungary), Cristina Alexandrina ȘTEFĂNESCU, Ph.D. (Babeș-Bolyai University, Faculty of Economics and Business Administration,

Accounting and Audit Department, ClujNapoca, Romania), Daniela ȘTEFĂNESCU, Ph.D, (University of Medicine, Pharmacy, Sciences and Technology of Tîrgu Mureș, Romania), Florica ȘTEFĂNESCU, Ph.D. (University of Oradea, Romania), Simona-Laura ȘUTA, Ph.D. (University of Oradea, Faculty of Letters, Oradea, Romania), Alina luliana TABIRCA, Ph.D. (Valahia University of Târgoviște, Romania), Teodora-Mihaela TARCZA, Ph.D. (University of Oradea, Faculty of Economic Sciences, Department of Management-Marketing, Romania), Maria TĂTĂRUȘANU, Ph.D. ("Alexandru Ioan Cuza" University of lași, Romania), Diana Alexandra TÂRNĂVEANU, Ph.D. (West
University of Timişoara, Faculty of Economic and Business Administration, Department of Business Information Systems, Timițoara, Romania), Carmen TODERAȘCU, Ph.D. ("Alexandru loan Cuza" Úniversity of lași, Romania), Claudia Simona TIMOFTE, Ph.D. (University of Oradea, Faculty of Law, Oradea, Romania), Safiye TOKMAK, Ph.D. (Celal Bayar University, Manisa, Turkey), Alvair Silveira TORRES JUNIOR, Ph.D. (Business College at University of São Paulo, São Paulo, Brasil), Mihaela TULVINSCHI, Ph.D. ("Ștefan Cel Mare" University of Suceava, Faculty of Economic Sciences and Business Administration, Suceava, Romania), Naiana ȚARCĂ, Ph.D. (University of Oradea, Faculty of Economic Sciences, Department of Management-Marketing, Romania), Claudia Elena ȚUCLEA, Ph.D. (Bucharest University of Economic Studies, Faculty of Commerce, Department of Tourism and Geography, Romania), loana VADASAN, Ph.D. (West University of Timișoara, Faculty of Economics and Business Administration, Romania), Valentina VASILE, Ph.D. (Institute of National Academy Romanian Academy, Bucharest, Romania), Marian Catalin VOICA, Ph.D. (Petroleum \& Gas University of Ploiești, Faculty for Economic Sciences, Romania), Utku YAPICI, Ph.D. (Adnan Menderes University, Aydin, Turkey), Monica ZAHARIE, Ph.D. ("Babeș-Bolyai" University, Cluj-Napoca, Romania), Andreea lleana ZAMFIR, Ph.D. (Bucharest University of Economic Studies, Faculty of Management, Romania), Deniz ZÜNGÜN, Ph.D. (HRM Department, Celal Bayar University, Ahmetli Meslek Yüksekokulu V.H.S.,Manisa, Turkey).

\section{Acknowledgement}

The Annals of the University of Oradea. Economic Sciences Journal - TOM XXX 2021 wishes to acknowledge all individuals for their assistance with the peer reviewing of manuscripts for this issue, IT support, on-line and print publishing: 
Abrudan Leonard Călin, Ph.D.; Almasan Alina, Ph.D.; Acatrinei Carmen, Ph.D.; Andreescu Nicoleta Alina, Ph.D.; Anton Sorin, Ph.D.; Ban Olimpia, Ph.D.; Barbu Ionel, Ph.D.; Bâc Dorin, Ph.D; Beleneși Marioara, Ph.D.; Benea Ciprian , Ph.D.; Bențe Corneliu, Ph.D.; Bițoiu loana Teodora, Ph.D.; Boca Gratiela, Ph.D.; Bodog Simona, Ph.D.; Bogdan Victoria, Ph.D.; Borma Afrodita, Ph.D; Boghean Florin, Ph.D.; Botezat Elena, Ph.D.; Brancu Laura, Ph.D.; Brânzilă Carina, Ph.D.; Bucurean Mirela, Ph.D.; Buta Simona, Ph.D.; Chirilă Viorica, Ph.D.; Chis Alexandru, Ph.D.; Ciortescu Elena, Ph.D.; Cismas Laura, Ph.D.; Ciurea Maria, Ph.D.; Coita Ioana, Ph.D.; Constantin Felicia, Ph.D.; Constantin Cristinel, Ph.D.; Cristina-Laura Abrudan, Ph.D.; DanielaTatiana Agheorghesei (Corodeanu), Ph.D.; Diaconu (Maxim) Laura, Ph.D.; Dornean Adina, Ph.D.; Droj Laurentiu, Ph.D.; Feder Emőke-Szidónia, Ph.D.; Popescu Felix, Ph.D.; Filip Bogdan, Ph.D.; Firtescu Bogdan, Ph.D.; Florea Adrian, Ph.D.; Florea Ramona, Ph.D.; Fora Andreea-Florina, Ph.D.; Fotache Gabriela,
Ph.D.; Gherai Dana, Ph.D.; Göndör Mihaela, Ph.D.; Gradea Cristina, Ph.D.; Grecu Eugenia, Ph.D.; Hatos Roxana, Ph.D.; Horea loana-Claudia, Ph.D.; Kardos Mihaela, Ph.D.; Lacurezeanu Ramona, Ph.D.; Matica (Balaciu) Diana, Ph.D.; Meșter loana, Ph.D.; Moisa Claudia, Ph.D.; Negrea Adrian, Ph.D.; Aksoz Ozan, Ph.D.; Panait Mirela, Ph.D.; Para Iulia, Ph.D.; Pieloch- Babiarz Aleksandra, Ph.D.; Pop AnamariaMirabela, Ph.D.; Pop-Cohuț loana, Ph.D.; Popa Adela, Ph.D.; Popescu Felix, Ph.D.; Porumb Andra-Teodora, Ph.D.; Roșca Remus, Ph.D.; Rus Luminita, Ph.D.; Rusu Sergiu, Ph.D.; Sava (Pintea) Diana, Ph.D.; Săveanu Tomina, Ph.D.; Schebesch Klaus Ph.D.; Scorțe Carmen, Ph.D.; Secară Oana, Ph.D.; Sechel loana Cristina, Ph.D.; Sehleanu Mariana, Ph.D.; Sim MonicaAriana, Ph.D.; Simuț Ramona, Ph.D.; Sirghi Nicoleta, Ph.D.; Stoian (Bobalca) Claudia, Ph.D.; Șuta Simona, Ph.D.; Tabirca Alina, Ph.D.; Țarcă Naiana, Ph.D.; Vadașan Ioana, Ph.D.; Zamfir Andreea, Ph.D.; Ioan Ceghi, Cosmin Știr. 


\section{TABLE OF CONTENTS}

SECTION: ECONOMICS, BUSINESS ADMINISTRATION, TOURISM AND STATISTICS.

ECONOMIC AND FINANCIAL STABILITY FOR WATER and WASTEWATER OPERATORS IN ROMANIA

Kinga-Erzsébet BAKÓ, Árpád-Zoltán FÜLÖP, Alina STANCIU

NEW BUSINESS MODELS GENERATED BY TECHNOLOGICAL

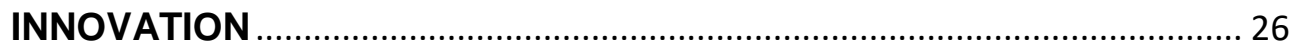

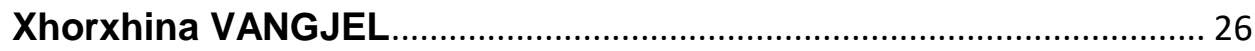

EFFECTS OF HYDROGEN PRODUCTION ON ECONOMIC GROWTH IN THE EUROPEAN UNION 35

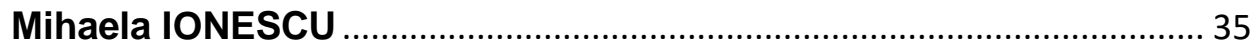

CORPORATE GOVERNANCE, RESEARCH AND ECONOMIC GROWTH IN EUROPEAN COUNTRIES

Iulia (ELENES) PLATONA

ROMANIA: UNIVERSITY GRADUATES BETWEEN EMPLOYMENT AND UNEMPLOYMENT

Eva SZABO

TRENDS AND PERSPECTIVES ON ENTREPRENEURIAL EDUCATION IN ROMANIA AND THE EU

Casiana ILLE

THE RELATIONSHIP BETWEEN ENTREPRENEURSHIP AND NATIONAL COMPETITIVENESS

Khanh Hung DOAN 65

THE ROLE OF THE VIETNAMESE EDUCATION SYSTEM IN STARTING A BUSINESS.

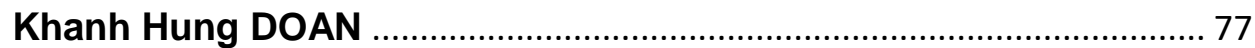

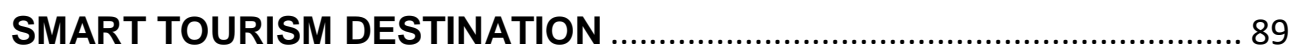

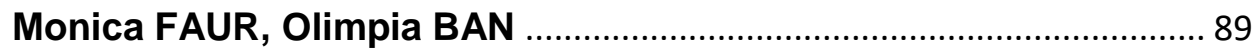


DIGITAL PROMOTION FOR HOTELS OF BĂILE FELIX- VÂRTOP RESORTS. CONTENT QUALITY ANALYSIS

Miruna Diana MOZA 95

DIGITIZATION OF THE ECONOMY - REPORTING TO THE TOURISM INDUSTRY: THE GENERAL FRAMEWORK OF REGULATION, PROJECTIONS AND THE CURRENT SITUATION 105

Miruna Diana MOZA 105

CONSIDERATIONS ON THE IMPACT OF SUSTAINABLE DEVELOPMENT ON TOURISM PHENOMENON

Nicoleta Georgeta BUGNAR, Liana-Eugenia MEȘTER, AndreeaFlorina FORA

THE MULTIFUNCTIONALITY AND SUSTAINABILITY OF SMALL AND MEDIUM ENTERPRISES IN TOURISM-BASED RURAL COMMUNITIES

Oleg PETELCA, Ciprian-Constantin PĂTRĂUCEANU, Iurie BEȘLIU

HOW THE PANDEMIC HAS CHANGED THE TOURISM INDUSTRY ... 132

Afrodita BORMA.

FEATURES OF SUSTAINABLE DEVELOPMENT AT THE LEVEL OF SMES 140

József GÖNCZI 140

ACHIEVING THE SUSTAINABLE DEVELOPMENT GOALS. 147

Aurel Constantin LUPU, Oana Raluca IVAN

ANALYSIS OF ECONOMIC GROWTH AND INCOME INEQUALITY IN ROMANIA IN THE PERIOD 1990-2019

Bianca VEZENTAN 155

THE IMPACT OF SINGLE-PARENT FAMILIES' SOCIAL VULNERABILITIES ON CHILDREN 166

lleana VARGA 166 
THE ECONOMICAL AND FINACIAL IMPLICATIONS OF RENEWABLE ENERGY SOURCES

Alexandra Maria BELE (LĂCĂTUȘ).

MONETIZATION OF ENVIRONMENTAL EXTERNALITIES FOR

ECONOMIC ANALYSIS. CASE STUDY: URBAN MOBILITY IN ORADEA

Ovidiu - Vasile GULER, Corina BOLOȘ 188

DOES THE PARETO PRINCIPLE APPLY IN THE INNOVATION FIELD IN ROMANIA?

Alina BABA. 198

DECISION-MAKING MECHANISMS REGARDING THE

ESTABLISHMENT OF THE FINANCING SOURCES OF THE INVESTMENT PROGRAMS IN PUBLIC UTILITY SERVICES

Aniko KUNTZ, Cristina DRIHA. 207

CORRUPTION AND MONEY LAUNDERING - BASIC COMPONENTS OF ECONOMIC AND FINANCIAL CRIME

Ioan FEHER, Sorin Nicolae BORLEA 219

TAX AVOIDANCE AND TAX EVASION IN EU: TRENDS AND EFFECTS

Emil Gheorghe GUIAȘ, Codruța Mihaela HĂINEALĂ. 229

THE EVOLUTION OF FISCAL PRESSURE IN DEVELOPED E.U. COUNTRIES AND ITS DETERMINANTS 239

Raluca Andreea GHETU, Cristina-Simona CĂPĂȚîNĂ, Petre BREZEANU 239

THE RELATIONSHIP BETWEEN VAT GAP AND ECONOMIC OR INSTITUTIONAL VARIABLES

Ionela BUTU, Petre BREZEANU, Adriana PORUMBOIU, Sorina Emanuela ȘTEFONI 250

COMPARATIVE ANALYSIS OF VALUE ADDED INTELLECTUAL CAPITAL AT SMALL AND MEDIUM ENTERPRISES 
Tibor TARNÓCZI, Edina KULCSÁR 260

THE IMPACT OF BASEL BANKING REGULATION ON FINANCIAL TRANSACTIONS

Margit CSIPKÉS, Rebeka NAGY, Sándor NAGY 272

THE IMPACT OF THE COVID-19 PANDEMICS OVER THE FINANCIAL PERFORMANCE AT THE LEVEL OF THE MAIN PHARMACEUTICAL OPERATING IN CENTRAL AND EASTERN EUROPE

Laurentiu DROJ, Goran KARANOVIC, Ioan Gheorghe TARA 283

CONSIDERATIONS REGARDING THE IMPACT OF THE COVID-19 PANDEMICS OVER THE FINANCIAL PERFORMANCE AT THE LEVEL OF THE TOURISM COMPANIES OPERATING IN CENTRAL AND EASTERN EUROPE 291

Laurentiu DROJ, Gabriela DROJ 291

ARIMA vS. MACHINE LEARNING IN TERMS OF EQUITY MARKET FORECASTING 299

Iulian-Cornel LOLEA, Ioan-Radu PETRARIU, Adriana GIURGIU.... 299 THE DIFFERENCE BETWEEN IFRS AND US GAAP IN FINANCIAL

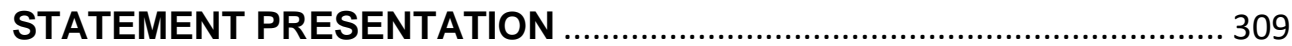

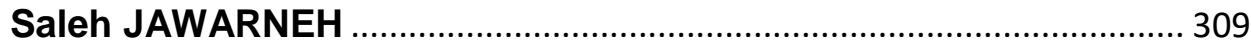

SECTION: MANAGEMENT, MARKETING, ECONOMIC INFORMATICS AND CYBERNETICS.

DEMOGRAPHIC AND ECONOMIC FACTORS INFLUENCING THE REAL-ESTATE MARKET IN ROMANIA

Remus Dorel ROȘCA, Sebastian ȘIPOȘ-GUG

PARTICULARITIES OF CSR PROGRAMS DURING THE COVID-19 PANDEMIC

Simona Aurelia BODOG, Nicoleta Alina ANDREESCU 329 GLOBALIZATION AND INTERNATIONALIZATION OF THE EDUCATION MANAGEMENT. 
A THEORETICAL VIEW ABOUT AGILE MANAGEMENT IN BANK SECTOR

Valentin Partenie MUNTEANU, Paul DRAGOS. 344

THE IMPACT OF STAKEHOLDERS IN AGILE SOFTWARE DEVELOPMENT.

Paul DRAGOS 353

WORKING FROM HOME - A COMPARATIVE STUDY BETWEEN THE BEGINNING OF THE PANDEMIC PERIOD AND A YEAR LATER.

Mirela BUCUREAN 363

THE ECONOMIC AND SOCIAL IMPACT OF TELEWORK. THE CASE OF ROMANIA

Elena-Florentina MATEI, Ioana Manuela MINDRICAN 371

THE TRUSTEE'S OBLIGATION TO INFORM THE PRINCIPAL ON THE PROGRESS OF THE MANDATE. THE ACCOUNTING MANAGEMENT AND THE REPORT.

Dana TULAI 384

NON-PROFIT ORGANIZATIONS DENSITY, SOCIALLY VULNERABLE CATEGORIES AND ECONOMICAL DEVELOPMENT FROM VOLUNTARY AND GOVERNMENT FAILURE THEORIES PERSPECTIVE

Marcela-Sefora NEMȚEANU, Dorin-Cristian COITA, Mihaela-Teodora TARCZA. 393

THE WAY IN WHICH BIHOR COUNTY'S MOUNTAIN GUESTHOUSES ARE USING SOCIAL MEDIA TO ATTRACT CUSTOMERS.

Naiana TुARCĂ. 404

INVESTIGATING THE IMPORTANCE OF CUSTOMER LIFETIME VALUE IN MODERN MARKETING - A LITERATURE REVIEW 410

Adela-Laura POPA, Dinu Vlad SASU, Teodora Mihaela TARCZA ... 410 
SECTION: INTERNATIONAL BUSINESS, EUROPEAN INTEGRATION, FOREIGN LANGUAGES AND BUSINESS ENVIRONMENT

ICSID CASES IN 2020, AFFECTED OR NOT BY COVID 19 418

Mihai BERINDE, Dana Maria PETRICA, Liana-Eugenia MESTER.... 418

THE PRINCIPAL FACTORS THAT DRIVE THE ECONOMIC COMPETITIVENESS

Dana-Teodora MIERLUT,, Adriana GIURGIU

TRADE BETWEEN CENTRAL AND EASTERN EUROPEAN COUNTRIES AND THE RUSSIAN FEDERATION IN THE CONTEXT OF SANCTIONS AND COUNTER-SANCTIONS 435

Livia CEBOTARI 435

OPTIMISER LE TRAVAIL D'EQUIPE GRACE A LA MAITRISE DES LANGUES ETRANGERES / OPTIMIZING TEAMWORK BY KNOWLEDGE OF FOREIGN LANGUAGES 448

Rodica BOGDAN 448

THE IDIOMATIC VOCABULARY OF THE PANDEMIC 453

Monica-Ariana SIM, Anamaria Mirabela POP 453

THE PERKS AND DOWNSIDES OF TEACHING ENGLISH ONLINE .... 465

Cristina-Laura ABRUDAN, loana-Claudia HOREA 465

TEACHING BUSINESS ENGLISH ONLINE. ASSIGNMENT ACTIVITIES AND TESTS IN MOODLE 473

loana Claudia HOREA, Cristina Laura ABRUDAN 473 


\section{SECTION: ECONOMICS, BUSINESS ADMINISTRATION, TOURISM AND STATISTICS}




\title{
ECONOMIC AND FINANCIAL STABILITY FOR WATER and WASTEWATER OPERATORS IN ROMANIA
}

\author{
Kinga-Erzsébet BAKÓ ${ }^{1}$, Árpád-Zoltán FÜLÖP ${ }^{1}$, Alina STANCIU ${ }^{2}$ \\ ${ }^{1}$ Phd student at the University "1 Decembrie 1918" Alba lulia and Assistant lecturer \\ at Sapientia University Cluj-Napoca, e-mails: bako.kinga@harviz.ro,
} fulop.arpad@harviz.ro

2Phd student at the University "1 Decembrie 1918" Alba lulia, e-mail: alecse.alina@gmail.com

\begin{abstract}
The financial stability of public enterprises in the field of water and sewer must be a vital feature. An economically unstable enterprise, which is threatened by incapacity for payment and bankruptcy, cannot ensure an activity of general public interest. This empirical research is based on the data obtained from the annual financial statements of regional water and sewerage operations in Romania for 2014-2019. Based on these data we calculated working capital, working capital requirements and net treasury. The processed data were grouped by the seven development regions and the average values were calculated. In the research we started from the average values at national level, comparing them with the average values obtained by development regions. Although there are quite large deviations from one development region to another compared to the national average, in all regional water and sewerage operators the net treasury has positive value. We examined whether there is a correlation between the economic performance of a water and sewerage operator and the three variables: working capital, required working capital and net treasury. The result of the statistical analysis is significant and confirms the existence of this correlation. The existing correlation does not determine the direction of the correlation, i.e. whether the net profit has an effect on working capital, working capital requirements and net treasury or vice versa. The research shows that public enterprises in the water and sewerage sector are financially stable in the period 2014-2019. We in the conclusions also presented the possibilities for expanding the research in future periods.
\end{abstract}

Keywords: water utility financiar stability, working capital, public enterprise.

Classification JEL: L95, Q25, M21, M49

\section{Introduction}

Both researchers and practitioners believe that the economic and financial stability of an enterprise is an essential condition for optimal functioning. The financial stability of an enterprise reduces the effects of changing market factors and becomes an advantage in obtaining loans, capital from potential investors and choosing business partners.

In the case of Public Enterprises in general and water and sewerage operators in particular, economic stability is paramount, as they provide basic public services for society. Financially stable enterprises under capable of 
economic growth and in this way generate new jobs and taxes paid to the state budget.

In these conditions it is especially important to have indicators that allow assessing the financial stability of a company in the long term. The economicfinancial stability of an enterprise can be characterized by indicators of working capital, working capital requirements and net treasury.

In this article we analyze the economic and financial stability of water and sewerage operators in Romania and the effect of financial balance on their performance.

\section{Literature review}

Many researchers approach the problem of working capital as a primordial problem of the functioning of an enterprise ( Bureau \& Py, 2021) (Dyreng \& Mayew \& Schipper, 2017). The existence of an adequate working capital brings advantages for the company and is an internal source of financing of the activity (Fadil \& St-Pierre, 2016). Many specialized works address the problem of the working capital expressed by Net Global Working Capital (NGWC) calculated with the formula (Petrescu, 2010), (Țilică și Ciobanu, 2019), (Juhel \& Dufour \& Severin, 2015), (Niculescu, 2005):

\section{NGWC = Stable (acyclic) resources - Stable (acyclic) assets}

Net Global Working Capital is calculated on the basis of the functional balance sheet (Vâlceanu, Robu and Georgescu, 2005).

Other researchers believe that working capital can be approached quantitatively and qualitatively (Guthmann, 1953), (Boopathi \& Leeson, 2016). Working funds (fr, fonds de roulement) by qualitative approach is equivalent to the notion of working capital. The financial stability of a company depends on how it is able to cover short-term liabilities from cyclical assets. Through a different approach, the Working Fund contributes to ensuring the working capital needs for current operations.

Working capital can be can be considered an indicator of the liquidity of a company (Tarnóczi, Fenyves \& Vörös, 2014). Companies may face the risk of insolvency if the working capital is negative (Horváth, 2020). An important task of financial management is to manage this risk and procure adequate working funds from internal sources (from working capital) or from external sources (long-term loans, capital attraction).

As is clear from the above, for assessing the financial stability of an enterprise the working capital indicator is naturally complemented by the required working capital indicator. The required working capital is calculated using the formula:

Required Working Capital $(R W C)=($ Inventories + Receivables + Expenses in advance up to one year) - (Short-term debt-Treasury bank loans + Advance income up to one year)

In the analysis of the working capital and the needs for working capital we can use the following indicators (Robu et al., 2014): 
Duration of Rotation Required Working Capital $\left(D R_{R W C}\right)=$

Security Margin Rate $(S M R)=$

Financing Rate of Required Working Capital $\left(R_{F R W C}\right)=$

Financing Rate of Cyclical Operating Assets $\left(R_{F C O A}\right)=$

Financing Rate of Required Working Capital due to Treasury

Credits $\left(R_{F R W C T C}\right)=$

where:

NTU - Net Turnover, TCRED - Treasury Credits

With these indicators, we can analyze in detail the financial stability rates of the enterprise.

\section{The method of research used and case study}

As a research method, we conducted a review of the literature and a case study in the water and sewerage sector in Romania. The database was made on the basis of the Annual Financial Statements of the regional water and sewerage operators in Romania for the period 2014-2019. Data were collected from 42 regional operators representing $95.54 \%$ of the major water and sewerage operators in Romania. As the first step of the analysis, we calculated the average FR, NFR and TN at the country level for the period 2014-2019. 


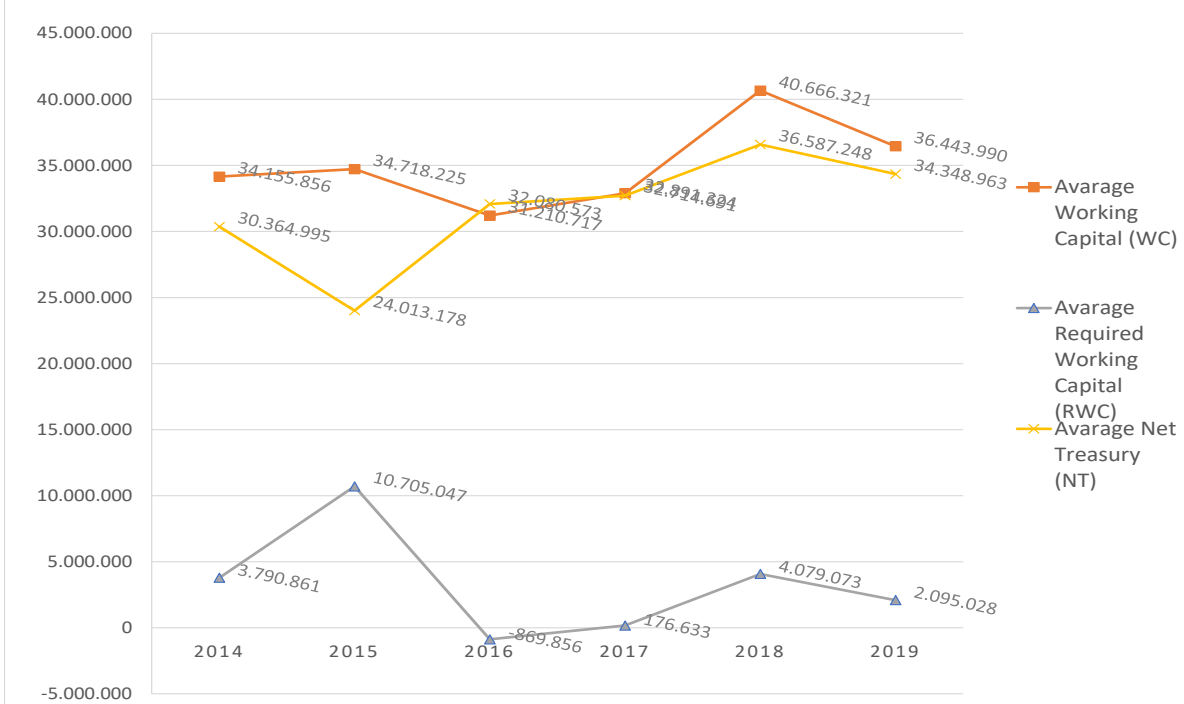

Figure no. 1 the dynamics of average WC, RWC and NT in water and sewerage operators in the period 2014-2019 at the country level (source: own elaboration)

As follows from Figure no.1 the average working capital at the country level during the period analyzed does not show much fluctuation. In the period 20152016 there is a small decrease in their value. In theory, these high average values present a good financial balance for the companies in the sector, but too high WC values can generate capital costs if these resources have been attracted from longterm loans. The other theoretical variant that these attracted resources generate dividend expectations can be excluded in this sector of activity, since the profit generated by these enterprises is reinvested as a result of the legal regulations in force.

At the regional level, the financial stability of water and sewerage operators shows deviations from the national average (figure no.2), but in each region the average Working Capital is positive the same as the Net Treasury.
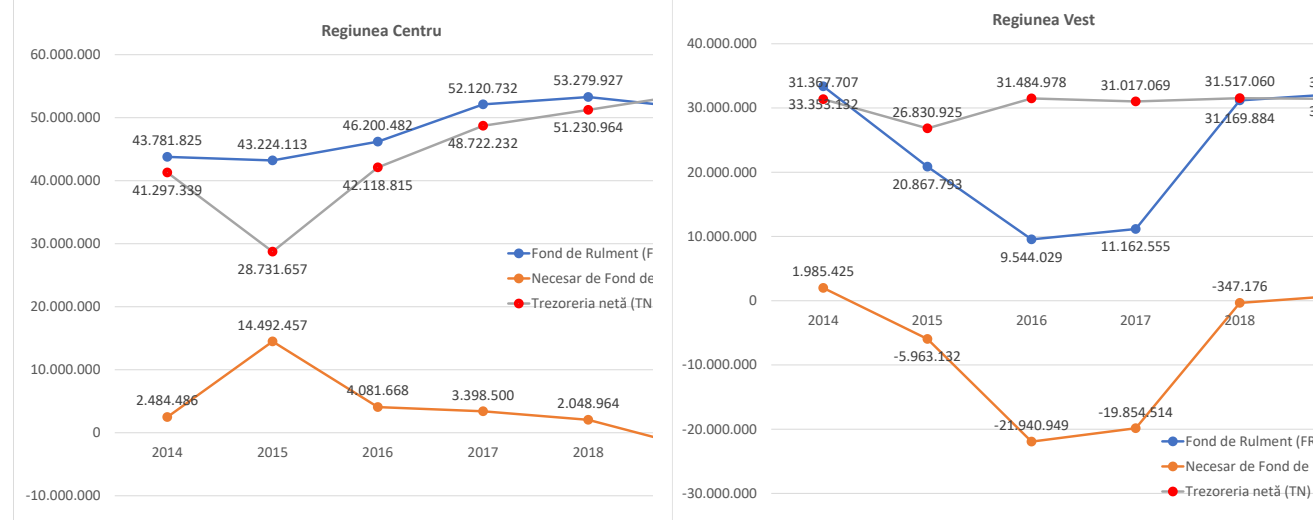

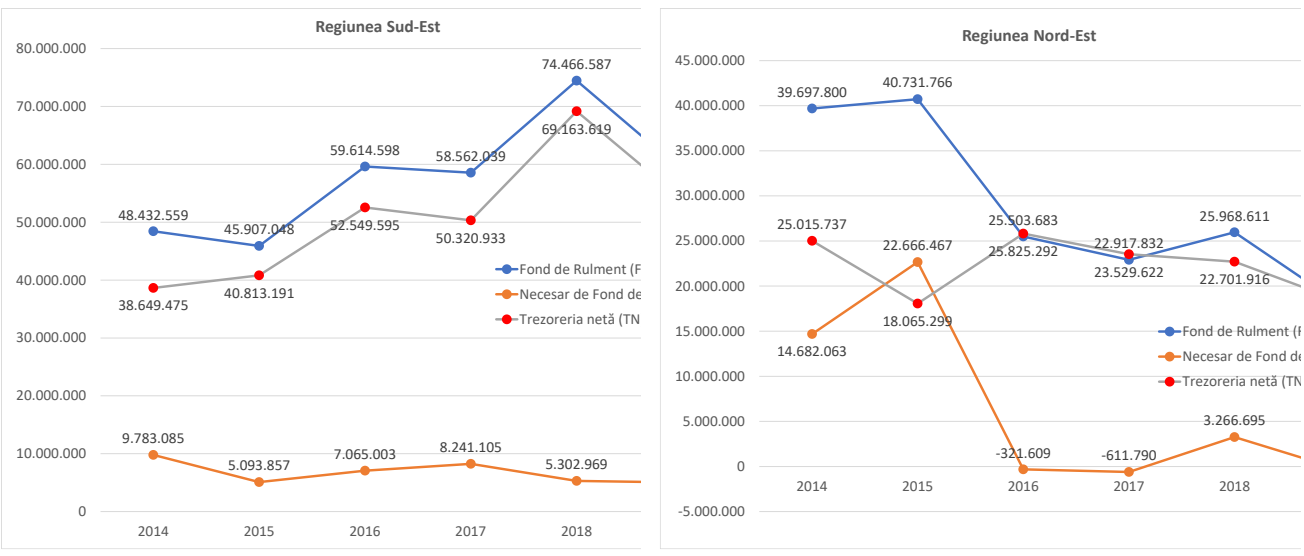

Figure no.2 Dynamics of average Working Capital, Required Working Capital and Net Treasury at the level of regional water and sewerage operators in the Central, West, South-East and North-East regions in the period 2014-2019 (source: own elaboration)

In the North-East Region, both the Working Capital and the Net Treasury are constantly declining but retain positive value. In the South-East Region values are increasing with the exception of 2019. It would probably be useful to conduct a comparative analysis of businesses in the two regions to find the explanations and factors that led to the increase and decrease in working capital and Net Treasury.

To investigate whether there is a relationship between economic-financial balance and economic performance (net profit) we conducted a statistical analysis. In the analysis with the help of SPSS we examined the correlation between Net Profit and Working Capital, Required Working Capital and Net Treasury.

Table no.1. Correlations between Net Profit and WC, RWC and NT at regional water and sewerage operators

\begin{tabular}{|l|l|r|r|r|}
\hline \multicolumn{2}{|c|}{} & \multicolumn{1}{|c|}{ WC } & \multicolumn{1}{c|}{ RWC } & \multicolumn{1}{c|}{ NT } \\
\hline \multirow{2}{*}{$\begin{array}{l}\text { Net } \\
\text { Profit }\end{array}$} & Pearson Correlation &, $582^{* *}$ &, $170^{* *}$ &, $564^{* *}$ \\
\cline { 2 - 5 } & Sig. (2-tailed) &, 000 &, 008 &, 000 \\
\cline { 2 - 5 } & $\mathrm{N}$ & 240 & 240 & 240 \\
\hline \multirow{3}{*}{ WC } & Pearson Correlation & 1 &, $494^{* *}$ &, $846^{* *}$ \\
\cline { 2 - 5 } & Sig. (2-tailed) & 240 &, 000 &, 000 \\
\cline { 2 - 5 } & $\mathrm{N}$ &, $494^{* *}$ & 240 & 240 \\
\hline \multirow{3}{*}{ RWC } & Pearson Correlation &, 000 & 1 &,- 045 \\
\cline { 2 - 5 } & Sig. (2-tailed) & 240 &, 490 \\
\cline { 2 - 5 } & $\mathrm{N}$ &, $846^{* *}$ &,- 045 & 240 \\
\hline \multirow{3}{*}{ NT } & Pearson Correlation &, 000 &, 490 & 1 \\
\cline { 2 - 5 } & Sig. (2-tailed) & 240 & 240 & 240 \\
\cline { 2 - 5 } & N & 240 & \\
\hline
\end{tabular}

(source: own elaboration) 
From the statistical analysis it follows that there is a strong and significant correlation between the Net Profit variable and the WC and NT variables and a less strong but significant relationship between the Net Profit and RWC.

The correlation is strong but cannot establish the cause-effect relationship, that is, we cannot determine whether the increase in Net Profit has an effect on Working Capital and Net Treasury or vice versa.

\section{Conclusions}

Economic-financial stability is of great importance in the functioning of an enterprise. Financially stable businesses are more attractive to both potential investors and banks when lending.

In the case of regional water and sewerage operator's financial stability characterized by Working Capital, Required Working Capital and Net Treasury has corresponding values, even too high. These public undertakings providing vital services to both the population and other entities are financially stable.

The average values recorded in working capital and net Treasury in the developing regions are different, but in all regions, they have positive values.

The highest average values are recorded in the South-East Development Region (probably due to the largest operator of water and sewerage, that of Constanta). The lowest average values are recorded in the South-West region where two out of the five operators have negative Working Capital, but maintain a positive Net Treasury because they also have negative Required Working Capital.

Of course, the size of the working capital can theoretically be influenced by the size of the net result, the size of the dividends distributed, the change in the medium and long-term debts, the net value of fixed assets and the change in the share capital. In the water and sewerage sector these factors generally come down to the influence of Net Profit (Loss), change in medium and long-term debts and investment policy.

Given that at the level of the water and sewerage sector the net treasury has quite high values, it can be the problem of poor financial management related to this element, where there are resources that could be invested at least in the short term in government securities or other similar titles that are acceptable for public enterprises.

In later research it would be interesting to analyze whether there is a correlation between "the stability of" general managers (CEO) and the performance and economic stability of these businesses.

\section{References:}

1. BOOPATHI C. \& LEESON J., (2016), „Concept of working capital management', International Journal of Commerce, Business and Management, Vol. 5, No.2, pp. 372-377 - https://www.researchgate.net/profile/JohnLeeson/publication/313477460 CONCEPT OF WORKING CAPITAL MANAGE MENT/links/589c1e9b458515e5f454a60b/CONCEPT-OF-WORKING-CAPITALMANAGEMENT.pdf

2. BUREAU Benjamin \& PY Loriane, (2021). "La situation financière des entreprises: forces et faiblesses à la veille de la crise sanitaire," Bulletin de la 
Banque de France, Banque de France, issue 233. - https://publications.banquefrance.fr/la-situation-financiere-des-entreprises-forces-et-faiblesses-la-veille-de-lacrise-sanitaire

3. DYRENG Scott D. \& MAYEW William J. \& SCHIPPER Katherine, (2017). "Evidence of Manager Intervention to Avoid Working Capital Deficits" Contemporary Accounting Research, John Wiley \& Sons, vol. 34(2), pages 697725, June. - https://doi.org/10.1111/1911-3846.12291

4. FADIL Nazik \& ST-PIERRE Josée, (2016). "Croissance des PME et autonomie financière: le rôle des pratiques d'affaires", Post-Print hal-01704988, HAL.

https://www.researchgate.net/publication/322599887 Croissance des PME et au tonomie financiere le role des pratiques d'affaires

5. GUTHMAN H.G. (1953). „Analysis of Financial Statements”, New York

6. HORVÁTH, P. (2020). „Analysis of the composition, property and financial situation of agricultural enterprises in the Southern Great Plain region", International Journal Of Engineering And Management Sciences, 5(4), 2-20.

7. JUHEL Jean-Claude \& DUFOUR Dominique \& SEVERIN Eric, 2015. "Approche Dynamique Du Besoin En Fonds De Roulement", Post-Print hal01527951, HAL. - https://EconPapers.repec.org/RePEc:hal:journl:hal-01527951

8. KATONA Flóra \& TÖMORI Gergö, (2021). "Comparison Of Hungarian And Romanian Soft Drink Producer Companies Based On Their Financial Situation", SEA - Practical Application of Science, Romanian Foundation for Business Intelligence, Editorial Department, issue 25, pages 15-21, May. https://seaopenresearch.eu/Journals/articles/SPAS 25 2.pdf

9. NICULESCU M. (2005). „Diagnostic financiar - vol.2”, Editura Economică, București

10. ROBU V., ANGHEL I., ȘERBAN E. C. (2014), „Analiza economicofinanciară a firmei", Editura Economică, București

11. TARNÓCZI, T., FENYVES, V. \& VÖRÖS, P. (2014). „Problems of using traditional financial ratios to measure corporate performance". Acta Scientiarum Socialium, 17(40), pp. 121-134. 


\title{
NEW BUSINESS MODELS GENERATED BY TECHNOLOGICAL INNOVATION
}

\author{
Xhorxhina VANGJEL \\ Department of Economy and Business, Faculty of Economics, The University of \\ Oradea, Oradea, Romania \\ xhorxhinavangjel@yahoo.com
}

\begin{abstract}
The evolution of technology has caused a revolution in almost every fragment of the entrepreneurial sector, especially in terms of adapting business models to innovation. The management of a business in a competitive market has become increasingly unpredictable. Leadership style has changed the way the business model is framed through modern strategic thinking or management. By applying new information technologies, businesses need to constantly reflect in order to redesign the business models they use. Business models under the pressure of time changes have changed the format of operation and approach, depending on the "innovation" factor. Today, companies around the world feel under direct pressure to operate in efficient solutions, designed to fully adapt to the various and comprehensive strategic business management activities. As a result of technological evolution, organizations find it easier to intervene in the markets, to increase their operating segments in the market, as well as to change the forms of the way the product is delivered to the customer. This has brought uncertainty in their managerial work but has also significantly facilitated the environment in which businesses operate. Even for many businesses technological development is the motto of their existence. Many companies themselves have been established on the basis of internet technology while from many others technological evolution is exploited to take advantage of another level in the market. The use of the software industry in business is considered a key factor of computerization due to the economic benefits, expressed in fast and intermediary transactions, cost reduction, revenue growth, competitive advantages, product diversity and saving of nonrenewable resources. Studying the impact of technology and innovation on business models is essential to explore how companies innovate, need and should innovate the business model. The purpose of this paper is to advance research on the perspective offered by innovation in the business model. The aim is to emphasize the importance of technological development in the creation of digital businesses, hoping to inspire managers and entrepreneurs to compete in the market not only by applying the latest technology available, but also by creating their innovations to make their business more profitable and more sustainable. The novelty of this study corresponds to a general analysis of "modern business models", in the way how business models in combination with technological evolution, mature and bring to the stage new business models, those provoked by technological trends.
\end{abstract}

Keywords: technological innovation; business models, digital enterprises, internationalization, e-business, e-commerce.

JEL classification: M10; O30 


\section{Introduction}

The complexity of the current market, the production and transmission of material goods, the application of new technologies, the raising of awareness, responsibility and social requirements, have inevitably influenced the productive philosophy of companies.

Once a new business is initiated, it is destined to use and adapt a certain business model that will serve to design the internal organization and value creation for the business. Naturally, under the impact of technology evolution, businesses need to better reconceptualize internal organizational activities, improve them in relation to time changes, in parallel with new developments and above all deepen them in the managerial organization of work.

Managers and entrepreneurs under the influence of innovation and rapid development of the global market, spontaneously impose change on the company."Innovative managers" explore new products for existing markets. They also explore new markets for existing products. Meanwhile companies are exploring new products for new markets. (Edison \& Wang 2018)

Under the inspiration of various promotional techniques, companies tend to continuously publicize their own "identity" on the market.Leaders and managers of organizations are constantly exploring new business models that have the potential to positively increase their competitive performance in the market, as well as to increasingly influence consumer behavior.

The literature review shows that researchers are continually linking business models to change processes.An interesting definition of innovation in business models is found in the principles of Joseph Schumpeter, known for inventing the term "creative destruction" in the field of economics. (Sako 2012)

Thus, the innovation of business models translates into a new market, a recreation of the way businesses produce, a new philosophy regarding the way businesses do business. In this sense (Sako 2012) implies a close and inseparable link between business models and new technology.So it highlights modern arguments, saying that if a new technology does not take the form of a product launched on the market, then the technology remains unused and therefore we have no value created.So, based on these arguments we can say that this author sees in a way business models as a catapult of technological mechanisms and processes based on value creation.

Integration of work processes, influenced by the digitization of processes refers to the need for an updated digital infrastructure.Adapting production processes to industrial revolutions and technological changes means constantly replacing equipment and updating the communication networks that help the production system.

Considering that every technological development brings always more advanced and automated methods in production or provision of services, is constantly emphasized necessity for continuous investment in equipment, production infrastructure and systems.

Technological transformation, healthy fiscal and capital practices, increase flexibility, renew more than ever business models in constant change.

Many companies have created business websites which play an essential role in the internal structural relations of the firm or even in promoting the efficiency of external relations. 
The use of websites serves for employees in the company as a regulator of communication and dissemination of information via email.

This facilitates communication between the entrepreneur, manager or staff. It also affects the efficiency of the use of the supply network.Makes information exchanges with suppliers, distributors or vendors more manageable. The customer also has the opportunity to get acquainted with a descriptive picture about the company, the products it offers, serving at the same time as a mechanism to communicate with the company about various services around the framework of what the company offers.

\section{Digital Challenge for Business Innovation: Becoming a Modern Digital Enterprise}

Once change towards digitalization in the business context was conceived as a limited distribution phenomenon and somewhat of a "myth", but in recent decades has become an inevitable necessity, a non-negotiable need.

The digital transformation and Internet as in any sector of the economy, has "occupied" also the environment where businesses develop commercial activity. Leadership style in organizations has changed "behavior". Because in the world of digital business, entrepreneurs and managers are the first to experience the taste of change. And it is precisely these who are the first to lead these changes. Being already not just a choice, but rather a purpose, the challenge of adapting the organization to the implementation of new technologies in business is inevitable.

The paradigm of "digitalization" in the economic context includes a set of processes of using digital technologies that improve a business model, with the aim of creating new opportunities to use the potential of the firm and that is finalized in higher revenues for the organization. (Acedo \& Jones, 2007)

Increasing customer expectations for the speed, range and quality of product or service delivery, mean the development of new business restructuring capabilities and processes.

Due to the technological evolution in the economic sector, businesses have changed not only the existing infrastructure, systems and structures, but also the strategy of the company itself, following a complete change in the current business model.

Information, communication technologies, evolution and digital technology is creating huge benefits in terms of performance that different companies show in the market. According to a report from the Harvard Business School, digitalization is presenting the integrated use of analytics, big data, the cloud, the Internet of Things "loT", mobile phones, applications, which together are driving the pace of significant and long-term changes in the development of the business sector. According to the report, now "Digital transformation in the economy has become the new normal, a inevitable innovation and now this is not more a preference but a necessary choice, it is a matter of survival." (Kerschberg, 2017)

Business Roundtable (2007), an association of senior executives (CEOs) of United States companies emphasizes the importance that companies must place on their online business. For them it is necessary that "companies assess their dependence on the Internet, in terms of the prospect that the business is able to provide vital operations in function, as soon as possible even in the event of a major disorder or disruption of the Internet proliferation". As the optimal management of such a 
situation, it is vital to minimize the inconvenient consequences of business as a whole, but also to minimize the negative impact on the economy and overall security of the country. Also Business Roundtable (2007) concludes that "business is not able to handle with prudence all significant internet disruptions" being vulnerable to any change in this regard.

\section{Harmonizing Business With IT: Web 2.0}

The digital infrastructure has created space for the creation of new business models, encouraging "the conversion of new technologies into commercial value". (Sako 2012). How you use e-commerce or web applications, simultaneously affects a company's cost and revenue.

The use of "E-Commerce", "Web 2.0", "Cloud services" or the "pay as you go" calculation model, influences the possible development of new business models, mediating both sides of trade, producer-consumer and reduces the need for an expensive infrastructure. In the literature, the current emphasis is placed on Web 2.0 technology, in international marketing strategies and dimensions.

The term Web 2.0, widely used by Tim O'Reilly and CEO of O'Reilly Media, has been defined as a set of economic, social and technological trends that underlie the next generation of the Internet (Musser and O'Reilly2006). According to this study, the Web 2.0 application is based on four distinct characteristics: The website as a platform; Content and data impose applications as a "dynamic force"; Such an architectural framework encourages users to contribute; A cheap software, easy to build and use, where its approval should be seen more as an opportunity than as a cost.

Studies that talk about the Web 2.0 application are few, but it seems that this application has a growing trend. Considering that technological developments are advancing day by day, of course new forms of e-commerce application will appear. This will definitely stimulate the competitiveness of enterprises and enable competitive advantages in the global market (Constantinides 2010)

Through the facilities offered by the Web 2.0 application, companies are also given space to balance deficiencies in resources or ideas by using external resources, which involves business strategy. (Jim Bell, Sharon Loane 2010) The creation of social networking sites known as social media such as Facebook, Whatsapp, Viber, YouTube, Twitter, LinkedIn, Instagram, Qzone, Tumblr, Line etc., have led companies to redefine the role of technology in terms of development and promoting in the online world the product that the business offers.

\section{Moderated business models by technology: E-business, E-commerce and E-marketing}

Precisely from the fact that business development is increasingly based on the use of the Internet, seen in the positive aspect this allows entrepreneurs to keep their audience up to date with any latest business trends or changes. So by informing the audience, the use of technology and the Internet serves to keep consumers closer to the business.Customers now quickly access online shopping websites and get the information they consider important.Thus the consumer has more access to the image of the business and to the recognition of the products launched on the market at different times by the firms. The growing interest of 
consumers to be informed in real time, has prompted many companies to develop "E-business", "E-commerce" or to apply "E-marketing".

In recent decades, the framing and commitment of businesses in the context of the Internet has moderated business models by influencing the development of a new business model, that of "e-business".

E-business refers to the beginning of the planning and implementation of the electronic business process. (Meier \& Stormer 2009)

Five tools on the Internet are proposed with significant capabilities influencing the success of e-business: product selection by the buyer, online payment, credibility displayed by the seller, shopping trips and errors in shipping the product.At the same time, four main objects are identified on the Internet that affect the success of e-business: the ease of making purchases, the ecology of the Internet, tradecustomer interaction and the value of the product.(Torkzadeh \& Dhillon, 2002)

In the literature studies regarding e-business models, three different classifications are defined: e-procurement, e-organization and e-commerce. To rich this result, the nine main types of business model most often found in the e-commerce literature have been studied by authors of the literature: Brokerage Model, Advertising Model, Infomediary Model, Merchant Model, Affiliate Model, Manufacturer Model, Community Model, Subscription Model, Utility Model(Abdollahi, 2011).

If we mention a classic, traditional business activity, we say that it consists of four main elements: Product Offering, Product Ordering, Payment of the Product, Product delivery.At the moment that the realization of one of these constituent elements is done on the Internet, then we are dealing with e-commerce. ECommerce is positioned as one of the main trends of recent years.Many people have built their own online stores and they trade their goods worldwide. After creation, there is a lot of work to be done for e-commerce management, because building a website is just the beginning.E-commerce is not a simple online store, but it is a real company and should be thought and managed as such.

Website should be designed in accordance with "business-user" requirements. Collaboration with all project stakeholders: development team, business owner, the quality of the website factors, consumers/users of website, is very important. (Lee \& Kozar 2006)

The concept of "e-commerce" consists of everything that refers to the way of doing business online quickly, without cost, without barriers being applied on a global scale and in real time twenty-four hours a day without applying the same sales method as in the traditional business model. E-commerce has intensively impacted businesses by improving infrastructure and resource allocation. It has obviously created an economy with tremendous potential to improve the efficiency of global trade because the competitive market conveys flexibility, a wide range of products, drastic cost reductions and significant profit margins. (Javalgi \& Ramsey 2001)

There are a number of features of e-commerce that frames companies to move beyond the traditional model of doing business and get involved in online business models: availability, interactivity, interaction, global spread, universal standards where the standard called the Internet is the basis, wide range of applications, density of information and communication;personalization / image of the firm and logo. (Laudon \& Laudon, 2007).

The Internet and doing business through e-commerce offers consumers a variety of products to choose, and not only that, because it also serves as the perfect option for trading. 
From the moment that we talk about business, we are also talking about marketing. The term marketing refers to the identification and satisfaction of specific human and social needs, specifically as defined by Philip Kotler, "Marketing can be described as a social process by which individuals and groups get what they need, through the creation, supply and trade offree of valuable products and services. "

The growth of social media has an impact on the world of E-marketing.It does not happen that an organization can not reach customers and their expectations through one social media platform or another.

Creating relationships with the consumer through media or electronic platforms makes the exchange of ideas, products or services more convenient, by simultaneously balancing the pleasures of the seller, as well as the buyer (Ngai, 2003).

E-marketing as an integral part of e-commerce influences brand awareness, creates potential for audience growth and target clientele as well as business promotion. This whole process of business exposure translates into revenue generation for the company. The role of e-marketing is to create an online connection between the company and the target customers, based on the concept of coherence, according to the emotions that the company wants to convey.

\section{The Paradigm of Innovation and Internationalization}

Today, the success of a business in both the internal and external markets is ensured by innovation. Innovation is the main positive driver of economic growth in today's global economy. (Bruland \& Mowery 2004).

The term "open innovation" first used by Chesbrough (2003), highlighted how large companies flexibly combine new technologies from outside the company and those developed within the company to form new business models based on the influence of the technology network.

According to the OECD, product innovation is the process of "performing / creating" something new or "performing / creating" something in a new way. In business, innovation must also include the concept of improvement. So it basically consists of introducing a product / service that is new or that has been significantly improved in terms of features, purpose of its use, mode of operation, image, composition, materials, technical specifications, incorporated software, or evaluation positive by product / service users. (OECD 2005)

In a literature review, researchers saw progress in the role of the Internet in terms of internationalization (Jim Bell, Sharon Loane 2010), concluding on three stages of early and subsequent contributions to Internet use. The Internet in the first stage of early contributions is seen as a "facilitator" factor that has allowed companies to establish a "global presence": Companies have faster and more efficient communication opportunities. The interaction between companies creates opportunities for more accurate information on international markets. The Internet in the second stage of contributions is seen as an "enabling" factor for "new eofferings": Companies conduct transactions online. Companies have the opportunity to constantly introduce new electronic offers. Creating new business models based on changing the network of information and action in supply chains. In recent contributions, the Internet has been seen as a "creator" or "promoter" of innovative opportunities internationally, creating opportunities for "co-creation" and interaction between companies. 


\section{Conclusions}

In economic activities the use of the internet, positively helps businesses to offer their products or services in a wider market with lower transaction costs and reduced investments to reach new clients. In the ranking of the most successful companies in the world lead those companies that stand out first for innovative capabilities. So it is obvious that the most innovative, businesses perform better financially.In the context of the firm's financial performance, leadership style should convey a supportive education about "diffusion of innovation". This will help businesses to understand their position in the market where they really are and to define their objectives more clearly so that they can be positioned where the business has prospects to be positioned. This would also encourage strategic planning of the firm's long-term policies.In the eraof massive internet proliferation, the acquisition of contemporary views, innovation oriented culture and the leadership of companies in the spirit of compromise with innovation,influences them to improve their competitive performance in the global market. The purpose of this paper is to expand the visionary research aspects, regarding the impact of implementation creativity and innovation on business models. In the end, innovation in business models does not have a strict definition, but it is a constant state of disagreement with the "status-quo" of the entrepreneurship. The analysis shows that the approach of innovation in business, increases the vigilance towards responsibilities, often questioning the management and innovation capacities of the firm. In terms of innovation-oriented culture in business models, as an asset that turns competition into an advantage, it is recommended a continuous adaptive manifestation of conformity and functionalization of some concrete steps related to initiatives to apply all formats of software industry in business, in order to ensure high performance.

\section{References:}

1. Abdollahi, G., and Leimstoll, U. (2011), "A Classification for Business Model Types in E-commerce". AMCIS 2011 Proceedings - All Submissions.Paper 88.

2. Acedo, F., and Jones, M. (2007), Speed of internationalization and entrepreneurial cognition: Insights and a comparison between international new ventures, exporters and domestic firms. Journal of World Business, Elsevier, Vol. 42(3), 236-252.

3. Amit, R., and Zott, C. (2012), Creating value through business model innovation.

4. Baden-Fuller, C. and Haefliger, S., (2013), Long range planning, Business models and technological innovation.

5. Bell, J. and Loane, Sh. (2010), New-wave' global firms: Web 2.0 and SME internationalization, Journal of Marketing Management, Vol. 26: 3, pp.213 - 229.

6. Booz\&Co (2013), The 2013 Global Innovation Study: Navigating the digital future.

7. Bruland, K. and Mowery, D. (2004), Innovation through time.

8. Business Roundtable (2007), Growing Business Dependence on the Internet New Risks Require CEO Action. Business. Washington DC. [Online], Available:https://www.yumpu.com/en/document/read/36199934/growing-businessdependence-on-the-internet-new-risks-require- 
9. Cavalcante, S., Kesting, P. and Ulhøi, J. (2011) "Business model dynamics and innovation: (re)establishing the missing linkages", Management Decision, Vol.49, No.8, pp. 1327-1342.

10. Chaffey, D. (2007), E-business and E-commerce Management: Strategy, Implementation and Practice.

11. Chaudhury, A. andKuilboer, JP. (2001), E-business and E-commerce Infrastructure: Technologies Supporting the E-business Initiative.

12. Chesbrough, H. (2003), Open innovation: The new imperative for creating and profiting from technology. Boston: Harvard Business School Press.

13. Chesbrough, H. (2003), Open Innovation: The New Imperative for Creating and Profiting from Technology. Boston: Harvard Business School Press. [Online], Available: https://www.nmit.edu.my/wp-content/uploads/2017/10/Open-Innovationthe-New-Imperative-for-Creating-and-Profiting-from-Technology.pdf

14.Chesbrough, H. (2010), Business model innovation: opportunities and barriers.

15. Constantinides, E. (2010), Connecting Small and Medium Enterprises to the New Consumer: The Web 2.0 as Marketing Tool. IGI Global. DOI:10.4018/978-161520-627-8.ch001

16. Dutta, S. (2012), The Global Innovation Index 2012: INSEAD and WIPO.

17. Edison, H., Wang X., Jabangwe, R., and Abrahamsson, P. (2018), Innovation Initiatives in Large Software Companies:A Systematic Mapping Study, [Online], Available: https://arxiv.org/pdf/1802.05951.pdf

18. Fingar et al. (2003), Extreme Competition:Innovation and the Great 21st Century Business Reformation.

19. Gambardella A. \& McGahan A.M. (2010), Business-model innovation: General purpose technologies and their implications for industry structure. Long Range

Planning, Vol.43, pp. 262-271. [Online], Available:

http://www.businessmodelcommunity.com/fs/Root/8jat2-

1 s2 0 S0024630109000594 main.pdf

20. Javalgi, R., Ramsey, R. (2001), "Strategic Issues of E-Commerce as an

Alternative Global Distribution System”, International Marketing Review, Vol. 18, No. 4, pp. 376-391.

21. Kenneth, L. C. and Jane, L. P. (2014), Management Information Systems, Managing the Digital Firm. New York: Pearson. [Online], Available:

22. Kerschberg, B. (2017), How Digital Disrupts Operations, Business Processes And Customer Experience.

23. Kotler, P. (2003), Marketing Management. 11th Edition, Prentice-Hall, Upper Saddle River, pp.685.

24. Kotler, P., (2007), Marketing Management, Mondadori Editori, Milano.

25. Laudon, J. P., and Laudon, K. C. (2007), Management Information Systems:

Managing the Digital Firm, 10th Edition.

26. Leea, Y., \& Kozarb, K. A. (2006), Investigating the effect of website quality on e-business success: an analytic hierarchy process (AHP) approach. Decision Support Systems, 42(3), 1383-1401.

27. Musser, O'Reilly and The O 'Reilly Radar Team (2006), "Web 2.0 Principles and Best Practices", p.4. [Online], Available:

https://entreprisedigitale.typepad.com/main/files/web20 report excerpt.pdf 28. Ngai, E.W.T., (2003), "Internet marketing research (1987-2000): a literature review and classification", European Journal of Marketing, Vol. 37 No. 1/2. 
29.OECD (2005), Oslo manual guidelines for collecting and interpreting innovation data. Luxembourg: Statistical Office of the European Communities.

30. Sako M. (2012), Technology Strategy and Management, Business Models for Strategy and Inovation, Vol. 55, no. 7.

31. Spieth, P., Schneckenberg, D. and Matzler, K. (2016), R\&D Management, Exploring the linkage between business model (\&) innovation and the strategy of the firm.

32. Torkzadeh, G., and Dhillon, G. (2002), Measuring factors that influence the success of Internet commerce. Information Systems Research, 13(2), 187-204. DOI:10.1287/isre.13.2.187.87

33. Wirtz BW. (2011), Design-Process-Instruments, Business Model Management.

34. Zott, C. and Amit, R. (2007), "Business Model Design and the Performance of Entrepreneurial Firms," Organization Science 18, no. 2: p.181-199. 


\title{
EFFECTS OF HYDROGEN PRODUCTION ON ECONOMIC GROWTH IN THE EUROPEAN UNION
}

\author{
Mihaela IONESCU \\ University of Oradea, Doctoral School of Economic Sciences, Oradea, Romania, \\ ss mihaela@yahoo.com
}

\begin{abstract}
In this article the author presents some aspects of the hydrogen market, this fuel is essential to support the European Union's commitment to achieving climate neutrality by 2050.

In 2020, the crisis caused by the Covid-19 pandemic has given a boost by speeding up the global long-term challenge of climate change, with more and more countries committing to achieving "zero net" emissions.

The energy system in the single internal market is responsible for $75 \%$ of greenhouse gas emissions. According to the Green Deal Pact. In the context of the crisis caused by the Pandemic Corona, the European Commission issued the Hydrogen Strategy in which it provided for an investment plan in green energy with the aim of economic recovery in Europe. In this sense, green hydrogen can be the fuel that contributes to reducing energy costs at European level.

Decarbonisation leads to a significant increase in the role of electricity, which can cover the demand of over $50 \%$ of final energy by 2050 , compared to about $20 \%$ today.

Hydrogen contributes to the security of energy supply by reducing dependence on the import of fossil energy and natural gas. Thus, the diversification of energy supply takes place by facilitating the implementation of renewable energy sources. This is assessed by the estimation of imported fossil fuels that will be replaced by hydrogen based on domestic renewable sources.

Green hydrogen can be obtained from clean energy where investments in renewable energy, whose prices are falling, and innovation are a viable solution for the green economy. Hydrogen does not emit greenhouse gases and does not pollute the air when used.

In Romania, the potential for renewable energy production is estimated to be almost ten times higher in 2030 than at present, which creates a significant opportunity to use some of this potential in the production of hydrogen that can replace fossil fuels.
\end{abstract}

Keywords: Decarbonisation; economic growth; Green Deal Pact; green hydrogen; renewable energy sources; wind farm

JEL Classification: E23

\section{European context}

The Member States of the European Union have made a firm commitment to the Paris Agreement and its objectives. The goal of Europeans is to become climate neutral in 2050 (The Paris Agreement).

The energy system in the single internal market is responsible for $75 \%$ of greenhouse gas emissions. According to the Green Deal Pact (COM (2019) 640 final), in the context of the crisis caused by the Pandemic Corona, the European 
Commission issued the Hydrogen Strategy on 8 July 2020 which set out a green energy investment plan aimed at economic recovery in Europe. In this sense, green hydrogen can be the fuel that contributes to reducing energy costs at European level. Hydrogen is essential to support the European Union's commitment to achieving climate neutrality by 2050 and to the global effort to implement the Paris Agreement.

In line with the European Union's Hydrogen Strategy (COM (2020) 299 final), European countries play a significant long-term role for green hydrogen obtained by electrolysis using renewable electricity.

The European Union's strategic position based on the high potential of offshore energy from the North Sea and the Baltic Sea to the Mediterranean and the Black Sea is essential for Europe to achieve its 2030 carbon reduction targets and become neutral from the point of view of view of the impact on the climate by 2050 (.COM 2020741 final).

\section{Hydrogen demand in the European Union}

In the European Union, offshore wind energy currently produces clean energy that is cheaper than electricity from fossil fuels.

Green hydrogen can be used in those sectors where electrification is difficult, especially heavy transport, the steel and chemical fertilizers industry.

The first offshore wind farm in the world was installed in Denmark and is a successful demonstration project.

The Netherlands is considering the use of blue hydrogen, using natural gas as a raw material, carbon sequestration and storage, as a provisional measure. However, Germany, Spain and Italy are skeptical about "blue hydrogen". France is the only country in Europe that relies on nuclear power generation (although many of its nuclear power plants are nearing the end of their lives), producing hydrogen by electrolysis called "purple hydrogen" using nuclear electricity.

Germany seems to place the most emphasis on the use of hydrogen, although it is not expected to be able to meet all the demand for hydrogen from domestic production, low-carbon hydrogen imports will play a significant role.

At the other extreme, Spain, with a high potential for large amounts of cheap solar energy, is considered to be a significant exporter of hydrogen. Italy is based on imports from North Africa.

Hydrogen is currently used in the European Union, in proportion of $2 \%$ with the premises of its use up to about $24 \%$ of the European energy mix in 2050.

The current demand for hydrogen is predominant in the chemical refining and ammonia industry, the steel industry, the construction sector and in heavy transport (Figure 1). 


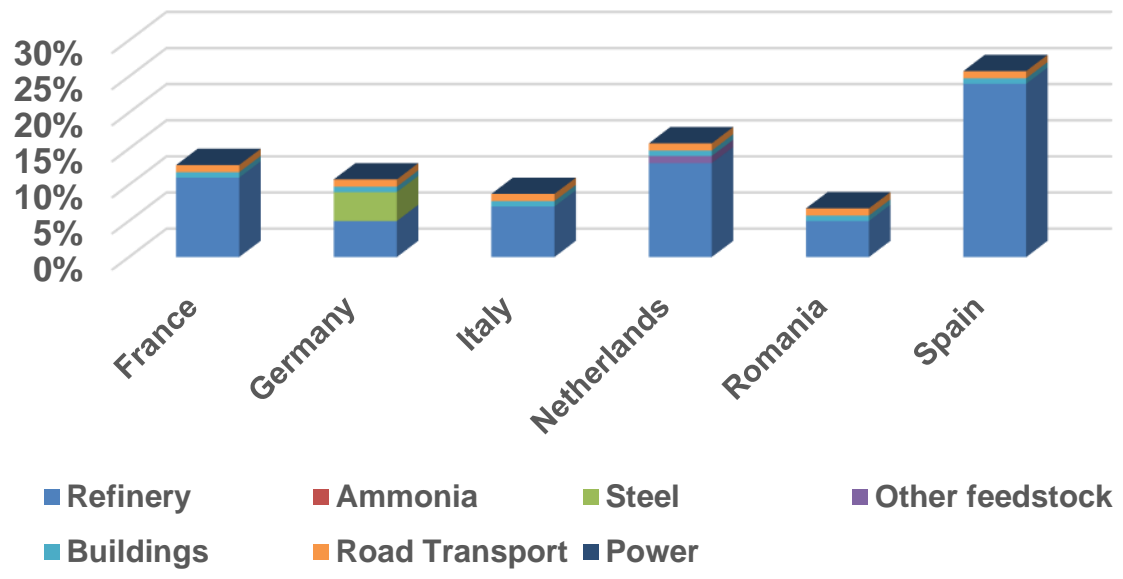

Figure 1: Demand for low-carbon hydrogen by country and sector in 2030. Low scenario

Source: Authors' analysis

The European Commission believes that only hydrogen from renewable energy will be sustainable in the long run. Therefore, only this type of hydrogen is addressed and supported by the European strategy. The European Commission has determined that hydrogen production will be supported by European funds.

The analysis of two scenarios was performed for the energy market in Romania and five markets in the European Union by calculating the penetration of low carbon hydrogen, as a percentage of total energy consumption in each key sector of demand, both the lowest scenario and the highest.

The data presented in Table 1 show that the highest percentage comes from the refinery sector. This is explainable because there is already a hydrogen market in refineries and in the petrochemical sector (along with ammonia production).

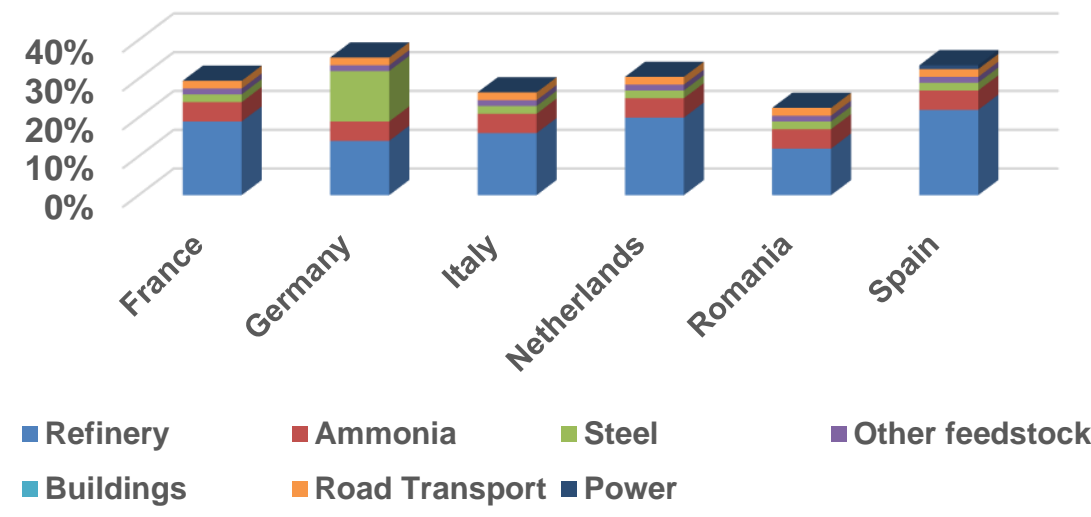

Figure 2: Demand for low-carbon hydrogen by country and sector in 2030. High scenario

Source: Authors' analysis 
However, as can be seen from Figure 2, the total energy demand of each sector has a significant impact in forecasting the total hydrogen demand.

Currently, hydrogen obtained from water electrolysis accounts for less than $1 \%$ of hydrogen production in the six countries. However, due to the decarbonisation ambitions accompanied by the expansion of renewable energy sources, the future potential for hydrogen production is high.

In general, there are two electricity supply options: the supply of electricity from offgrid installations and the supply of electricity from the national grid.

Currently $96 \%$ of the hydrogen consumed comes from burning fossil fuels.

For the production of pure hydrogen that does not release carbon into the atmosphere, it is produced by electrolysis of water using renewable or nuclear energy. Approximately 22 TWh of green electricity is needed to produce 15 TWh of hydrogen.

Even if in the lowest scenario, in the transport sector, the penetration is only $1 \%$ or $2 \%$ (in the case of the highest scenario) in the 2030 demand forecasts, this translates into a significant proportion (between $25-30 \%$ ) of total hydrogen demand.

Similarly, in the construction sector, a hypothesis of $0.75 \%$ percentage penetration in the low scenario and $7.5 \%$ percentage in the highest scenario (with the same value in all countries) leads to significant variations in the estimated demand.

\section{Effects of the development of the hydrogen market in Romania}

According to estimates on renewable energy, in Romania the potential for electricity production in RES will be almost ten times higher in 2030 than at present, which creates a significant opportunity to use some of this potential in generating renewable energy. to produce hydrogen by electrolysis.

In Romania, in the first phase, the development of hydrogen production capacities of $1500 \mathrm{MW}$ is foreseen, the financing of which is supported by the Modernization Fund (Table 1).

With regard to the transport of hydrogen, it can be transported in a mixture with methane gas using the natural gas transmission infrastructure built under BRUA.

Given that the European Commission gives a significant long-term role to green hydrogen obtained by electrolysis using renewable electricity, Romania is forced, if necessary, to speed up the abandonment of the exploitation and use of fossil fuels for hydrogen production.

From the scenarios presented by the Romanian authorities regarding the exploitation of fossil fuels, more precisely regarding the Decarbonization Plan of the Oltenia Energy Complex, we found that this plan, with a total value of over 1.3 billion euros, does not comply with the principles of European funding. the company's total CO2 emissions will increase by about $28 \%$ by 2030 compared to 2020. The restructuring and decarbonisation plan is not sustainable given the plans to use coal in 2030 without setting a deadline for its elimination. fuel from energy production. 
Table 1. Estimated investments in the hydrogen market in the next period

\begin{tabular}{|l|c|c|}
\hline & $\begin{array}{c}\text { Electrolysis } \\
\text { capacities for } \\
\text { hydrogen } \\
\text { production (MW) }\end{array}$ & $\begin{array}{c}\text { Estimated } \\
\text { investments } \\
\text { (Mil. Euro) }\end{array}$ \\
\hline France & 1164 & 674 \\
\hline Germany & 1843 & 1160 \\
\hline Italy & 779 & 418 \\
\hline Netherlands & 5969 & 3285 \\
\hline Romania & 1500 & 775 \\
\hline Spain & 2820 & 1598 \\
\hline
\end{tabular}

Source: Hydrogen Europe, 2020

Romania's intention to continue using coal is contrary to the European decarbonisation targets set by the European Green Pact, regarding the accelerated rise in the price of carbon emissions and the negative effects on air quality.

This delay in eliminating the use of coal has endangered the energy company and its employees in the medium and long term. The protests of the miners in the Jiu Valley in February 2021 reflect the results of the disastrous restructuring of the '90s and recent years.

The resources allocated from the Fair Transition Fund for economic diversification and for the requalification and active inclusion of miners in the Jiu Valley will be accessible if Gorj and Hunedoara counties aim to significantly reduce greenhouse gas emissions.

\section{Conclusions}

The European Commission adopted, at the end of 2019, the European Green Pact "Green Deal", in which the European Union aims to become a world leader in combating the effects of climate change and the first continent with zero net greenhouse gas emissions in 2050. The European Green Pact leads us to a profound technological transformation. This plan has a significant impact on the European economy and society. Achieving the target will be a major challenge given that, under current energy and climate forecasts, emissions can only be reduced by $60 \%$ by 2050 . Basically, a sustainable and sustainable transformation of the economy is desired, by removing fossil fuels, promoting clean, renewable energy and developing a circular economy.

Hydrogen is essential to support the European Union's commitment to achieving climate neutrality by 2050 and to the global effort to implement the Paris Agreement.

Making these changes requires a huge need for investment. The European Commission intends to mobilize one trillion euros in this over the next decade. But in order to truly feel the benefits of such a change and to put the European Union's ambitions into practice, a significant part of the investment will need to be directed towards creating a strong and independent European industry that can deliver solutions to the challenges., generating added value in the economy. 
Rising carbon prices have led to the collapse of coal production, so that fifteen EU countries have adopted national plans for the total elimination of coal by 2050 . Coal replacement plans provide for the use of clean energy from renewable sources and natural gas. . But the states of the European Union are dependent on natural gas imports, which has led to a focus on increasing energy from renewable sources. In this context, the funds supported by the European Union are provided for hydrogen obtained from energy produced from renewable sources.

Since 2012, Romania is going through a process of modernization of the energy sector in accordance with the objectives of the "Green Deal Pact" of 2019, so, in parallel with the liberalization processes of electricity and natural gas markets, the aim was to attract investors in section.

In terms of investments in clean energy, in Romania was built the largest wind farm located on a continent, in the wind farm located in the Dobrogea area where over $3,500 \mathrm{MW}$ of clean wind energy are installed but also 1,350 MW installed in forovoltaic panels. Thus, the mandatory target that Romania had to meet by 2020 , of $24 \%$, was reached in 2011. According to the provisions of the European Energy Strategy, hydrogen is currently used in the European Union, in proportion of $2 \%$ with the premises its use up to about $24 \%$ of the European energy mix by 2050 . In these conditions, it is imperative that, in Romania, the plan of the Oltenia Energy Complex be in accordance with the provisions of the European Green Pact, Gorj and Hunedoara counties be helped to access European funds to create new jobs in the area, jobs that can , through requalification, to be also oriented towards the energy sector based on new technologies.

In order to achieve the objectives of implementing the development of hydrogen production technologies, a more efficient bureaucratic system is needed, reducing the time from approval to commissioning of the plant from 10 years to 2-3 years.

So far, forced by European targets, Romania has taken small steps to decarbonize the energy system, but the race for 2030 has not yet begun. However, we have the opportunity to adapt to the requirements of the Green Deal Pact and at the same time become a major player in the energy market. energy in the region.

\section{References:}

1. In 2015, 196 parties met under the Paris Agreement to keep global average temperature rise well below $2{ }^{\circ} \mathrm{C}$ above pre-industrial levels and to continue efforts to limit this temperature rise to $1.5^{\circ} \mathrm{C}$ above preindustrial levels.

2. The Paris Agreement is a treaty under the United Nations Framework Convention on Climate Change, which governs measures to reduce carbon dioxide emissions from 2020. The agreement was negotiated during COP-21 in Paris and was approved on December 12, 2015.

3. Communication from The Commission to The European Parliament, The European Council, The Council, The European Economic and Social Committee and The Committee of The Regions, The European Green Deal, Brussels, COM (2019) 640 final, 11.12.2019.

4. Communication from The Commission to The European Parliament, The Council, The European Economic and Social Committee and The Committee of The Regions Powering a climate-neutral economy: An EU Strategy for Energy System Integration, Brussels, COM (2020) 299 final, 8.7.2020. 
5. Communication from The Commission to The European Parliament, The Council, The European Economic and Social Committee of The Regions. An EU Strategy to harness the potential of offshore renewable energy for a climate neutral future, COM 2020741 final, Brussels, 19.11.2020.

6. The Modernization Fund is a mechanism designed to finance investments for the modernization of the energy sector in the 10 European countries with a GDP per capita lower than 60\% compared to the EU average, including Romania. The budget of the fund is variable, consisting of an allocation of $2 \%$ of the total amount of carbon certificates put up for auction in accordance with the rules and procedures set out in European regulations. In the context of rising forecasts of the price of $\mathrm{CO} 2$ certificates, we could have 6-7 billion euros available by 2030 .

7. Romgaz and OMV Petrom want to set up the first hydrogen production farm from wind sources - Niculae Havrilet,, 12.11.2020 accessed on 10.03.2021.

8. Scenario for a failed transition. Analysis of the decarbonization plan of the Oltenia Energy Complex, Greenpeace Romania, February 2021.

9. www.hidrogeeurope.eu 


\title{
CORPORATE GOVERNANCE, RESEARCH AND ECONOMIC GROWTH IN EUROPEAN COUNTRIES
}

\author{
Iulia (ELENES) PLATONA \\ Department of Marketing and International Economic Relations, Faculty of \\ Economics and Business Administration, West University of Timișoara, Timișoara, \\ România \\ iulia.elenes74@e-uvt.ro \\ iuliaplatona@gmail.com
}

\begin{abstract}
The german continental model of corporate governance is long term oriented satisfying the different interest of stakeholders-the state, the employees, the society in general and the anglo-saxon model is short term oriented to the purpose of creating value for the shareholders of the company. The research and development objective are corelated with the objective of german model of stakeholder value or of the objective of the anglo-saxon model of shareholder value. We use Eurostat data for European countries for regression analysis to find the relation between gross domestic product as measure of economic growth with the general expenditure for research and development for businness, goverment and academia. We analyse if fixed effects or random effects are more appropriate for our model. The regression analysis shows that the fixed effects model fitts better to our research model.
\end{abstract}

Keywords: corporate governance; research; economic growth

JEL Classification: F43

\section{Literature review}

Starting from the seminal thesis of Berle and Means (1932) that the only purpose of the company is to create value for its shareholders until now, there is no unitary conception regarding the definition of the term "corporate governance". The range of the term is very wide, starting from the supervision of companies and their control based on the mechanism according to which the "stakeholders" exercise control over the "insiders" (Picot 1995) and the management of the company so that their interests are protected,(John, Sembet 1998) until the analysis the interdependencies between the way this enterprise is run and the control exercised over the management and the connection of these interdependencies with the success of the enterprise from the point of view of investors. (Martens 2000).

The concept of corporate governance does not have a unitary definition because it covers a wide range of distinct economic phenomena. The term "corporate governance" has its roots in the Greek "kybernetes" and starts from the Latin "gubernator" and "Corporation" derives from the Latin "corpus". (Allain, 2002).

Feleaga (2006) makes an interesting presentation of the meaning of the term "corporate governance", which in the French academic environment, has been translated most often by corporate governance (government $d$ 'entreprise) and the 
author points out that the English word "governance" is different from the word "government", and for fundamental reasons: governance refers to a device that involves at the same time institutions, relationships, rules and behaviors, is more than the structure represented by the word government .

The translation of the term "corporate governance" must be made considering the anglo-saxon context, which refers to large listed companies, public corporations, which appeal to public savings. The central theme of corporate governance is for Hans Caspar von der Crone (2001) the regulation of the relationship between shareholders as owners on the one hand and the management of the enterprise on the other hand, which is governed by the main agent relationship.

"Corporate governance" refers to the effectiveness of the mechanisms that minimize the conflicts illustrated by the agent theory resulting from the managerial act in general, and in particular refers to legal procedures that prevent managers from expropriating minority shareholders from assets. Warncke (2005) consider that in a broader sense "corporate governance" defines the institutional and legal framework as the internal instruments of the enterprise that have an influence on the management and control of the enterprise as well as on its success. The basic pillars of corporate governance are transparency and accountability to shareholders and other interest groups affected by the company's decisions, in a word "stakeholder".

The shareholder structure and the cultural specificity led to the creation of corporate governance systems adapted to the models of the national specificity continental and Anglo-Saxon models respectively, the "outsider" type systems being specific to the Main Agent problem between owners / shareholders and managers. "Insider" or continental issue Main Agent between the dominant shareholder and the small shareholders. (Roe, (2000), Berndt (2000), Waldenberger (1999), Hobs (2001)). The Anglo-Saxon countries are characterized by highly dispersed driven structures and are characterized as "outsider" systems. In these systems the main agent problem focuses on harmonizing the interests of managers with those of small shareholders. For continental Europe, "insider" systems are specific, focusing on the main agent issue of the significant shareholder, which has a significant package of shares. (Roe (2000), Berndt (2002)). There has long been a heated debate in the economic literature on the issue of orientation towards Shareholder or Stakeholder Value. Bahnmüller and Fisecker (2003) use the WISO database to describe the most important aspects of this debate. The concept of management based on shareholder value principles requires a greater impetus to increase profitability, which results in shortening the horizon of plans made, orientation towards fast and short-term income ("Short Termism"). Managers are oriented towards satisfying the shareholders' desire for quick income

Ther german continental model of corporate governance is long term oriented satisfying the different interest of stakeholders-the state, the employees, the society in general and the anglo-saxon model is short term oriented to the purpose of creating value for the shareholders of the company. The research and development objective are corelated with the objective of german model of 
stakeholder value or of the objective of the anglo-saxon model of shareholder value.

\section{Research metholdology}

For the empirics of economic growth related to research and development we inspire ourselves from the article of (Romer, Mankiw, Weil 1992) employing a Cobb Douglas function in logarithm form for the reason to transform the relation to a linear form.

$$
\log _{e} Y=\alpha_{0}+\sum \alpha_{i} \log _{e} I_{i}
$$

Where, $Y$ is the output, I - the input vector and $\alpha_{i}-$ the estimated coefficients; $\mathrm{Y}=\mathrm{C}^{\alpha} \mathrm{M}^{1-\alpha}, \mathrm{C}$ is the capital and $\mathrm{M}-$ the labor

We use Eurostat data for European countries for regression analysis to find the relation between gross domestic product as measure of economic growth with the general expenditure for research and development for businness, goverment and academia. The dependent variable is the gross domestic product and the independent variables are general expenditures for research and development in the business sector, in the public sector and in the higher education sector.

\section{Regression output and conclusions}

We estimated the following models, using fixed effects and random effects.

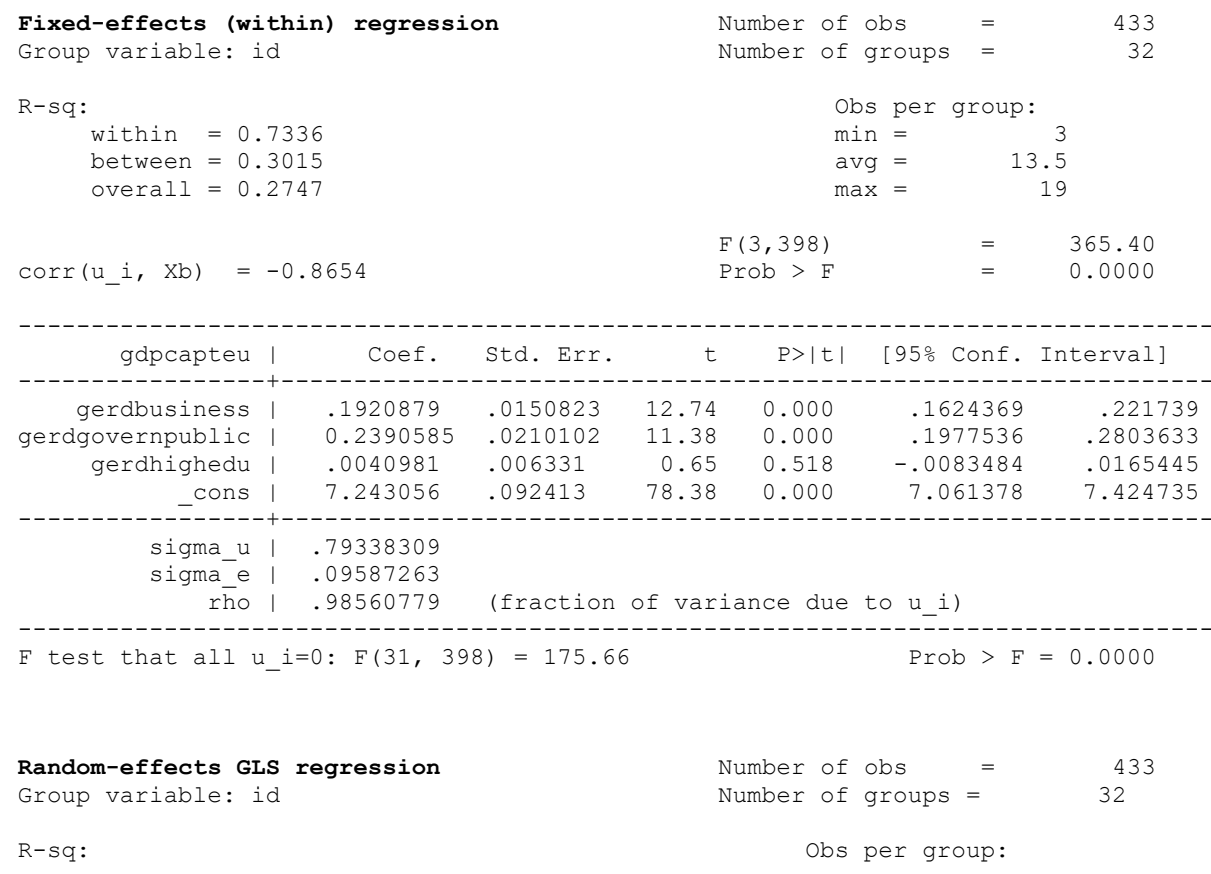




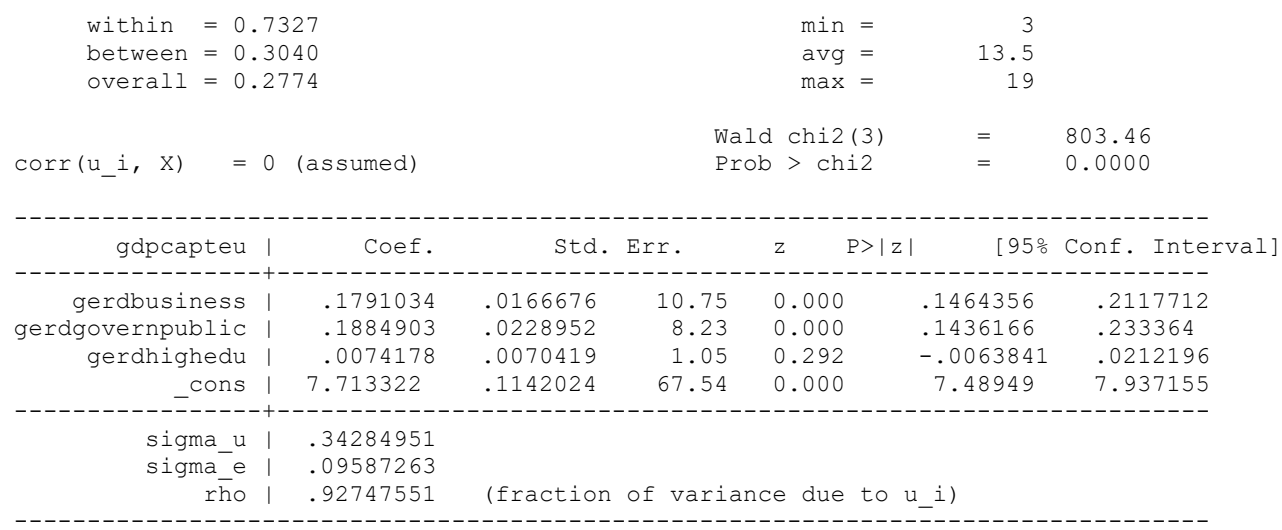

In order to select the adequate model, we performed the Hausman test, based on which we chose the model with fixed effects (Prob>chi2 $=0.0000)$

. hausman m1re mlfe

\begin{tabular}{|c|c|c|c|c|}
\hline & $\begin{array}{l}\text { (b) } \\
\text { m1re }\end{array}$ & $\begin{array}{l}\text { (B) } \\
\text { m1fe }\end{array}$ & $\begin{array}{c}(b-B) \\
\text { Difference }\end{array}$ & $\begin{array}{c}\operatorname{sqrt}\left(\text { diag }\left(V \_b-V_{-} B\right)\right) \\
\text { S.E. }\end{array}$ \\
\hline $\begin{array}{l}\text { gerdbusiness } \\
\text { gerdgovern c } \\
\text { gerdhighedu }\end{array}$ & $\begin{array}{l}.1791034 \\
.1884903 \\
.0074178\end{array}$ & $\begin{array}{l}.1920879 \\
.2390585 \\
.0040981\end{array}$ & $\begin{array}{r}-.0129845 \\
-.0505682 \\
.0033197\end{array}$ & $\begin{array}{l}.0070944 \\
.0090973 \\
.0030833\end{array}$ \\
\hline
\end{tabular}

$\mathrm{b}=$ consistent under $\mathrm{Ho}$ and $\mathrm{Ha}$; obtained from xtreg

$\mathrm{B}=$ inconsistent under $\mathrm{Ha}$, efficient under Ho; obtained from xtreg

Test: Ho: difference in coefficients not systematic

\begin{tabular}{|c|c|}
\hline $\operatorname{chi2}(3)$ & $\begin{array}{ll}= & (\mathrm{b}-\mathrm{B}))^{\prime}\left[\left(\mathrm{V}_{-} \mathrm{b}-\mathrm{V}_{-} \mathrm{B}\right)^{\wedge}(-1)\right](\mathrm{b}-\mathrm{B}) \\
= & 689.04\end{array}$ \\
\hline Prob>chi2 & 0.0000 \\
\hline
\end{tabular}

$\mathrm{R}^{2}$ also tells us the percentage of variation in $\mathrm{Y}$. in our case the GDP that is accounted for by its regression on $X$ in our case GERD business, GERD higher education, GERD Government.

In general an $\mathrm{R}^{2}$ that is close to 1 tells us that the predicted values and the actual values are close together, in contrast a low value of $\mathrm{R}^{2}$ tells us that the regression line does not fit the data well and we can clearly see a larhe amount of distance between the actual values and the predicted values. If $R^{2}$ is 1 the predicted vales fit perfectly the actual values.

The between $\mathrm{R}^{2}$ reports in what measure the variance between separate panel units my model explains for

The within $\mathrm{R}^{2}$ reports in what measure the variance within the panel units my model explains for

The overall $R^{2}$ explains the weighted average of between $R^{2}$ and overall $R^{2}$.

Performing the Hausman test we observe the probability for fixed effects is below 0.05 this means that we use fixed effects. We introduce fixed effects model because we want to control for the individual specific effects and the time specific effects of each country, because when an omitted variable is corelated with the included variables it causes bias. 


\section{References:}

1.Alain, R. (2002): Corporate Governance und Management Entlöhnung, Wirtschaftswissenschaftliches Zentrum (WWZ), Universität Basel, Abteilung Organisation, Führung und Personal, Lizentiatarbeit, eingereicht bei: Prof. Dr. Werner Müller

2. Bahnmüller, R., Fisecker, C. (2003): Dezentralisierung, Vermarktlichung und Shareholderorientierung im Personalwesen. Folgen für die Stellung und das Selbstverständnis des Personalwesens und die Interaktionsmuster mit dem Betriebsrat, FATK Forschungsinstitut für Arbeit, Technik und Kultur, an der Universität Tübingen.

3. Berndt, M, (2000): Global Differences în Corporate Governance Systems. Theory and Implicaţions for Reforms, Harvard John M. Ohlin Center for Law; Economics and Business Discussion Paper $\mathrm{Nr}$ 303,

4. Feleagă, N., Vasile, C. (2006): Guvernanţa întreprinderii între clasicism şi modernism, [Online], Available http://store.ectap.ro/articole/121.pdf

5. Hobs R. (2001): Shareholding and Corporate Governance: Theory and Evidence on Economic Performance, ESRC Centre for Business Research, University of Cambridge

6. John K., Senbet, L.W. (1998) Corporate governance and board efectiveness Journal of Banking \& Finance 22 p. $371 \pm 403$

7. Knuth, M. (1999): Managementüberwachung durch den Aufsichtsrat, Ein Beitrag zur Corporate Governance Diskussion aus agencytheoretischer Sicht, S. 1

8.Mankinw, G, Romer D, and Weil D. (1992) A contribution to the empirics of economic growth. Berkely Edu Papers

9. Roe, M, J, (2000a): Political Foundations for Separating Ownership from Corporate Control, Columbia Law and Economics Working Paper No 155

10. Roe, M. (2000b): Political Precondiţions to Separating Ownership From Corporate Control, Columbia Law Schoo The Center for Law and Economic Working Paper, No 155, Online available: http://papers.ssrn.com/paper.taf?abstract_id=165143, Stand 11.06.2005

11. Waldenberger F., (1999): Die Marktkontrolle im deutschen und japanischen Modell der Unternehmenserfassung, Japan Zentrum, Ludwig MaximiliansUniversität München, Working Paper

12. Warncke, M. (2005): Prüfungsausschuss und Corporate Governance Einrichtung, Organization und Überwachungsaufgabe, Erich Schmidt Verlag, 13. Von der Crone, H., G. (2001): Corporate Governance und Reputation Vom Nutzen eines guten Rufes für Manager und Unternehmen, Fokus der Wirtschaft, Neue Bürcher Zeitung Nr. 22 


\title{
ROMANIA: UNIVERSITY GRADUATES BETWEEN EMPLOYMENT AND UNEMPLOYMENT
}

\author{
Eva SZABO \\ Doctoral School of Economic Sciences, Faculty of Economic Sciences, \\ University of Oradea, Oradea, Romania \\ szaboeva2021@yahoo.com
}

\begin{abstract}
Over the years, European countries, including Romania, have tried to reduce unemployment and increase the number of university graduates. The quality and attractiveness of higher education play an important role because a solid university education can be the path to a successful career and a secure financial life. In the last decade, was intensified efforts to convince Romanian people to pursue a specialization at least to the bachelor's level. Except 2005, the number of university graduate women is higher than men, which shows their confidence in university education programs. The counties of Bucharest, Iași, ClujNapoca, Timiș and Constanța between 1996-2018 have the highest number of university graduates, and these counties also host the best universities in Romania. The quality of higher education must be in line with the personal aspirations of students and national targets. The attractiveness of Romanian university programs is demonstrated by the growing number of foreign students, especially from Arab countries and Africa. But a university education is just one piece of the puzzle, it is also vital to integrate graduates into the work field. Unemployment is one of the vulnerabilities that significantly affects young people. In 24 years, the number of unemployed aged between 30-39 years with a university degree was 98.796, a proportion of 36\% - 64\% in favour of women (63.078). Women still face great difficulty in finding a job even though they have a university degree. The lowest percentage of unemployed with a university degree in the number of university graduates were registered in 1995 (1.15\%) and the highest in 2010 (6.06\%). The lowest number of unemployed with university degree among the regions was registered in the North-West (68.989).
\end{abstract}

Keywords: unemployment; university education; university graduates

JEL Classification: I21; I23; J60

\section{Introduction}

The unemployment rate and the number of graduates with higher education are topics that represent interest for both Romania and the European Union. The specialized literature offers us analyses such as the dynamics of the number of graduates of Romanian universities in the period 2005-2010 (Popovici, 2011); youth unemployment rate between 2009 - 2011 in the European Union and implicitly in Romania concluding that young people with university education in Romania have more difficulties in finding a job than in other Member States (Boajă, 2011); the risk of exclusion from the labour market of young people aged between 15 and 24 in Bihor County (Chipea, 2011); the divergence between the higher 
education system and the Romanian labour market between 2009 - 2010 (Stanciu, Banciu, 2012); the causes of unemployment among young people in Romania and the measures that have been taken to combat them. (Barbulescu, 2012); the loss of a highly qualified labour force and the associated loss of economic potential, the motivation of migration of young Romanians based on a survey conducted in MayJune 2012 among graduates of higher education (Vasile, 2012); the dynamics of economic growth taking into account indicators such as the number of students, unemployment, investments in research and development, population and migration in seven Romanian cities, namely: Brașov, Cluj, Constanța, Craiova, lași, Ploiești and Timișoara in the period 1996-2010. (Berea et al., 2014); regional macroeconomic analyzes on the number of unemployed with higher education and the difficulties in integrating graduates on the labour market in Romania. (Simionescu, Naroș, 2019)

\section{Methodology}

The purpose of this article is to identify the relationship between higher education graduates and the unemployment rate. Studying the evolution of unemployment, I propose to highlight the fact that in the regions where the number of graduates with higher education is significant, the unemployment is lower. Even if a massive number of college graduates can generate the phenomenon of over-qualification, which is often a barrier to employment both from the perspective of the employer who expects a staff turnover and high salary demands and from the perspective of employees who face a feeling of frustration, however, this phenomenon is smaller in Romania. Young Romanians more easily accept a job below the level of qualification, either because their financial situation is precarious or because they hope that, once employed, they can access more suitable jobs for their qualification. Research methods used in this article are techniques such as scientific observation, documentary analysis, data analysis and conclusions. Data on the number of the unemployed, unemployment rate and the number of graduates with higher education in Romania between 1996-2020 were collected from the website of the National Institute of Statistics.

\section{The number of university graduates}

Education is important for everybody. A solid university education can be the path to a successful career and a secure financial situation. In Romania between $1996-$ 2018, a total of 14.302 .557 persons obtained a university degree, with 404.875 more women than men. The highest number of 784.958 graduates (365.564 male and 419.394 female) was registered in 2007 . Unfortunately, at the time of writing the article, we still do not have definite data for 2019 and 2020. As we can see from figure 1, years in which the number of graduates exceeded the threshold of 700.000 were 2004 (722.635), 2007 (784.958), 2008 (739.432) and 2009 (704.172). 


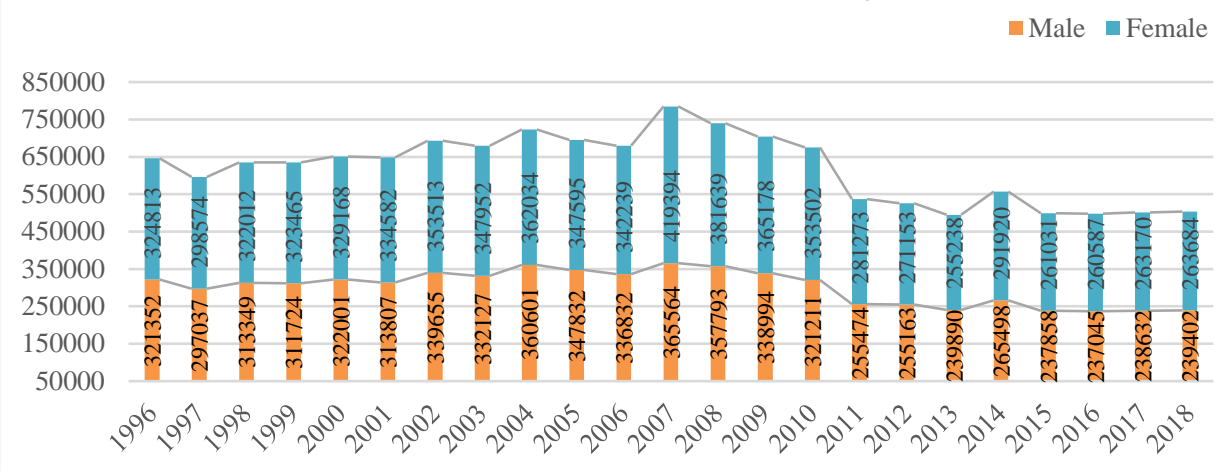

Figure 1: Male and female graduates of university education in Romania between $1996-2018$

Source: created by the author, based on calculations performed on INS data

The decrease in the population's income during the crisis has led many potential students to reconsider their professional development. Except for 2015, the number of female graduates is higher than men, which shows that they give more importance to a university degree than men. Years between 2003 - 2010 was beneficial for Romania because a multitude of foreign students came to obtain a diploma at Romanian Universities: 2003 (1049 male, 862 female); 2004 (980 m., 732 f.); 2005 (862 m., 817 f.); 2006 (669 m., 807 f.); 2007 (1072 m., 1481 f.); 2008 (990 m., 948 f.); 2009 (948 m., 962 f.) and 2010 (1.115 m., 1.040 f.). But overall, more male than female foreign students accumulate knowledge and implicitly obtain a certificate at the universities. The programs that manage to attract large numbers of foreign students are within the Faculties of Medicine, the Faculty of Architecture and the Faculty of Engineering. The specializations of these Faculties are still men dominated. For example, the Polytechnic University of Bucharest trains an average of 1.000 foreign students, most from Arab countries.

The situation by counties between 1996 - 2018 is showing that the highest number of graduates were registered in Bucharest (1.993.282 graduates), the best year being 2007 (140.084 graduates) and 2013 the unfavourable with just 60.866 graduates. This is not a surprise because we are talking about the capital which over the years had an average population of 2.465.328. Most of those who come for studies stay in the city because the possibility of finding a well-paid job is high, $25 \%$ above the national average.

The second place is occupied by lași county with some 712.058 graduates, on average 30.959 graduates. The possibilities offered by the city of lasi is attractive for the inhabitants of the North-East regions. Those in the city of Iași earn on average $15 \%$ more than the national average. Due to the proximity of the Republic of Moldova, on average 60.000 citizens (60\% students) from the Republic of Moldova residing in lasi County.

Cluj county is in third place with 612.544 graduates, the lowest number obtained in 2013 (22.076 graduates) and the highest in 2007 (34.666 graduates). There are 11 
universities in Cluj-Napoca, six public and five private. We must not forget that the universities in Cluj-Napoca offer lines of study in Romanian, Hungarian, German, English and French. Only at the University of Medicine and Pharmacy "luliu Hațieganu", annually come 600 foreign students. In fourth and fifth place are the Timiș counties (533.783 graduates) and Constanța (520.482 graduates) who manage to obtain over 500.000 graduates in 22 years. We must not forget that based on World University Rankings the best universities in Romania are BabeşBolyai University located in Cluj - Napoca, Alexandru Ioan Cuza University located in lași, the University of Bucharest, Grigore T. Popa University of Medicine and Pharmacy located in lași, and the West University of Timişoara. (World University Rankings 2016, 2017, 2018) The lowest value among the counties was registered in Giurgiu (111.968 graduates), with the highest value in 2004 (5.948 graduates) and the lowest in 2018 (3.864 graduates).

The quality of higher education must be in line with the personal aspirations of students and national targets. Romanian universities are constantly trying to align with European and international requirements and expectations. However, the number of registered unemployed entitled to money with a university degree between 1996 - 2018 is significant. The highest value was recorded in 2009 (41.616 people), the lowest in 2018 (6.982 people), and since 2011 is taking place a steady decline.

\section{Unemployment evolution in Romania}

The highest percentage of the unemployment rate was registered in $1999(11.8 \%)$ and the lowest in 2019 (2.9\%). The North-West region (counties: Bihor, BistrițaNăsăud, Cluj, Maramureș, Satu Mare, and Sălaj) manage to record the highest value of the unemployment rate in 1999 (10\%) and the lowest in 2019 (2\%). The region focusing on job creation and employment. Bihor county manages to register the maximum unemployment rate in 1999 (6\%) with $5.8 \%$ less than the national rate and the minimum rate in 2019 (1.4\%) with 1.5\% less than the national rate. In the Center region (counties: Alba, Brașov, Covasna, Harghita, Mureș, and Sibiu) the highest value was registered in 1999 (11\%) and the lowest in 2019 (2.6\%). The region values are above the national values from $2002(9 \%$, by $0.6 \%$ more than the national value) until 2014 (5.5\%, by $0.1 \%$ more than the national value). Mureș and Brașov's counties register values lower than the national rate in 13 and 14 years. In the North-East region (counties: Bacău, Botoșani, lași, Neamț, Suceava, and Vaslui) the highest value is registered in 1999 (14.9\%) and the lowest in 2019 (4.3\%).

The general values of the regions are above the national values in every year. In the South-East region (counties: Brăila, Buzău, Constanța, Galați, Tulcea, and Vrancea) the highest value of the unemployment rate is registered in 1999 (13.2\%) and the lowest in 2019 (4.2\%). The general values of the regions are above the national values in every year. In the South - Muntenia region (counties: Argeș, Călărași, Dâmbovița, Giurgiu, lalomița, Prahova, and Teleorman) the highest value is registered in 1999 (11.8\%) and the lowest in 2019 (3.4\%). The general values of the regions are above the national values since 2001 . The Bucharest - Ilfov region (composed of Bucharest and Ilfov) registered the highest value of the unemployment rate in 1999 (6.9\%, 4.9\% below the national rate) and the lowest in $2019(1.1 \%, 1.8 \%$ below the national rate). The general values of the regions are 
below the national values in each year from 1996 to 2020. The South-West Oltenia region (counties: Dolj, Gorj, Mehedinți, Olt, and Vâlcea) registered the highest value in $1999(11.7 \%)$ and the lowest in $2007(5.1 \%)$. The general values of the region are above the national values except for $1996(6.5 \%, 0.1 \%$ less than the national level) and 1999 (11.7\%, 0.1\% less than the national level). In the Western region (counties: Arad, Caraș - Severin, Hunedoara, și Timiș) the highest value of unemployment rate was registered in 1999 (12.6\%) and the lowest in $2019(2.6 \%)$. The region values are above the national values in three years $1998(10,6 \%$, by $0.2 \%$ more than the national value) $1999(12.6 \%$, by $0.8 \%$ more than the national value) and 200 (9.5\%, by $0.7 \%$ more than the national value). Between 1996-2018, neither Arad county nor Timișoara county registered values above the national unemployment rate.

\subsection{Unemployed with university degree}

Those who complete a university specialization hope to find quick a stable and well-paid job in their field. However, a significant number of graduates are unemployed in Romania. The highest number of unemployed people with a university degree was registered in 2009 (41.616 people) and the lowest in 2019 (6.887 people). The trend from 2009 is declining, which is a positive evolution. The general number of unemployed women with a university degree is higher than that of men, between 1996 - 2019 were a total of 266.359 (58\%) women and only $189.962(42 \%)$ men. The lowest percentage of unemployed with a university degree in the number of university graduates were registered in $1995(1.15 \%)$ and the highest in 2010 (6.06\%), as we can see in figure 2.

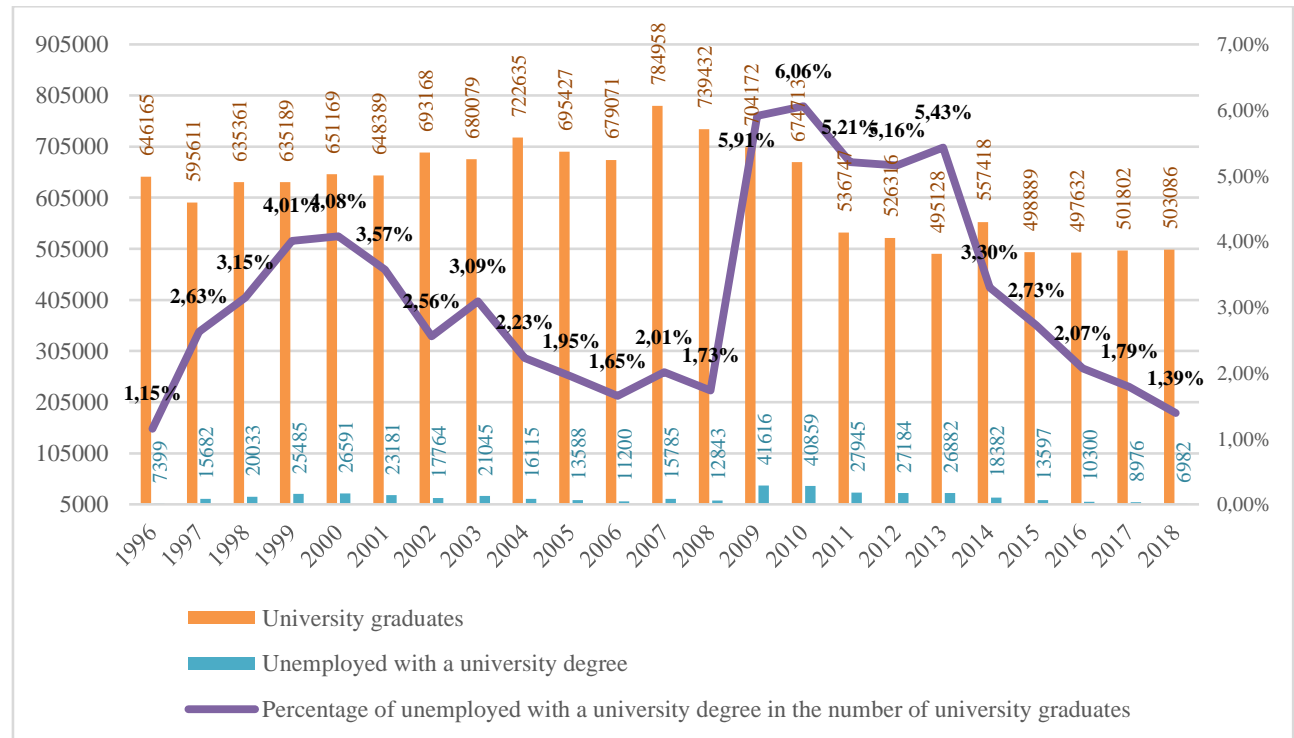

Figure 2: Percentage of unemployed with a university degree in the number of university graduates between 1996 - 2018

Source: created by the author, based on calculations performed on INS data 
Unemployment is one of the vulnerabilities that significantly affects young people. The number of unemployed aged under 25 years with a university degree between 1996-2019 was 115.296, 40.094 men, and 75.202 women. The highest number of women was reached in 2009 (7.308) and the lowest in 2018 (403). Those aged between 25-29 years are in fourth place regarding the unemployed with a university diploma, more precisely 86.973 people, of which 53.901 (62\%) women and $33.072(38 \%)$ men.

In 24 years, the number of unemployed aged between 30-39 years with a university degree was 98.796 , a proportion of $36 \%-64 \%$ in favour of women (63.078). Among those aged between 40-49 years, we are talking about some 90.406 unemployed with a university degree, 10.320 more women than men (40.043). In the category of those aged between 50-55 years, some 40.754 unemployed with university training were registered. It is the age category in which the number of men (22.251) is higher than that of women (18.503). Through those over 55 years, we are talking about some 24.096 unemployed people with a university degree, 5.312 women and more than three times as many men (18.784). Between 1996 - 2019, the North-West region registered 68.989 unemployed people with a university degree. The lowest value among the regions. The situation in the counties that forming the region was the following: Bihor 14.848 unemployed, Bistrița-Năsăud 6.992, Cluj 21.918, Maramureș 13.265, Satu Mare 5.099, and Sălaj 6.867. The Central region record some 74.650 unemployed, the highest number in Brașov county (22.484) and the lowest in Covasna county (3.969).

The North-East region has the highest value among the regions, 87.290. On the first place is lași county 19.171, on the second place Bacău county 17.257, on the third place Suceava county 16.575 , on the fourth place Neamt county 15.291 , on the fifth place Botoșani county 10.434 , and on the last place with the lowest value Vaslui county 8.562. 69.352 unemployed people with university training were registered in the South-East region, the highest values in Constanța (19.069) and Galați counties (19.058), and the lowest number in Tulcea county (4.039).

The counties of Sud-Muntenia regions over the years record some 77.532 unemployed with a university degree divided as follows: Arges county $23 \%$, Călărași county $5 \%$, Dâmbovița county $16 \%$, Giurgiu county $4 \%$, lalomița county $6 \%$, Prahova county $31 \%$, Teleorman county $15 \%$. The Bucharest - Ilfov region report the second-highest value among the regions 84.948. Adding the number of unemployed in the five counties of the South-West Oltenia region, we receive the result of 84.821 people between $1996-2019$, divided thus: Dolj $33 \%$, Gorj $23 \%$, Mehedinți $11 \%$, Olt $14 \%$ and Vâlcea $19 \%$. The number of unemployed people with higher education in the West region reaches 69.204. Most of them are registered in Hunedoara (24.842) and Timiș (21.940) counties.

\section{Conclusions}

Romanians believe in the importance of education, nothing shows this better than $14,302,557$ university diplomas issued in the period 1996-2018. Out of the desire to attract as many students as possible, universities are constantly improving the educational offer. The effort made over the years has been rewarded with the fact that since 2016 five universities in Romania are listed in the world university ranking. Most graduates are in the big cities where a famous university operates, 
and most of them find a job in these cities after graduation. Bucharest, Constanța, Cluj-Napoca, lași and Timișoara are the cities with the best values. At the opposite pole are the counties like Giurgiu, Covasna and Tulcea, which in the absence of famous universities fail to attract a significant number of students and future employees.

In the last fifteen years, there has been a gradual change, so that the number of female graduates has become higher than the number of male graduates, as women see in university education the path to a well-paid job. However, women with a higher education degree find it more difficult to find a job than men. More and more foreign students choose to study in Romania because tuition fees are lower than in other countries, and courses and teaching are of European level.

\section{References}

1. Barbulescu A.P. (2012), Youth unemployment in Romania and measures to combat it, in Procedia Economics and Finance, No.3, pp. 1196-1201

2. Boajă D. M. (2011), Youth unemployment rate In European Union. Regional approach-Romania, in Annals of the University of Craiova, Economics Series, Vol.1, 39, pp. 1-6

3. Berea C. B., Otoiub A., Bucerzan P. I. (2014), Determinants of economic growth in cities acting as growth poles in regions from Romania, in Procedia Economics and Finance, Vol. 10, pp. 357-365

4. Chipea F. (2011), Riscuri de excluziune pe piaţa muncii din România a grupului de tineri de 15-24 de ani, in Sociologie Românească, Vol.9, No. 4, pp. 45-67

5. Manea, N. P. (2014), The analysis of perception of master students regarding the quality of educational services of Bucharest universities, in Procedia Economics and Finance, 15, pp.746-751

6. Popovici A. (2011), The dynamics of the Romanian universities graduates number in the 2005-2010 period, in Annals of Faculty of Economics, Vol.1, No.2, pp. 193-199

7. Simionescu M., Naroș M. S (2019), The Unemployment of Highly Educated People in Romania. A Panel VAR Approach, in Studia Universitatis "Vasile Goldiș" Arad, Economics Series, Vol.29, No.3, pp. 20-37

8. Stanciu, S., Banciu, V (2012), Quality of higher education in Romania: are graduates prepared for the labour market? in Procedia-Social and Behavioral Sciences, 69, pp. 821-827

9. Vasile V. (2012), Crisis impact on employment and mobility model of the Romanian university graduates, in Procedia Economics and Finance, 3, pp. 315324

10. Instituțul Național de Statistică (INS) - Online: https://insse.ro/cms/ [Accessed: 16.04.2021]

11. World University Rankings 2016, 2017, 2018 - Online: https://www.timeshighereducation.com/world-university-rankings, [Accessed: 16.04.2021] 


\title{
TRENDS AND PERSPECTIVES ON ENTREPRENEURIAL EDUCATION IN ROMANIA AND THE EU
}

\author{
Casiana ILLE \\ Doctoral School of Economics, Faculty of Economic Sciences, University of \\ Oradea, Oradea, Romania \\ casiana.ille@gmail.com
}

\begin{abstract}
Entrepreneurial education (EE) has been a blossoming subject over the past years especially due to its importance and relevance to the economy both regionally and globally. The academic world still needs to conduct sustained research on the topic in order to fully throw a light on the importance that EE has on the society and its decisive role in transforming it. Economic, financial and EE has gained new dimensions lately, with an important raise of the focus both in theory and practice. This research studies the need for EE and financial literacy. In Europe, recent surveys show that young people acknowledge their lack of knowledge regarding entrepreneurship and state that schools should help them have an entrepreneurial mindset and know more about finances. In today's dynamic environment and especially after the covid-19 crisis, the need on the workplace has changed and the skills that can be acquired through entrepreneurship and financial training and acknowledged by scholars, population, businesspeople and media as vital for the way things work in today's economy. Teaching individuals how to think entrepreneurial becomes even more important in times of crises, or in a dynamic environment, where creativity, adaptability and innovation are key for survival. Key trends and developments are analyzed and the actors involved in shaping and raising awareness regarding financial illiteracy and the need for $E E$.

This paper combines literature review methods and it also develops a conceptual debate around the research conducted in the field of EE with the purpose of contouring a consolidated methodological approach based on the so-far experience linked with today's challenges. Due to the fact that EE is now one of the fastest growing research subjects in the world, an important emphasis has to be placed on the comprehension of the connection between business management practices and the academic theory, as research has previously indicated. The outcome of this analysis aims to throw more light to understanding the evolution EE has had and provides an overview of the relevant trends in the field.
\end{abstract}

Keywords: education; entrepreneurship.

JEL Classification: I25; L26.

\section{Introduction}

The existing literature on $\mathrm{EE}(\mathrm{EE})$ is rich and complex and it addresses the nature, motivations and predictors, entrepreneurial traits, influence of the economic environment, policies to foster and enhance its effectiveness etc. (Badulescu \& Badulescu, 2014) and the information regarding entrepreneurship is consistent, 
diverse but unsystematic and contradictory even if it is referring to the entrepreneurial spirit, the motivations, specificities determined by gender, education, economic environment or personality (Badulescu \& Badulescu, 2013).

Studies that have implied seemingly experimental methods have acknowledged that EE will reveal shy effects or no effects on short-term results such as entrepreneurial intentions (Oosterbeek, et al., 2010) but might enhance noncognitive competences that are significant for entrepreneurship (Rosendahl Huber, et al., 2014). Even if empiric studies and analyses have found weak or no link between EE and the motivation of starting a business, it has been proved that the link between entrepreneurial performance and EE is quite important and that there is a positive relation between the two in terms of income, firm survival or growth and profits (van der Sluis, et al., 2008), (Unger, et al., 2011) (Van Praag, et al., 2013). The so-far findings displayed by the literature in regards to the effectiveness of $\mathrm{EE}$ leads to the conclusion that the success of EE approach consists of the theoretical relevance of practical curriculum (Elert, et al., 2015) because successful entrepreneurship is rather related to being faced with previous entrepreneurial experience than formal education (Dencker, et al., 2009), (Folta, et al., 2006), (McNally, et al., 2013), (Toft-Kehler, et al., 2014) and the acquisition and enhancement of the skills desired in entrepreneurship are more important and relevant for success rather than a degree (Lazear, 2004), (Wagner, 2003). The majority of the studies sought to measure the effect of EE on the development of entrepreneurial-enhancing assets such as knowledge, skills, intentions to launch a business or general positive perception regarding entrepreneurship mostly because these outcomes can be measured as indicators right after the completion of the educational program (Elert, et al., 2015).

$\mathrm{EE}$ is an important tool to be used in order to enhance regional development and it is important that the concerned actors cooperate toward reaching the same goal that benefits and strengthen the entrepreneurial intention of the society (Anderson, et al., 2017).

\section{Key trends and developments in European EE}

As EE has been historically an important engine for economic growth in the United States (OECD, 2008), Europe has the opportunity to learn from this experience and implement the appropriate measures to the old continent. A first important issue to be observed is that in the US, most of the leading 100 businesses are only 20-30 years old, while in Europe many of ones included in the top have been here for over 100 years and as Birch states in 2002, it is important for the vitality of an economy that old companies evolve or are replaced by more dynamic firms that renew the economy (Birch, 2002). In Europe, the focus on entrepreneurship only started to grow in the mid-1990s, while in the US the direction was given more than 50 years earlier (Twaalfhoven \& Wilson, 2004). An important difference between EE in Europe versus EE in the US is the definition and focus of entrepreneurship; in the US the focus is put on the growth-oriented companies, while in Europe entrepreneurship refers to nurturing SMEs which hold an important role in the European economy and there is even a kind of legacy as far as SMEs are concerned, most of them are family-owned. Wilson (2002) argues that just because a business is large, that doesn't make it less entrepreneurial 
than a smaller one and that studies after studies have shown that SMEs are not growth-oriented (OECD, 2008).

While SMEs play an important role in the European economy (99\%) there are 25 million European SMEs, one of their main challenges is that they still encounter several growth-stagnant issues. Only 600.000 SMEs export goods outside of the European Union, less than 2,5\% (European Commission, 2020). All companies have to be supported and encouraged even though the ones with the most impact on dynamism, innovation and competitivity are those that are growth-oriented. The issues identified almost ten years ago by the European Commission still persist nowadays and they are: the skills of young people, low exposure to entrepreneurship and the lack of role models, high administrative and financial complexity, the low focus on growth entrepreneurship and expansion and increased focus on the other hand on small and middle-sized enterprises (SMEs) (OECD, 2008). The focus has to shift from the old traditional educational purpose, to create good employees, to equipping the young people with an entrepreneurial mindset that will enable individuals to succeed in this dynamic environment and economies to nurture innovation, competitivity, and other entrepreneurial-driven tools for economic and societal development (OECD, 2008).

Recent studies still illustrate the same persisting issues that were identified ten years ago. Since the 2008 crisis, unemployment and financial insecurity continued to expand and when the economy was starting to be back on track, the global 2019 pandemic reset the status-quo and in Europe, unemployment rate was raised from 6.4\% in March 2020 to 8.1\% in March 2021 (Eurostat, 2021). As a solution to these issues, policy makers, academics and media stress out the role and importance of financial and EE into all levels of education. Ransome (2014) argues that "The working world has changed. A university education used to guarantee a long-term job in a large company. Not anymore. Today, large companies are disappearing. Employment opportunities are short-term. Most people in tomorrow's working world will find employment filling niche gaps, providing goods and services. People who are unprepared for that reality will be unable to provide for themselves. They will need to think like entrepreneurs" (Ransome, 2014).

The policy makers, theoreticians and others that support the implementation of financial and EE for everyone argue that this training would benefit in particular the individuals living in low-income communities due to the fact that this would secure and empower both the individuals and the communities financially (Arthur, et al., 2018). The literature regarding EE has exponentially grown in the past decades, but even so most of the research is directed towards business activities rather than educational pursuits (Ratten \& Jones, 2021) and this limits its applicability to other different contexts (Bechard \& Gregoire, 2002). Due to the fact that entrepreneurship should be taught in a practical way, educators should use innovative teaching techniques such as virtual reality or gaming, as Ratten \& Jones (2021) suggest.

Teaching entrepreneurship becomes even more important in times of crisis when special skills and attitudes are required in order to survive. The covid-19 crisis determined business ventures and business people that gathered to find solutions and EE is now needed more than ever due to its approach regarding creativity and positive thinking (Kraus, et al., 2020); entrepreneurship is needed in the society due to its role in creating societal development and keeping peace and its 
approach has to change now after this global crisis to a direction that takes into account the latest developments in the social and economic environment, the crisis management aspect and digital transformation in EE (Ratten \& Jones, 2021).

Financial education (FE) and economic education have been seen by many as a part of the EE and it does not only imply handing over financial information and knowledge, but also, developing better financial behavior and attitudes. A fundamental indicator of an individual's ability to take the most appropriate financial decision is the level of financial literacy. Nowadays, the focus that has been shifting from the traditional understanding of finance toward financial innovation, as the European Banking Authority (EBA) FE Report 2019-2020 has shown, setting a roadmap to digital financial literacy, crypto assets, cybersecurity and disclosure to customers via digital means. With more FinTech services, businesses improve their interaction with the customers with digitalized services that compete with the traditional finance methods. Financial empowerment is an essential tool for acquiring financial stability and in the European region (EBA Consumer Trends, 2019, fig. 1, p. 13). In order to increase financial literacy, schools, workplaces, NGOs, training firms, governments have various opportunities to shape the financial development of future consumers, citizens and employees because this will determine the overall financial development. display an effective FE, the initiatives taken have to be large and scalable (Lusardi, 2019). Latest studies suggest that an integrated approach regarding FE from a behavioral economics point of view could be a more appropriate approach, due to the fact that people's financial behavior (e.g.: excessive borrowing) is determined by multiple factors and only by researching those psychological, social, cultural aspects and others, the complexity of the issue can be understood and the behavioral biases taken into account, because behavioral sciences argue that being informed does not mean necessarily that individuals will make informed choices but on the contrary, consumer behaviors are sometimes incoherent and irrational (de Meza, et al., 2008), (Erta, et al., 2013). School-based education has an important role and can be transformational for young people (Lusardi, 2019) and well-planned education programs together with teacher education and high school FE requirements are linked to higher credit scores among young adults in the USA (Urban, et al., 2020) for OECD's Program for International Student Assessment (PISA). The latest Report shows that between 2012 and 2018 the mean performance in financial literacy did not change significantly, but there has been a 20 score points raise between 2015 and 2018 (from 476 to 496 points) but the highest level of proficiency in financial literacy, level 5 was still only attained by $10 \%$ of the students across OECD countries (OECD, 2020). The comparison between 2012 and 2018 shows significant changes only in the case of two countries out of the 9 with data from both years: Estonia, where the mean performance was improved by 18 score points and Australia, where it was lowered by 15 score points (OECD, 2020). The need of FE in college is also an important aspect not only for future entrepreneurs or managers that need to manage their enterprises' finance but also for individuals that need an increasingly complex knowledge to manage their own finances over the lifetime. Clark et al (2017) demonstrates that FE can be also delivered in the workplace, conducting a study regarding a targeted adult financial training program in 2013 with the employees of the US Federal Reserve System. The study concluded that the training led to 
significant changes in the financial planning and decision-making of the employees regarding retirement planning behavior and investment portfolios (Clark, et al., 2017). With regards to the delivery methods for FE targeting adults, it has been demonstrated that video formats have a higher impact than narration on shaping the financial behavior (Heinberg, et al., 2014). Training providing companies play an important role in disseminating financial knowledge and the role of private companies in mitigating financial literacy should be explored more. Due to the previously stated issue of financial illiteracy, FE should be also provided in the community, targeted to specific groups. There are numerous ways and places to creatively display FE and a contemporaneous example is given by the International Federation of Finance Museums (IFFM) that developed a framework for cooperation between museums to develop and implement innovative ideas to promote financial literacy globally (IFFM, 2021). Through initiatives like the these, museums engage old and young people in pursuing financial literacy.

Through their platforms and agendas, international organizations promote a standardization that can undermine states' authority and autonomy in setting targets and own local indicators (Rinne, 2008). The OECD Learning Compass 2030 incorporates a great deal of recommendations toward an interdisciplinary approach throughout different domains and emphasizes the inter-relatedness of knowledge, skills, attitudes and values that enable fair and sustainable economies with the need of creativity and innovation for the people to succeed in today's economic environment where non-routine cognitive skills such as creativity, social and emotional skills are vital (OECD, 2018). The emerging role of private actors and NGOs is not only shifting power, but also engaging a different discourse with regards to $\mathrm{EE}$. One of the most prominent international organizations that fosters EE is Junior Achievement, a non-profit (Elert, et al., 2015).

National states also play an important role in the development of entrepreneurship and financial literacy, yet their role is insufficiently explored in practice. The EU reports suggest that governments invest inadequately in their human resource and that they do not contribute enough in promoting EU's competitiveness (European Commission, 2012, p. 4). A year later, the European Commission releases a report that compares the top policies among countries in the EU regarding EE and the contributions of the member states towards EE, coming from different ministries (European Commission, 2013). The report highlights Denmark as the best example of a coherent policy with four ministries working together through a partnership managed by a private organization (Amiel, et al., 2021). This approach of "shaming" the under-performant European states with regards to EE involvement can be constructive, creating a certain competition among member states that could result in better defining, implementing and measuring EE.

\section{Entrepreneurship and FE in Romania}

Research has shown that participation in EE programs raises the probability of engaging in entrepreneurial activities by $35 \%$ on average a total of which 7 percentual points come only from the improved self-perceptions regarding their entrepreneurial skills by the participants (European Commission, 2019). In the EU is optional and only a handful of countries have made it compulsory. "On average, 
EU countries spend about one third of their public expenditure for education on pre-primary and primary education; $41 \%$ on secondary education; and $15 \%$ on tertiary education. Looking at different education sectors, real expenditure on secondary and post-secondary education decreased $(-1.3 \%$, between 2016 and 2017) and increased in pre-primary and primary education $(+1.4 \%)$, as well as tertiary education (+1.7\%)" (European Commission, 2019, p. 17). As far as Romania is concerned, the forementioned Report states that "public spending on education is low in EU comparison, while the sector's investment needs are high" (European Commission, 2019, p. 19). The recommendations are that additional funding is desirable and also better support for teachers to raise the quality of education through sustained professional development. As far as adult learning is concerned, the proportion is still low despite the demand for upskilling and reskilling.

Data included in the last Global Entrepreneurship Monitor (GEM) Report for Romania show that more than $42 \%$ of the established business owners have at least post-secondary education and more than half of the intentional entrepreneurs have a secondary degree. Young entrepreneurs therefore are inclined toward obtaining higher education in Romania, just like the established business owners and the higher rates of entrepreneurs that have graduate experience are among the young entrepreneurs. The National Experts Survey (NES) is a part of the Global Entrepreneurship Monitor (GEM) methodology and the main purpose of the survey is to assess the national context in which businesses start and operate. It assesses various entrepreneurial framework conditions and other topics related to entrepreneurship that help with a better understanding of business' creation and

growth. Due to the lack of harmonized national measures, NES is the only international comparable data that specifically addresses the environmental influence factors for businesses performance and it focuses solely on entrepreneurial framework conditions instead on general economic factors (EFC). Data collected from national experts selected on a basis of reputation and experience is encompassed on a Likert scale, where 1 means completely false and 5, 7 or 9 means completely true, according to the expert. The scoring scales have been extended to 9 points since 2015, but it started with a 1-5 scale that is still kept for comparability reasons. The questions are regarding entrepreneurial finance, government policy, government entrepreneurship programs, EE, R\&D transfer, commercial and legal infrastructure, entry regulations, physical infrastructure and cultural and social norms. With regards to EE in Romania, according to national experts, "the EE in primary and secondary school is ranked lower than in postsecondary, vocational, professional, college and university education in all analyzed countries from the efficiency-driven economies from the European Union in 2014" (Dezsi-Benyovski, et al., 2014, p. 41). The highest value given by national experts for the Romanian EE is for the question regarding if "Colleges and universities provide good and adequate preparation for starting up and growing new firms" showing relatively high level of confidence with regards to the ability of the Romanian universities to prepare young people to start and grow new companies, the highest score compared to the other countries included in the study, followed by Lithuania, while the lowest score was given for the Croatian colleges and universities. Even if compared to the other countries included in the study, Romanian EE is scored slightly higher, the rating is still not satisfying and 
display an important need for enhancing the quality of the EE provided at all levels. The need for raising the level and quality of the entrepreneurial and FE is not only in the hands of the public institutions The role of the society and culture in fostering an entrepreneurial mindset is an important indicator of the entrepreneurship levels in a certain country but it can be viewed also as an indicator of the level of EE provided. As far as cultural and social norms in the view of national experts are concerned, the summary of the study shows that Romania is not as supportive as a society for their entrepreneurs compared to Lithuania or Poland, but still shows more support than Hungary or Poland (GEM, 2014). The highest score was obtained at the following statement: "The national culture encourages creativity and innovativeness" (2.78); while the lowest when the issue in question was whether "The national culture encourages entrepreneurial risk-taking" (2.29). The statements were rated on a scale from 1-5 with 1 meaning "totally agree" and 5 "totally disagree". In order to raise awareness regarding the essential role and the positive effects of entrepreneurship on the societal welfare, EE plays a major role in modelling a society that welcomes and supports entrepreneurship.

While formal education plays a major role in equipping young people with entrepreneurial skills, there are non-governmental actors such as non-profit organizations like Junior Achievement Romania or Erasmus for Entrepreneurs, that play an important role EE and FE in partnership with the public educational system.

When it comes to financial literacy, the numbers are not optimistic, as a 2020 OECD report shows after a survey conducted between 2019-2020 with the purpose of assessing financial literacy. 26 countries were included in the study and 125.787 adults were interviewed. The results represent the sum of three elements (OECD, 2020): 1. Financial knowledge score (takes the range 0 to 7); Financial behavior score (takes the range 0 to 9); 3. Financial attitude score (takes the range 1 to 5 ).

The results show the scores out of the total of 21 points and the average scores are 12.7 for all countries and 13 for OECD members. Romania (11.2) is among the most financially illiterate countries in survey, together with Italy (11.1) and Colombia (11.2) while the most well-performing scores were achieved by Hong Kong (14.8), Slovenia (14.7) and Austria (14.4) (OECD, 2020). The report shows that even the highest scores that were achieved by adults in Hong Kong were still only at $71.1 \%$ of the total, which only suggests that a basic level of financial knowledge, some long-term healthy attitudes towards saving money and handling finances and general financial prudent behavior (OECD, 2020). Even if the score of Romania is low when compared to the reference 21 points, when compared to the average score, the difference is not high, with less than 2 score points below other countries, even developed economies such as Germany and 1.5 below average of all the surveyed countries, scoring nevertheless slightly higher than Italy. Compared to Moldova, Romania achieved lower scores in all three domains, knowledge, behavior and attitude and the lowest score was achieved by Romania in the area of financial knowledge. Knowledge can model behavior and attitude; therefore, a proper FE would raise the financial awareness and knowledge, which will therefore enhance the financial behavior and attitude.

The main organizations involved in Romanian FE are the commercial Banks, the Romanian Banking Associations, the NBR in partnership with the Ministry of 
Education, Bank Deposit Guarantee Fund and several NGO's (National Bank of Romania, 2015). The main target groups identified by the NBR are the pupils and students, teachers, banking/business communities, the academic management, the media and the public at large. The tools proposed by NBR in the spread of financial literacy for the target groups are seminars, public conferences, group visits, digital tools and written materials. There are several projects developed to raise financial literacy in Romania and the results are showing a growing positive outcome in terms of participants in the programs which are developed in partnership by private and public companies, together with several NGO's. More digital tools have to be developed in order to reach the young people and local projects should be implemented by creating private-public partnerships and enhanced cooperation with the entrepreneurship and FE providers. There are steps taken in the correct direction for setting a proper framework for EE and FE in Romania, starting with 2011 a new Law of Education was adopted with the purpose of modelling the Romanian educational system to today's labor market needs and economic, financial and EE are part of the reform process in Romanian education (Lacatus, 2016). Starting with the new educational law, FE was incorporated in the school curricula with one program approved for the middle school level and one at high school level. The recommendation is that all educational institutions that are interested in delivering FE should develop an optional program concerning financial issues.

\section{Conclusions}

EE is an important topic in the business world and it has been intensely researched the academic in field due to the fact that the literature has to provide a direction for the fast-changing world and businesses, states and organizations have tried to provide solutions and directions. GEM report 2019/2020 suggests that the directions needed for empowering aspiring entrepreneurs are "policy changes or educating more or educating differently" (p. 16). The international organizations that seek to raise awareness regarding financial illiteracy and the need for EE suggest that the challenge is to find the proper ways and the proper channels for promoting them. The main identified issues among young people are the skills of young people, low exposure to entrepreneurship and the lack of role models, high administrative and financial complexity, the low focus on growth entrepreneurship and expansion and increased focus on the other hand on SMEs (OECD, 2008).

The responsibility of the governments remains to create the proper implementation framework where NGO's, universities and private companies unite efforts to promote EE and financial literacy. As far as the methods are concerned, theoreticians advise that EE should be taught in a practical way, using innovative techniques and teaching should be focused on providing the students with an entrepreneurial mindset rather than the traditional approach that was focused on delivering good employees.

As far as Romania is concerned, the findings reveal a low level of financial literacy,

Romania being one of the least financially literate in the surveyed countries as OECD has shown in latest study but scoring slightly higher than Italy, close to Germany's score and just slightly below the average score of the surveyed 
countries with 1.5 score points below the average. Several authors argue that the role of the state in providing financial and $E E$ is debatable, due to the lack of transparency and due to the political aspect, where parties can divert funds and use them to their own interest. OECD and the EU have tried to raise awareness, conduct surveys to assess the need for training and provide the framework for the stakeholders to meet, exchange ideas and further implement them. In Europe there are discrepancies between countries and also between genders regarding financial literacy, even in the most developed European countries.

Several measures have been imposed by the Romanian state as a consequence of the international surveys, placing Romania among the most financially illiterate countries in the world and also due to the national experts' commission assessment, that revealed a mediocre approach toward economic, financial and EE. There are two courses that are taught at undergraduate level, one in middle school and one in high-school that aim at teaching young people basic financial knowledge. Nevertheless, there are several authors that argue the fact that state's involvement is debatable, taking into consideration lobby groups and powerful politicians.

In today's dynamic world, financial knowledge and an entrepreneurial mindset are vital for the future success of young people. Technology and digitalization have changed the economic environment as we know it and the financial empowerment of individuals is important for the development of society at large and for the avoidance of future crises. Collaboration between universities, schools, the private sector, governments and regional and international organizations can support the healthy development of EE and financial literacy and could be the key to formulating the best strategies and setting future directions.

\section{References:}

1. Anderson, G., Ferreirra, J. \& Marques, C. S., 2017. EE and training as facilitators of regional development: A systematic literature review. Journal of Small Business and Enterprise Development, Volume 25, pp. 17-40.

2. Badulescu, A. \& Badulescu, D., 2013. How Entrepreneurial are Doctoral Students? Some Evidence from Romania. Journal of Eastern Europe Research in Business \& Economics, Volume 2013.

3. Badulescu, D. \& Badulescu, A., 2014. Managing Entrepreneurship in Higher Education Institutions - Case Romania. MEST Journal, July, 2(2), pp. 1-9.

4. Buchheit, P., 2015. The incredible shrinking middle class: Half of the country is either living in poverty or damn near close to it. Salon, 23 DEcember.

5. Clark, R., Lusardi, A. \& Mitchell, O. S., 2017. Employee financial literacy and retirement plan behavior: a case study. Economic Inquiry, 55(1), p. 248-259.

6. Dencker, J. C., Gruber, M. \& Shah, S. K., 2009. Pre-Entry Knowledge, Learning, and the Survival of New Firms. Organization Science, 20(3), pp. 516537.

7. Dezsi-Benyovski, A., Nagy, A. \& Szabo, T. P., 2014. Entrepreneurship in Romania-Country Report, s.I.: Global Entrepreneurship Monitor.

8. EBA Consumer Trends, 2019. EBA Consumer Trends Report, s.l.: European Banking Authority.

9. Erta, K., Iscenko, Z., Hunt, S. \& Brambley, W., 2013. Applying behavioural economics at the Financial Conduct Authority. London, UK: Financial Conduct Authority. 
10. European Comission, 2020. Unleashing the full potential of European SMEs, s.l.: s.n.

11. European Commission, 2012. Rethinking education: Investing in skills for better socio-economic outcomes, s.l.: s.n.

12. European Commission, 2013. Reigniting the entrepreneurial spirit in Europe.

13. European Commission, 2018. EntreComp: The European Entrepreneurship Competence Framework. Luxembourg: Publications Office of the European Union. 14. European Commission, 2019. Education and Training Monitor 2019 Romania, Luxembourg: Publications Office of the European Union.

15. Eurostat, 2021. Euroindicatiors 54/2021 - 30 April 2021, s.l.: Eurostat.

16. Folta, T. B., Johnson, D. R. \& O'Brien, J., 2006. Uncertainty, irreversibility, and the likelihood of entry: An empirical assessment of the option to defer. Journal of Economic Behavior \& Organization, November, 61(3), pp. 432-452.

17. GEM, 2014. Entrepreneurship in Romania-Country Report, Global entrereneurship Monitor.

18. Heinberg, A. et. al, 2014. Five steps to planning success: experimental evidence from US households. Oxford Review of Economic Policy, 30(4), p. 697724.

19.IFFM,2021.Available at: https://financemuseums.org/ [Accesed 2021].

20. Kraus, S. și alții, 2020. The economics of COVID-19: initial empirical evidence on how family firms in five European countries cope with the corona crisis. International Journal of Entrepreneurial Behavior \& Research, 26(5), pp. 10671092.

21. Lacatus, L. M., 2016. FE in Romania. International Handbook of Financial Literacy, pp. 321-328.

22. Lazear, E. P., 2004. Balanced Skills and Entrepreneurship. American Economic Review, 94(2), pp. 208-211.

23. Lusardi, A., 2014. Financial Literacy: Do People Know the ABCs of Finance?. s.l.:Global Financial Literacy Excellence Center.

24. Lusardi, A., 2019. Financial literacy and the need for FE: evidence and implications. Swiss Journal of Economics and Statistics, Volume 1, p. 155.

25. McNally, J. J., Martin, B. C. \& Kay, M. J., 2013. Examining the formation of human capital in entrepreneurship: A meta-analysis of EE outcomes. Journal of Business Venturing, March, 28(2), pp. 211-224.

26. OECD, 2005. Recommendation on Principles and Good Practices for Financial, Paris: DIRECTORATE FOR FINANCIAL AND ENTERPRISE AFFAIRS.

27. OECD, 2008. EE in Europe, s.I.: European Foundation for Entrepreneurship Research.

28. OECD, 2017. Entrepreneurship at a Glance 2017, Paris: OECD Publishing. 29. OECD, 2017. PISA 2015 results (Volume IV): students' financial literacy, Paris: PISA, OECD Publishing.

30. OECD, 2018. OECD Future of Education and Skills for 2030, Paris: OECD Publishing.

31. OECD, 2019. Society at a Glance 2019: OECD Social Indicators, Paris: OECD Publishing.

32. OECD, 2020. OECD/INFE 2020 International Survey of Adult Financial Literacy, Paris: OECD Publishing.

33. OECD, 2020. PISA 2018 Results ARE STUDENTS SMART ABOUT MONEY? VOLUME IV, Paris: OECD Publishing. 
34. OECD, I. a., 2018. The Application of Behavioural Insights to Financial Literacy and Investor Education Programmes and Initiatives, s.I.: IOSCO and OECD.

35. Oosterbeek, H., van Praag, M. \& ljsselstein, A., 2010. The impact of EE on entrepreneurship skills and motivation. European Economic Review, Volume 48, p. 442-454.

36. Ransome, A., 2014. A father's plea: Why isn't entrepreneurship part of the curriculum?:The Globe and Mail.

37. Ratten, V. \& Jones, P., 2021. Covid-19 and EE: Implications for advancing research and practice. The International Journal of Management Education, 19(1). 38. Ratten, V. \& Jones, P., 2021. Entrepreneurship and management education: Exploring trends and gaps. The International Journal of Management Education.

39. Rinne, R., 2008. The growing supranational impacts of the OECD and the EU on national educatinal policies and the case of Finland. Policy Futures in Education, 6(6), pp. 665-680.

40. Romanian National Bank, 2015. FE...matters!, Minsk: Banca Nationala a Romaniei.

41. Rosendahl Huber, L., Sloof, R. \& Van Praag, M., 2014. The effect of early EE: Evidence from a field experiment. European Economic Review, Volum 72, pp. 7697.

42. Toft-Kehler, R., Wennberg, K. \& Kim, P. H., 2014. Practice Makes Perfect: Entrepreneurial-experience Curves and Venture Performance. Journal of Business Venturing, 29(4), pp. 453-470.

43. Twaalfhoven, B. \& Wilson , K., 2004. Breeding More Gazelles: The Role of European Universities. EFER, Issue October.

44. Unger, J. M., Rauch, A., Frese, M. \& Rosenbusch, N., 2011. Human capital and entrepreneurial success: A meta-analytical review. Journal of Business Venturing, 26(3), pp. 341-358.

45. Urban, C., Schmeiser, M., Collins, M. J. \& Brown, A., 2020. The effects of high school personal FE policies on financial behavior. Economics of Education Review, Volume 78.

46. van der Sluis, J., van Praag, M. \& Vijverberg, W. P., 2008. Education and Entrepreneurship Selection and Performance: A Review of the Empirical Literature. Journal of Economic Surveys, December, 22(5), pp. 795-841.

47. Van Praag, M., Van Witteloostuijn, A. \& Van Der Sluis, J., 2013. The Higher Returns to Formal Education for Entrepreneurs versus Employees. Small Business Economics, 40(2), pp. 375-96.

48. Wagner, J., 2003. Testing Lazear's Jack-of-All-Trades View of Entrepreneurship with German Micro Data. Applied Economics Letters, Volume 10, pp. 687-689. 


\title{
THE RELATIONSHIP BETWEEN ENTREPRENEURSHIP AND NATIONAL COMPETITIVENESS
}

\author{
Khanh Hung DOAN \\ Doctoral School of Business Administration, Bucharest University of Economic \\ Studies, Bucharest, Romania \\ doankhanhhung.hat@gmail.com
}

Abstract: Currently, entrepreneurship is identified as an important factor for contributing to the economic development of the nation as well as the change of society. Entrepreneurship creates wealth, jobs, and economic growth in the country. Furthermore, a prominent feature of entrepreneurship is the enhancement of the country's competitiveness. Therefore, building and improving the nation's entrepreneurship is an urgent requirement to promote the country's competitiveness in the best way. In this paper, the relationship between national competitiveness and entrepreneurship is confirmed through quantitative analysis methods. In addition, the influence of entrepreneurship on the national competitiveness of countries in the world is also introduced. The specific objective of the study is to present two related indexes, namely the global entrepreneurship index and the global competitiveness index. Furthermore, through the assessment and comparison of these two indicators, the study also analyzes the relationship between entrepreneurship and national competitiveness. The paper's analysis is based on data covering 124 observed samples, provided by the Global Entrepreneurship Monitor in 2019 and the Global Competitiveness Report in 2019. Besides, analytical methods such as the graphic method, regression method were also performed. From this, it proved that there is existence a close relationship between the two indicators. The results show that the more entrepreneurship is raised, the more competitive the country will be. Therefore, the government needs to have policies that contribute to the development of national entrepreneurship. Herein, can contribute to supporting and promoting the competitiveness of the country. Finally, the presented results contribute to the promotion of studies assessing the influence of entrepreneurship and startups on national competitiveness. The paper ends with some discussion of the results and implications of the study.

Keywords: Global Entrepreneurship Index; Global Competitiveness Index; entrepreneurship, national competitiveness.

JEL Classification: $010 ; M 10 ; M 21$

\section{Introduction}

Currently, along with the development of the globalization process that is taking place in the world, the role of the competitiveness of each country is increasingly important. It shows the strength and capacity of each country. Herein, national competitiveness plays a role in promoting economic development, improving the country's labor productivity, attracting foreign investment, etc. Enhancing national 
competitiveness is an urgent requirement in the process of international integration and fierce competition among countries today. Thus, how to improve national competitiveness in the context of fierce competition of integration, while ensuring sustainable development is always a new issue that needs to be solved.

The researchers point out that the competitiveness of countries not only depends on external factors such as foreign investment capital, fluctuations in international markets, etc. but also depends on the internal factors of the country such as infrastructure, science, and technology level, human resources, human development level, etc. Among them, the entrepreneurship factor can be mentioned. Nowadays, more and more businesses are established and strongly developed thanks to the increasing mechanisms, policies, and entrepreneurship, especially in developing countries. A country with many active businesses will contribute to accelerating the transformation of the economy and the growth model of the economy. It will affect the country's competitiveness. Since then, the central role of entrepreneurship has been increasingly recognized. In addition, it is argued that entrepreneurship and innovation are driving competitiveness in all three aspects of the country's sustainable development (Herman, 2018). Therefore, it is necessary to consider the influence of entrepreneurship on national competitiveness. Governments need to consider the impact of entrepreneurship on national competitiveness specifically. Based on this, it can choose the best models of entrepreneurship development and contribute to improving national competitiveness. From there, countries accelerate economic growth, promote the start-up process and contribute to the existence and sustainable development.

This article will present a summary of the relationship and the influence of entrepreneurship on national competition. In addition, identification of key trends and gaps of entrepreneurship to the national competition is also introduced. After that, the study continues to make a general assessment of the influence of entrepreneurship on national competitiveness based on the analysis of the surveyed countries in the world.

The study was conducted based on data collected from the Global Entrepreneurship Monitor (GEM) in 2019 and data collected from the 2019 Global competitiveness report of the World Economic Forum (WEF). Finally, there are some conclusions and suggestions for improving research on the influence of entrepreneurship on national competitiveness. The paper is structured as follows: the first section provides a brief literature review of the studies, the second section explains the methodology used by the authors in this paper, and the third section the results of the research, while the final part is the conclusion and discussion of the research findings of the study.

\section{Literature Review}

\subsection{The relationship between entrepreneurship and national competition}

Currently, there is quite a lot of research on entrepreneurship as well as the characteristics and roles of entrepreneurship. Entrepreneurship has attracted the attention of both researchers and policymakers over the past decades (Al-Sartawi et al., 2019). It demonstrates the significant role of entrepreneurship in socioeconomic development. More and more research is being done on the aspects and features of entrepreneurship as well as the role and relationship of 
entrepreneurship on social and national factors and characteristics. Among them is the relationship between entrepreneurship and national competitiveness. Many scholars have emphasized the importance of economic competitiveness for business performance and economic development as well. However, few quantitative studies analyze the interrelationship between competitiveness and its role in increasing entrepreneurial activities at different stages of development (Rostami et al., 2019) as well as the purpose of improving the competitiveness of the countríes.

National competitiveness is a diverse concept and has many different characteristics. Therefore, entrepreneurship affects national competitiveness in many ways. Various studies (Szirmai et al., 2011), on the one hand, show that entrepreneurship can contribute to job creation, growth, and economic development through innovation. On the other hand, entrepreneurship contributes to economic growth (Korez-Vide and Tominc, 2016; Szabo and Herman 2012). Besides, Grilo and Thurik (2005) argued that entrepreneurship is at the heart of innovation, competitiveness, economic growth, and job creation. Accordingly, SMEs enterprises have an indispensable role in the process of improving competitiveness and establishing innovation systems. The entry of new small businesses puts constant pressure on existing enterprises to cut costs and increase productivity. At the same time, the growth of SMEs strengthens the economy's ability to create new jobs (Cuckovic and Bartlett, 2007). In addition, Fagerberg and Saprasert (2011) determined that innovative entrepreneurship is being considered a key element of the modern developed economy and is often associated with economic growth and technological progress (Al-Sartawi et al., 2019). However, the impact of entrepreneurship in the economy varies according to the characteristics of entrepreneurship, which in turn depends on the stage of economic development (Korez-Vide and Tominc, 2016; Herman, 2018). Douhan and Henrekson (2008) have shown a strong positive relationship between effective entrepreneurship and the innovation of the economy and its adaptability, thereby increasing the competitiveness of the economy. Thus, entrepreneurship, briefly reviewed in this paper, can be the driving force that enables the transformation of regional resources into regional and national competitiveness, added value, economic growth, and development. Practice proves that innovation and entrepreneurship are considered essential elements of national competitiveness (WEF, 2017).

In particular, understanding entrepreneurship is rooted in space making it a factor of national and regional competition (Nicolae et al., 2016). By research done in Romania, Nicolae et al. (2016) concluded that regional differences should be calculated when formulating national competition policy. Huggins and Williams (2011) also identified that less competitive regions are using to account issues related to entrepreneurship and business development as a tool to enhance regional competitiveness. Although there is a substantial policy in these areas in less competitive regions, entrepreneurship and entrepreneurship policy at the regional level is multidimensional, with policies ranging from those with economic or social orientation. However, research by Huggins and Williams (2011) also shows that there is a tension between using business policy as a tool to improve competitiveness in the region or to address economic and social disadvantages. Therefore, there is a need for more specific assessments of the role of entrepreneurship in regional competitiveness to limit possible drawbacks. 
At the national level, Aisyah and Saputra (2021) argued that in the current era of globalization, essential parts of entrepreneurship are the development of economic competitiveness to increase the welfare of the community, especially nations. Countries need to improve entrepreneurship and innovation, thereby contributing to the country's competitiveness (Aisyah and Saputra, 2021). Besides, the study of Korez-Vide and Tominc (2016) also stated that the developed business sector has a significant influence on economic growth and the success of national economies. It ultimately determines the competitiveness of that country (Korez-Vide and Tominc, 2016).

At the international level, Zahra and Dianne Hansen (200) also identify entrepreneurship as playing a role in promoting global competitiveness. In reality, it can be seen that entrepreneurship is increasingly attracting attention about its role in decision-making policies that can promote economic and social development. There has also been increased attentiveness on how entrepreneurs innovate and, therefore, in doing so, contribute to a higher level of international competition (Ferreira et al., 2017).

Herman (2018) explored the relationship between innovation, entrepreneurship, and national competitiveness at the EU level. From there, it aims to highlight how innovation and entrepreneurship can influence the level of competition and inclusive development in these countries. The results show that there is a significant difference between the group of countries with medium and low innovation performance and the group of countries with high and very high innovation performance in terms of competitiveness, innovation, entrepreneurship (Herman, 2018). Therefore, there is a need for concrete actions to improve the national competitiveness of EU countries through a level of creativity and entrepreneurship (Herman, 2018). In addition, the European Innovation Scoreboard report (EU, 2017) highlighted that the competitiveness of the European economy and the well-being of European citizens depend on innovation and entrepreneurship. Innovation and entrepreneurship increase productivity and promote economic growth, thereby enhancing the competitiveness of countries (EU, 2017). Reinforcing the point above, Fernandes et al. (2020) determined that innovation impacts competitiveness, and entrepreneurship shape the competitiveness of EU countries.

However, Amorós and Cristi (2008), in their study on the relationship between entrepreneurship and competitiveness of Latin American countries, determined that entrepreneurship has an inverse relationship with national competition and development. As the nation's economy recovers, entrepreneurship will decline. Besides, when entrepreneurs haven't a job, they only start a business (Amorós and Cristi, 2008). In more detail, Amorós and Cristi (2008) showed that for developing countries, competitiveness is directed more towards structural productive efficiency rather than enhancing the nation's entrepreneurial dynamics. Therefore, entrepreneurship may have less of a role to play in enhancing the country's competitiveness and may reduce the country's competitiveness.

\subsection{Global Entreperneurship Index}

The Global Entrepreneurship Index is a composite index that measures elements of a country's startup ecosystem. This index showcases the quality of entrepreneurship and support for the startup ecosystem. According to Ács et al. (2019), The Global entrepreneurship index identifies three levels for a country's 
score, including overall GEI score, scores for Individuals and Organizations, and pillar level. The GEM program began to examine and evaluate the role of entrepreneurship in national economic growth in 1999. Accordingly, the program has evolved into a worldwide survey of entrepreneurship. Since the start of the GEM project in 1999, GEM has recently surveyed and assessed entrepreneurship in more than 130 countries. In which, the main aim of the GEM project is to measure and define entrepreneurship in each country.

All GEM data is published and collected from the website www.gemconsortium.org, as well as GEM entrepreneurship research reports. This database is heavily used in entrepreneurship research by various researchers (Filculescu, 2016; Mrożewski and Kratzer, 2016; Harms and Groen, 2017) because this data allows for compare ratings between different countries in the world as well as have an in-depth analysis on the factors affecting entrepreneurship of each country. It helps to empirically address the characteristics of business at the national level as well as the realities of entrepreneurship in those countries. The Global Entrepreneurship Index (GEI), a composite index that measures both the quality of entrepreneurship in a country and the level and depth of the startup ecosystem that supports it, tends to be the highest in innovation-oriented economies and is positively correlated with the level of development (GEDI, 2017). In addition, this index represents an expansive view of the entrepreneurial phenomenon and facilitates the identification of its strengths and weaknesses, opening the door to policy modification and the promotion of appropriate actions towards entrepreneurship.

The Global Entrepreneurship Index measures the development of entrepreneurship comprehensively through the following key indicators:: Product Innovation, Process Innovation, High Growth, Opportunity Perception, Startup Skills, Risk acceptance, Networking, Cultural support, Technology Absorption, Human Capital, Competition, Internationalization, Risk Capital (Ács et al., 2019).

The entrepreneurship research results of the Global Entrepreneurship Report have helped leaders and researchers have an overview and detailed view of entrepreneurship not only of each country studied but also of the whole world. From there, they can propose solutions and policies that contribute to promoting entrepreneurship in their country.

\subsection{Global Competitiveness Index}

The Global Competitiveness Report is an annual bulletin published by the World Economic Forum (WEF), first released in 1979. The 2019-2020 report covers 141 economies, that major and prominent economy (Schwab, 2019). This report aims to assess the ability to provide a high or low level of prosperity for the population in each country. In particular, this report publishes the "Global Competitiveness Index" (GCl) to measure the trends of institutions, policies, factors that make up the current state, and the limits of economic prosperity.

Since 2004, the global competitiveness report ranks countries based on a global competitiveness index. It is a highly comprehensive index to measure national competitiveness, which captures the national macroeconomic and microeconomic foundations. (Sala-iMartin et al., 2011). GCl was developed by Xavier Sala-iMartin and Elsa V. Artadi (2004). Currently, GCl is widely cited and used in many documents for many academic studies as well as many articles in prestigious journals. The Global Competitiveness Report is based on the top four factors considered to affect a country's competitiveness index: inflation, infrastructure, 
skilled labor, and level of corruption. Each year, the WEF ranks approximately 130 countries globally in the Global Competitiveness Index and publishes that figure in the Global Competitiveness Report.

The economic data of the report are collected from the countries participating in the survey (hard data), and the results are taken from the investigation of enterprises and economic experts (soft data). This report has been made for decades and shows an overview and comprehensive picture of the strengths and weaknesses of the national economies, thereby identifying opportunities and challenges themselves. WEF ratings also reflect factors affecting a country's business environment, which are also fundamental to sustainable economic growth.

However, in terms of reliability, many experts now say that the report is only relative and does not affect investors' confidence. In addition, whether the information and input materials used for analysis are standard or not is still a matter to consider, but this is the basis for governments to refer to.

In addition, this report has been built on more than 110 variables, of which twothirds come from the Executive Opinion Survey, and one-third come from publicly available sources such as the United Nations. Based on this, the variables are organized into twelve pillars, with each pillar representing an area considered to be an important determinant of competitiveness. - Institutions.

- Appropriate infrastructure.

- Stable macroeconomic framework.

- Good health and primary education.

- Higher education and training.

- Efficient goods markets.

- Efficient labor markets.

- Developed financial markets.

- Ability to harness existing technology.

- Market size-both domestic and international.

- Production of new and different goods using the most sophisticated production processes.

- Innovation.

All these 12 pillars interact and influence each other. Weaknesses in one subject often harm others. In general, the pillars are essential to a certain extent for the economy. However, because of the different stages of development of countries, they affect them in different ways.

\section{Methodologies}

\subsection{Research purposes}

The main aim of the study is to test the hypothesis that national entrepreneurship has a positive influence on national competitiveness. In addition, through the evaluation and comparison of two important criteria that is the Global Entrepreneurship Index and the Global Competitiveness Index by statistical analysis methods, the article also shows the relationship of the two indexes above.

\subsection{Data collection}

The global entrepreneurship index data of this study were collected based on GEM (2019) data. The total number of observed samples in the GEM data for countries 
is 137 , corresponding to 137 different countries and territories. Besides, National competitiveness data is also collected based on the data of the World Economic Forum (WEF) 2019, Global Competitiveness Report. The total number of countries and territories analyzed on the Global competitiveness index in 2019 includes 141 countries and territories, corresponding to 141 observed samples collected.

Due to the difference in the number of observed samples between different countries in the above reports, we have analyzed and used the observed samples countries and territories that share the data of both reports. The total number of observations collected for that study was 124 observations. The author will use these 124 observed samples to analyze in the study. The results of descriptive statistics Entrepreneurship index and National competitiveness index collected from GEM and WEF are shown in Table 1. The total number of observed samples is 124 samples. The GEI mean of 35,061 was rated as average. Besides, the average value of the national competitiveness index is 61,728 , which is assessed at a high level.

Table 1: Descriptive Statistics

\begin{tabular}{|l|c|r|r|r|c|}
\hline & N & Minimum & Maximum & Mean & $\begin{array}{c}\text { Std. } \\
\text { Deviation }\end{array}$ \\
\hline GEI & 124 & 8.8 & 86.8 & 35.061 & 19.4923 \\
\hline GCl & 124 & 35.1 & 84.8 & 61.728 & 11.9410 \\
\hline Valid N (listwise) & 124 & & & & \\
\hline
\end{tabular}

Source: Author's own research results.

\subsection{Data analysis}

The analytical method used in this paper is the graph analysis method and the regression analysis method used to analyze the influence of entrepreneurship on the country's competitiveness. Regression is an analytical method to see how the independent variable affects the dependent variable when the independent variable changes. Here, the study aims to examine how entrepreneurship affects national competitiveness. If the Sig. value of the F-test is statistically significant (Sig. value < 0.05), that is, the model built is significant. In addition, the results Sig. value of the t-test corresponding to the GEI independent variable is statistically significant (Sig. value < 0.05), that is, the GEI independent variable has a statistically significant effect on the $\mathrm{GCl}$ dependent variable. The steps of data processing, descriptive statistics, graph analysis, and regression analysis were performed using SPSS 23.0 software.

\section{Results}

\section{Influence of entrepreneurship on national competitiveness}

Firstly, the study was conducted using a graphical method to determine the relationship between the two factors: entrepreneurship and national competition. The graph showing the relationship between entrepreneurship and the country's competitiveness is shown in figure 1. Through figure 1, the arrangement of observation points on the graph can be observed. There is a relationship between entrepreneurship and national competition. That relationship is a positive one. As the value of GEl increases, there is an increase in the value of $\mathrm{GCl}$. Besides, the 
value of $\mathrm{GCl}$ changes when there is a change of $\mathrm{GEl}$ is homogenous. We can draw a clear regression line located in the center of the points on the graph. This result shows that $\mathrm{GCl}$ and $\mathrm{GEI}$ have a linear relationship with each other.

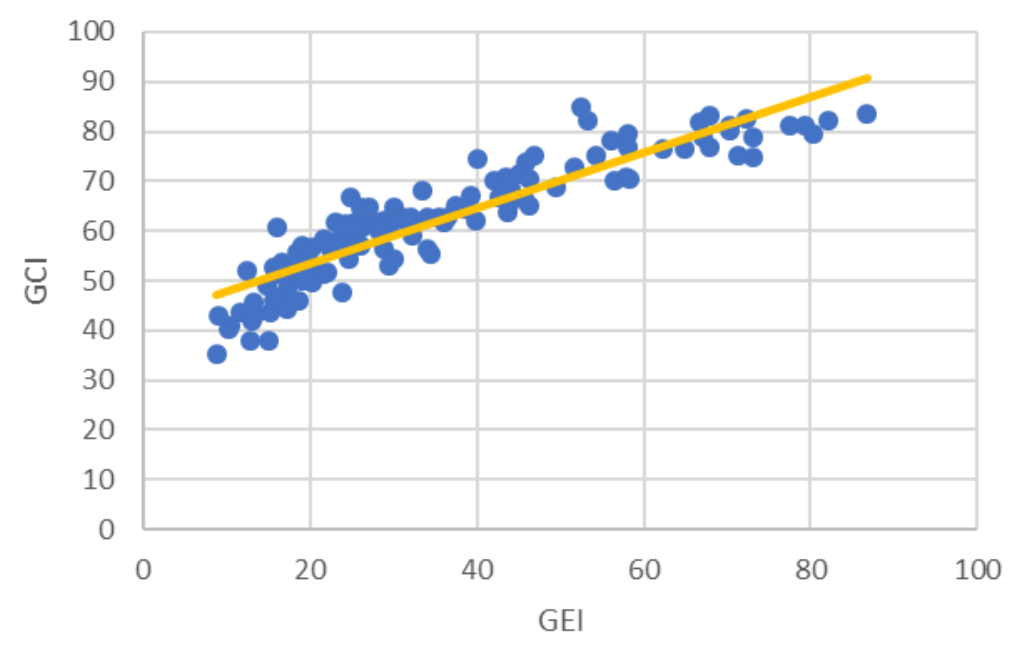

Figure 1: Correlogram between GEI and GCl in 2019 Source: Author's own research results.

To conduct regression analysis to determine the relationship between entrepreneurship and national competitiveness, the Pearson correlation coefficient was studied and used to analyze the statistical relationship between two variables, $\mathrm{GCl}$ and $\mathrm{GEl}$. The analysis results in Table 2 show that the two indexes $\mathrm{GCl}$ and GEI have a close and direct correlation with each other (Pearson $=0.911$ ). Besides, this Pearson correlation coefficient is also statistically significant with the significance level of 0.05 (Sig. value $<0.05$ ).

Table 2: Correlations

\begin{tabular}{|l|l|l|l|}
\hline \multicolumn{2}{|c|}{} & GEI & GCI \\
\hline \multirow{2}{*}{ Pearson Correlation } & GEI & 1 & $0.911^{* *}$ \\
\cline { 2 - 4 } & GCl & $0.911^{* *}$ & 1 \\
\hline \multirow{2}{*}{ N } & GEI & 0.000 & 0.000 \\
\cline { 2 - 4 } & GCl & 0.000 & 0.000 \\
\hline & GEI & 124 & 124 \\
\cline { 2 - 4 } & GCl & 124 & 124 \\
\hline
\end{tabular}

${ }^{\star *}$. Correlation is significant at the 0.01 level (2-tailed).

Source: Author's own research results.

To analyze the influence of the Global Entrepreneurial Index (GEI) on the Country Competitiveness Index $(\mathrm{GCl})$, the study conducted a regression analysis based on the OLS econometric regression model. The regression model has the following formula:

$$
\mathrm{GCl}=\beta_{0}+\beta_{1} \cdot \mathrm{GEI}+\varepsilon(1)
$$


The results of the analysis of the conditions of the carried out econometric model in table 4 show that the model (1) built above has a significance level of 0.05 because the Sig value. of the F-test is statistically significant (Sig. value $<0.05$ ).

Table 3: Model Summaryb

\begin{tabular}{|c|c|c|c|c|c|c|c|c|c|c|}
\hline \multirow[b]{2}{*}{ Model } & \multirow[b]{2}{*}{$\mathbf{R}$} & \multirow[b]{2}{*}{$\begin{array}{c}\mathbf{R} \\
\text { Square }\end{array}$} & \multirow[b]{2}{*}{$\begin{array}{c}\text { Adjusted } \\
\mathbf{R} \\
\text { Square }\end{array}$} & \multirow{2}{*}{$\begin{array}{c}\text { Std. } \\
\text { Error of } \\
\text { the } \\
\text { Estimate }\end{array}$} & \multicolumn{5}{|c|}{ Change Statistics } & \multirow[b]{2}{*}{$\begin{array}{l}\text { Durbin- } \\
\text { Watson }\end{array}$} \\
\hline & & & & & $\begin{array}{c}\text { R } \\
\text { Square } \\
\text { Change }\end{array}$ & $\begin{array}{c}F \\
\text { Change }\end{array}$ & df1 & df2 & $\begin{array}{l}\text { Sig. F } \\
\text { Change }\end{array}$ & \\
\hline 1 & $0.911^{\mathrm{a}}$ & 0.830 & 0.829 & 4.9369 & 0.830 & 597.596 & 1 & 122 & 0.000 & 1.908 \\
\hline
\end{tabular}

a. Predictors: (Constant), GE

b. Dependent Variable: GCI

Source: Author's own research results.

Table 4: ANOVA ${ }^{a}$

\begin{tabular}{|l|l|r|r|r|r|c|}
\hline \multicolumn{2}{|c|}{ Model } & Sum of Squares & \multicolumn{1}{c|}{ df } & Mean Square & \multicolumn{1}{c|}{ F } & Sig. \\
\hline \multirow{3}{*}{1} & Regression & 14564.939 & 1 & 14564.939 & 597.596 & $0.000^{\mathrm{b}}$ \\
\cline { 2 - 7 } & Residual & 2973.452 & 122 & 24.373 & & \\
\cline { 2 - 7 } & Total & 17538.391 & 123 & & & \\
\hline
\end{tabular}

a. Dependent Variable: $\mathrm{GCl}$

b. Predictors: (Constant), GEI

Source: Author's own research results.

Besides, the analysis results in table 3 also show that the value of $R^{2}=0.830$, that is, the change of GEI variable explains $83.0 \%$ of the change of $\mathrm{GCl}$. The results of the Durbin-Watson test (value is 1.908) show that the model does not have autocorrelation.

From that, the regression analysis based on the OLS model is estimated as shown in Table 5. In which, the regression results for the values of the independent variable (entrepreneurship) and the dependent variable (competitiveness) (see table 5):

$$
\mathrm{GCl}=42.155+0.558 \times \mathrm{XEI}(2)
$$

The results show that the coefficient of the GEI variable is statistically significant with a significance level at 0.05 (Sig. value $<0.05$ ). In addition, the analysis results also show that when the dependent variable is the GEI changes by 1 unit, $\mathrm{GCl}$ will change by 0.558 units.

Table 5: Coefficients ${ }^{\mathrm{a}}$

\begin{tabular}{|c|c|c|c|c|c|c|c|c|}
\hline & \multirow{2}{*}{ Model } & \multicolumn{2}{|c|}{$\begin{array}{l}\text { Unstandardized } \\
\text { Coefficients }\end{array}$} & \multirow{2}{*}{$\begin{array}{c}\text { Standardized } \\
\text { Coefficients }\end{array}$} & \multirow[t]{2}{*}{$\mathbf{t}$} & \multirow{2}{*}{ Sig. } & \multicolumn{2}{|c|}{$\begin{array}{c}95.0 \% \\
\text { Confidence } \\
\text { Interval for B } \\
\end{array}$} \\
\hline & & B & $\begin{array}{l}\text { Std. } \\
\text { Error }\end{array}$ & & & & $\begin{array}{l}\text { Lower } \\
\text { Bound }\end{array}$ & $\begin{array}{l}\text { Upper } \\
\text { Bound }\end{array}$ \\
\hline \multirow{2}{*}{1} & (Constant) & 42.155 & 0.915 & & 46.059 & 0.000 & 40.343 & 43.967 \\
\hline & GEI & 0.558 & 0.023 & 0.911 & 24.446 & 0.000 & 0.513 & 0.603 \\
\hline
\end{tabular}

a. Dependent Variable: GCI

Source: Author's own research results. 


\section{Discussion and Conclusion}

Entrepreneurship now plays a significant role in the goals and strategies of countries. From there, it can contribute to develop of the country and enhance its competitiveness of that country. By improving the country's competitiveness, it can help the country develop more sustainably and efficiently, as well as contribute to attracting foreign investment, improving the prestige and efficiency of the country on the international market. Therefore, it is momentous to focus on developing the nation's entrepreneurship.

The study confirmed the hypothesis of a positive relationship between entrepreneurship and competitiveness. The results have shown that through statistical analysis methods, mathematical analysis has determined that there is existence a close relationship between the two indexes, namely the national competitiveness index and the global entrepreneurship index. Besides, entrepreneurship has a positive impact on the competitiveness of the country. This influence is quite good. When entrepreneurship increases by one unit, it will increase national competitiveness by 0.558 units. In addition, the results of graph analysis on the relationship between entrepreneurship and national competitiveness also show that the influence of entrepreneurship on national competitiveness is quite uniform. The results of the regression line coincide with the points on the graph, so entrepreneurship and national competitiveness have a linear relationship with each other. This result has implications for policymakers of countries to develop policies on entrepreneurship with the goal of developing national competitiveness in accordance with the realities of their country.

In addition, this study has certain limitations related to the nature and characteristics of the data used for analysis in this paper. The samples of the study are based on a global structured survey conducted by GEM and WEF. However, the number of observed samples used in the study is still modest, not covering all countries in the world. Besides, the study can not go into the deep analysis of the effects of entrepreneurship on national competitiveness because it was based on available data. Future studies can go deeper into the measure of factors in the country's competitiveness. Furthermore, it may be possible to use a combination of many different criteria to assess the impact on the country's competitiveness in a more comprehensive way.

\section{References}

1. Ács, Z.J., Szerb, L., Lafuente, E. and Márkus, G. (2019). Global entrepreneurship and development index 2019. The Global Entrepreneurship and Development Institute, Washington, D.C., USA.

2. Aisyah, H. and Saputra, N. (2021). Innovation And Entrepreneurship For Competitiveness In The ASEAN: An Empirical Analysis. Jurnal Ekonomi Pembangunan, 19(01), pp. 57-69.

3. Al-Sartawi, A.M.M., Badawi, S., Hanoon, A., Hamdan, A., Reyad, S. and Razzaque, A. (2019). Entrepreneurship Education and Country Competitiveness: Avenues for Future Research in the Arab Countries. In European Conference on Innovation and Entrepreneurship (pp. 59-XXIV). Academic Conferences International Limited. 
4. Amorós, J.E. and Cristi, O. (2008). Longitudinal analysis of entrepreneurship and competitiveness dynamics in Latin America. International Entrepreneurship and Management Journal, 4(4), pp. 381-399.

5. Borozan, Đ. (2009). Enhancing Regional Competitiveness Through The Entrepreneurship Development. Interdisciplinary Management Research, 5.

6. Cuckovic, N. and Bartlett, W. (2007). Entrepreneurship and competitiveness: the Europeanisation of small and medium-sized enterprise policy in Croatia. Southeast European and Black Sea Studies, 7(1), pp. 37-56.

7. Douhan, R., and Henrekson, M. (2008). Productive and destructive entrepreneurship in a political economy framework. Stockholm, Sweden; Research Institute of Industrial Economics; IFN Working Paper (2008) No. 761.

8. European Union (EU) (2017). European Innovation Scoreboard 2017. [Online] Available: http://ec.europa.eu/DocsRoom/documents/24829. [22 Nov 2021]

9. Fagerberg, J. and Sapprasert, K. (2011). National innovation systems: the emergence of a new approach. Science and public policy, 38(9), pp. 669-679

10. Fernandes, C.I., Veiga, P.M., Ferreira, J.J., Teixeira, S.J. and Rammal, H.G. (2020). The Impact of Innovation and Entrepreneurship on Competitiveness. In Technological Innovation and International Competitiveness for Business Growth (pp. 97-117). Palgrave Macmillan, Cham.

11. Ferreira, J.J., Fernandes, C.I. and Ratten, V. (2017). Entrepreneurship, innovation and competitiveness: what is the connection?. International Journal of Business and Globalisation, 18(1), pp. 73-95.

12. Filculescu, A. (2016), The heterogeneous landscape of innovation in female-led businesses - cross-country comparisons, Management \& Marketing. Challenges for the Knowledge Society, Vol. 11, No. 4, pp. 610-623.

13. Grilo, I. and Thurik, R. (2005). Entrepreneurial engagement levels in the European Union.

14. Harms, R. and Groen, A. (2017). Loosen up? Cultural tightness and national entrepreneurial activity. Technological forecasting and social change, 121, pp. 196204.

15. Herman, E. (2018). Innovation and entrepreneurship for competitiveness in the EU: an empirical analysis. In Proceedings of the International Conference on Business Excellence (Vol. 12, No. 1, pp. 425-435). Sciendo.

16. Huggins, R. and Williams, N. (2011). Entrepreneurship and regional competitiveness: the role and progression of policy. Entrepreneurship \& Regional Development, 23(9-10), pp. 907-932.

17. Korez-Vide, R. and Tominc, P. (2016). Competitiveness, Entrepreneurship and Economic Growth. In Competitiveness of CEE Economies and Businesses (pp. 2544). Springer International Publishing.

18. Mrożewski, M. and Kratzer, J. (2017). Entrepreneurship and country-level innovation: Investigating the role of entrepreneurial opportunities. The Journal of Technology Transfer, 42(5), pp. 1125-1142.

19. Nicolae, M., Ion, I. and Nicolae, E. (2016). Regional differences in entrepreneurial perceptions and implications for the Romanian competitiveness policy. Management \& Marketing, 11(1).

20. Rostami, N., Khyareh, M.M. and Mazhari, R. (2019). Competitiveness, entrepreneurship, and economic performance: Evidence from factor-, efficiency-, and innovation-driven countries. Economic Annals, 64(221), pp. 33-64. 
21. Sala-iMartin, X., Bilbao-Osorio, B. and Blanke, J. (2011). The Global Competitiveness Report 2011-2012, World Economic Forum.

22. Sala-i-Martin, X. and Artadi, E. V. (2004). The Global Competitiveness Index. Global Competitiveness Report. In World Economic Forum.

23. Schwab, K. (2019), The Global Competitiveness Report 2019, World Economic Forum.

24. Szabo, Z.K. and Herman, E. (2012). Innovative entrepreneurship for economic development in EU. Procedia Economics and Finance, 3, pp. 268-275.

25. Szirmai, A., Naudé, W. and Goedhuys, M. (Eds.) (2011). Entrepreneurship, innovation, and economic development. Oxford University Press.

26. World Economic Forum (2017). The Global Competitiveness Report 2017. Geneva: World Economic Forum.

27. Zahra, S.A. and Dianne Hansen, C. (2000), Privatization, Entrepreneurship, And Global Competitiveness In The 21st Century, Competitiveness Review, 10(1), pp. 83-103 


\title{
THE ROLE OF THE VIETNAMESE EDUCATION SYSTEM IN STARTING A BUSINESS
}

\author{
Khanh Hung DOAN \\ Doctoral School of Business Administration, Bucharest University of Economic \\ Studies, Bucharest, Romania \\ doankhanhhung.hat@gmail.com
}

\begin{abstract}
The education system plays an important role in human development. It is not only in terms of improving knowledge, solving social problems on many levels but also contributing to the development of the economic activities of a country. Moreover, entrepreneurship and entrepreneurial activities are also strongly influenced by the education system of the country. Today, entrepreneurial activities play an increasingly significant role in the development of the country. Therefore, it needs to be paid attention to and focused on the building of an educational environment suitable to the characteristics of entrepreneurship. From there, it is possible to create a dynamic environment, promote business development and start business activities of the country. This paper first provides a brief overview of the role of education in entrepreneurship. Next, the research method and research results are presented on assessing the current status of the role of the national education system in starting a business in Vietnam. The study is based on the analysis of data collected from the report provided by The Amway Global Entrepreneurship Report in 2018 (AGER) on national entrepreneurship in the specific case of Vietnam. Finally, the paper ends with some suggestions and conclusions of the study.
\end{abstract}

Keywords: education system; entrepreneurship; starting business; Vietnam.

JEL classification: I25; M13; M21

\section{Introduction}

In recent years, entrepreneurship and starting a business have always been interested and focused on development. This more and more enterprises are established and thrive. Furthermore, entrepreneurship and starting a business will contribute to the economic and social development of the country. Entrepreneurship is identified as the driving force for socio-economic development. Therefore, entrepreneurship plays an increasingly important role in the development policy of countries (Păunescu and Molnar, 2020). Besides, the goal of developing entrepreneurship on sustainability is a goal of countries around the world. So, it can be said that entrepreneurship and starting a business play a significant role in the national development policies, not only in developing countries but also in developed countries. Furthermore, entrepreneurship is considered a priority area in the national social and economic development policies (Fairlie, 2011).

In particular, the role of the education system in entrepreneurship and starting a business is increasingly appreciated and noticed. Education contributes to the promotion of individual entrepreneurship, supporting the necessary knowledge. It is 
not only at the start-up stage but also at the entire stage of business operation (Uzunidis et al., 2014; Păunescu et al., 2018). Therefore, countries need to have appropriate policies and regulations for education as well as the entrepreneurship and characteristics of that country. From there, it is possible to create the best educational environment for entrepreneurship, contributing to supporting, maintaining, and enhancing business start-up and business operations.

This article attempts to supplement a study of the current state of the educational system's influence on entrepreneurship and starting a business. The main objective of this paper is to assess the influence of the education system on entrepreneurship and starting a business, especially in a transitional economy and Vietnam's education system is still weak. In addition, differences in assessments of different groups based on the demographics of entrepreneurs are provided. Herein, a detailed view of the influence of the education system can be obtained. To accomplish the goals, the paper used an extensive review of the relevant literature and research to analyze the statistical data collected from The Amway Global Entrepreneurship Report (AGER) in 2018 on entrepreneurship, motivation, and desire to start a business in countries around the world. Finally, the conclusions and discussion of the research results are presented.

This paper has four main parts. The first part is an overview of the literature on the research issues. The second part introduces the research method used in this study. The third part presents the research results after data analysis and processing, as well as some initial evaluation of the research results. The final section concludes and discusses the results obtained from the study with some limitations and suggestions for future research directions.

\section{Literature review}

\subsection{The relationship between education and entrepreneurship}

Currently, there are many studies show that entrepreneurship plays an essential role in the economic and social development of each country (Hartono and Muzayanah, 2020; Prasetyo and Kistanti, 2020). Furthermore, entrepreneurship is considered as one of the main drivers for economic and social development, as generating many benefits both financially and socially around the world (OkahEfogo and Timba, 2015; Păunescu and Molnar, 2020). Therefore, promoting and enhancing entrepreneurship is a significant task of each country. Uzunidis et al. (2014) stated that the resources that entrepreneurs need to excel can be grouped into three main categories: (1) knowledge through education and professional experience; (2) financing through savings, loans, or grants; and (3) relationships through networks, family relationships, and personal relationships. There are many factors that affect entrepreneurship, such as policy, law, tax, technology, economic situation, income, age, social status, education, etc. Education is considered one of the important factors affecting business intention (Galloway and Brown, 2002; Fayolle et al., 2006; Zhang et al., 2013). Policymakers also believe that increasing the level of entrepreneurship can be achieved through education (European Commission, 2003) and primary education in entrepreneurship (Varadarajan Sowmya et al., 2010). Păunescu et al. (2018) also emphasized that education level is considered to be a strong determinant of entrepreneurial readiness and decision of entrepreneurs. Drucker (1985) further determined that entrepreneurship is a 
discipline. Therefore, it can be learned (Drucker, 1985). In addition, the establishment of startups is a core matter of entrepreneurship, and it requires basic knowledge, skills, and entrepreneurial behavior (Gartner, 1988). From there, some, if not all, aspects of entrepreneurship can be taught (Kuratko, 2005). Thus, education is the simple way to individual opportunity and social growth, and entrepreneurship education is especially significant to promote a bigger global economy (Varadarajan Sowmya et al., 2010).

According to Augustine et al. (2018), entrepreneurship education was first taught at Harvard University in 1947, and became popular in business schools in the 1970s, and began to receive the attention of scholars worldwide. Since then, many stories about the great benefits of entrepreneurship, such as economic, social, and educational, have been taught. It has led to an increase in entrepreneurship education programs in higher education institutions in the world (Charney and Libecap, 2000).

Do Paco et al. (2015) assessed that entrepreneurship education has a role to play in promoting entrepreneurial intentions and furthering enterprising citizens by improving management knowledge and developing psychological attributes and behaviors associated with entrepreneurship. Păunescu and Vidovic (2020) also argued that entrepreneurship courses contribute to awakening academic curiosity about the necessary topics and contents of social enterprises. Evaluating specifically, Piperopoulos and Dimov (2015) also observed that the nature of the entrepreneurship course - whether theoretically or practically oriented - creates a distinct framework for entrepreneurship, especially creating high efficiency for practical orientation courses of entrepreneurship courses for entrepreneurship. In addition, some studies suggest that higher education is an important factor in entrepreneurial decisions (Kerrin et al., 2017; Morales and Marquina, 2013; Mitchelmore and Rowley, 2013; Nehete et al., 2011).

Besides, many studies have shown that education has a positive effect on entrepreneurship/starting a business on many factors:

- Firstly, entrepreneurship education helps increase the ability to learn and identify new business opportunities (Hussain and Norashidah, 2015). Such knowledge leads to increased quantity and innovation of opportunities associated with technology (Shepherd and DeTienne, 2005). Learning entrepreneurial skills and competencies will lead to individuals perceiving new possible ventures, thereby affecting entrepreneurship (Krueger et al., 2000; Zhao et al., 2005). Besides, social entrepreneurship education helps people acquire the necessary skills and knowledge (Păunescu and Vidovic, 2020).

- Secondly, research shows a positive association between social desire and entrepreneurial intention (Tkachev and Kolvereid, 1999; Bae et al., 2014). Research by Moore (2002) concludes there is a positive relationship between education and the probability of starting a business. Besides, Fellnhofer's study (2018) also showed that individuals' perceptions of entrepreneurial ability and business intention were significantly different before and after exposure to business stories. Thus, entrepreneurial aspirations can be influenced through education (Krueger and Brazeal, 1994), and support for entrepreneurship from relevant sources (possibly educational programs) can increase the likelihood of entrepreneurship (Riquelme and AI Lanqawi, 2016).

- Thirdly, entrepreneurship courses help to gain knowledge about starting a new business in a better and faster way that leads to more value from similar 
opportunities (Zhao et al., 2005; Davidsson and Honig, 2003). Furthermore, education includes not only the development of economic skills but also the focus on business realities (Păunescu et al., 2018) and improving one's effectiveness (Diaz-Garcia et al., 2015). Researchers advocate entrepreneurship education as an alternative to traditional learning about the basics of how to run a business. Topics of recognition and exploitation of opportunities, creativity, and innovation to promote social development (Sánchez, 2011) were also appreciated.

Research by Kerrin et al. (2017) confirmed that, even in emerging economies with poor education systems, courses in entrepreneurship increase the desire for entrepreneurship and entrepreneurship. Following the same idea, research conducted by Diaz-Garcia (2015) in the academic field demonstrates a higher interest in the desire to start a business in students after completing a course in entrepreneurship. Furthermore, Pajarinen et al. (2006) argued that the evidence suggests that educated entrepreneurs are more important in developing regional economies than less educated entrepreneurs. Accordingly, more educated entrepreneurs are more likely to innovate, use modern business models, and base their businesses on new technologies (Pajarinen et al., 2006).

However, some studies suggest that the influence of education on entrepreneurial intention is limited (Byabashaija and Katono, 2011) or has no effect on entrepreneurship (Praaf and Ophem, 1995). Specifically, a study in Serbia on the educational level of entrepreneurs showed that only $10.8 \%$ of the total number of entrepreneurs surveyed had a college or university degree, and the rest have less than a university degree or have not completed primary school (Stefanović and Stošić, 2012). This result is explained by unsatisfactory work conditions, so people choose to start a business or because of unemployment (Stefanović and Stošić, 2012). Deli (2011) argued that people with less ability to become entrepreneurs are not necessary, while those with higher skills choose to start a business because of opportunity. Research by Păunescu et al. (2018) pointed out that in Romania, it is not that the higher the educational attainment, the stronger the desire to start a business. Therefore, we need an overview of the role of education in entrepreneurship.

\subsection{Education system for entrepreneurship in Vietnam Invest in the education system in Vietnam}

Table 1: State budget spent on education system in Vietnam

\begin{tabular}{|c|c|c|c|c|}
\hline Criteria & $\mathbf{2 0 1 5}$ & $\mathbf{2 0 1 6}$ & $\mathbf{2 0 1 7}$ & $\mathbf{2 0 1 8}$ \\
\hline Budget for Education system (Billion USD) & 8.003 & 8.504 & 9.355 & 9.995 \\
\hline Budget for Higher system (Billion USD) & 0.664 & 0.850 & 0.907 & 0.996 \\
\hline $\begin{array}{c}\text { GDP of Vietnam (Billion USD) } \\
\text { Ratio of state budget expenditure for } \\
\text { education and training to GDP (\%) }\end{array}$ & 193.2 & 205.3 & 223.9 & 240.5 \\
\hline $\begin{array}{c}\text { Ratio of state budget expenditure for higher } \\
\text { education to GDP (\%) }\end{array}$ & 0.34 & 0.14 & 4.56 & 4.14 \\
\hline $\begin{array}{c}\text { Ratio of state budget for Higher system for } \\
\text { Education system (\%) }\end{array}$ & 8.3 & 10 & 9.42 & 0.41 \\
\hline
\end{tabular}

Source: Nguyen and Cicea (2019) 
Investment in the education system is an essential issue of any country. Table 1 shows the extent of national budget investment in the education system in Vietnam between 2015 and 2018. Through table 1, we can see that the percentage of Vietnam's budget investment in education is still low. Although the budget value increases, the level of investment in education accounts for a small proportion and has little change over the years. The investment rate for Vietnam's education system accounts for about $4.14 \%$ of the total GDP value (in 2017, there was an increase of $4.56 \%$ but decreased to $4.14 \%$ in 2018). Herein, the investment rate for higher education only accounts for about $10 \%$ of the total investment rate for the education system in Vietnam. It reflects that the Vietnamese government has not focused on investing in higher education and higher education but only investing in other levels of education such as secondary education and primary education. This result has a significant impact on entrepreneurship education activities in Vietnam.

\section{Some support programs for entrepreneurship education in Vietnam}

Identifying entrepreneurship and starting a business as key to economic development in Vietnam, the Vietnamese government also considers and focuses on promoting the development of entrepreneurship through support programs, education, and training programs for students and other entrepreneurs. In recent years, Vietnam has had some policies to promote the entrepreneurship of the country, including enacting through the "Supporting the national innovative start-up ecosystem to 2025" - Project 884; "Supporting start-up in students until 2025" project 1665, "Propaganda, education, advocacy and support for women to participate in solving some social issues related to women period 2017 - 2025" project 939 (Vietnamese Government, 2016a; 2016b; Vietnam Women's Union, 2017). These policies have had strong effects on entrepreneurship as well as starting a business in Vietnam. Furthermore, if there are more and more training programs, entrepreneurial activities are carried out on many levels and in many different localities. These programs not only contribute to the promotion of entrepreneurship but also enhancement of knowledge and information support of entrepreneurs. Therefore, this is a significant driving force contributing to the promotion and support of entrepreneurship and improving the sustainable development of businesses in Vietnam.

\section{Evaluation of entrepreneurship education in Vietnam}

To assess the overall performance of Vietnamese startup education, the author used two indicators, Basic School Entrepreneurial Education And Training and Post School Entrepreneurial Education And Training, from the GEM report. These are two indicators that give an overview of entrepreneurship education in Vietnam. The results in Table 2 show that the evaluation level of entrepreneurship education in Vietnam is low (Basic School Entrepreneurial Education And Training is under 2, and Post School Entrepreneurial Education And Training is under 3 out of 5 scales). Besides, this rating tended to decrease from 2013 to 2015 and recovered in 2017, but the overall trend is still down. It raises the issue that entrepreneurship education in Vietnam has not been focused on and is concerned by stakeholders. In addition, entrepreneurs have not yet appreciated the activities of the entrepreneurship education program at all educational levels in Vietnam.

In recent years, although the Vietnamese government has paid particular attention to the development of entrepreneurship education, the effectiveness of those 
educational programs is still limited. Therefore, an overview of the assessment of Vietnam's education policies on entrepreneurship and entrepreneurship is needed. From there, it provides some solutions and recommendations to the Vietnamese government that can make changes, adjust policies in a way that is suitable for different characteristics of different audiences and ensure the development, promote entrepreneurship, starts a business in Vietnam in the best way.

Table 2: Entrepreneurial Education in Vietnam over years

\begin{tabular}{|c|c|c|c|c|}
\hline Criteria & $\mathbf{2 0 1 3}$ & $\mathbf{2 0 1 4}$ & $\mathbf{2 0 1 5}$ & $\mathbf{2 0 1 7}$ \\
\hline Basic School Entrepreneurial Education And Training & 1.97 & 1.83 & 1.57 & 1.83 \\
\hline Post School Entrepreneurial Education And Training & 2.64 & 2.64 & 2.53 & 2.61 \\
\hline
\end{tabular}

Source: Global Entrepreneurship Monitor (2021)

\section{Research Methodology}

The purpose of this paper is to assess the actual impact of the education system on starting a business in Vietnam. From there, there is an overview of the role of education in entrepreneurship activities in Vietnam today. To achieve the above purpose, the paper has analyzed through statistic data collected from the survey of The Amway Global Entrepreneurship Report (AGER) in 2018. Accordingly, AGER is a global survey to survey the public about the state of entrepreneurship as well as the motivation and desire to start a business of individuals in countries around the world. The Amway Global Entrepreneurship Report (AGER) 2018 is based on a survey of 48,998 entrepreneurs in 44 countries in the world, including different continents. The data of the research were collected at the 2018 AGER survey. The question in the AGER Report relevant to the education system used for analysis is:

- With which of the following statements about your country do you agree?

- For starting and running a business, the education system in my country teaches people the skills they need.

To conduct an assessment of the influence of national policies on entrepreneurship, the analytical method used in this paper is the statistical analysis method. The data were entered, scanned, and analyzed through Microsoft Excel software to identify patterns and extract relevant factors for the study. The results are presented related to the data statistically.

\section{Results}

Out of the 48,998 observations obtained from the AGER report, the total number of observed samples in the AGER research data for the year for Vietnam includes 1040 observed samples. This paper will use all of these 1040 observed samples to conduct analysis in our research.

Statistical analysis results show that there is a high rate of agreement (more than $50 \%$ of individuals choose the given factors), and there is a significant difference in those ratings among the national factors affecting and running a business. However, the agreement rate on The influence of the education system on starting a business and running a business is the lowest (61.9\%) compared to other criteria such as The national tax policies which have the highest approval rate with $77.5 \%$ 
of respondents, followed by Beneficial economic situation (70.5\%), Technology availability $(66.5 \%)$, The national rules and regulations $(63.8 \%)$, and finally The national education system (61.9\%). This result proves that, although the influence of the education system is highly appreciated, it is still not considered in the factors affecting the operation and management of enterprises.

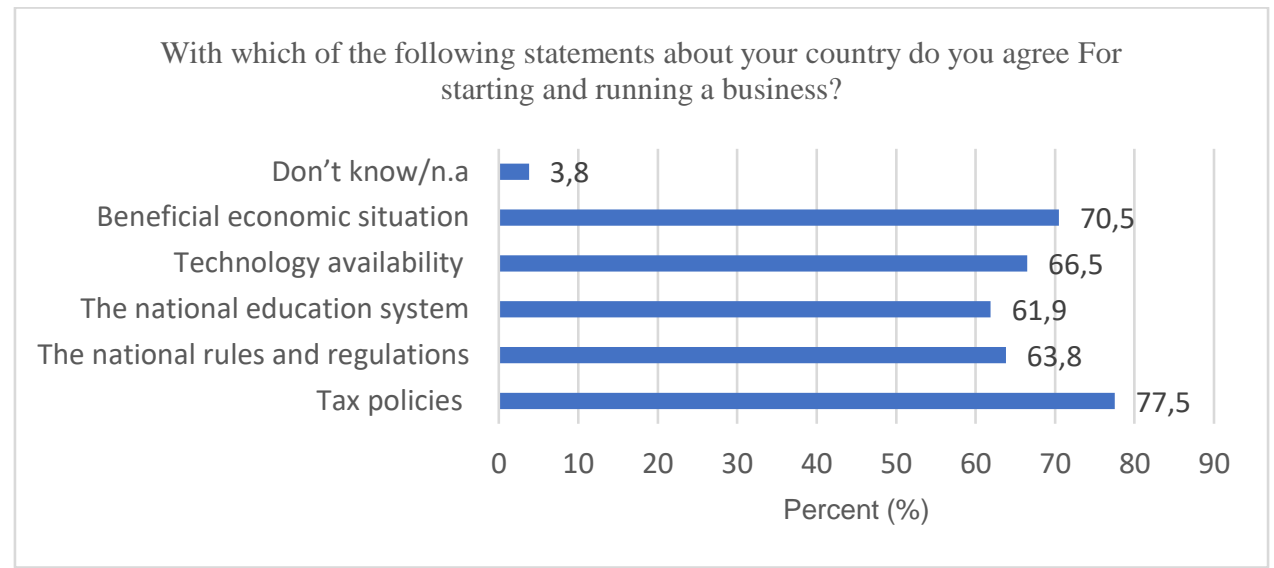

Figure 1: National factors affecting starting a business

Source: Compiled by the author using data from AGER.

In addition, comparing the difference between the assessment level in Vietnam compared with the average level in Asia and the average level in the world, the Vietnamese education system is rated higher than the average level of Asia (53\%) and the whole world (40\%). This result shows that the role of the education system still has a strong influence on entrepreneurship and starting a business in Vietnam.

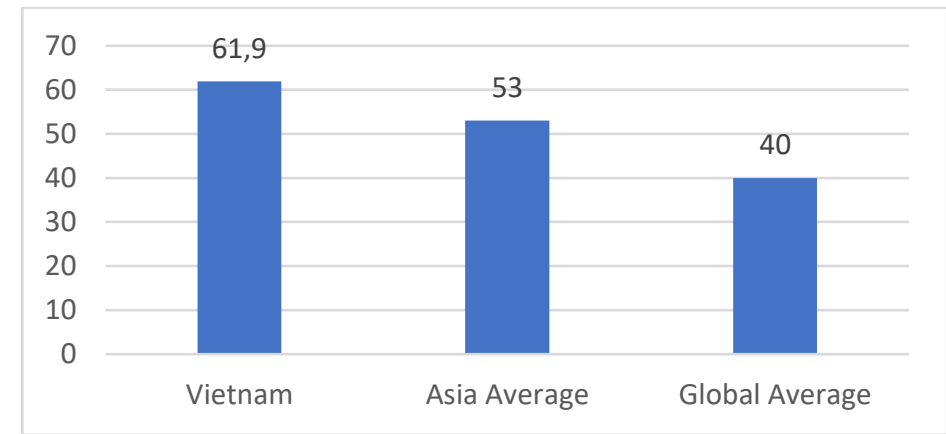

Figure 2: Comparison of consent rates for Vietnamese education with Asia averages and Global averages

Source: Compiled by the author using data from AGER.

To further clarify the difference in assessment for the education system in Vietnam, the paper continues to go into a detailed assessment of different target groups, characteristics, and criteria.

Statistical analysis shows a difference in the degree of agreement about the influence of the national education system in Vietnam on entrepreneurship. In 
detail, the consent rate of females $(67.3 \%)$ is higher than that of males $(55.9 \%)$. Regarding age, individuals with older age rated higher than individuals with younger. The consent rate of individuals aged from 36 to 69 was $67.7 \%$, and the individuals aged from 15 to 35 years old was $57.2 \%$. This result shows that there is a big difference in the assessment of age as well as gender.

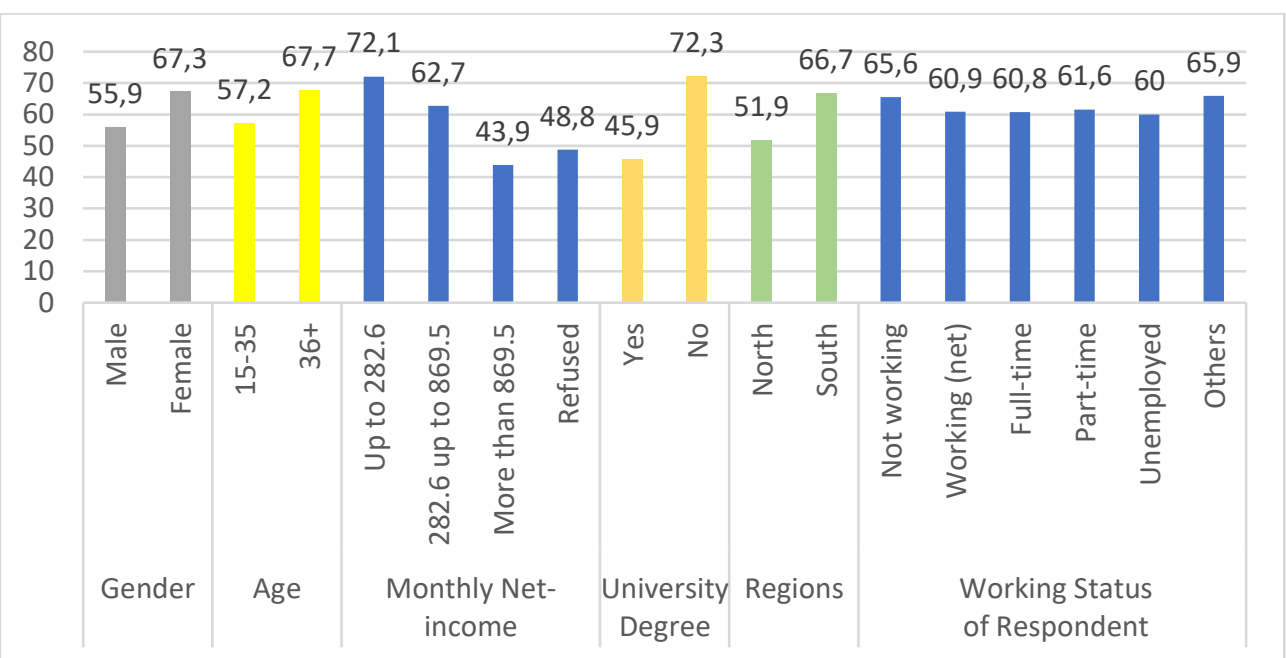

Figure 3: Differences in individual groups' evaluations of the education system Source: Compiled by the author using data from AGER.

Regarding the structure of respondents by Net-income, there is a tendency to gradually decrease the rate of agreement when the income of individuals increases. The highest rating rate was $72.1 \%$ for the lowest income group (\$280/month) and fell to $43.9 \%$ for the highest income group (more than $\$ 1300 /$ month). This result suggests quite interestingly that the higher the income, the less important the influence of education in providing the skills and knowledge needed to start a business.

Regarding university degrees, among the agreement respondents, $45.9 \%$ have a university degree, and $72.3 \%$ do not have a university degree. It is quite true with the proportion of people with university degrees in Vietnam today when the proportion of people with university degrees tends to increase over the years but still does not account for a high percentage of the population. Besides, in Vietnam, many people who do not have a university degree are hard to find a job, so they will start a business more than those who have a university degree. So, people without university degrees have some difficulties when they lack some knowledge to apply in their business activities, and they think that the education system will support this. However, studying in Vietnam is still academic, with much theory, little practice/practice, so the percentage of university degree holders agreeing is not high (only $45.9 \%$ ).

In addition, the agreement rate of individuals living in the South $(66.7 \%)$ is higher than that of respondents living in the North of Vietnam (51.9\%). This result is understandable because the economy in Vietnam is more developed and has a much more dynamic business environment than in the North. Therefore, many 
highly qualified people looking for job and business opportunities are higher in the South than in the North.

Regarding the characteristics of employment status, the group of Not working individuals had the highest rating $(65.6 \%)$ compared to the remaining groups with a fairly balanced assessment (about 61\%).

Through the analysis, the results show that there is the influence of the national education system on entrepreneurship in Vietnam is uneven. In this respect, the majority of surveyed individuals agree that the national education system has an influence on entrepreneurship and starting a business in Vietnam. Furthermore, the education factor is not the most important factor when starting a business. It is also influenced by internal factors of individuals as well as external social and environmental factors more than educational factors. In addition, characteristics such as age, monthly income, university degree, employment status, and place of residence are useful in determining differences in the influence of national education on entrepreneurship and starting a business.

\section{Discussion and Conclusion}

Entrepreneurs are always expected to improve their qualifications, knowledge, and skills to meet their learning needs, improve their professional skills and adapt to the changing business and social environment. From there, entrepreneurs can ensure the development and enhancement of enterprises' operations. Therefore, countries and governments need to have solutions and policies for the education and training system in a reasonable way to contribute to ensuring the development of entrepreneurship of individuals in the best way.

However, the results in this paper in Vietnam show that although the education system has an impact on entrepreneurship, it is the most underrated criterion compared to others when starting a business. Another aspect that needs to be mentioned is that education needs to focus on differences in individual characteristics because there are differences in assessment between different groups. From there, the government can come up with appropriate solutions to improve the effectiveness of the education system in promoting and supporting entrepreneurial activities and starting businesses.

In general, the national education system has many benefits, meanings. It contributes different significant roles in the development of the country and each individual. Thus, it can be seen and understood that an indispensable role of the education system is to help individuals have the foundation and initial knowledge and foster and improve each person's capacity. From there, its contribution is to help entrepreneurs start their business smoothly, limiting certain mistakes in their business process. Therefore, identifying and analyzing the influence, role, and relationship of education on entrepreneurship is an interesting issue. This issue needs to be studied the next time.

In addition, the study has some limitations. First, because it is based on the available data of AGER, there is little analysis of other aspects of the influence of the education system on entrepreneurship and starting a business. Besides, it is also hard to go into the specific analysis of the characteristics of the education system. Therefore, the study has many limitations and cannot generalize all the 
characteristics of the research subjects. These are good research directions that can be done in the future.

\section{References}

1. Augustine, I.J., Emmanuel, E.B., Sunday, A., Inalegwa, I. and Ogilegwa, A.D., (2018). Entrepreneurship Education and Economic Growth of Benue State (2007 2016). Journal of Business and Management, 20 (5), pp. 62-75.

2. Bae, T.J., Qian, S., Miao, C. and Fiet, J.O. (2014). The relationship between entrepreneurship education and entrepreneurial intentions: A meta-analytic review. Entrepreneurship theory and practice, 38(2), pp. 217-254.

3. Byabashaija, W. and Katono, I. (2011). The impact of college entrepreneurial education on entrepreneurial attitudes and intention to start a business in Uganda. Journal of Developmental Entrepreneurship, 16(01), pp. 127-144.

4. Charney, A. and Libecap, G.D., (2000). The impact of entrepreneurship education: an evaluation of the Berger Entrepreneurship Program at the University of Arizona, pp. 1985-1999.

5. Davidsson, P. and Honig, B. (2003). The role of social and human capital among nascent entrepreneurs. Journal of business venturing, 18(3), pp. 301-331.

6. Deli, F. (2011). Opportunity and necessity entrepreneurship: Local unemployment and the small firm effect. Journal of Management Policy and Practice, 12(4), pp. 38-57.

7. Díaz-García, C., González-Moreno, Á., and Sáez-Martínez, F.J. (2015). Ecoinnovation: insights from a literature review. Innovation, 17(1), pp. 6-23.

8. Díaz-García, C., Sáez-Martínez, F. and Jiménez-Moreno, J. (2015). Assessing the impact of the "Entrepreneurs" education programme on participants' entrepreneurial intentions. International Journal of Educational Technology in Higher Education, 12(3), pp. 17-31.

9. Do Paço, A., Ferreira, J.M., Raposo, M., Rodrigues, R.G. and Dinis, A. (2015). Entrepreneurial intentions: is education enough?. International Entrepreneurship and Management Journal, 11(1), pp. 57-75.

10. Drucker, P.F. (1985). Entrepreneurial strategies. California Management Review, 27(2).

11. European Commission, (2003). Green Paper: Entrepreneurship in Europe, Luxembourg.

12. Fairlie, R.W. (2011). Entrepreneurship, economic conditions, and the great recession. IZA Discussion Paper No. 5725. Bonn, Germany: IZA.

13. Fayolle, A., Gailly, B. and Lassas-Clerc, N. (2006). Assessing the impact of entrepreneurship education programmes: a new methodology. Journal of European Industrial Training, 30(9), pp. 701-720.

14. Fellnhofer, K. (2018). Narratives boost entrepreneurial attitudes: Making an entrepreneurial career attractive?. European Journal of Education, 53(2), pp. 218237.

15. Galloway, L. and Brown, W. (2002). Entrepreneurship education at university: a driver in the creation of high growth firms?. Education+ Training, 44(8/9), pp. 398405.

16. Gartner, W.B. (1988). "Who is an entrepreneur?" is the wrong question. American Journal Of Small Business, 12(4), pp. 11-32. 
17. Hartono, D. and Muzayanah, I. F. U. (2020). The roles of entrepreneurship on regional economic growth in Indonesia. Journal of the Knowledge Economy, 11(1), pp. 28-41.

18. Hussain, A. and Norashidah, D. (2015). Impact of entrepreneurial education on entrepreneurial intentions of Pakistani Students. Journal of Entrepreneurship and Business Innovation, 2(1), pp. 43-53.

19. Kerrin, M., Mamabolo, M.A. and Kele, T. (2017). Entrepreneurship management skills requirements in an emerging economy: A South African outlook. The Southern African Journal of Entrepreneurship and Small Business Management, 9(1), pp. 1-10.

20. Krueger Jr, N.F. and Brazeal, D.V. (1994). Entrepreneurial potential and potential entrepreneurs. Entrepreneurship theory and practice, 18(3), pp. 91-104.

21. Krueger, N.F., Reilly, M.D. and Carsrud, A. L. (2000). Entrepreneurial intentions: A competing models approach. Journal of Business Venturing,15(5/6), pp. 411-432.

22. Kuratko, D.F. (2005). The emergence of entrepreneurship education: Development, trends, and challenges. Entrepreneurship theory and practice, 29(5), pp. 577-597.

23. Mitchelmore, S. and Rowley, J. (2013). Entrepreneurial competencies of women entrepreneurs pursuing business growth. Journal of small business and enterprise development, 20(1), pp. 125-142.

24. Moore, C.S. and Mueller, R.E. (2002). The transition from paid to selfemployment in Canada: the importance of push factors. Applied Economics, 34(6), pp. 791-801.

25. Morales, C.E. and Feldman, P.M. (2013). Entrepreneurial skills, significant differences between Serbian and German entrepreneurs. Journal of CENTRUM Cathedra: The Business and Economics Research Journal, 6(1), pp. 129-141.

26. Nehete, R.S., Narkhede, B.E. and Mahajan, S.K. (2011). Investigation of entrepreneurial skills for better performance of manufacturing SMEs. International Journal of Engineering Science and Technology, 3(7), pp. 5515-5525.

27. Nguyen, T.H.T. and Cicea, C. (2019). Budget allocation policy for public higher education in Vietnam: a short radiography and future trends. In Proceedings of the International Management Conference (Vol. 13, No. 1, pp. 448-456). Faculty of Management, Academy of Economic Studies, Bucharest, Romania.

28. Okah-Efogo, F. and Timba, G.T. (2015). Female entrepreneurship and growth in Cameroon. African Journal of Economic and Management Studies, 6(1), pp. 107-119.

29. Pajarinen, M., Rouvinen, P. and Yla-Anttila, P. (2006), Ministry of Employment and the Economy, Helsinki.

30. Păunescu, C. and Molnar, E. (2020). Country's entrepreneurial environment predictors for starting a new venture-evidence for Romania. Sustainability, 12(18), 7794.

31. Păunescu, C. and Vidovic, D (2020), Social Entrepreneurship Education in Academia: A MOOC Scheme Analysis, Proceedings of the 3rd International Conference on Economics and Social Sciences, ISSN 2704- 6524, pp. 491-501.

32. Păunescu, C., Popescu, M.C. and Duennweber, M. (2018). Factors determining desirability of entrepreneurship in Romania. Sustainability, 10(11), 3893. 
33. Piperopoulos, P. and Dimov, D. (2015). Burst bubbles or build steam? Entrepreneurship education, entrepreneurial self-efficacy, and entrepreneurial intentions. Journal of small business management, 53(4), pp. 970-985.

34. Praag, C.M.V. and Ophem, H.V. (1995). Determinants of willingness and opportunity to start as an entrepreneur. Kyklos, 48(4), pp. 513-540.

35. Prasetyo, P.E. and Kistanti, N.R. (2020). Human capital, institutional economics and entrepreneurship as a driver for quality \& sustainable economic growth. Entrepreneurship and Sustainability Issues, 7(4), pp. 2575-2589.

36. Riquelme, H.E. and Al-Lanqawi, A.M. (2016). The desire that propels entrepreneurial intentions. Journal of Entrepreneurship, Management and Innovation, 12(2), pp. 123-150.

37. Sánchez, J.C. (2011). University training for entrepreneurial competencies: Its impact on intention of venture creation. International Entrepreneurship and Management Journal, Vol. 7 No. 2, pp. 239-254.

38. Shepherd, D.A. and DeTienne, D.R. (2005). Prior knowledge, potential financial reward, and opportunity identification. Entrepreneurship theory and practice, 29(1), pp. 91-112.

39. Stefanović, S. and Stošić, D. (2012). Age and education as determinants of entrepreneurship. Facta Universitatis-series Economics and Organization, 9(3), pp. 327-339.

40. Tkachev, A. and Kolvereid, L. (1999). Self-employment intentions among Russian students. Entrepreneurship \& Regional Development, 11(3), pp. 269-280. 41. Uzunidis, D., Boutillier, S. and Laperche, B. (2014). The entrepreneur's 'resource potential'and the organic square of entrepreneurship: definition and application to the French case. Journal of Innovation and Entrepreneurship, 3(1), 1. 42. Varadarajan Sowmya, D., Majumdar, S. and Gallant, M. (2010). Relevance of education for potential entrepreneurs: an international investigation. Journal of small business and enterprise development, 17(4), pp. 626-640.

43. Vietnam Women's Union (2017). Propaganda, education, advocacy and support for women to participate in solving a number of social issues related to women period 2017 - 2025. Project No.939. [07 Nov 2021] (In Vietnamese).

44. Vietnamese Government (2016a). The project "Supporting the national innovation start-up ecosystem to 2025". Project No.884. [Online], Available: http://vanban.chinhphu.vn/portal/page/portal/chinhphu/hethongvanban?class_id=2 \&_page $=1 \&$ mode=detail\&document_id=184702, [07 Nov 2021] (In Vietnamese). 45. Vietnamese Government (2016) $)$. The project "Supporting start-up in students until 2025". Project No.1665. [Online], Available: https://thuvienphapluat.vn/vanban/Giao-duc/Quyet-dinh-1665-QD-TTg-2017-de-an-Ho-tro-hoc-sinh-sinh-vienkhoi-nghiep-den-nam-2025-365846.aspx. [07 Nov 2021]. (In Vietnamese).

46. Zhang, Y., Duysters, G. and Cloodt, M. (2013). The role of entrepreneurship education as a predictor of university students' entrepreneurial intention. International Entrepreneurship and Management Journal, 10, pp. 623-641.

47. Zhao, H., Seibert, S.E. and Hills, G.E. (2005). The mediating role of selfefficacy in the development of entrepreneurial intentions. Journal of Applied Psychology, 90(6), 1265. 


\title{
SMART TOURISM DESTINATION
}

\section{Monica FAUR ${ }^{1}$, Olimpia BAN ${ }^{2}$}

'Doctoral School of Economic Sciences, Faculty of Economic Sciences, University of Oradea, Oradea, Romania

${ }^{2}$ Department of Economics and Business, Faculty of Economic Sciences,

University of Oradea, Oradea, Romania

faurmonica1984@gmail.com

olimpiaban2008@gmail.com

\begin{abstract}
The dynamic of the contemporary society has determined the implementation of the technology in all areas of activity. The tourism sector has answered the new challenges by offering some alternatives aimed at ensuring the increase of the tourism destinations competitiveness: using ICT to collect data, information about tourists, using new technologies in order to increase tourists' satisfaction and locals' welfare; the interconnectivity of the interested parties (authorities, tourism service providers, tourists, locals) through digital platforms; offering a unique experience, customized services to tourists using ICT, increasing the degree of competitiveness of the tourism destinations and their sustainable development with the help of new technologies; the innovation offered by ICT as differentiation element of the tourism offers of a destination. Thus, the smart tourism destination represents an approach centred on capitalizing the advantages offered by ICT contributing to the increase of competitiveness and sustainability of tourism destinations. The purpose of this paper is to present different approaches of the smart tourism destination.
\end{abstract}

Keywords: tourism destination; smart tourism destination; ICT.

JEL Classification: A1; M1; Z3; Z31; Z32; Z33.

\section{Introduction}

According to the World Tourism Organization (2019) smart tourism is a step forward in respect to the destination management and it involves: management, innovation, technology, accessibility and sustainability (World Tourism Organization, Digital Transformation, 2019).

As far as the European Commission's approach is concerned, smart tourism is a type of tourism that answers the new challenges and demands of this sector, which undergoes continuous changes, including the evolution of the digital tools, products and services, equal opportunities of access to all tourists, sustainable development of the areas, support for creative industries and local heritage (European Commission, Tourism, 2020).

In 2018, the European Commission started for the first time a competition in order to designate the "European Capital of Smart Tourism". 38 cities and 19 Member States of the European Union applied for the title of European Capital of Smart Tourism in 2019. In 2019, the winners were: Helsinki and Lyon. In 2019, the competition for the European Capital of Smart Tourism was organized in 35 cities 
from 17 Member States of the European Union. Gothenburg and Málaga were declared winners of the title of European Capital of Smart Tourism for 2020.

The cities participating in the competition were invited to present and share their innovative projects, ideas and initiatives implemented in each of the four sections of the competition: accessibility (opportunity to travel for all tourists even for those with disabilities, means of transport, which ensures easy access to all categories of tourists), digitalization (offering products and services using ICT), sustainability (protection of natural and human resources in balance with the economic development), cultural heritage and creativity (efficient exploitation of the cultural heritage and creative industries so as to offer unique experiences to tourists) (European Commission, European Capital of Smart Tourism, 2020).

\section{Methodology of the research}

This paper seeks to highlight different approaches regarding smart tourism destination. The steps performed in carrying out this research were the following: studying the literature, selecting the papers according to the number of citations using the Google Scholar database, qualitative analysis of the selected papers and issuing some conclusions.

\subsection{Smart tourism destination}

Lamfus and Alzua-Sorzabal (2013) define the smart tourism destination by taking into account the manner in which technology can help the destination become a more suitable place to meet the needs of locals and tourists. As far as the "smart city" notion is concerned, Lamfus and Alzua-Sorzabal (2003) consider that the entire concept and its development is based on the development and implementation of the Information and communications technology (ICT) and on the involvement of the city's citizens.

The authors approach the concept through the implementation of new technologies in the performance of tourism activities, in order for these to contribute to the increase of tourists' satisfaction and the locals' welfare.

Buhalis and Amaranggana (2013) consider that the implementation of technology in tourism destinations requires interconnecting the interested parties by means of platforms, with the help of which information on tourism activities can be immediately accessed.

Buhalis and Amaranggana (2013) believe that the purpose of using ICT in tourism activities is to enhance the tourism experience, to improve the efficiency of resource management in order to maximize both the competitiveness of the destination and consumer satisfaction, while demonstrating long-term sustainability.

Buhalis and Amaranggana (2014) state that smart tourism destinations are essential for providing personalized services to tourists, taking into account several aspects including: real-time access to information in order to collect data regarding the users, giving feedback on the provided services as well as a dynamic platform, which would allow the exchange of information between the interested parties so as to promote integrated services.

The approach formulated by Buhalis and Amaranggana points out to the entire complexity of the concept in terms of the interested parties and of the advantages arising from the implementation of ICT in tourism destinations. 
Gretzel et al (2015) define smart tourism as the one supported by integrated efforts within a destination in order to find innovative ways to collect and capitalize the data derived from the exploitation of the infrastructure, social connections, government sources and people, together with the use of advanced technologies in order to transform them into experiences, valuable business proposals with a clear emphasis on efficiency, sustainability and new experiences during the trip.

The authors interpret the smart tourism destination as a useful tool for obtaining valuable information from all interested parties.

Lamfus et al (2014) consider that a tourism destination is smart when it intensively uses the technological infrastructure provided by a smart city to: improve the tourism experience and empower destination management organizations, local institutions and tourism companies in order to take decisions and act on the information collected, managed and processed through the technological infrastructure. In the authors' view, the use of ICT for obtaining valuable information represents the main advantage for the interested parties. Information that helps to establish decisions on the design of new tourism products and their marketing in the most advantageous conditions.

Lopez de Avila (2015) defines the smart tourism destination as being based on a state-of-the-art infrastructure, guaranteeing the sustainable development of tourism areas and facilitating the interaction and integration of tourists, improving the locals' quality of life. This definition is of topicality and it highlights the need to redirect the management policies of the tourism destination for the medium/long term performance of sustainable tourism activities in order to ensure the integration and interaction of tourists and the increase of locals' quality of life.

Xiang et al (2015) consider that the smart tourism destination has been adopted as a strategic tool for destinations around the world, in order to support the provision of tourism experiences to tourists, to efficiently communicate with consumers and to measure and evaluate the competitiveness of the tourism destination. The definition stated by the authors represents a vision that has communication as a central element. The purpose of this communication is to obtain information, process it and then create tourism products and services that would generate the increase of the competitiveness of the tourism destinations.

Vargas-Sánchez (2016) suggests the following definition: the smart tourism destination is based on an extensive use of state-of-the-art technologies in order to create an advanced digital space through an integrated network of management systems, platforms, any kind of data so as to improve the overall management of the destination and to ensure its differentiation and competitiveness.

$\mathrm{Li}$ et al (2016) consider that smart tourism represents the ideal place to meet the tourists' needs and increase their satisfaction, while achieving the distribution and use of resources. Li et al (2016) also appreciate that smart tourism represents an omnipresent tourism information service offered to tourists during the trip and a bilateral flow of information between the tourists and the interested parties (2016). In comparison to the previously formulated approaches, the authors note the role of technology implementation in tourism activities as a means of efficient use of resources (human, financial, material and informational). These resources contribute to the achievement of the objectives of any tourism destination, namely attracting tourists.

Jovicic (2017) formulates an approach according to which the smart tourism destination is a knowledge-based destination, where ICT is used in order to provide 
a platform that allows a quick exchange of information regarding the tourists. According to this point of view, the use of ICT in choosing a tourism destination represents a cognitive process based on tourists' selection of the information obtained from different sources: Internet, specialized tourism sites, travel blogs and tutorials. By using technology, the tourist has very fast access to information sources on tourism products or services $\mathrm{s} / \mathrm{he}$ is interested in.

Vecchio (2017) formulates as the final objective of the smart tourism destination the increase of the tourism experience maximizing the destination competitiveness and consumers' satisfaction paying attention to long-term sustainability. Supplying some tourism products, designed to meet the tourists' needs, leads to a favourable position on the tourism market, in accordance with the principles of a sustainable exploitation and development of natural and anthropogenic tourism resources.

Jasrotia and Gangotia (2018) link smart tourism destinations with smart cities. Starting from this premise, the authors define the smart tourism destination as smart cities that use information technology and innovations to offer pleasures and experiences to tourists. The authors condition the development of smart tourism by the cities where ICT has been successfully implemented. This fact would limit the possibility to develop smart tourism in rural areas, even in case the infrastructure of these places would allow it.

Liberato et al (2018) state that a smart tourism destination should be able to incorporate technological development and develop innovative activities. Moreover, these destinations should also be able to combine these capabilities with digital spaces, information processing and tools, which allow transferring the technology and exchanging knowledge. The authors' approach offer a technical perspective on the concept of smart tourism regarding the implementation of new technologies in the tourism sector.

Serra and Baidal (2018) consider that smart tourism destinations are receiving an increasing attention from government organizations and destination management organizations, by means of policies implemented in many destinations. The same authors (2018) state that the impact of the policies regarding smart tourism destination remains largely unknown. In this context, the destination management organizations (DMO) play a central role in implementing government policies on smart tourism.

Shafiee et al (2019) talk about smart sustainable tourism destination and consider that the major challenge of current tourism destinations is to find solutions, which would allow a smarter use of resources and improve the locals' and residents' quality of life through sustainable means. The authors approach the concept from the point of view of the new directions that should be pursued in the development of tourism activities for tourism destinations.

In Figure 1, a schematic representation of the elements that contribute to the delimitation of the concept of smart tourism destination was created. 


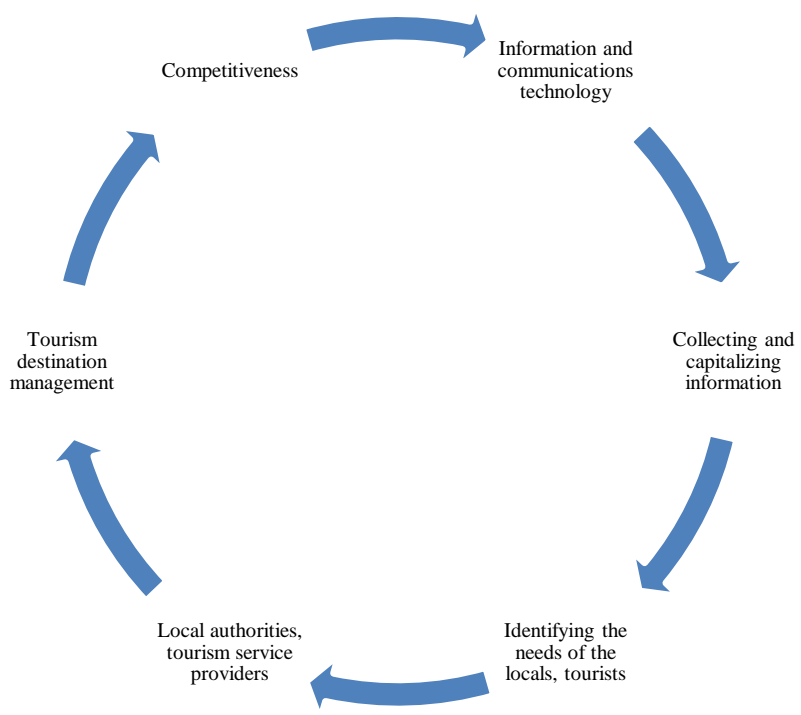

(Source: Made by the author)

Figure 1: Approaching the concept of smart tourism

\section{Limitations and further research}

The smart tourism destination represents a way to correlate the needs of tourists with the interests of the tourism service providers and local authorities by using ICT. This approach of the tourism destination issue represents a common result of all the interested parties so as to ensure the competitiveness of tourism destinations, under the conditions of the ICT implementation in the performance of tourism activities.

This paper represents an attempt to illustrate different points of view regarding the smart tourism destination. The limits of this paper are given by the fact that a selection of specialized papers was made using only the criterion of the number of citations thus, not achieving a global presentation of this issue.

In the future, it would be advisable to study the interdependence between the current approaches of the concept of tourism destination: smart tourism destination, sustainable tourism destination and friendly tourist destination.

\section{References}

1. Buhalis, D. and Amaranggana, A. (2013) 'Smart Tourism Destinations', Information and Communication Technologies in Tourism, pp. 553-564, DOI: 10.1007/978-3-319-03973-2_40.

2. Buhalis, D. and Amaranggana, A. (2014) 'Smart Tourism Destinations Enhancing Tourism Experience Through Personalisation of Services', Information and Communication Technologies in Tourism, pp. 377-389, DOI 10.1007/978-3319-14343-9_28.
3. European
Commission,
Tourism, https://ec.europa.eu/growth/sectors/tourism/offer/sustainable en, [29 Dec 2020]. 
4. Femenia-Serra, F. and Ivars-Baidal, J.A. (2018) 'Do smart tourism destinations really work? The case of Benidorm ', Asia Pacific Journal of Tourism Research, DOI: 10.1080/10941665.2018.1561478, pp. 1-20.

5. Gretzel, U., Kopera, S. and Koo, C. (2015) 'Smart Tourism Challenges', Journal of Tourism, Vol. XVI, No.1, pp. 41-47.

6. Gretzel, U., Sigala, M. and Xiang, Z. (2015) 'Smart tourism: foundations and developments', Electronic market, pp. 314-323.

7. Gretzel, U., Werthner, H., Koo, C. and Lamsfus, C. (2015) 'Conceptual foundations for understanding smart tourism ecosystems', Computers in Human Behavior 50, pp. 558-563.

8. Jasrotia, A. and Gangotia, A. (2018) 'Smart cities to smart destinations: A Review Paper', Journal of Tourism Intelligence and Smartness, Vol. 1, Issue 1, pp. 47-56.

9. Jovicic, D.Z. (2017) 'From the traditional understanding of tourism destination to the smart tourism destination', Current Issues in Tourism, pp. 1-7, DOI: $10.1080 / 13683500.2017 .131320$

10. Lamsfus, C. and Aurkene, Alzua-Sorzabal (2013) 'Theoretical Framework for a Tourism Internet of Things: Smart Destinations', tourGUNE Journal of Tourism and Human Mobility, pp.1-21.

11. Lamsfus, C., Martin, D., Alzua-Sorzabal Aurkene and Torres-Manzanera, E. (2014) 'Smart Tourism Destinations: An Extended Conception of Smart Cities Focusing on Human Mobility', Information and Communication Technologies in Tourism, pp. 363-375, DOI 10.1007/978-3-319-14343-9_27.

12. Li, Y., Hu, C., Huang, C. and Duan L. (2016) 'The concept of smart tourism in the context of tourism information services', Tourism Management, pp. 1-8, http://dx.doi.org/10.1016/j.tourman.2016.03.014.

13. Liberato Costa, P.M., Alén-González, E. and Azevedo Liberato, D.F.V. (2018) 'Digital Technology in a Smart Tourism destination: The Case of Porto', Journal of Urban Techology, DOI: 10.1080/10630732.2017.1413228,pp. 1-47.

14. López-Sánchez, Y. and Pulido-Fernández, J. (2017) 'Factors influencing the willingness to pay for sustainable tourism: a case of mass tourism destinations', International Journal of Sustainable Development \& World Ecology, 24:3, pp. 262-275, DOI: 10.1080/13504509.2016.1203372.

15. Shafiee, S., Ghatari, A.R., Hasanzadeh, A. and Jahanyan, S. (2019) 'Developing a model for sustainable smart tourism destinations: A systematic review', Tourism Management Perspectives, 31, pp. 287-300.

16. Vargas-Sánchez,A. (2016) 'Exploring the concept of smart tourist destination', Enlightening Tourism. A Pathmaking Journal, 6 (2), pp. 178-196.

17. Vecchio, P. (2017) 'Creating value from Social Big Data: Implication for SmartTourism Destinations', Information Processing and Management, pp. 1-13, http://dx.doi.org/10.1016/.ipm.2017.10.006.

18. World Tourism Organisation, Policy and Destination Management, https://www.unwto.org/policy-destination-management, [03 lan 2021].

19. World Tourism Organisation, Tourism Statistics Data, https://www.unwto.org/tourism-statistics-data, [23 lan 2021].

20. Xiang, Z., Tussyadiah, I. and Buhalis, D. (2015) 'Special Issue on Smart Destinations: Foundations, Analytics, and Applications', Journal of Destination Marketing \& Management, 4(3), pp.143-144. 


\title{
DIGITAL PROMOTION FOR HOTELS OF BĂILE FELIX- VÂRTOP RESORTS. CONTENT QUALITY ANALYSIS
}

\author{
Miruna Diana MOZA \\ PhD Field: Business Administration, Doctoral School of Economics, University of \\ Oradea, Oradea, Romania \\ moza.miruna@gmail.com
}

\begin{abstract}
Nowadays, digital promotion is a new "means" of communication between companies and the potential customer. One of the basic tools as regards the online promotion in the tourism industry, respectively the hotel industry is the website. This is a complex business card, conveyed by technology, a digital sample provided to the customer, a first impression that may bring less or more value. The website aims to direct all efforts in making known the package/service offered, to provide potential customers with all the necessary information, to determine potential customers to visit and also to act. Thus, this paper aims to analyze how hotels in two tourist resorts situated in Bihor county, namely Băile Felix and Vârtop Arieșeni, are promoted via the website. The paper proposes a specific grid for websites analysis, based on observation, using the FisherRosenberg pattern as a method of scaling and drawing a series of conclusions, of trends and main shortcomings and possibilities for improvement.
\end{abstract}

Keywords: digital promotion; website; hotel industry

JEL Classification: M31; M37; Z33; L83

\section{Introduction}

The emergence of the Internet has led to the change of some essential elements in the field of promotion. However, the phenomena that led to this change may be rendered into two words, namely: digitalization and connectivity. The first of these two, digitalization, aims to change information, texts, images and sounds into a socalled bitstream that can be sent in real time from one corner of the world to any other place and connectivity refers to the creation of computer networks.

The hospitality and tourism industry has been one of the so-called major beneficiaries of this change, both in terms of services provided, new types of businesses adopted and the method used to communicate with customers. (Tajeddini, Ratten, Merkle, 2020) The Internet has become over time one of the most used means of communication in the tourism sector, being the optimal channel for creating the connection between the tourism economic operator and the potential customer. Thus, there has been a swift change in the way customers have begun to interact with businesses in this field, especially in terms of information relevance and time efficiency. (Ferreira, Ratten, Dana, 2017)

In this context, the digital promotion was also integrated, the promotion process also crossing the boundaries of digitalization. According to N. Lupu, most customers use these digital channels "to buy holidays, to book tickets for various means of transportation, hotel rooms or any other tourist services", the internet becoming today, one of the most important sources of tourist information. (Lupu, 
2010). In response to these activities and due to the mobility that characterizes the tourism industry, namely the fact that unlike other industries, it is the only one in which supply can not move towards the demand, digital promotion has gained more and more ground.

The internet continued thereby to have a significant influence on tourism and travels. H. Kim, Z. Xiang \& R. Fesenmaier analyzed a series of data taken from the Pew Research Center, according to which, in $2010,73 \%$ of US Internet users were searching online for information about travel. (Kim, Xiang, Fesenmaier, 2015). Another similar study and its results are presented by Eurostat. According to this study, in 2014, 4 out of 10 Europeans searched online for travel information, being deemed a major communication channel for the tourism sector. (Eurostat, 2015). Thus, in order to meet them and to be able to provide all the necessary information in order to attract customers, digital promotion was indeed necessary. Now, more than ever, in this pandemic context which has been a turning point for tourism, digital promotion plays a crucial role.

Having as main motivations: presence in the virtual space, dissemination of information, customer service, increasing public interest, access to various important target markets (Saviciuc, 2016), digital promotion is an essential pillar of the existence of a tourism business today. R.O. Yusuf stated that there existed a close relationship between the consumer's decision to buy and the information transmitted via the relevant websites with quality content. (Yusuf, 2009). Hence, this article mainly analyzes the websites, as they represent a more complex business card through technology, a digital sample given to the potential customer, a signature, a first impression that may bring less or more value depending on the quality and the experience provided.

Following an analysis performed in 2014, on all existing hotels in the List of tourist facilities with classified accommodation function, according to Cojocea MariaLuminiţa, promotion in the tourism industry is an issue that needs to be improved, the online promotion being the solution necessary to save tourism. Following this analysis, the conclusions were that "most hotels do not know how to promote themselves, often, in fact aggravating their situation by promotion." (Luminița, 2014)

Starting from the above and the increasing importance of business digitalization in this field, this paper aims to supplement and implicitly continue the work previously presented, analyzing promotion means in the digital environment, respectively the websites of the hotels within two tourist resorts in Romania, Bihor County, namely: Băile Felix and Vârtop Arieșeni both in terms of quantity and quality. This research comes as an update of the previous one, having the purpose of marking the evolution during the 7 years and at the same time having as starting point a series of hypotheses established on the basis of the mentioned research.

\section{The research purpose and methodology (content analysis of the pension websites in Felix and Vârtop Arieșeni)}

The decisional topic of this paper arises from the need of a thorough and in-depth approach to the analysis of digital promotion in Romanian tourism, respectively hotels, especially those situated in two areas near Oradea, one of the most developed Romanian cities, which has recently become a tourist city and enjoys 
the admiration of both national and international tourists. Thus, in order to perform this analysis, two tourist areas were chosen, namely the area of the Apuseni Mountains and Băile Felix area. Following the analysis of the interregional study on rural tourism development and employment boosting in Bihor and Covasna counties (O.T.P Consulting, 2015) it was noted that tourism in Bihor county is concentrated within two geographical poles, namely Apuseni Mountains and Băile Felix. Starting from this, Băile Felix and Vârtop (Arieșeni) were chosen as resorts of interest for the analysis. Although the second listed resort is located on the border between Bihor county and Alba county, Bihor county has no other resorts in this area (of the Apuseni mountains) that may be analyzed (e.g. Stâna de Vale- one hotel), thus opting for the analysis of the mountain resort Vârtop (Arieșeni).

Baile Felix is the largest spa in Romania, enjoying a special position in the west of the country, the main attractions being the thermal waters, wellness centers, hotels and treatment centers (Strutz, 2020). As regards the accommodation capacity, the resort has numerous accommodation facilities, namely 16 hotels, pensions and villas, cumulating a total of over 7,000 accommodation places, respectively 11,000 according to other sources. (Ban, Droj, 2019).

Vârtop-Arieșeni is an area also situated in western Romania, on the boundaries of Alba and Bihor counties, being a mountain area characterized by karst regions, an element that offers a high potential in terms of tourism. A mountain area with attractive landscapes and known for winter sports, hikes and tourist attractions unique in the country, the resort has a tourist potential which, according to studies is insufficiently exploited. (Dudaș, 2009).

The purpose of this research is to create an overview on the way the hotels of the two resorts are promoted in the digital environment and simultaneously identify remedial solutions. The hotel network in Bihor county.

Starting from the conclusions of the paper "Online promotion of hotels in Romania: Compromise between deficiencies and advantages?" published in 2014 by Luminița Cojocea, according to which all tourism promotion campaigns are inefficient as at the micro level, "respectively at the level of the accommodation establishment, the situation is inapproprate to promotion" (Cojocea, 2014) the research objectives were:

identification of of the hotel establishment in the digital environment (especially of its own website) and of a general data set

development of the analysis grid

analysis of the website complexity and evaluation of the items set in the grid (using the Fishbein-Rosenberg scaling method)

determining the general score for each hotel establishment

finding the most common deficiencies and their relevance

development of a general set of conclusions and recommendations

Having as reference work the one mentioned above and at the same time, a series of data and statistical analyzes used, the following hypotheses were set:

$\mathrm{H} 1$ : Incidence of unpleasant situations is found among two and three-star hotels

$\mathrm{H} 2$ : The description of the hotel is blended into the description of the resort/area where the hotel is situated

H3: Promotion is inappropriately performed, is of medium and low quality (50 points-30 points)

The research method used to obtain the necessary data was observation. This research method, although time consuming, aims to record patterns or people, 
objects or events, in a systematic manner, the purpose being to obtain information of interest, (Naresh, 2004). In this case, the purpose was to register patterns in order to identify the ways of digital promotion used by hotel establishments. Moreover, it was decided to use a structured observation, in which plans for the data selection and registration are explicitly used. Thus, for the purposes of observation, an observation grid was set, respectively a plan provided with all the factors to be analyzed and subsequently evaluated. The research used disguised observation, this being simultaneously an assisted one, because the observation was made electronically, using the computer and the Internet.

An evaluation grid has been established for carrying out the research. 20 items were included in this evaluation grid. Each item has been assigned an importance on a scale of 0 to 10 as follows, depending on their importance to the customer:

Table 1: Evaluated items and their importance

\begin{tabular}{|l|l|}
\hline Item & Importance \\
\hline Errors or non-existent web domains & 10 \\
\hline Organization's slogan identified on the site & 2 \\
\hline Administrative information & 3 \\
\hline Room and service presentation & 10 \\
\hline Presentation of rates & 10 \\
\hline Existence of images & 10 \\
\hline Online booking & 8 \\
\hline Online payment & 8 \\
\hline Existence of contact information & 10 \\
\hline Existence of the map and location of the hotel & 8 \\
\hline Connection - Customer account & 5 \\
\hline Newsletter subscription & 4 \\
\hline External link to social networks & 9 \\
\hline Existence of a search button & 5 \\
\hline Bilingual site (available in several languages Ro/En) & 10 \\
\hline Site adapted to the mobile phone & 10 \\
\hline Text-graphics percentage (30\% -70\%) & 8 \\
\hline Attractive design & 8 \\
\hline Existence of the testimonial section & 8 \\
\hline Using the natural environment as a promotional element & 7 \\
\hline
\end{tabular}

Source: Created by author

Each item has been subsequently evaluated, on a scale from 0 to 10 as 0 represents a degree of non-fulfillment of the item, 5 represents a partial degree of fulfillment and 10 an integral degree of fulfillment. In order to establish these scales and the general score for each hotel establishment, the Fishbein-Rosenberg scaling method was used. This method of scaling allows the evaluation of the stimuli that have been analyzed considering the importance assigned to each criterion and the degree of fulfillment. Being also referred to as the scale with a constant sum distributed as a percentage among the research variables or on all 
stages of the scale, this is the most efficient general solution of the report scale." (Săvoiu, 2004).

Thus, a number of 12 hotels of the two previously mentioned resorts were analyzed. The sampling was of the census-type. In order to conduct the research, a list of hotel establishment has been drawn up based on the on-site visits and the information available on the Booking.com website. The initial sample included all the hotels in the two resorts, but from this point of view the research was limited, namely the lack of their own websites about many establishments or their group (the case of SC Turism Felix SA), thus, the analysis included hotels that have their own website. We analyzed 8 hotels in Băile Felix and the 5 websites that belong to S.C Turism Felix S.A. and 3 hotels in Vârtop-Arieșeni, these are the only ones that have their own website.

\section{Research results. Most commonly deficiencies found}

After analyzing the 12 hotels and drawing up an overall score based on the evaluation grid created and the method of scaling use (Fishbein Rosenberg), it turned out that $83.33 \%$ of hotels scored above average, which suggests a relatively high interest of hotels regarding to promotion via their own website. As for the hotels in Băile Felix, $77.77 \%$ of the establishments reached scores above average and in Vârtop resort, out of a total of 3 hotel establishments, all reached an average score. The scores obtained were higher in terms of hotels in Băile Felix, compared to hotels in Vârtop resort.

Only one of the websites analyzed presented errors, being temporarily closed and the following message was displayed on the site's page: "We will be back soon", thus, out of a total of 12 hotels, we subsbequently focused on 11 of them. The second criterion analyzed, namely the existence of a slogan, was of little importance, due to the low attention that the client pays to them. Out of the total of 7 hotel establishments, they posted their slogan on the site, these being simple slogans such as "Thank you, our pleasure!" -Hotel Hyperion - Băile Felix or "Relaxing at the foot of the mountain" - Hotel Zâna Văii Arieșeni. However, a series of errors were also identified, being noticed a slogan such as: "Special services. Rooms from eur 60/night". Thus, it was found that both potential customers and hotel owners attach little importance to this fact.

The hotel description presents administrative data regarding the number of available rooms, buildings, etc., all hotels falling within a standard pattern of description. Another "key" element unanimously accepted and found in the presentation of hotels was the presentation of the rooms, with the exception of one of them. A similar importance, i.e. 10 points, was attached to the presentation of rates. In this context, a percentage of $66.66 \%$ of the analyzed sites posts their rates. A common deficiency was the presentation of the prices of the promotional packages on the occasion of the Easter or Christmas holidays, the standard prices for extra-season periods not being indicated.

The third element of major importance is deemed to be the existence of images. Their importance is known and understood by all hotels. Regardless of the quality of the images, all the analyzed hotels have a photo gallery section, respectively images.

Online booking, another element of high importance being conferred 8 points, is a shortcoming for hotels in the two areas. Less than $50 \%$ of them $(41.66 \%)$ have this 
tool, for the rest of the hotels, the booking being made either through other sites such as Booking.com or by phone. Simultaneously with the analysis of online bookings, the analysis of the possibility to pay online was also performed. Likewise, in this area, the analyzed hotels have deficiencies, so only 1 of the 5 hotels that have the possibility to book online, also ensures the possibility to make payment by card, which is currently a major deficiency.

The importance of contact information, a set of vital information, is understood by hoteliers, this aspect being checked by all hotels, including the one whose site is temporarily closed. The map, another tool that comes to meet the customer's needs, facilitating an additional activity to be carried out by that individual, is a strong point of $75 \%$ of the hotels under analysis.

Another analyzed aspect, with a relatively low importance, represented the client account, this being set up for the purpose of customer loyalty-enhacing, respectively keeping. Only one of the analyzed hotels has such a possibility, the interaction with the "house customers" being this way much easier. The possibility of subscribing to the newsletter also fell into the same category, with a similar purpose. However, this possibility is ensured by the only hotel mentioned above, namely Hotel Lotus Therm Băile Felix, the hotel that recorded the highest score in the evaluation grid.

External links to social networks, although they represent today a "must-have", we may assert that they still constitute a deficiency. $75 \%$ of the hotel sites grant this possibility, but even in these cases the links are not visible or represent only the addresses that need to be accessed, without incorporating a hyperlink. Their purpose is to meet the potential customer and familiarize it with the whole story and, respectively, to put it in touch with all the ways to promote the hotel. Furthermore, about the aim to meet the customer's needs is the following aspect analyzed, namely the existence of the search button, the search bar, which, although has a relatively low importance, gives the site a note of efficiency. However, a small percentage of hotels use this tool (33.33\%).

One of the most important aspects was the availability of the site in several languages. We deemed this aspect to be an essential one related to the position of Bihor county, close to the borders and the need to make available these resorts to international tourists. Although a "must-have" of the times we live in, hotels are slow to provide sites that may be accessed in several languages. However, $41.66 \%$ ensure this opportunity, but all hotels are situated in Băile Felix, a fact that may be explained by the actual experiences with foreign customers and the number of foreign customers who step on the threshold of hotels. One thing is for sure, the offer should be available in a language of international circulation to provide a chance to know and a possibility to train the demand. In addition to the availability of the site in several languages, adapting the site to the phone screen is another very important element. With a higher rate than in the case of the previous tool, the hotels adapted the site for the mobile phone in a proportion of $83.33 \%$.

The way the relationship between graphics and text is distributed is another element with defining effects on a potential customer's interaction with the website. Starting from a generally accepted ratio of $30 \%$ text, $70 \%$ graphics, this is respected in the proportion of $83.33 \%$. This report has obvious influences on the design, so at the same time the degree of attractiveness of the design was analyzed. In this context, a series of negative aspects were reported, among which we may list: the chromatics used (black and white site), the quality of the uploaded 
images, the website organization, the arrangement on the page. This aspect includes a multitude of sub-aspects that need to be closely analyzed, but, following the analysis, there is an attractiveness of the design among $58.33 \%$ of the sites.

The possibility to write testimonials or to read the testimonials written by other customers, although it is a useful tool, is provided only by $58.33 \%$ of the sites, for the rest, this element being on the list of possibilities for improvement.

The last element was the inclusion of the natural environment in the hotel promotion. However, it was found that both the thermal waters and the mountain area are present in the promotion of the hotel establishment, both through complex descriptions of the benefits of thermal waters and by presenting the existing mountain natural environment in the area in proportion of $75 \%$, being also hotels whch promote themselves only by the services provided. Moreover, it is important to note that in the description of the hotel, they do not describe the area, but indirectly integrate the elements into the content.

Therefore, we may note that hotel websites, as a promotional tool, include the basic elements targeted: contact information (100\%), the existence of images $(91.66 \%)$, room presentation $(83.33 \%)$, the site adaptation to mobile phone $(83.33 \%)$. However, there are shortcomings in the presentation of rates, which is also essential for customer information (66.66\%) and the availability of the site in several languages $(41.66 \%)$. In other words, hotel websites meet the minimum, basic requirements, representing a good way to display a set of information, without creating a connection with the customer or without offering an experience. The hotel that should be taken as a good practice example is the Lotus Therm Băile Felix Hotel, which meets the criteria mentioned above and strives to customize the interaction with the potential customer.

At the same time, a relatively low score is reached by the three-star hotels, the highest score going to the five-star hotel. An exception to the rule is Cristalin Hotel in Vârtop, which, although meets the conditions of a five-star hotel, its score is at the lower limit of the top.

Other aspects noted after the analysis will be presented in the following paragraphs.

Lotus Therm Hotel Băile Felix is an example of digital promotion via the website

President Hotel Băile Felix has as web domain www.baile-felix.ro, thus, in a search of the type: Băile Felix on Google search engine, President Hotel is indicated among the first results, the same hotel ensures a virtual hotel tour and also a map to identify the facilities/buildings, which is a strong point of the site.

Hyperion Hotel Băile Felix presents, in addition to the basic tools analyzed, a series of additional tools such as: exchange rate, temperatures in the resort, the website is based on a blog that takes the form of a website.

Zâna Văii Hotel of Vârtop Arieșeni provides a Live section that broadcasts live images on the slope.

In other words, the most common deficiencies are represented by the possibility of booking directly on the site, respectively making payments, which makes it difficult to meet the customer's needs and reflects a lack of digitization in the analyzed areas. Likewise, in terms of the degree of digitalization and the tendency to offer the customer an experience and interact with it, we may mention as a deficiency and lack of the possibility to create a customer account, to subscribe to the newsletter or to write a testimonial. Moreover, the availability of the site in several 
languages is a lethal aspect that is overlooked by many hotels, so the foreign tourists' interaction with the site is limited or even rendered impossible.

\section{Conclusions}

Therefore, a trend of improvement may be noticed in terms of promotion via the hotels' websites. 7 years after the study "Online promotion of hotels in Romania: Compromise between deficiencies and advantages?" - L. Cojocea, the online promotion of hotels is no longer an issue that needs to be urgently improved, falling within the basic limits of the importance of having its own site and promotion. Thus $\mathrm{H} 1$ : the incidence of unpleasant situations is found among 2 and 3-star hotels is a confirmed hypothesis. Average of 5 -star hotels is $73.85 \mathrm{p}$, average of 4 -star hotels is 75.61 and the average of 3 -star hotels is 55.22 .

Table 2: Score reached following the analysis

\begin{tabular}{|l|l|l|l|}
\hline Position & Hotel & Stars & Score \\
\hline 1 & Lotus Therm Hotel & 5 & 92,15 \\
\hline 2 & President Hotel & 4 & 84,31 \\
\hline 3 & Hyperion Hotel & 3 & 77,83 \\
\hline 4 & SC Turism Felix SA & $4 ; 3 ; 3 ; 3 ; 2$ & 77,12 \\
\hline 5 & Zana Vaii Hotel & 3 & 73,2 \\
\hline 6 & Monaco Hotel & 3 & 72,54 \\
\hline 7 & Aventus Hotel & 4 & 67,32 \\
\hline 8 & Four Season Hotel & 3 & 64,7 \\
\hline 9 & Nicoleta Hotel & 3 & 59,47 \\
\hline 10 & Cristalin Hotel & 5 & 55,55 \\
\hline 11 & Ami Hotel & 3 & 35,29 \\
\hline 12 & Hotel Vital & 3 & 6,53 \\
\hline
\end{tabular}

Source: Created by author

The second hypothesis - $\mathrm{H} 2$ : the description of the hotel is blended into the description of the resort/area in which the hotel is situated, it is refuted, the description of the hotels being made by presenting a set of administrative information. However, the resort description and benefits are mentioned by the sites.

The third hypothesis - H3: the promotion is inadequately carried out, medium and low quality (50 points - 30 points), it is refuted, in the analyzed areas Băile Felix and Vârtop Arieșeni, the quality reaching an average-higher level, the average score recorded by the hotels under analysis being 63.83.

The tourism may be saved by an on online promotion, but we deal with major shortcomings in the promotion of tourist areas and hotels abroad, this being also caused by the availability of sites in an international language. In this way, the possibility for foreign tourists to interact with the site is limited or prevented. As deficiencies generally encountered and at the same time aspects that need to be improved, we list the following: the possibility of booking directly from the site, respectively making payments, which complicates the process of meeting the 
customer's need and reflects a lack of digitization in the analyzed areas, lack of a testimonials section.

This research had as a starting point a focus group in order to establish the importance of each element of the analysis, but it is deemed to improve the study and conduct a survey among potential customers in order to set concrete and wellfounded evaluation criteria, improve the grid and the importance of each element of that grid. Another limit of the research is the fact that the website is a validation, a confirmation of the information collected by other promotion methods, presenting thus the products and services provided. In other words, the website represents the interface, the fundamental link between demand and supply rather than the primary element, by which the potential customer discovers a certain location, a certain hotel.

\section{References}

1. Analyze of Hotel Ami (2021) [Online] Available: http://www.hotelami.ro/ [12.03.2021]

2.Analyze of Hotel Aventus (2021)[Online] Available: https://hotelaventus.ro/[12.03.2021]

3.Analyze of Hotel Cristalin (2021) [Online] Available: https://www.hotelcristalin.ro/ [15.03.2021]

4.Analyze of Hotel Four Season (2021) [Online] Available: https://www.4seasons.ro/ [16.03.2021]

5.Analyze of Hotel Hyperion (2021) [Online] Available: https://www.hotelhyperion.ro/ [17.03.2021]

6.Analyze of Hotel Lotus Therm (2021) [Online] Available: https://lotustherm.ro/ro/ [19.03.2021]

7.Analyze of Hotel Monaco (2021) [Online] Available: https://www.hotelmonacofelix.ro [19.03.2021]

8.Analyze of Hotel Nicoleta (2021) [Online] Available: https://hotelnicoleta.ro/ [20.03.2021]

9.Analyze of Hotel President (2021) [Online] Available: https://www.baile-felix.ro/ro/ [20.03.2021]

10.Analyze of Hotel Turism Felixn (2021) [Online] Available: https://www.felixspa.com/ro/ [21.03.2021]

11Analyze of Hotel Vital ( 2021) [Online] Available: https://www.vitalfelix.ro/ [21.03.2021]

12.Analyze of Hotel Zâna Văii (2021) [Online] Available: https://www.zanavaii.ro/ [22.03.2021]

13.Ban, O. \& Droj L. (2019) Comparative analysis of the accommodation online offer for băile felix (romania) and hajdúszoboszló (Hungary) ToSEE - Tourism in Southern and Eastern Europe, Vol. 5

14. Cojocea, L. (2014) Promovarea online a hotelurilor din România: Compromis între deficienţe şi avantaje?, Conference: Association of the Romanian Economics Faculties Conference

15.Dudaș, A. (2009) SWOT analysis of tourism and agro tourism offer in „VârtopArieşeni" area-Apuseni mountains, Annals of the University of Oradea, Fascicle: Ecotoxicology, Animal Husbandry and Food Science and Technology 
16.Ferreira, J., Ratten, V. \& Dana L. (2017) Knowledge spillover- based strategic entrepreneurship, International Entrepreneurship and Management Journal, Springer, Vol. 13

17. Kim, H.,Xiang, Z. \& Fesenmaier R. (2015) Use of The Internet for Trip Planning: A Generational Analysis. Journal of Travel \& Tourism Marketing, Vol.16.

18. Kotarba, M. (2018) Digital Transformation of Business Models, Warsaw University of Technology, Faculty of Management, Warsaw, Poland, 2018 19. Lupu, N. (2010) Hotelul. Economie și management, Ed. C.H.Beck, București 20.Naresh, M. (2004) Marketing Reaserch- An Apllied Orientation, 4 th edition, Prentice Hall,

21. O.T.P.C Consulting (2015) Model integrat de dezvoltare a resurselor umane din mediul rural în vederea ocupării forței de muncă în sectorul turistic Studiu interregional de dezvoltare a turismului rural și stimularea ocupării forței de muncă în județele Bihor și Covasna [Online] Available: https://core.ac.uk/download/pdf/78473558.pdf [10.03.2021]

22. Savciuc, O. (2016) Promovarea online ca instrument al strategiilor de comunicare în era digitală, Fostering Knowledge Triange in Moldova: 2016 Conference Proceedings, Academy of Economic Studies of Moldova, Centre for Studies in European Integration

23.Schwertner, K. (2017) Digital transformation of business, Faculty of Economics and Business Administration, Sofia University, Bulgaria

24.Strutz, R. (2020) Baile Felix \& Oradea, Romania, 2020, [Online] Available: https://play.google.com/books/reader?id=1d9BAgAAQBAJ\&hl=ro\&pg=GBS.PP1 [12.03.2021]

25.Statistics on ICT use in tourism, (2019) [Online]: https://ec.europa.eu/eurostat/statisticsexplained/index.php?title=Archive:Statistics on ICT use in tourism\&oldid=420578 [10.03.2021]

26.Săvoiu, G. (2004) Cercetări şi modelări de marketing Metode cantitative în cercetarea pieţei, Editura Universitară, București

27. Tajeddini, K., Ratten, V. \& Merkle, T. (2020) Tourism, Hospitality and Digital Transformation: Strategic Management Aspects, Routledge, New York, 2020 28. Yusuf,R. (2009) Measure the impact of viral marketing, The purchase decision A field study [Online], Available: http://iefpedia.com/arab/wpcontent/uploads/2009/11/21R [ 05.04.2021] 


\title{
DIGITIZATION OF THE ECONOMY - REPORTING TO THE TOURISM INDUSTRY: THE GENERAL FRAMEWORK OF REGULATION, PROJECTIONS AND THE CURRENT SITUATION
}

\section{Miruna Diana MOZA}

PhD Field: Business Administration, Doctoral School of Economics, University of Oradea, Oradea, Romania

moza.miruna@gmail.com

\begin{abstract}
The way people carry out their daily activities has changed with digitalization. The digitalization process has highlighted its own effects on the economy as well as on society. Also, the way people travel has changed in terms of digitalization. Opportunities offered by this digitization process bring significant potential benefits. Thus, this paper proposes to make a brief foray and analyze the official documents that speak, plan and design the digital economy, which provides a set of projections of the digitalization of the economy, especially in the field of tourism. The analysis will be theoretical. In addition, this paper aims to give a brief overview of the current framework of the digital economy and to provide an analysis of the degree of involvement of public authorities at national level in the digitization of tourism in European countries and the number of online bookings in the same countries.
\end{abstract}

Keywords: economy, digitization, digital economy, official documents, projections

JEL classification: $A 19, D 83,033$,

\section{Introduction. Brief history of the "new economy" - the digital economy.}

Named in the literature and in the specialized field as a "new economy", the digital economy requires the use of information technology, in order to achieve the main business processes, namely planning, management and marketing. (R. Kling, $R$. Lamp, 2002). The concept of "digital economy" was first mentioned in Japan during the 1990 recession. The concept was later mentioned 5 years later in Don Tapscott's book The Digital Economy: Promise and Danger in the Age of Networked Intelligence. (1995). This is the first paper that talks about how digital networks will influence the business environment.

The impact of digitalization on the economy has become an area intensively researched by economic analysis offices and other agencies, so the Administration for Economics and Statistics has been reporting on the results of the digital economy since 1998. Over time the digitalization of the economy has received new valences and gave rise to new concepts and topics of general interes.The first interventions of the European Commission in the field of digitization were made in 2000. The European Union institutions understand at that time the importance of the Internet and technologies in the business environment and thus, "digital law" becomes one of the ten priorities of the year 2000. 
Digital transformation has become the engine of business in various fields. An area of interest was also the tourism sector. Within it, digitalization has boosted competitiveness. To this end, the European Commission has implemented a number of actions with a view to integrating companies operating in this sector into global digital value chains. At the same time, the improvement of the capacity to create more jobs was considered.

In 2010, the European Commission launches the "Digital Agenda for Europe". This was the first of seven initiatives in the Europe 2020 Strategy for Sustainable Growth. This agenda was the successor to the ICT strategy "i2010" of the European Commission 2005-2008. That agenda proposed a much wider scope. Its aim was to stimulate the European economy by providing sustainable economic and social benefits. Its areas of action included: creating a digital single market, exchanging information and setting standards, trust and security, fast and ultra-fast internet access, research and innovation, improving literacy and digital inclusion, the benefits of ICT to society, other international aspects of the digital agenda. (European Commission, 2010)

\section{The current situation of official documents, programs, projects and projections of the digitalization of the economy}

Since 2000, the European Commission has shown a growing interest in digitizing the economy. Tourism has always been an area of interest. Why is this happening? Data provided by the European Union show that in 2018, the tourism industry provided jobs to $11.7 \%$ of Europe's population. It is of great economic importance, representing at the same time $10 \%$ of the G.D.P of the European Union. This is precisely why all the commissions of the European Union are of great interest in this field. (European Parliament, 2021)

The OECD has also constantly analyzed developments in the digitalisation of the economy, progress and opportunities for the future. All these reports, programs and guidelines have been summarized in this chapter.

\subsection{General aspects and reflections in the tourism sector}

One of the new concepts launched with the Digital Agenda for Europe was the "digital single market", which later became a 2015 strategy that included a series of initiatives to remove barriers to cross-border e-commerce and stimulate investment in T.I.C. Thus, the DSM (Digital Single Market) strategy represented for the period 2014-2020 a point of great interest, being based on 3 main pillars, namely: facilitating the access of consumers and businesses to digital goods and services, throughout Europe, creating the right conditions and for digital networks to grow and maximize the growth potential of the digital economy (European Commission, 2015)

In the context of the Digital Single Market, the European Commission has also turned its support to the tourism industry, establishing four sets of initiatives:

Improving the business environment and increasing investment in the tourism sector, through better use of EU funding

Stimulating digitalization in this industry and the use of online marketing tools Improving the skills and competencies of this sector in order to improve career prospects and identify and retain professionals in the field 
Raising Europe's profile as a tourist destination, complementing promotion efforts at regional and national level in order to attract a greater tourist flow in Europe.

Following a political agreement between the European Commission, the European Council and the European Parliament, the N.I.S (Network and information Security) Directive (European Commission, 2015) on network and information security was adopted in 2015 . This has played a key role in what we call the digitalization of the economy. In 2016, the directives on the general regime for the protection of personal data are repealed (European Commission, 2015).

However, the first step taken by the European Commission towards what we call digital tourism and the digitalisation of this sector was launched in 2015. The socalled "Digital Tourism Network" was an informal forum for the tourism industry in the European Union / Its purpose was to facilitate discussions on the common challenges and opportunities that the digital transformation brings to the tourism industry. Moreover, the forum also served as a facilitator of the exchange of good practices and of stimulating the innovation capacity of tourism enterprises (especially SMEs). This network subsequently contributes to the formation of new actions that will aim to support the digital development of the industry. Thus, in 2016, the European Commission conducts a consultation in this regard and publishes two reports on the digitization of tourism.

The OECD (2015) presents in the OECD Digital Economy Outlook 2015 report the possibilities of capitalizing on the potential of the digital economy as an engine for innovation of countries, targeting numerous sectors of activity and industries. It sets out the current state and prospects of the digital economy, the main trends in the ICT sector and the effects of the digital economy on growth and development in various industries, including the tourism industry. According to the report, the potential for companies to adopt and use the Internet and digitalisation in all sectors is huge, and O.E.C.D. governments are increasingly aware of the need to develop the digital economy. The aim is to stimulate economic and social growth through national digital agendas. (O.E.C.D, 2015)

At the same time, in 2015, the United Nations launches the post-2015 development agenda. It sets out a number of sustainable development goals, including internet access to create an inclusive and global digital economy.

The 2017 O.E.C.D Digital Economy Outlook report highlights a number of key ideas: O.E.C.D governments meet the challenges of digital transformation in all branches of the economy; communication infrastructure and services are being modernized; the use of T.I.C is unequally distributed between countries, between companies and between individuals; digital innovation and digital transformation bring important changes to the labor market; concerns about digital security and privacy limit the widespread adoption of T.I.C and business opportunities; artificial intelligence raises a number of political and ethical questions; the potential of the blockchain faces a number of technical obstacles and political challenges. (O.E.C.D, 2017). Also in 2017, the European Commission launches the report "Management and Content Provision for ICT and Tourism Business Support Portal". The project aims to increase the competitiveness of tourism businesses using ICT. According to him, SMEs in this industry will be supported to acquire and adopt the necessary technologies and skills. The report sets out, for each EU member state: the level of digitization, the way data is processed, the attitude towards digitization and the existing challenges. (European Commission, 2017) 
In 2018, the final report "Digitalization in tourism" is published. Their aim was to analyze the challenges and opportunities of digitalisation in tourism, how these challenges and opportunities affect different stakeholder groups and to discuss how they could be addressed. It was found that there are five major needs in terms of the activity of tourism SMEs, namely: skills, funding, infrastructure, mentoring and political support. Moreover, the recommendations offered were summarized as follows: continuous consultation in the chain of SMEs-public authorities, professional associations, technical assistance in the form of digital training courses, promotion of infrastructure in rural areas and beyond. However, their implementation requires collaboration with other complementary industries.

The year 2020 brings to the fore a new report provided by the OECD, named Digital Economy Outlook 2020. The current pandemic of COVID-19 has amplified all aspects of digital transformation and the way countries interact with digital technology. At the same time, it highlighted the need for a more inclusive approach to digital transformation.

OECD countries are strengthening their strategic approach to digital transformation policy, so by mid-2020, 24 OECD countries had a national strategy aimed at digitizing the economy. The report also highlights the implementation and the effects of the digital divide. There are major differences between large firms and small firms. If for large companies, e-commerce represented in $2019,24 \%$ of turnover, for small companies, the share represented was $10 \%$. Such gaps also exist among individuals, the differences in use by age groups and level of education persisting to date.

The measurement of the progress in which the member states of the European Union act in the direction of a digital economy is made through D.E.S.I. indicator (Digital Economy and Society Index). This indicator refers to five major areas, namely: connectivity, human capital, internet use, digital technology integration and digital public services. (I.N.S, 2020)

The data provided by this index reveals the current situation of Romania in this context, thus, in terms of connectivity, there is an upward trend 2014-2017 and a maintenance trend with small decreasing influences in the period 2017-2019. In the field of internet services use, the digital environment shows an accelerated growth, so in $2019,71.6 \%$ of people used the internet regularly, an increase of $23.9 \%$ compared to 2014. Moreover, a significant increase it was also found among online transactions. Digital technology in enterprises is also presented in the report. According to him, the digital sphere provided $7.4 \%$ of turnover, $10.3 \%$ of enterprises bought cloud services, which is implicitly a trend of digitalization in enterprises and SMEs receive more and more digital orders and the share of companies who used social networks in 2019 was $33.2 \%$.

At the level of the European Union, this indicator shows similar trends and an upward trend. Internet use has increased year by year, with $85 \%$ of Europeans using the internet at least once a week. At the EU level, the purchase of cloud services accounts for much higher percentages from companies, namely $38.5 \%$. General connectivity and digitalization of households have improved significantly, and human capital has also increased in the context of the skills of internet users. (I.N.S, 2020)

Connectivity is also continuing to improve in OECD countries, communications subscriptions are growing sharply and policy and regulatory measures are being put in place to manage them as efficiently as possible and to facilitate the 
implementation of access to these facilities. The report also highlights the implementation and the effects of the digital divide. There are major differences between large firms and small firms. For large companies, e-commerce in 2019 accounted for $24 \%$ of turnover. For small companies, it accounted for only $10 \%$ of turnover. Such gaps also exist among individuals, the differences in use by age groups and level of education persisting to date.

Big data also offers more and more opportunities for companies and consumers. However, security and confidentiality issues arise in this context. The report highlights the added importance of OECD countries' efforts to identify policy solutions to digital security issues and to stimulate good practice. (O.E.C.D, 2020)

\subsection{Harmonization of digital markets - as a central objective}

The harmonization of digital markets has remained one of the clear objectives of the European Commission. Over time, this goal has also been one of the key policies through which the EU supports its Eastern European partners. To this end, the project called EU4DIGITAL was born. It aims to expand the Digital Single Market to Eastern partners, contributing to economic growth, creating new jobs, improving people's lives and supporting the business environment.

In this context, the EU supports the reduction of roaming charges, the creation of a high-speed broadband network which in turn will contribute to the growth of the economy, the expansion of online services and a coordinated and organized cyber security. These measures help to remove barriers to online services for citizens, administration and business. Under these conditions it will be easier to attract investment, sales will increase, and launching and developing a Start-up will be much easier.

The EU4DIGITAL initiative brings together the following actions and programs:

- EU4DIGITAL networks - bringing together EU representatives and Eastern partners to work on key issues,

- EU4DIGITAL facility - a 3-year program (2019-2022) that promotes the highlights of the digital economy in line with EU rules and practices,

- EU4DIGITAL broadband strategies - (2018-2020) is a World Bank project that supports Eastern countries in creating national strategies for highspeed data networks

- EU4DIGITAL Cybersecurity East - a project that aims to strengthen cybersecurity and increase trust in the use of online services.

- EU4DIGITAL EaPConnect - expanding the digital infrastructure to bring together scientific studies and education

The European Investment Bank also talks about Digitalisation in Europe 20202021 in the "Digitalisation in Europe 2020-2021" Report. It is a balance of evolution. This balance sheet sets out the pace of adaptation of digital technologies and, implicitly, their impact in both the European Union and the United States. The report highlights a number of issues specific to the digitalisation of the economy.

In the first instance, in order to achieve sustainable growth, Europe must embrace and tap into the potential of digital technology. The digital revolution has already transformed the economy, although many of these changes have only just begun. Asked by the European Investment Bank, a significant percentage of EU companies believe that this process of business digitalization has been accelerated by the COVID-19 pandemic. 
Another trend mentioned in the report is the importance of adopting digital technology in order to remain competitive in the market. Moreover, although the adoption of digital technologies by European businesses is growing, this growth is not enough to reach the level of those in the U.S.A.

Very large discrepancies between countries are also mentioned in this report. While some EU member states are at the forefront of global digitalisation, others are failing to keep up with this development. The data show that digitized companies are much more productive, so according to the report, digitization is an opportunity and not a risk.

A measure mentioned in the report of the European Investment Bank aims to identify and solve the problems that hinder the evolution of digitalization. Thus, in order to accelerate innovation and the adoption of digitalisation, Europe must take into account the three key issues: a functioning and permissive system, sound financial support for investment and a European vision to combat imbalances within the European Union.

In this context, in order to boost the development of this sector, the EU has launched the Digital Europe Program, which provides funding focused on the digitalisation of businesses, public administrations and citizens. Digital technology and infrastructure play a key role in our private lives as well as in the business environment. We rely on this activity to communicate, work, learn and innovate. At the same time, the COVID-19 pandemic highlighted not only how much we rely on the availability of technology but also how important it is not to rely on systems and services from external sources, thus paving the way to achieve this goal, a digital Europe, independent and efficient.

The program provides funding and strategic support in 5 key areas: supercomputing (high data processing power); Al (Artificial Intelligence) - Al (Artificial Intelligence); Cybersecurity; Advanced digital knowledge (among the population); The widespread use of digital technologies in business and society. This program has 7.5 trillion Euros, complementing the rest of the existing programs and is part of a long-term strategy, called the Multiannual Financial Framework 2021 - 2027. (European Commission, 2021).

At the same time, the Connecting Europe Facility (C.E.F DIGITAL) program focuses on the development of digital infrastructure in the transport, telecommunications and energy sectors, all of which have clear influences in the field of tourism. Some important issues are: the development and wider coverage of high-capacity networks, including 5G; increase the security, resilience and capacity of the main EU networks, boost the digitalisation of energy and transport networks.

C.E.F DIGITAL aims to finance the installation of $5 \mathrm{G}$ systems along the main transport routes, highways, ports and railways, which will pave the way for new innovative services, through artificial intelligence, both for the population and for the transport of goods. At the same time, these projects will give rise to "smart communities", with applicability in schools, public institutions, hospitals, etc.

For the same purpose, it is desired to extend quality networks in isolated areas (islands or rural areas), but also of submarine cables that will ensure connectivity between Member States and other partners. (European Commission, 2021)

The OECD report on "Digitization: policy-making, improving lives" also highlighted the need to close the gaps that exist in order to address the opportunities of the digital age. It was therefore considered that a deeper understanding of the need for 
these changes is imperative and affects the whole economy and society. (O.E.C.D, 2019)

Referring to digitalisation and sustainability, in 2021 the European Economic and Social Committee launched an exploratory opinion setting out a series of recommendations, proposals and requests as follows:

Call for policies to establish a digital economy, enabling workers, consumers, SMEs, large companies and non-profit economic operators to benefit equally, especially in rural areas. These policies included issues such as: developing fiscal policies to ensure that digital companies pay their tax contributions, adjusting competition and monopoly legislation, using R.G.P.D for social media and ecommerce platforms

Demand for transparent, fair and environmentally friendly ICT production chains, ambitious energy standards and an extension of the EU Ecodesign Directive

Call for appropriate policy measures to help strengthen practices such as: increased use of ICTs that have mitigated energy-intensive work practices and lifestyles as a result of the pandemic

Recognize the key importance of developing sustainable smart cities, including innovative approaches to integrated mobility, energy and tourism. (European Economic and Social Committee, 2021)

In the tourism industry, the promotion of digital transformation has continued through many types of activities: the existence of a tourism business portal, including various articles and tools useful to entrepreneurs on managing the tourism business in the digital age, webinars and local workshops in 5 major cities in Europe.

Following the public consultation and analysis of the current context, the European Union has launched a renewed policy initiative to support the sustainable adaptation of EU Member States' education and training systems in the digital age, implementing an Action Plan for Digital Education (2021- 2027). This plan does not directly target the digitalization of the economy but indirectly supports this process. $\mathrm{He}$ has a long-term vision of increasing the quality and accessibility of high-level education. (Digital Education within the Directorate-General for Education, Youth, Sport and Culture, 2021).

Numerous operational programs and solutions for organizing and supporting the process of digitization of the economy have emerged at the level of all EU member states. Ministries of the economy are increasingly promoting digital services in the business environment.

\section{Involvement of public administrations at national level in the field of tourism. Analysis and effects.}

The methodology used for this study consisted in the analysis of literature, official documents, previous and current research and official reports, which focus on the field of digitization of economic sectors and especially tourism.

The methodology used for this study consisted of the analysis of specialized literature, official documents, previous and current research and official reports, which focus on the field of digitization of economic sectors, especially in tourism

The experience of developed countries has shown that information technology has an increased impact on the country's competitiveness and the opportunities they discover. The reporting and implementation of all policies imposed at European level has differed from country to country. The involvement of public 
administrations and professional associations has also been variable. The report on digitalization in tourism, of 2018 presents an important aspect in this context, namely: the involvement of public administrations and professional associations in the digitalization of business. It has previously been shown that public administrations can play an important role in developing initiatives such as funding certain programs. At the same time, their involvement was highlighted less in projects or technical elements of digitization.

The way of implementation and involvement has varied at the level of European countries. In the following, we took into account as a reference variable, the involvement of the public administration at national level. Thus, it was found that $75 \%$ of European public administrations were involved in supporting the digitization of tourism. In the top of the most active countries were the Nordic countries. The activities implemented at the level of European countries, with the help of local administrations, aimed, concretely, to carry out actions such as: gathering information, providing financial support, assistance for e-governance, while professional associations focused on educational activities, support for providing financing and marketing media such as websites, online transactions and more.

Thus, according to the Tourism Digitization Report 2018, we notice that the Nordic countries (Finland, Denmark, Sweden, the Netherlands) have the highest levels of digitalization, at the end of the list being the Eastern European countries.

In the Nordic countries, $70 \%$ of tourism SMEs have shown that they have an average level of digitalization, while in Eastern European countries there is a percentage of $44 \%$.

An example of good practice, implemented by Finland, was to create digital ecosystems at national level and to make tourism services available on as many digital channels as possible both nationally and globally. Thus, pilot projects were carried out, focused on the digital experience of tourists in four areas. It has contributed to the personalized development of digital know-how and services, subsequently, a national hub has been implemented and e-learning and digital training activities for tourism. For the future, a digital inventory of tourism assets is being pursued. (O.E.C.D, Finland, 2021)

In parallel with this analysis, we found it useful to analyze the number of holidays booked in European Union countries, using online booking. Thus, the following information was taken from Eurostat on the number of online bookings in the countries between the two main categories mentioned above.

Table 1 Number of internet booking of the main means of accommodation in 2018

\begin{tabular}{|c|c|c|c|c|c|c|}
\hline & \multicolumn{3}{|c|}{ Nordic Countries } & \multicolumn{3}{|c|}{ Eastern Europe Countries } \\
\hline Country & Sweede & Finland & Netherland & Albania & Montenegro & Latvia \\
\hline $\begin{array}{l}\text { Internet } \\
\text { booking } \\
\text { of the main } \\
\text { means } \\
\text { of } \\
\text { accomodat } \\
\text { ion }\end{array}$ & $\begin{array}{l}8,269,86 \\
1\end{array}$ & $\begin{array}{l}6,210,93 \\
3\end{array}$ & $5,865,395$ & 16,883 & 47,082 & 157,476 \\
\hline
\end{tabular}

Source:https://ec.europa.eu/eurostat/databrowser/view/TOUR DEM TTORG cus tom $1768446 /$ default/table?lang=en 
Therefore, as can be seen in the table above, the countries that are part of the category of Nordic countries, register values of online booking with an average of about 10 times higher than the Eastern countries.

Drawing a parallel with the previously analyzed study, regarding the active involvement of public administrations in the digitalization of tourism, we find that the effects of these positive policies are obvious. Thus, the countries in which the involvement of the public authority has increased shares (70\%), Sweden, Finland and the Netherlands, enjoy the highest values of online booking at European level, while countries in the Eastern category, where the involvement in digitization it was minimal, it records the lowest values.

This analysis presents as limits a number of aspects such as: the number of online bookings is not conditioned only by the involvement of public administrations in the digitization of tourism. Here we can involve other factors such as: major differences in terms of tourism potential of countries, differences in the economic development of the country and in terms of quality of services. Thus, this paper will be the basis for other research, which will develop this topic, analyzing in detail all the influencing factors according to which online bookings in the Nordic countries have such significant values as opposed to those in Eastern Europe. At the same time, it will be possible to provide a guide to good practice and a set of recommendations for countries in the second category.

Moreover, Eastern European states, being members of the EU, have allocated funds for digitization, but due to administrations, often inefficient, this money is either not absorbed or used inefficiently.

Thus, I believe that at the level of the European Union, it would be useful to set up a group of professionals to help raise the standards of all countries in terms of digitization. Moreover, it would be useful to carry out support activities to contribute to the development of digitization in this area.

\section{Conclusions}

The current situation in Europe reflects a conventional digital divide. Moreover, the current state of regulations is uneven. Each country approaches this issue in its own way and has influences from the great economic powers. While some countries enjoy unlimited capabilities to turn data into digital intelligence and business opportunities, which are later used for economic and social development, there are also some countries whose capabilities in this area are limited, thus speaking of a disadvantage.

Where public administrations have been involved in digitization and have done so in an appropriate way (eg the Nordic countries, Finland), the results have not been long in coming. Thus, it is easy to see from the two statistics provided (involvement of public administrations in digitization and the number of bookings made online) that in countries where we talk about implementing activities to develop digitization and the number of tourists who choose online bookings is much bigger.

A multitude of operational programs, agendas, reports, organizational solutions and individual activities of major organizations exert their influence in the field of digital development. Involved in this subject since 2000, the European Commission is continuously focusing on facilitating digitization and removing barriers. 5 years 
later, the European Commission's interest in integrating the concept into tourism appears, launching the orientation of activities towards digital tourism. The promotion of digital tourism and the digitization of tourism leaves room for many other interpretations, being the solution for many other problems encountered in this sector and at the same time, a step towards the future.

Recent years have brought new attributes to the development of digitalization. In this regard, the strengthening of the strategic approaches of OECD countries was exemplified. Thanks to the COVID-19 pandemic, by the middle of 2020, 24 of these countries already had a complex national strategy developed in this regard.

\section{References:}

1.Digital Education in the Directorate-General for Education, Youth, Sport and Culture, 2021, [Online], Available: https://ec.europa.eu/education/education-in-theeu/digital-education-action-plan ro [16.Oct.2021]

2.European Commission, (2010), A Digital Agenda for Europe, Commission Europeana, Communication from the commission to the european parliament, the council, the european economic and social committee and the committee of the regions, Brusseles

3.European Commission, (2015), A Digital Single Market Strategy for Europe, Communication from the commission to the european parliament, the council, the european economic and social committee and the committee of the regions, Brusseles

4. European Commission, (2015), Commission welcomes agreement to make EU online environment more secure, [Online], Available: http://europa.eu/rapid/pressrelease IP-15-6270 en.htm [23.Oct.2021]

5.European Commission, (2015), Aging on Commission's EU data protection reform will boost Digital Single Market, [Online], Available: https://ec.europa.eu/commission/presscorner/detail/en/IP 15 6321 [01.Nov.2021]

6. European Commission, (2017), Management and Content Provision for ICT and Tourism Business Support Portal Final Report

7.European Commission, (2018), Digitalization in Tourism, Final report

8.European Commission, (2021), The Digital Europe Program, 2021, [Online], Available: $\quad$ https://digital-strategy.ec.europa.eu/en/activities/digital-programme [02.Nov.2021]

9.European Commission, (2021), The Digital Europe Program, 2021, [Online], Available: $\quad$ https://digital-strategy.ec.europa.eu/en/activities/digital-programme [02.Nov.2021]

10.European Economic and Social Committee, (2020), Digitization and sustainability - the status quo and the need for action from the perspective of civil society, (exploratory opinion)

11.European Investment Banck, (2021), Digitalization in Europe Report: 2020-2021 12.EU4 DIGITAL, 2021, [Online], Available: https://eufordigital.eu/discover-eu/theeu4digitalinitiative [04.Nov.2021]

13.European Parlament,(2021), Tourism, [Online]. Available https://www.europarl.europa.eu/factsheets/en/sheet/126/tourism [13.Dec.2021]

14. Eurostat, (2021), Number of trips by type of organisation, Internet booking of the main accommodation, [ Online]. Available 
https://ec.europa.eu/eurostat/databrowser/view/TOUR DEM TTORG custom 17 68446/default/table?lang=en [10.Dec.2021]

15.I.N.S, (2020), Index of the digital economy and society (D.E.S.I), 2020

16.Kling, R. \& Robert, L. (2002). IT and Organizational Change in Digital Economies. Center for Economic Studies \& University of Maryland

17.OECD, (2015), Digital Economy Outlook 2015, [Online], Available: https://read.oecd-ilibrary.org/science-and-technology/oecd-digital-economyoutlook-2015 9789264232440-en\#page15 [ 05.Nov.2021]

18. OECD, (2017), Digital Economy Outlook 2017, [Online], Available: https://read.oecd-ilibrary.org/science-and-technology/oecd-digital-economyoutlook-2017 9789264276284-en\#page15 [05.Nov.2021]

20. OECD, (2019), Going Digital: Shaping Policies, Improving Lives, [Online], Available: $\quad$ https://www.oecd.org/publications/going-digital-shaping-policiesimproving-lives-9789264312012-en .htm [09.Nov.2021]

17.OECD (2020), Finland, [ Online], Available: https://www.oecdilibrary.org/sites/cb702fad-en/index.html?itemld=/content/component/cb702fad-en

[14 Dec.2021]

21. Tapscott, D., (1997) .The digital economy: promise and peril in the age of networked intelligence. New York: McGraw-Hill 


\title{
CONSIDERATIONS ON THE IMPACT OF SUSTAINABLE DEVELOPMENT ON TOURISM PHENOMENON
}

\author{
Nicoleta Georgeta BUGNAR, Liana-Eugenia MEȘTER, Andreea-Florina FORA \\ Faculty of Economic Sciences, University of Oradea, Oradea, Romania \\ nicoleta.bugnar@gmail.com \\ Imester@uoradea.ro \\ andreea.fora@gmail.com
}

\begin{abstract}
Since 2010, the European Commission, through the Communication "Europe, No1 World Tourism Destination - A New Political Framework for Tourism in Europe", has drawn the attention to the fact that local / urban tourism strategies should be essential to the way in which cities promote or limit the extension of tourism services; thus, the increase in the number of tourists in cities and the lack of local tourism policies can lead to negative pressures on the local (environmental, cultural and social) environment.

In the research, we will analyze how the explosive economic growth trend of the analyzed region (in our case due to the massive absorption of European funds for urban infrastructure and for industrial development) has positively or negatively affected the tourism sector of the area. The objective of the research will be: identification of local officials with the elaboration and implementation of sustainable tourism policies related to sustainability and identification of specific factors of influence - local vision on sustainability, local action instruments and, implicitly, the tourist flow generated compared to the economic growth level of the region.
\end{abstract}

From a methodological point of view, the research combines two levels of analysis: the comparative analysis of local economic development plans and strategies with local tourism policies as well as the comparative analysis of economic growth indicators of the region with the tourism indicators for the chosen period.

A comparison between local development strategies and local tourism policies allows us to identify whether the growth of the tourist phenomenon in the region is a mere consequence of the development of the region or it is based on a strategic thinking of tourism development. The idea behind this research is based on the fact that other studies have demonstrated that the notion of sustainable tourism in major European cities remains out of the local political agenda, without discussing possible conflicts between urban tourism and negative externalities.

Keywords: sustainable development, economic growth, tourism, local policies.

\section{JEL Classification: J61}

\section{Sustainability challenges identified in tourist cities}

The increase in the number of tourists and, implicitly, in the accommodation capacity in the big European cities has led to an accentuation of the pressure on the (limited) urban / rural resources and the challenge of the coexistence between residents and visitors. The way in which the development of cities / tourist areas 
has been planned and managed in the last decades has had as a consequence the amplification of the conflicts with the local population (Colomb, C. and Novy, J. (2017).

The analysis of current tourism policies in major European tourist destinations reveals that only a few of them address the conflicts between tourism and the negative consequences generated. Increasing tourism remains a priority for all European local communities.

The sustainability approach in the development of tourism is particularly sensitive because tourism is an important element in the use of resources, in social and environmental changes (Rutty, M. et al. 2014). Therefore, the implementation of sustainable tourism policies remains the main task for the coming years. The contemporary tourism system is characterized by a massive growth, where fast and cheap travel, affordable accommodation facilitates this massive mobility of international and domestic tourism (Williams, A. 2013, 511-53). The increase in investment, hotel construction, technological innovations attract even more tourists to big cities. European Union countries host $40 \%$ of international tourism, especially in the Mediterranean and Western Europe, and are expected to grow from 448 million to 762 million by 2030 (UNWTO, 2018).

Thus, sustainable tourism policies become essential for how cities / areas promote or limit the expansion of tourism-oriented services (accommodation, retail, and hospitality) in and around the city. Tourists and residents share limited space, but "visitors' use of local facilities that were not built for them" can cause problems. (Ashworth, G. and Page, S.J., 2011, 1-15). In this context, the increasing number of tourists in cities and the seasonality of tourism can lead to a stronger pressure on the local environment.

The side impacts of tourism contribute, in many cases, to the negative perception of residents against the development of tourism, which is becoming a contested phenomenon in cities around the world. Urban changes oriented towards tourist attractiveness have created negative externalities at the level of the local community (Colomb, C. and Novy, J., 2017).

A higher density of tourists has a direct impact on:

- Real estate market - due to the increase in the number of buildings / rooms meant for tourism and new hotels in specific urban areas will increase the average price of housing;

- Resident-oriented services - they may suffer from hospitality, cultural and retail services for visitors;

- The quality of the environment (C02, PM, NOx, SOx etc.) - due to the transport of tourists (coaches; private vans; cruises and aviation);

- Increasing waste (plastic, food, energy, water etc.) - these are produced by tourists and industry;

- Water and energy resources.

In the literature, based on the experience of large European metropolises, development trends have been identified, which if not carefully controlled are opposed to the concept of sustainability.

- Overcrowding and pressure in very popular tourist areas.

- Socio-demographic development of very popular tourist areas.

- Increasing tourism in cities.

- Increasing sensitivity to the geopolitical situation. 
- The use of metropolitan infrastructures by tourists.

- New intermediaries and tourist activities.

- Increasing the offers and new types of tourist accommodation.

- Increasing the relative influence of tourism on the world economy.

- New profiles of tourists, visitors, and residents.

- Changes in residents' perception of tourism.

On the other hand, out of the desire for financial gain and to occupy a leading position in the international tourism sector, the challenges to which city managers must respond are: increasing transport capacity and infrastructure, increasing the number of accommodation in order to receive more tourists, the need to diversify the offer both in space and time as traditional tourist places are saturated, the need to innovate to improve visitor satisfaction.

\section{Integrating sustainability into tourism policies}

In general, it has been found that environmental and social sustainability is not sufficiently embedded in tourism development policies. Tourism is present in local development plans only through quantitative indicators, very rarely through crosscutting integration in community development.

In the Development Plan for Barcelona (Tourism Strategic Plan, Tourism Mobility Plan - https://ajuntament.barcelona.cat/turisme/en/strategic-plan/documents and Special Tourism Accommodation Plan http://ajuntament.barcelona.cat/plaallotjaments-turistics/es) sustainability is linked to the city and not only to the destination competitiveness. Sustainability is one of the seven initial provisions of the plan; In Lisbon, the Strategic Tourism Plan for the Lisbon Region 2015-2019 (Câmara Municipal de Lisboa, 2017) focuses on economic and marketing issues, sustainability criteria are not explicitly present in Lisbon. In Paris, (Tourism Strategy 2022 Plan - https://pro.parisinfo.com/actualites/actualite-touristique/Dossiers/ schema-touristique-paris-2022) sustainability is mainly related to the quality of life of local citizens, and in terms of "sustainable tourism development" the specific objectives and action plans remain unclear.

Another issue of sustainability in tourism is related to the deadline for implementing local development strategies. Sustainable development must be seen as a longterm strategy, which runs counter to local development policies (usually lasting 4-6 years) that tend to correspond to political mandates. The question is who should take care of the sustainability of tourist destinations - the leaders of local communities or public stakeholders. In general, in Europe, tourism strategies are designed by local governments, with the exception of Barcelona where we have a more diverse and shared leadership between private and public sector stakeholders (Dredge, D and all, 2016).

The creators of tourism strategies have concluded that, in addition to basic tourism services (transport, accommodation, restaurant), to achieve sustainability in this area must be carefully analyzed other key areas, such as urban planning, local transport and mobility. For example, stakeholders in Barcelona and Lisbon mentioned as defining elements for sustainable development: the local economy, jobs and business, transport and mobility, urbanism and tourism (Vera Pais, 2018). For Paris, the areas of interest are urbanism, tourism, mobility and transport (Marie de Paris (2016) - see Figure 1. 


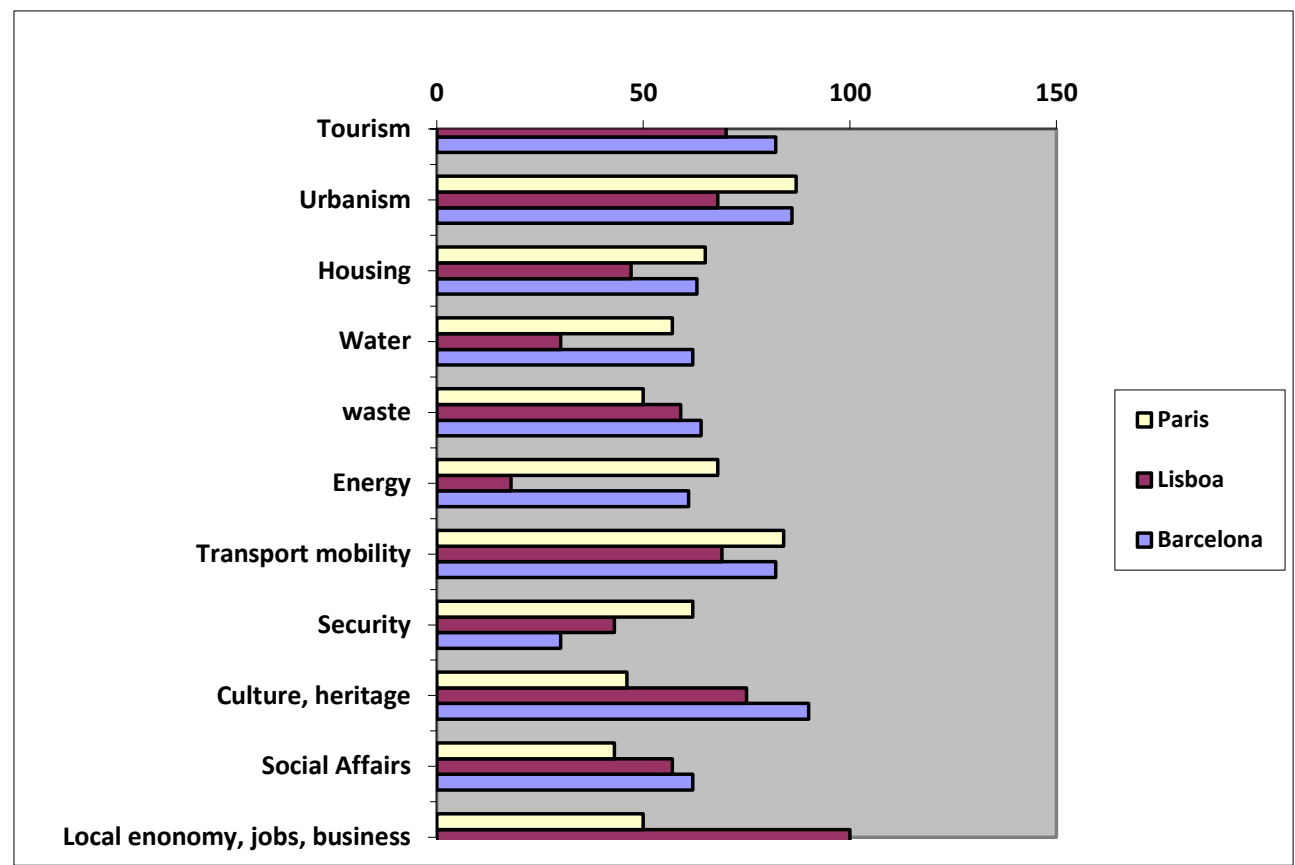

Figura 1 - Areas are involved on the sustainability of tourism

Source: Adapted from World Tourism \& Travel Council (2017) City travel \& tourism impact 2017 Europe. London

Following a comparative analysis of the influencing factors in tourism sustainability policies, on three tourist destinations - Barcelona, Lisbon, and Paris - the following situation was reached - see Figure 2.

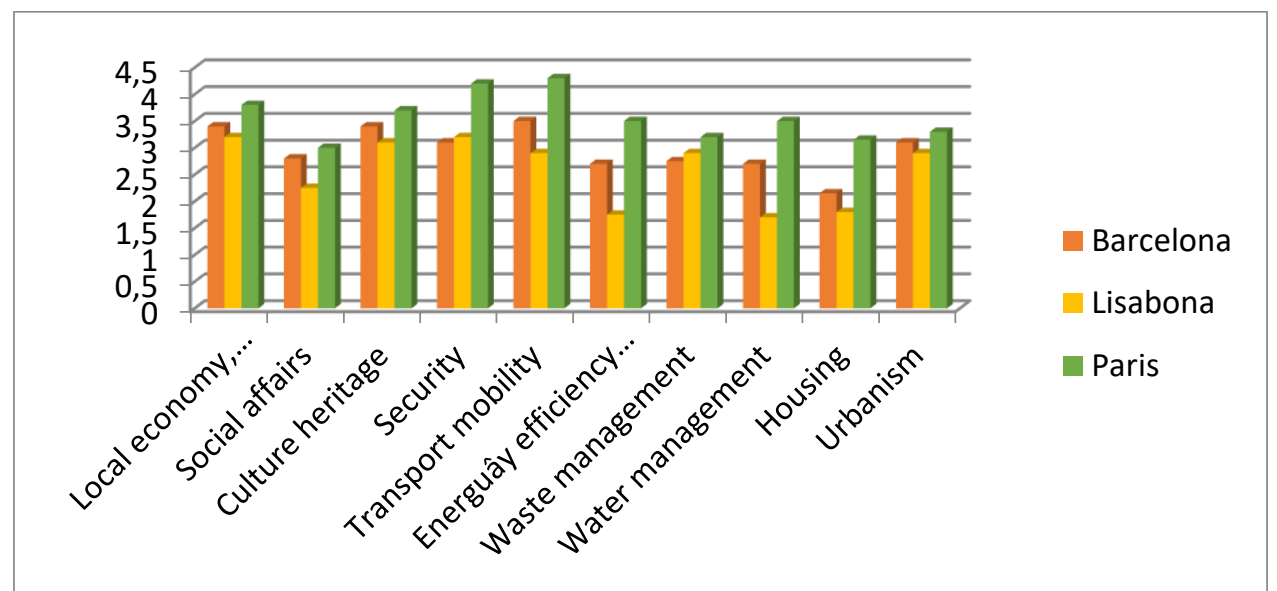

Figure 2 The influencing factors in tourism sustainability policies (1 low to 5 high) Source: Adapted from World Tourism \& Travel Council (2017) City travel \& tourism impact 2017 Europe. London 
We can note that tourism decision-makers have shared common concerns, but local tourism policies are quite diverse among cities. The problems are generated by the lack of coordination between the various departments of the city, there is ample room for improvement in terms of integrating various urban policies into tourism strategies.

The phenomenon of overcrowding is thought of as the enemy of sustainability in tourism being characterized by high concentration of tourists and tourist services in historical or commercial specific areas. This overcrowding in some areas could lead to an increase in the cost of living for locals, the replacement of houses with tourist apartments, a higher demand for certain products and services, which would have the effect of reducing the quality of life for locals. The phenomenon of migration of highly skilled labor, wealthy tourists and students contributes to rising rental prices and, consequently, forces lower-income residents to migrate to other urban / rural areas. In response to this problem, strategy makers (Colomb, C. and Novy, J.,2017) need to think of innovative planning policies, such as:

- Metropolitan tourism policies to spread tourists to wider geographical areas,

- Spatial planning policies through the development of tourist objectives on large territorial areas,

- Spatial hotel planning for the management of the accommodation offer,

- High taxation in areas with high tourist agglomeration

- Local businesses planning, maintaining a correct balance between their permanent and seasonal nature,

- Urban mobility strategies for tourist areas to prevent congestion around the main attraction areas.

Tourism is a large consumer of natural resources (water, energy, food etc.), therefore, it is necessary to reduce excessive consumption and environmental pollution resulting from tourism activities. Tourist mobility is a serious problem, as it is based on high-carbon forms of transport (planes, cruises, cars, etc. Therefore, it is very important to develop sectoral mobility plans for tourists by:

- Introduction of tourism indicators in the development of public transport policies.

- Adaptation of public and collective forms of transport during the seasonal periods, including the management of tourist bus traffic avoiding overcrowding and pollution of local sites.

- Promoting the use of eco-transport (eg. bicycles) and stimulating pedestrian routes

- Ensuring waste recycling strategies, banning the use of disposable plastics

- Energy and water efficiency measures in hotels, transport and tourism facilities.

\section{Conclusions}

To be supported by local communities and civil society, tourism should make a positive contribution to the sustainable development of the area in which it is practiced. Therefore, local community leaders can do this if they take into account a number of recommendations:

- Identify the main governmental / regional / local actors responsible for the design and implementation of tourism policies related to social and environmental sustainability. 
- Analyze the integration of sustainability [environmental and social] in tourism strategies and the impact of tourism growth on the area.

- Analyze the perceptions of stakeholders about the role of sustainability in urban tourism policies;

- Identifying innovative strategies and policy instruments that address issues related to sustainable tourism;

- Proposed a set of recommendations to promote policy making and good governance for sustainable tourism.

The assessment of sustainability is the first step in understanding the real impact of tourism on local / regional destination. This should be done in collaboration with external experts, monitoring and transparency are essential to gather information and to properly inform local sustainability decision makers. Policy coherence and cross-cutting coordination between different local development strategies are needed, by strengthening destination management beyond economic promotion and marketing. Mitigation and prevention of negative environmental impact should be ensured by integrating different policies, strategies and practices related to natural resource management and social equity objectives. Trends in the quantitative growth of tourism must be redefined from the perspective of sustainability. The exponential increase in the number of tourists in a destination will further increase the environmental and social conflicts, will endanger the quality of the destination. Mobility and transport models should be modified to reduce carbon emissions related to low-cost airlines, road transport and cruises. National and local transport authorities need to implement clean mobility and public transport to cope with targeted climate change. The regulation of the real estate market and the shared economy is another key issue in which there is a combination of regulatory and legal policies at local, national, and European level that must ensure access to housing for permanent residents.

\section{References}

1. Ashworth, G. and Page, S.J. (2011) Urban tourism research: Recent progress and current paradoxes, Journal of Tourism Management, 32, 1-15.

2. Câmara Municipal de Lisboa (2017) Atlas Social de Lisboa. Lisboa. Entidade Regional de Turismo da Regiăo de Lisboa/Visitlisboa (2015) Strategic Tourism Plan for the Lisboa Region. Lisboa.

3. Colomb, C. and Novy, J. (2017) Urban Tourism and its discontents. An introduction in Colomb, C. and Novy, J. (2017) Protest and Resistance in the Tourist City. Routledge Editure.

4. Dredge, D, Gyimóthy, S., Birkbak, A., Jensen, T. E. \& Madsen, A. K. (2016) The impact of regulatory approaches targeting collaborative economy in the tourism accommodation sector: Barcelona, Berlin, Amsterdam and Paris, Impulse Paper No 9 prepared for the European Commission DG GROWTH. Aalborg University, Copenhagen.

5. Marie de Paris (2016) 2022 Tourism Strategy Plan, Development Plan. Paris.

Rutty, M. et al. (2014) The global effects and impacts of tourism. An overview in Hall, M., Göosling, S. and Scott, D. (2014) 7 The Routledge Handbook of Tourism and Sustainability. Routledge, New York. 
6. Vera Pais (2018) Lisbon. Urban Tourism and Sustainability Policies. Presentation at Tourism Ecoforum, May 2018, Barcelona. http://www.global-ecoforum.org/tef2018

7. Williams, A. (2013) Mobilities and Sustainable Tourism: path-creating or pathdependent relationships?, Journal of Sustainable Tourism, 21:4, 511-53.

8. UNWTO (2018) European Union Tourism Trends 2017, World Tourism Organization.

9. World Tourism \& Travel Council (2017) City travel \& tourism impact 2017 Europe, London.

10. http://ajuntament.barcelona.cat/pla-allotjaments-turistics/es/

11. http://pro.parisinfo.com/content/download/149746/16039462/version/1/file/ Strategie-tourisme-2022-Plan-d\%27actions.pdf

12. https://ajuntament.barcelona.cat/turisme/en/strategic-plan/documents

13. https://pro.parisinfo.com/actualites/actualite-touristique/Dossiers/schematouristique-paris-2022. 


\title{
THE MULTIFUNCTIONALITY AND SUSTAINABILITY OF SMALL AND MEDIUM ENTERPRISES IN TOURISM-BASED RURAL COMMUNITIES
}

\author{
Oleg PETELCA ${ }^{1}$, Ciprian-Constantin PĂTRĂUCEANU², lurie BEȘLIU ${ }^{3}$ \\ ${ }^{1}$ Alexandru loan Cuza University of lași, România \\ 2University of Oradea, România \\ ${ }^{3}$ Alecu Russo State University of Bălți, Republic of Moldova \\ oleg.petelca@gmail.com \\ patrauceanuc@yahoo.com \\ iurie.besliu@gmail.com
}

\begin{abstract}
The economic impact of tourist activity depends largely on the character of the area or space where it is practised (e.g., developed, developing or less developed). It also depends on the administration or, in broader terms, management of this complex activity and finality through consumption. The latter is related to both customer satisfaction and the satisfaction of the travel agency providing services, to the degradation of certain traditions and the disturbance of the economic, social, cultural, demographic and environmental balance in local communities. The globalisation process and the technological evolution determine visible and behavioural changes because competitiveness is related to technological efficiency. Tourism can generate substantial income, thus contributing to regional development and dynamizing the labour market and companies activating in that sector. By allocating various funds, we can improve the quality of services and renovate accommodation facilities, which enhances the popularity of the location and increases income, implicitly. This paper approaches rural tourism and entrepreneurship within a microeconomic approach. It is motivated by the fact that the most common tourist activities are small and medium enterprises, which are not always sustainable enough businesses. Hence, awakening the entrepreneurial spirit is one of the most notable challenges for the actors involved in small and medium enterprise development in rural areas. This paper highlights the role and challenges of small and medium enterprises activating in the tourism field in rural areas. In addition, the paper proposes a way for overcoming the constraints and difficulties imposed by rural communities, based on the connection between the traditional rural community and a human network existing outside the traditional territorial community. This network extending beyond the traditional territorial border may be complementary to the rural community. In this context, strategic cooperation becomes relevant; it is the solution for overcoming the challenges faced by other industries, too. Furthermore, rural tourism allows producers to mobilise (on a wider scale) the local resources redeemed within the mono-farm activities. Thus, they may attain the goal of using and preserving their rural heritage.
\end{abstract}

Key words: rural tourism; development; rural area: recreation; entrepreneurship; small and medium enterprises

JEL classification: L83; Q26; Z32 


\section{Introduction}

The phrase "rural tourism" has a broad connotation: it indicates tourist activity, in general, unfolded in rural areas, as well as tourist activities carried out by agricultural producers. Agritourism defines the tourist activity of agricultural producers, while rural tourism is often used concerning agritourism. In this respect, rural tourism acquires various interpretations. An increasing number of researchers from developing countries are working on community-based rural homestays, especially in the Asia Pacific region (Janjua et al, 2021). In this paper, rural tourism includes the agritourism practised by agricultural producers and community-based activities (i.e., tourist activity carried out by rural residents or by a group of rural residents, not necessarily in the agricultural field, but in tourist activities related to agriculture). This paper brings a contribution to theoretical and empirical research on rural tourism from a microeconomic perspective.

While research in the community tourism field has extended gradually to doublefolded topics (environmental and social), they have accounted for most studies, while the economic aspects have not represented a focusing point. It is one of the reasons why entrepreneurship in the tourism-based rural areas often face sustainability challenges at the end of the public or international support projects. One should investigate entrepreneurship in rural tourism extensively to improve this situation through both quantitative and qualitative approaches. It is one of the most common issues in every rural area, in developing and developed economies alike.

The purpose of this study is to determine the benefits of rural tourism, to find out to what extent rural communities use the benefits of rural tourism and to find solutions to use the benefits of rural tourism for the sustainable development of rural communities.

\section{Methodology}

In the study, the deductive logical approach was used. It was based on the elaboration of judgments that anchored on independent statements considered correct and not contradictory. The technique of abstraction has been used in order to bring the concrete elements to their general essentials and to highlight the most general aspects in the form of concepts. The articles studied were selected from the Web of Science database. Articles were searched for by the words "sustainability of rural tourism". After reading the name, the relevant articles were selected. Selected articles and materials from bibliographic lists that were accessed were studied.

\section{Tourism-based rural communities}

Within tourism-based rural communities, entrepreneurship is thought to encompass the activities carried out by operators introducing innovations in their products. It would also include innovations in production processes and the organisation of local resource management. Ultimately, it would comprise the creation of supply. Consequently, the purpose of tourism-based rural communities is to make a change and create demand for the products manufactured by the community through the collective efforts of communities. The decisive force for rural 
transformation is the transition to a post-productive society, which in rural areas, is characterized, among other things, by the reorientation of the economics from agriculture to tourism. The rural landscape is becoming an agricultural production area into a consumption area for tourism and housing (Epuran, 2021).

\subsection{Development of multifunctionality through rural tourism}

Multifunctionality entails positive effects, and it is defined as a common product generated by agricultural production and creating benefits. Multifunctionality involves a new social role for agriculture. However, it does not mean that multifunctionality automatically generates a new income source for agricultural producers. Multifunctionality has been defined as general positive effects created due to the technical combination between tourist activity and agriculture products. It means that it is impossible to make a technical distinction from the agricultural production process. In an agrarian community, the community functions, namely the share capital of the community or the community capital (Zahra \& McGehee, 2013; Knollenberg, Brune, Harrison, \& Savage, 2021), ensuring the survival of the members, is crucial for generating multifunctionality. This function is the prerequisite of rural community tourism. In this respect, multifunctionality is also a consequence of the institutional community of communitarian function. Multifunctionality is not internalised, and it does not generate income opportunities automatically. Consequently, efforts are necessary to attract incomes for the parties interested in the progress of rural communities focusing on tourist activities.

\subsection{Community tourism}

A community-based approach has been widely used in developing economies to overcome various social and economic challenges. Walzer (2009) has focused on small enterprise and entrepreneurship issues for practicians in the context of local economic development. Robinson and Green (2011) have also tried to mitigate the gap between theory and practice within their case studies. Fink et al. (2013) have used case studies focusing on rural small enterprises from the perspective of community entrepreneurship concerning Central Europe. Haughton (2013) has collected case studies on the economic development of communities, notably in the United Kingdom and Ireland. Fortunato and Clevenger (2017) investigated the progress of communities deeply rooted in a culture based on entrepreneurship and leadership development. Despite increasing attention paid to community progress and entrepreneurship, this matter is still under-investigated in the tourism field. However, it is worth noting several case studies on community tourism (Heesup, Taeyeon, Amr, Taeyeon \& Wansoo, 2019; Manhas, Gupta \& Gupta, 2014, Janjua et al, 2021). In this respect, we mention three major characteristics within the studies above, most of them carried out in developing countries or targeting developing countries. Hence, poverty reduction was the purpose of rural community tourism progress. To this end, community participation has been one of the favourite topics. Secondly, out of the three factors (environmental, social and economic), in the sustainability field, environmental and social factors have represented a focus point. Some studies have even approached the two aspects jointly. Thirdly, methodological/qualitative approaches have constituted the most common types of investigations. There is not just one method of development but it is their combination that generates positive effects on the territory and on the communities that populate it (Ivona, 2021). 


\section{Enhancing multifunctionality}

The issue with enhancement through market mechanism is that multifunctionality markets have not been fully determined, which means that both customers and producers often fail to recognise the relevance of the multifunctionality effects. Under these circumstances, it is hard to enhance them suddenly; hence, we should consider a staged approach to enhancement (Ohe, 2011). Such a gradual enhancement is an innovative process, hence the name "gradual innovation". Producers may enhance the effects as the diversification of agrarian activity progresses through the management efforts of entrepreneurs. Thus, as farm diversification advances, tourism operators have more possibilities of enhancing effects. It is often said that rural tourism is a relative example of the success of recreational components within the enhancement process (OECD, 2005). The effects of multifunctionality concern a new agrarian business by forming a new role for agriculture in society. In the initial phase, most customers and producers fail to observe the value of the positive effects generated by producers, despite producers being aware of the positive effects per se. Naturally, the demand level is still low in this phase, while producers reach their optimum level only from a private and not from a social point of view. If the positive effect does not exist, the private optimum point is also the socially optimum point. However, this is not the case when positive effects occur. In this phase, the effect is not valorised, which means that society receives benefits without paying producers any price (Ohe, 2011). For instance, if producers fail to acknowledge the actual value of the effect, they conduct their activity in the private optimum point. It is reasonable behaviour for producers when the price of the positive effect is not paid. However, if producers do not increase the income, there is no perspective for developing a new rural business in the long run. Hence, something should be done to enhance the positive effects, to determine a new and economically viable activity.

The next step is enhancement per se, but rural tourism studies show that it is both impossible and impractical to pass directly from zero to perfect enhancement. In the following phase, producers realise the importance of enhancing the positive effects, and they try to get back the average price (i.e., the material costs); hence, at that point, they receive the average price. However, a part of the positive effect is still uncovered. Some producers conduct their activity at this level. For instance, in this case, producers assume they run leisure activities not because they seek profit but because they want to cover the material costs and avoid losses. (Ohe, 2007).

Such behaviours depend on the producers' attitudes on how they place positive effects within their agrarian business. Namely, if they see positive effects as a new income opportunity or as volunteering services for the community. It is, of course, a matter of personal choice. At a business level, rural tourism activity is still not viable. Therefore, it is necessary to advance to a new level. The network must be extended through exchanges between producers and customers to get to the next level because the extension of this network helps producers obtain several opportunities to develop new ideas for better enhancing measures. It is due to rural tourism being an intangible product, unlike traditional food production leading to tangible goods, which may be stored for a certain period. The service has a production and consumption simultaneity, which means that customers must be 
present physically when production takes place (Niță \& Butnaru, 2005). There are two types of simultaneity: temporal and spatial. Temporal simultaneity means that it is not possible to store services and, as such, inventory may not be adjusted by supply. Spatial simultaneity indicates that it is not possible to ship services and, as such, shipping cannot be adjusted by supply.

In the case of rural tourism, if customers wish to enjoy the experiences of harvesting grapes, they should come and visit the location in the summer or autumn, when the grape harvest takes place. Otherwise, they miss their chance. Hence, locality and agrarian heritage provide simultaneity to rural tourism, adding diversity and differentiating it from other services. These features suggest two advantages. Firstly, the rural tourism market may be segmented temporally and spatially, creating an opportunity to develop a local culture-based rural tourism activity (Ohe \& Ciani, 2011). The tangible and intangible factors related to rural heritage (i.e., local cuisine, traditional architecture, agrarian lifestyle and warm rustic hospitality) could be considered ingredients of culture-based rural tourism activity. Thus, rural tourism allows producers to mobilise, on a larger scale, the local resources redeemed in the case of mono-farm production activity and to use and conserve their rural heritage. If producers reach this point, price elasticity lowers, which means that producers may take price initiatives, thus feeling less pressure to change the shipping costs. Another advantage of simultaneity is that the exchange and feedback between producers and customers occur easily during services provision. The meaning of feedback is essential for rural tourism businesses because the feedback of customers shows their satisfaction and complaints. From feedback, producers learn the potential needs of customers and how to improve the quality of services. They also learn to trust their capacity as producers and see their local community as a reliable destination for tourists. In this respect, feedback and exchange are necessary conditions for innovations in rural tourism (Ohe, 2007).

On the other hand, simultaneity also has downsides because non-storability and non-shipping generate a significant gap between peak and off-season demand, which is known as an issue of demand seasonality. Seasonality inevitably causes income fluctuations due to the inefficient use of resources (entailed by mid-season congestion and off-season underuse). This fluctuation is further accelerated by the meteorological conditions, given that rural tourism targets tourists outside the rural areas. For these reasons, fluctuations should be reduced to a minimum for effective use of agricultural resources and stable activity of agricultural enterprises. It means that service management is crucial for successful rural tourism from various perspectives (Lovelock \& Wirtz, 2016). If producers run a viable business, the enhancement of the positive effects of multifunctionality is a success. The change depends on the management capacity of producers. Therefore, software aspects (i.e., management of services) are more relevant for innovation than hardware aspects in the mobilisation of rural and agricultural resources concerning rural tourism activity. The intriguing characteristic of rural tourism is that multifunctionality improves through rural tourism, which creates a new social value continuously, though it is not viable initially. Rural tourism may create an opportunity for a new service and product within this social value. In this respect, one should not underestimate the relevance of multifunctionality. Ohe proves in his research the empirical evidence for the positive recursive relationship between multifunctionality and rural tourism. He concludes that community work generates 
and improves multifunctionality, while positive effects may be enhanced by a community relying on rural tourism than by an individual agricultural producer.

Considering the enhancement of agriculture multifunctionality positive effects, if the enhancement of positive effects is complete, we examine the characteristics of rural tourism. In a traditional rural economy, agricultural products are generally shipped from rural areas to urban markets (and consumed there). A typical example of this assumption is "The Isolated State" of von Thunen (Clark, 1973). In this case, the market of agricultural products (i.e., food) is located exclusively in the urban area. Of course, the residents within the rural areas go to local agrarian shops to buy food, and this behaviour is considered a traditional food buying category. On the other hand, rural areas attracted urban inhabitants to buy local products from the agrarian shops and enjoy rural tourism. People visiting the rural areas buy fresh agricultural products and enjoy quality leisure time. It indicates that the purchase behaviour displayed by urban residents shifts from urban to rural areas, besides the traditional agricultural product flow from the rural to the urban areas. This trend is considered an outcome of the developing rural market.

There are two markets, separated spatially: urban market and rural market. Though it means that prices are specific to each market, there is a difference if prices are based on the manufacturing location. Hence, we assume a different location for each and a difference between production and consumption place. Secondly, shipping costs must be considered (due to the different markets locations and the distinct production and consumption places). Producers must deliver the agricultural products to the urban market; also, urban residents must visit the rural areas to enjoy rural tourism. The tourists may include the shipping in the cost of a tour to the rural area (i.e., the shipping cost is not additional). Thus, the travel expenses are deductible, given the positive utility. In other words, if travel to the rural area is seen as a form of rural tourism for which urban residents are willing to pay transportation fees, this is one of the conditions justifying the creation of rural markets for urban residents.

Third of all, the contents of shipping fees comprise the following: (a) the direct shipping of agricultural products and processed foods; (b) in the case of travel, the public transportation cost or the cost of car fuel, including a driving opportunity cost and (c) the psychological transportation cost. The last depends on the preference for the rural area, different from one customer to another, and the attractiveness of the destinations. Therefore, the psychological cost for a customer who prefers rural areas is lower than for a consumer with a lower propensity for them. Fourth of all, it is assumed that the implicit cost in food purchase by residents on each market (i.e., the urban market for urban residents and the rural market for rural inhabitants) is zero.

Fifthly, the rural market comprises local and urban residents, too. Because the purchase behaviour of residents on rural markets is dominated by daily consumption behaviour, it is essential to develop rural markets. Hence, the number of visitors from the densely populated urban areas adds to the residents.

There are differences between the goods purchased while travelling to a rural area and the traditional agricultural products bought from an urban market. Goods available on an urban market are regular agricultural products within rural areas. These products are generally shipped through the mass distribution systems of agricultural cooperatives, retailers and distributors to urban markets (displaying high demand and providing consumption). In this respect, it is a mass market. 
Usually, the cost of products includes shipping, and it influences price increases. On the other hand, in the rural markets where tourism flourishes, urban residents are the dominant components of demand. Specifically, rural tourism products are services included in farm accommodation, meal services in farm restaurants, agricultural and rural experiences and farm visits for leisure purposes. The direct sale of agricultural products and processed goods are also included in the category of rural tourism products because customers normally cover shipping costs at the purchase point. Products listed as services (as we mentioned before) have a production and consumption simultaneity. Essentially, customers pay for shipping to get to the destination because they cannot enjoy the services unless they visit the production site, when and where such services are available. Whatever the shipping/transportation fee chosen by customers, they pay the actual travel cost, including the one for visit opportunity. The size of markets for rural tourism goods is significantly smaller than the mass market for traditional agricultural products. Hence, the market of rural tourism services is considered a niche market, as the literature often highlights. It is assumed that these characteristics lead to higher elasticity of demand concerning regular agricultural products such as food. In the context of multifunctionality, while rural tourism may provide income by using the advantages generated by multifunctionality, regular agricultural products are considered neutral for the use of multifunctionality by cashing in income from agricultural production. These markets are not thought to replace producers but represent an addition. When considering the two possible markets, it is easier to extend perspectives towards farm diversification.

\section{Conclusions}

The features of rural tourism entail two advantages. Firstly, the rural tourism market may be segmented temporally and spatially. This division creates an opportunity to develop a culture-based local tourism activity in rural areas. Tangible and intangible factors related to rural heritage (i.e., local food, traditional architecture, agrarian lifestyle, rustic hospitality) represent ingredients of culture-based rural tourism. Hence, rural tourism allows producers to mobilise on a broader scale the local resources previously unused in the case of mono-farm production activity. It provides the chance to use and preserve their rural heritage. Another advantage is that simultaneity allows exchange and feedback between producers and customers through service provision. The meaning of feedback is essential for rural tourism businesses because customers' feedback shows the satisfaction and dissatisfaction points accurately. From feedback, producers may learn potential customers' needs and ways to improve the quality of services. Feedback also allows them to trust their capability as producers and the rural community they grew up in as a reliable destination for tourists.

If producers can manage the business efficiently, the enhancement of the positive effects of multifunctionality would be a success. This change depends on the producers' management capacity. Hence, the software aspects (i.e., service management) are more relevant for innovation than hardware aspects in the mobilisation of rural and agrarian resources for rural tourism activity. The intriguing characteristic of rural tourism is that multifunctionality improves through rural tourism. Thus, it creates a new social value permanently (though the social value may not be viable initially). Rural tourism may create an opportunity for a new 
service and product from the social value. In this respect, one should not underestimate the relevance of multifunctionality.

Rural tourism allows producers to mobilise, on a wider scale, the local resources redeemed in the case of mono-farm production and get the chance of using and conserving their rural heritage. If producers attain this goal, price elasticity lowers, which means that producers may take price initiatives, thus mitigating the pressure on changing shipping costs.

\section{References:}

1. Clark, C. (1973). The value of agricultural land. Oxford: Pergamon Press.

2. Epuran, G.; Tescas,iu, B.;Tecău, A.-S.; Ivasciuc, I.S.; Candrea, A.N. (2021) Permaculture and Downshifting-Sources of SustainableTourism Development in Rural Areas, Sustainability, 13(230), pp. 1-19.

3. Fink, M., Loidl, S., \& Lang, R. (2013). Community-based entrepreneurship and rural development: creating favourable conditions for small businesses in Central Europe. Abingdon: Routledge.

4. Fortunato, M., \& Clevenger, M. (2017). Toward entrepreneurial community development: leaping cultural and leadership boundaries. New York: Routledge.

5. Haughton, G. (2013). Community economic development. London: Routlege.

6. Heesup, H., Taeyeon, E., Amr, A.-A., Taeyeon, B., \& Wansoo, K. (2019). Community-Based Tourism as a Sustainable Direction in Destination Development: An Empirical Examination of Visitor Behaviors. Sustainability, 11(2864), pp. 1-14.

7. Ivona A., (2021). Sustainability of Rural Tourism and Promotion of Local Development, Sustainability, 13(6), DOI: 10.3390/su13168854, pp. 1-7.

8. Janjua, ZU., Krishnapillai, G., \& Rahman, M. (2021). A Systematic Literature Review of Rural Homestays and Sustainability in Tourism. Sage Open, 11(2), DOI 10.1177/21582440211007117, pp. 1-17.

9. Knollenberg, W., Brune, S., Harrison, J., \& Savage, A. (2021). Identifying a community capital investment portfolio to sustain a tourism workforce. Journal of Sustainable Tourism, pp. 1-17.

10. Lovelock, C., \& Wirtz, J. (2016). Service marketing: people, technology, strategy, 7th Global edn. Singapore: Pearson.

11. Manhas, P., Gupta, D., \& Gupta, A. (2014). Strategic development policies and impact studies of sustainable rural and community-based tourism. Delhi: Primus Books.

12. Niță, V., \& Butnaru, G. (2005). Gestiune hotelieră - curs, aplicații, grile. Iași: Editura Tehnopress.

13. OECD. (2005). Annual Report, [Online], Available: https://www.oecd.org/about/34711139.pdf [01 Nov 2021]

14. Ohe, Y. (2007). Multifunctionality and rural tourism: a perspective on farm diversification, Journal of International Farm Management, 4(1), pp. 1-23.

15. Ohe, Y. (2011). Evaluating internalization of multifunctionality by farm diversification: Evidence from educational dairy farms in Japan. Journal of Environmental Management, 92(3), pp. 886-891.

16. Ohe, Y., \& Ciani, A. (2011). Evaluation of Agritourism Activity in Italy: Facility Based or Local Culture Based? Tourism Economics, 17(3), pp. 581-601.

17. Robinson, J., \& Green, G. (2011). Introduction to community development: theory, practice, and service-learning. Thousand Oaks: Sage Publications. 
18. Walzer, N. (2009). Entrepreneurship and local economic development. Lanham: Lexington Books.

19. Zahra , A., \& McGehee, N. (2013). Volunteer Tourism: A Host Community Capital Perspective. Annals of Tourism Research, 42, 22-45. 


\title{
HOW THE PANDEMIC HAS CHANGED THE TOURISM INDUSTRY
}

\author{
Afrodita BORMA ${ }^{1}$ \\ ${ }^{1}$ Department of Economics and Business, Faculty of Economic Sciences, \\ University of Oradea, Oradea, Romania \\ aborma@uoradea.ro
}

\begin{abstract}
The tourism industry has been one of the industries most affected by the pandemic. The borders were closed one by one, travel was limited or even banned, and people were asked to stay in their homes. For tourism, 2020 has been a continuous decline. In 2020, tourism was among the sectors most affected by the COVID-19 pandemic, due to the travel restrictions as well as other precautionary measures taken in response. In 2020, the number of nights spent at European Union (EU) tourist accommodation establishments totaled 1.4 billion, down by $52 \%$ compared with 2019. Market research confirms that 2020 has become the year of domestic tourism. 1 March 2021 marks a year since the beginning of the most difficult period in the tourism industry. People's desire to travel has not disappeared, but their behavior regarding the scheduling of the next vacation has changed. In 2021, tourists tend to choose more isolated destinations, with more green space and away from mass tourism. And while storm clouds appear to be dissipating in 2021 with the start of the vaccination campaign, there are still many questions about what this year's trip will look like. As the pandemic shows no signs of stopping soon and the vaccination campaign is progressing slowly due to the limited number of vaccines and logistical organization problems, tourism cannot stop and wait for better times. And, moreover, the future of this industry seems at this moment an equation with unknown Ns. The challenges will be especially for those who receive tourists, because they must give them the confidence to start traveling again as in the past. The aim of European tourism policy is to maintain Europe's position as a top tourist destination, while maximizing the industry's contribution to growth and employment and promoting cooperation between EU countries. Business Magazine identified five key questions for tourism entrepreneurs to determine how and where tourists will spend their holidays in 2021.
\end{abstract}

Keywords: tourism industry; COVID-19 pandemic; European Union; Romania.

JEL Classification: L83; Z32

\section{Introduction}

Tourism is a complex ecosystem that includes many actors: providers of information and offline and online services (tourist offices, digital platforms, travel technology providers), travel agencies and tour operators, accommodation service providers, destination management organisations, tourist attractions and passenger transport activities. Tourism and transport are also based on major industrial sectors (e.g., construction, aircraft manufacturing, shipbuilding sectors, etc.). Following the COVID-19 pandemic, the tourism industry has been among the 
most affected industries. As a result of travel and other restrictions, tourism has gradually ceased its operations in the first quarter of 2020 in the EU and worldwide. The OECD estimates that this decline in activity ranges between $45 \%$ and $70 \%$, depending on the duration of the health crisis and the pace of recovery (according to the European Commission, 2020:9-11).

\section{Research Methodology}

In this paper, we have focused both on a quantitative, as well as a qualitative analysis. To conduct the quantitative analysis, we used statistical data provided by Insse.ro and Eurostat and, in terms of the qualitative analysis, we focused our attention both on documentaries (eBook Horeca, European Commission, etc.), as well as on the interview conducted by Business Magazine on "How and where will we spend our holidays in the future?" The 5 questions proposed by Business Magazine seek answers/solutions with regards to the changes resulting in the behaviour, attitude and expectations of tourists, following the COVID-19 pandemic.

\section{Tourism in Europe and in Romania during January and July 2020 (statistical data)}

In 2020, the number of accommodations in tourist units in the EU has halved in the first eight months of the year, compared to the same period in 2019. Overnight stays in tourist reception facilities in EU countries during January and August 2020 stood at 1.1 billion, two times less than in the same period in 2019, amid the effects of the coronavirus pandemic (COVID-19), according to data published by Eurostat. The largest decrease in the number of overnight stays recorded in the tourist reception facilities in the EU was in April (95\%) and May (89\%) 2020, compared to the same months in 2019, when Europe was practically closed. During July and August 2020, the number of overnight stays registered in the tourist reception structures in the EU decreased by 37\% compared to the similar period in 2019 (according to NIS, 2020). The pandemic that locked up countries around the world did not bypass Romania either.

Table 1. Arrivals in tourist reception structures with accommodation functions period 01.01-31.08

\begin{tabular}{|l|r|r|r|}
\hline & \multicolumn{3}{|c|}{$\begin{array}{c}\text { Arrivals in tourist reception structures with } \\
\text { accommodation functions } \\
\text { m.u. -thousands- }\end{array}$} \\
\cline { 2 - 4 } & $\begin{array}{c}\text { Period } \\
\text { Jan-Aug 2019 }\end{array}$ & $\begin{array}{c}\text { Period } \\
\text { Period } \\
\text { Jan-Aug 2020 } \\
\text { Jan-Aug 2019 } \\
\text { compared to } \\
\text { Jan-Aug 2020 }\end{array}$ \\
\hline Total & 9137.0 & $\mathbf{4 3 6 7 . 4}$ & $\mathbf{4 7 . 8}$ \\
\hline Romanian tourists & 7317.0 & 4006.7 & 54.8 \\
\hline $\begin{array}{l}\text { Foreign tourists of } \\
\text { which: }\end{array}$ & 1820.0 & 360.7 & 19.8 \\
\hline
\end{tabular}




\begin{tabular}{|l|r|r|r|} 
- Europe & 1351.7 & 277.8 & 20.6 \\
\hline (European Union) & 1052.5 & 205.9 & 19.6 \\
\hline - Asia & 245.2 & 41.0 & 16.7 \\
\hline - North America & 127.4 & 19.5 & 15.3 \\
\hline - South America & 14.3 & 2.7 & 18.9 \\
\hline - Africa & 13.1 & 3.5 & 26.7 \\
\hline
\end{tabular}

Source: conducted by the author based on the information provided by NISES in the Press Release no. 260/2.10.2020

The arrivals registered in the tourist reception structures in the period 01.01 31.08 .2020 amounted to 4367.4 thousand, representing a decrease by $52.2 \%$ compared to the same period in 2019.

Of the total number of arrivals, during 01.01-31.08.2020, the arrivals of Romanian tourists in the tourist reception structures with accommodation functions represented $91.7 \%$, while foreign tourists represented $8.3 \%$. Regarding the arrivals of foreign tourists in the tourist reception structures, the largest share was represented by tourists from Europe (77.0\% of total foreign tourists), and of these, $74.1 \%$ were from countries belonging to the European Union.

Table 2. Overnight stays in tourist reception structures with accommodation functions - period 01.01-31.08

\begin{tabular}{|c|c|c|c|}
\hline & \multicolumn{3}{|c|}{$\begin{array}{l}\text { Overnight stays in tourist reception structures with } \\
\text { accommodation functions }\end{array}$} \\
\hline & & & u. -thousands- \\
\hline & $\begin{array}{c}\text { Period } \\
\text { Jan-Aug } 2019\end{array}$ & $\begin{array}{c}\text { Period } \\
\text { Jan-Aug } 2020\end{array}$ & $\begin{array}{c}\text { Period } \\
\text { Jan-Aug } 2019 \\
\text { compared to } \\
\text { Jan-Aug } 2020\end{array}$ \\
\hline Total & 20874.1 & 10163.4 & 48.7 \\
\hline Romanian toursits & 17294.2 & 9382.5 & 54.3 \\
\hline $\begin{array}{l}\text { Foreign tourists of } \\
\text { which: }\end{array}$ & 3579.9 & 780.9 & 21.8 \\
\hline - Europe & 2574.1 & 590.2 & 22.9 \\
\hline (European Union) & 1982.4 & 431.6 & 21.8 \\
\hline - Asia & 546.9 & 103.2 & 18.9 \\
\hline - North America & 273.6 & 41.7 & 15.2 \\
\hline - South America & 30.2 & 6.2 & 20.5 \\
\hline - Africa & 25.4 & 8.0 & 31.5 \\
\hline
\end{tabular}

Source: conducted by the author based on the information provided by NISES in the Press Release no. 260/2.10.2020 
The overnight stays registered in the tourist reception structures in the analysed period amounted to 10163.4 thousand, representing a decrease by $51.3 \%$ compared to those in 2019. The average length of stay during January and August 2020 was 2-3 days for both Romanian and foreign tourists (according to NIS, 2020).

Of the total number of overnight stays, during 01.01-31.08.2020, the overnight stays of Romanian tourists in the tourist reception structures with accommodation functions represented $92.3 \%$, while the overnight stays of foreign tourists represented $7.7 \%$. Regarding the overnight stays of foreign tourists in the tourist reception structures, the largest share was represented by tourists from Europe ( $75.6 \%$ of total foreign tourists), and of these, $73.1 \%$ were from countries belonging to the European Union.

\section{European Union endeavours to support tourism affected by the COVID-19 pandemic}

The EU has relieved EUR 1 billion as a guarantee for the European Investment Fund in order to help 100,000 SMEs across the EU, including in the field of tourism. The Commission encourages collaboration between regions, to share, test and implement new smart solutions for recovery, creating a new value chain for an innovative, responsible and sustainable tourism. The Commission also aims to ensure that passenger and traveller vouchers become a viable and attractive alternative to reimbursing cancelled trips, in the context of the COVID-19 pandemic. Over time, several digital platforms have been created in an attempt to support and promote tourism in Europe. One of these digital platforms is the "Europeana", which promotes the European cultural heritage, showcasing cultural jewellery and "hidden gems" from across Europe. At the same time, the European web application "Cultural gems" will launch, in the second half of the year, a campaign serving as ambassador of the citizens to support proximity tourism. In cooperation with the Member States, the Commission will continue to support the exchange of information and encourage Europeans to discover the diversity of Europe's landscapes, cultures and experiences by organising various competitions, such as: "European Capital of Smart Tourism" and "European Destinations of Excellence" (according to the European Commission, 2020:13-17).

\section{How the pandemic has changed tourism and the hospitality industry}

Europe represents half of the tourist destinations at global level, and the situation is particularly difficult for tourism-dependent countries such as Spain, Italy, France and Greece. Travel restrictions imposed in the context of the COVID-19 pandemic have decimated the tourism sector, a major player in the EU economy. The borders were closed one by one, travel was limited or even banned, and people were asked to stay in their homes.

\section{A few perspectives ...}

After a year of restrictions and lockdowns, we should not be surprised to see an increase in popularity of the health tourism, wellness tourism, spiritual tourism and possibly religious tourism. It is, eventually, a rediscovery of the self (according to Antoniou, K. 2021) 
Sabin Costea says that "the pandemic constituted a major financial blow for the industry in which he works", stating the following: "The impact for us, I'm talking about the tourism industry at large, has been colossal. In a few weeks, our years of planning and sales work have been wiped out. And for almost a year now, since March 2020, there has been a strong feeling that we are fighting in vain". From Pricop's perspective here are some opinions expressed by tourists: „You feel tension, aggressiveness. Somehow, people no longer travel as prior to the pandemic" says Ana-Maria Leu. "I chose accommodations in small towns, with apartments or rooms in villas with private bathroom, I have always worn a mask indoors or when interacting with the hosts at the accommodation, and the hand sanitizer was always at hand. I have avoided crowded areas and beaches and used to choose the most secluded table at terraces" says Sorina Severin (according to Pricop, S. 2021).

\section{Restaurants and changes in customer consumption behaviours}

For the restaurant segment, a dramatic decrease in traffic and the number of customers around the world was observed, in a context where, for several months, locations have been closed in Romania, most businesses opted for the development of a new line of business, that of delivery, which remains a clear plan for the future as well. During the lockdown, most of the well-known chefs moved to social media, where they started cooking different recipes and answering questions from those who used to watch their shows. Home-cooked food and home-made bread have become the new trend of 2020 - the amounts of flour, yeast, frozen foods and canned food sold have doubled (sometimes tripled), compared to the same period in 2019 (according to eBook Horeca 2020:14-15).

\section{Behaviour changes in the Hotel industry}

For the hotel segment, the lockdown period has brought about the closing of the locations and the cancellation of reservations for several months. Certain hotels abroad have opted to transform conference and event spaces into mini-offices, places where Zoom meetings can be organised with TV walls, web cams or spaces that integrate virtual reality, broadcast online events or virtual scenes are created. In Romania, architects and designers focus their attention on island-based design, with generous spaces between visitors, dividing walls made of vegetation or through art exhibitions (according to eBook Horeca 2020:22)

\section{How and where will we spend our holidays in the future?}

Business Magazine has identified five key questions for players in the tourism industry. Thus, the representatives of five of the largest travel agencies in Romania were selected to answer the following questions: Is the era of city breaks on the wane? Are charter flights the future of Romanian tourism? Will we choose cars to the detriment of planes? Will mass tourism be replaced by luxury tourism? Could Romania become a significant name on the world tourism map? (according to Roșca, C. 2021). 


\section{Is the era of city breaks on the wane?}

Prior to the pandemic, low-cost airlines and travel agencies used to offer various compelling promotions and travel packages, in order to attract as many tourists as possible. If you were lucky and patient, you could fly from Bucharest to Rome for Lei 100 or 200 (round trip), the fare being lower than for a train ride from the Capital city to the northern part of the country.

However, the pandemic has cancelled the phrase "city break" from the travellers' vocabulary. The multiple restrictions, the changing travel conditions and the costs of PCR tests required by most countries are strong enough reasons to make tourists look for vacations in their own country. In the opinion of tourism industry specialists, the demand in city breaks will dramatically surge once the pandemic will come to an end. "In the long run, I don't think that city breaks or short vacations abroad will die "..." On the other hand, we see an increase in local city breaks, so within the country. We are still talking about short vacations, only that instead of being in France, Spain or Italy they are in Romania" (according to Javier Garcia del Valle, CEO of Happy Tour).

\section{Are charter flights the future of Romanian tourism?}

Until recently, Romania has not had direct flights to exotic destinations such as the Maldives, Kenya, Zanzibar or the Dominican Republic. During the pandemic, however, the first direct flights occurred. Christian Tour Group, one of the largest players in Romanian tourism, has launched a series of charter flights, and entrepreneur Cristian Pandel, the owner and CEO of the business, says the future sounds good. "We are glad that after so many difficult months, in which tourism was down, towards the end of the previous year we could see a growing appetite of local tourists for remote, exotic and warm destinations, during the cold season in Romania." Thus, this pandemic, although it was like a hurricane over tourism worldwide, it also brought a positive side, precisely by the launching of these direct charter flights, for the first time, to exotic long-haul destinations, he added.

\section{Will we choose the car to the detriment of planes, for safety reasons?}

There are still many questions regarding COVID-19, and one of them relates to the way the disease is transmitted. People are afraid, many of them, that is why planes (closed spaces accommodating several hundred passengers) are considered with scepticism. Alin Burcea, the owner of the Paralela 45 travel agency, believes that the plane has strong enough arguments not to feel that its position is threatened. "I do not think that this pandemic will lead to an increase of the number of car trips. It is more convenient to travel to Antalya (Turkey) in just one hour and 20 minutes by plane, and not by car, a journey that would take two days, with a stop for one night of accommodation", he explains.

\section{Will mass tourism be replaced by luxury tourism?}

Under the current conditions, in which the risk of spread of any disease increases with the number of people in one place, some specialists have circulated the information according to which countries could rather branch out to luxury tourism. Thus, with a smaller number of visitors, revenues could be similar. Could this be a long-term solution? "It seemed so, at the beginning of the pandemic (that there is a branching out to luxury - ed. n.), but as other countries began to open up, I noticed a return to the old travel behaviours," says Sorin Stoica, owner of the Eturia travel 
agency, specialized in exotic destinations. He takes Egypt as an example, which is a mass destination, and here the number of charters has reached unprecedented records. These are direct flights from Romania to the resorts at the Red Sea Hurghada and Sharm El Sheikh.

\section{Could Romania become a significant name on the world tourism map?}

The closure of the borders of most countries worldwide has determined local travellers to discover/rediscover tourist attractions in their own country. In the local market of Romania, many accommodation facilities and restaurants or cafés have been developed in recent years, at Western standards and at reasonable prices. Industry players say that rural and ecological tourism can be winning bets for Romania. "The development of rural tourism in Romania was happening prior to the pandemic, as well, not at an accelerated pace, but it increased both quantitatively and qualitatively. The holiday vouchers used by many tourists not only for the seaside but to get to know new areas of the country have driven this trend ", says Dan Goicea, CEO and founder of the Cocktail Holidays travel agency. Tourist guesthouses, by the fact that they are smaller accommodation units, in general, many even in remote areas, some with rates targeting lower budgets, represent an attraction and, implicitly, a solution for many nature lovers, not only for holidays, but also for weekends and even for working and relaxing at the same time, added the entrepreneur. "Those who have discovered or rediscovered rural areas will return in the future, as well." Rural Romania is a very attractive destination, not only for Romanians, but also for foreigners, having one of a kind areas and products, where nature, architecture, traditions, gastronomy and culture so beautifully intertwine. "Many foreigners who know the destination, know that Romania is the last place to find wildlife in Europe."

\section{Conclusions}

Considering current technology, it is time to focus on nature, culture, adventure and experiences to build a new travel and tourism industry (according to Trends HRB Magazine, 2020:39). The travel conditions imposed by the COVID-19 (testing/vaccination) will limit the options to travel abroad, but also nationally for people who have not been vaccinated. Sources of income are another issue that will affect tourism at global level, because many people have lost their jobs during the pandemic. In 2021, tourists will continue to travel to nearby destinations. They will more often go outdoors and will opt for shorter vacations (sometimes even by tent, minimizing the possibility to interact with other people). They will prefer to rent villas, apartments, caravans or those accommodation units that offer them a more generous personal space. Tour operators will try to organise group tourist programs differently: to offer smaller means of transport to a destination instead of large buses, to organise private tours (suitable for extended families/groups of friends travelling together), etc. being concerned with distancing, hygiene and ensuring safe travel conditions for tourists. Furthermore, the public accommodation and catering units will seek to implement new rules of hygiene and distancing (in the rooms, restaurant, common indoor or outdoor areas), to develop more attractive programmes for guests, to offer them contactless experiences (at check-in/check-out, restaurant, bar, other services), to include room-service among 
the usual services they provide (especially, if they did not previously have this service) and to provide guests with excellent internet connection, as well as "work friendly" rooms (just as the "work from home" concept, for some time now, the "work from hotel" concept has emerged.

\section{References:}

1. Antoniou, K, (2021). Post - pandemic travel: the trends we'll see when the world opens up again. [Online] Available: https://theconversation.com/post-pandemictravel-the-trends-well-see-when-the-world-opens-up-again-153401 [25 Nov 2021].

2. Comisia Europeană, (2020). Turism și transport în 2020 și ulterior (European Commission, Brussels,13.05.2020, on vouchers offered to passengers and travellers as an alternative to reimbursement for cancelled package travel and transport services in the context of the COVID-19 pandemic) [Online] Available: https://ec.europa.eu/info/sites/default/files/communication-commission-tourismtransport-2020-and-beyond ro.pdf [22 Nov 2021].

3. Horeca, (2020), eBook, [Online] Available:

https://www.businessdays.ro/blog/business-development/schema-de-ajutorhoreca-500-milioane-euro-in-total-pentru-domeniul-ospitalitatii [26 Nov 2021]. 4. INS, (2020). Comunicat de presă, Nr. 260 / 2 octombrie 2020, (NIS, Press release No. 260/ October 2, 2020) [Online] Available: https://insse.ro/cms/sites/default/files/com presa/com pdf/turism08r20 0. pdf [25 Nov 2021].

5. Pricop, S., (2021), Turistul de pandemie, temerar sau „răspândac” de virus? Experiențele românilor care au călătorit în străinătate. (The pandemic tourist, bold or the one who spreads the virus? The experiences of Romanians who traveled abroad) [Online] Available: https://romania.europalibera.org/a/turismul-inpandemie-vacante-romani/31074180.html [13 Nov 2021].

6. Revista Trends HRB, nr.43, nov-dec.2020, (Trends HRB Magazine no.43) [Online] Available: https:/www.trendshrb.ro/revista/2020-43uer8wer8weha8ksdds7sd/pdf/2020-43-uer8wer8weha8ksdds7sd.pdf [25 Nov 2021].

7. Roșca, C (2021), Business Magazin. 5 întrebări despre viitorul turismului. (Business Magazine. 5 questions about the future of tourism)._[Online] Available: https://www.zf.ro/eveniment/business-magazin-5-intrebari-viitorul-turismului-apusera-city-break-19947190 [13 Nov 2021]. 


\title{
FEATURES OF SUSTAINABLE DEVELOPMENT AT THE LEVEL OF SMES
}

\author{
József GÖNCZI \\ Doctoral School of Economic Sciences, Faculty of Economic Sciences, University \\ of Oradea, Romania \\ jozsef.gonczi@rove.ro
}

\begin{abstract}
SMEs represent a large share of the enterprises on the national and EU level. This article proposes to examine the applicability of CSR policies for SMEs. SMEs differ from large enterprises in many aspects of their financing, functioning, culture and relationship with shareholders and stakeholders. SME social responsibility practices cannot solely be judged by the same measure as the CSR practices of large enterprises due to the inherently different nature of the different sized enterprises.
\end{abstract}

Keywords: small and medium sized enterprises (SMEs); sustainability; corporate social responsibility (CSR)

JEL Classification: M14

\section{Introduction}

Recognizing the important role of SMEs, there are more and more EU projects on the social responsibility of SMEs. At the same time, the literature on corporate responsibility and related projects usually start from the characteristics of this type of activity of multinational companies, on the basis of which the standards of responsibility are established. The corporate responsibility practices of large companies are seen as a benchmark even when research is specifically targeted at SMEs. (Jenkins, 2004, Supino, Proto, 2006). However, this practice, as well as the "policies" resulting from these empirical findings, are potentially inadequate in terms of macro-sustainability in at least three respects.

For corporate sustainability and CSR, there is no theoretical or empirical evidence that current CSR and dominant corporate sustainability practices actually contribute to positive ecological and social processes at macro level (Banerjee, 2008). In other words, it does not necessarily consider that a sustainable practice would be the norm when judging the sustainability of companies. On the other hand, there may be responsibility programs for SMEs that they cannot comply with because of their differences to large companies that are considered the norm. Thus, even despite the adequacy of the interpretation of corporate responsibility (i.e. its real sustainability, social and environmental benefits), they will not be able to be applied by SMEs. Thirdly, we can ignore the aspects of responsibility and the structural characteristics of the functioning of SMEs, which are missing in large companies due to fundamentally different characteristics. 


\section{Significance and share of SME sustainability}

It is an extremely relative thing to say that "an enterprise is small". A several factors influence this, ranging from the scope of activities to the number of employees. Therefore, it may not be most appropriate to create general rules. The diversity of the concept is well justified by the fact that, for example, in banking practice, the concept of small business is defined based on completely different criteria than in aid policy. (Kállay, Imreh, 2004).

International practice is probably uneven precisely because of the above. In the United States, for example, sectoral differentiation is used in terms of support, which allows for a much finer positioning of interventions. In specific cases, even EU Member States deviate from the basic definitions (Table 1) - despite the adoption of general rules. It is clear that it depends a lot on the activity which companies are considered small in a certain sector. On the other hand, in the European Union it was necessary to clearly identify the companies that could receive various subsidies. In the context of accession, the definition of SMEs has been changed several times by national legislation in recent years. In Romania, Law 346 of 2004 regulates SMEs.

After the 2004 enlargement, there were about 26 million SMEs in the EU. In the EU, $99.8 \%$ of companies are SMEs and $91.5 \%$ are micro-enterprises with less than 10 employees, about two thirds of the Union's employees are employees of SMEs. The data in Romania are like those in the EU, although they show a higher share of employment in Romania but lag behind in terms of added value.

In Romania, $88.4 \%$ of companies are micro-enterprises. The share of small companies is $9.5 \%$, that of medium-sized companies is $1.8 \%$ and that of large companies is $0.3 \%$. SMEs employ $65.8 \%$ of private sector employees. That is, due to their weight, the impact of their overall performance on sustainability and wellbeing is decisive despite the extremely low weight of individual SMEs (Jenkins, 2004). On the one hand, through their role in employment, they determine the wellbeing of a significant part of society and, on the other hand, according to estimates, which are very difficult to control, they are responsible for about $70 \%$ of the business sector's impact on the environment.

Table 1. Criteria for the size categories of Romanian companies

\begin{tabular}{|c|c|c|c|}
\hline Criteria & Microenterprise & Small enterprise & $\begin{array}{l}\text { Medium sized } \\
\text { enterprise }\end{array}$ \\
\hline $\begin{array}{l}\text { Maximum number of } \\
\text { employees (average number of } \\
\text { employees) }\end{array}$ & $f<10$ & $10-49$ & $50-249$ \\
\hline Net annual turnover & $\leq$ EUR 2 million & $\leq$ EUR 10 million & $\leq$ EUR 50 million \\
\hline Total assets & $\leq$ EUR 2 million & $\leq$ EUR 10 million & $\leq$ EUR 43 million \\
\hline
\end{tabular}

Source: Law 346/2004 
One of the biggest problems with the SME sector is that it is an extremely heterogeneous sector. Numerous studies (Ernst, Young, 1999) divided small and medium-sized enterprises into categories based on different aspects. In each case, it was established that there is a significant difference between the groups and the individual categories. In addition, SMEs are present in several different sectors, as part of different supplier networks, with different management styles and ownership structures (Jenkins, 2004).

Despite their diversity, a significant number of actors in the sector still have common characteristics that have a significant impact on their role of responsibility and sustainability. Consequently, in the next part of the paper, we first analyze the differences between SMEs and large companies, then the resulting differences in responsibility.

\section{Differences between SMEs and large companies}

One of the key structural differences between SMEs and large companies is in terms of access to finance. In general, access to finance is one of the classic areas of competitive disadvantage for SMEs. These problems are practically explained by high relative transaction costs (Kállay, 2000). Fighting the constant lack of funds, financing problems accompany many companies, and liquidity problems are inherent in the daily life of a small company. This is also typical for companies that do not have problems with management or the running of the business. Obviously, liquidity issues determine perceptions of sustainability issues at some level.

The first financing alternative is financing from own resources (supplemented by the resources of relatives and friends). It is well known that a significant proportion of small businesses are simply undercapitalized from the outset and often the available resources do not cover start-up costs either.

The next alternative is to involve external sources, i.e. "loan-type" financing. The financing needs of small businesses are small, so the problem of high relative transaction costs necessarily arises. In addition, SMEs generally do not have a credit history, do not have mature banking relationships, and a lack of transparency and insufficient collateral play a role in the fact that external financiers generally consider loans to them to be even riskier. Logically, their bargaining power is weak compared to financial institutions, which makes it difficult to develop appropriate structures. At the same time, banks' attitudes towards SMEs are currently changing in a positive direction, with special small business packages being developed considering the specifics of the sector.

The third alternative is "equity" financing, in which an external investor is involved in the shareholding. The sale of shares requires even more serious preparation, so that the relative costs of the transaction related to raising financial resources are even higher. Moreover, the closed nature of the shareholder circle and the aversion of small business owners to allow other external owners to enter the company allow only to a very small extent the possibility to raise funds through external ownership.

The second main feature is the key role of the owner-manager (because the two "positions" often coincide in the case of SMEs, i.e. the owner and the management are not separate) (Vyakarnam et al., 1997). The owner-manager is the engine of the company, he performs most of the tasks related to the administration of the company, so the company can not do without him in the long run. He is responsible 
for several functions of the business and performs several tasks at the same time (Spence, 2006). In addition, the person of the entrepreneur is often the "brand" of the company. Due to his/her prominent role, the functioning of an SME is largely determined by the values, nature, attitudes, qualifications and experience of the owner-manager (Vives, 2006). The entrepreneur plays a key role in shaping the value system of the business and the organizational culture is very dependent on the owner-entrepreneur. In addition, due to the overlapping of roles above, there is a lack of both owner control over management and the ability for management to influence owners.

The next group of characteristics refers to the unstructured and informal nature of the functioning of SMEs. The organization of multi-person micro-enterprises and SMEs is also unstructured in most cases. At the beginning, the division of labor develops spontaneously, there are no job descriptions, the tasks following the tradition. Usually, they have the same level of management, and the ownerentrepreneur who has only direct subordinates holds the position of director. However, with growth, a two-tier management is formed, where the ownerentrepreneur manages through several managers. The leadership style is direct, there are no formal elements in it, and in many cases it is based on the principle of authority.

The owner usually controls directly, with manual control, without control systems (Vecsenyi, 2003). The organizational system is characterized by informal relations, and a low degree of bureaucracy (Béza et al., 2007), there are no formal management structures with specialized staff (Jenkins, 2006). There is no independent organizational structure separate from members (separate organizational culture, information system, internal regulations, etc.), this is replaced by regular personal contact, personally coded and moderated relationships of each person. Because participants are very often family members and, when they are not, their relationship is familiar - the subordinate is often invited to the boss's office, who is directly involved in the production process or services - there is no need for rules for production consultations, for decisionmaking powers, etc. (Matolay et al., 2008).

SMEs can pursue goals other than increasing or maximizing profits (for example, generating a decent income for the owner and employees, independent work). Business owners can model these businesses with very different motivations. In the case of enterprises that provide for the living of entrepreneurs - and, according to some estimates, $73 \%$ of Romanian enterprises are like this - for example, the basic objective is providing for the taxpayers, the implementation of a lifestyle without external financing of capital, with minimal growth. In addition, unlike large enterprises, the content value of the company may be completely different from the financial return. For many company managers, the company is primarily a job, a means of meeting the needs of the family, i.e. potentially different objectives / aspects may appear than maximizing efficiency (Béza et al., 2007).

SMEs are usually resistant to regulation (including voluntary regulation), distrustful of bureaucracy, and less susceptible to institutional pressures (e.g., regulation, benchmarking, government agencies, pressure from public and private interest groups) (Jenkins, 2006).

Unlike large companies, where obtaining information is not a problem, the ownerentrepreneur often does not have time to make informed decisions and obtain the right information ("an entrepreneur who is dizzy from his daily routine misses one 
thing the most - time") (Béza et al., 2007, p.29.). For them, the Internet, which is often the most important source of information today, is not available because they have no IT skills. Thus, their information is often obtained on the basis of their daily contacts. They cannot afford to have professional management, to hire renowned consultants, the management is in the hands of the company owners and their information system is often incomplete (Béza et al., 2007). Moreover, the training of the owner-manager may be insufficient to understand certain consequences of regulatory requirements or to manage the necessary technology. (Cambra, Fierro et al., 2007).

The next feature is the "integration" of SMEs (Supino, Proto, 2006, Fuller, Tian, 2006), their relationship with the local community (Szlávik et al., 2006). SMEs are part of the community that provides them with resources and a market, often including all four market segments that affect business life, namely the capital market, the labor market, the materials and components market and the sales market. That is, on the one hand, they have not only formal but also informal relationships with the community; they see their environment not only as a type of market, but also as a "living space". For them, "this world means, first of all, nature, and only after that, a market" (Matolay et al., 2008, p.20.). SME owners and managers are strongly integrated into the local community, making them more dependent on its stability and prosperity, especially as most employees and business partners live here (Jenkins, 2004). Thus, they are much more dependent on the regional workforce compared to large companies (The Gallup Organization, 2007).

Due to integration, SMEs differ greatly from large companies in that they have different typical stakeholders. Many SMEs operate in local markets and are not subject to international pressure, and NGOs pay little attention to them because they focus (their limited resources) on "big fish" (Vives, 2006). SMEs, unlike large companies, are not the focus of media attention (Spence, 2006). Instead of a general focus on social issues (which is typical of large companies), SMEs focus more on the local community. Because they often consist of a unit that relies on a local workforce, the owner-manager is tied up locally, and the markets are more local than those of large companies. However, in many cases, they are less visible to the local community due to the lower volume of activities and geographical isolation from the community when operating in industrial parks (Jenkins, 2004), which can act to the detriment of responsibility to the local community. In addition, for many SMEs, the only stakeholder representative is often a large customer who, in principle, determines their operations (Jenkins, 2004).

However, even if the relationships with SME stakeholders cannot be very different from those of large companies, the "management" of these relationships is very likely to be different. For SMEs, these relationships are more informal, based on trust and characterized by intuitive personal commitment (Spence, 2006). The power gap between the company and stakeholders is smaller because their bargaining power is weaker when dealing with customers, suppliers and financial institutions (Béza et al., 2007). As the power gap isn't as big in their relations with stakeholders as in the case of large companies and their stakeholders, they are not able to influence the outcome of the process to such an extent (Jenkins, 2004). Large companies are probably more likely to engage in well-designed strategic relationships with stakeholders (i.e., in their case, we encounter formal, regulated, well-planned stakeholder management) the results of which can be largely 
influenced by companies (Spence, 2006, Jenkins, 2004). Shareholders, as stakeholders, are often absent (ownership and management are not separate), and their resources are often obtained in the informal capital market instead of the formal market (Matolay et al., 2008).

The key role of employees as stakeholders in SMEs is closely linked to integration and stakeholders. That is, SMEs are by nature local institutions, their ownermanagers, their customers and their employees are members of the same community. Most employees know the owner-manager directly (and vice versa) (Vives, 2006). In addition, the company is very dependent on a few key people (Béza et al., 2007), which also indicates the priority of employees.

Jenkins's (2004) synthesis study, which examines the cultural limitations of the applicability of large corporate responsibility practices to SMEs, draws very similar conclusions to those we have described so far (Table 2).

Table 2. Cultural differences between large and small enterprises

\begin{tabular}{|l|l|}
\hline Large enterprises & Small enterprises \\
\hline order & untidy \\
\hline formal & informal \\
\hline accountability & trusting \\
\hline information & personal observation \\
\hline clear demarcation & overlapping \\
\hline planning & intuitive \\
\hline corporate strategy & "tactically strategic" \\
\hline control measures & "I do it my way" \\
\hline formal standards & personally monitoring \\
\hline transparency & ambiguous \\
\hline functional expertise & holistic \\
\hline systems & "freely" \\
\hline positional authority & owner-managed \\
\hline formal performance appraisal & Customer/network exposed \\
\hline
\end{tabular}

Source: Jenkins (2004, p. 40.)

\section{References:}

1. Banerjee, S. B. 2008. Corporate social responsibility: The good, the bad and the ugly. Critical Sociology, 34, 1, pp. 51-79.

2. Béza D. - Csapó K. - Farkas Sz. - Filep J. - Szerb L. (2007): Kisvállalkozások finanszírozása. Perfekt, Budapest.

3. Cambra-Fierro, J. - Hart, S. - Polo-Redondo, Y. 2008: Environmental Respect: Ethics or Simply Business? A Study in the Small and Medium Enterprise (SME) Context. Journal of Business Ethics, 82, pp. 645-656.

4. Ernst\&Young 1999: Thematic Evaluation of Sturctural Fund Impacts on SMEs. Synthesis Report. Commission of the European Communities, Brussels. 
5. Fuller, T. - Tian, Y. 2006: Social and Symbolic Capital and Responsible Entrepreneurship: An Empirical Investigation of SME Narratives. Journal of Business Ethics, 67, pp. 287-304.

6. Jenkins, H., 2004. A Critique of Conventional CSR Theory: An SME Perspective. Journal of General Management, 29, 4, p. 37-57.

7. Kállay L. 2000: Mikrohitelezés piaci alapon. Közgazdasági Szemle, 47, 1, pp. 41-63.

8. Kállay L. - Imreh Sz. 2004: A kis- és középvállalkozásfejlesztés gazdaságtana. Aula, Budapest.

9. Matolay R. - Petheő A. - Pataki Gy. 2007: Vállalatok társadalmi felelössége és a kis- és középvállalatok. Nemzeti ILO Tanács, Budapest.

10. Supino, S. - Proto, M. 2006: The CSR: a Big Challenge for Small Business. Conference paper, Corporate Responsibility Research Conference, Dublin.

11. Szlávik J. - Pálvölgyi T. - Csigéné Nagypál N. - Füle M. 2006: CSR in small and medium-sized companies: Evidence from a survey of the automotive supply chain in Hungary and Austria. Kutatási jelentés: Rhetoric and Realities: Analysing Corporate Social Responsibility in Europe (RARE). A Research Project within the EU's Sixth Framework Programme.

12. Vecsenyi J. 2003: Vállalkozás. Az ötlettöl az újrakezdésig. Aula, Budapest.

13. Vives, A. 2006: Social and Environmental Responsibility in Small and Medium Enterprises in Latin America. Journal of Corporate Citizenship, Spring, pp. 39-50.

14. Vyakarnam, S. - Bailey, A. - Myers, A. - Burett, D. 1997: Towards an Understanding of Ethical Behaviur in Small Firms. Journal of Business Ethics, 16, pp. 125-136. 


\title{
ACHIEVING THE SUSTAINABLE DEVELOPMENT GOALS
}

\author{
Aurel Constantin LUPU, Oana Raluca IVAN \\ "1 Decembrie 1918" University of Alba Iulia, Alba Iulia, Romania \\ aurel.lupu@uab.ro \\ raluca.ivan@uab.ro
}

\begin{abstract}
The purpose of this paper is to examine the state of Romania's sustainable development using statistical indicators (green investments, employment rate, GDP expenditure on research, development, and innovation, greenhouse gas emissions, share of renewable energy in gross final energy consumption, early school leavers, tertiary educational attainment, and people at risk of poverty or social exclusion). The method used in this research work is bibliographical and statistical research. The topic of sustainability has experienced a new upswing. Society demands sustainable business from companies and wants transparent information in return. The importance of sustainable action is also reflected in investment decisions: the classic financial key figures are no longer the exclusive reason for an investment. Rather, non-financial indicators are expected to provide further information about the long-term value of a company. In 2014, EU member states adopted a directive to expand the reporting of large capital market-oriented companies, credit institutions, financial services institutions and insurance companies. Since 2017, this Nonfinancial Information (NFI) Directive has been mandatory for capital market-oriented companies in Austria within the framework of the Sustainability and Diversity Improvement Act (NaDiVeG). In concrete terms, this means that capital market-oriented companies must publish a non-financial statement or a separate non-financial report in addition to the management report. The number of companies generating and providing non-financial information to interested users is steadily increasing around the world, while the quality of disclosure of such information is increasing. Year by year, as evidenced by numerous studies and stakeholder surveys. In Romania, green initiatives have resulted in an increase in the share of renewable energy in total energy consumption, a decrease in school dropouts, and an increase in the number of students enrolled in bachelor's degree programs.
\end{abstract}

Keywords: non-financial reporting; sustainable development; disclosure; regulations; performance indicators; stakeholders.

JEL classification: B55, F63, F64 


\section{Introduction}

The evolution of non-financial reporting may be seen in all of the EU's member countries. The new regulations' main goals are to improve information transparency of the results of companies' activities on society and the environment, strengthen organizations' reputations, and increase confidence in their commercial activities; and to systematize the process of introducing public non-financial reporting. It is important to keep an eye on company annual reports, which include metrics that describe the social and environmental elements of their operations.

I highlight the most well-known and widely used GRI (Global Reporting Initiative) standards and conceptual frameworks for integrated IR (Integrating Reporting) reporting, despite the fact that there are a large number of international and national corporate reporting standards that form requirements for the disclosure of various aspects of sustainable development.

Furthermore, in light of current trends in the development of issuing company reporting, as well as the increased focus on stable development factors, it is necessary to highlight the practice of developing American standards in the field of Sustainability Accounting Standards Board Standards (SASB Standards). It governs disclosure requirements for companies whose shares are listed on the US stock exchange; a special initiative Despite the presence of common approaches, the standards under consideration have significant differences in terms of both the target audience and the requirements for the content of the disclosed information, accounting for industry features, and other important factors to consider when selecting a governing framework for the development of corporate reporting.

Organizations should build a set of key performance indicators (KPIs) that correspond to each of the aforementioned areas in order to achieve the sustainable development goals. The scorecard's development outcomes might be presented in the form of a table. In the establishment of a system of key performance indicators, both quantitative and qualitative indicators are employed. Quantitative indicators of long-term development can be both financial and nonfinancial in nature. Quantitative non-financial indicators include the number of jobs created, the number of employees who have undergone or will undergo retraining, will increase qualifications, will enter a new profession, will reduce the number of jobs with hazardous working conditions, occupational diseases and injuries, and the volume of emissions, discharges, and waste.

The capital and operating expenses of the organization related to environmental activities, as well as the corresponding monetary benefits from them are examples of cost (financial) indicators. For example, the growth of revenue from the sale of certified environmentally friendly products, the creation of new brands, the growth of energy efficiency, the reduction of payments for excess discharges, emissions of pollutants in the environment; fines are examples of cost (financial) indicators. The use of quantitative indicators allows for comparisons in the dynamics as well as with other firms' similar indicators. 
Qualitative indicators of sustainable development are used to assess the degree of achievability of a specific result, such as the quality of life, employee satisfaction, product compliance with world scientific and technical standards, and so on, as well as for the analysis of non-financial strategies, such as regulatory, operational, social, environmental, and reputational strategies. Traditional units can be used to quantify qualitative markers of sustainable development (points, coefficients and ratings.

\section{Research methods}

This research paper's technique consists of bibliographical and statistical research. The current state of the art in the topic of sustainable development is covered in the bibliographical research. The statistical data collecting is covered by statistical research. Eurostat data was used to compile the study's data, which was then processed and evaluated.

The data is provided in statistical tables, which is a means for describing the indicators that the completed analysis is based on, as well as creating existing links between its component pieces. Graphical representations have been used to highlight the scope and/or variance of data submitted to statistical study in order to demonstrate their progression through time. We offer an innovative approach to assess Romania's condition of sustainable development (Table 1). The suggested methodology for assessing Romania's sustainability is based on Gogan and Draghici's model from 2013 [1]. The following are the characteristics of the suggested model for evaluating and analyzing Romania's sustainable development:

Examining Romania's present condition in terms of sustainable development in comparison to the European Union;

establishing goals for putting the country on a sustainable path;

Highlighting the adjustments that are required for long-term sustainability;

Determine the resources available or required for long-term growth;

Sustainable development is incorporated into economic and financial reports (at national and organizational level).

Creating a framework for long-term development. This will not only build a dynamic strategy, but it will also entail a continual improvement process in order to turn sustainable development into financial advantages.

Perspectives are being assessed. The suggested model takes into account the three pillars of sustainable development: the economic, the environment, and the social. Each of these pillars has two or three indicators that allow us to compare the condition of sustainability in Romania to that of the European Union (28 countries).

This paradigm allows for cross-country comparisons while concentrating on the dynamic of sustainable development. 
Table 1: Key performance indicators on sustainable development

\begin{tabular}{|l|l|}
\hline Significant aspects & Key Performance indicators \\
\hline Economy & $\begin{array}{l}\text { Employment rate } \\
\text { Gross domestic product } \\
\text { Gross domestic Expenditure on research and innovation }\end{array}$ \\
\hline Environment & $\begin{array}{l}\text { Greenhouse gas emissions } \\
\text { Share of renewable energy in gross final energy } \\
\text { consumption }\end{array}$ \\
\hline Social & $\begin{array}{l}\text { Early leavers from education } \\
\text { Tertiary educational attainment } \\
\text { People at risk of poverty }\end{array}$ \\
\hline
\end{tabular}

Source: Developed by the author

\section{Findings}

In Romania, the green economy is linked to long-term growth. Romania has taken some important efforts in the transition to a green economy by developing policies in crucial sectors such as the National Strategy for Sustainable Development 2030. Over the period 2014-2020, Romania received EUR 30.8 billion through eight national programs, amounting to an average of 1.548 euros per person. The breakdown of investments from structural and cohesion funds and with national cofinancing on axes of intervention is presented in Figure 1.

Green initiatives in Romania have resulted in an increase in the share of renewable energy in total energy consumption (19\% in 2021), a decrease in school dropout (15.3\% in 2019), and an increase in the number of students enrolled in bachelor programs amounted to 27,111 in the school year 2019-2020. This represented a growth of approximately 25 percent compared to the academic year 2014-2015. The job situation in Romania is problematic. Romania has lost 23.3 percent of its working-age population owing to emigration during the last three decades, 17 resulting in a 0.6 percent to 0.9 percent decline in annual GDP growth. Over 3 million people are said to have fled the nation, with a considerable number of highly skilled individuals among them.

Romania's population is expected to fall by 22 percent by 2050 , the steepest projected global decline, due to a combination of emigration, high mortality, and low birth rates, according to the Ministry of Health. Demographers estimate that Romania's population will fall by 22 percent by 2050 , the steepest projected global decline, due to a combination of emigration, high mortality, and low birth rates. At least three steps are necessary to improve the situation:

Targeted activation strategies and integrated public services should be strengthened, with a focus on those who are the most excluded from the labor market.

Make education a top priority. Instead of the existing 3.7 percent, allocate $6 \%$ of GDP to education.

Ensure that there is a deeper commitment to collaboration and multi-stakeholder partnerships, particularly at the grassroots level. 


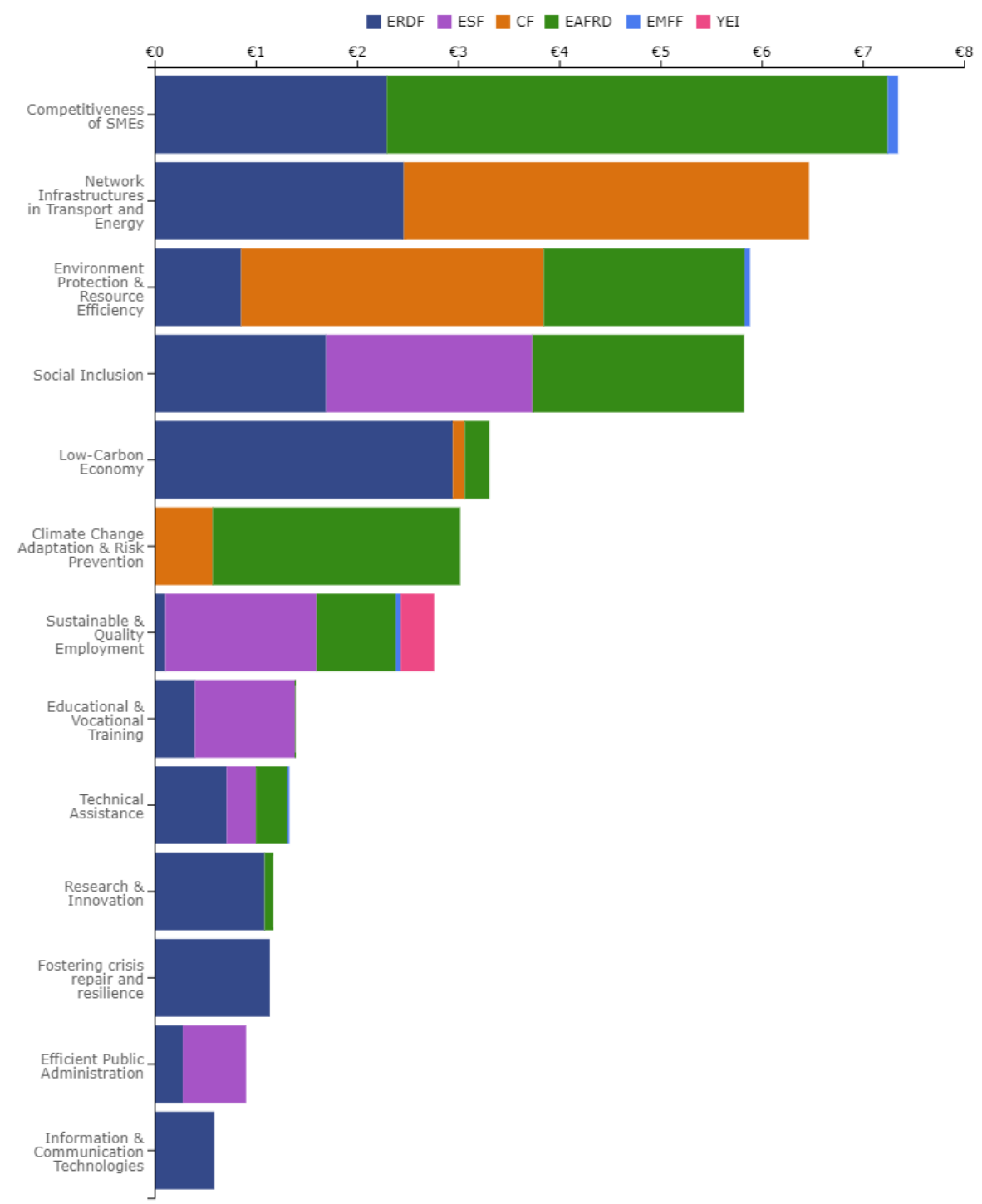

Figure 1: Total budget in Romania, billion Eur

Source: https://cohesiondata.ec.europa.eu/countries/RO

ERDF - European Regional Development Fund

ESF - European Social Fund

YEI - Youth Employment Initiative

CF - Cohesion Fund

EAFRD - European Agricultural Fund for Rural Development

EMFF - European Maritime \& Fisheries Fund

Romania needs to keep implementing renewable energy projects and steps targeted at updating the road transportation sector, as well as launching a carbon capture and storage (CCS) project and a forestry program. Romania must also improve the delivery of the green certificate program, provide financial assistance 
for renewable energy projects, and take measures to increase the capacity of renewable energy power and heat generation. It is not too late to change the current unsustainable development trajectory. This necessitates not just study, but also education, participation, and increased concerns about alternative civic obligation as well as political bravery.

If we look in the Figure 2, we can observe that Romania took initiatives from 2008 until 2019 to improve in most of the areas besides research and development expenditure and early leavers of from education and training. These two areas are critical, and a concrete strategy is needed to reach national targets. A good thing is that from 2008 until 2019 the number of people at risk of poverty or social exclusion decreased and it goes beyond the national targets set. Romania must continue with programs in this area considering the pandemic situation which can lead to an increase of poverty.

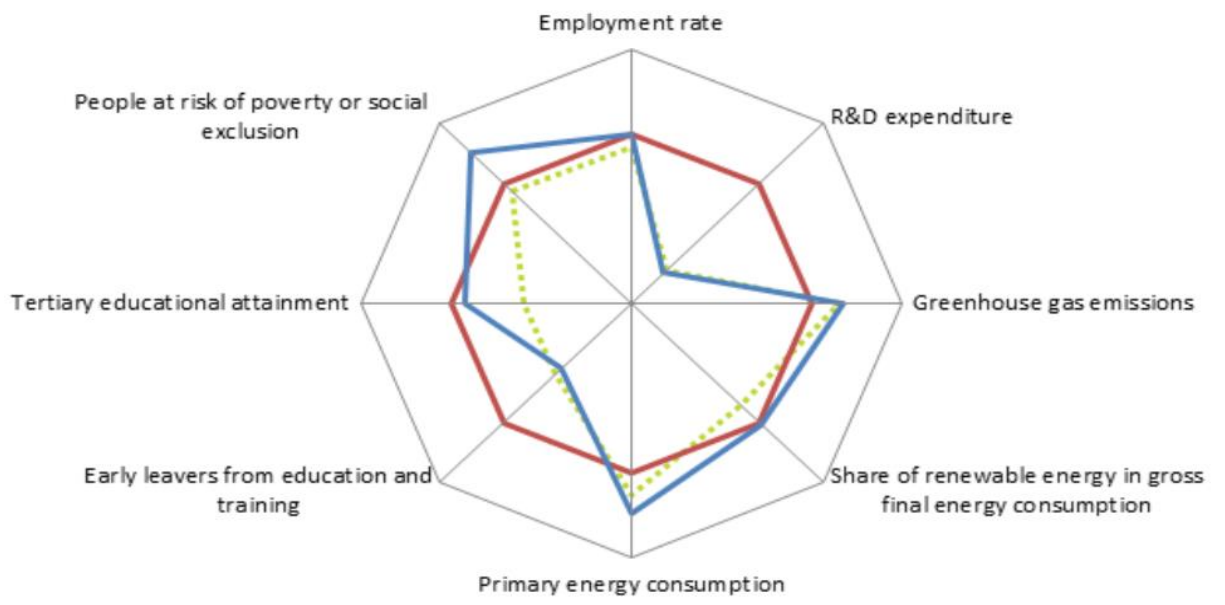

:2008 D National Target DMost recent data

Figure 2: Change since 2008 in relation to national targets, 2019 Source: Eurostat statistics

\section{Conclusion}

For many businesses, developing public non-financial reporting that takes into consideration best practices and international standards is a relatively new task, which inevitably leads to challenges in practice.

To address them, it is necessary to collect, compile, and share experiences in a format that is accessible to a broad range of stakeholders: in the form of specialized reviews and publications in professional journals; the organization of meetings, open dialogues, webinars, and other activities for the exchange and discussion of experience. 
Natural resources are in threat under current conditions, yet green solutions for long-term growth may be produced via research and innovation. Increasing employment, reducing carbon emissions, raising the share of green in total consumption, energy efficiency, lowering the dropout rate, reducing poverty, and increasing the rate of graduates are all examples of sustainable development. Sustainable development is achieved by the creation of a competitive economy, a green economy, and the stimulation of green investments in the three pillars of sustainable development: environment, economy, and society. Because Romania's unemployment rate is lower than that of the European Union, the country has to engage in new job creation. New jobs can be created through green investments and the development of new sustainable businesses. Romania has taken significant steps toward long-term growth, and she recognizes that the only way out of the crisis is via long-term development.

Future growth should be intelligent, long-term, and inclusive. The world, according to sustainable development, should be viewed as a system made up of three key components: society, environment, and economics. These components are interdependent, meaning that any change in one induces changes in the other two. Sustainable development entails ongoing expansion that does not degrade living quality, and society should be greener tomorrow than it is now.

Romania faces a dilemma in terms of sustainable development, due to the lack of a sustainable development model. The four methods that comprise the basic mechanism of sustainability are sustainability management, sustainable innovation, sustainable eco-efficiency, and obtaining and preserving sustainable competitive advantages. A model of sustainable development suitable in Romanian society will be constructed on the foundation of these four sustainable development methods.

\section{References:}

1. European Commission (2011), Roadmap to a Resource Efficient Europe. In: communication from the Commission to the European Parliament, the

2. Council, the European Economic and Social Committee and the Committee of the regions, Brussels, 2011.

3. Pauli GA (2010), The blue economy: 10 years, 100 innovations, I (H) million jobs. Paradigm Publicatioms; 2010.

4. European Environment Agency (2013), Towards a green economy in Europe, EU environmental policy targets and objectives 2010-2050. In Report no .8/2013.

5. Eurostat (2013), Smarter, greener, more inclusive? In Eurostat Statistical Book, 2013.

6. European Commission (2010), Skills for green jobs. In European synthesis Report, 2010.

7. RIDS. About sustainability (report in Romanian language). In Report of the Romanian Institute for Sustainable Development; 2014.

8. European Environment Agency (2012), Ecosystem resilience and resource efficiency in a green economy in Europe. In Environmental indicators report, 2012.

9. UNEP. Towards a Green Economy: Pathways to Sustainable Development and Poverty Eradication, 2011.

10. Ocampo J.A. (2005), Beyond Reforms: Structural Dynamics and Macroeconomic Vulnerability. In the Quest for Dynamic Efficiency: 
Structural Dynamics and Economic Growth in Developing Countries, Stanford University Press; 2005.

11. Trica C.L., Papuc M. (2013) Green economic grow the premise for sustainable, In Theoretical and Applied Economics, Volume XX (2013), No. 1(578), pp. 131-140.

12. Dima B., Dima S.M., Lobont O.R.(2013), New empirical evidence of the linkages between governance and economic output in the European Union

13. in Joumal of Economic Policy Reform, Volume 16, Issue I, 2013, pp. 68-89.

14. Lobont OR. New altemative possibilities for measuring poverty in Romania in Cross-Cultural Management Journal, Volume XV

15. Lobont O.R., Nicolescu A. C. (2012), Controversies and Perspectives on Public Sector Performance Measurements, Analele Universitätii Ovidius

16. Constanta. Seria: Stiințe Economice, Volume XII, Issue 2, 2012, pp. 11991203

17. C. Popovici, Geurt van de Kerk, A. Manuel (2009), Regional Sustainable Society Index, RSSI. Romania, on its way to a sustainable society, 2009.

18. Gogan, L. M., Draghici, A (2013) A model to evaluate the intellectual capital. Procedia Technology, Vol. 9, 2013 pp.867-875.

19. European Commission (2013), Operational Programme "Environment" Programme under Convergence objective co-funded by European

20. Regional Development Fund (ERDF) and the Cohesion Fund (CF), 2013

21. National Institute of Statistic (2014), Sustainable Development Indicators, 2014.

22. Draghici, A, Fistis, G., Sirbu, R, Draghici, G. (2014), Leadership In Sustainability-An Opportunity For Green Skills Developement in Romania, 2014, pp. 1043-1050.

23. Jackson, S. E., Renwick, D. W., Jabbour, C. J. \& Muller-Campn, M. (2011). State-of-the-art and future directioms for green human resource management: Introduction to the special issue. Zeitschrift flir Personalforschung (ZtP), 25(2), 99-116.

24. Luna, H., Martin, S., Scott, W., Kemp, S., \& Robertson A. (2012), Universities and the green economy: graduates for the future. Higher Education Academy, UK, 2012.

25. Pronk J (2012), Millennium Development Goals to Sustainable Development Goals, In: The 2012 International Symposium on Cultural Diplomacy 


\title{
ANALYSIS OF ECONOMIC GROWTH AND INCOME INEQUALITY IN ROMANIA IN THE PERIOD 1990-2019
}

\author{
Bianca VEZENTAN \\ Doctoral School of Economic Sciences - University of Oradea, \\ Oradea, Romania
}

\begin{abstract}
The paper aims to analyze the relationship between economic growth and income inequality in Romania in the period 1990-2019. The "Gross Domestic Product" (GDP) per capita indicator from the World Bank database was used to show the evolution of economic growth, and the GINI Coefficient was extracted from the Standardized World Income Inequality database to analyze income inequality. Romania's macroeconomic result (GDP per capita) registered a continuous growth trend in the period 1990-2019. The Gini coefficient has followed the same dynamics. At first sight, this fact highlights that the phenomenon of economic growth has widened the gap between the rich and the poor in Romania in the examined period.
\end{abstract}

Keywords: economic growth, income inequality, GDP per capita, Gini coefficient

Jel Codes: O47, O15, E01

\section{Introduction}

The relationship between economic growth and the evolution of income inequality is intensively studied by the economic literature in recent years, following the conclusions of various studies showing that the phenomenon of economic growth and development is accompanied by income distribution effects that are not always fair. More specifically, even if economic well-being in general increases, by increasing the wealth obtained, this may have the effect of increasing inequality in the distribution of income in society. The topic is of interest to policy makers as well, with the emergence of concepts such as social cohesion and inclusive development. Both are objectives of specific European Union (EU) policies. Thus, the promotion of social cohesion is the goal of the policy of the same name in the $\mathrm{EU}$, and social inclusion is also pursued through community social policy.

As an EU Member State, Romania aligns with these policies and implements measures at national level, through its own social policies.

This paper aims to analyze the relationship between economic growth and income distribution in Romania in the period 1990-2019, based on the time series extracted from the World Bank database and the Standardized World Income Inequality Database.

The paper is structured as follows: after the introduction, in the second section, the concepts we work with are presented, then a short literature review on the relationship between economic growth and income inequality is inserted; in the fourth section the evolutions of the two statistical indicators are described and analyzed; the fifth section comprises a discussion of the findings and the last part is dedicated to the conclusions. 


\section{Conceptual basis}

\subsection{Economic growth}

Most economists agree that the phenomenon of economic growth means an increase in the amount of useful economic effects obtained in a given period of time (lonescu, 2005, p.162).

In the economic literature this concept is used broadly and narrowly. In a broad sense, it means the increase of national wealth, national income, domestic product, in a given period of time. In a narrow sense, it refers to the positive evolution of the national income or the domestic product per capita in a given period. Regardless of the meaning, economic growth targets the quantitative side of economic results, as a whole and per capita, and involves not only the expansion of production potential, but also their combination with a higher economic yield.

The measurement of economic growth is done using statistical indicators such as gross domestic product, gross national product or national income.

In practice, the appreciation of the standard of living of a nation is achieved through the gross domestic product per capita, the purpose of economic policies being to stimulate its growth.

In order to analyze the evolution of the gross domestic product per capita in the case of Romania, we extracted time series from the World Bank database, opting for the Purchasing Power Parity (PPP) unit of measurement, for the period 19902019.

\subsection{Income inequality}

The Gini coefficient is the most common tool for measuring income inequality internationally. It measures the distribution of income, comparing the income statement of each household with the income statement of all other households. By construction, the coefficient is expressed as a percentage value between 0 and 100. A Gini coefficient equal to 0 indicates perfect income equality; a Gini coefficient equal to 100 would mean that all the income obtained in the economy belongs to a single household, which would indicate the perfect income inequality. We used the Gini coefficient available for Romania from the Standardized World Income Inequality Database. In this database, the calculation of this coefficient is based on observations collected from the OECD Income Distribution Database, Socio-Economic Database for Latin America, EUROSTAT, World Bank and national statistical offices (Solt, 2020).

\section{The relationship between economic growth and income inequality: a brief literature review}

The issue of income inequality has preoccupied economists and gained new importance since the Great Recession. Some authors have argued that income inequality is a major problem of our time, supported by the empirical observation that market income inequality - measured by the Gini coefficient - has increased substantially since the mid-1970s in industrial economies; a development that contrasts unfavourably with a long previous period, when inequality fell from the 
predominantly high levels of the early twentieth century (Peterson, 2017). "A high and persistent income inequality is considered intrinsically undesirable. However, assessing whether higher-income inequality is delaying economic growth has proven to be a challenge and is much disputed in the literature. Theoretically, the effect can go both ways. An increase in income inequality resulting, for example, from substantial rewards to risky entrepreneurship and innovation, could stimulate economic growth. In contrast, greater inequality could affect economic growth if low-income households are persistently less productive due to slower accumulation of human capital and higher financial exclusion" (Aiyar and Ebeke, 2020). According to some empirical studies, there is little consensus. Some studies have found a significant and negative effect of inequality on growth and its duration (Ostry and Berg, 2011; Ostry, et.al, 2014; Cingano, 2014), and others have found no systematic negative effect of inequality on growth (i.e., Forbes, 2000; Kraay, 2015). Barro (2000) reports that the growth-inequality relationship is sensitive, respectively, to the level of incomes in the country and to the time horizon taken into account, while other authors have sought to demonstrate that the relationship is nonlinear or oscillating (Banerjee and Duflo, 2003; Brueckner et al., 2015).

A number of studies examine the variability of US state data to show that inequality of opportunity negatively affects the future income growth of the poor and positively affects that of the rich (Marrero and Rodríguez, 2013; Hsieh et al., 2013). The idea is that inequality of opportunity can affect economic growth, as it prevents the accumulation of human capital by low-income people. Moreover, perceptions of inequality of opportunity, which affect individual aspirations, can also reduce investment in human capital.

In the international literature, the study on inequality of opportunity has received less attention, especially due to the difficulty of measuring equal opportunities in a comparable way between countries. However, there has been significant recent progress in this area, with measured equality of opportunity, using cross-border data on different indices of intergenerational mobility, such as the elasticity of a person's income (or education) to parental income (or education) (Aiyar and Ebeke, 2020).

In economies of low opportunity, income inequality has a greater influence on growth. An increase in income inequality tends to take root over generations due to various market failures related to social stratification. This delays growth, for example by impeding the development of human capital or causing the misallocation of talent. And on the other hand, in countries with high equal opportunities, an increase in income inequality is slightly reversed precisely because people on low incomes have access to the same opportunities as others. Therefore, in such societies, an increase in income inequality is less detrimental to growth (Aiyar and Ebeke, 2020).

Inequality of opportunity could influence the marginal effect of income inequality on growth, taking into account various mechanisms. Thus, Aiyar and Ebeke (2020) provide three examples. First of all, the existence of unequal access to education could lead to the loss of educational opportunities, following a shock of income, therefore to a slower increase in future productivity. More precisely, this idea has been researched in the literature, where income inequality in the presence of financial constraints prevents poor families from investing optimally in schooling, thus affecting growth (Galor and Zeira, 1993). Second, in an economy 
characterized by structural rigidities in labour markets, a shock that worsens the distribution of income could further disadvantage outsiders; otherwise it could create unequal opportunities for insiders and outsiders."The effects of hysteresis could translate this disadvantage into longer-term growth"(Aiyar and Ebeke, 2020). The third mechanism could be linked to unequal access to finance. An income shock in the presence of credit constraints could be understood as investment opportunities wasted among the lower percentages of income distribution, resulting in lower aggregate growth. Benabou (1996) and Getachew (2010) show that when the amount that can be borrowed is rationed, an idiosyncratic credit shock can perpetuate inequality and reduce growth. "Due to declining yields, resource-poor households tend to have the highest marginal return on capital and when these high-yield investment opportunities are abandoned, the aggregate productivity suffers" (Aiyar and Ebeke, 2020).

Breunig and Majeed (2020) conducted recent research and focused on the impact of income inequality on economic growth. They extended their work by asking whether inequality and poverty, separately or jointly, have an impact on economic growth. Inequality has been assumed to negatively affect growth through several channels. Researchers have argued that inequality can lead to underinvestment in education, health and physical capital, leading to lower growth. Such underinvestment may be linked to a lack of resources, namely poverty, rather than inequality itself. She argues that the view of poverty is an additional channel that can hinder economic growth. Poverty and inequality can also interact to have a negative impact on growth. Likewise (Stiglitz, 2013) and others have argued that inequality can compromise institutions that spread the welfare of all members of society. The relationship between income inequality and economic growth has been extensively studied over the past 25 years, with research reporting a number of findings, including claims that inequality is detrimental to growth, that inequality is irrelevant to growth, and that inequality helps growth. The theory is ambiguous in terms of expected effects. Inequality can affect economic growth in a number of complex ways and through different channels (Breunig and Majeed, 2020). The literature has shown that poverty can have a negative impact on investment and GDP growth, especially when financial markets are not well developed. López (2006) support the hypothesis that poverty delays growth through various channels, including education, institutions, health, and physical capital accumulation.

Breunig and Majeed (2020) find that inequality interacts with high levels of poverty to have a negative and significant impact on economic growth. In other words, for higher levels of poverty, inequality negatively affects economic growth. This negative impact increases as poverty increases.

Another conclusion of these does not suggest that inequality has a positive role to play in economic growth. There are a variety of reasons why countries may want to reduce inequality, even if there is no impact on economic growth. These reasons may include the impact of inequality on social cohesion and institutions.

On the other hand, Islam and McGillivray (2020) consider that wealth inequality is certainly important in the relationship between economic growth and income inequality, in recent years increasing interest in the study of wealth inequality. Oxfam (2016) notes that the richest 62 people in the world have the same wealth as the poorest half of the world combined. 
The ratio of billionaire wealth to GDP is also used as an alternative measure of wealth inequality. Empirical results suggest that wealth inequality has significant negative effects on cross-border economic growth. This statistically significant negative impact of wealth inequality on growth persists even when measures of income and wealth inequality are included in the same specification, which clearly demonstrates the dominance of wealth inequality over income inequality in relation to inequality and growth.

Other authors (i.e., Howarth and Kennedy, 2016) consider that in advanced industrial societies, the level of rising inequality has strongly contributed to the gap between per capita income and the Sustainable Economic Welfare Index (ISEW), which is now called Genuine Progress Indicator (GPI). Although income growth is often interpreted as a measure of increasing social welfare, environmental economists have long argued that the growth process generates a wide range of social and environmental costs that serve to decouple the relationship between wealth and material prosperity (Victor, 2008).

The relationship between income inequality and economic growth has been extensively studied in recent years, with a number of findings, including claims that inequality is detrimental to growth, that inequality is irrelevant to growth, and that inequality helps growth. The theory is ambiguous in terms of expected effects. Inequality can affect economic growth in a number of complex ways and through different channels.

\section{The evolution of the gross domestic product and of the income distribution in Romania in the period 1990-2019}

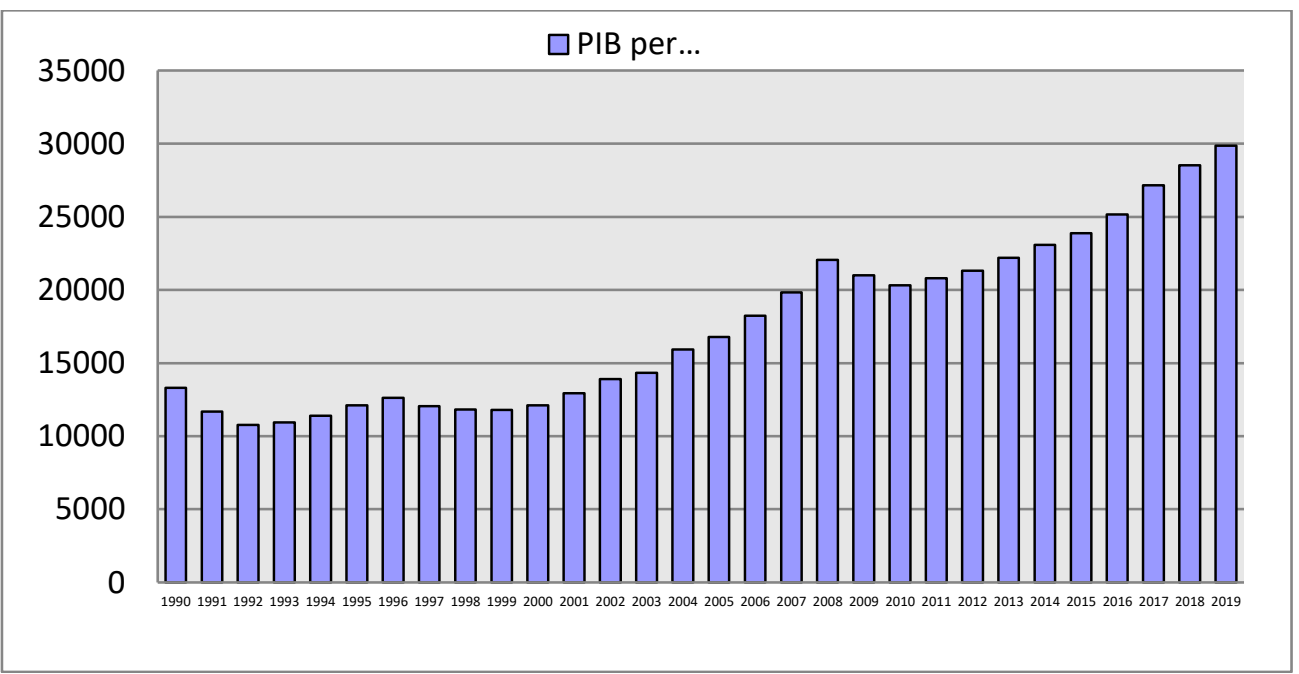

Figure 1: Evolution of the GDP per capita indicator for the period 1990-2019 (PPP, 2007 USD international constant)

Source: World Bank data processing, 2021

The gross domestic product per capita registered an increasing trend in the analyzed period, from 13,302.47 USD in 1990 to $29,857.64$ USD in 2019, 
representing an increase of 2.16 times in 30 years. Starting with the analysis of the evolution of GDP in 1990, it gradually decreases until 1992 to 10,757.39 USD. It is easy to see that 1990 is the first year of the new power after the fall of the communist regime. The revolution that took place in Romania in 1989 produced a multitude of changes in society. With the fall of this regime, the new power wanted to replace the socialist economy with the market one, based on free competition, Romania being in a period of transition to this economy. Thus, in the following years there was a period of search and redefinition with ascents and descents. After the revolution, the state gradually but not completely withdrew from its role of ensuring welfare (Ferge, 1997) because before the revolution the state was the main means of achieving social rights for all citizens.

The aim was to include the whole population in one form or another of protection, people were obliged by law to find a job, work being compulsory, but at the same time, the job was practically guaranteed by state and the right to an income was established as a right based on citizenship. There follows a slight period of economic recovery, Romania managing to recover between 1993 and 1996 registering a value from 10,936.72 USD, to 12,627.20 USD, again following a worsening of the economic situation until 1999 when the value of GDP- reaches $11,803.37$ USD. An explanation for this situation may be due to the fact that after the Revolution the possibility of early retirement was introduced as an alternative to unemployment. Thus, in 1997 the number of pensioners increased by exceeding 400,000 the number of employees, this circumstance is due both to the low number of employees and their desire to move in a new direction, ie to the private one. Thus, the decrease in the number of the active population was made both at the expense of the number of unemployed and at the expense of the decrease in the number of the employed population. From 2000 to 2008, the value of GDP increased rapidly from USD 21.09.55 to USD 22,044.30 and decreased again in 2009-2010 due to the economic and financial crisis. Georgescu (2013) states that the net flows of FDI (Foreign Direct Investment) in Romania amounted to values between 5 and 9 billion euros per year, in 2007 remaining in this range (7.25 billion euros) and reaching a peak in 2008 (9.5 billion euros), in 2009 they collapsed to 3.5 billion euros.

Despite a slight recovery in international capital flows recorded globally in 2010 , in Romania net FDI flows continued their contraction, falling to 2.2 billion euros, and in 2011 and 2012 falling even below 2 billion euros, respectively at only $1 / 5$ of the level recorded in the pre-crisis period. And from 2011 GDP grows rapidly until 2019 to $29,857.64$ USD, a year that records the highest value of GDP in the analyzed period. In fact, both the final aggregate consumption by sustainability according to data taken from Eurostat increased steadily from 2010 to 2019, and exports and imports by EU Member States had the same upward trend according to statistics taken from the elected site.

Based on data extracted from the Standardized World Income Inequality Database, the Gini Coefficient registers an ascending trend for the analyzed period, from the value of 22 in 1990 to 33.8 in 2019. It increases considerably from the beginning of the analyzed period until 2007 inclusively. At the same time, EUROSTAT statistics on the at-risk-of-poverty rate according to the poverty line have the same upward trend. The Gini coefficient starts to decrease from 2007 from 33 to 2010 to 32.6 . 


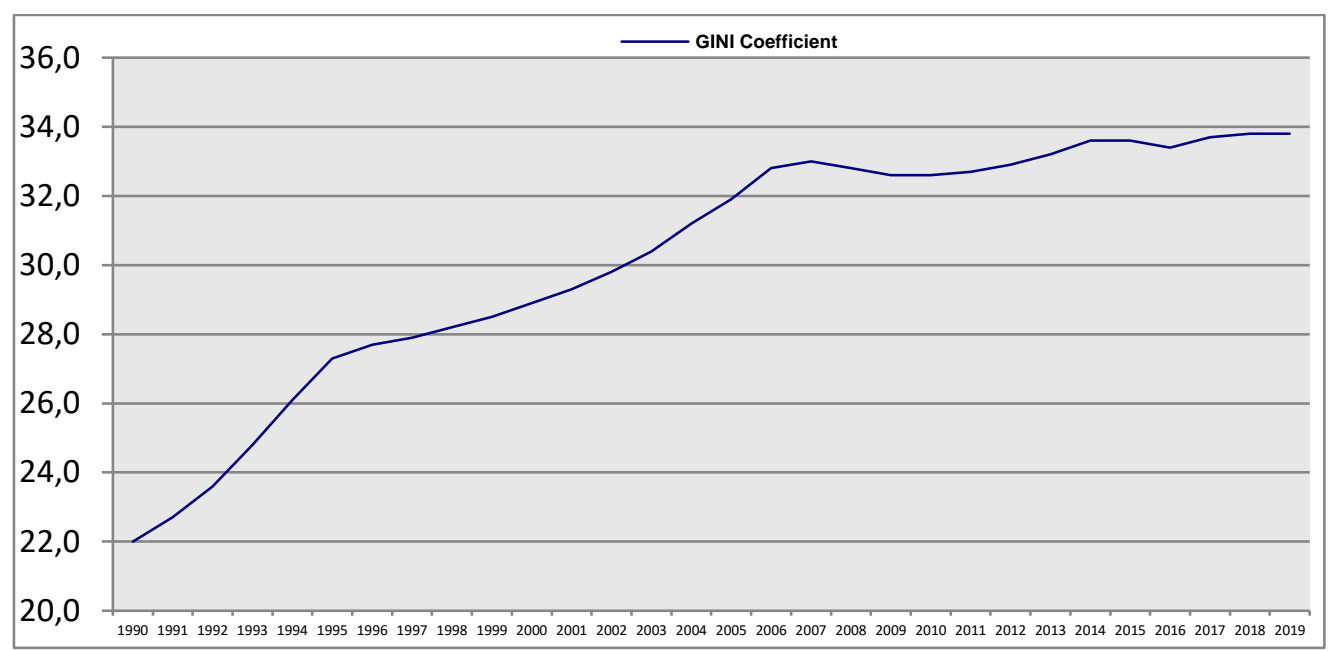

Figure 2: The evolution of the Gini coefficient in Romania during 1990-2019

Source: processing according to Standardized World Income Inequality Database, 2021

Moreover, the poverty risk rate according to the poverty line decreases from 2007 from 24.6 percent to 21.6 percent in 2010, increasing to increase by 2015 to 24.4 percent. Situation that also happens in the case of the Gini coefficient which increases until 2015 reaching the value of 33.6 and the year 2016 indicates a slight decrease to 33.4 and will increase again until 2019 when it registers the value of 33.8. This situation is influenced by the gradual decrease of the participation rate in education and training from 1.6 percent in 2011 to 0.9 percent in 2018.

According to Molnar (2010), "inequality is considered too great and unjust due to the huge gap between the living conditions of the majority of the population and the luxurious life of the rich, the well-known fact that many of the great and very high fortunes and incomes come from activities or capital accumulated in the underground economy, by breaking the law or by exploiting the weakness of the legal system, as well as by acts of corruption, while many poor people have neither the opportunity nor the possibility / ability to get a job, with much less one that allows for a decent income".

The value of the statistical correlation coefficient between the two time series is 0.89 . Its value indicates a positive association between the two variables, an association that is statistically significant, a conclusion obtained after applying the ANOVA test, which indicates a $P$ value of $1.64 \mathrm{E}-23$.

The coefficient of determination is 0.7921 , a value also high, indicating the close link between them, namely that the variation of one variable can be determined in proportion of $79 \%$ of the variation of the other, provided that the other factors remain constant. It is therefore suggested that the two variables evolve closely related to each other, respectively the growth of GDP per capita is related to the increase of income inequality.

As we can see in Figure 3, the two considered variables (logGDP per capita and Gini coefficient) are tightly evolving in the examined period of time, the series values are placed on both sides of the regression line. 


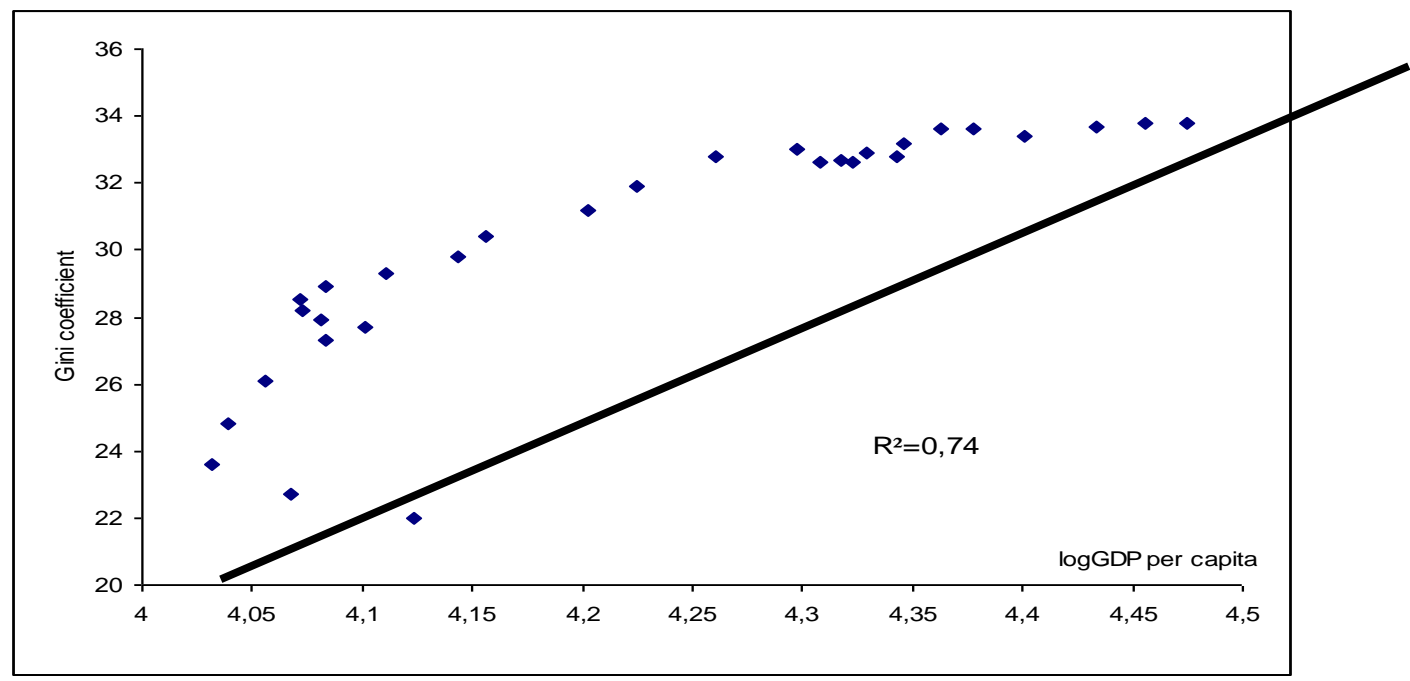

Figure 3: Dependence between logGDP per capita and Gini coefficient, in Romania (1990-2019)

Source: author's own computation based on World Bank and Standardized World Income Inequality Data, 2021

I used another statistical indicator to highlight the phenomenon of economic growth in Romania, namely, GDP per capita growth (aggregates on constant 2010 US dollars) from World Bank database.

The figure 4 highlights the evolution of this indicator for the period of 1991 to 2019. We can notice the first years, until 1993, a period of negative growth followed a positive evolution and then a fall in 1997 to 1999.

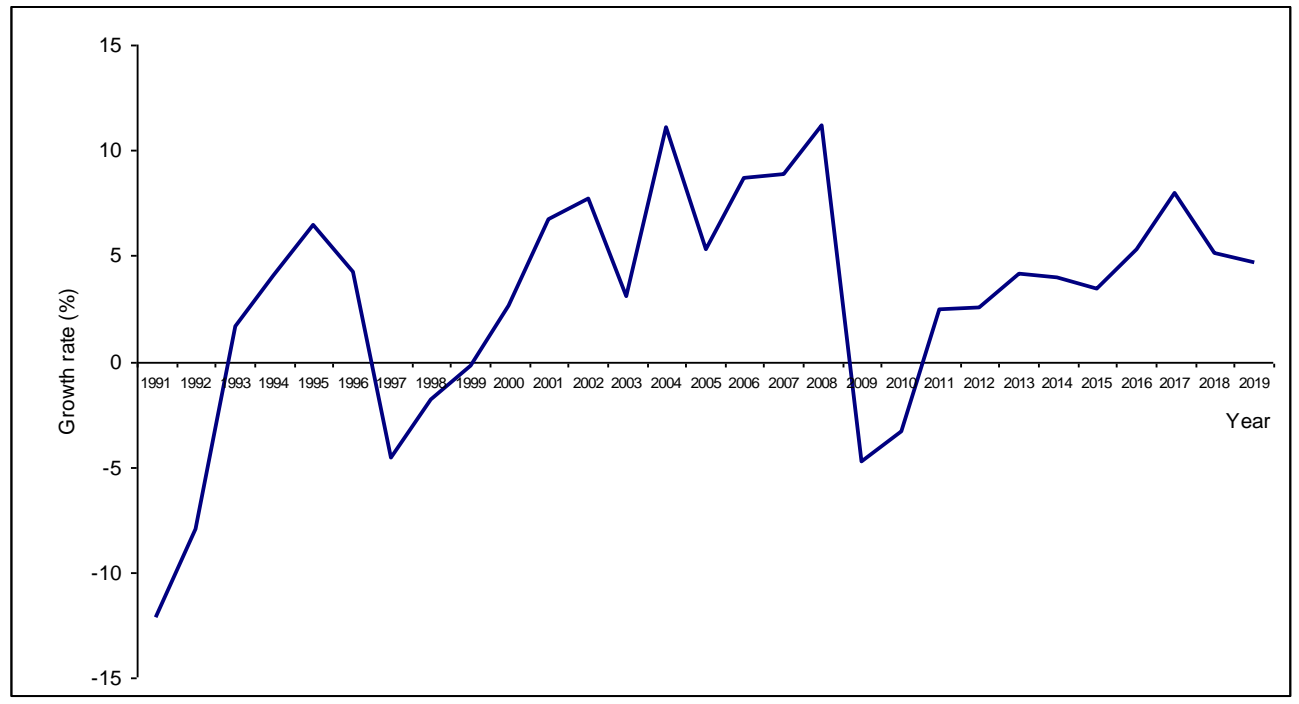

Figure 4: Dynamics of growth rate in Romania (1991-2019)

Source: author's own computation based on World Bank data, 2021 
The period of 1999 -2008 the Romanian economy registered positive values of the growth rate. The effects of international crisis are obvious in 2009-2010, with a fall of the growth rate to negative values. After 2010, the trend is ascendant, excepting the last years (2018-2019). In spite of this sinusoidal evolution, the upward trend of the growth rate is obvious. Meanwhile, the income inequality registered a similar trend.

\section{Discussion}

As we said in the GDP analysis, the transition period from the socialist economy to the market economy influences the relationship between GDP and the Gini coefficient. At the beginning of the period, inequality increased because many households suffered higher or lower income losses due to high inflation and the economic recession, and others became richer, by right or wrong means. Later, inequality increased due to the increase in property incomes, salaries and incomes from self-employed activities related to certain professions and jobs, given the persistence of a large number of low and very low income households, related to lack of qualifications and employment opportunities, as well as large family responsibilities (Molnar, 2010).

Another aspect of the considerable disagreement regarding the effect of inequality on economic growth is addressed by (Shin, 2012) which examines both the positive and negative relationship between the two phenomena, which argues that income inequality refers to disparities in income distribution, ie to the difference between rich and poor. Moreover, (Barro, 2000) concludes that the effect of income inequality on economic growth is different depending on the state of economic development. Income inequality in poor countries delays economic growth, but income inequality in rich countries encourages economic growth. Romania is not among the rich and highly developed countries according to EUROSTAT statistics comparing the evolution of GDP in all member countries of the European Union (EU). Analyzing the two hypotheses, Romania would fall into the group of developed countries, which is debatable. This situation is also encountered in the analysis of the United States and France, cases of industrialized nations, according to reports in recent years the rate of economic growth of the United States is higher than that of France and yet the United States suffers a higher income inequality than France. According to case studies in the United States and France, we can assume that there is a positive relationship between income inequality and economic growth (Shin, 2012). This situation is also present in the case of Romania, being a developing country, income inequality encourages economic growth, proven by analyzing the relationship between the two factors, economic growth and income inequality, because the saving rate of rich people is higher than that of the poor. Redistributing income from rich to poor reduces the savings rate of the economy as a whole and could therefore lead to a decline in economic growth. Another reason is that the redistribution of income could reduce the incentive for the rich to work hard and this could also lead to a decline in economic growth. As a result, we can deduce that income equality makes economic growth lower and income inequality makes it higher. 


\section{Conclusions}

The present paper provides an overview of the negative relationship between economic growth and income inequality in Romania after 1990. There are several factors influencing economic growth phenomenon that contributed to the worsening of income distribution: transition to the market economy, employment, investment, governance and political factors, international crisis and influence of globalization There are also underestimated factors, with potential to contribute to a fair distribution of income. For instance, as Candidate State, Romania had the opportunity of pre-accession EU funds and now, as Member State, Romania has access to European funds, for extension of capital investments and human capital development, increase of national competitiveness, access to international markets through trade openness.

As future research directions, I intend to develop a deeper analysis regarding the factors influencing the relationship between economic growth and income inequality in Romania and European Union countries, such as: fiscal and economic policies and institutional factors.

\section{References:}

1. Aiyar, S., Ebeke, C. (2020) 'Inequality of opportunity, inequality of income and economic growth ', World Development, Vol. 136, pp 105115

2. Banerjee, A., Duflo, E. (2003) 'Inequality and growth: What can the data say?', Journal of Economic Growth - Springer, Vol. 8(3), pp 267-299.

3. Barro, R.J. (2000) 'Inequality and growth in a panel of countries', Journal of Economics. Vol. 5(1), pp.5-32.

4. Brueckner, M., et.al. (2015) 'National Income and its Distribution', Journal of Economic Growth - Springer, Vol. 20(2) (June), pp. 149 - 175.

5. Cingano, F. (2014) 'Trends in Income Inequality and its Impact on Economic Growth', OECD Social, Employment and Migration Working Paper, 163.

6. Ferge, Z. (1997) The Perils of the Welfare State's Withdrawal', Social Research, Vol.64, no.4, pp.1381-1402.

7. Forbes, K. (2000) 'A reassessment of the relationship between inequality and growth', American Economic Review, American Economic Association, Vol. 90(4), pp 869-887.

8. Galor, O., Zeira, J. (1993) 'Income distribution and macroeconomics', Review of Economic Studies, Vol. 60, pp 35-52.

9. Georgescu, G.(2013) Romania in post-crisis period: foreign direct investments and effects on external financial balance, MPRA Paper. no. 46531

10. Howarth, R.B., Kennedy, K, (2016) 'Economic growth, inequality, and wellbeing', Ecological Economics, Vol. 121, pp 231-236

11. Hsieh, C., et.al. (2013) 'The Allocation of Talent and U.S. Economic Growth', NBER Working Paper 18693 (Cambridge, Massachusetts: National Bureau of Economic Research).

12. Ionescu, C. (2005) 'Paradigmele dezvoltării', București: Editura Economică.

13. Kraay, A. (2015) ' Weak Instruments in Growth Regressions: Implications for Recent Cross-country Evidence on Inequality and Growth', Policy Research Working Paper Series 7494 (Washington: World Bank). 
14. Islam, M.R., McGillivray, M. (2020) ' Wealth inequality, governance and economic growth', Economic Modelling, Vol. 88 , pp 1-13

15. Kraay, A. (2015) 'Weak Instruments in Growth Regressions: Implications for Recent Cross-country Evidence on Inequality and Growth', Policy Research Working, Paper Series 7494 (Washington: World Bank).

16. Marrero, G., Rodríguez, J. (2013) 'Inequality of opportunity and growth', Journal of Development Economics, Vol. 104, pp 107-122.

17. Molnar, M. (2010) 'Inegalitatea veniturilor gospodăriilor în România',Revista $\begin{array}{lllrl}\text { Română de Statistică, } & \text { No.7, } & \text { pp. }\end{array}$ (https://www.revistadestatistica.ro/Articole/2010/A3ro_7_2010.pdf) [9 November 2021]

18. Muinelo-Gallo, L., Roca-Sagalés, O. (2013) 'Joint determinants of fiscal policy, income inequality and economic growth', Economic Modelling 30, pp.814824.

19. Ostry, J., Berg, A. (2011) 'Inequality and Unsustainable Growth; Two Sides of the Same Coin?' IMF Staff Discussion Note No. 11/08 (Washington: International Monetary Fund).

20. Oustry, J.,et.al. (2014) 'Redistribution, Inequality, and Growth', IMF Staff Discussion Note No. 14/02 (Washington: International Monetary Fund).

21. Oxfam, (2016) ' An Economy for the 1\%', Oxfam GB for Oxfam International, Oxford.

22. Peterson, E.W.F. (2017) 'Is Economic Inequality Really a Problem? A Review of the Arguments', Social Sciences, MDPI, Vol. 6(4), pp. 1-25.

23. Shin, I. (2012) 'Income inequality and economic growth',Economic Modelling, Vol. 29. pp. 2049-2057.

24. Solt, F. (2020) 'Measuring Income Inequality Across Countries and Over Time: The Standardized World Income Inequality Database', Social Science Quarterly, vol.101, Issue 3, pp. 1183-1199. (https://onlinelibrary.wiley.com/doi/10.1111/ssqu.12795)

25. Stiglitz, J.E. (2013) 'The Price of Inequality', W. W. Norton, New York, NY.

26. The Standardized World Income Inequality Database, SWIID Version 9.1, May 2021

(https://dataverse.harvard.edu/dataset.xhtml?persistentld=doi:10.7910/DVN/L M4OWF) [8 November 2021]

27. Victor, P. (2008) 'Managing without growth', Edward Elgar, Cheltenham.

28. World Bank Data. World Development Indicators. GDP per capita, PPP (constant 2017 international USD)

(https://data.worldbank.org/indicator/NY.GDP.PCAP.PP.KD) [ 8 November 2021]

29. World Bank Data. World Development Indicators. GDP per capita growth (\%), (constant 2010 international USD)

(https://data.worldbank.org/indicator/NY.GDP.PCAP.KD.ZG) [ 28 November 2021] 


\title{
THE IMPACT OF SINGLE-PARENT FAMILIES' SOCIAL VULNERABILITIES ON CHILDREN
}

\author{
lleana VARGA \\ University of Oradea, The Departament of Social Science, Doctoral School of \\ Sociology, Oradea, Romania \\ ileanavarga@yahoo.com
}

\begin{abstract}
The current work describes the single-parent family in theory from the perspective of the vulnerable social group, which requires state intervention for protection and specialized and adapted support. The characteristics of social vulnerability and the types of vulnerabilities are being presented synthetically in order to identify the vulnerability of the social group of the single-parent family. Among elements of vulnerability of the single-parent family a special presentation is given to those that negatively impact the shaping of children character educated amidst such groups, as they emerge from the specialized studies on the matter. We are aiming the low academic achievement of such children, more prevalent criminal behaviour, integration problems in the school environment and in the students' group, features that may be influenced by the absence of a parent, by financial and emotional problems of family members. The single-parent family stands for a social unit with a more and more prevalent identification in contemporary society, which makes up for a legitimate object of interest as to knowing data on its functionality, the difficulties it faces, the quality of its relations with society, the positive and negative elements that mark childrens' life. The profile of the single-parent family and membership to this type of family may have an influence through destructured internal family social capital, so that the family's structural deficiencies, family relations that do not match an optimal family environment, lead to medium and long-term effects on child development. By acknowledging the effects of family structure on the behaviour of single-parent family children, a certain framework of potential actions and steps may be outlined which can provide them with a safety net and can ensure them with the fundamentals of an adequate social, academic and professional life. On the ground of shared responsibility, this approach must involve all significant actors that have potential of active and proactive involvement in relation to the issue of children from single-parent families.
\end{abstract}

Key words: social vulnerability, single-parent family, social inclusion, social exclusion, educational implications.

Jel Codes: Z13; 120

\section{Introduction}

The societal traits (the political regime, legislation, general educational standards, social policies, level of economic development) hallmark the way in which families perform their role. The globalization process obviously impacts today's standard of living, triggering essential change both in the structure and the functioning of social institutions, family and school level included. Due to its status, the family needs to 
provide relevant response to challenges in the contemporary world in terms of family life settlement, its effectiveness, especially in what children's education is concerned.

Family is the outmost social institution, in which the temporal and cultural factor makes the difference. As an institution, the family gives individuals a chance to adapt and evolve on the social hierarchy. In this perspective, the nuclear family as a social system, performs several basic functions: integration, adaptation, goal achievement, values preservation, keeping of cultural models (Chipea, 2000, p.37). Family structure fulfils one important function in every society: most children in developed countries are being raised within a family, although the type of that family may change during their lifetime. A family generally provides a child with opportunities to become a stable and self-sufficient individual, like, for instance, getting him access to school education. Children's future rate of success heavily depends on the household in which they are being raised. Nevertheless, a child cannot choose his/her family and is bound to accept a hypothetical situation in which his/her family is not able to provide him/her with the best opportunities.

Family structure has been deeply altered during the last half of the $20^{\text {th }}$ century. The second demographic transition which has occurred since the 60' s through the end of the 80's in the developed countries, has implied the decreasing of the fertility rate, that of marriage, an increase in the divorce rate, and an increase in childbirth in the case of single women, determining thus an increase in terms of single-parent families. The traditional model of a married couple with one or more children relying on the father who caters for the family while the mother runs the household and looks after the children is no longer self-evident in the developed countries. This results in more and more children being raised in an unstable family (De Lange, Donkers et. Wolbers, 2014, 329-350).

The single-parent family " is an asymmetrical family structure consisting of a single parent and his/her child/children, as a a result of either death of the other parent, or of divorce, or of one of the parent's leaving the family, or of the parent's decision of not getting married, or of the decision to adopt made by a single person, or of unintended pregnancy ( and childbirth ) in an open-relationship, especially in the case of teenage parents (Mitrofan et. Ciuperca, 1997, p.41). One specific feature in defining the single-parent family aims at its functional capability. The nuclear family fulfils or tends to fulfil its society impacting roles (the socializing, the biological, the educational, the economic and the affective functions), while the single-parent family, due to its structural incompleteness, may find itself in various difficulty instances, being unable to fulfil the roles that naturally incur to the family structure.

\section{Social vulnerability and its characteristics}

Vulnerability has a multidimensional character which needs to be analyzed in connection with elements of the economic context and the degree of access to resources. Thus, vulnerability is being identified and analyzed at both the individual and the collective level, as well as at the societal level. Vulnerability occurs in connection with a series of factors which contribute to its occurrence and to its persistence, following that vulnerable groups are being more or less affected by it. The social environment, with its economic, cultural, political dimensions may stimulate social vulnerability, or it may contribute to its continuation. In this context, the awareness of the role of social barriers acting with respect to the process of change is important. " The vulnerable group means people or families that are at 
risk of losing their ability to cater for their daily life needs, due to medical condition, disability, poverty, drug or alcohol addiction or other such situations leading to economic and social vulnerability (Law no. 292/ 2011, art. 6. P)

Approached on a broad acception, one may identify vulnerability either at the communication, cognition, institutional, relational, economic or social level....

Cognitive and communicational vulnerability

This type is ascribed to individuals which may not have the ability to grasp the gist of the information they receive and thus cannot act rightfully and conscientiously in their future demeanours. Cognitive vulnerability may refer to individuals who may find themselves in various situations and in the position to make a quick judgement, while for a certain period of time they cannot make use of their capabilities. To this category may belong people who are hospitalized, sedated, stressed, or otherwise hindered in their ability to grasp or participate to various studies or activities. On the other hand, communicational vulnerability comprises within its range such individuals that lack the ability to understand or decide, thus being unable to participate to various research stages, studies or other diverse activities. Under this heading one may include people who cannot understand or speak the language in which the conversation is being acted.

Institutional vulnerability

This type of vulnerability may refer to individuals who have decisional ability but are unable to speak out, their freedom of speech being limited due to the formal environment in which they have to act.

Social/informal subordination determined vulnerability

Individuals ascribed to this type of vulnerability may have a subsidiary position with respect to another person (for instance women who may participate to an activity or conversation, but do not do so as they take into account their husbands' unwillingness ).

Medical vulnerability

Under this heading we may group very ill patients or those who perceive their being part of a study or experiment as being their only chance of getting well. Due to this condition, the patients take virtually no consideration to the risks they are facing, being bound to take full part due to their precarious state.

Economic vulnerability

Economic vulnerability refers to impoverished people, those living in precarious conditions, as well as to low-income people who may find difficulties in accessing food or health care.

Social vulnerability

It is a way of perceiving certain groups, thus triggering their discrimination, depriving their respective members by disregarding their contribution to society. Being part of these groups equals to having a precarious material condition, with no possibility to make it by yourself, more often than not resorting to social care.

We are dealing with social vulnerability when the state of potentiality leads to deprivation specifically due to the lack of achievement of opportunities needed for change. Social issues of vulnerable groups, that is of those groups in which vulnerability has transitioned from the state of potentiality to that of actual reality, are being addressed by some authors in terms of social constructionism, a sociological approach that values the idea that people build realities in the context of interactions (Cojocaru, 2005, pp. 22-42). " Social constructionism inquiry focuses mainly on explaining processes by which people describe, explain or interpret the 
world in which they live (including themselves)" (Gergen, 1985, p.266).

\section{The impact on children of single-parent family as vulnerable social group, from the perspective of specialized studies}

We hold the single-parent family as a vulnerable social group at risk of social exclusion and we will be analyzing it from this perspective (Stanciu, 2008).

Analyzing the issue of social exclusion and inclusion implies the awareness of such elements of the social and economic context and of the individuals' living standards. Be they makers or executors of policy, it is important for each of them to concentrate their effort to take responsibility of the efficient social risk management and of the implied intervention. At the same time, we are pointing out the need of key actors' involvement with unitary and agreed mechanisms and instruments in a formally organized frame.

In this respect one of the main actors is the family.

The educational implications on children from single-parent families are among the most emphasized. Sociological studies on single-parent families show that schooling in educational institutions with high rate of single-parent family children negatively impacts childrens' academic performance, notwithstanding the educational institution's socio-economic status, size or environment (De Lange, Dronkers et Wolbers, 2014; Woessmann, 2015). The negative correlation between single-parent families and children's educational performance that studies have pointed out in the United States is no particular case, on the contrary it may be extended to almost every Western nation. Therefore, the possible explanations for this negative correlation should be general enough as to apply to all countries, not only to the US. This should mean that along with the classical variable of the socioeconomic composition of schools (which has been constantly emphasized) there are other indicators that point out to the interdependent and substantial relation to educational performance, such as the rate of single-parent families. Research has also shown that quality teachers' shortage negatively impacts pupils' educational performance, an indicator which is strongly associated with singleparent families, as they are frequently compelled to move house to poorer neighbourhoods after divorce or family breakdown. In some countries, such as the US, school resource is significantly correlated with the fiscal resource of various disticts or neighbourhoods.

As far as the impact on children of single-parent family characteristics is concerned, various outcomes of single-parent families' children's cognitive development may be identified. Besides the realization that raising in a singleparent family negatively impacts pupils' academic achievement, irrespective of their way of assessment ( PISA tests scoring, school grades, high school graduation, extent of schooling... ), studies have also targeted the assessment of the impact on children's behaviour of such single-parent families' features as (some of which we will be analyzing hereby ): the gender of the parent in charge of the child's raising and education, the sex of children raising in single-parent families, parents' involvement in children's academic activity.

Thus, some studies (Lee, Kushner \& Cho, 2007) may difference the issue in correlation with the parent raising the children in a single-parent household. The Lee, Kushner \& Cho study has made use of a national database in order to examine the outcome of parent gender, children's sex and parents' involvement in schooling on various indicators of academic achievement of pupils from single- 
parent families.

First of all, the results of the above mentioned study may indicate there is no significant variation in academic achievement between teenagers living in singleparent households along with their mother and teenagers living in single-parent households with their father, thus invalidating results of previous studies. Some previous research had signaled most children living with single mothers recorded higher rates of academic achievement (Featherma, Hauser, 1978), just like other research had reported that children living with single fathers reached higher level of academic success (Mulkey, Crain, Harrington, 1992). Secondly, by looking at the correlation between the gender of parents and the child's gender, the study has shown no significant variation with respect to academic achievement between teenagers living with same-sex parent and teenagers living with a parent of the opposite sex.

This outcome contradicts the theoretical foundation underpinning the argument of the same-sex parent. Thirdly, the results found by Lee, Kushner \& Cho may indicate the fact that no significant difference has been shown between teenagers having lived with strongly involved single parents and teenagers having lived with less involved single parents. Sons having lived with single fathers, sons having lived with single mothers and daughters having lived with single mothers recorded the same or lower rate of academic achievement irrespective of low or high level of parental involvement, daughters having lived with single fathers alone recorded higher rates of academic achievement whilst their single fathers have been more involved in their academic activities. That is to say daughters having lived with single parents showing high level of parental involvement have scored.

Better than any other group on the four variables of academic success being studied.

The question then arises as to why daughters having lived with single parents showing high level of parental involvement score better than other groups as far as the academic achievement is concerned?

The explanations to this outcome brought by the above mentioned authors argue that when children and teenagers see their parents as friends parental authority is being compromised, endangered either by excessive identification to the same-sex parent, or by being too much deactivated with the parent of the opposite sex, as suggested by the specialized studies on development of gender identity. There ought to be certain boundaries between parents and children, in order to differentiate them from friends or other acquaintances, the authors argue. Previous research may indicate that fathers are less likely to become friends with their daughters than with their sons, having reported a certain uneasiness as to the inception of secondary sexual characteristics during teenage. Fathers are more compatible with sons, as they are abler to identify with the inception of male teenage from their own experience. The modelling effect of parents, differentiated by gender distance, may explain the fact that daughters having lived with single fathers with high level of parental involvement have scored higher in terms of educational performance, in the occurrence fathers may feature the characteristics of both parent and "coach", unlike a friend or confidant. Fathers may not identify with their daughters in terms of their social and interpersonal interests the way mothers may. Fathers's focus is more task-driven, in the occurrence on the educational performance, while mothers act in a more wholistic way, so as to being more tolerant and less demanding with respect to the task. In other words, the 
"instrumental" role of fathers and the "socio-affective" role of mothers may appear more evident with respect to girls.

Longitudinal studies have also been carried out on cognitive and behavioural outcomes of children from various types of single-parent families.

Studies carried out by Carlson and Corcoran (2001) have been paradigmatic in this respect in which they used data from the National Longitudinal Survey of Youth in the USA in order to inquire the impact of various family structures in a longitudinal way, on both behavioural and cognitive outcomes of 7 to 10 years old children. The above mentioned authors have explored four possible mechanisms by which family structure may impact children. Children's outcomes , they noted, vary along economic resources, parental socialization, childhood stress and mother's psychological mood. The survey extends previous research to four dimensions. The study has focused thoroughly on cognitive outcomes by making use of more recent data from national surveys, which has allowed the researchers to also include children of older mothers, and thus make use of a more representative sample in terms of mother age. Several mechanisms by which family structure might impact children performance have been explored and also the way family structure impacts behavioural as well as cognitive outcomes has been examined, which has allowed comparing and contrasting the impact of family structure.

\section{Conclusions}

Of all the above studies' outcomes, we may synthesize the following:

- Children living for a longer period of time in a single-parent family are more likely to show poor behavioural and cognitive outcomes, than children living for a shorter period of time in such single-parent families, an inference that corroborates such data recorded by other surveys that have also been shown in the current as well as in the previous documents

- Children raised in single-parent family structures show since birth and throughout the highest risk of developing inadequate behaviour and reaching below average academic achievement

- The above mentioned differences are constant, as long as only children's characteristics are controlled the family structure has big and significant initial impact: as opposed to children from two-parent families, children from any other type of family structures show a higher rate of behavioural issues and significantly lower scores in cognitive tests. When support measures to mothers' mental wellbeing are included, the scope of the initial impact of family structure shrinks by a third or even by more for the behavioural issues rate. Additional income, on the other hand, reduce the scope of the impact of family structure on both behaviour and cognitive outcomes, while in the final model almost all the consequences of family structure reach very low and unimportant standards once adequate income and a positive mental state are being ensured.

- Gender is an important predictor as far as the children's behavioural outcomes are concerned: girls feature less behaviour issues.

- Mothers' mental health is important to children behaviour; depression risk is being associated with a higher rate of behaviour issues, while adequate life management (control) is associated with fewer problems for children. 
- Income is strongly and negatively associated with behaviour issues, while quality family time is associated with fewer behaviour issues

- Cognitive results of children are mirrored statistically only through mathematical data. Children from deprived environments generally score less than children from normal environments.

- Girls score significantly higher in reading tests, although no difference has been recorded for the mathematics tests.

- Low birth weight is being associated with lower scores in mathematics tests

- Mothers' economic status is a strong predictor of both cognitive results (reading and maths), while mothers' level of education and mental health show no correlation whatsoever.

- Income has a significantly positive impact on scores reached in reading and Maths, while the quality of home environment has a strong impact on mathematical ability and a significant impact on reading skills.

The conclusions to be drawn are likely to be similar in many respects to those signaled by previous research. Also, the survey made by the two authors shows that there are many effects of some variables stemming from the family structure which are being reduced or eliminated when a series of control variables are being included. Mothers' educational score is a strong predictor of cognitive results, just like income is a predictor especially in the case of reading scores. Although research has found that all impact of family structure on mathematical performance has vanished as soon as other control variables (income, material condition, mental health etc.) have occurred, in the case of the two tests - maths and reading - several effects have been persistent, some of which have not demonstrated the expected way.

Certainly, the single-parent family and children from its specific environment may show various elements of vulnerability, with respect to social behaviour, social integration, school integration and school performance, juvenile crime, drug consumption, emotional level. Membership of single-family group significantly impacts children education and development, not only the awareness of its effects, but also the identification and the implementation of intervention measures aiming at their protection being very much needed.

\section{References:}

1. Carlson, M. J., \& Corcoran, M. E. (2001). Family structure and children's behavioral and cognitive outcomes. Journal of marriage and family, 63 (3), 779-792.

2. Chipea F. (2001), Familia contemporană. Tendințe globale și configurații locale, Editura Expert București

3. Cojocaru, Ş. (2004), Abordarea problemelor sociale din perspectiva vulnerabilităţii sociale. Revista de Cercetare şi Intervenţie Socială. vol. 5. Holt România şi Universitatea „Al.I.Cuza”. Departamentul de Sociologie şi Asistenţă Socială. Editura Lumen. Iaşi. pp.657-658.

4. Cojocaru, Ș. (2005), Metode apreciative în Asistența socială. Ancheta, supervizarea și managementul de caz", Editura Polirom, lași

5. De Lange, M., Dronkers J., Wolbers, M. H.J., (2014), Single parent family forms and childrens educational performance in a comparative perspective 
effects of schools, share of single-parent families Radboud University Nijmegen The Neterlands

6. Gergen, K.J. (1985), The social constructionism movement in modern psychology, American Psychologist, 40 (3), pp. 266-275

7. Lee, S. M., Kushner, J., \& Cho, S. H. (2007), Effects of parent's gender, child's gender, and parental involvement on the academic achievement of adolescents in single parent families. Sex Roles, 56 (3-4), 149-157.

8. Lee, D., \& McLanahan, S. (2015), Family structure transitions and child development: Instability, selection, and population heterogeneity. American sociological review, 80 (4), 738-763

9. Mitrofan I., Ciupercă, C. (1997), Psihologia relațiilor dintre sexe, Editura Alternative, București

10. Stanciu, M. (coord.) (2008), Condiții de viață ale familiilor cu copii din România, București, Institutul de Cercetare a Calității Vieții

11. Woessmann, L. (2015). An international look at the single-parent family; family structure matters more for US students. Education Next, 15 (2), 4250.

12. http://cometc.unibuc.ro/subiecti-vulnerabili.html

13. Legea asistenţei sociale nr. 292/2011, publicată în Monitorul Oficial, Partea I, nr. 905 din 20.decembrie 2011 


\section{SECTION FINANCE, BANKING, ACCOUNTING AND AUDIT}




\title{
THE ECONOMICAL AND FINACIAL IMPLICATIONS OF RENEWABLE ENERGY SOURCES
}

\author{
Alexandra Maria BELE (LĂCĂTUȘ) \\ ${ }^{1}$ Doctoral School of Economic Sciences, University of Oradea, Oradea, Romania \\ lacatusalex@yahoo.com
}

\begin{abstract}
More and more often, we talk about the use of renewable energy from the perspective of environmental protection. Competitive pressure in which reliability and efficiency are the key elements in capital development that shape the development plan of countries every year. However, we cannot look at this issue only from a climatic point of view. On a large scale, the production and the development of industries must thrive to the new standards, adapting also from the technological and financial point of view. The most visible effects are quantifiable in the form of employment, increase or decrease in GDP, dynamics of budget revenues and expenditures, applied taxonomy, and investment impact. In no country does the improvement of renewable energy take place without financial, social, and political support. EU countries have decided to allocate significant public funds under various support schemes for the progress of this sector. Accelerating the development of renewable energy sources (RES) also involves the introduction of mechanisms involving the use of private capital. In turn, this has effects on the level of local acceptance for development projects. In other words, this article presents first of all a synthesis of the key elements of the literature, dealing with the scientific, technical, economic, financial and environmental elements. The most important aspect is related to the contribution of the six renewable energy sources to the achievement of sustainable objectives. The purpose of this article is to provide information on how European Union countries have managed both fiscal and economic revenues from renewable energy sources. In order to establish the economic and financial efficiency of renewable energy sources, the mechanism and functionality of pricing systems were studied. The progress made by the countries studied is determined in particular by the degree of achievement of the objectives imposed by the European Union. Presenting the latest trends in RES, we pointed out the systems that support the development of renewable energy through solutions adopted as financial and environmental measures.
\end{abstract}

Keywords: Renewable Energy, Finance, Renewable energy financing, Innovative energy finance.

JEL Classification: Q4, Q5, H23

\section{Introduction}

The demand for renewable energy has grown in recent years. Contemporary society has understood that the use of these resources ensures sustainable economic and social development and at the same time helps the well-being of the green environment. First of all, every society needs energy to meet its basic 
needs and to make production processes work normally. In other words, renewable energy sources play a key role in both the delivery of energy services and climate change mitigation. Starting from the premise that renewable resources have a huge potential for economic development, this paper captures the current contribution of these resources from a financial point of view. Thus, they revolve around revenues and costs, tariff barriers and financing instruments.

As we well know, energy is the basis of the development of modern civilization. For this reason, it is difficult to estimate the quality of life in a society with a developed energy. The energy sector is gradually eliminating the raw forms of work, contributing to the increase of the greatest value for humanity - the increase of individual freedom. The only way to deal with probably the most important problems today - environmental degradation, climate change and all the harmful consequences for humans and the planet as a whole is to use renewable sources. The issue of the possibility of resolving the environmental situation and reducing global climate change processes has been repeatedly raised by the world community. Aware of the seriousness of the problem and the consequences it can have at the international level, countries are trying to make every effort to solve it.

Although there is no widely accepted definition for what we call energy efficiency, some authors such as Bhattacharyya (2011) believe that most approaches are based on the simple relationship between the, the output of a useful process or energy input into a process" (Filippini, Massimo, Hunt, Lester C., 2015). Looking at efficiency, energy does not produce outputs. This is accompanied by the contribution of certain elements such as capital to produce certain achievements (Bian, Hu, Wang, \& Xu, 2016).

\section{Literature review}

The Paris Agreement was an extremely important document for sustainable development. At the summit, 192 countries adopted a new global climate agreement, which replaced the Kyoto Protocol and aimed to stop global warming. $\mathrm{He}$ was the promoter of the meeting of the representatives of the UN member states in 2015, which resulted in a project entitled "Transforming our World: The 2030 Agenda for Sustainable Development". It identifies 17 global goals for sustainable development, and their purpose is to provide an opportunity to address at least in part the most pressing issues facing humanity today. These include combating poverty, hunger, improving health, quality education, gender equality, clean water and sanitation, renewable energy, decent work and growth, innovation, and infrastructure, reducing inequality, sustainable development of cities and communities, responsible consumption, control climate, underwater and land life, peace and justice, partnership for goals. And as can be deduced, the priority is the development of renewable energy, because it is a precondition for solving all other problems (United Nations, 2015).

Renewable energy is an inexhaustible source of energy from an ecological point of view, which does not change the functional structure of the Earth and which offers an opportunity to reduce the burden of the resource base and the global consumption of resources. In other words, it leads to overcoming poverty and responsible consumption (Ukrainian Association of Renewable Energy, 2021). 
Since the publication of the Brundtland report in 1987, concerns about sustainable development have led us to prefer the term renewable energy to the terms "alternative energy" or "new and renewable energy". Focused on the regeneration criterion, the current terminology covers several types of energy sources that do not exactly match the previous terms, more focused on the diversification of sources (energy security perspective) or technological innovation. It is common to define renewable energies as opposed to fossil fuels such as oil, coal or gas and whose natural formation takes several thousand years. However, the establishment of renewable energy lists is common in both the United States and Europe, but their nature is both imperative and exhaustive (Febvre, 2010).

Beyond these terminological meanings, the most common definition of renewable energy is given by Directive 2009/28 / EC, respectively by Art.2 which says that "energy from renewable sources" means "energy from non-fossil renewable energy". In this category we have,, hydroelectric power, aerothermal, biomass, geothermal, hydrothermal and ocean energy, wind, solar, biomass, waste fermentation gas, wastewater treatment plants and biogas " (European Parliament, 2009).

\section{Economic and financial efficiency of renewable energy sources}

An important aspect to be clarified is related to the efficiency of these energy resources. First of all, we will see this as a strategy that reduces energy consumption, for the same service provided and leads to a reduction in ecological, economic and social costs related to energy production and consumption while allowing an increase in the quality of life of all. the inhabitants of the planet and future generations (Cochet, 2000). In other words, efficiency itself is given in the capacity to deal with global economic crises and to avoid them by managing the multiple environmental constraints.

Currently, the GDP of each country is especially important because it shows the size of the market and the purchasing power of residents. Apergis and Payne (2010), using variables such as capital formation, GDP, labour, and renewable energy consumption, demonstrated that there is a two-way relationship between economic growth and renewable energy consumption.

Classical and neoclassical economists did not explicitly consider the energy factor in their production function. In the days of the classics, the economy was linked to land, labour and capital. That is why we do not have the energy applied in the production function. But over the years, the importance of energy has increased through industrialization. D.I. Stern, C.J. Cleveland (2004) divides neoclassical economics growth patterns into three ideologies.

The first theory insists that technological variations are the most important factors influencing economic growth and production function. In this case, first, the economy reaches a level of equilibrium, when improving technology develops economic growth rather than capital (BEHNAME, 2012).

Energy efficiency transforms the common vision of energy as a factor in power and profit into a vision of energy in response to needs. The RES classification crosses quite different levels both in terms of market organization and public intervention in favour of their development. Obviously, the renewable energy market is by far the most advanced, following in this respect the electricity market in general, the peculiarity of the latter is that it can be transported and changed in 
real time. Thus, various investment support mechanisms have emerged, such as tax exemptions or tax reductions, investment aid, direct price support or tax refunds (Cochet, 2000).

In studied literature, the classification of energy instrument mechanisms, by their dichotomous nature are accentuated by supply or demand stimulation systems. They aim to stimulate the increase of installed capacity or energy production. In practice, however, two basic mechanisms can be distinguished that have become the basis for the operation of various support systems to produce energy from renewable sources in EU countries: the price system and the system for forming the quantities of energy generated, also called quota (UNEP, 2012).

The implementation of the provisions of Directive 2001/77 / EC of the European Parliament and of the Council on the promotion of electricity from renewable sources in the internal market in electricity brings benefits in the form of increasing the share of renewable energy sources in the country's energy balance. comprehensive investment in renewable energy (European Parliament and the Council, 2001). To implement energy efficient solution, it is necessary to have a economic rationale approach. First this solution must be highly cost-effective, before are made any investments in order to have options with expensive low carbon (R. Cowart, 2014).

Due to the fact that energy is used in several different processes it is necessary to use a diversity of instruments. One problem in this is the mixing of these energy efficiency tools that can lead to targeting difficulties (Rosenow, Kern, \& Rogge, 2017).

From a terminological point of view, it is necessary to make the distinguish between energy efficiency and energy saving. These concepts must be viewed separately, as their outcome does not always coincide. Decrease in energy efficiency does not always lead to energy savings. In other words, the two terms exist and operate independently. This is due to the 'rebound effect' which involves offsetting efficiency improvements by improving comfort or use in larger quantities (Malinauskaite, and Others, 2019)

Based on this principle, there are several mechanisms to support renewable energy sources. According to the regulatory method, we find the tariff system, used in most countries. It is set in advance for a longer period, while the price indicates if the tariff is paid to renewable energy producers by the energy distributors, who then transfer these costs to the transmission system operator (s). The final cost of the support mechanism is born by the final energy consumers (Couture \& Gagnon, 2010).

One support mechanism for energy producers from renewable energy sources is the use of green certificates. They are a significant support for companies operating in this industry. RES plants are in many cases technologically complex (biogas plants) and involve high investment costs. To help companies that produce energy from renewable sources, the European Union offers them assistance in the form of a certificate of origin (known as green certificates), which is sold on the open market (EUROPEAN COMMISSION, 2011).

In other words, green certificates, granted monthly to producers by TSOs, can be sold to suppliers on the centralized market of green certificates and / or on the market of bilateral contracts. Manufacturers sell their electricity on the electricity market at the market price (for conventional electricity). Selling green certificates 
to suppliers brings them additional revenue to cover the higher costs of using renewable energy sources. The electricity market and the green certificates market are separate and operate independently (EUROPEAN COMMISSION, 2011).

\section{The research methodology and results}

First of all, the study starts by analysing renewable energy investments at a global, and European level. However, special attention was paid to Romania's position in this context compared to other EU Member States. Thus, in the case of financial instruments, balance sheet financing, grants, project-level debt, and project-level equity were taken into account. In particular, the analysis includes the analysis of investments in the field of electricity which are based on the following technologies Hydropower, Wind Energy, Geothermal Energy, Solar Energy, Biofuels, Biomass and Biogas.

This article is based on empirical data extracted from a wide range of primary and secondary sources. These have been delimited according to the private or public nature of the financial and investment flows. Regarding the financing of renewable sources, it includes data related to the revenues and costs of the components that directly contribute to the operation of the system. Moreover, to emphasize the special role that these resources play in the economic and financial dynamics of European countries, but especially we analysed the evolution of green certificates as some of the most innovative and profitable green financing instruments.

\subsection{Energy efficiency and financial implications}

Currently, all EU Member States have implemented support tools for the development of renewable energy. The financial instruments used indicate that it is possible to combine different types of financing from different fields of application depending on the level of advancement of technological and economic development of the market. The result is the efficiency and effectiveness of the use of these sources. Thus, in the following analysis we followed the evolution of the indicator indicating energy efficiency based on data provided by (Eurostat, 2021) from 1990 to 2019. The indicator measures the level of energy consumption and the distance from the 2020/2030 objectives. Saving energy could improve security of energy supply by reducing dependence on fuel imports. From this it can be deduced that the improvement of energy efficiency leads to the prosperity of the competences of European industry and services, and for households it is reflected in the reduction of energy costs. According to data from (Eurostat, 2021) energy savings could also help reduce GHG emissions from fuel combustion. Quantities of energy are expressed in fuel-specific units such as in thousands of tonnes, in Gigawatt-hours or terajoules (TJ). The energy efficiency indicators included in this data set are 1000000 tonnes of oil equivalent (Mtoe).

In the chart below, the first five countries with the highest degree of energy efficiency have been selected. This category includes Germany, Spain, France, Italy and Poland. We also took by comparison the situation of Romania to determine its progress in relation to the EU level towards Europe 2020 target for 
energy efficiency and the stage of development of the objectives defined in Directive 2012/27 / EU on energy efficiency. First, a constant trend can be noticed throughout the analysed duration, without major fluctuations. Between 1990-2006, a gradual increase can be observed, after which a slight decrease begins until 2014 when the trend becomes a constant one. The most energy efficient country is Germany with a maximum of 332.75 Mtoe reached in 2006 and a minimum of 282.71 Mtoe in 2019. In 2nd place is France with a maximum of 260.92 Mtoe in 2005, followed by Italy with 180.83 Mtoe, Spain with 138.85 Mtoe and Poland with 101 Mtoe in 2018.

According to Directive 2012/27 / EU the target values for primary energy 2020 for the European Union must be less than 1483 Mtoe or for final energy around 1086 Mtoe. In addition, for 2030, primary energy Mtoe of energy consumption must not exceed 1273 Mtoe and for final energy less than 956 Mtoe. Regarding Romania, the values reported at the level of the European Union are much below average. Since 1990, the trend has been downward from 62.36 Mtoe in 1990 to 31.97 in 2019. Compared to other countries, if we follow the trend in 2019 , we can say that Romania's energy efficiency is $0,32 \%$ compared to the value reached by Poland and $0.26 \%$ compared to Spain.

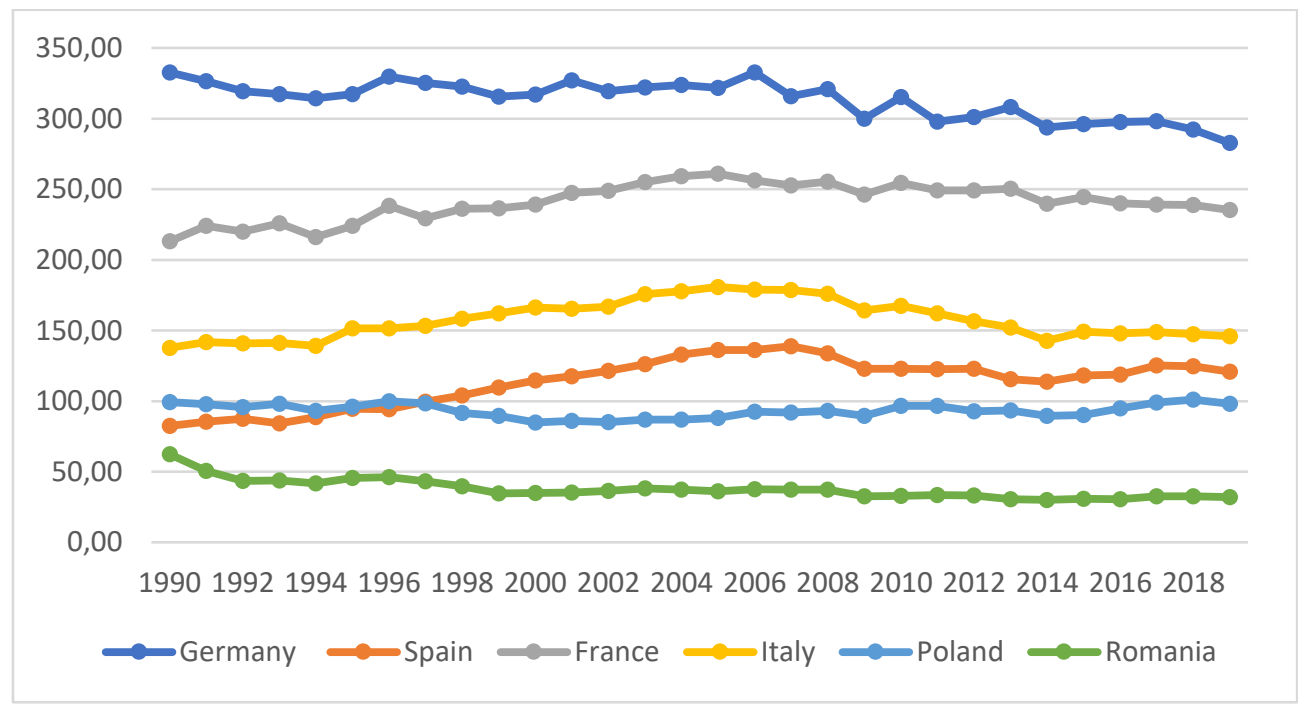

Figure 1: The most energy efficient countries in EU

Source: own editing based on data from EUROSTAT

From a fiscal point of view, energy efficiency is reflected in the revenues collected from energy taxes and duties. In this sense, we followed the evolution of energy taxes considered an indicator of the efficiency of renewable resources. Moreover, with the help of data collected from EUROSTAT, the progress made by the countries of the European Union was monitored in order to achieve the objective of efficiency in terms of resource use but also for the correct setting of prices. Environmental taxation has had a major influence on the dynamics of energy taxes, especially since the tax base is a physical unit with a negative impact on the 
environment. The studied period is between 1995-2019 and includes EU member states. According to EUROSTAT (2021) the indicator measures the total amount of energy tax revenues in millions of euros. It indicates the dimensions that energy taxes take in monetary units to supplement the quotas of energy taxes paid by the consumer. Energy taxes are a subcategory of environmental taxes in addition to taxes on pollution, resources, and transport.

First of all, the attention was focused on the situation of Romania compared to the other EU states. Thus, to be able to show how many times the level decreased or increased compared to the base period, we calculated the fixed base indicators according to the following calculation relation:

$$
I_{t / 1}=\frac{y_{t}}{y_{1}}
$$

At the same time, to show how many times, the level of the indicator increased or decreased compared to the previous period, indices based on the chain were calculated according to the following calculation formula:

$$
I_{t} /_{t-1}=\frac{y_{t}}{y_{t}-1}
$$

From these two equations we can conclude that: $I_{t} / 1=\Pi I_{t} / t-1$.

This shows us that the ratio of the level of the indicator to be compared and the level of the indicator used as a basis for comparison expresses the extent to which the phenomenon y changed during the period considered.

In the chart below we have transposed the situation of the indices with chain base starting from 1996 and until 2019 for Romania in terms of energy taxes. Overall, the trend is constant, with major fluctuations until 2003. The highest increase between 1996/1997 was 1.80202 and 1.298461 between 1997/1998. It is noteworthy that starting with $2017 / 2016$ began a steady progress that reached 1.177895. The situation of fixed-base indices for energy taxes in Romania was reported to 2008 as the base year due to the fact that in that period new laws were introduced that favoured the green tax system. As we can notice, the trend is an ascending one with small fluctuations between the years 2000-2003, respectively 2007-2011. The highest increase compared to the previous year was recorded in 2019 being 2.239002 , respectively 1.900851 in 2018 . 


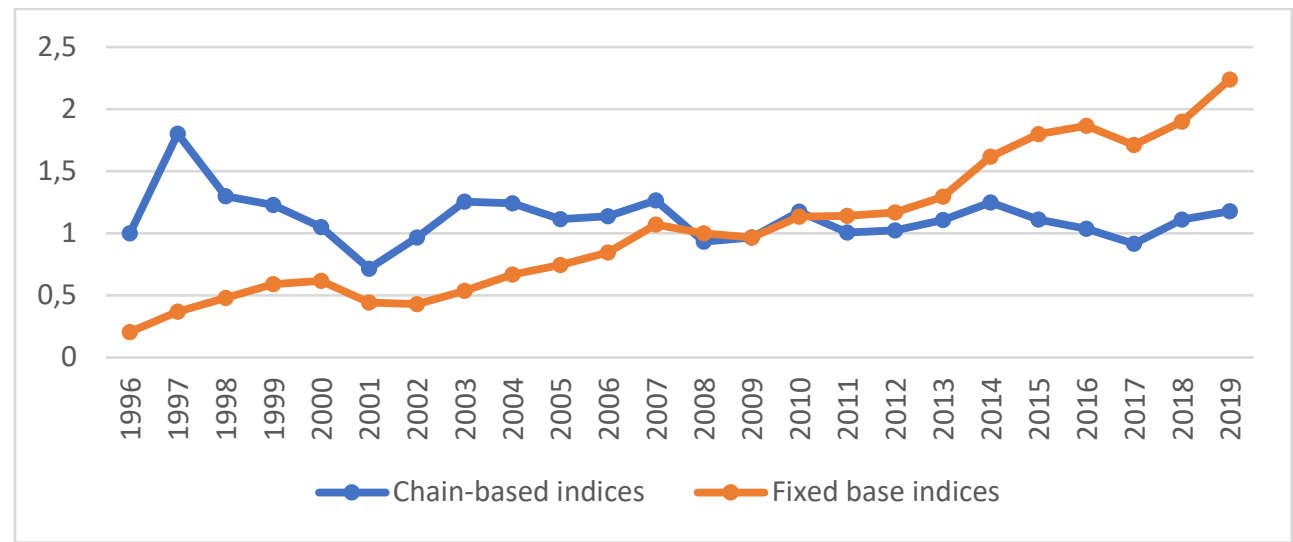

Figure 2: The index with the chain base of energy taxes in Romania Source: own editing based on data from EUROSTAT

The first category analysed is that of the states with the highest revenues from energy taxes. This includes Germany, Italy, France, Spain, the Netherlands, Sweden, Austria, Poland, and Belgium. The trend is a constant one that follows an ascending slope, without major fluctuations. However, some major fluctuations can be noticed, especially in Germany, where the peak reached in 2003 in the amount of EUR 50,473 million suffered a decrease of up to EUR 45,627 million in 2007. The increase in energy tax revenues in the period 2002-2007 is due to in the principle of introducing a national strategy and climate protection programs that have led to special tax treatments (Rosenberg, Schopp, Neuhoff, \& Vasa, 2011). With a considerable difference, we note the evolution of France, but especially of Italy, which although it had a constant trend until 2008, starting with 2009 had a significant increase of up to 47,453 million euros. Compared to this level of taxes, Romania is well below the average of the first countries, more precisely in 2019 the accumulated energy taxes represent $0.09 \%$ of the value of revenues from energy taxes in Germany. 


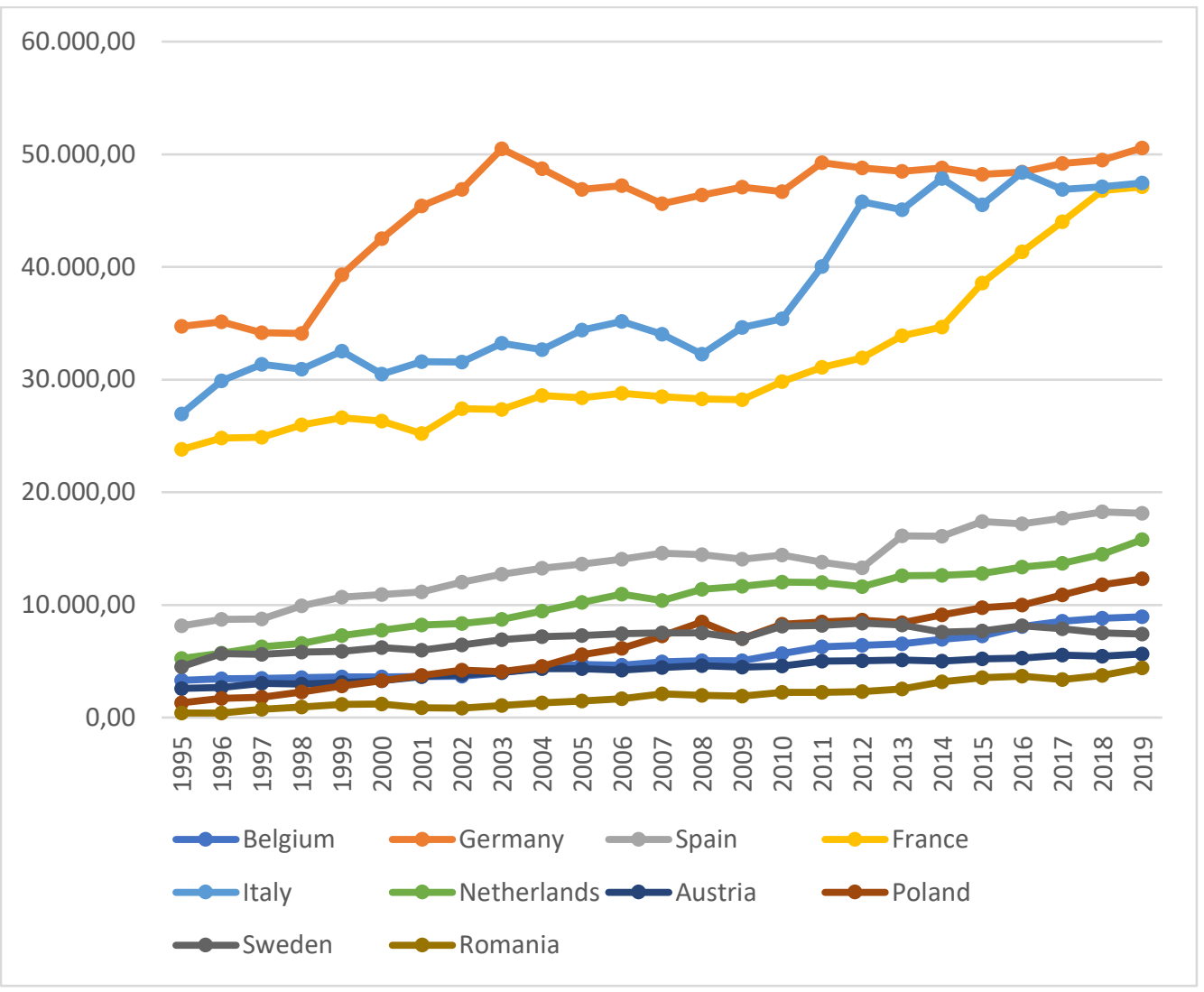

Figure 3: The highest revenues from energy taxes in the European Union

Source: own editing based on data from EUROSTAT

\subsection{Financial investment trends of Renewable Energy}

One of the European Union's priorities is to develop the energy sector using efficient technologies. Reducing the costs of green energy procurement and achieving leadership in the use of low-carbon technologies have been key objectives for economic development. This cannot be achieved without specific funding mechanisms. Thus, the analysis of the study begins with an overview of global investment trends in renewable energy. Thus, the first graph is based on data collected from (IRENA, 2020) from 2013 to 2018. 


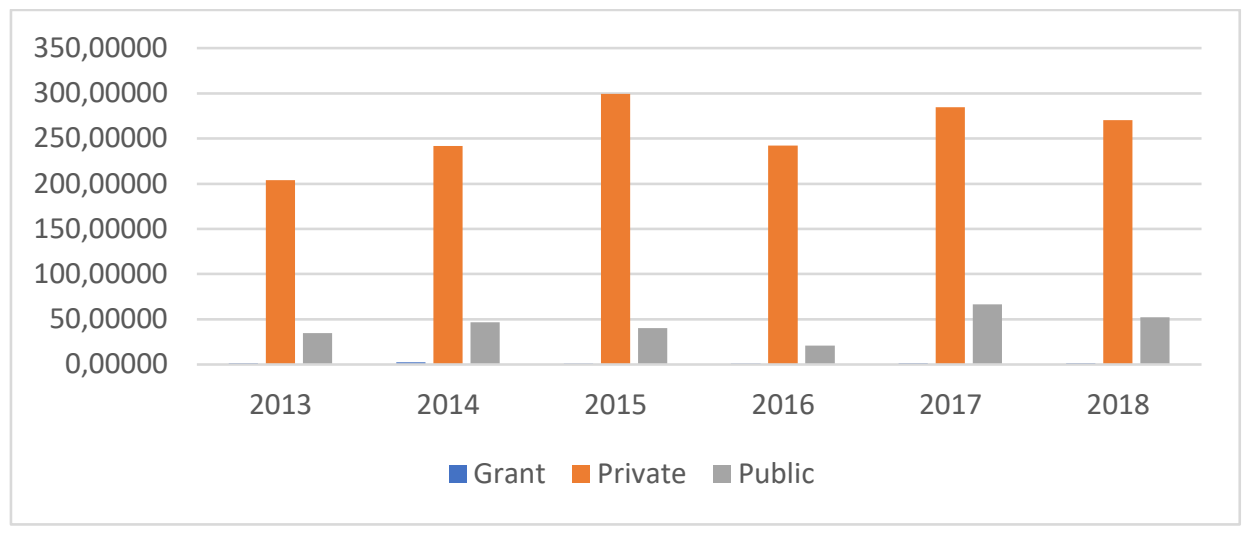

Figure 4: Global investment trends in renewable energy Source: own editing based on data from IRENA

A first important aspect to mention is related to the fact that financial sources are given by three categories: grants, private and public sources. As we can see from the chart below, private financing has the largest share. On average, private funding greatly covers the contribution of the other two categories. The smallest investments were based on grants, and the lowest values were recorded in 2015 amounting to USD 0.94488 trillion, with a remarkable decrease from a maximum of USD 2.32416 trillion. In terms of public sources, they fluctuated significantly, especially between 2015-2017, when there was a halving of USD 4050281 billion, following a rapid increase of up to USD 6664978 billion.

In terms of the potential for financing energy investments, the most important source is funds from the European Investment Bank (EIB), whose lending activity is in line with the EU's strategic development directions. EIB funds are offered in the form of loans and lines of credit. The first form is addressed to public institutions, banks and large private companies. The credit line mechanism is intended for financial institutions that separate funds allocated in accordance with the EIB's investment priorities.

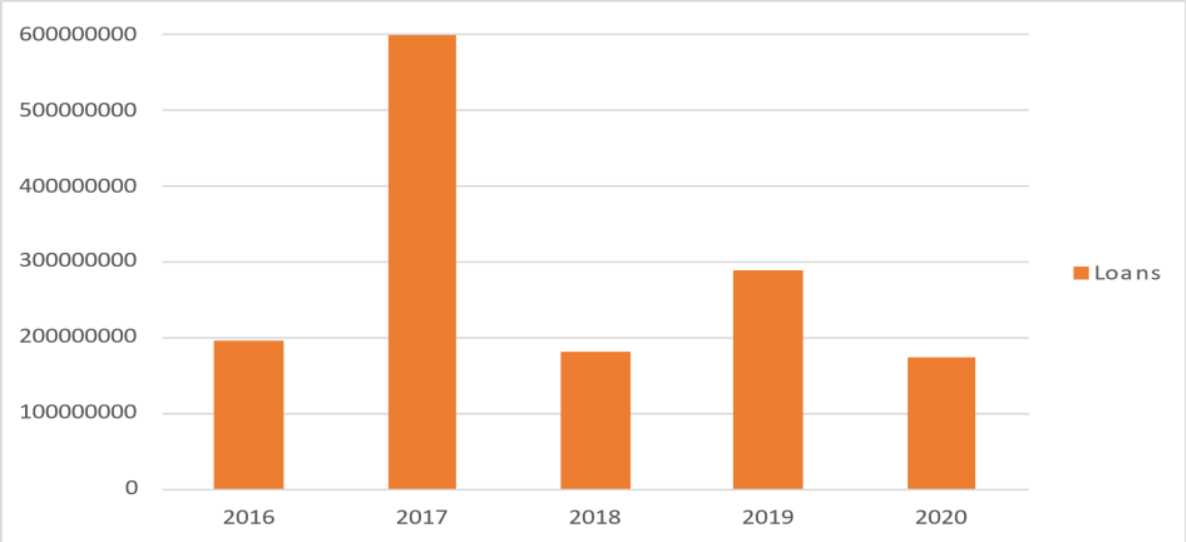

Figure 5: Loans allocated for energy purposes

Source: own editing based on data from European Investment Bank 
The graphic shows the evolution of EIB lending from 2016 to 2020. In the period under review, the amount of EIB funds allocated for energy purposes amounted to over EUR 1,438,383,681. Although there are significant fluctuations, especially between the years 2017-2018 when there is a sharp decrease from EUR $600,060,670$ to EUR $180,200,000$. In 2017, the largest loans were granted in the amount of EUR 100,820,806 for "Infrastructure fund investing in large energy projects with a focus on renewable energy". Another significant amount of EUR $55,000,000$ was awarded for the Pan-European infrastructure fund targeting transport energy renewable energy efficiency ICT (broadband) and water treatment sectors. At the opposite pole, the lowest investments of 1,750,432 EUR were granted for "Equity-type loan to Fund focusing on energy transport wastewater telecommunications and social infrastructure investments" mainly in Nordic countries. At the same time, the smallest loans were granted in 2020. A significant amount of EUR $61,000,000$ was granted for the fund providing debt to developers of small and medium sized RE projects and Energy Transition projects across the EU with a $50 \%$ focus on France. At the same time, EUR 40,000,000 has been allocated for investment in an equity fund providing growth capital to SMEs in the energy transition sector through minority equity participations, while EUR $30,000,000$ is top-up fund to be established alongside Eiffel Energy Transition Fund with the aim of providing funding to renewable energy project developers that face scarcity of funding in the delivery of projects due to disruption caused in lending markets and project cycles as a result of COVID-19.

\section{Conclusions}

In conclusion, the energy sector has an important contribution to the sustainable growth of the economy. The global and European priority is the development of renewable energy. Energy efficiency requires the intelligent use of financing mechanisms and the instruments that govern them. Accelerating the need for development requires creating a balance between public and private investment. Energy tax regulations act as a lever in optimizing taxes and duties in order to stabilize socio-economic processes. Based on the analysis, it can be argued that the budget schemes have encouraged the increase of fiscal revenues. In this sense, we can note that there were no major fluctuations, the trend being kept constant. However, the differences in energy taxes between EU countries are considerable. In other words, it is advisable to use low tax rates with a limited number of tax benefits, as this stimulates the real sector of the economy. Germany, Spain, France are the countries that are most energy efficient, both in terms of investments made in this sector and in terms of the financial leverage used. As for Romania, since 2007 there can be a development in this sector, but from a financial point of view it can be said that it is below the EU average.

As can be seen, European funds largely support the development of renewable energy sources and market mechanisms. The demand for energy produced depends directly on the pricing system, but also on the control of production volume. RES installations are in many cases technologically complex and require high investment costs. In this regard, countries have opted for assistance in the 
form of grants or loans. At the same time, an innovative and increasingly used financing tool is the green certificate, and its development prospects are becoming increasingly attractive to investors.

\section{References}

1. Apergis N., Payne J.E. 2010a, Renewable energy consumption and economic growth: evidence from a panel of OECD countries. Energy Policy; 38:656-60;

https://econpapers.repec.org/article/eeeenepol/v_3a38_3ay_3a2010_3ai_3a1_3ap 3a656-660.htm.

2. $\quad$ Apergis N., Payne J.E. 2010b, Renewable energy consumption and growth in Eurasia. Energy Econ, forthcoming; https://ideas.repec.org/a/eee/eneeco/v32y2010i6p1392-1397.html

3. BEHNAME, M. (2012). LA CONSOMMATION D'ENERGIE RENOUVELABLE ET LA CROISSANCE ECONOMIQUE DANS L'EUROPE DE L'OUEST. Available https://revecon.ro/articles/2012-2/2012-2-10.pdf

4. Cochet, Y. (2000). Stratégie et moyens de développement de l'efficacité énergétique et des sources d'énergie renouvelables en France. Available https://www.vie-publique.fr/sites/default/files/rapport/pdf/014000086.pdf

5. COMISIA EUROPEANĂ. (2011). Certificate verzi pentru promovarea producerii energiei electrice. Available

https://ec.europa.eu/competition/state_aid/cases/240906/240906_1249037_223_2. pdf

6. Couture, T., \& Gagnon, Y. (2010). An analysis of feed-in tariff remuneration models: Implications for renewable energy investment. Energy Policy, 955-965.

Available

https://www.sciencedirect.com/science/article/abs/pii/S0301421509007940

7. European Parliament and of the Council. (2001). Directive 2001/77/EC of the European Parliament and of the Council. Available https://eur-

lex.europa.eu/eli/dir/2001/77/oj

8. EUROPEAN PARLIAMENT. (2009). DIRECTIVE 2009/28/EC OF THE EUROPEAN PARLIAMENT AND OF THE COUNCIL of 23 April 2009 on the promotion of the use of energy from renewable sources and amending and subsequently repealing Directives 2001/77/EC and 2003/30/EC. Official Journal of the European Union. Available https://eur-lex.europa.eu/legal-

content/EN/TXT/PDF/?uri=CELEX:32009L0028\&from=RO

9. EUROSTAT. (2021, March). Energy taxes. Available https://ec.europa.eu/eurostat/cache/metadata/EN/t2020_rt300_esmsip2.htm

10. Febvre, C. (2010). Energies renouvelables: comparaison entre le droit des Etats-Unis et de l'Union européenne. Available https://www.lepetitjuriste.fr/wpcontent/uploads/2011/05/PT\%20Energies\%20renouvelables\%20comparaison\%20 entre\%20le\%20droit\%20des\%20Etats\%20Unis\%20et\%20de\%201\%20Union\%20eu rop\%C3\%A9enne.pdf

11. HE EUROPEAN PARLIAMENT AND THE COUNCIL OF THE EUROPEAN UNION. (2012, October 25). DIRECTIVE 2012/27/EU OF THE EUROPEAN PARLIAMENT AND OF THE COUNCIL. Available https://eur-lex.europa.eu/legalcontent/EN/TXT/HTML/?uri=CELEX:32012L0027\&from=EN

12. https://ec.europa.eu/eurostat/cache/metadata/EN/nrg_ind_eff_esms.htm 


\section{IRENA. (2020). GLOBAL LANDSCAPE OF RENEWABLE ENERGY}

FINANCE. Available https://www.irena.org/-

/media/Files/IRENA/Agency/Publication/2020/Nov/IRENA_CPI_Global_finance_20 20.pdf

14. Rosenberg, A., Schopp, A., Neuhoff, K., \& Vasa, A. (2011). Impact of Reductions and Exemptions in Energy Taxes and Levies on German Industry. Available https://www.climatepolicyinitiative.org/wpcontent/uploads/2011/12/Reductions-and-Exemptions-on-Energy-Taxes.pdf 15. Stern, D.I., Cleveland, C.J., 2004, Energy and Economic Growth, Rensselaer Working Papers in Economics No. 0410, Rensselaer Polytechnic Institute, USA.

16. UKRAINIAN ASSOCIATION OF RENEWABLE ENERGY. (2021, February 21). Available https://uare.com.ua/en/

17. UNEP. (2012). Feed-in Tariffs as a Policy Instrument for Promoting Renewable Energies and Green Economies in Developing Countries. Available https://unfccc.int/files/documentation/submissions_from_parties/adp/application/pdf /unep_us ws2.pdf

18. United Nations. (2015). Transforming our World: The 2030 Agenda for Sustainable Development. Available https://sustainabledevelopment.un.org/post2015/transformingourworld/publication 19. Stern, D.I., Cleveland, C.J., 2004, Energy and Economic Growth, Rensselaer Working Papers in 20. Economics No. 0410, Rensselaer Polytechnic Institute, USA; https://www.researchgate.net/publication/24125107_Energy_and_Economic_Grow th

21. Bian, Y., Hu, M., Wang, Y., \& Xu, H. (2016). Energy efficiency analysis of the economic system in China during 1986-2012: A parallel slacks-based measure approach. Renewable and Sustainable Energy Reviews 55, 990-998. Available https://www.sciencedirect.com/science/article/abs/pii/S1364032115012605?via\%3 Dihub

22. Filippini, Massimo, Hunt, Lester C. (2015). Measurement of Energy Efficiency Based on Economic Foundations. Energy Economics, 1-34. Available https://www.sciencedirect.com/science/article/pii/S0140988315002467?via\%3Dihu b

23. Malinauskaite, J., Jouhara, H., Ahmad, L., Milani, M., Montorsi, L., \& Venturelli, M. (2019). Energy efficiency in industry: EU and national policies in Italy and the UK. Energy, 255-269. Available https://www.sciencedirect.com/science/article/pii/S036054421930146X

24. R. Cowart. (2014). Unlocking the Promise of the Energy Union: Efficiency First Is Key. The Regulatory Assistance Project, Montpelier, VT, Available https://www.raponline.org/document/download/id/7401/

25. Rosenow, J., Kern, F., \& Rogge, K. (2017). The need for comprehensive and well targeted instrument mixes to stimulate energy transitions: The case of energy efficiency policy. Energy Research \& Social Science. Available https://www.sciencedirect.com/science/article/pii/S2214629617302797 


\title{
MONETIZATION OF ENVIRONMENTAL EXTERNALITIES FOR ECONOMIC ANALYSIS. CASE STUDY: URBAN MOBILITY IN ORADEA
}

\author{
Ovidiu - Vasile GULER, Corina BOLOȘ \\ University of Oradea, Doctoral School of Economic Sciences, Faculty of Economic \\ Sciences, The Finance - Accounting Department, Oradea, Romania \\ guler.ovidiu@gmail.com,boloscorina@gmail.com
}

\begin{abstract}
One of the main limitations identified in the specialized literature is represented by the insufficient quantification of the environmental externalities in the process of carrying out the economic analysis within the cost-benefit analysis for the urban mobility projects specific to the local public authorities. Cost-benefit analysis is an essential tool for prioritizing public investment. The research methodology used in this paper includes data analysis, observation and data modeling. The purpose of this paper is represented by the analysis of the monetization of the environmental externalities specific to the economic analysis of the projects in the field of urban mobility of Oradea Municipality. Economic analysis involves estimating the contribution of a public investment to the economic well-being of a city, region or country and is very important because it also includes the economic and social benefits of an investment. In Romania, the economic analysis is mandatory for all investment projects that involve conducting a feasibility study. Socio-economic analysis involves making fiscal corrections, corrections for externalities and transformation into accounting prices. Externalities can be positive or negative and can be caused by production or consumption. Negative externality is an external cost and positive externality is an external benefit. In performing a cost-benefit analysis when an investment is analyzed from an economic point of view, externalities must be quantified from a monetary point of view. Shadow prices are monetary values attributed to externalities. These shadow prices are used in economic analysis specific to cost-benefit analysis. Shadow prices are assigned when market prices are not known accurately or when it is difficult to quantify certain costs. An example of a shadow price is the value attributed to the emission cost of one tonne of carbon dioxide. A limitation of this paper is represented by the fact that we analyzed only the environmental externalities specific to urban mobility. In future works I want to expand the research of other externalities and to carry out the economic analysis at the level of investment projects of local importance.
\end{abstract}

Keywords: economic analysis, monetization; externalities, urban mobility, public investments, shadow price

JEL classification: $H 72 ; H 83 ; Q 56 ; R 53$

\section{Introduction}

In this paper we aim to analyze the importance of monetizing environmental externalities. For example, I will present the savings resulting from the implementation of 8 projects in the field of urban mobility in Oradea. The deadline for completion of these projects is 2023 . 
The purpose of this paper is to create an indicator that analyzes the monetization of environmental externalities for a city. Thus, this paper wants to improve the specialized literature in the field of financial resources allocation, taking into account the realization of a correct economic analysis and the awareness of the socio - economic impact of the projects.

In Romania, the economic analysis is mandatory for all investment projects that involve conducting a feasibility study, in accordance with Government Decision no. 907 of 2016, Annex 4 - Feasibility study, section 4.7 Economic analysis. At the same time, the economic analysis is mandatory at the level of projects financed from European Union funds.

Externalities can be positive or negative and can be caused by production or consumption. Negative externality is an external cost and positive externality is an external benefit. In performing a cost-benefit analysis when an investment is analyzed from an economic point of view, externalities must be quantified from a monetary point of view. Positive externalities of consumption can be represented by: increasing the level of education of individuals (positive impact on society by increasing living standards or lowering the unemployment rate), the use of applications that transmit data that can be used by other citizens.

Shadow prices are monetary values attributed to externalities. These shadow prices are used in economic analysis specific to cost-benefit analysis. Shadow prices are assigned when market prices are not known accurately or when it is difficult to quantify certain costs.

Economic analysis involves estimating the contribution of a public investment to the economic well-being of a city, region or country and is very important because it also includes the economic and social benefits of an investment. Socioeconomic analysis involves making fiscal corrections, corrections for externalities and transformation into accounting prices.

The cost / benefit analysis involves performing an analysis between the total investment cost following the socio-economic analysis of the project. Thus, the total value of the project is adjusted to economic values from financial values by using conversion factors. The cost / benefit analysis for projects financed from European funds is carried out in compliance with the provisions of the Guide for Cost - Benefit Analysis of investment projects, a guide developed by the European Commission, Directorate-General for Regional Policy.

The municipality of Oradea has a policy for the development of urban mobility in accordance with the protection of the environment. Thus, the main purpose of urban mobility is to improve the mobility and transport of people in Oradea while environmental protection involves reducing greenhouse gas emissions.

The problem from which this paper starts is represented by the lack of sufficient quantification of environmental externalities in the analysis of projects in the field of urban mobility of local importance.

\section{Literature review}

Economic analysis is a subject studied in the literature. Economic analysis is essential for selecting projects that are economically and socially efficient.

Sunstein Cass (2017) wonders if people think better in a foreign language and the answer is that to some extent yes. Thus, cost / benefit analysis can reduce the risk caused by certain institutions that can cause serious errors. Geistfeld Mark (2018) 
makes a connection between welfare ("welfarism") and cost-benefit analysis. Thus, all potential losses and gains are included in the cost-benefit analysis of the change in welfare.

Revesz Richard (2016) presents the existing debate in academia on the need and feasibility of conducting cost / benefit analysis of externalities in the financial field. Thus, externalities in the field of environmental protection are quantified in the cost / benefit analysis but the quantification and monetization of externalities imposed by financial regulations is much more difficult.

Sinden Amy (2016) mentions the importance of cost-benefit analysis considering that it is one of the three ways to achieve environmental protection objectives along with feasibility study and health standards. Thus, it is a decision-making technique that takes into account the costs and benefits of an action.

Masur Jonathan and Eric Posner (2011) consider that regulatory agencies do not take sufficient account of the problem of lack of employment. Thus, the feasibility analyzes present the problem of employment in a summary and theoretical way.

The main difference between financial analysis indicators and economic analysis indicators is that financial analysis is performed at the level of financial flows while economic analysis involves assessing the impact on society as a whole. Economic analysis is very important because the effects of a project cannot be quantified only at the monetary level, the effects of a project must be analyzed as a whole from the point of view of the socio-economic impact.

Birdsall Nancy and Griffin Charles (1993) believe that population growth leads to the existence of certain negative externalities such as increased pollution, global warming or increased living standards for certain social categories. Thus, in this paper will be analyzed the negative externalities generated by urban pollution.

Eskeland Gunnar (2000) considers that negative externalities can be reduced not only by changing consumption habits but also by carrying out activities that are less polluting by consumers, producers and government. At the same time, it proposes the introduction of taxes to be applied to all polluters regardless of how rich or poor they are. I agree with this approach and since this idea was enunciated in 2000, it has been applied at the level of the European Union.

Florio Massimo (2006) considers that investments in infrastructure in the member states of the European Union are necessary. For the choice of projects, costbenefit analysis is an important tool, but there are certain problems with shadow pricing or information asymmetry. I consider that the cost-benefit analysis is an essential tool for prioritizing investment projects.

Zhao Shirong (2020) emphasizes the need for the correct assessment of shadow prices so that environmental regulators can make the right decisions. At the same time, an important goal is to combat global warming and reduce greenhouse gas emissions.

\section{Externalities and shadow prices}

Externalities can be positive or negative and can be caused by production or consumption. Negative externality is an external cost and positive externality is an external benefit. In performing a cost-benefit analysis when an investment is analyzed from an economic point of view, externalities must be quantified from a monetary point of view. If the financial analysis of an investment is made from the point of view of cash flows, the economic analysis includes, in addition to cash flows, externalities (positive and negative). 
According to the CBA guide published by the European Commission (2014), externalities do not have an impact on the transactions that take place between the producer and the users but have an impact on a third party that does not receive any compensation. Thus, the CBA guide (p. 61) defines externality as a cost or benefit that over a third party without monetary compensation.

Examples of negative externalities generated by production are represented by pollution (air pollution, noise pollution, water pollution, soil pollution, light pollution, municipal waste, nuclear waste) that cause climate change. Negative externalities caused by consumption can be represented by traffic jams that have as a negative effect the increase of pollution and the increase of the time that people spend in traffic (decrease of the quality of life). The city of Oradea has taken a series of measures to reduce traffic jams so as to reduce pollution and time spent in traffic.

The CBA guide prepared by the European Commission (2014) mentions several externalities (p. 88) that will be analyzed in the cost-benefit analysis for projects financed from European funds. These externalities can be positive or negative and are represented by: travel time, operating cost of vehicles, accidents, noise emissions, air pollution, greenhouse gas emissions. In carrying out the cost-benefit analysis, these externalities will be monetized.

Positive externalities are found in the literature under various names such as external profit or external economy. The positive externalities of production are represented by the benefits at the level of the society created in the production of some goods or services and which are not compensated. Examples of positive production externalities are represented by the benefits brought for the progress of the research - development - innovation society. Other examples are the creation of free software or the restoration of historical monuments. In Oradea, we want to restore as many historical monuments as possible.

Positive externalities of consumption can be represented by: increasing the level of education of individuals (positive impact on society by increasing living standards or lowering the unemployment rate), the use of applications that transmit data that can be used by other citizens.

Regarding the current society, externalities are analyzed mostly from the point of view of the environmental cost. The European Union and the democratic states (United States, Canada, Australia or Japan) are the engine of the fight against pollution and climate change. Two important moments were represented by the Kyoto Protocol, Japan in 1997 and the Paris Agreement in 2015 by which the states of the world want to reduce pollution. Pollution has harmful effects (negative externalities) on people because due to pollution people get sick and the costs of hospitalization and medical treatments increase. Also due to diseases caused by pollution, some people lose their ability to work, ie additional costs for society. Since Romania's accession to the European Union (2007) in our country began to be aware of the importance of reducing pollution by allocating structural funds for areas related to reducing pollution: waste management, construction of railways, subway, increasing the use of public transport through procurement of trams or electric buses.

Shadow prices are monetary values attributed to externalities. These shadow prices are used in economic analysis specific to cost-benefit analysis. Shadow prices are assigned when market prices are not known accurately or when it is difficult to quantify certain costs. An example of a shadow price is the value attributed to the emission cost of one tonne of carbon dioxide. 


\section{Case study: Monetizing the externalities of projects in the field of urban mobility in Oradea}

The municipality of Oradea has a policy for the development of urban mobility in accordance with the protection of the environment. Thus, the main purpose of urban mobility is to improve the mobility and transport of people in Oradea while environmental protection involves reducing greenhouse gas emissions. Oradea implements 8 projects financed by the Regional Operational Program $2014-2020$, priority axis 4 , investment priority 4.1 , financing axis through which urban mobility is supported. A condition for the projects to be financed is represented by the observance of the rules of sustainable development and the projects must be environmentally friendly.

The method of calculating the costs of greenhouse gas emissions, according to the CBA guide of the European Commission (p. 63) is given by the following calculation formula:

Cost of $\mathrm{GHG}$ emissions $=\mathrm{V}_{\mathrm{GHG}} \times \mathrm{C}_{\mathrm{GHG}}$

Where:

$\mathrm{GHG}=$ greenhouse gas;

$V_{G H G}=$ incremental volume (difference between the version without project and the version with project) measured in carbon dioxide equivalent;

$\mathrm{C}_{\mathrm{GHG}}=$ updated carbon dioxide shadow price for the analysis year.

Table 1: Greenhouse gas savings - percentage (2027 - 2021) in Oradea

\begin{tabular}{|c|c|c|c|c|c|}
\hline \multirow[b]{2}{*}{ Project } & \multicolumn{3}{|c|}{$\begin{array}{c}\text { Greenhouse gas emissions } \\
\text { (tonnes of CO2 equivalent per } \\
\text { year) }\end{array}$} & \multirow{2}{*}{\begin{tabular}{|c|} 
Greenhouse \\
gas saving \\
economy - \\
absolute \\
value (2027 - \\
$2021)-$ \\
tonnes of \\
CO2
\end{tabular}} & \multirow{2}{*}{$\begin{array}{c}\text { Greenhou } \\
\text { se gas } \\
\text { savings - } \\
\text { percentag } \\
\text { e (2027 - } \\
2021)\end{array}$} \\
\hline & 2017 & 2023 & 2027 & & \\
\hline $\begin{array}{l}\text { Construction of the } \\
\text { new tram line from } \\
\text { Calea Aradului - } \\
\text { Cantemir, Oradea }\end{array}$ & $47,718.50$ & $44,881.80$ & $44,849.20$ & $2,869.30$ & $6.01 \%$ \\
\hline $\begin{array}{l}\text { Underground } \\
\text { passages in Emanuil } \\
\text { Gojdu Square, Oradea } \\
\text { - phase } 1\end{array}$ & $2,192.50$ & $2,037.90$ & $2,036.40$ & 156.10 & $7.12 \%$ \\
\hline $\begin{array}{l}\text { Underground } \\
\text { passages in Emanuil } \\
\text { Gojdu Square, Oradea } \\
\text { - phase } 2\end{array}$ & $2,024.80$ & $1,894.90$ & $1,893.50$ & 131.30 & $6.48 \%$ \\
\hline $\begin{array}{l}\text { Pedestrian areas in } \\
\text { Oradea (Rogerius, } \\
\text { losia and Nufarul) }\end{array}$ & 135.40 & 107.70 & 107.70 & 27.70 & $20.46 \%$ \\
\hline Mobility corridor & $62,931.00$ & $60,388.00$ & $60,723.00$ & $2,208.00$ & $3.51 \%$ \\
\hline
\end{tabular}




\begin{tabular}{|c|c|c|c|c|c|}
\hline $\begin{array}{l}\text { Nufarul - Cantemir, } \\
\text { Oradea }\end{array}$ & & & & & \\
\hline $\begin{array}{l}\text { Acquisition of } 10 \text { trams } \\
\text { - phase } 1\end{array}$ & $47,718.50$ & $45,239.30$ & $45,206.40$ & $2,512.10$ & $5.26 \%$ \\
\hline $\begin{array}{l}\text { Acquisition of } 10 \text { trams } \\
\text { - phase } 2\end{array}$ & $47,718.50$ & $45,239.30$ & $45,206.40$ & $2,512.10$ & $5.26 \%$ \\
\hline $\begin{array}{l}\text { Pedestrian areas in the } \\
\text { central area } \\
\text { (Ferdinand Square, } \\
\text { Aurel Lazar Street, } \\
\text { Libertatii Street and } \\
\text { the left bank area of } \\
\text { Crisul Repede) }\end{array}$ & 619.10 & 452.90 & 452.50 & 166.60 & $26.91 \%$ \\
\hline Total & $211,058.30$ & $200,241.80$ & $200,475.10$ & $10,583.20$ & $5.01 \%$ \\
\hline
\end{tabular}

Source: table made by the author following the analysis of the 8 traffic studies carried out by the Municipality of Oradea

In this table are presented the greenhouse gas savings as a result of the implementation of these 8 projects. There is a reduction of greenhouse gas emissions from 2017 (the year analyzed in traffic studies) to 2027 (the target year of project implementation results) by $5.01 \%$. This complex indicator that shows the reduction of greenhouse gases in Oradea through these 8 projects involves savings of 10,583.20 tons per year of carbon dioxide.

In accordance with the analysis of the European Investment Bank (2013, p. 25) on environmental externalities, several scenarios were developed to evaluate the monetization of environmental externalities with values between 40 euros / tonne of carbon dioxide equivalent (the central scenario for 2020) and 231 euro / ton of carbon dioxide equivalent (high scenario for 2050). This assessment takes into account the damage caused by these greenhouse gas emissions, damage to both human health and other relevant issues. In this analysis, the value of 96 euro / ton of carbon dioxide equivalent was taken into account (high scenario for 2030). The 2030 scenario was considered because it is the closest year in the analysis of the European Investment Bank in relation to 2027, the target year of the indicators from the 8 traffic studies. Thus, this price per ton is multiplied by the amount of carbon dioxide saved as a result of the implementation of these projects. As can be seen, the annual saving as a result of the monetization of this positive externality is represented by $1,015,987.20$ euros. Therefore, in 10 years only from the carbon dioxide economy 10.15 million euros are saved. We must say that pollution in the city brings increased costs to the health of the population and reducing pollution has a beneficial impact from a socio-economic point of view.

As can be seen from this table, not all projects have the same impact on the savings resulting from the reduction of greenhouse gas emissions. Thus, projects involving the movement of private cars involve higher carbon dioxide emissions while projects involving the movement of pedestrians involve lower carbon dioxide emissions. 
Table 2: Positive environmental externalities as a result of the implementation of the 8 urban mobility projects in Oradea

\begin{tabular}{|l|r|r|r|r|}
\hline \multicolumn{1}{|c|}{ Project } & $\begin{array}{c}\text { Greenhouse } \\
\text { gas saving } \\
\text { economy - } \\
\text { absolute value } \\
\text { (2027 - 2021) - } \\
\text { tonnes of CO2 }\end{array}$ & $\begin{array}{c}\text { Greenhouse } \\
\text { gas savings } \\
\text { percentage } \\
\text { (2027 - 2021) }\end{array}$ & $\begin{array}{c}\text { The cost of } \\
\text { one tonne } \\
\text { of CO2 } \\
\text { equivalent } \\
\text { (euro) }\end{array}$ & $\begin{array}{c}\text { Annual } \\
\text { economy } \\
\text { (euro) }\end{array}$ \\
\hline $\begin{array}{l}\text { Construction of the new tram } \\
\text { line from Calea Aradului - } \\
\text { Cantemir, Oradea }\end{array}$ & $2,869.30$ & $6.01 \%$ & 96.00 & $275,452.80$ \\
\hline $\begin{array}{l}\text { Underground passages in } \\
\text { Emanuil Gojdu Square, } \\
\text { Oradea - phase 1 }\end{array}$ & 156.10 & $7.12 \%$ & 96.00 & $14,985.60$ \\
\hline $\begin{array}{l}\text { Underground passages in } \\
\text { Emanuil Gojdu Square, } \\
\text { Oradea - phase 2 }\end{array}$ & 131.30 & $6.48 \%$ & 96.00 & $12,604.80$ \\
\hline $\begin{array}{l}\text { Pedestrian areas in Oradea } \\
\text { (Rogerius, losia and Nufarul) }\end{array}$ & 27.70 & $20.46 \%$ & 96.00 & $2,659.20$ \\
\hline $\begin{array}{l}\text { Mobility corridor Nufarul - } \\
\text { Cantemir, Oradea }\end{array}$ & $2,208.00$ & $3.51 \%$ & 96.00 & $211,968.00$ \\
\hline $\begin{array}{l}\text { Acquisition of 10 trams - } \\
\text { phase 1 }\end{array}$ & $2,512.10$ & $5.26 \%$ & 96.00 & $241,161.60$ \\
\hline $\begin{array}{l}\text { Acquisition of 10 trams - } \\
\text { phase 2 }\end{array}$ & $2,512.10$ & $5.26 \%$ & 96.00 & $241,161.60$ \\
\hline $\begin{array}{l}\text { Pedestrian areas in the } \\
\text { central area (Ferdinand } \\
\text { Square, Aurel Lazar Street, } \\
\text { Libertatii Street and the left } \\
\text { bank area of Crisul Repede) }\end{array}$ & 166.60 & $26.91 \%$ & 96.00 & $15,993.60$ \\
\hline & $\mathbf{1 0 , 5 8 3 . 2 0}$ & $\mathbf{5 . 0 1 \%}$ & 96.00 & $\mathbf{1 , 0 1 5 , 9 8 7 . 2 0}$ \\
\hline
\end{tabular}

Source: table made by the author following the analysis of the 8 traffic studies carried out by the Municipality of Oradea

The two projects that create pedestrian routes involve reducing greenhouse gas emissions by over $20 \%$ but in absolute terms the annual savings (calculated according to the specific methodology) is lower than the savings from projects that provide for the purchase of trams.

The $5 \%$ reduction of greenhouse gas emissions is not enough, and these projects must be continued with other projects regarding the acquisition of trams and buses, the construction of new underground passages to streamline traffic, the construction of park \& ride parking lots at the edge. the city, the construction of bicycle lanes, the creation of new pedestrian routes as well as the encouragement of increasing the average number of passengers in private cars. 
Table 3: Analysis of the variation of annual savings resulting from the monetization of environmental externalities

\begin{tabular}{|l|r|}
\hline Project & Annual economy in 2027 (euro) \\
\hline $\begin{array}{l}\text { Portfolio consisting of } 8 \text { mobility projects - } \\
\text { project scenario }\end{array}$ & $1,015,987.20$ \\
\hline Variation $+1 \%$ & $1,026,147.07$ \\
\hline Variation $-1 \%$ & $1,005,827.33$ \\
\hline Variation $+5 \%$ & $1,066,786.56$ \\
\hline Variation $-5 \%$ & $965,187.84$ \\
\hline Variation $+10 \%$ & $1,117,585.92$ \\
\hline Variation $-10 \%$ & $914,388.48$ \\
\hline Variation $+25 \%$ & $1,269,984.00$ \\
\hline Variation $-25 \%$ & $761,990.40$ \\
\hline
\end{tabular}

Source: table made by the author following the analysis of the 8 traffic studies carried out by the Municipality of Oradea

At the same time, in table no. 3 an analysis is made of the variation of the registered savings as a result of the monetization of the environmental externalities. This analysis involves 8 scenarios of positive and negative variation $(1 \%, 5 \%, 10 \%$ and $25 \%)$. Thus, through these 8 projects in the field of urban mobility, superior results could be obtained, but also inferior to those resulting from the traffic study. Thus, greenhouse gas emissions could be reduced through complementary measures such as increasing the frequency of public transport, increasing the average number of people in private vehicles or using more nonmotorized transport (bicycles, scooters, walking).

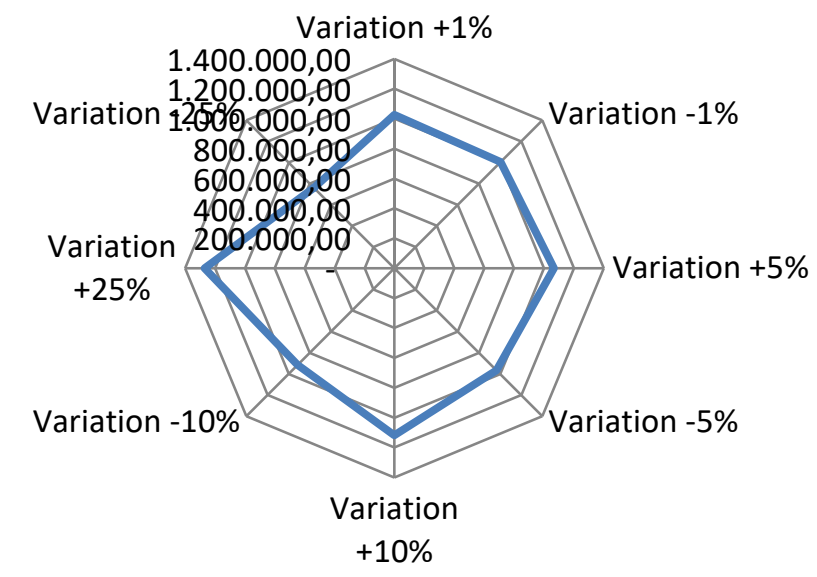

Annual economy in 2027 (euro)

Figure 1: Analysis of the variation of annual savings resulting from the monetization of environmental externalities

Source: figure made by the author following the analysis of the 8 traffic studies carried out by the Municipality of Oradea 


\section{Conclusions}

This paper presents the monetization of the environmental externalities of the 8 urban mobility projects financed by the Regional Operational Program $2014-2020$. There is a reduction of greenhouse gas emissions from 2017 (the year analyzed in traffic studies) to 2027 (the target year of project implementation results) by $5.01 \%$. This complex indicator that shows the reduction of greenhouse gases in Oradea through these 8 projects involves savings of 10,583.20 tons per year of carbon dioxide.

The purpose of this paper is represented by the analysis of the monetization of the environmental externalities specific to the economic analysis of the projects in the field of urban mobility of Oradea Municipality. The municipality of Oradea has a policy for the development of urban mobility in accordance with the protection of the environment. Thus, the main purpose of urban mobility is to improve the mobility and transport of people in Oradea while environmental protection involves reducing greenhouse gas emissions. The problem from which this paper starts is represented by the lack of sufficient quantification of environmental externalities in the analysis of projects in the field of urban mobility of local importance.

In accordance with the analysis of the European Investment Bank (2013, p. 25) on environmental externalities, several scenarios were developed to evaluate the monetization of environmental externalities with values between 40 euros / tonne of carbon dioxide equivalent (the central scenario for 2020) and 231 euro / ton of carbon dioxide equivalent (high scenario for 2050). This assessment takes into account the damage caused by these greenhouse gas emissions, damage to both human health and other relevant issues. In this analysis, the value of 96 euro / ton of carbon dioxide equivalent was taken into account (high scenario for 2030). The 2030 scenario was considered because it is the closest year in the analysis of the European Investment Bank in relation to 2027, the target year of the indicators from the 8 traffic studies. Thus, this price per ton is multiplied by the amount of carbon dioxide saved as a result of the implementation of these projects. As can be seen, the annual saving as a result of the monetization of this positive externality is represented by $1,015,987.20$ euros. Therefore, in 10 years only from the carbon dioxide economy 10.15 million euros are saved. We must say that pollution in the city brings increased costs to the health of the population and reducing pollution has a beneficial impact from a socio-economic point of view.

Regarding the current society, externalities are analyzed mostly from the point of view of the environmental cost. The European Union and the democratic states (United States, Canada, Australia or Japan) are the engine of the fight against pollution and climate change. Two important moments were represented by the Kyoto Protocol, Japan in 1997 and the Paris Agreement in 2015 by which the states of the world want to reduce pollution. Pollution has harmful effects (negative externalities) on people because due to pollution people get sick and the costs of hospitalization and medical treatments increase. Also due to diseases caused by pollution, some people lose their ability to work, ie additional costs for society. Since Romania's accession to the European Union (2007) in our country began to be aware of the importance of reducing pollution by allocating structural funds for areas related to reducing pollution: waste management, construction of railways, subway, increasing the use of public transport through procurement of trams or electric buses. 
A limitation of this paper is represented by the fact that I analyzed only the environmental externalities specific to urban mobility. In future works I want to expand the research of other externalities and to carry out the economic analysis at the level of investment projects of local importance.

\section{References:}

1. Boloş Marcel loan (2007), Buget şi trezorerie publică, Editura Universităţii Oradea

2. Birdsall Nancy, Griffin Charles (1993), Population growth, externalities and poverty, The World Bank, Working Paper, Available at SSRN: https://papers.ssrn.com/sol3/papers.cfm?abstract_id=3351859

3. Czichowsky Christoph, Muhle-Karbe Johannes, Schachermayer Walter (2013) Transaction Costs and Shadow Prices in Discrete Time, Available at SSRN: https://papers.ssrn.com/sol3/papers.cfm?abstract_id=2342201

4. Eskeland Gunnar (2000), Externalities and Production Efficiency, The World Bank, Development Research Group, Public Economics

5. Florio Massimo (2006), Multi-Government Cost-Benefit Analysis: Shadow Prices and Incentives, Available at SSRN: https://papers.ssrn.com/sol3/papers.cfm?abstract_id=3200965

6. Geistfeld Mark (2018), Cost-Benefit Analysis Outside of Welfarism, Available at SSRN: https://papers.ssrn.com/sol3/papers.cfm?abstract_id=3172315 7. Masur Jonathan și Posner Eric (2011), Regulation, Unemployment, and Cost-Benefit Analysis, Available at SSRN: https://papers.ssrn.com/sol3/papers.cfm?abstract_id=1920441

8. Revesz Richard (2016), Cost-Benefit Analysis and the Structure of the Administrative State: The Case of Financial Services Regulation, Available at SSRN: https://papers.ssrn.com/sol3/papers.cfm?abstract_id=2733713

9. Sinden Amy (2016), Cost-Benefit Analysis, Available at SSRN: https://papers.ssrn.com/sol3/papers.cfm?abstract_id=2831832

10. Sunstein Cass, Is Cost-Benefit Analysis a Foreign Language?, 2017, Available at https://papers.ssrn.com/sol3/papers.cfm?abstract_id=2893401

11. Zhao Shirong (2020), The Shadow Prices of $\mathrm{CO}_{2}, \mathrm{SO}_{2}$ and $\mathrm{NO}$ x for U.S. Coal Power Industry 2010-2017: A Convex Quantile Regression Method Available at SSRN: https://papers.ssrn.com/sol3/papers.cfm?abstract_id=3692709

12. European Comission (2014), Guide to Cost - Benefit Analysis of Investment Projects, https://ec.europa.eu/regional_policy/sources/docgener/studies/pdf/cba_guide.pdf 13. European Investment Bank (2013), The Economic Appraisal of Investment Projects at the EIB, Available at: https://www.eib.org/attachments/thematic/economic_appraisal_of_investment_proj ects_en.pdf

14. HG Romania nr. 907 / 2016 on the stages of elaboration and the content framework of the technical-economic documentation related to the objectives / investment projects financed from public funds

15. Traffic studies carried out by The Municipality of Oradea for 8 urban mobility projects (2018)

The work was supported by University of Oradea, Doctoral School of Economic Sciences 


\title{
DOES THE PARETO PRINCIPLE APPLY IN THE INNOVATION FIELD IN ROMANIA?
}

\author{
Alina BABA ${ }^{1}$ \\ ${ }^{1}$ Doctoral School of Economic Sciences, Faculty of Economic Sciences, University \\ of Oradea, Oradea, Romania, baba.alina79@gmail.com
}

\begin{abstract}
The technological transfer entities can obtain income by establishing robust partnerships with the business environment and using the fiscal facilities offered by the region where they produce the innovation, applying for nonrefundable funds, attracting individual donors, charging a membership contribution to the organization members, exploitation of innovation produced by the sale of intellectual property. A robust innovation ecosystem is based on public and private investments which complement each other to reduce the risks and to divide profits by increasing the capacity of innovation and technological transfer of the technological transfer entities. The Gauss distributions are continuous probability distributions. These are" normal" distributions which illustrate the likelihood that a certain event takes place. A gauss distribution has the shape of a bell with most values distributed around the average value and can be fully described by variance and mean. A classic example is the distribution of patents value or profit obtained because of sale of intellectual property rights. The Pareto-type distributions are found in other phenomena around us, such as the size of economic entities follows a Pareto distribution. Pareto-type distributions are more suitable to describe the economic phenomena than the Gauss distributions, for instance, $80 \%$ of the world richness is held by $20 \%$ of population (principle $80-20$ which means $80 \%$ of results are caused by $20 \%$ of causes). The innovation phenomenon is deeply systemic, multifactorial, multifunctional, dynamic and complex, determined by the whole socio-economic background which influences the innovation ecosystem. Therefore, its study for the highlighting of the intervention opportunities at level of fiscal and financial policies, but also at operational level, requires an adequate, multilateral and complete systemic approach.
\end{abstract}

Keywords: technological transfer; innovation; finances

JEL Classification: $\mathrm{O} 32$

\section{Introduction}

In the market economy of innovation, which is dynamic and in which the participants are autonomous and efficient, there is a major difference between those who fund and those who lead technological transfer entities. Seldom, it happens that one and the same person funds the activity of a technological transfer entity and at the same time, is its creator or manager. On the other hand, for the entities which create innovation to appear and develop, it is necessary that two types of characters collaborate well. Sometimes, we are in the situation of information asymmetry, which means that the managers of the technological 
transfer entities hold much more specialised/scientific information than the possible funders of innovation. On the other hand, there is a moral hazard, which means high risk (above a justified limit) which is undertaken by those who fund the technological transfer entities. The implication of these facts is that finally, the financing costs of ETT will be higher than in ordinary companies, and the negative impact is especially on start-ups and spin-offs which only deal with research and development and unlike the large industrial companies which hold production departments, they do not afford to use own funds for multiplication of the results of the research-development-innovation activity.

As for the situation of start-ups on the technological transfer market, it is even more complicated. First of all, they are facing all the problems which a newly founded entity has, to which we can add the need for presenting a sufficiently wellstructured business plan which can attract financing and which fully answers the reservations which the financiers - who do not understand the scientific or innovation problems - normally have. In addition, we have to think that the national states or European Union are trying to come up with solutions and opportunities of public policies in the field (such as, the differentiated taxation of technological transfer companies, but also the access to dedicated financing lines). In conclusion to the above, even if we need to understand that the financial mechanisms of technological transfer entities are different from those of the other companies, we need to analyse why they are different and what these differences are.

\section{Literature review}

In general, investments in innovation have costs which are classified in the following categories: costs for research and development (R\&D), capital expenditure for equipment, staff training costs, costs for multiplication of innovation, design costs, marketing costs and costs for the advertising of innovation produced. Depending on the nature of innovation and the technology used, these costs can differ, but on average, the costs for research-developmentinnovation represent over $50 \%$ of total, and from this category the staff costs (researchers, engineers etc.) represent $50 \%$. This means that from the total costs of a technological transfer entity, over $25 \%$ of funds are used only for the payment of researchers. In addition, we have to take into account also the salary costs of technicians, technologists and workers involved in the production stage, the salary costs for the design, marketing and advertising stage, for the management and brokerage of innovation produced.

A highly qualified human resource is essential for the functioning of a technological transfer entity, and in its absence (by migration to other companies or by dismissal), the entity becomes incapable of fulfilling its role. On the other hand, because of potential volatility of human research resource, the research and development costs will follow a model of cost adjustment so that the technological transfer entity tries to maintain itself at a sub-optimal level of applied scientific production. (Lach, S. and Schankerman, M. (2008). Of course, it is likely that the entity contacts research and development activities from outside, but if it renounces its own research, it will turn into an ordinary company. What we can see from the practice of the latest decades is that, on one hand, most of ETTs increase their research and development costs to a certain extent, and on the 
other hand, the demand of research-development-innovation services increases towards the technological transfer entity.

The analysis of finances of technological transfer entities has to take into account the less predictable nature of the profit which can be generated; in other words, a research idea can be promising, but there is a long way to the marketing of the product and the reception of profit. In order to analyse accurately the need of the market economy which can be satisfied by the innovation which the ETT could produce, we studied data from varied sources (Scherer, F.M. (1998): the portfolios of patents from the American universities, the results of a study on German patents, the stock exchange profits from three samples of start-ups in high technology field. In this analysis, we noticed a variation of distributions of profits from innovation, some of them are close to normal distributions, while others are closer to a Pareto type distribution in which there is no variance. In this latter case, we have examples of successful innovative companies (the giants such as Microsoft, Google, Facebook etc.) which obtain a very high profit compared to the invested amount and are" models" for the business world, but for each of them, there are millions of companies which fail. Practically, in this situation the classical risk evaluation methods cannot work and we cannot apply an analysis of the diversification strategy of technological transfer entities.

The variance of distribution is calculated by the following formula:

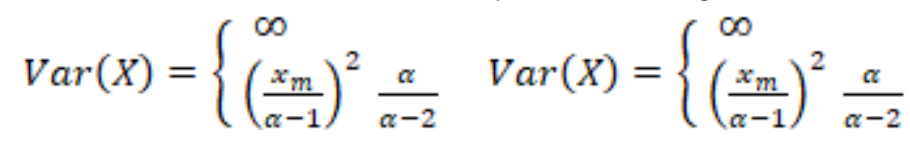

if $\alpha \leq 2$ there is no variance.

Another mechanism for financing technological transfer entities is the leverage effect by which the entities can use borrowed capital for the purchase of assets and for development. But what is the theoretical model of financing of technological transfer entities? In order to answer this question, we will start from the neo-classical model of marginal profit (difference between the marginal cost and the marginal income).

According to the following formula:

$$
M P K=c_{t}=p_{t}-\frac{(1-\delta)}{(1-\rho)} p_{t+1}
$$

The marginal product of capital (MPK) which is used for a period of time $t$ is equal to its price minus what the ETT receives from the sale of capital until time $t+1$ and which in this formula is represented by $(1-\delta) p t+1$ from which we extract the rate of return $\mathrm{P}$ which is received by the investor after the taxes of the entity are paid (Bronwyn H. 2009).

The formula above contains implicitly three factors that will affect the finances of a technological transfer entity: the rate by which the knowledge capital thus created is depreciated or becomes outdated, the rate of return requested and the rate of change of the real price for the research-development activity (the input price of the research-development activity is directly proportional to the output price of the company) (Bronwyn H. 2009). 
The capital cost for the beneficiary of innovation will include both the investment cost and the adjustment by interest and depreciation rates, the capital earnings and taxes. It is obvious that the marginal product of capital increases when $(1-\delta)$ increases. This happens also when (1-P) decreases, for instance, as a result of reducing taxes for $R \& D$ activities.

\section{Hypotheses: The PARETO principle in the innovation field in Romania and in European Union}

In order to answer the question if the Pareto principle applies in innovation field in Romania and European Union, we conducted an analysis of the Pareto distribution principle regarding the patents obtained in Romania during the years 2018, 2019 and 2020 in five fields: agriculture, environment, biotechnology, IT and food. From this research, we can see that most patents obtained are in environmental field, which represents 4.81\% (year 2018), 4.68\% (year 2019) and $4.82 \%$ (year 2020) of total number of patents.

Table 1: Number of patents in Romania for the analysed period 2018-2020

\begin{tabular}{|l|l|l|l|l|}
\hline No. & Field & $\mathbf{2 0 1 8}$ & $\mathbf{2 0 1 9}$ & $\mathbf{2 0 2 0}$ \\
\hline 1. & Agriculture & 5 & 12 & 4 \\
\hline 2. & Environment & 35 & 39 & 43 \\
\hline 3. & Biotechnology & 1 & 0 & 0 \\
\hline 4. & IT & 3 & 0 & 2 \\
\hline 5. & Food & 3 & 0 & 2 \\
\hline 6. & All fields & 727 & 834 & 892 \\
\hline
\end{tabular}

Source: Data processed according to the information available at https://ro.espacenet.com

This shows that in the environmental field there are persons who are interested in innovation and technological progress to whom a large number of other actors is added. We are thinking first of all of a large number of companies to which we can add governmental organizations (universities and research institutes) as well as non-governmental organizations which create an ecosystem favourable to research and innovation. We must not forget that Romania has inherited from the Communist age a high number of environmental problems, population and media have become more and more interested in these issues and the European Union offers every year large amounts of money for the resolution of environmental issues (including for research, development and innovation).

The second field which is well-appreciated is agriculture. This field excelled in the year 2019. However, we can easily see that there are few patents obtained during the analyzed period in the smart specialization fields in Romania. We would have expected that the number of patents in IT field was much higher, taking into account that this field probably represents the top field of Romanian economy, if we were to consider just the weight of this field in the gross domestic product. The same thing can be said about biotechnologies, which from the point of view of 
investment cost ratio to the benefits achieved, represents the most profitable field. Chart 8 illustrates this discrepancy.

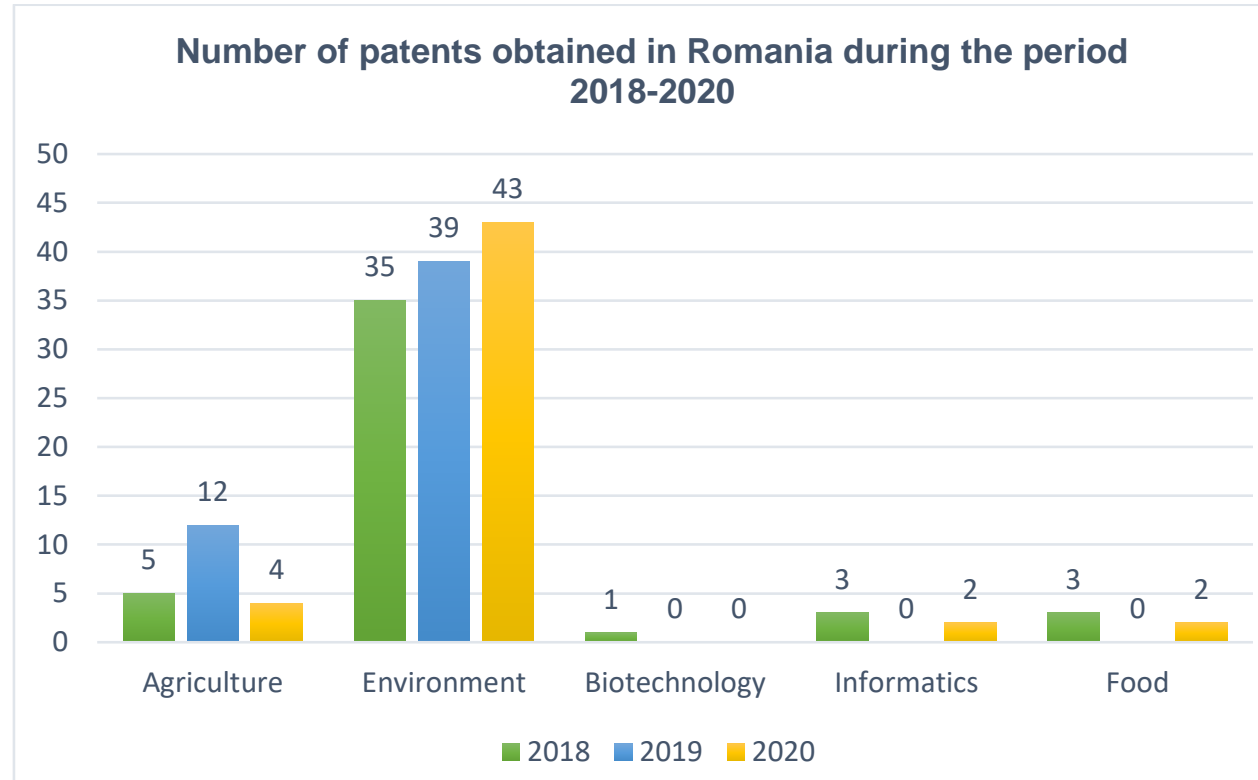

Figure 1: Number of patents in Romania during the period 2018-2020 for the five fields analysed

Source: Data processed according to the information available at https://osim.ro/

In order to make a benchmark analysis between Romania and the European Union, we will make a parallel with the number of patents obtained at European level in the same smart specialization fields.

Table 2: Number of patents published in English in EU during the analyzed period 2018-2020

\begin{tabular}{|l|l|l|l|l|}
\hline No. & Field & $\mathbf{2 0 1 8}$ & $\mathbf{2 0 1 9}$ & $\mathbf{2 0 2 0}$ \\
\hline 1. & Agriculture & 10304 & 10560 & 17650 \\
\hline 2. & Environment & 10766 & 12467 & 16570 \\
\hline 3. & Biotechnology & 10200 & 10300 & 10500 \\
\hline 4. & IT & 3371 & 2219 & 1609 \\
\hline 5. & Food & 10050 & 11376 & 10456 \\
\hline
\end{tabular}
https://ro.espacenet.com 


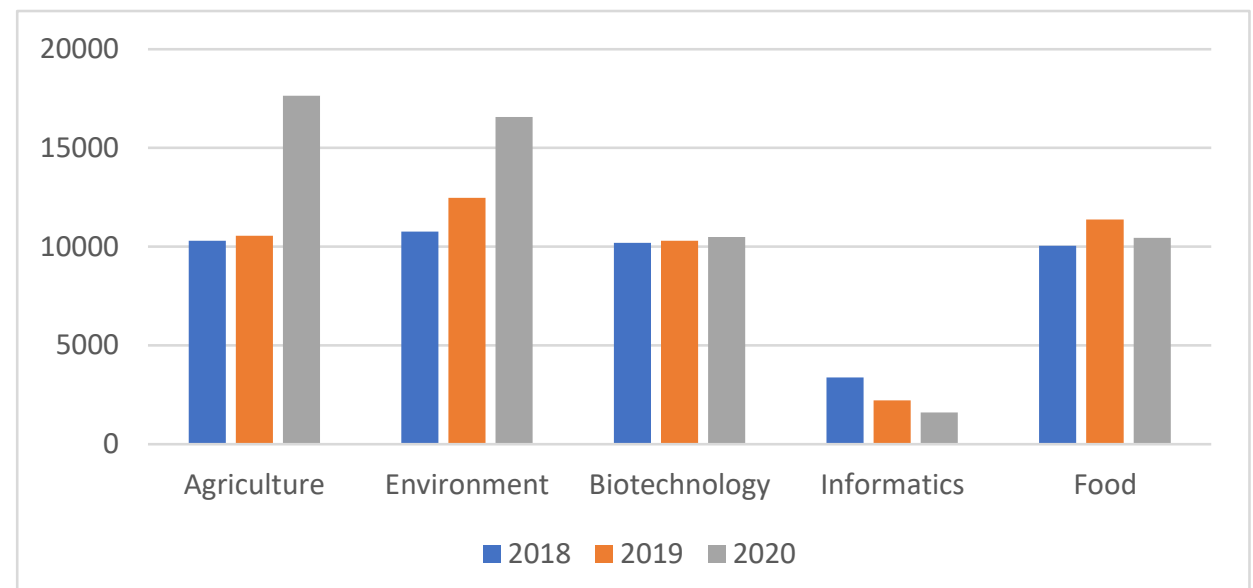

Figure 2: Number of patents in European Union during the period 2018-2020 for the five analysed fields

Source: Data processed according to the information available at https://worldwide.espacenet.com/

According to Figure 2 we can see that the same fields: agriculture and environment are on top positions. In the year 2020 we can see a marked increase of patents in agriculture and environmental fields, which shows that there is a capital disposed to invest in innovation produced for these fields. In the other fields studied, we can see a limited increase for biotechnologies and a decrease of innovation produced in IT and food fields. We can see that four of the five fields, which are agriculture, environment, biotechnologies and food are grouped according to the number of patents in EU, which gives the image of a balanced development.

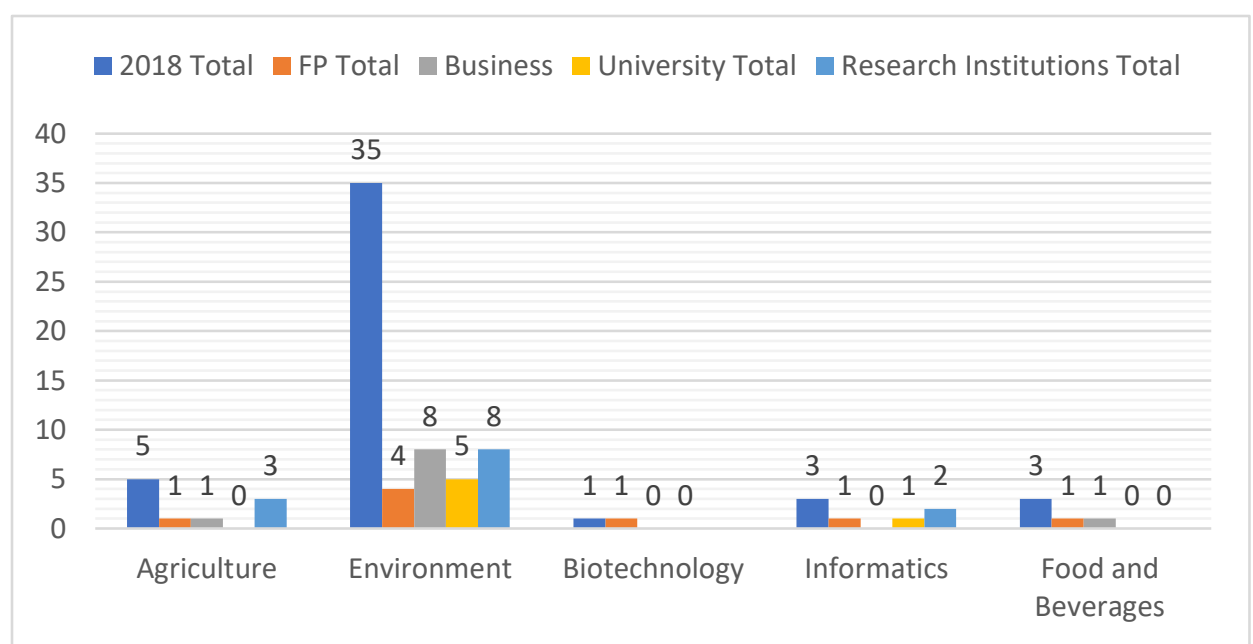

Figure 3: Distribution of patents in the year 2018 in Romania

Source: Data processed according to the information available at https://osim.ro/ 


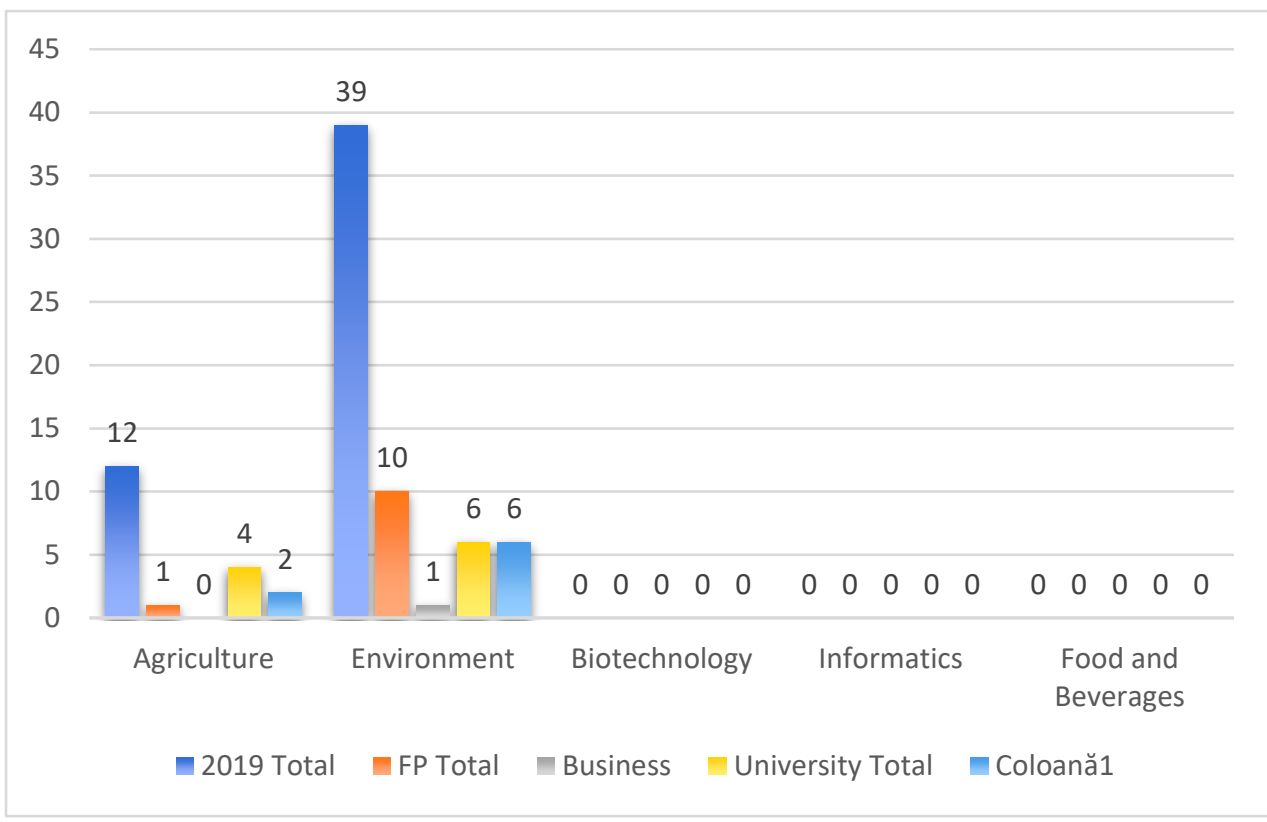

Figure 4: Distribution of patents in 2019 in Romania

Source: Data processed according to the information available at https://osim.ro/

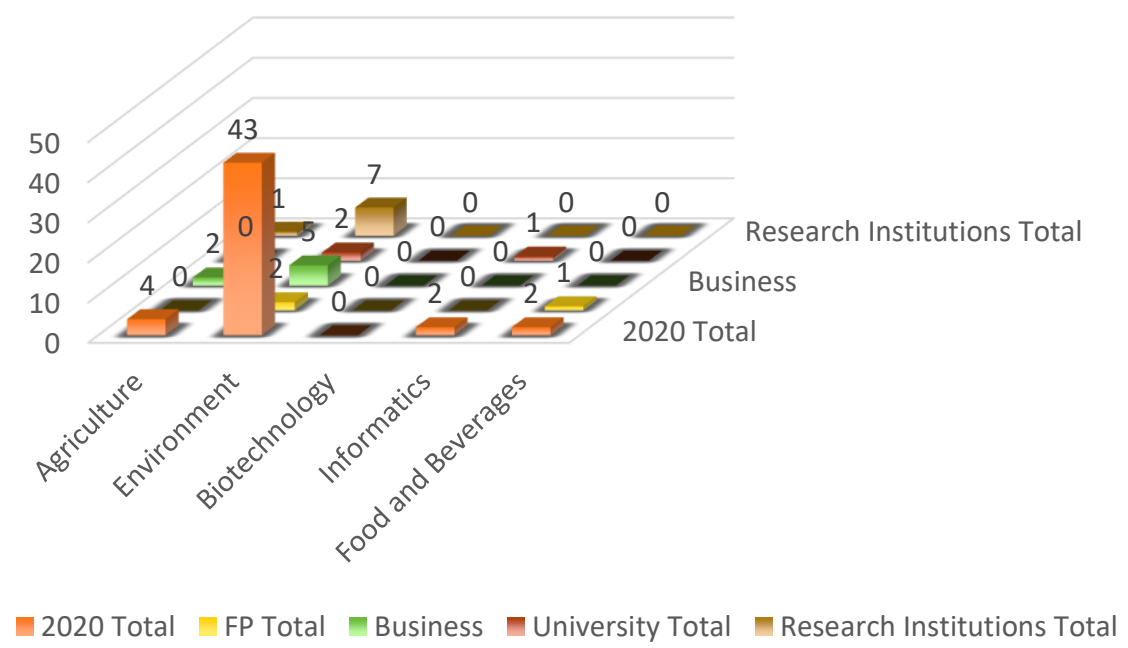

Figure 5: Patents of Romania during the period 2018-2020

Source: Data processed according to the information available at https://osim.ro/ 


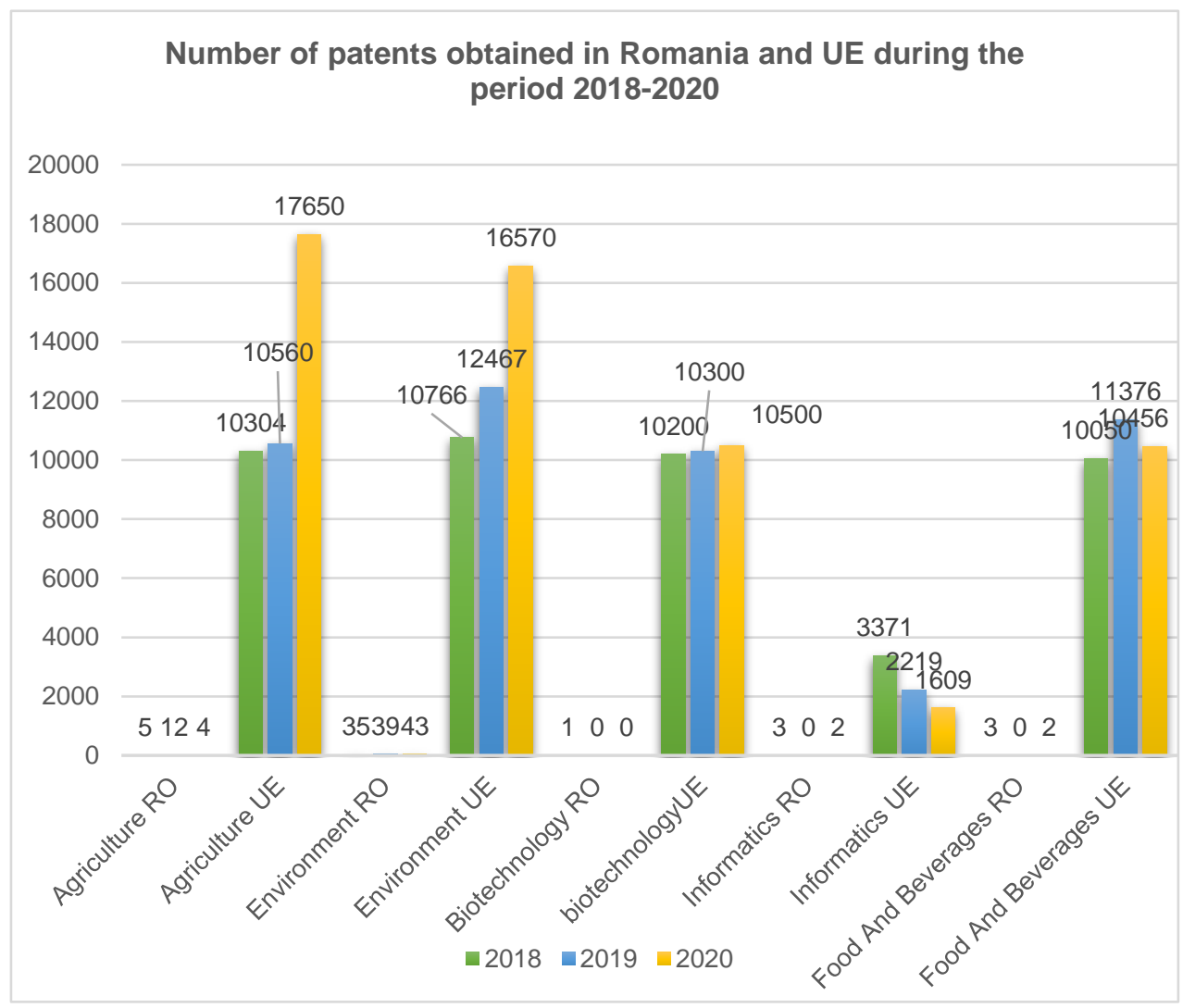

Figure 6: Patents of Romania-EU during the period 2018-2020

Source: Data processed according to the information available at https://osim.ro/; https://patentscope.wipo.int/search/en/search.jsf

\section{References:}

1. Bronwyn H. Hall (2009), The 'funding gap': financial markets and investment in innovation. The New Economics of Technology Policy. Edward Elgar Publishing; 2009.

2. Grossman GM, Helpman E. (1991), Innovation and growth in the global economy. MIT press; 1991.

3. Guidelines On Programming For Innovation And The Implementation Of The EIP For Agricultural Productivity And Sustainability (2014) ec.europa.eu. European Commission - Directorate-General For Agriculture And Rural Development; 2014, Available from:

https://ec.europa.eu/eip/agriculture/sites/default/files/pb guidelines eip implement ation 2014 en.pdf

4. Egidi M, Marris RL, Viale R, editors.(1992), Economics, bounded rationality and the cognitive revolution. Edward Elgar Publishing; 1992.

5. Modigliani F, Miller MH. (1958), The cost of capital, corporation finance and the theory of investment. The American economic review. 1958 Jun 1;48(3):261-97. 
6. Modigliani F, Miller MH.(1963), Corporate income taxes and the cost of capital: a correction. The American economic review. 1963 Jun 1;53(3):433-43.

7. Drucker P.(2014), Innovation and entrepreneurship. Routledge; 2014 Sep 15.

8. Ramanathan K. An Overview of Technology Transfer and Technology Transfer Models [Internet]. http://tto.boun.edu.tr/. Boğaziçi University Technology Transfer Office; Available from:

http://tto.boun.edu.tr/files/1383812118 An\%20overview\%20of\%20TT\%20and\%20 TT\%20Models.pdf

9. Saul Lach, Mark Scankerman (2008), Incentives and invention in universities. The RAND Journal of Economics; Volume 39, Issue 2, Summer 2008.

10. Scherer M. Frederic (1998), The Size Distribution of Profits from Innovation. Annales d'Economie et de Statistique, 1998, no. 49/50, pp. 495-516.

11. Study On Dynamics Of Labour Market For The Main Employing Industries In Romania During The Period 2016-2017. www.piarom.ro. Patronatul Investitorilor Autohtoni PIAROM; Available from:

https://www.piarom.ro/studiu-privind-dinamica-pietei-muncii-la-nivelul-principalelorindustrii-angajatoare-din-romania-in-perioada-2016-2017/ 


\title{
DECISION-MAKING MECHANISMS REGARDING THE ESTABLISHMENT OF THE FINANCING SOURCES OF THE INVESTMENT PROGRAMS IN PUBLIC UTILITY SERVICES
}

\author{
Aniko KUNTZ, Cristina DRIHA \\ Doctoral School of Economic Sciences, Faculty of Economic Sciences, University \\ of Oradea, Oradea, Romania \\ ancsaktz@gmail.com \\ cristina.driha@gmail.com
}

\begin{abstract}
This paper is an empirical study that addresses a topical issue in terms of decision-making methods for setting up sources of funding for investment programs in public utilities in Romania. In order to ensure a high level of security and accessibility, equal treatment, promotion of universal access and users' rights, public utilities are subject to specific public service obligations. Considering that in the utilities services there is still a process of implementation of the European requirements regarding the satisfaction of the quantitative and qualitative requirements of the users; consumer protection and quality of life, environmental conservation in accordance with specific regulations in force, sustainable development, protection and capitalization of the public and private domain of territorial administrative units, it is necessary to introduce modern management methods to achieve these desired. The deepening of the notions, of the particularities in the field, creates the premises for finding optimal and viable solutions regarding the improvement of the legal framework of functioning and operation in the public utilities services, so that the decisional and financial mechanisms are the optimal ones in the concrete socio-economic conditions. Considering the public and permanent functioning of the public utility services, the approached topic is of a real interest for any entity in the field concerned with the efficient, economic and effective management of the public utility system. In this regard, the establishment of the maintenance, replacement, development fund for all entities in the field of public utility services (and not only for those receiving external funds) is a real opportunity, highlighted and supported by existing investment programs in the field of water, sewerage, wastewater treatment and rainwater collection.
\end{abstract}

Keywords: public utility services, public utility system, royalty, development replacement maintenance fund, public utility service

JEL Classification: K11, L32, L95, L97, L98.

\section{Introduction}

Public utility services with an impact on housing are those public services that through the organization and functioning must ensure, as also provided by national legislation, a higher level of quality and safety, promoting the principle of universality, accessibility and equal treatment for all users, ensuring transparency regarding their rights. The sum of the services that ensure the satisfaction of the basic public and social requirements of the communities represents the public 
utility services. These include: "the following areas: water supply; sewerage and wastewater treatment, collection, sewerage and drainage of rainwater; thermal energy supply in centralized system; sanitation of localities; public lighting; natural gas supply; local public passenger transport" due to the Law no. 225/2016 amending and supplementing the Law on community services of public utilities no. $51 / 2006$, updated. These services are provided by the technical-municipal infrastructure specific to each field of activity, being included in the public domain of the locality in which it is located. They are called public utility systems by the legislator.

We notice the fundamental difference between the notion of: public utility service which represents the set of activities of general interest carried out for the inhabitants of a community operating with the goods from the public utility system and the second notion, which represents a set of goods.

In order to follow the evolution at terminological and conceptual level, through the prism of the legal and constitutional framework, but also from the perspective of transposing the European directives in the national legislation that marked each period after the 90s we studied authors such as: Anastase, I., (2008), Bancioi and Zaharia (2006), Bedrule-Grigoruta, M., V., (2007), Bucurean, M., (2006), Constantin, DL, (2004), Corcodel, Şt.F., (2016), Demeter and Klarik (2003), Dinu (2016), Dumitraşcu, V., (2006), Grigorescu (2010), Focşăneanu (2011), Horvath (2001), Icu (2020), Klarik (2004), Kolumban (2003), Matei and Anghelescu (2010), Miricescu and others (2010), Puie, O., (2012). Niculescu, M., Lavalette, G. (1999), Parlagi, A., P., (2009) and last but not least the national legislation.

\section{The architecture of the system of organization and functioning of public utility services in Romania}

The architecture of the system of organization and functioning of public utility services reflected the form of implementation of the central and local public administration reform over the years, undergoing a series of changes imposed by the existing situation at national level, as well as by the objectives and strategies assumed by the Treaty. Romania's accession to the European Union in terms of environmental and quality requirements.

Beginning with 90's, the entities operating in the public utility services have undergone a series of changes, as follows: the county enterprises of communal households are transformed into enterprises of local subordination, only to later become autonomous companies, distinct or not, by types of activity. However, the way of organization, the pace of change was strongly influenced by the type of public utility, by special regulations in each field (eg: the field of electricity has a different evolution from local transport), so that the architecture of the system of organization and operation of public utility services is different from an administrative point of view (local, county) even within the same type of activity (an eloquent example is the field of drinking water and sewerage services). Autonomous utilities are publicly owned economic units, which have taken over in their patrimony the entire assets of state enterprises, without making the difference between the public and private patrimony of the state, respectively between the public and own patrimony of the utility. With the accession to the European Union, the need arose for the legal regulation of competences in the different types of public utility services, thus, the exercise of exclusive competences by the local 
public administration authorities at the level of communes and cities was provided regarding the supply of water, sewerage and sewage treatment, public lighting, sanitation and local public passenger transport (art. 21, letter f) -i) of the Framework Law on decentralization no. 195/2006, with subsequent amendments and completions) and the exercise of powers shared by the local public administration authorities at the level of communes and cities with the central public administration authorities regarding the supply of thermal energy produced in a centralized system (art. 24, letter a) of Law no. 195/2006, with subsequent amendments and completions).

At the same time, "responsibilities for the provision of some of the Community services of public utility may fall to inter-community development associations, which are cooperation structures acting on the basis of the mandate granted by decisions of the deliberative authorities of the member administrative-territorial units and the statute of the association" (Law on local public administration no. $215 / 2001$, with subsequent amendments and completions). The purpose of the inter-community development association is to establish, organize, regulate, finance, operate, monitor and jointly manage the public utility services provided within the competence of the member administrative-territorial units, as well as the joint realization of projects and public investments of zonal or regional interest destined to the establishment, modernization and / or development, as the case may be, of the systems of public utilities afferent to these services, as a structure of collaboration and inter-community cooperation of the member administrativeterritorial units.

In February 2006, the Romanian Government approved the national strategy on accelerating the development of community public utility services, a national strategy that was the basis for the substantiation, elaboration and implementation of the Multiannual Plan for the development of community public utility services (art. 1 of Decision no. 246 of 16 February 2006, National Strategy for Accelerating the Development of Community Utilities, republished). The multiannual development plan for community public utility services aims to ensure the extension, modernization and efficiency of community public utility services and their related technical and municipal infrastructure to European standards, in accordance with the commitments applicable to community public utility services, assumed by Romania by the Treaty of Accession to the European Union, signed by Romania in Luxembourg on April 25, 2005, ratified by Law no. 157/2005. The multiannual development plan for community services of public utilities is correlated with the National Development Plan, which is the document of strategic planning and multi-annual financial programming that aims to guide and stimulate Romania's economic and social development, in order to achieve economic and social cohesion. The national development plan was drawn up at the request of the European Commission as one of the basic requirements for accessing, initially structured pre-accession funds (Phare, Ispa, Sapard) and then structural and cohesion funds.

In this regard, we emphasize the indisputable role of inter-community development associations that provide the unitary legal and institutional framework for implementing the provisions of the National Strategy for Accelerating the Development of Community Utilities and the Multiannual Plan for the Development of Community Utilities. 
From the point of view of the architecture of the system of organization and functioning of public utility services, the important moment is 2016 when following the change of the legal framework, the local public administration authorities are free to decide on the management of public services under their responsibility. the possibility to manage the services directly, on the basis of a management decision, or to entrust their management, respectively all or only part of their own competences and responsibilities regarding the provision of a service, or of one or more activities included in the respective service, based on a management delegation contract (Art. 22 of the Law on Community Public Utilities Services no. $51 / 2006$, republished, with subsequent amendments and completions, as amended by Law no. 225/2016).

"The public utility services are the responsibility of the local public administration authorities or, as the case may be, of the inter-community development associations aiming at the public utility services, according to the mandates granted to them by decisions of the deliberative authorities of the member administrative-territorial units. The local public administration authorities have exclusive competence, under the law, in all matters regarding the establishment, organization, management and operation of public utility services, as well as in the creation, development, modernization, rehabilitation and operation of public or private property of the administrative-territorial units that make up the public utility systems" (Law no. 225/2016 amending and supplementing the Law on community services of public utilities no. 51/2006).

Two or more administrative-territorial units, may cooperate and associate within the competences of their deliberative and executive authorities, may cooperate and associate, in accordance with the law, in order to establish inter-community development associations with the aim of providing jointly of community public utility services and the establishment, modernization, rehabilitation and / or development, as the case may be, of the related public utility systems. Intercommunity development associations aiming at public utility services are cooperation structures with legal personality of private law and public utility status recognized by law, intended to exercise and jointly exercise the powers of local public administration authorities regarding the provision / provision of public services. public utilities, established in their charge (Law no. 215/2001, republished, with subsequent amendments and completions, and of the Framework Law on decentralization no. 195/2006) "The legal relations between the local public administration authorities or, as the case may be, between the inter-community development associations aiming at the public utility services and users, established on the basis of the legal provisions, are legal relations of administrative nature, subject to legal norms of public law. Public utility services are provided / provided through operators or regional operators. The legal relations between the local public administration authorities and the operators, established on the basis of the provisions of the present law, are subject to the legal norms of public or private law, as the case may be."

As mentioned also in previous reviews a conclusion of those presented is that the diversity and complexity in the field of public utility services is all the more accentuated as each type of public utility service (water supply; sewerage and wastewater treatment: collection, sewerage and drainage of rainwater; centralized heat supply; sanitation of localities; public lighting; natural gas supply; local public passenger transport) are different from the perspective of the operating area, so 
there are utilities organized at the level of local administrative unit (communes, cities, municipalities with or without the metropolitan area), county (full or partial coverage) or regional, each being regulated both by a general legal framework and by special laws, which gives it specificity.(Aniko Kuntz, 2019, Indicatori specifici în analiza performanţei financiare a serviciilor de utilităţi publice)

\section{Public utility service in the field of water, sewerage and wastewater treatment, collection, sewerage and drainage of rainwater in Romania}

As a result of the fact that the public water supply and sewerage service has a direct impact on the health of the population, the quality of life and last but not least on their standard of living, at the time of signing the Accession Treaty, Romania has undertaken important commitments to transpose the acquis communautaire in the drinking water and wastewater sector. These represent the transposition of Directive 98/83 on the quality of water intended for human consumption, Directive 91/271 / EC / 19916, as amended and supplemented by Directive 98/15 / EC / 19987 on the treatment of urban waste water. In this sense, Romania is committed to making large investments in a relatively short transition period. At the same time, due to the fact that the entire territory of Romania was declared a sensitive area, all human settlements with over 10,000 inhabitants had the obligation to make investments related to high-performance treatment plants.

According to the Report on the sectoral investigation launched by Order no. 82 from 15.02.2017 "Romania declared its entire territory as a sensitive area, this aspect implying the obligation that all human agglomerations with more than 10,000 inhabitants be provided with treatment plants with advanced degree of treatment. In this sense, the appropriate strategic direction is represented by the promotion of major regional infrastructure investment projects, doubled by the regionalization of utilities as a key element in improving the quality of services and the efficiency of capital and operating costs".

In fact, since the pre-accession period to the European Union, the operators of public utility services in the field of water and sewerage have carried out important programs with various sources of financing (EBRD, ISPA or SAMTID). Through the continuous evolution of the economic and social situation, combined with the alignment to the legislative changes of the period, not least through the emergence of regional operators and inter-community development associations, public utilities in the field of drinking water and sewerage have registered a significant development. primarily by the volume of investments made. Existing operators become regional operators of the public water supply and sewerage service, in order to create the premises for accessing investment projects with European funding related to the Sectoral Operational Program Environment 2007-2013, followed by those in the Large Infrastructure Operational Program 2014-2020. In order to ensure the necessary co-financing for the implementation of the ISPA, SAMTID and SOP Environment programs, external loans have been committed. Most of these operators have accessed external loans, especially state-guaranteed EBRD loans. In these loan agreements, the EBRD imposed a program of measures to improve financial and operational performance, the main conditions of which were: increase tariffs for public utilities, debt service coverage through cash flow; control of customer debts, control of production costs and establishment of the I.I.D Fund (maintenance, replacement, development). As the existence of this 
fund proved its usefulness in daily practice, but also because the process of redirecting European funds to the aspects of economic and social cohesion in the context of Romania's accession to the European Union continued, the need to create a legal framework. This is all the more so as there has been legislation since 2003 that the financing treaties and memoranda between the Romanian Government and the European Commission enter into force on the date of their signing, without the need to go through their ratification procedure (Law no. $590 / 2003$ on treaties). Considering that the rules and procedures of the European Commission, imposed as a way of working to the entities that accessed these nonreimbursable funds, but not assumed by the Romanian Government, led to a series of discrepancies with the financial-accounting rules generally applicable in Romania, the legislator approves 2005 Emergency Ordinance no.198 on the establishment, supply and use of the Maintenance, Replacement and Development Fund for public service infrastructure development projects that benefit from nonreimbursable financial assistance from the European Union. The purpose of the existence of this fund remains essentially identical to the one provided by the loan agreements, respectively to ensure the necessary sources to cover the public debt service, as well as to ensure the continuity in the operation of the public utility services. The emergency ordinance regulates the minimum obligations of the operator or administrative-territorial unit regarding the establishment of the IID Fund, allowing the modification according to the concrete conditions of the projects and the requirements of the financiers, but limits the initiation competence at the Ministry of Public Finance (GEO no.198 / 2005, updated). The supply source of the fund is at least equal to: the royalty related to the concessioned goods, the profit tax paid by the operator to the administrative-territorial unit; cash and cash equivalents, amounts from undistributed net profit, respectively dividends made, VAT paid from the IID Fund and subsequently recovered from the state budget, other own sources of the operator (if applicable). The inclusion of the royalty in this fund actually provides the sources of financing for future investment works in the public utility system, an important desideratum considering the permanent character and the continuous operation regime of the public utility services.

In the case of water and sewerage, according to the service concession contracts, the royalty represents a certain percentage of the value of the invoiced production, ensuring the legislative provision according to which the royalty represents the source of future investments in the field.

We mention that in the field of water and sewerage utilities the IID fund is constituted at the level of operators and not at the level of inter-community development associations, which has the disadvantage that the implementation of the National Strategy on accelerating the development of community public utility services is difficult. development of community public utility services, respectively the National Development Plan Also, each operator has its own development and tariff strategy, limited by their operational risk, so that unitary and nondiscriminatory consumer access is applicable in view of the existing conditions in the areas operating.

Viewed through the investment programs implemented in the field of water, sewerage and wastewater treatment, rainwater collection, we can unequivocally conclude that the IID fund has proven its usefulness. 
4. Empirical study on investments made in the Maintenance Fund, replacement of development in the field of water, sewerage and wastewater treatment, rainwater collection in Romania

In this study we will follow the following aspect:

a) the royalty situation according to the ARA radiography for 2019;

b) The volume of investments made from the IID fund in the period 2012-2019, according to the same source;

c) The volume of investments made by the beneficiary operators and / or not of the MUDP program.

In the database of the Romanian Water Association (ARA) are registered 43 operators in the field of water and sewerage, who have expenses with a royalty between $1 \%$ and $16 \%$ of the value of the invoiced production, the average being cc. $4.5 \%$, according to the study on the radiography of the financial performances of water and wastewater operators in Romania for 2019.

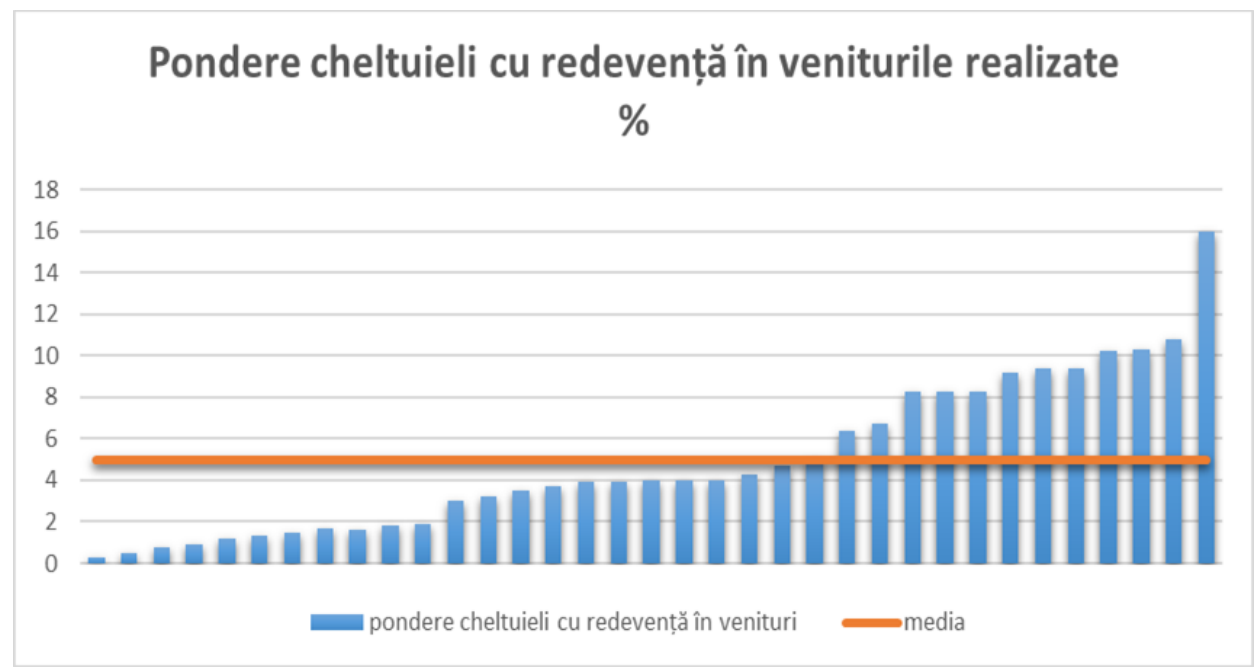

Figure 1: Expenses with royalty from the value of invoiced production Source: Own processing according to ARA data base

The royalty thus conceived, as the main source of supply of the fund, ensured the realization of investments in the amount of 1.405.099.869 lei, in the period 20122019 (according to the information provided by ARA.) Unfortunately, there is no database on the volume of investments made from IID fund for a longer period of years. For comparability, we transformed the value in lei / year into euro / year, using the average euro exchange rate per year, according to the NBR communication. We further used these data to highlight the value of investments made from IID sources by the 43 regional operators in the period 2012-2019.

Table 2: Volume of investments euro / year period 2012-2019

\begin{tabular}{|c|c|c|c|c|c|c|c|c|}
\hline An & $\mathbf{2 0 1 2}$ & $\mathbf{2 0 1 3}$ & $\mathbf{2 0 1 4}$ & $\mathbf{2 0 1 5}$ & $\mathbf{2 0 1 6}$ & $\mathbf{2 0 1 7}$ & $\mathbf{2 0 1 8}$ & $\mathbf{2 0 1 9}$ \\
\hline Total & 31.054 .838 & 33.230 .638 & 36.083 .704 & 35.321 .972 & 42.050 .309 & $\begin{array}{c}36.551 .0 \\
60\end{array}$ & $\begin{array}{c}48.713 .25 \\
9\end{array}$ & 46.361 .365 \\
\hline
\end{tabular}

Source: Own processing according to ARA data base 


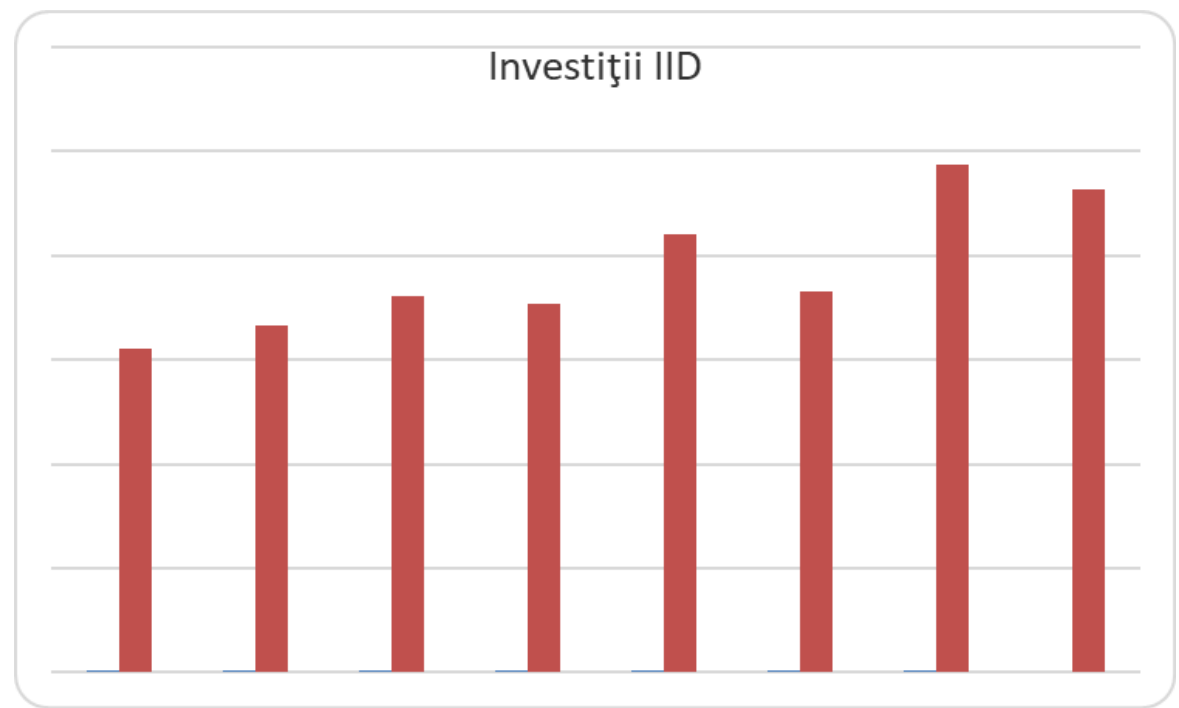

Figure 2: Evolution of investments for the period 2012-2019 Source: Own processing according to ARA data base

We can observe their increasing trend at national level, even if we establish this trend by comparing it at the level of several years and not by comparing it with the previous year. In my personal opinion, due to the lack of unique regulations on the definition / delimitation and classification of major repair and modernization works, it is possible that some operators, in certain periods, will be borne by the sources related to the production activity, in terms of maintenance costs. and repairs. The motivation is a very simple one to avoid the elaboration of the documentation and authorizations necessary for the investment works, but with major implications regarding the correctness and reality of the information provided at national level.

Out of a total of 43 operators, 15 were beneficiaries of the Municipal Utilities Development Program, implemented between 1995 and 2000. The main objectives of the project in the water supply sector were: rehabilitation of distribution networks (including installation of water meters to consumers), restoration of adductions, rehabilitation of wells and springs, construction of tanks, automation of water plants, rehabilitation and modernization of hydrophore stations, introduction of a system for monitoring flows and pressures in the system. It took place in two stages, as follows:

- MUDP I: Iasi, Mures, Timis, Brasov and Dolj;

- MUDP II: Arad, Bacau, Braila, Constanta, Vrancea (Focsani), Bihor, Dambovita (Targoviste), Bistrita, Botosani, Cluj

If we follow the evolution of the investments made from the maintenance, replacement, development fund at these 15 operators, which represent approximately $30 \%$ of the total regional operators in Romania, we will find that they give $43 \%$ of the total investments made at national level, in the analyzed period. 
Table 2: The value of investments made from the investment fund through the M.U.D.P.

\begin{tabular}{|c|c|c|c|}
\hline Year & Total & $\begin{array}{c}\text { M.U.D.P. } \\
\text { Program }\end{array}$ & $\begin{array}{c}\text { Without } \\
\text { M.U.D.P. } \\
\text { Program }\end{array}$ \\
\hline 2012 & 31.054 .838 & 15.496 .338 & 15.558 .500 \\
\hline 2013 & 33.230 .638 & 15.018 .277 & 18.212 .361 \\
\hline 2014 & 36.083 .704 & 14.368 .999 & 21.714 .705 \\
\hline 2015 & 35.321 .972 & 17.357 .136 & 17.964 .836 \\
\hline 2016 & 42.050 .309 & 15.794 .647 & 26.255 .662 \\
\hline 2017 & 36.551 .060 & 16.778 .306 & 19.772 .753 \\
\hline 2018 & 48.713 .259 & 20.606 .169 & 28.107 .090 \\
\hline 2019 & 46.361 .365 & 20.523 .256 & 25.838 .110 \\
\hline General Total & 309.367 .145 & 135.943 .127 & 173.424 .018 \\
\hline
\end{tabular}

Sursa: Own processing according to ARA data base

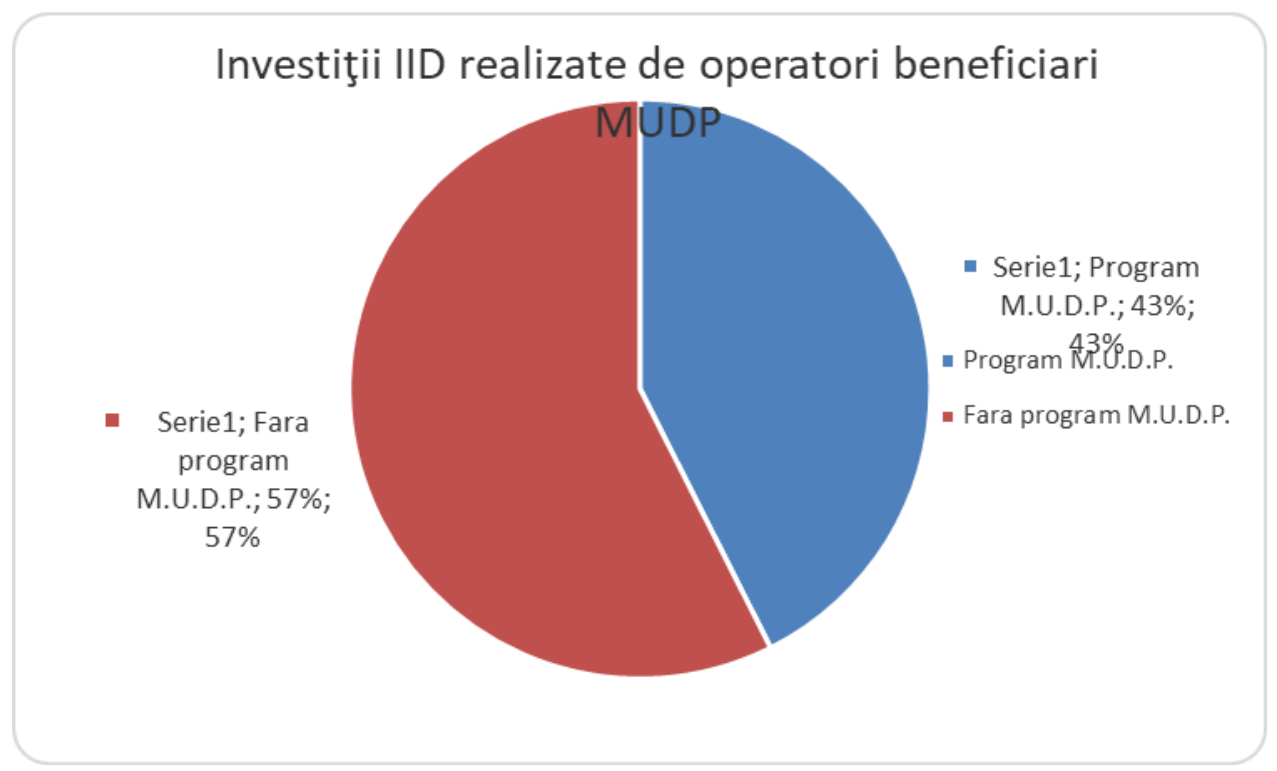

Figura 2: IID investments made by MUDP beneficiaries

Sursa: Own processing according to ARA data base 
Given the volume of investments made, we can unequivocally conclude that the existence of this fund has proved its usefulness, especially since their implementation takes place after the payment of the debt service, which proves a good financial balance, with a cash flow. positive, at the level of the entire field of public water and sewerage services.

From the point of view of the operators, other advantages of setting up the fund are:

- ensuring continuity in the operation of public utility services, by reducing the risk of operation due to the fact that neither the operating expenses nor the cash flow do not include the costs of modernization, replacement, development of the public utility system (these being pursued separately by a separate chapter of the investment plan),

- also the debt service has ensured the distinct financing source, without charging the costs of the operators, costs that are the basis for the calculation of the operating tariffs. Through this financing mechanism, the effort to modernize, replace, develop the public utility system remains with the owner (territorial administrative unit), without distorting the tariffs applied to users by including both royalties and debt service. ;

- creates the premises for continuing and / or accessing investment programs in public utility systems of regional or zonal interest that benefit from nonreimbursable financing from the European Union, by ensuring the co-financing of these programs, facilitating access to these projects;

From the point of view of the owners of the public utility system, the advantages would be the following:

- ensuring the implementation of the National Strategy on sustainable development, protection and capitalization of the public and private domain of the administrative-territorial units, not least the acceleration of the development of community services of public utilities in a unitary and non-discriminatory way

- compliance with the commitments assumed by Romania through the Accession Treaty regarding the quality requirements, protection and conservation of the environment, in accordance with the acquis communautaire,

- ensuring the source of financing of investments from this distinct fund, has the direct effect of eliminating and / or considerably reducing the subsidies for investments from the state or local budget,

- also ensures the correlation of the national legal framework with the requirements of the treaties and financing memoranda of the European Commission, from a financial-accounting and fiscal point of view, having as direct effect transparency and comparability in the activity of evidence and reporting at all levels.

- compliance with the purpose for which the royalty was defined as a source of financing for future investment works in the public utility system, an important goal considering the permanent character and the continuous operation regime of the public utility services

In our personal opinion, in Romania, there is a legislative vacuum precisely in the traceability of financing public utility systems, in the sense that the royalty obtained by exploiting the public and private patrimony of territorial administrative units, corroborated with the permanent character and continuous operation of utility services public, generates the need to "reinvest" the royalty in the system, decision-making and financial mechanism regulated only partially. This deficiency 
is solved in other forms, such as subsidies or tariff increases for public utilities, but solutions that have many shortcomings, both economically and socially.

\section{Conclusions}

The establishment of inter-community development associations ensures the necessary framework for the organization, regulation, financing, operation, monitoring and joint management of public utility services provided within the competence of the administrative-territorial member units, as well as the joint realization of investment projects, public works of zonal or regional interest intended for the establishment, modernization and / or development, as the case may be, of public utility systems. Also, these associations ensure the implementation of the National Strategy on accelerating the development of public utilities, the Multiannual Plan for the development of public utilities, respectively the National Development Plan and last but not least facilitates access to nonreimbursable funds, cross-border, overall provisions with a special impact on public utility services, especially in terms of environmental and quality issues, materialized by firm commitments to make investments in the field. The establishment of the maintenance, replacement, development fund at the level of inter-community development associations ensures the source of financing for the implementation of all the desideratum in the field of public utility services.

Considering the permanent character and the continuous operation regime of the public utility services, there is an indisputable need to continue the implementation of multiannual development projects aimed at developing the infrastructure of public utility services, improving the environment and quality, setting up the maintenance fund, replacement, development being an element of interest and a starting point in the study of performance and in the elaboration of diagnostic analyzes applicable to the entities in the field of public utility services.

\section{References}

1. Anastase,I.,Managementul serviciilor publice de interes local.Echilibrul BowenLindhal-Samuelson într-o nouă perspectivă, Performance and Risks in the Europen Economz, vol3, univ-danubius.ro,2008;

2. Bărbulescu, C., Bâgu, C.,Managementul producţiei, vol. II - Politici manageriale de producţie, Editura Economică, Bucureşti, 2001;

3. Bedrule-Grigoruta,M.,V.,Managementul serviciilor publice, Note de curs,Ed.Tehnopress laşi, 2007;

4. Constantin,D.L., Elemente fundamentale de economie regională, Ed.ASE, Bucureşti, 2004;

5. Demeter, J., Klarik,L. A., Regionalis torekvesek Erdelyben, Europrogress, nr.6,pp.11-14, Budapest,2003;

6. Dinu, C.G., Influenţa Directivei 214/23/UE privind concesiunile asupra dreptului naţional român, Revista Transilvană de Ştiinţe Administrative, 2 (39), pp. 7387,2016;

7. Grigorescu, A., Serviciile publice între nevoia cetăţeanului şi posibilităţile administraţiei, Caietul ştiinţific al I.S.A. „Paul Negulescu” nr.12,2010, online https://mpra.ub.uni-muenchen.de/25132;

8. Icu, M.M., Aspecte esenţiale privind regimul juridic al bunurilor imobile din domeniul privat, Revista on-line Universul Juridic, 10 ian.2020; 
9. Focşăneanu,D., Şuţa, C.,Tatu, C.,Popescu,M., Serviciile publice.Consideraţii asupra legislaţiei şi practicii comunitare în domeniu, în contextul elaborării proiectului Codului Administrativ, Revista Transilvană de Ştiinţe Administrative, 1(28),pp31-39,2011;

10. Klarik, L.A, Rolul regiunilor în construcţia europeană. Studiu de caz asupra regionalismului din România, Revista Transilvană de Ştiinţe Administrative, nr.3, Cluj-Napoca, pp.76-82,2004;

11. Kuntz, A., Indicatori specifici în analiza performanţei financiare a serviciilor de utilităţi publice, 2019;

12. Kuntz Aniko, Driha Cristina A Keynesian Model Applied To The Water And

Sewage Public Utility Operators, paper published in Annals of Faculty of

Economics, University of Oradea, Faculty of Economics, vol. 1(2), pages 179-191, December 2020.

13. Matei ,L., Anghelescu S., Dezvoltarea locală. Concepte şi mecanisme, Ed.Economică, Bucureşti, 2010;

14. Mitlin,D., Walnycki,A., Water utilities'strategies for cost recovery and their consequences for universal access, Journal of development studies, 2020;

Repere legislative:

15. Legea nr.15/1990 privind reorganizarea unităţilor economice de stat ca regii autonome şi societăţi comerciale, publicat M.Of. nr. 98/08.08.1990;

16. Legea nr.151/1998 privind dezvoltarea regională în România, publicat M.Of. nr. 265/16.07.1998, abrogat;

17. Legea nr.213/1998 privind proprietatea publică şi regimul juridic al acesteia, publicat M.Of. nr. 448/24.11.1998;

18. Legea nr.51/2006 serviciilor comunitare de utilităţi publice, republicat M. Of. nr. 121/05.03. 2013;

19. Legea nr. 225/2016 pentru modificarea Legii serviciilor comunitare de utilitati publice nr. 51/2006, publicat in M. Of. nr. 942/23.11.2016;

20. Legea nr.241/2006 serviciului de alimentare cu apă şi canalizare, republicat M. Of. nr. 679/08.09. 2015;

21. Legea-cadru nr. 195/2006 a descentralizării, publicat M.Of. nr. 453/25.05.2006,abrogate

22. Legea nr.286/2006 pentru modificarea şi completarea Legii administraţiei publice locale

23.Raport de activitate 2019 al Autorităţii Naţionale de Reglementare pentru Serviciile Comunitare de Utilități Publice;

24. Raport asupra investigaţiei sectoriale declanşate prin Ordinul nr. 82 din 15.02.2017. 


\title{
CORRUPTION AND MONEY LAUNDERING - BASIC COMPONENTS OF ECONOMIC AND FINANCIAL CRIME
}

\author{
Ioan FEHER ${ }^{1}$, Sorin Nicolae BORLEA ${ }^{2}$ \\ ${ }^{1}$ Doctoral School of Economic Sciences, Faculty of Economic Sciences, University \\ of Oradea, Oradea, Romania, nelufeher@gmail.com \\ 2 Faculty of Economic Sciences, University of Oradea, Oradea, Romania; Faculty \\ of Economics, Computer Science and Engineering, Western University Vasile \\ Goldis, Arad, Romania; European Research Institute, Babes-Bolyai University Cluj- \\ Napoca, Romania,snborlea@yahoo.com; nicolae.borlea@ubbcluj.ro
}

\begin{abstract}
Economic and financial crime is based on three main pillars, namely the underground economy, corruption and money laundering. Corruption seen as a central element of the phenomenon called economic and financial crime is likely to seriously distort the health of the economic environment in a state, altering democratic governance and the rule of law, in fact a real threat to economic development on the principles of market economy. In the following we will refer to theoretical approaches of the literature on the phenomenon of corruption, revealing a possible form of quantification, respectively how it affects the economic environment and the social implications associated with the manifestations of this phenomenon. We aim to perform a theoretical analysis of the corruption term, and then develop the study with the analysis of real implications in society. The research in question is intended to be a basis for understanding the phenomenon in correlation with the complexity of social implications, in order to subsequently propose concrete solutions to combat it, aiming to limit it and its adverse effects on the economy and society. The phenomenon of money laundering can be considered a reaction of the private environment to the fiscal strategy of the state. In this paper we have analyzed this phenomenon to reveal the methods and means used by different people to mask certain amounts of money of dubious origin, in order to reintegrate financial flows into legal economic circuits. The use of the methodology for investigating the specialized literature, followed by the analysis and synthesis of data, allowed us to identify the main implications of corruption in the economic and social ecosystem of the state, respectively the structuring of money laundering techniques and methods.
\end{abstract}

Keywords: economic-financial crime, underground economy, corruption, tax evasion, money laundering

JEL classification: H26

\section{Introduction}

Corruption seen as a central element of the phenomenon called economic and financial crime is likely to seriously distort the health of the economic environment in a state, altering democratic governance and the rule of law, in fact a real threat to economic development on the principles of market economy. In this study we refer to theoretical approaches of the literature on the phenomenon of corruption, 
revealing a possible form of quantification of it, respectively how it affects the economic environment and the social implications associated with the manifestations of this phenomenon. We aim to perform a theoretical analysis of the term corruption, and in subsequent works we will complete the study with the analysis of real implications in society. The research in question is intended to be a basis for understanding the phenomenon in correlation with the complexity of social implications, with the subsequent goal of proposing concrete solutions to combat it, aiming to limit it and its adverse effects on the economy and society. By investigating the literature, followed by data analysis and synthesis, we were able to identify the main implications of corruption in the economic and social ecosystem of the state.

In Europe there is a more consistent presence of the phenomenon in former communist countries, which seems to have difficulties in building and functioning of democratic institutions, in increasing the education and training of the population, and in determining appropriate behaviors (Donato et al. 2010). The inconsistency of the legal framework in these countries, amid political and social instability, is a favorable condition for the spread of corruption at all levels.

In fact, corruption significantly burdens the democratic government and the rule of law, an impediment with a negative impact on investment and economic growth (Mauro, 1995).

The phenomenon of money laundering - subsumed by economic and financial crime - is associated, as a beginning, with the beginning of the 20th century and can be considered a response of some economic actors to the fiscal policies of the state. In the situation of obtaining consistent profits from criminal activities, those involved must identify solutions to dispose the resulting money without drawing attention to the illegal activity from which they resulted. This is done by concealing the sources, changing their form, or redirecting the funds to a place where they do not raise suspicions to the authorities.

Despite the measures taken by various states to prevent and combat this practice, it has so far not been possible to reduce it, although at European level, has been adopted since 2005 Directive 2005/60 /EC of the European Parliament and of the Council on the prevention of the use of financial system for the purpose of money laundering and terrorist financing.

Analyzing the specialized literature, we found that money laundering is not treated in a unitary way and in connection with the specific activities of economic and financial crime, without revealing clear correlations between the phenomenon of money laundering and corruption. This article proposes an inventory of the means and methods used to launder money, so that we can later try to identify a relationship (from the perspective of favoring factors or common elements) between the phenomenon of corruption and money laundering.

\section{Defining and quantifying corruption}

According to the World Bank's definition, also highlighted by Achim and Borlea (2019), "corruption is the illegal use of public resources for personal gain", while Transparency International (2019) defines corruption "as the abuse of power entrusted to obtain private benefits".

Attempting to quantify corruption, as well as the underground economy, is an approach with an extremely high degree of relativity, practice showing that both the phenomenon of corruption and the concept of underground economy cannot be 
inscribed in any strict pattern from the point of mathematical view, in the absence of relevant statistical bases. Corruption is not representative for the entire underground economy because the concept of underground economy in a broad sense also includes segments such as self-consumption or criminal type (drug trafficking, arms trafficking etc).

Because it is a difficult phenomenon to quantify, the literature has tried several ways to approach / classify corruption. As indicated by Achim and Borlea (2019), in terms of the severity of corruption, it can be classified as small, large or medium.

Data from Transparency International (2019), in the report "Global Barometer on Corruption", shows that about $25 \%$ of the world's population said they were in a position to pay bribes to access public services.

The calculation of the corruption level has been in the attention of Transparency International since 1995, when the Corruption Perceptions Index (CPI) was launched, which is based on corruption data from specialized surveys conducted by several independent institutions. Surveys used to draw up the CPI raise questions about the misuse of the civil service for personal gain, focusing, for example, on bribery by public procurement officials and embezzlement of public funds, thus leading to administrative corruption.

The literature has tried various forms of defining corruption in order to create a framework as realistic as possible for a quantification closer to the perception of the phenomenon in reality. In this sense, we highlight the approaches of Klitgaard (2015), who proposes the following formula:

$$
\mathrm{C}=\mathrm{M}+\mathrm{Dp}-\mathrm{R}
$$

where $\mathrm{C}$ is corruption, $\mathrm{M}$ is the monopoly position, $\mathrm{Dp}$ is discretionary power, and $R$ is responsibility. Corruption can occur where there is a cumulative monopoly situation, a discretionary power is exercised regarding the distribution or provision of the monopoly, respectively there is no regulated liability regarding the distribution made.

The presented formula unequivocally indicates the factors favoring corruption, practically highlighting the predisposition of the public governance area in the development of this phenomenon. The monopoly situation in the allocation of (budgetary) resources in conjunction with the discretionary allocation of financial funds (depending on certain subjective interests), without any constraints or rigors (both institutional and legislative or law enforcement) is likely to contribute to the emergence and development of the corruption phenomenon.

\section{Implications of corruption on the economic and social axis}

Corruption manifests itself both in individual forms and in intercalated form, affecting differently the democratic governance, respectively the market economy, with implications of the most diverse felt in the economic, social and political spheres.

As Bîznă (1999) also captures, a common form of corruption manifestation at the national level refers to the misappropriation of budgetary funds in personal interest. In the first stage, the main authorizing officer allocates to the legal entities subordinated to the public administration the amounts necessary for carrying out the activity, paying salaries, making investments, etc. Subsequently, in order to achieve their own objectives, these institutions enter into contractual relations with economic agents specialized in carrying out certain works which, in turn, conclude subcontracting contracts with natural / legal persons, on certain fields of activity. 
However, these subcontractors include, directly as shareholders or indirectly, through their relatives, those main authorizing officers who have the size and destination of the allocated funds. In fact, the described procedure of this form of corruption reveals the standard scheme by which the funds destined to achieve the objectives of public interest are "directed" for the benefit of some private interests.

A comparative study of the World Economic Forum (2018), entitled "Global Competitiveness Report", highlights risks associated with corruption. The values were centralized on the basis of business surveys for EU Member States. Higher values indicate a relatively better situation (chart 1 and 2). The situation of Eastern European countries, which are constantly lower, is relevant. However, in the situation of Romania there is a slight upward trend in the analyzed period (20152018).

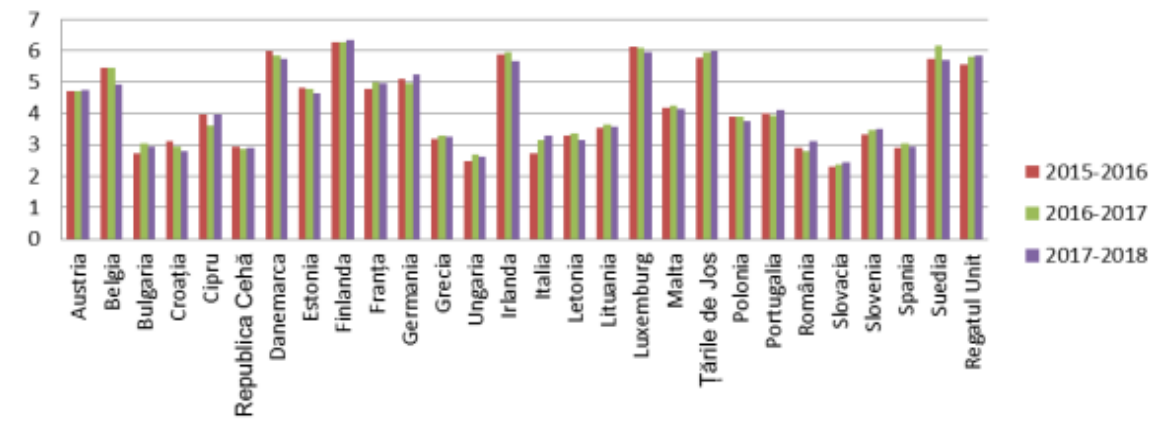

Figure 1: Misappropriation of budgetary funds in personal interest Source: World Economic Forum, Global Competitiveness Report, 2018

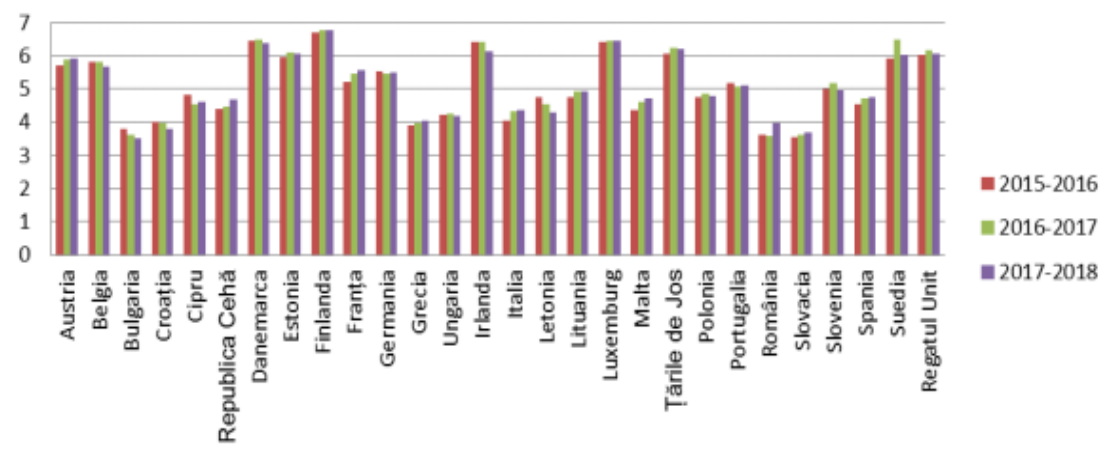

Figure 2: Undue payments and bribes

Source: World Economic Forum, Global Competitiveness Report, 2018

The complex forms of corruption manifestation affect differently the democratic governance, respectively the market economy, with implications of the most diverse felt by both the economic and the social sphere.

Various studies mentioned by Achim and Borlea (2019) highlight the negative impact of corruption on fiscal policies. Relevant is the analysis of Kaufman (2010) who established a direct relationship between corruption and fiscal deficits, 
highlighting that this phenomenon reduces tax revenues, increases public spending, affects competitiveness and economic growth.

On the other hand, the literature Gupta et al (2002) and the European Parliament (2015) highlight a direct relationship between corruption level and social inequality, respectively poverty. Countries with a high level of corruption have lower literacy rates and higher mortality rates due to poor health services with privileged access for different sections of the population.

100

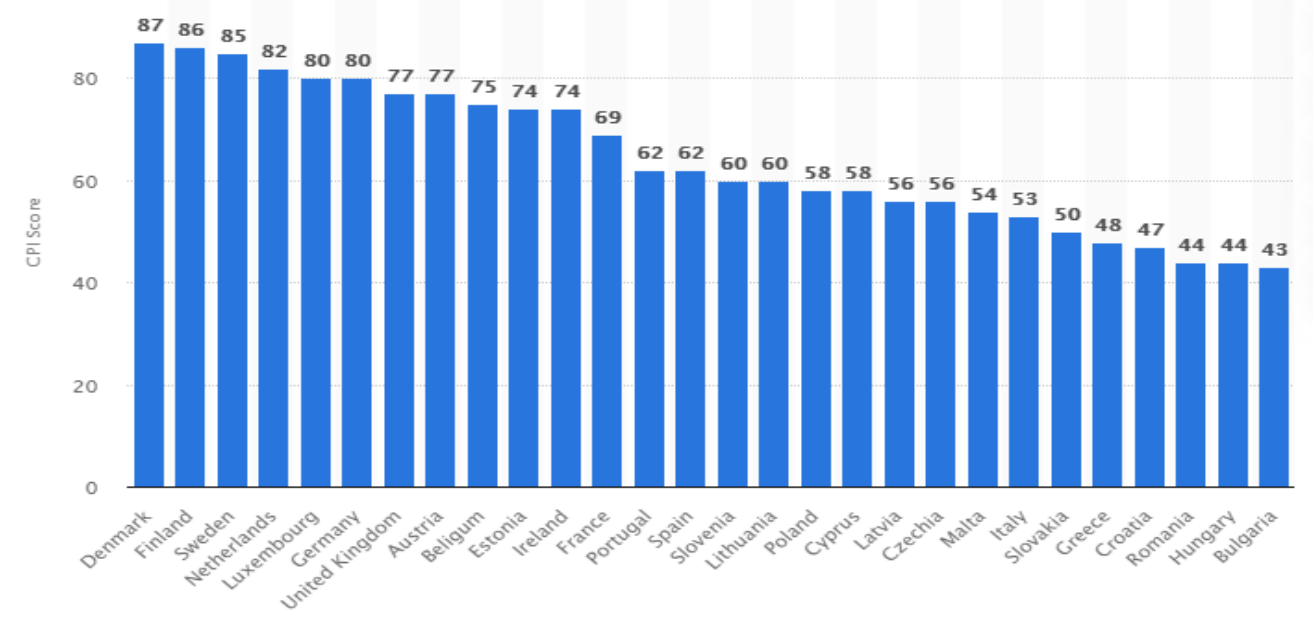

Figure 3: Corruption perception index score in European Union countries, 2019

Source: Clark, 2020, Statista, 2020

The statistical study (Clark, 2020) on the corruption perception index is a composite indicator that includes various data on corruption precepts in areas such as: bribery by civil servants, refunds in public procurement, embezzlement of state funds and effectiveness government efforts to combat corruption. The highest possible score in the perception of corruption is 0 , while a score of 100 indicates that no corruption is perceived in that country. It can be seen (chart no. 3) that developed countries in the EU have the highest score of perception of corruption, while Romania, with a score of 44, has almost the lowest value, along with other Eastern European countries.

The complexity of corruption is highlighted in some studies that propose an approach from another perspective, namely its ability to contribute to economic development through the possibility of shortening bureaucratic flows. As the study developed by Hoinaru et al (2020) shows, corruption can also have the role of "lubricant" of economic mechanisms, in addition to the obvious "defeat" of them, with an indirect contribution to economic growth.

According to the aforementioned study, which analyzed a large database over the period $2005-2015$, it is found that corruption and the underground economy are predominantly present in underdeveloped countries, their higher levels being correlated with low levels of economic development. and durable.

Based on this fact, which unequivocally reveals the harmful role of corruption and the underground economy on the models of healthy and sustainable 
development of states, evidence has been found that the phenomenon of corruption can also be seen as a way to circumvent the law in order to obtain greater economic benefits and, as a result, to contribute to economic development.

Of course, this side of the complexity of the corruption phenomenon has different economic and social effects depending on the development degree of an economy. For an economy with a high degree of development, corruption itself can have a strictly negative effect, seizing economic mechanisms and affecting the state's insistence, by altering decision-making levers. On the other hand, for states with poorly developed economies, in the short term, corruption can have a "positive" role in the economy, having the function of mechanisms "lubrication", caught short-circuiting excessive bureaucratic effects, with a direct effect on economic growth. However, the deprivation of national budgets of available funds for the implementation of development state policies is a negative long-term issue. As a result, reducing corruption is the long-term solution to ensure healthy growth and sustainable development in the economy.

Due to the complexity of the phenomenon, the study of corruption cannot be limited only from the perspective of the present analysis. Certain favorable factors contribute decisively to the development of corruption diversity forms: the high degree of political and administrative power concentration in the state; the fragile democratic system; strong bureaucratic system; low standard of living etc.

The inventory of the phenomenon consequences is an exhaustive process, also surprised by the studies carried out by Mauro (1997) and Gray and Kaufmann (1998), among the most relevant consequences being mentioned: the decrease of the production factors efficiency; the competitive environment depreciation, the depreciation of public services quality and the decrease of level investment.

\section{The relationship corruption - money laundering. Techniques and methods of money laundering}

In a broad sense, money laundering consists in the money transfer from an illegal activity to a legal business, with the aim of inducing the idea of legality money origin (OECD, 2017). In fact, the multitude of literature definitions converge towards the model synthesized by Achim and Borlea (2019), respectively "the process of disguising illegally procured sources through criminal procedures in order to give them a legal appearance". The authors summarize the common central element of the corruption - money laundering relationship: the tendency to evade the regulations regarding the calculation and payment of tax debts owed by economic actors. Both phenomena produce the same type of effects, without a clear delimitation: the decrease of the state budget revenues in parallel with the supply of the underground economy, artificially increased public expenditures, respectively the slowdown of economic growth.

The literature captures a multitude of methods used by economic actors in the money laundering process, but the mechanism underlying the process itself can be summarized in three major stages, according to the document "Training Manual on Combating Money Laundering and Terrorist Financing" (2002) published by the National Office for Preventing and Combating Money Laundering.

The first stage - placement - is the "escape" of cash resulting from illegal activity, aimed at breaking down funds from illicit sources, those obtained legally, the former may be subject to law enforcement. Basically, at this stage, the subject of the money laundering crime introduces the illegally obtained profit into the 
financial circuit. After the "injection" of illegally obtained funds into the financial system, the second stage takes place - stratification. The operation involves the process of money "movement" between different accounts, the obvious purpose being to hide their origin. At this stage, a series of funds transfers take place to remove them from their source. These may be aimed at buying and selling investment instruments, or the person carrying out the money laundering operation may transfer the funds, electronically, to a number of accounts in various international banks. After successfully completing the two mentioned stages, the people involved move on to the third stage - integration. This represents the funds "reinsertion" in the legal economic circuit. Offenders can then choose to invest funds in the real estate, luxury goods or business markets.

If the whole process is successfully completed, the integration circuits will send again the results of the laundering in the economic circuit (chart no. 4), the money re-entering the financial system in the form of "clean" funds, the result of honest business activities.

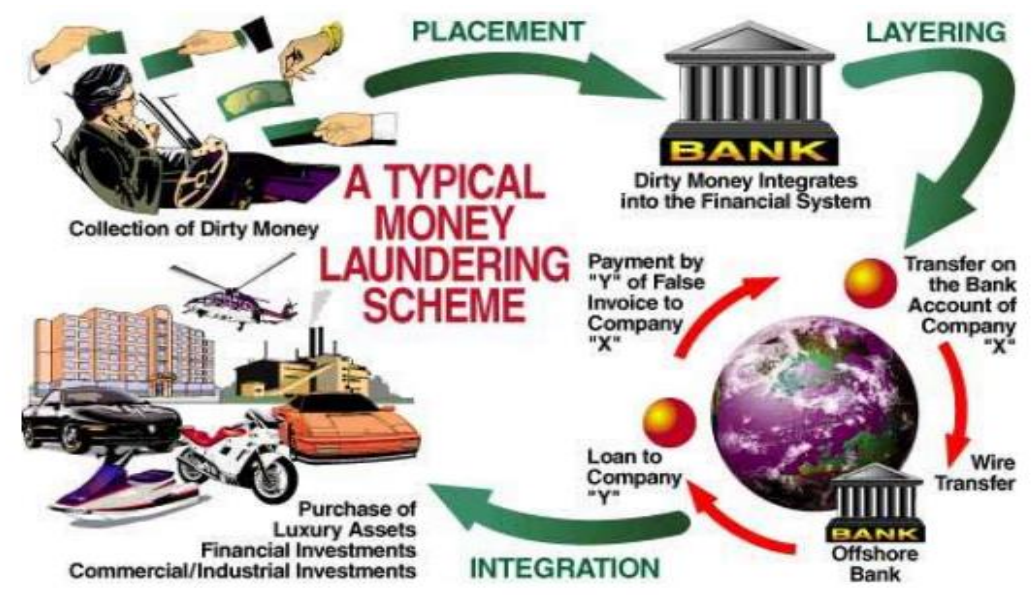

Figure 4: Money laundering circuit

Source: National Office for the Prevention and Combating Money Laundering "Manual for the Prevention of Money Laundering and Terrorist Financing", 2002

The manual for the Prevention of Money Laundering and Terrorist Financing (2002) has classified various techniques for simulating the legal origin and / or concealing the illicit origin of money, as follows:

Money laundering in the context of legal business activities controlled by organized crime is done by: overestimating the price of a good; false business transactions; unregistered purchases and processing of raw materials.

The purpose of using these techniques is to give a source of legality to illegal funds: either by an invoice higher than the real value of the goods paid or by a completely false invoice that could be used to justify illicit trafficking (of drugs). The "illegally" purchase of raw materials with illegally obtained money allows the offender to launder money at the next sale. 
International practice allows the classification and exemplification of several categories of methods used for money laundering, among the most used being:

a. Money laundering through cash transactions: the exchange of large sums from one currency to another, without any obvious economic purpose; the exchange of large quantities of low value banknotes into high value banknotes; unusually large cash deposits and withdrawals made by a customer whose activities normally involve the use of non-cash payment instruments; unusually large cash deposits and withdrawals made by a customer who normally uses a current account; a customer who makes several deposits on the same day at different cashiers or bank branches; cash withdrawals immediately after replenishing the account; crediting of the company's accounts by their associates / administrators, followed by repeated withdrawals justified as "loan repayment", etc.

b. Money laundering through bank accounts: the use of accounts that do not reflect normal banking or commercial activities, but are used only for deposits or withdrawals; large cash withdrawals from an account, previously inactive, or from an account to which a significant amount has just been unexpectedly transferred from another account opened in the country or abroad; making frequent and substantial transfers of funds that cannot be clearly identified as having an economic justification; large amount transfers, withdrawn on the same day in the form of a "loan repayment", etc.

c. Money laundering by electronic bank transfers: frequent transfers from the account of a legal entity to the account of a natural person without any reference to the transfers nature; the frequent transmission or reception of large volumes of electronic transfers to and from offshore companies; regular deposit or withdrawal of large sums by electronic transfers to / from or through countries that are known as sources of narcotics or whose banking secrecy laws facilitate money laundering, etc.

d. Money laundering through external operations: use of credit lines and other financing methods to make external transfers when the transaction does not justify the normal activity of the client; the establishment of large balances, inconsistent with the economic activity performed by the client, followed by subsequent transfers to foreign accounts; making external payments in advance for imports for which the goods were not delivered, not followed by a refund of the advance paid, respectively justification of advance payments, etc.

e. Money laundering through credit operations: customers who repay loans unexpectedly quickly with funds from unknown sources; the purpose stated by the client for the loan is not justified and proposes a cash guarantee or mentions it when specifying the purpose of the loan, etc.

\section{Conclusions, limits and research directions}

The three main pillars of economic and financial crime, namely the underground economy, corruption and money laundering converge on the same goal: avoiding the tax obligations payment resulting from economic activity, reducing tax revenues having a direct impact on limiting the levers available to the state to ensure durable economic development.

The corruption and money laundering study cannot be limited only from the perspective of this analysis. Certain favorable factors contribute decisively to the diversity development forms of corruption: the high degree of political and administrative power concentration; the fragile democratic system; strong 
bureaucratic system, low standard of living, etc., which may be the subject of future research.

The phenomenon consequences inventory is an exhaustive process, also surprised by the studies carried out by Mauro (1997) and Gray and Kaufmann (1998), among the most relevant consequences being mentioned: the efficiency decrease of production factors use; the depreciation of the competitive environment, the depreciation of public services quality and the decrease of the investment level. Of course, further studies in this segment may lead to further conclusions.

Acknowledgement: This work was supported by a grant of the Romanian Ministry of Education and Research, CNCS - UEFISCDI, project number PN-III-P4-ID-PCE2020-2174, within PNCDI III.

\section{References}

1. Achim M.V. and Borlea N.S., (2020), Economic and financial crime. Corruption, shadow economy and mony laundering. Springer Nature Switzerland AG;

2. Achim, M.V., Borlea, N.S., (2019), Criminalitatea Economico-Financiară, Editura Economică, București;

3. Bîznă, A.M., (1999), Evaluarea Economiei Informale - Corupţia şi evaziunea fiscală, Studii și cercetări economice, vol. 110, din cadrul Institutului Naţional de Cercetări Economice "Costin C. Kiriţescu", Centrul de Informare şi Documentare Economică, [Online], available:

http://www.ince.ro/Publicatii/Publicatii online/Alina\%20Mihaela\%20BiznaEvaluarea\%20economiei\%20informale\%20\%E2\%80\%93\%20corup\%C8\%9Bie\%2 0\%C8\%99i\%20evaziune\%20fiscal\%C4\%83.pdf, [24.10.2020];

4. Clark, D., (2020), Corruption perception index score of countries in the European Union 2019, Statista 2020, [Online], available: https://www.statista.com /statistics/873736/ corruption-perception-index-european-union/\#statisticContainer, [31.10.2020];

5. Donato, R., Gooroochurn, N., Görg, H., (2010), Corruption and Productivity Firmlevel Evidence from the BEEPS Survey, în Kiel Working Paper No. 1632, June 2010, Kiel Institute for the World Economy, Germany, [Online], available: https://www.researchgate.net/publication/45455630 Corruption and Productivity Firmevel Evidence from the BEEPS Survey/link/0912f50e721211deda000000/d ownload, [01.11.2020];

6. Grey, C. W., Kaufmann, D., (1998), Corruption et development, Finances \& Development, 1998, [Online], available: https://www.imf.org/external/pubs/ ft/fandd/1998/03/pdf/gray.pdf, [05.10.2020];

7. Gupta, S., Abed, G.T., (2002), Governance, corruption \& economic performance, IMF, [Online], available: https://www.imf.org/external/pubs/nft/2002/govern/, [01.11.2020];

8. Hoinaru R., Buda, D., Borlea S.N., Văidean V., Achim M.V., (2020), The impact of corruption and shadow economy on the economic and sustainable development. Do they "Sand the Wheels" or "Grease the Wheels"?, Sustainability 2020, 12(2), 481, [Online], available: https://www.researchgate.net/publication/338483900 The Impact of Corruption and Shadow Economy on the Economic and Sustainable Development Do T hey Sand the Wheels or Grease the Wheels, [25.10.2020]; 
9. Klitgaard, R., (2015), Addressing corruption together, în The development Assistance Committee: Enabling Effective Development, OECD, [Online], available: https://www.oecd.org/dac/conflict-fragilityresilience/publications/FINAL\%20Addressing\% 20corruption\%20together.pdf, [25.10.2020];

10. Kaufman, D., (2010), Can corruption adversely affect public finances in industrialized countries?, april 19, Washington, [Online], available: https://www.brookings.edu/opinions /can-corruption-adversely-affect-publicfinances-in-industrialized-countries/, [02.04.2020];

11. Mauro, P., (1995), Corruption and Growth, The Quarterly Journal of Economics, Vol. 110, No. 3, Oxford University Press, [Online], available: invalid link, downloaded from: https://academic.oup.com/aje/articleabstract/110/3/681/1859244?redirectedFrom=fulltext, [27.10.2020];

12. Mauro, P., (1997), Why Worry About Corruption?, IMF, 1997, [Online], available: https://www.imf.org/external/pubs/ft/issues6/issue6.pdf, [27.10.2020];

13. OECD, (2017), Shining light on the shadow economy: Opportunities and threats; [Online], disponibil la: https://www.oecd.org/tax/crime/shining-light-on-theshadow-economy-opportunities-and-threats.pdf, [20.03.2020];

14. Oficiul Național pentru Prevenirea și Combaterea Spălării Banilor, (2002), Manual de instruire privind combaterea spălării banilor și a finanțării terorismului, [on line], available: http://www.onpcsb.ro/pdf/ MANUAL\%20INSTRUIRE\%20\%20ROMANA.pdf, [22.11.2020];

15. European Parliament, (2005), Directive 2005/60 / EC of the European Parliament and the Council from 26 October 2005 on the prevention financial system use for the money laundering and terrorist financing purpose, [Online], available: https://eur-lex.europa.eu/legalcontent/EN/TXT/PDF/?uri=CELEX:32005L0060\&from=RO, [30.10.2020];

16. European Parliament, (2015), Cost of corruption in developing countries - how effectively is aid being spent?, [Online], available: https://www.europarl.europa.eu/ RegData/etudes/STUD/2015/549042/EXPO STU(2015)549042 EN.pdf [30.10.2020];

17. Transparency International, (2019), What is corruption?, [Online], available: https://www.transparency.org/en/what-is-corruption, [29.10.2020];

18. Transparency International, (2019), Barometru Global privind Corupția, [Online], available: https://www.transparency.org.ro/ro/tiropage/indicele-deperceptie-coruptiei-2019, [29.10.2020];

19. World Economic Forum, (2018), The Global Competitiveness Report 20162018, [Online], available: https://www.weforum.org/reports/the-globalcompetitiveness-report-2016-2017-1/ and http://reports.weforum.org/globalcompetitiveness-index-2017-2018/, [03.04.2021]. 


\title{
TAX AVOIDANCE AND TAX EVASION IN EU: TRENDS AND EFFECTS
}

\author{
Emil Gheorghe GUIAȘ, Codruța Mihaela HĂINEALĂ \\ Doctoral School of Economic Sciences, Faculty of Economic Sciences, University \\ of Oradea, Oradea, Romania \\ guiasemil@gmail.com \\ codruta.haineala@gmail.com
}

\begin{abstract}
The main purpose of this article is to study the concept and aspects of tax avoidance and tax evasion, their causes, trends and effects in the European Union(EU). In recent years, the debate on international tax policy has focused on tax avoidance strategies and tax evasion. Cases of tax evasion and tax evasion have become increasingly common. These phenomena were triggered by several factors. Some of them relate to European principles such as those relating to the free movement of persons, goods and capital, which led to the diversification and complexity of trade, under conditions of imperfect legislation. Other factors are the social and economic ones generated by the onset of the economic crisis. Another set of factors that have been favorable circumstances for the development, the phenomenon of tax avoidance and tax evasion, are those related to the degree of taxation that differs from one-member country to another and different tax systems. This expansion of the phenomenon of tax avoidance and tax evasion generates negative effects on the European economy, which are making their mark on the economy. In this context, concerns have arisen at EU level to create a legislative framework to mitigate these phenomena. As these two phenomena (tax avoidance and tax evasion) cannot be completely eradicated, it is very important to find the most efficient measures to combat them. Another element specific to the European Union that generates tax evasion and tax avoidance is Value Added Tax (VAT). As with any tax, Value Added Tax presents opportunities for tax avoidance and evasion. European Union experts believe that tax avoidance and tax evasion are important factors limiting revenue mobilization. Tax evasion and tax avoidance affect us all. ese phenomena occur both within a country and within the European Union, but also globally. That is why one country cannot solve the problem alone. The European Union and the Member States must work more together and at international level to combat the problem in the country within the Union but also outside the borders of the European Union. Thus, in principle, legislators can affect the decisions of the subjects by defining the boundary between legality and illegality. The purpose of this paper is to investigate the trends and effects resulting from tax avoidance and tax evasion behavior.
\end{abstract}

Keywords: tax avoidance, tax evasion, tax fraud, VAT evasion, underground economy

JEL Classification: H2, H6 


\section{Introduction}

Both tax evasion and tax avoidance are a large-scale economic and social phenomenon of great magnitude and importance that many states face, to a greater or lesser extent. The size and causes of these two phenomena differ from one geographical region to another. In the case of the European Union we can talk about it as a geographical queen, but also within this area there are big differences from one country to another in terms of size and causes of the phenomenon of tax evasion or tax avoidance. The existence of a large number of tax obligations, as well as their size, have constantly generated tendencies to avoid or evade taxation. Given the causes and proportions of tax evasion and tax avoidance, and whatever the control measures are, can't talk, in terms of the results obtained, about eradicating this phenomenon, one can only talk about its limitation. The phenomenon of tax evasion and tax avoidance are an integral part of the underground economy, being present in all areas of income-generating activities. Legislative inconsistencies and gaps in the European Union as well as different taxation from one country to another stimulate the taxpayer's ingenuity, causing him to seek and apply various procedures to circumvent the law and optimize his business so as to pay as few taxes and duties as possible.

While tax planning strategies that use complex group structures to minimize a company's tax burden without violating tax laws can be morally reprehensible or highly questionable, they are not illegal, newspapers report evidence of extensive tax avoidance activities by multinational corporations almost daily (Lisowsky, 2010).

The creation and maintenance of public infrastructure and the provision of government services is a key factor for economic development. Within the European Union, there are big differences between the degree of development of the countries that make it up.

In many countries of the Union with a lower degree of development, the lack of public service provision slows down economic growth and undermines efforts to improve the living standards of the population. There are a number of explanations, one of which is the lack of tax revenue.

In recent years, the academic and political debate on development finance and development aid has raised the issue that tax avoidance and tax evasion could undermine the capacity of European Union countries and especially of less developed countries to finance their public sectors. This view is based, inter alia, on the perception that the underground economy in these countries is larger than in those with a higher degree of development. The term "underground economy" does not have a universally accepted definition. In the context of taxation and revenue mobilization a useful definition of "underground economy" would include undeclared income from the production of legal goods and services, either from monetary or barter transactions, so all economic activities that would generally be taxable, if they were reported to the tax authorities (Friedrich, and Dominik, 2000). Tax evasion is possible by capitalizing on elements with high tax risk. The globalization of the economy of the European Union has favored the emergence of the European dimension of tax evasion through double taxation, high heterogeneity manifested in national tax regimes and, so different levels of fiscal pressure, which led to multiple tax avoidance opportunities. 


\section{Definitions, Components, Trends and Effects}

\subsection{Definitions and Components}

- Tax avoidance. It is the phenomenon of legitimate minimization of taxes and maximization of income after tax, using methods included in the tax code. Companies avoid taxes by considering all legitimate tax deductions and credits and shielding tax revenues by establishing employee retirement plans and other means, all legal and according to the Internal Revenue Code or State Tax Codes.

- Tax loopholes. A tax loophole is "tax avoidance". Tax avoidance is a clause, a loophole or a hole in the tax laws that taxpayers can take advantage of to reduce their taxes. It is a way to avoid paying taxes, but since it is in the Tax Code it is not evasion. Because the tax code is so complex, tax experts have found ways to reduce taxes for their customers without breaking the law, taking advantage of parts of the law. If you are tempted to use a tax loophole, keep in mind that tax laws are complex and difficult to interpret. An honest and competent tax expert can relieve taxpayers of crossing the line from tax avoidance to tax evasion.

- Tax shield are another tax avoidance strategy. A tax shield is a deliberate use of tax-deductible expenses to offset taxable income.

- Tax evasion, uses illegal means to avoid paying taxes. Usually, tax evasion involves hiding or distorting income. This could be the concealment of income, which consists in not recording all the income in the accounting records or not declaring it to the tax authorities. Another way is to reduce the tax base by recording in accounting fictitious expenses from companies with "ghost" behaviour. Another way is to hide or not declare cash transactions or hide money in offshore accounts. Tax evasion is part of a general definition of tax fraud, which is the intentional unlawful non-payment of taxes.

- Fraud, can be defined as "an act of cheat or distortion" and this makes someone who avoids taxes - misleading Member States' tax administrations into revenue or expenditure.

- Transfer prices, are the prices at which a company transfers tangible assets, and intangible assets, or provide services to affiliated companies. Within the meaning of the OECD Report (Organisation for, Economic Co-Operation and Development) an "affiliated company" is a company that meets the conditions set out in Article 9, subparagraphs 1a) and 1b) of the OECD Model Tax Convention. Under these conditions, two companies are affiliated if one of the companies participates directly or indirectly in the management, control or capital of the other, or if "the same persons participate directly or indirectly in the management, control or, capital" of both companies (if both companies are under joint control). In order to steal the payment of the tax, the taxpayer turns to protected areas in fiscal terms. Gradually, tax and financial engineering schemes were developed by multinational companies through which there were different combinations based on tax avoidance or even tax evasion behaviours. Thus, a company can capitalize on the advantage offered by areas with reduced taxation by declaring income earned in another country in the form of invoicing by the mother company or subsidiary. The transfer pricing mechanism is a way for tax evasion to take shape. Frequent manifestations of this kind have led to the need to exercise strict fiscal controls in the consolidated financial statements of the 
group of companies, in particular in the light of the origin of the declared income and the tax regime applicable to them.

- Value Added Tax Evasion

For EU companies, VAT is levied on most sales and purchases of goods in the EU. In such cases, VAT is levied and is due in the EU country where the goods are consumed by the final consumer. VAT is also levied on services when they are provided in each EU country. VAT is not levied on exports of goods to nonEU countries. In such cases, VAT is levied and due in the country of importation and it is not necessary to declare any VAT as an exporter. However, when exporting goods, you will need to provide documentation as proof that the goods have been transported outside the EU. Such proof could be provided by presenting to the tax authorities a copy of an invoice, a transport document or an export customs record. This proof will have to be provided in order to be able to deduct in full any VAT receivable that was paid in a previous export transaction. Insufficient documentation may mean that the taxpayer is not entitled to a refund of VAT related to the export of goods.

Like any tax, VAT is vulnerable to evasion and fraud. Its credit and repayment mechanism offer unique opportunities to avoid taxation and tax evasion, and this has recently become a major concern in the European Union.

VAT avoidance and evasion transactions can take several forms:

- Sub-reported sales. A merchant can only report a portion of sales by counterfeiting records and accounts, or taxpayers may or may not issue an invoice. VAT invoices were issued, but not declared by their issuer.

- Avoid registration. Such cases are relatively few. These are companies that operate close to the level of turnover exemption at which registration becomes a mandatory VAT payer. A taxpayer could fragment his business so that each part of the business falls below the VAT exemption threshold.

- Incorrect classification of goods. When traders have sales of goods or services that are taxable at different rates of VAT, or some of them do not fall within the scope of the tax (items exempt under VAT). Merchants can reduce their debt by calculating a lower VAT Pro-Rate.

- Omission of self-deliveries. Refers to goods or services produced by the enterprise and consumed by the owner or employees, in principle taxable. This is a relatively unimportant category in the most developed economies.

- Tax collected but not remitted. This can be possible either through false accounting

(below reported sales, as above), by technical bankruptcy before the payment of the tax or in other ways. More specifically, the evasion of companies with "ghost" or "missing merchant" behaviour. These are companies registered for VAT purposes that collect VAT from customers but disappear before paying the tax.

\subsection{Trends and Effects}

In order to counter tax evasion, the tax authority must, of course, first identify transactions with a high tax risk. Although this is more difficult, it is generally easier than discovering tax evasion, because tax evasion by definition involves distorting the facts or intentionally concealing them from the authorities.

International tax evasion has developed in the context of over-directing investment flows to emerging countries. To ensure that foreign direct investment acts as an 
engine of economic growth, emerging countries have used, in addition to the low cost of labour, a tax advantage, providing incentives to foreign investors. This is also true within the EU because there are significant development gaps between the countries that make up the union.

Recently, many studies have been directed at the tax advantages that support absolutely artificial, inconsistent economic systems to attract foreign investors. In general, the analysis showed that foreign investments targeted only under tax advantages do not ensure solid economic growth, as they are temporary.

Regarding the EU, seven EU countries have been accused of being tax havens.

Countries such as Belgium, Cyprus, Hungary, Ireland, Luxembourg, Malta and the Netherlands are accused by the European Parliament of having the characteristics of a tax haven and facilitating aggressive tax planning. This is mentioned in a report issued by the European Parliament in the first half of 2019. The report, it was adopted by the European Parliament's General Assembly and it was prepared mainly by the European Parliament's Committee on Financial Crimes and Tax Evasion. The adoption of the report by the European Parliament gives it political weight.

The report by the European Parliament's Committee on Financial Crimes and Tax Evasion is based on data published by accounting and law firms, which revealed tax optimization operations built in some EU countries.. Tax optimization operations have allowed large companies such as Allergan, Apple, Disney, GlaxoSmithKline, IKEA, Koch Industries, Nike and Skype to create tax avoidance opportunities. The seven countries identified in the report include some of the smallest nations in Europe and together represent less than $9 \%$ of the total population of the European Union.

Petr Ježek, chair of the European Parliament's Committee on Financial Crimes and Tax Evasion, responsible for drafting the report, says the seven countries identified in the report have managed to facilitate aggressive tax planning practices over many years due to their power to block reforms. in the EU Council.

The seven countries identified in the commission's report include some of the smallest nations in Europe. Together they represent less than $9 \%$ of the total population of the European Union.

The adoption of such reforms requires the unanimous agreement of all EU Member States. Petr Ježek explains in the report the lack of unanimity, which is due to the fact that some EU countries "clearly take advantage of the unequal and unfair situation".

The report published by the European Parliament could lead to the elimination of opportunities for tax optimization and the imposition of EU regulations in the seven countries mentioned in the Commission's report.Therefore, companies wishing to benefit from reduced taxes without the risk of being affected by EU anti-tax evasion measures are advised to carry out operations in countries that have not been accused by the European Parliament of being tax havens. Este dată ca și exemplu, Bulgaria, ca țară membră UE cu cele mai mici cote ale impozitului pe venitul corporativ și al persoanelor fizice (ambele rate sunt de 10\%) și cele mai mici costuri cu forța de muncă din UE (5,30 EUR pe oră. Bulgaria este o locație excelentă pentru optimizarea fiscală, fără să fie necesară evitarea taxării, deoarece are cote de impozitare scăzute.

Tax revenues within the EU remain high compared to other advanced economies. 
In 2018, mandatory taxes and social contributions in the 27 Member States of the European Union (UE-27) (UE-27 represents the European Union without the United Kingdom) accounted for $40.2 \%$ of GDP. The tax burden (The tax burden is measured as tax revenue collected as a percentage of GDP) in the EU it is high compared to other advanced economies (Graph 1), almost 6 pp above the OECD average. In particular, it was almost $16 \mathrm{pp}$ above the level in the United States, which significantly reduced their income tax in 2018 (2.5 pp lower than in 2017), This decrease is mainly due to the decrease in income and property taxes. The United Kingdom also had a relatively low tax burden in 2018 (33,8\%), UE-27 it was 1 pp over UE-28 (EU-28 European Union and United Kingdom). The tax burden in the euro area $(40,5 \%)$ was higher than in UE-27 (EU-19 represents the euro area). Tax revenues from UE-27 as a percentage of GDP increased slightly in 2018, reaching 40,2\% (0.2 pp higher than in 2017), see Graph 2. The tax-GDP ratio in the euro area also rose slightly in 2018 to $40,5 \%$, i.e. a supplement of $0.2 \mathrm{pp}$ compared to 2017. In both the EU-27 and the euro area, tax revenues were higher in 2018 than at any time in the previous decade.

Tax revenues relative to GDP increased in most Member States (20 out of 27) in 2018, especially in Luxembourg (1.6 pp) and Romania (1.4 pp). The largest decreases were recorded in Denmark (0.9 pp) and Hungary (0.8 pp). In 2018, tax revenues were higher than in 2008 in 19 Member States, for example Greece with an increase of $7.1 \mathrm{pp}$, while Ireland recorded the largest decrease, $6.4 \mathrm{pp}$.

The tax burden in the EU differs greatly between Member States (Chart 3), countries such as France (46.5\%), Denmark (45.1\%) and Belgium (44.8\%) having the highest tax revenue relative to GDP, and countries such as Ireland (22.6\%) and Romania (26.3\%) have the lowest tax burden.

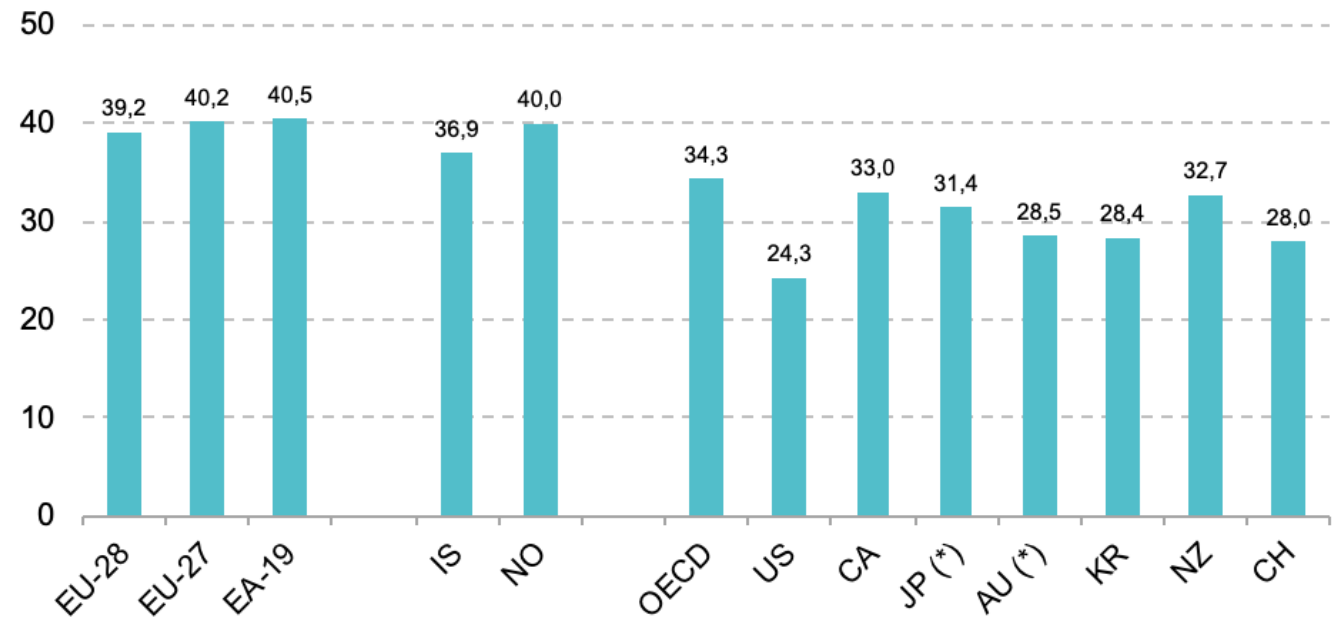

Graph 1: Tax revenue (including compulsory actual social contributions), EU and selected countries, 2018 ( $\%$ of GDP)

Source: European Commission, DG Taxation and Customs Union, based on Eurostat and OECD data. ( $\left.{ }^{*}\right)$ OECD data for JP and AU from 2017. 


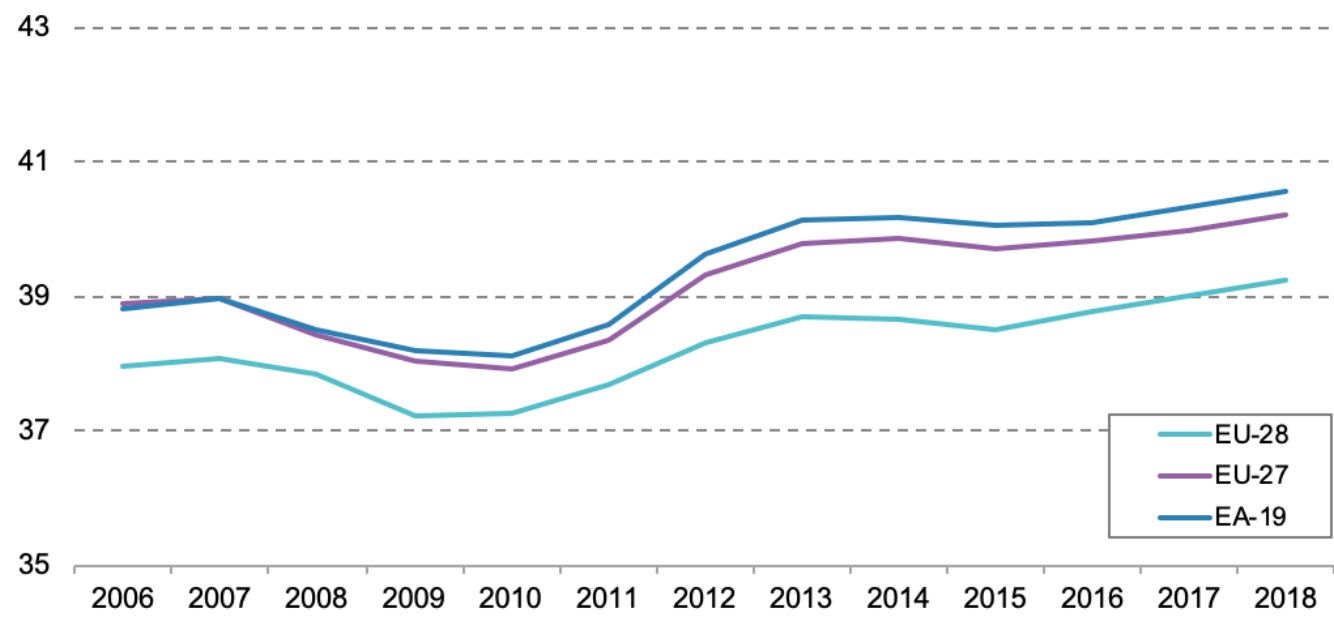

Graph 2: Tax revenue (including compulsory actual social contributions), EU-28, EU-27 and EA-19, 2006-2018 (\% of GDP).

Source: Eurostat (online data code: gov_10a_taxag).

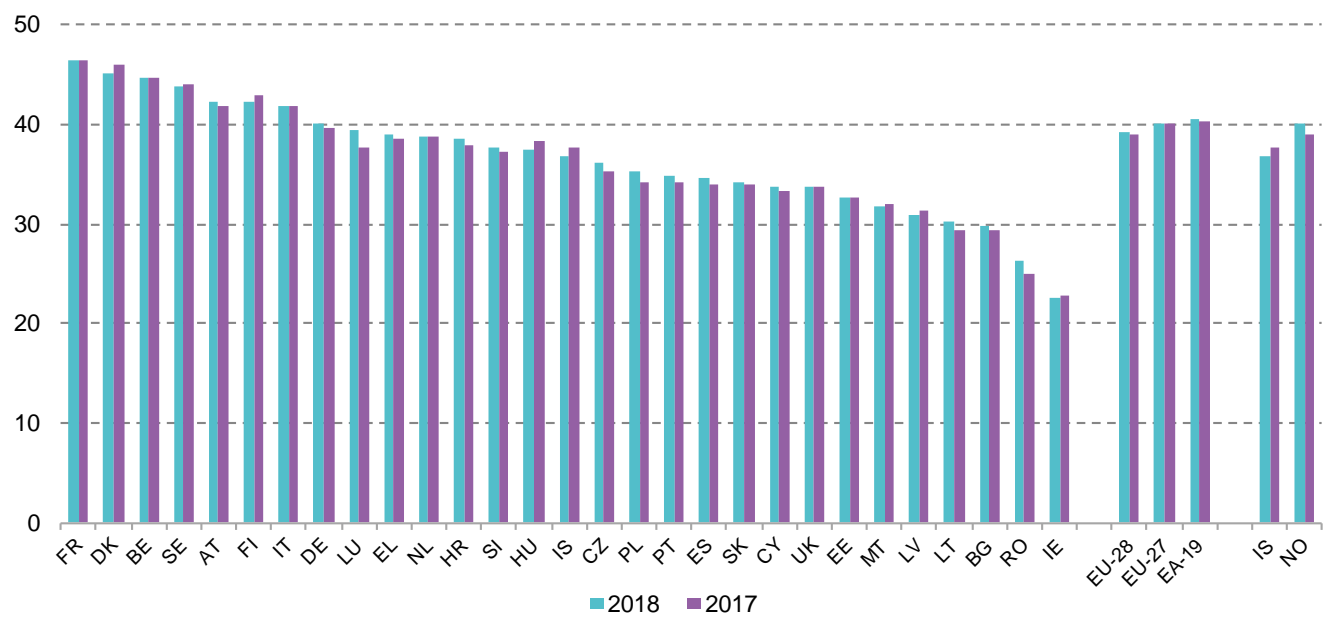

Graph 3: Tax revenue (including compulsory actual social contributions), 20172018 (\% of GDP)

Source: Eurostat (online data code: gov_10a_taxag).

A number of recent publications have linked budget revenue losses to tax evasion and tax avoidance in weaker EU economies. The phenomenon of evasion within these countries is related to the financial support that these countries receive through development aid. Many of these publications conclude that aid dependence could be significantly reduced if those countries were able to eliminate tax avoidance and tax evasion. 


\section{Conclusions}

Based on the analyses carried out by EU experts at Union level, the idea that concrete measures must be taken to reduce the economic gap between countries in order to combat tax evasion and tax avoidance is becoming increasingly clear. Another measure would be to reduce the tax burden in order to comply as voluntarily as possible. Tax administrations in the least developed Member States also need to work to eliminate legislative gaps and better monitor and collect taxes. Following the awareness of this state of affairs, the report A8-0170 / 2019 was presented to the European Parliament in 2019 " financial crimes, tax evasion and avoidance of tax obligations" by the Special Commission on Financial Crimes tax evasion and avoidance of tax obligations. Between the ideas that have emerged in this report we will refer to a few:

- often, existing tax rules cannot keep up with the growing speed of the economy; the current international and national tax rules were conceived mainly at the beginning of the twentieth century; states that there is now an urgent need to reform the rules so that international, European and national tax systems are adequate for the new economic, social and technological challenges of the 21 st century;

- a tax jurisdiction has control only over the tax issues related to its territory, while economic flows and some taxpayers, such as multinational corporations and people with high financial resources, operate worldwide;

- considers that fair taxation and the determined fight against tax fraud, tax evasion, aggressive tax planning and money laundering play a central role in creating a fair society and a strong economy, while defending the social contract and the rule of law;

- a fair and efficient tax system is essential to combat inequalities, not only by financing public spending to support social mobility, but also by reducing income inequalities;

- the most urgent priority is to reduce the fiscal gap resulting from tax fraud, tax evasion, aggressive tax planning and money laundering, as well as their impact on national and EU budgets, to ensure a level playing field and tax equity among all taxpayers and between them, to combat growing inequalities and to build confidence in the democratic policy-making process, by ensuring that fraudsters do not have a competitive tax advantage over honest taxpayers;

- Joint efforts at EU and national level are essential to defend the EU budget and national budgets against losses from unpaid taxes;

- only if tax revenues are collected fully and efficiently can states provide quality public services at affordable prices, including education, healthcare and housing services, security, crime control and emergency response, social security and social assistance, enforcement of labour and environmental standards, combating climate change, promoting gender equality, public transport and essential infrastructures, to stimulate and, if necessary, to stabilize socially balanced development, to move towards the achievement of sustainable development goals; 


\section{References:}

1. European Commission, Taxation and Customs Union (2011). Taxation trend in European Union, Focus on the crisis, The main impact on EU tax system [online]. Aveilable from: https://ec.europa.eu/eurostat/documents/3217494/5730669/KS-EU11-001-EN.PDF/fec0c5ff-e858-481c-904c-c291cf9804b8?version=1.0 [accessed 10 April 2021].

2. European Commission (2015). Communication on tax transparency to fight tax evasion and avoidance [online]. Aveilable from: https://eur-lex.europa.eu/legalcontent/EN/TXT/?uri=celex\%3A52015DC0136 [accessed 8 April 2021].

3. European Commission (2015). Study on structures of aggressive tax planning and indicators, Taxation Papers, Working Paper No. 61 [online]. Aveilable from: https://ec.europa.eu/taxation customs/sites/taxation/files/docs/body/taxation paper 61.pdf [accessed 8 April 2015].

4. European Commission (2020). The tax trend in the European Union [online]. Aveilable from: https://ec.europa.eu/taxation customs/business/economic-analysistaxation/taxation-trends-eu-union en [accessed 9 April 2021].

5. European Commission, Taxation and Customs Union (2021). Taxation data [online].

Available

from:

https://www.google.ro/url?sa=t\&rct=j\&q=\&esrc=s\&source=web\&cd=\&cad=rja\&uact =8\&ved=2ahUKEwjGsJaksKfvAhVMDewKHb9ABZEQFjAKegQIAxAD\&url=https\% 3A\%2F\%2Fec.europa.eu\%2Ftaxation customs\%2Fbusiness\%2Feconomicanalysis-taxation\%2Fdata-taxation en\&usg=AOvVaw0eAaREO 9D1lpDnnSURX2I [accessed 7 April 2021]

6. European Parliament, EPRS (2015). Bringing transparency, coordination and convergence to corporate tax policies in the European Union: I -Assessment of the magnitude of aggressive corporate tax planning, Study 2015 [online].Available from: https://op.europa.eu/en/publication-detail/-/publication/7b54c958-f63d-11 e5-852901aa75ed71a1/language-en [accesed 9 April 2021].

7. European Parliament, EPRS (2016). Bringing transparency, coordination and convergence to corporate tax policies in the European Union: II -Evaluation of the European Added Value of the recommendations in the ECON legislative owninitiative draft report, Study 2016 [online]. Available from: https://op.europa.eu/en/publication-detail/-/publication/7b54c958-f63d-11e5-852901aa75ed71a1/language-en [accessed 7 April 2021].

8. European Parliament (2018). Listing of tax havens by the EU [online]. Aveilable from: https://www.europarl.europa.eu/cmsdata/147404/7\%20-\%2001\%20EPRSBriefing-621872-Listing-tax-havens-by-the-EU-FINAL.PDF [accessed 6 April 2021]. 9. European Parliament (2019). Reporton financial crimes, tax evasion and tax avoidance[online]. Available

from:

https://www.europarl.europa.eu/doceo/document/A-8-2019-0170 RO.html

[accessed 10 April 2021].

10. Financial-Monetary Research Center (2016). Analysis bulletin Nr.13/

September 2016 [online]. Aveilable from: http://cefimo.ase.ro/wp-

content/uploads/2018/02/CEFIMO Buletin $\mathrm{nr} 13$ 2016.pdf [accessed 6 April 2021]. 
11. Friedrich, S. and Dominik, H. E. (2000). The Shadow Economy in Western Europe [online]. Copenhagen: Rockwool Foundation Research Unit. Available from:https://www.researchgate.net/publication/227390150 The Shadow Economy [accessed 8 April 2021].

12. NoMoreTax (2020). Seven EU countries were accused in being tax havens [online].Available from: https://nomoretax.eu/seven-eu-countries-were-accused-inbeing-tax-havens [accessed 9 April 2021].

13. Lisowsky, P. (2010) Seeking shelter: Empirically modelling tax shelters using financial statement information [online]. Boston: University Qestrom School of Business, Available from: https://papers.ssrn.com/sol3/papers.cfm?abstract id=1089148\# [accessed 6 April 2021].

14. OECD (2015). Measuring and monitoring BEPS, Action 11 - 2015 final report [online]. Aveilable from: https://www.oecd.org/ctp/measuring-and-monitoring-bepsaction-11-2015-final-report-9789264241343-en.htm [accessed 20 February 2021]. 15. Petre, B., Sorin, C., and Ana, P. S.(2011). Forms of Tax Evasion in Romania. Analytical Perspective. Annals of the University of Petroşani, Economics [online], 11(1), pp33-42. Available from: https://www.upet.ro/annals/economics/pdf/2011/Brezeanu\%20-Celea-Stanciu.pdf [accessed 6 April 2021]. 


\title{
THE EVOLUTION OF FISCAL PRESSURE IN DEVELOPED E.U. COUNTRIES AND ITS DETERMINANTS
}

\author{
Raluca Andreea GHETU1', Cristina-Simona CĂPĂȚîNĂ ${ }^{1}$, Petre BREZEANU² \\ ${ }^{1}$ Doctoral School of Finance, Bucharest University of Economic Studies, Bucharest, \\ Romania \\ ${ }^{2}$ Phd Professor, Department of Finance, Bucharest University of Economic Studies, \\ Bucharest, Romania \\ gheturaluca93@yahoo.com \\ capatinacristina12@stud.ase.ro \\ petre.brezeanu@fin.ase.ro
}

Abstract: Since 1970, the intensity of implementing budgetary policies in the two categories of states, developed states, and emerging states, has been observed in Europe. These policies had the effect of increasing the levels of taxation, also called progressive taxation, at that time. To stop this phenomenon of progressive taxation, the Maastricht Treaty and then the Stability and Growth Pact have had the effect of forcing states to adopt different fiscal policies to reduce the feeling of fiscal pressure made necessary by budgetary deficiencies and public debt accumulated over time. In fact, since the 1990s, each Member State of the European Union has interpreted the treaties mentioned above separately; some states reduced spending, while others preferred to impose more significant fiscal pressure on citizens by raising taxes and fees.

In our article, we analyze and disseminate the general fiscal pressure of some developed countries in the European Union. We identify the economic priority indicators that influence the phenomenon of fiscal pressure, such as the level of direct taxes, indirect taxes, the growth rate of gross domestic product, and the level of public debt, providing an overview of economic development over the last three decades.To this end, the authors have developed an econometric model that captures the factors that influence the fiscal pressure in several developed countries of the European Union in the period 1995-2018.

Keywords: fiscal pressure; tax evasion; direct taxes; indirect taxes; public debt; GDP growth rate

JEL classification: H26; H71

\section{Introduction}

Taxes and fees represent a significant source of state budget revenue, indispensable for any state. What is the tax, and what is its power and role in the economy? The literature shows that the tax is defined as a mandatory financial tax imposed on a taxpayer by a government organization for government funding (Charles E. McLure Jr., 2015). This shows that the payment of taxes by taxpayers to the government is mandatory to increase budget revenues.

A definition found in the literature, "taxable income is the income remaining after deducting the costs of the production and business process" (Nguyen Huu Cung, 
2015), shows that the phenomenon of fiscal pressure is indispensable in an economy. The fiscal burden on the economy is inevitable, the essential aspects being related to the citizens' resistance to this phenomenon and the governors.

The scientific and conceptual approaches to pressure were explained over time. According to the literature, fiscal pressure represents the tax burdens on the shoulders of citizens, with a risky and high endurance (Talpos and Enache, 2001; Brezeanu, 2009). Since this phenomenon arose, specialists worldwide have been looking for economic measures and policies to reduce the harmful causes of rising tax levels. Therefore the fiscal pressure is of global interest to all specialists.

According to the literature, in the case of developed countries, policies have been adopted to relax tax burdens, with various measures to change or move the levels of progressive taxation on direct taxes, to reduce the phenomenon of fiscal pressure. Many authors have shown that, since the 1990s, developed countries have reduced the tax burden on indirect taxes (value-added tax, excise duties) but increased the level of the direct tax burden (income tax, corporate income tax, income tax on micro-enterprises, and others)

This study is conducted to show the level of general fiscal pressure, direct and indirect taxes in developed countries, compared to the average level of the European Union. Also, essential factors in dealing with any issue related to fiscal pressure are the level of public debt and the annual growth rate of gross domestic product. The first part of the article provides an overview of several seven developed countries in the European Union, analyzing fiscal pressure, direct taxes, indirect taxes, public debt, and the growth rate of gross domestic product. Developed countries were chosen according to geographical location. We focused on three states north of the European Union, Sweden, Finland, and Denmark. In Western Europe, we chose France and Spain, and in Central Europe, we chose Luxembourg and Germany. The final results are compared with the average level of the European Union. The comparative analysis is examined every five years, starting with 1995.

In the second part of the article, we present and analyze multiple regression, having as a dependent variable the fiscal pressure and as independent variables the level of direct and indirect taxes, the level of public debt, and the annual growth rate of the gross domestic product. Ignoring these economic indicators by developed countries creates adverse effects on state budgets by creating financial deficits. In order to restore the optimal levels of budget deficits, it is necessary to implement new budgetary fiscal measures.

\section{Literature review}

The present article is based on the teachings of Murray L. Weidenbaum, one of the great economists of the financial, economic field, who recounted the events of 1968, regarding the tax increases of taxes and duties, due to the rise in public debts and budget deficits. He presented through various specialized articles the negative impact of the fiscal pressure phenomenon on the personal incomes of the citizens, especially on the consumption and saving indicators. It has shown that tax increases, temporary or permanent, produce the effects desired by states but have adverse effects on taxpayers' consumption and investment expenditures, negatively influencing the living standards of taxpayers. Another author (Nguyen, 2020) states in his scientific paper that the role of taxes is an indispensable one of 
the regulatory instruments regarding states' social and economic development, regardless of whether they are part of the group of developed states.

At the same time, a high level of fiscal pressure leads to an increase in the criminal phenomenon in the long run. Bernasconi et al. (2014) showed that an increase in the tax rate increases tax evasion. According to the same study, people's decisions to evade paying taxes depend on how they adapt to the level of fiscal pressure. In an era characterized by high capital mobility, abuses in the global financial system make it difficult to collect taxes and enforce the law. Tax revenues can help governments finance development and reduce dependence on foreign aid, which is why preventing and combating fraud has a critical role to play. In recent years, the intra-community VAT (value-added tax) system has been misused by new types of tax fraud, such as the so-called intra-community fraud scheme (MTIC), as well as fraud carousel. These types of economic crime bring losses of billions of VAT revenue to the E.U. Member States each year, including the Union. In 2015 alone, carousel fraud has led to losses of about 50 billion euros (European Parliament, 2018).

In his scientific article from 2016, Ruesga presents that fiscal pressure is widespread worldwide and not exclusively for a particular country or continent, which is under the sign of various limitations of government programs in different states.

Regarding the concept of fiscal policy, the author Zacary reports in 2014, in the literature as "the set of financial decisions that the state adopts to ensure the financial resources necessary to perform its duties." Regarding the economic instruments for limiting the increase of public debt levels, we find in the literature authors (Mara, 2011) who assume that a correct analysis of public spending, taxation levels, and loans can positively influence public debt.

Regarding the indicator used in this study, we find in the literature an empirical study conducted on a sample of 21 states, which stated that financial systems and economic growth have an adverse correlation. (Arnold, 2008) The empirical study concluded that a one-unit increase in the different tax rates of different taxes (direct, indirect) could positively influence economic growth only if progressive tax rates are used in productive areas. He also said that a high level of annual GDP growth could increase tax rates. In support of those mentioned in the literature (Vasiliauskaitè \& Stankevičius, 2009), they found a significant and positive interaction between the two indicators in the study they conducted with tax systems and growth data. Positive outcomes on cointegration between growth rate and fiscal burden have been consistent in the literature with studies written by (Sconac 2021), (Zachary 2014) for Zimbabwe, and (Matloja 2016) for South Africa.

Several scientific and empirical studies showed that general fiscal pressure is treated with different indicators such as direct taxes, indirect taxes, public debt, living standards, gross domestic product, and corruption rates. Many authors have concluded that when governments observe a very high level of overall fiscal pressure, they tend to reduce tax burdens (Romano, 1993; Chaney et al., 2002; Eaton and Nofsinger, 2004; Butu et al., 2020, Chen, 2021).

\section{Shared analysis of the determinants of the fiscal pressure phenomenon}

The phenomenon of fiscal pressure is essentially a macroeconomic concept, found actively in all states, which is not classified as a tax, being a purely quantitative 
phenomenon, macroeconomic (corresponds to the measure of fiscal pressure level), and microeconomic, if we relate it to the income of each citizen.

Table 1 presents the general fiscal pressure in the developed countries, starting with 1995.

Table 1: Level of general fiscal pressure- Percentage of GDP

\begin{tabular}{|l|l|l|l|l|l|l|}
\hline & $\mathbf{1 9 9 5}$ & $\mathbf{2 0 0 0}$ & $\mathbf{2 0 0 5}$ & $\mathbf{2 0 1 0}$ & $\mathbf{2 0 1 5}$ & $\mathbf{2 0 2 0}$ \\
\hline European Union & 40,5 & 41,1 & 39,7 & 39,1 & 40,9 & 41,4 \\
\hline Denmark & 48,2 & 48,6 & 49,4 & 46,3 & 47,3 & 47,3 \\
\hline Finland & 45,1 & 46 & 42,2 & 40,7 & 43,7 & 41,9 \\
\hline Germany & 40,8 & 42 & 39,1 & 38,8 & 42,1 & 41,9 \\
\hline Sweden & 46,3 & 49 & 47 & 43,4 & 43,2 & 43,6 \\
\hline Spain & 46,3 & 49 & 47 & 43,4 & 43,2 & 43,6 \\
\hline France & 43,9 & 45 & 44,4 & 44,2 & 44,7 & 44,5 \\
\hline Luxembourg & 37,4 & 38,6 & 39,3 & 38,9 & 38,4 & 40 \\
\hline
\end{tabular}

Source: own calculation based on AMECO data accessed on 19.10.2021

As the literature shows, we can see that the general level of fiscal pressure, compared to the average general level of the European Union, is higher in developed countries. One of the differences between developed and developing countries is that even though they have a higher level of pressure than the general average of the European Union, the living standards are much higher due to fiscal policies correctly adopted and implemented. We can see that Denmark has been at the top of the rankings since 1995, with an average level of general fiscal pressure in the period $1995-2020$ of $47.85 \%$. We can see that, at the end of 2020, after 25 years,

Luxembourg occupied the first place of the ranking for the first time, with a percentage of $47.5 \%$. The state with the lowest level of fiscal pressure is the Spanish state, with an overall average level of fiscal pressure of $34.5 \%$.

In Table 2: Direct taxes - Percentage of GDP, we present the level of direct taxes for the seven states analyzed compared to the average level of the European Union.

Table 2: Direct taxes - Percentage of GDP

\begin{tabular}{|l|l|l|l|l|l|l|}
\hline & $\mathbf{1 9 9 5}$ & $\mathbf{2 0 0 0}$ & $\mathbf{2 0 0 5}$ & $\mathbf{2 0 1 0}$ & $\mathbf{2 0 1 5}$ & $\mathbf{2 0 2 0}$ \\
\hline European Union & 11,8 & 12,9 & 12 & 11,7 & 12,7 & 13,1 \\
\hline Denmark & 29,9 & 29,3 & 30,3 & 28,5 & 30,6 & 30,7 \\
\hline Finland & 16,8 & 20,4 & 16,9 & 15,4 & 16,5 & 15,9 \\
\hline Germany & 11,9 & 12,7 & 10,9 & 11 & 12,3 & 12,8 \\
\hline Sweden & 18,9 & 21,3 & 21 & 18,1 & 18,3 & 18,2 \\
\hline Spain & 9,5 & 9,7 & 10,8 & 9,1 & 9,9 & 11,2 \\
\hline France & 8 & 11,8 & 11,3 & 11,2 & 12,7 & 13,3 \\
\hline Luxembourg & 14,7 & 14,2 & 13,7 & 14,3 & 14,3 & 15,7 \\
\hline
\end{tabular}

Source: own calculation based on AMECO data accessed on 19.10.2021 
We can see that the level of direct taxes for developed countries is significantly higher than the average level of the European Union. This time, Denmark is in first place with the highest level of direct taxes for the whole analyzed period. France and Spain have a relatively low level of tolerability of direct taxes for the characteristics of developed countries, both being close to the average level of the European Union.

The fiscal structure of the direct taxes included in the analysis consists of income taxes (including that of individuals), profit tax, dividend tax, micro-enterprise tax, without considering taxes on salaries or social contributions.

Next, we present in Table no.3 Indirect taxes - Percentage of GDP, the value of indirect taxes, percentage of GDP compared to the average level of the European Union.

Table 3: Indirect taxes - Percentage of GDP

\begin{tabular}{|l|l|l|l|l|l|l|}
\hline & $\mathbf{1 9 9 5}$ & $\mathbf{2 0 0 0}$ & $\mathbf{2 0 0 5}$ & $\mathbf{2 0 1 0}$ & $\mathbf{2 0 1 5}$ & $\mathbf{2 0 2 0}$ \\
\hline European Union & 12,5 & 13,3 & 13,8 & 112,9 & 13,5 & 13,3 \\
\hline Denmark & 16,9 & 16,7 & 17,4 & 16,2 & 16,3 & 15,8 \\
\hline Finland & 13,6 & 13,4 & 12,6 & 12,9 & 14 & 13,8 \\
\hline Germany & 10,4 & 10,8 & 10,4 & 10,9 & 10,8 & 10,4 \\
\hline Sweden & 21,2 & 22,4 & 22,4 & 22 & 21,5 & 21,7 \\
\hline Spain & 10 & 11,3 & 12,1 & 9,9 & 11,7 & 11,2 \\
\hline France & 12,3 & 13,1 & 11,9 & 12,7 & 16,2 & 16,4 \\
\hline Luxembourg & 11 & 13,2 & 13,4 & 12,4 & 11 & 11 \\
\hline
\end{tabular}

Source: own calculation based on AMECO data accessed on 19.10.2021

Regarding the level of fiscal pressure due to indirect tax rates, we see that most developed countries are below the average level of the European Union.

According to the literature, this result is an essential feature of budgetary policies adopted by developed countries. Only Sweden (with an average of $21.86 \%$ ), Denmark, and, in the last ten years, France have maintained a high level of the tax burden in terms of indirect taxes, above the average level of the European Union. Table no. 4: Gross public debt- Percentage of GDP, presents the relative level of public debt in the seven developed countries of the European Union.

Table 4: Gross public debt - Percentage of GDP

\begin{tabular}{|l|l|l|l|l|l|l|}
\hline & $\mathbf{1 9 9 5}$ & $\mathbf{2 0 0 0}$ & $\mathbf{2 0 0 5}$ & $\mathbf{2 0 1 0}$ & $\mathbf{2 0 1 5}$ & $\mathbf{2 0 2 0}$ \\
\hline European Union & - & 66,2 & 67 & 80,6 & 86,6 & 91,8 \\
\hline Denmark & 73,1 & 52,4 & 37,4 & 42,6 & 39,8 & 42,2 \\
\hline Finland & 55,2 & 42,5 & 39,9 & 46,9 & 63,6 & 69,2 \\
\hline Germany & 54,9 & 59,1 & 67,3 & 82,4 & 72,2 & 69,8 \\
\hline Sweden & 68,7 & 50,3 & 48,7 & 38,1 & 43,7 & 39,9 \\
\hline Spain & 61,5 & 57,8 & 42,4 & 60,5 & 99,3 & 120 \\
\hline France & 56,1 & 58,9 & 67,4 & 85,3 & 95,6 & 115 \\
\hline Luxembourg & 9,8 & 7,5 & 8 & 20,2 & 22 & 24,9 \\
\hline
\end{tabular}

Source: own calculation based on AMECO data accessed on 19.10.2021 
We can see that since 1995 Denmark, Sweden and France have had a relatively high level of public debt. However, the ranking of the analyzed developed states has changed with time. In 2010, Germany and France managed to borrow $85.3 \%$ and $82.4 \%$ of GDP. However, in 2015, we see that Germany managed to take into account the degree of public indebtedness of $60 \%$ indicated by the Maastricht Treaty and the recommendations of the Council of Europe. Instead, the Spanish state managed to surprise the European Council with a degree of indebtedness of $99.3 \%$ by 38.8 percent more than in 2010 . Finally, we note that in 2020,12 years after the economic crisis, Spain and France failed to take into account the recommendations of the Council of Europe, recording significant negative values of $120 \%$ and $115.7 \%$. Denmark, Sweden, and Luxembourg are the states that manage to be below the maximum indebtedness threshold recommended by the Maastricht Treaty in 2020.

\section{Methodology}

Panel regression is a modeling method adapted to the data of each panel. It is also called cross-sectional data or longitudinal data. This type of panel regression is widely used in econometrics, where the behavior of statistical units (i.e. panel units) is tracked over time. These units can be states, companies, countries, etc. Panel regression allows control for both the effect of the unit under consideration and the effect of time in estimating the regression coefficient.

The statistical form of the regression model with panel data has the following representation:

TAX_BURDEN $=\mathrm{C}(1)+\mathrm{C}(2)^{*}$ INDIRECT_TAXES + C(3)*DIRECT_TAXES + $\mathrm{C}(4)^{*} \mathrm{GDP}$ _GROWTH_ANNUAL__ $+\mathrm{C}(5)^{\star} \mathrm{GROSS}$ _PUBLIC_DEBT

\subsection{Sample and data}

In this study, we decided to use as a methodology the multiple regression model with panel data, taking as a dependent variable the general level of fiscal pressure, and considering as independent variables, the level of indirect taxes (\% GDP), public debt (\% GDP) and GDP growth rate. The analysis is performed at some developed countries in the European Union, Sweden, Finland, Denmark, Luxembourg, France, Spain, Germany. The period analyzed within the multiple regression is from 1995 to 2018, approximately 23 years, with an annual frequency of the analyzed data. The database was taken over from the World Bank, AMECO, and Transparency International.

Table 5: Variables used

\begin{tabular}{|l|l|}
\hline Symbol & Description \\
\hline INDIRECT_TAXES & Indirect taxes \\
\hline DIRECT_TAXES & Direct taxes \\
\hline GDP_GROWTH_ANNUAL__ & Gross Domestic Product Growth Rate \\
\hline GROSS_PUBLIC_DEBT & Public Debt \\
\hline TAX_BURDEN & Fiscal pressure \\
\hline
\end{tabular}

Source: Made by the author 
With the help of multiple regression with panel data, we want to analyze whether we can claim that these variables significantly influence each other.

\subsection{Results and discussion}

Table 6: Regression Results

\begin{tabular}{|l|l|l|l|l|}
\hline Variable & Coefficient & Std. Error & t-Statistic & Prob. \\
\hline C & 40.58260 & 0.646969 & 62.72723 & 0.0000 \\
\hline INDIRECT_TAXES & 0.055416 & 0.012042 & 4.601980 & 0.0000 \\
\hline DIRECT_TAXES & 0.018486 & 0.011841 & 1.561242 & 0.1204 \\
\hline GDP_GROWTH_ANNUAL_ & -0.034861 & 0.140939 & -0.247348 & 0.8050 \\
\hline GROSS_PUBLIC_DEBT & -0.011492 & 0.001830 & -6.279144 & 0.0000 \\
\hline \multicolumn{5}{|l|}{} \\
\hline R-squared & 0.202711 & F-statistic & 10.36072 \\
\hline Adjusted R-squared & 0.183146 & Prob(F-statistic) & 0.000000 \\
\hline Durbin-Watson stat & 0.055843 & & \\
\hline
\end{tabular}

Source: own processing in Eviews 7.1

In Table 6, Regression Results, following the analysis, it was found that the value of the determination ratio underlines and highlights the fact that $20.27 \%$ of the variance of the general level of fiscal pressure is reproduced by the multiple regression model made above.

The model equation is as follows:

TAX_BURDEN $=40.5825961231+0.0554163748857^{*}$ INDIRECT_TAXES + $0.0184862808898^{*}$ DIRECT TAXES

$0.0348608418224^{*}$ GDP GROWTH ANNUAL

$0.0114922596466^{*}$ GROSS_PUBLIC_DEBT

It is highlighted that the probability attached to the Fisher test (F-statistic) is visibly lower than the significance threshold of $5 \%$, which demonstrates that the validity of the multiple regression model is achieved.

As we can see, as the level of indirect taxes increases by one unit, the general level of fiscal pressure will increase by 0.055 percentage points, provided that the other analysis factors remain constant.

As direct taxes increase by one unit, the general level of fiscal pressure will increase by 0.018 percentage points.

Also, as the growth rate of the gross domestic product increases by one unit, the level of fiscal pressure will decrease by 0.034 percentage points, provided that the other factors remain constant.

At the same time, as the level of public debt increases by one unit, the level of fiscal pressure will decrease by 0.011 percentage points, provided that the other factors remain constant.

Next, we tested the normality as well as the homoscedasticity of the residues. 
Table 7: Residual homoscedasticity testing

\begin{tabular}{|c|c|c|c|c|}
\hline & \multicolumn{2}{|l|}{ Value } & df & Probability \\
\hline Likelihood ratio & \multicolumn{2}{|l|}{7.825175} & 7 & 0.3483 \\
\hline Restricted LogL & \multicolumn{2}{|l|}{-477.0647} & 163 & \\
\hline Unrestricted LogL & \multicolumn{2}{|l|}{-473.1521} & 163 & \\
\hline Variable & Coefficient & Std Frror & t-Statistic & Prob \\
\hline C & 40.42510 & 0.596290 & 67.79436 & 0.0000 \\
\hline INDIRECT TAXES & 0.063404 & 0.011456 & 5.534472 & 0.0000 \\
\hline DIRECT_TAXES & 0.010770 & 0.010292 & 1.046462 & 0.2969 \\
\hline GDP_GROWTH_ANNUAL & -0.045429 & 0.138493 & 0.328022 & 0.7433 \\
\hline GROSS_PUBLIC_DEBT & -0.011183 & 0.001608 & $-\overline{6} 954128$ & 0.0000 \\
\hline \multicolumn{5}{|c|}{ WeightedStatistics } \\
\hline R-squared & 0.241432 & F-statistic & \multicolumn{2}{|l|}{12.96961} \\
\hline Adjusted R-squared & 0.222816 & $\begin{array}{l}\text { Prob(F- } \\
\text { statistic) }\end{array}$ & \multicolumn{2}{|l|}{0.000000} \\
\hline Durbin-Watson stat & 0.054272 & & & \\
\hline & \multicolumn{4}{|c|}{$\begin{array}{l}\text { Unweighted } \\
\text { Statistics }\end{array}$} \\
\hline R-squared & 0.195429 & $\begin{array}{l}\text { Mean } \\
\text { dependent } \\
\text { var }\end{array}$ & \multicolumn{2}{|l|}{42.09643} \\
\hline Sum squared resid & 2905.964 & $\begin{array}{l}\text { Durbin- } \\
\text { Watson } \\
\text { stat }\end{array}$ & \multicolumn{2}{|l|}{0.054272} \\
\hline
\end{tabular}

Source: Author's contributions using EViews 7.1

The null hypothesis of this test implies the existence of homoscedasticity at the residue level, while the alternative hypothesis implies heteroskedasticity. The probabilities of the test, which are higher than the significance threshold of $5 \%$, underline the fact that the null hypothesis is accepted, which means that at the level of disturbing factors, the presence of homoscedasticity is noticed.

Next, we will test whether or not the perturbations belong to a normal distribution, using the Jarque-Bera test. Under the null hypothesis, the errors belong to a normal distribution, while the alternative hypothesis suggests that the errors are not part of a normal distribution. 
Table 8: Homoskedasticity testing

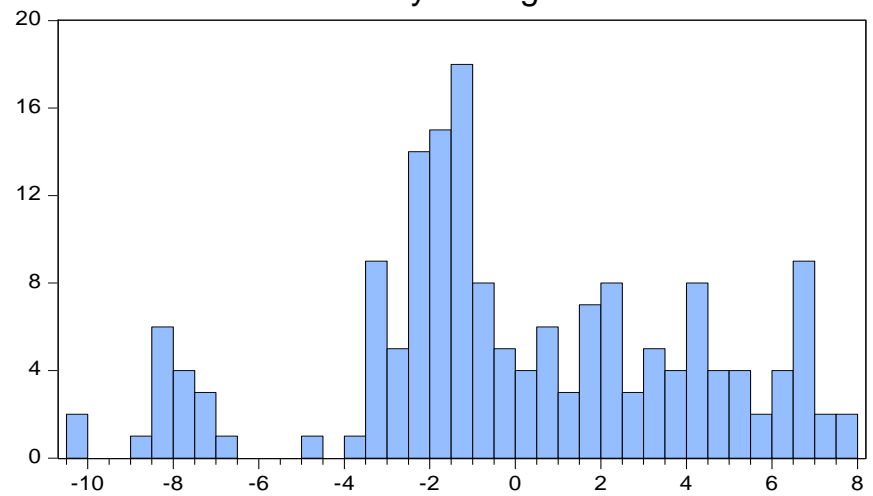

Series: Standardized Residuals Sample 19952018

Observations 168

Mean $\quad 4.04 \mathrm{e}-15$

Median $\quad-0.764265$

Maximum 7.666893

Minimum $\quad-10.38478$

Std. Dev. $\quad 4.152527$

Skewness $\quad-0.215654$

Kurtosis $\quad 2.710339$

Jarque-Bera 1.889508

Probability $\quad 0.388775$

Source: own processing in Eviews 7.1

The Jarque-Bera test is used in econometrics to test whether or not errors are part of a normal distribution. A perfectly normal distribution situation implies the skewness value equal to 0 and the kurtosis value equal to 3 . As long as these two reference values exceed the specified threshold, the obtained errors tend to no longer belong to a customarily destroyed distribution. The default test hypothesis is that the errors are part of a normal distribution. Referring to the significance threshold of $5 \%$, it is observed that the probability of the Jarque-Bera test is higher than the significance threshold of $5 \%$. This fact proves that the test's null hypothesis is admitted, so the errors are part of a normal distribution in the analyzed model.

\section{Conclusions}

Taxing citizens and collecting revenue efficiently is a cornerstone of any governess's training and survival.

The ability to tax citizens and collect revenue efficiently is a cornerstone of the formation and survival of any state and the basic principle of a successful fiscal policy.

According to the literature, it has been found that tax increases hurt economic growth in most states. However, in developed countries, the high level of taxes does not affect economic growth because developed countries have created a long-term environment conducive to new investment areas and are constantly attracting new investors.

Within fiscal policies, an important goal for developing their capacity is to accelerate economic growth, through various taxation systems, without creating a real tax burden on the shoulders of cities because they realize this taxation at a time. Economically favorable. An essential feature in the developed state of fiscal policies is the flexibility of policies, which manages to perfectly harmonize two strategic objectives, between controlling inflation and economic growth.

The final results show that direct and indirect taxes influence the evolution of fiscal pressure. There is a direct relationship between the fiscal pressure and the two variables in the regression model. 
Also, the growth rate of gross domestic product and government debt as the unit increases by one level decreases general fiscal pressure.

In conclusion, the seven states analyzed in the article will have progressive taxes on direct taxes, to the detriment of indirect taxes, and in general, a level of public debt below the average level of the Union.

At the same time, through the multiple regression performed, it was found that we cannot sustain a significant influence between the variables.

Finally, we emphasize that a critical feature in the development of any state depends on the ability of the tax system to generate annual economic growth. This can be achieved through their ability to turn savings into investment resources, to provide support through administrative reforms aimed at start-ups, and to provide financial peace to companies in times of stalemate.

\section{References:}

1. Adriana Elena Porumboiu, Ionela Butu, Raluca Ghetu, Petre Brezeanu (2020) REVERSE CHARGE AND VAT GAP - A MECHANISM TO TACKLE INTRACOMMUNITY VAT FRAUD, Strategica - International Academic Conference, vol. VIII, nr. I, pg. 396-412, ISSN 2734-746X;

2. Arnold, J. M. (2008). Do Tax Structures Affect Aggregate Economic Growth? OECD Economics Department Working Papers,1-29, Do Tax Structures Affect Aggregate Economic Growth?: Empirical Evidence from a Panel of OECD Countries I READ online (oecd-ilibrary.org).

3. Bernasconi, M., Corazzini, L., \& Seri, R. (2014). Reference dependent preferences, hedonic adaptation, and tax evasion: Does the tax burden matter? Journal of Economic Psychology, 103-118, DOl:10.1016/j.joep.2013.01.005;

4. Brezeanu P. Fiscalitate. Concepte. Metode. Practici, Editura Economică, Bucureşti, 1999;

5. BREZEANU, (2009) P.Fiscalitate: concepte, teorii, politici şi abordări practice. Bucureşti: Ed. WoltersKluwer;

6. Chaney, B. A. (2002). The effect of fiscal stress and balanced budget requirements on the funding and measurement of state pension obligations. Journal of Accounting and Public Policy, 287-313, https://EconPapers.repec.org/RePEc:eee:jappol:v:21:y:2002:i:4-5:p:287-313;

7. Charles E. McLure Jr."Taxation".Britannica. Retrieved 3 March 2015.

8. Chen, G. M. (2021). Costs and liabilities of U.S. public pension systems in a lowreturn environment. Journal of Pension Economics and Finance, 20(2), pages 169186, DOI: 10.1017/s147474721900043x;

9. Eaton, T. V. (2004). The effect of financial constraints and political pressure on the management of public pension plans. Journal of Accounting and Public Policy, 161-189, The effect of financial constraints and political pressure on the management of public pension plans - ScienceDirect;

10. I Talpoş, C Enache (2001), Carta Europeană a Autonomiei Locale, Timisoara; 11. Mara, E. \&. (2011). Fiscal Policy Impact on Inflation Volatility in Romania in The. Finante - provocarile viitorului/Finance - Challenges of the Future., 1 (13), 181-187, 013-24.pdf (ucv.ro).

12. Matloja, L. M. (2016). Changes in the optimal tax rate in South Africa. Munich

Personal RePEc, pages 1-20, https://mpra.ub.uni-muenchen.de/id/eprint/74342. 
13. McNabb, K.; LeMay-Boucher, Ph. (2014): "Tax Structures, Economic Growth and Development", Working Paper 22, www.ictd.ac, pp. 1- 3;

14. Nguyen uu Cung and Liu Hua (2013). "Tax Burden and Foreign Direct Investment: Theor and practice in Vietnam". Advances in Management and Applied Economics, vol., no., pp.85-103;

15. Nguyen uu Cung and Nguyyen Ti ong Nhung (2020). ," Impact of Economic Freedom and Corruption Perceptions Index on Foreign Direct Investment in Vietnam". European Scientific Journal, Vol 16, No. 7, 2020, pp:25-37;

16. Roberta Romano (1993). PUBLIC PENSION FUND ACTIVISM IN CORPORATE GOVERNANCE RECONSIDERED, COLUMBIA LAW REVIEW, Public Pension Fund Activism in Corporate Governance Reconsidered (yale.edu);

17. Ruesga, J. V. (2016). Economic sustainability and possibilities of action for the states, in the case of monetary integration: some notes for reflection, https://www.inderscienceonline.com/doi/abs/10.1504/PIE.2016.078078;

18. Sconac, N. K. (2021). Tax burden and economic growth in Lesotho: An estimate of the optimal tax burden. GrowingScience, 525-534, DOI: 10.5267/i.ac.2021.1.006.

19. Vasiliauskaitè, A., \& Stankevičius, E. (2009). ax burden management and GDP growth: A case of E.U. countries. Ekonomika ir vadyba, 14, 202-209, https://www.lituanistika.lt/content/22347.

20. Zachary, T. \&. (2014). Causal Relationship between Government Tax Revenue Growth and Economic growth: A case of Zimbabwe. Journal of Economics and Sustainable Development., 40-59, http://hdl.handle.net/11408/1225. 


\title{
THE RELATIONSHIP BETWEEN VAT GAP AND ECONOMIC OR INSTITUTIONAL VARIABLES
}

\author{
Ionela BUTU1, Petre BREZEANU², Adriana PORUMBOIU1, Sorina Emanuela \\ ȘTEFONI ${ }^{1}$ \\ ${ }^{1}$ Doctoral School of Finance, Bucharest University of Economic Studies, Bucharest, \\ Romania \\ 2Phd Professor, Department of Finance, Bucharest University of Economic Studies, \\ Bucharest, Romania \\ ionela butu@yahoo.com \\ petre.brezeanu@fin.ase.ro \\ adriana porumboiu@yahoo.com \\ stefonisorina@gmail.com
}

Abstract: VAT evasion reduces significantly the budget revenues and is often approximated by way of VAT Gap, which refers to the difference between the total VAT that should have been collected according to the applicable VAT Law (VTTL) and VAT actually collected by public budgets. The phenomenon of VAT Gap, to a greater or lesser extent, is an acute problem in all countries of the European Union (Member States), regardless of their level of economic development. Over the past two decades, the volume of VAT evasion has had an alarmingly upward trend. Therefore, the VAT Gap should be placed in a broader context than the economic one, also taking into account economic structure, institutional variables, legal, ethical and other dimensions that affect the business environment, respectively the society. Moreover, according to the World Economic Outlook "Growth and Institutions" (2003) IMF report, the institutional factor, as a general and defining arrangement for any economic system, it is the primary "responsibility" of gap development. The objective of this study is to analyse the strength and direction of the relationship between the VAT Gap and the following economic structure and institutional variables: Fiscal Freedom (FF), Government Effectiveness (GE), Human Development Index (HDI), Corruption Perceptions Index (CPI) and People at risk of poverty or social exclusion (AROPE). Our study is consolidated on a 2009 - 2018 database, for the EU-26 Member States, including United Kingdom, divided into four groups. Within the study, we developed a Spearman Correlation between VAT Gap and each variable, aiming to point up whether these variables have a strong positive or negative influence on the VAT Gap.

Keywords: VAT Gap; fiscal freedom; government effectiveness; human development; corruption; social aspects.

JEL Classification: E26; G41; H11; H26.

\section{Introduction}

Taxes represent the largest share of the state budget revenues, whose main purpose is to finance public goods and services and, widely, to help strengthen 
society. Therewith, the appearance of taxes, gave rise to other phenomenon, both economic and social, namely, tax evasion. Among these taxes, a significant proportion has the Value Added Tax (hereinafter only as VAT), therefore the focus of this paper will be on VAT.

Tax evasion refers both to direct and indirect taxes, but the causes are the same for both. So, the causes of tax evasion and avoidance are various, starting from general to causes specific to a certain economic period, or they can be causes of social, economic, moral, or political nature (Comandaru, 2018). Moreover, have been empirically identified other major causes of this phenomenon such as the complexity of the entire tax system and the intensity of government regulation (Shahini, 2015).

The tax system is composed of a set of taxes, but VAT is considered one of the most significant sources of government revenue globally. Moreover, the countries of the European Union stand out by above average government expenditure in terms of VAT contribution to government revenue. Therefore, VAT has become a main element of the tax system, both in developed and developing countries.

VAT evasion reduces significantly the budget revenues, and it may be approximated by way of VAT Gap, which refers to the difference between the total VAT that should have been collected according to the applicable VAT Law (further only as VTTL) and VAT actually collected by public budgets. It estimates revenue loss from fraud schemes, VAT evasion and avoidance, as well as due to bankruptcies, financial insolvencies or miscalculations. Fraud is considered the main cause of VAT Gap (European Commission, 2020).

Over the past two decades, the volume of VAT evasion has had an alarmingly upward trend. Furthermore, the most recent report provided by the European Commission (2020) indicates that at EU level, VAT Gap amounted to EUR 140 billion, which means $11.01 \%$ of the theoretical VAT liability, in 2018. The report also predicts a potential increase of VAT revenue losses in 2020 to $€ 164$ billion in 2020, due to the effects on the global economy of the coronavirus pandemic (European Commission, 2020). More than that, we can assert that VAT revenues are directly influenced by the VAT Gap. The lower the VAT Gap, the higher the rate of VAT revenue collection.

Thus, this paper will include the following: the main findings on this matter in the literature (Chapter 2 Review of the literature), the assumptions of our study and the variables used (Chapter 3 Aims of the research and defining the variables), the methods used together with our outcomes (Chapter 4 Research methods and results) and the conclusions (Chapter 4 Conclusion).

\section{Literature review}

Studies have empirically examined the factors that affect the collection of VAT revenues. Christie and Holzner (2006) investigated for the period 2000-2003 VAT losses in 25 European countries and highlighted a positive influence of the weighted average VAT rates on VAT losses. Other studies have pointed out that the efficiency of the collection of VAT systems decreases with the increase of tax rates and due to the reduction of the tax base on which it is applied and the increase of tax evasion (Agha and Haughton, 1996; Matthews, 2003).

Reckon (2009) assessed the estimates of the VAT Gap for EU countries. His study showed that the variables Corruption perceptions index (CPI) and the position of 
the legal institutions in the country have a statistically significant value in influencing the VAT Gap. Wider studies on the VAT Gap are provided by European Commission CASE studies (2020), using an econometric analysis that regressed the VAT Gaps on several explanatory variables in EU countries. The results showed that the tax collection gap is also influenced by the efficiency of governments in the management of the application of the tax in each country.

Zidkova (2014) analysed the impact of fifteen variables on the VAT Gap for the year 2002, respectively for the year 2006. The results showed that in 2006, contrary to the results for 2002, VAT Gap was not influenced by the standard VAT rate and the share of the shadow economy.

According to the World Economic Outlook "Growth and Institutions” (2003) IMF report, the institutional factor, as a general arrangement for any economic system is the primary "responsibility" of gap development. Furthermore, VAT productivity varies considerably from country to country in terms of revenue growth.

\section{Aims of the research and defining the variables}

The objective of the study is to analyse the strength and direction of the relationship between the VAT Gap and the following economic structure and institutional variables: Fiscal freedom (FF), Government effectiveness (GE), Human Development Index (HDI), Corruption Perceptions Index (CPI) and People at Risk of Poverty or Social Exclusion (AROPE). We are expecting a negative relationship between VAT Gap with FF, GE, HDI and CPI and a positive one with AROPE.

Next, we will present the target groups of countries and the variables used..

\subsection{Groups of countries}

There are significant differences in the profile of the informal sector and economic development levels beyond the various regions of Europe (The World Bank, 2012a). Regardless of the importance of VAT revenues in countries' budgets, the VAT Gap is part of the informal sector and the goal is to minimize its value. Moreover, according to Văcărel (2007) most of the developed countries are focused more on direct taxes, while indirect taxes are more specific to the budget revenues of less developed countries or emerging countries (Butu et al., 2019).

Also, Dronca (2016) distinguished into four different development level groups, depending on fiscal behaviour in the European Economic Area.

Considering the findings of the authors as presented in the previous paragraph, for the hereby study we divided the Member States in four groups, using as criteria two coordinates regarding the approach from the fiscal perspective and their level of development represented by GDP per capita:

- Southern Member States: Cyprus, Greece, Italy, Malta, Spain, and Portugal;

- Northern Member States: Sweden, Denmark and Finland;

- Central-Eastern Member States: Bulgaria, Croatia, Hungary, Romania, Latvia, Lithuania, Estonia, Czech Republic, Slovakia, Slovenia and Poland;

- Western Member States: France, Germany, Great Britain, Ireland, Luxembourg, Belgium, Netherlands, Austria.

In the following, we will present the main variable, VAT Gap, and in brief the economic structures and institutional variables. 


\subsection{Variables}

\subsubsection{VAT Gap}

VAT evasion reduces significantly the budget revenues, and it may be approximated by way of VAT Gap, which refers to the difference between the total VAT that should have been collected according to the applicable VAT Law (VTTL) and VAT actually collected by public budgets. It estimates revenue loss on account of fraud schemes, VAT evasion and avoidance, as well as due to bankruptcies, financial insolvencies or miscalculation, but fraud is considered the main cause of VAT Gap (European Commission, 2020).

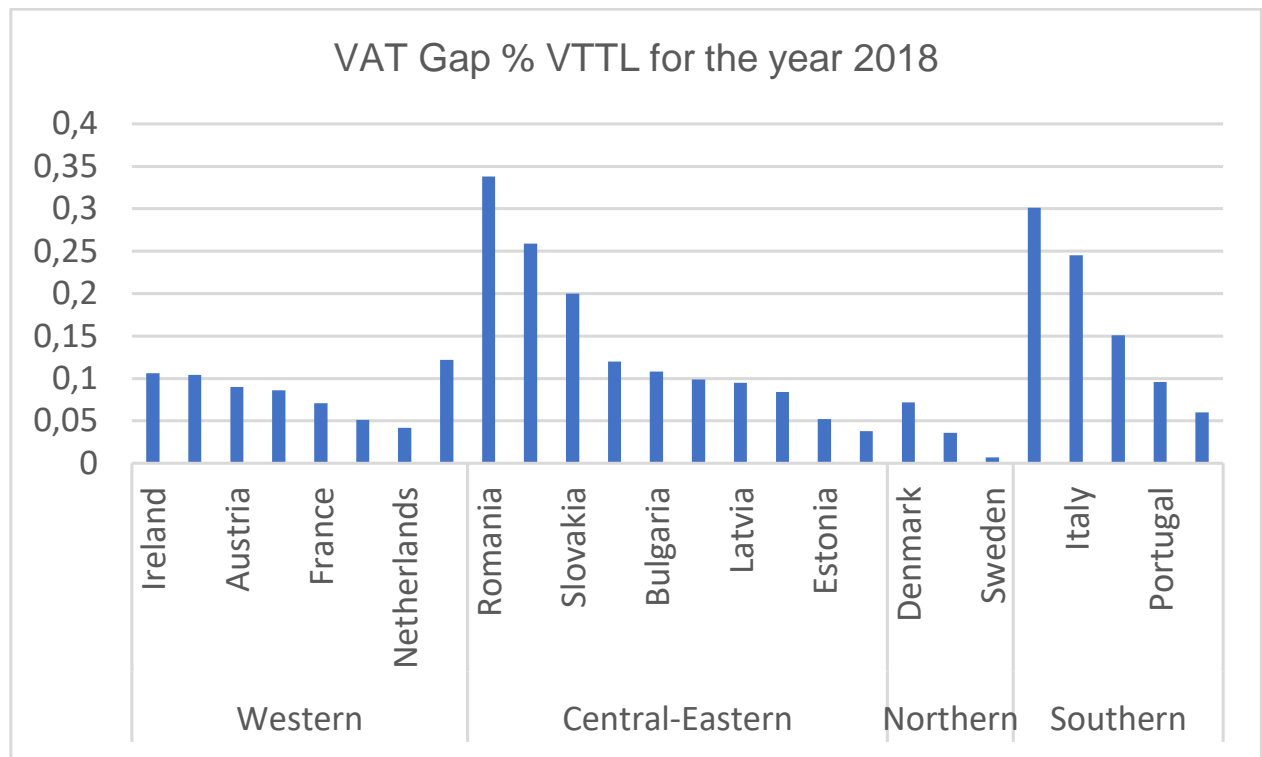

Figure 1: VAT Gap in the four groups of European countries for the year 2018.

Source: own compilation based on Study and Reports on the VAT Gap in the EU28 Member States, Final report, 2020

The first remark we can make from Figure 1 is that the Central-Eastern countries, which is composed of the "new" Member States, had higher levels of the VAT Gap compared to the "old" European Union states. Thus, we can observe an increase in the size of the VAT Gap from west to east. The values of VAT Gap are topped by Romania, a Central-Eastern country, which in 2018 recorded $33.80 \%$ VAT Gap of VTTL, followed by Greece, which is part of the Southern group. Even though 30 years have passed since the transition to democracy and the market economy, the shadow economy, which includes the VAT Gap is more widespread in the Central and Eastern European Member States, in comparison to the Western and Northern countries. Thus, it is not surprising that in the Nordic group, which includes developed countries, was registered the lowest percentage of VAT Gap in VTTL, in Sweden, $0.70 \%$. In addition, we observe an increasing trend in the VAT Gap from North to South. From an economic point of view, the countries of southern Europe 
face the problem of regional disparities. This is confirmed by the large differences between the VAT Gap values. While in Greece the VAT Gap \% of VTTL exceeds $30 \%$, in Spain the VAT Gap is only $6.00 \%$ of VTTL.

\subsubsection{Economic structure and institutional variables}

Regarding the quantification of economic and institutional background, we selected a series of indicators, taking into account both the directions presented in the previous chapter related to the literature, but also our novelty, as we chose a series of indicators that have not been studied in this embodiment and for these groups of countries, as per our research in the field. Table 1 highlights the variable and its acronym, the short description and the source of the variables, as well as the expected sign of the relationship.

Table 1: Definition of the variables

\begin{tabular}{|c|c|c|}
\hline $\begin{array}{l}\text { Variables } \\
\text { (Acronym) }\end{array}$ & Short description & $\begin{array}{l}\text { Source / } \\
\text { Expected } \\
\text { sign }\end{array}$ \\
\hline $\begin{array}{l}\text { Fiscal freedom } \\
\text { (FF) }\end{array}$ & $\begin{array}{l}\text { measures economic freedom using } 12 \\
\text { quantitative and qualitative factors. }\end{array}$ & $\begin{array}{l}\text { Heritage } \\
\text { Foundation / }\end{array}$ \\
\hline $\begin{array}{l}\text { Government } \\
\text { effectiveness } \\
\text { (GE) }\end{array}$ & $\begin{array}{l}\text { reflects the perceptions of the quality of } \\
\text { public services, the quality of the civil } \\
\text { service and the degree of its independence } \\
\text { from political pressures, the quality of the } \\
\text { policy and its implementation, and the } \\
\text { credibility of the government's commitment } \\
\text { to such policies. }\end{array}$ & $\begin{array}{l}\text { World Bank / } \\
\text { - }\end{array}$ \\
\hline $\begin{array}{l}\text { Human } \\
\text { development } \\
\text { index (HDI) }\end{array}$ & $\begin{array}{l}\text { is a summary measure of average } \\
\text { achievement in three key dimensions of } \\
\text { human development in a given country: } \\
\text { health, education and income. }\end{array}$ & $\begin{array}{l}\text { United } \\
\text { Nations } \\
\text { Development } \\
\text { Programme / }\end{array}$ \\
\hline $\begin{array}{l}\text { Corruption } \\
\text { perceptions } \\
\text { index (CPI) }\end{array}$ & $\begin{array}{l}\text { is a composite index, based on the results } \\
\text { of surveys of corruption, collected by } \\
\text { several respectable institutions. It ranks } \\
\text { countries based on how corrupt a country's } \\
\text { public sector is perceived to be by experts } \\
\text { and business executives. Less corruption } \\
\text { perceived is associated with higher values. }\end{array}$ & $\begin{array}{l}\text { Transparency } \\
\text { International / } \\
-\end{array}$ \\
\hline $\begin{array}{l}\text { People at risk of } \\
\text { poverty or social } \\
\text { exclusion } \\
\text { (AROPE) }\end{array}$ & $\begin{array}{l}\text { refers to the sum of persons who are: at risk } \\
\text { of poverty after social transfers, severely } \\
\text { materially deprived or living in households } \\
\text { with very low work intensity. }\end{array}$ & $\begin{array}{l}\text { Eurostat } \\
\text { database /+ }\end{array}$ \\
\hline
\end{tabular}

Source: adapted by authors based on public databases 


\section{Research methods and results}

In order to analyse the relationship between the VAT Gap and the economic structure and institutional variables, it was developed a Spearman Correlation that takes into account the data for 28 European Union Member States, divided into four groups. Due to lack of national data, we excluded Cyprus and Croatia, but we included United Kingdom, because in the period analysed it was still a Member State. The analysis considers 9 years, more precisely the period after the financial crisis, 2009-2018.

Correlation is a bivariate analysis that appraises the strength of the association between two variables and the direction of the relationship (Kendall and Stuart, 1973). In terms of the strength of association, a value of 0 indicates that there is no relationship, whereas a value of \pm 1 indicates a perfect correlation. Regarding the direction of the relationship, a positive sign indicates a direct relationship and the variables vary together, while a negative sign indicates an inverse relationship between the variables.

Table 2 lays out the results of running the Spearman Correlation for the four groups of European countries, between VAT Gap with each variable, as well as for the 26 European Union countries.

Table 2: Spearman correlation coefficients between VAT Gap with each variable

\begin{tabular}{|l|l|l|l|l|l|}
\hline $\begin{array}{l}\text { Countries } \\
\text { group }\end{array}$ & \multicolumn{4}{|l}{$\begin{array}{l}\text { Relation between VAT Gap \% of VTTL and economic structure and } \\
\text { institutional variables }\end{array}$} \\
\hline & FF & GE & HDI & CPI & AROPE \\
\hline EU & $-0.454^{* *}$ & 0.015 & $-0.701^{* *}$ & $-0.752^{* *}$ & $0.628^{* *}$ \\
\hline Western & 0.086 & -0.180 & 0.076 & $-0.322^{* *}$ & $0.597^{* *}$ \\
\hline $\begin{array}{l}\text { Central- } \\
\text { Eastern }\end{array}$ & -0.117 & -0.041 & $-0.666^{* *}$ & $-0.461^{* *}$ & $0.507^{* *}$ \\
\hline Northern & $0.601^{* *}$ & $-0.813^{* *}$ & -0.242 & $0.527^{* *}$ & -0.188 \\
\hline Southern & $-0.514^{* *}$ & -0.121 & -0.122 & $-0.697^{* *}$ & 0.253 \\
\hline
\end{tabular}

Source: Author's own processing using SPSS

Note: ${ }^{* *}$ Correlation is significant at the 0.01 level (2-tailed).

From Table 2 we can notice that at EU level, excepting Government effectiveness, all the coefficients of the variables had the expected sign and they are statistically relevant. Regarding the strength of the relationship, we can observe a relatively strong connection between VAT Gap and the variables, excepting GE.

Regarding Government effectiveness, the results show a negative relationship between VAT Gap and GE in all four groups of countries. Therefore, increasing the level of GE, by providing quality public services, transparency in public spending and investments in strategic areas determines decreases in the VAT Gap. Besides, the highest significant connection strength $\left(-.813^{\star *}\right)$ is found in the Northern group. This is not surprising, considering the Nordic countries generally had high values of GE in 2018 and have a balanced economic system that determines a high effectiveness of the governance process. In other words, countries with higher quality public services and higher transparency in public spending can tackle VAT evasion, which will reduce the VAT Gap. 
Unlike the four groups of countries, at EU level, there is a positive relationship between VAT Gap and Government effectiveness, but we have to consider that the value of its probability is not statistically relevant. This suggests that improving Government effectiveness increases the level of VAT Gap, which does not fold to reality. In this field, other studies suggested that in the countries with a high level of GE expressed through the perceptions of citizens on the quality of public services, the quality of the civil service, and the degree of its independence from political pressures will reduce tax evasion (Dronca, 2016; Ștefoni and Drăghia, 2020).

The variables Fiscal freedom (FF) and Human development index have had the same direction of influence on VAT Gap, excepting the Northern group. The coefficients of FF and HDI had an opposite direction at EU level and for "CentralEastern" and "Southern" groups and, contrary to our expectations, a positive sign for the Western group.

Even though FF and HDI had opposite directions of correlation coefficients at EU Level, for "Central-Eastern" and "Southern" countries, the strength of the correlation is stronger and significant for the last group in the case of FF $\left(-.514^{* *}\right)$, respectively, in case of $\mathrm{HDI}$, for "Central-Eastern" group $\left(-.666^{\star *}\right)$, that generally includes developing countries. Thus, in countries which are working progressively to achieve (1) high levels of FF transposed through quantitative and qualitative factors like tax burden, fiscal health, property rights, investment or financial freedom and (2) high level of standard of living and literacy, increased life expectancy, taxpayers are more likely to pay VAT, thus leading to the reduction of the VAT Gap.

Regarding the Corruption Perceptions Index variable, the results showed that excepting the "Northern" group, CPI had opposite direction of significant correlation coefficients for all groups of countries and at EU level, as was expected. In terms of strength of association, there is a low connection in the Western group $\left(-.322^{* *}\right)$, a medium one in the Central-Eastern group $\left(-.461^{\star *}\right)$ and Northern group $\left(.527^{\star *}\right)$, a strong one in the Southern group $\left(-.697^{* *}\right)$ and the highest value of the coefficient was registered at EU level $\left(-.752^{* *}\right)$. This suggests the importance of CPI on VAT Gap levels. Thus, at EU level, less corruption is perceived by experts and business executives, which means a higher CPI index, would lead to a reduced VAT Gap by increasing the efficiency of VAT collection.

On the other hand, there is a positive relation in the Northern countries, which means that when less corruption is perceived, the VAT GAP will increase, which may not always fold to reality. One explanation can be that the Northern States (Sweden, Denmark and Finland) are part of the most developed countries in terms of the value of gross domestic product per capita and are focused more on direct taxes than on VAT.

The coefficients of people at risk of poverty or social exclusion (AROPE) had the positive expected direction at EU level and for all groups of countries, excepting the "Northern" group. Even if we expect a strong positive relationship, there is a low opposite connection strength $(-0.188)$ in the "Northern" group. One explanation may be that the Northern group is made up of the most developed Member States at European level, with the lowest number of people at risk of poverty or social exclusion, and this variable will not influence the VAT Gap.

It is notable that the strength of association is also significant and above the average at EU level $\left(.628^{* *}\right)$, for the Western" $\left(.597^{* *}\right)$ and "Central-Eastern" $\left(.507^{\star *}\right)$ groups. This suggests that especially in these two groups, the variable 
People at risk of poverty or social exclusion can be treated as a significant element in assessing the VAT Gap level. Thus, in countries with a higher number of people at risk of poverty after social transfers, severely materially deprived or living in households with very low work intensity, the tendency to avoid paying VAT is higher, so VAT Gap will register wider levels.

To sum up, although the results between different groups of Member States may be dissimilar for the reasons set out in this section and the correlation dependency is coarse in strength and direction, we believe that the trends will harmonize in the future, when almost all the Member States are going to reach the appropriate levels of economic development.

\section{Conclusions}

As per the literature, it is stated that the fiscal and budgetary policies of states, as well as the effectiveness of the institutions have a significant role in defining the aspects of the economic environment in order to have a high degree of VAT collection, thus a lower VAT Gap. The results of this paper show that at EU level, increasing the level of Fiscal Freedom, Human Development Index and Corruption Perceptions Index are correlated with decreasing the values of VAT Gap.

Furthermore, after analysing the results of the Spearman correlations, we can conclude that in the groups that include developing countries, the results are as expected. In Central-Eastern and Southern groups of countries, there is a reverse connection between VAT Gap and the following variables: Fiscal freedom (FF), Government effectiveness, Human development index (HDI), Corruption perceptions index $(\mathrm{CPI})$ and a direct connection between VAT Gap and People at risk of poverty or social exclusion (AROPE). In terms of strength of the connection, while for the Central-Eastern that includes mostly developing countries, it was found a strong and significant connection between VAT Gap and HDI, for the Southern group, there is a strong and significant connection between VAT Gap and CPI.

On the other hand, contrary to the expected signs, in the Northern group, which is made up of the most developed Member States, there is a direct connection between VAT Gap and the following variables: Fiscal freedom (FF) and Corruption perceptions index (CPI).

Thus, our study shows that in the countries (1) with a high level of freedom in terms of tax, transposed through quantitative and qualitative factors like, tax burden, fiscal health, property rights, investment or financial freedom, (2) with an increased value of $\mathrm{HDI}$, translated through a high level of standard of living and access to knowledge and (3) with less corruption perceived by experts and business executives, the taxpayers are more inclined to comply with the VAT requirements. Their determination to comply will be reflected in a lower VAT Gap.

Moreover, the level of GE and the number of people at risk of poverty or social exclusion increase or decrease in the same direction as the level of VAT Gap, with reservations regarding GE, because its $p$-value is not relevant, in our study presented hereby. In countries with a higher number of people at risk of poverty after social transfers, severely materially deprived or living in households with very low work intensity, the tendency to avoid paying VAT is higher, so the VAT Gap will register wider levels. 
Although the results between different groups of Member States are contradictory and the correlation dependency is different in strength and direction, it can be said that the trends will harmonize in the future, when almost all the Member States reach the appropriate levels of competition and economic development.

In conclusion, as VAT has a relevant contribution to the financing of public goods and services, this relationship between VAT Gap and economic structure and institutional variables is relevant for economic development and institutional quality of the business environment and it can be further studied in studies elaborated for other groups of European countries and a longer period of time.

\section{References}

1. Agha, A. and Haughton J. (1996) "Designing Vat Systems: Some Efficiency Considerations," The Review of Economics and Statistics, Vol. 78, No. 2 pp 303308. https://www.jstor.org/stable/2109932.

2. Butu, I., Brezeanu P. and Ghețu, R. (2020) Reverse Charge and VAT Gap - A Mechanism to Tackle Intra-Community VAT Fraud, Strategica International Academic Conference - the 12th international management conference Strategica Preparing for Tomorrow, Today, October 15-16, Bucharest, Romania, pp 396-410.

3. Butu, I., Brezeanu P., Porumboiu, A., Ghețu R. (2019) "Theoretical Considerations on VAT Structure Rates in the European Union", FinanceChallenges of the Future, pp 54-61.

4. Christie, E. and Holzner, M. (2006) What explains tax evasion? An empirical assessment based on european data. wiiw Working Papers 40.

5. Comândaru, A. (2018) "The phenomenon of tax evasion and the need to combat tax evasion", The Journal Contemporary Economy, Vol. 3, Issue 3, pp 124-133.

6. Dronca, A. T. (2016) "The influence of Fiscal freedom, Government effectiveness and Human development index on tax evasion in the European Union", Theoretical and Applied Economics, Vol. XXIII, No. 4, pp 5-18.

7. European Commission (2020) Study and Reports on the VAT Gap in the EU-28 Member States, Final Report 2020, Center for Social and Economic Research (CASE) \& Institute for Advanced Studies [Online], Available: https://ec.europa.eu/taxation customs/system/files/2020-09/vat-gap-full-report2020 en.pdf [01 Nov 2021].

8. International Monetary Fund, (2003) World Economic Outlook, „Growth and Institutions". [Online],

Available: https://www.imf.org/en/Publications/WEO/Issues/2016/12/31/Growth-and-

Institutions [01 Nov 2021].

9. Kendall, M. G.; Stuart, A. (1973). The Advanced Theory of Statistics, Volume 2: Inference and Relationship, Sections 31.19, 31.21.

10. Mankiw, N.G., Weinzierl, M. and Yagan, D. (2009) "Optimal Taxation in Theory and Practice", Journal of Economic Perspectives, American Economic Association, Vol. 23, No 4, pp. 147-74.

11. Matthews, K. (2003) "VAT Evasion and VAT Avoidance: is there a European Laffer curve for VAT?" International Review of Applied Economics, Vol. 17, pp 105114. 
12. Reckon, LLP. (2009) Study to quantify and analyse the VAT Gap in the EU-25 member states. European Commission, Directorate-General for Taxation and Customs Union.

13. Shahini L. and Malaj A. (2015) "How can We Measure the VAT Fraud and Evasion? Case of Albania", European Journal of Economics and Business Studies Articles, Vol. 1, May - Aug.

14. Ștefoni, S. E. and Drăghia, A. (2020) "Impact of education and government effectiveness on the shadow economy", Theoretical and Applied Economics, No 3.

15. The World Bank (2012a). Doing Business 2012: Doing business in a more transparent world. Comparing regulation for domestic firms in 183 economies. [Online], Available: http://www.doingbusiness.org/reports/global-reports/doingbusiness-2012 [01 Nov 2021].

16. Văcărel, I. and the group (2008). Public Finance, Bucharest, Didactic and Pedagogical Publishing House.

17. Zidkova, H. (2014) "Determinants of VAT Gap in EU", Prague Economic Papers, Vol. 4, pp 514-530. 


\title{
COMPARATIVE ANALYSIS OF VALUE ADDED INTELLECTUAL CAPITAL AT SMALL AND MEDIUM ENTERPRISES
}

\author{
Tibor TARNÓCZI ${ }^{1}$, Edina KULCSÁR ${ }^{1}$ \\ ${ }^{1}$ Partium Christian University, Faculty of Economics and Social Science, \\ Department of Economics, Oradea, Romania \\ tarnoczi.tibor@partium.ro \\ kulcsar.edina@partium.ro
}

\begin{abstract}
Today, rapid and unpredictable changes in the economy, globalization, the technical revolution, competition intensification, the reviving of the service industry required rethinking the concept of corporate competitiveness. An important determinant of corporate successfulness consists in that knowledge and adequate information which positively contribute to the corporate value creation. Those intangible capital elements that play a crucial role in sustainable corporate value creation are intellectual capital. The knowledge, skills and competencies of managers and employees customer relations, the company's organizational structure are the main components of intellectual capital. Today, the software and the knowledge-based economies support the fact that the importance of intellectual capital has been growing in all sectors of the economy. The main aim of this study is to investigate the relationship between intellectual capital and corporate performance. To these, we carried out a comparative analysis of value added by intellectual capital for companies acting in different sectors from two neighbouring counties from Romania (Bihor) and Hungary (Hajdú-Bihar). The analysis is based on the financial statements for five years (2014-2018) of companies operating in agriculture, construction, manufacturing, wholesale trading, retail trade and transportation. We used the Value Added Intellectual Coefficient (VAIC) from Scorecard Methods as a measurement of intellectual capital. The investigation of the relationship between firms' performance and intellectual capital was performed using panel regression, where the established dependent variables were Operating Return on Assets (OROA), Operating Return on Sales (OROS) and the explanatory VAIC components: HCE, SCE, CCE. In the case of Romanian companies, a medium-strong correlation can be observed between OROA and VAIC components. In the case of Hungarian firms also a medium-strong correlation can be observed between OROS and VAIC components.
\end{abstract}

Keywords: intellectual capital, corporate value creation, human capital, customer capital, structural capital

Jel Classification: G3, G30, G32, O3, O30, O34

\section{Introduction}

Today, the economies become software and service-based moreover. Therefore the competitiveness of the industrial era was replaced by information competitiveness. Rapid and unpredictable changes in the economic environment, globalization, and competition's intensification required rethinking and 
reinterpretation of corporate competitiveness as a concept. Nowadays, the main determinants of corporate competitiveness are knowledge and adequate information. To become successful, companies should possess and adequately manage the knowledge by which the validation of core organizational competencies contributes to corporate value creation. The importance of these intangible capital elements has intensified in the recent year and becomes determinants of corporate competitive advantage strategically. The appropriate knowledge management, as a task, selects stores, packages, and communicates relevant information that influences corporate success to increase corporate performance and competitiveness (Bergeron, 2003). The sum of these intangible and non-financial capital elements possessed by a company and by which adequate management, company achieve sustainable competitive advantage is called intellectual capital. Among the elements of intellectual capital, we usually mention the totality of knowledge, skills and competencies possessed by employees and company managers. The customer capital and the efficient operational structures and information systems within the organization are also part of intellectual capital.

Besides gaining a competitive advantage, its long-term sustainability is also essential, so continuous monitoring of these intangible capital elements and examining their effects on corporate value creation becomes a vital function in the various life cycles of a company. An important task in knowledge management consists of quantifying and effectively managing the value added by intellectual capital. The definition and contents of intellectual capital and its proper measurement differ from author to author, therefore it is relatively difficult for an analyst to select the most appropriate method for research purposes (Chang and Hsieh, 2011). This study aims to carry out a comparative analysis of the value added of intellectual capital for companies operating in two different counties of Central and Eastern European countries (Romania and Hungary). The decomposing of intellectual capital into elements permits to compare the main factors that determine the value added of intellectual capital. It is also clear that the role of intellectual capital and the weight of its components may differ by sector in which the company is acting. Based on these, we also group the corporate's samples by different sectors to investigate the characteristics of the companies operating in each sector of economy in terms of intellectual capital. As we read in several articles dealing with intellectual capital, the relationship between intellectual capital and corporate performance and sustainable competitiveness is indisputable (Clarke et al., 2011; Chen et al., 2005, Chan, 2009, Bayraktaroglu et al., 2019). The main aim of this article is to investigate the relationship between intellectual capital and corporate performance.

\section{Review of literature}

In recent decades, increasingly significant differences between the book value and the market value of companies justify changes in the distribution of factors determining corporate value. A short time ago, the corporate value determinants were tangible elements, which can be shown in firms' balance sheet (machine, equipment, buildings), nowadays this is no longer typical. While the average book value of S\&P 500 companies averaged $95 \%$ of the market value in 1978, today, this ratio barely reaches $20 \%$ (Juhász, 2004, p. 5). According to Baruch Lev (2004) 
a skilled and experienced workforce, know-how, software, customer relationships, brand, unique organizational processes, models means more than half of the market capitalization of companies operating in the US. This lag can be explained by the increasing proportion and role of these intangible capital elements, which are not included in the firms' financial statement. Their role in knowledge-based economies has become increasingly important. Intellectual capital, as a concept, can be linked to Leif Edvinsson, who used it firstly in 1993 instead of the terminology of intangible assets.

However, these resources, which do not take material-physical or monetary form, extremely valuable to the company in term of corporates' value creation are called intellectual capital (Kaufmann - Schneider, 2004). According to Gu and Lev (2001), the intangible resources themselves do not represent value for a firm only if they contribute to the active processes of corporate value creation. In their opinion, the R\&D, marketing and advertising activities and the company's HR and IT practices are considered critical value-creating determinants (Harangozó, 2007). According to Edvinsson and Malone (1999), intellectual capital is "information and knowledge that serve to create value". Both Brennan and Connel (2000) and Edvinsson and Sullivan consider that intellectual capital is the totality of knowledge-based assets in a firm. However, according to Edvinsson and Sullivan, organizational knowledge can be considered intellectual capital, which can be converted into value (Pfeil, 2004). According to Hunter et al. (2005), knowledge-based assets not included in the financial statements that can be converted into profit can be considered intellectual capital.

The definition of intellectual capital, as an economic variable, is based on the difference between a corporate's book value and market value (Maditinos et al., 2011). By analyzing the definitions mentioned above, it can be stated that common features of intellectual capital include knowledge and the ability to create value (Vishnu and Gupta, 2014). In term of the main components of it, the intellectual capital varies from author to author. Black et al. (2001) argue that intellectual capital consists of the following components: innovation capital, structural capital, market capital, and goodwill. Kaplan and Norton (2005) consider human skills, talent, information systems, infrastructure and organizational capital elements as culture, leadership, teamwork as main components of intellectual capital. One of the best known and most widespread definitions of the elements of intellectual capital was developed by Edvinsson. In his view, intellectual capital consists of two main components: human capital and structural capital. It divides structural capital into two other parts, customer capital and organizational capital. Three components of intellectual capital are mentioned in the international literature: human capital, customer capital, and organizational capital (Sveiby, 2001; Wang et al., 2014; Nimtrakoon, 2015; Bontis et al., 2015). Human capital represents the skills, competencies, knowledge and experience of employees primarily. These human factors are those, which contribute to corporate's value creation. These capital elements can be linked to the individual and are closely related to the qualities, creativity, and problem-solving abilities of the employees. One consequence of inadequate knowledge management represents when employees leave the company and take with them the competencies and experience they have acquired. Besides the ability of value creation and its size, Boda (2008) consider it also important: the constituent elements of it and their ownership. In his view, the problem is that sometimes companies invest in these invisible equity elements 
(knowledge, skills, competencies), which the company does not own. The higher the level of knowledge, the more it depends on the carrier of knowledge, and it is more difficult to separate from it (Boda, 2008). Others cannot own human resources and the knowledge they possess.

In contrast with this, others can own structural capital. An important feature of structural capital is that it is independent of employees and company managers. Depending on the corporate culture, the types of capital components may differ (Bergeron, 2003). According to Edvinsson's approach, structural capital includes customer capital and organizational capital. Customer capital includes the companies' customer relationships, customer satisfaction, loyalty, trademarks, market share, distribution channels, brand name. Organizational capital includes organizational processes, structures, financial relationships, IT systems, and corporate culture as intellectual assets. Organizational capital includes organizational processes, structures, financial relationships, IT systems, and corporate culture as intellectual assets.

\section{Research methodology}

Several articles deal with studying the positive impact of intellectual capital and its performance on firm performance (Clarke et al., 2010; Maditinos et al., 2011; Goebel, 2015). The results of studies dealing with the correlation between intellectual capital and corporate performance in companies operating in different sectors (banking and finance, IT, hi-tech, pharmaceuticals, services, manufacturing) are quite different. Kamukama et al. (2010) suggest that differences in certain components of intellectual capital and their relationship with corporate performance are sector- and country-specific. The author classifies the development of the given country, sector, cultural differences and geographical location as the determinants of these differences. One of the most suitable methods for comparative analysis of the relationship between the intellectual capital components of companies operating in each sector is the Value Added Intellectual Coefficient (VAIC) (Sardo and Serrasquueiro, 2017).

In order to measure and adequately manage intellectual capital, it is essential to measure it. There are several ways to measure intellectual capital. Regarding this, Sveiby's (2010) work is decisive. In one of his papers, he mentions 42 methods, which can be divided into four major groups by their specificity: Direct Intellectual Capital methods (DIC), Market Capitalization Methods (MCM), Return on Assets (ROA), and Scorecard Methods (SC). While the methods from the first two categories determine intellectual capital at the organizational level with aggregate inputs and components, the methods from the latter two groups allow a more refined assessment of intellectual capital divided into components (Vishnu and Gupta, 2014).

In the present study, we used the Value Added Intellectual Coefficient (VAIC) as a measurement of intellectual capital. The great advantage of VAIC is that it decomposes the intellectual capital into elements, permitting in this way the assessment of value added by each element. Intellectual capital components are Capital Employed Efficiency (CEE), Human Capital Efficiency (HCE) and Structural Capital Employed (SCE). The comparative analysis of VAIC is based on the financial statements of enterprises settled in neighbouring counties (Bihor, HajdúBihar) of two Central and Eastern European countries (Romania and Hungary). 
The companies included in the study operate in different sectors of the economy. The enterprise data were collected for five years (2014-2018) from the official website of the EMIS database.

This study aims to perform comparative analysis of VAIC and its components using the countries mentioned above' enterprise data. We also try to investigate the effect of VAIC components on companies' performance. In the first part of the analysis, we calculate the VAIC for the examined period, and then we determine the main statistics of VAIC. Considering that the effect of VAIC could be industryand country-specific, we consider it important to determine the VAIC average of firms acting in the below mentioned economic sector. In this study, we determine the values of VAIC for companies operating in the following economic sectors: agriculture, construction, manufacturing, wholesale trading, retail trade and transportation. In Hungary, we used a totally of 653 firms' from Hajdú-Bihar County. In Romania, 687 firms' financial statements from Bihor County form the enterprise dataset.

Then we carried out a panel regression analysis to investigate the relationship between the components of VAIC and the firm's performance described by two return ratios (Operating Return on Sales - OROS and Operating Return on Assets OROA). We used the method of panel regression analysis. Panel data analysis can be viewed as multilevel hierarchical modelling, which allows us to examine different variables. The panel model combines the analysis of cross-sectional and timeseries data. The analysis was carried out with $\mathrm{R}$ statistics software system. The great advantage of this consist in the fact that it is an open-source program and contains the modules necessary for this study. Other advantages of this software are that it could be linked to an Excel spreadsheet. In this study, we used 'plm' and 'fPotrfolio' packages.

\section{Results of research}

In the first step of our empirical analysis, we determine the Value Added Intellectual Coefficient (VAIC), the main statistical features of both Hungarian and Romanian enterprises for the investigated period, and then we compare the results. The evolution of VAIC averages is presented in Figure 1. for the examined period (2014 - 2018).

Figure 1. shows the yearly evolution of VAIC for both Romanian and Hungarian firms. By comparing the graphs, different trends of VAIC could be observed for the investigated period. In the first period, the VAIC average slightly increases in the case of Romanian companies. From 2015, the VAIC mean decrease continuously until the end of the investigated period. Different evolution could be seen in the case of Hungarian companies' VAIC average. From 2014 to 2016, the VAIC values decrease significantly. In the next part of the investigated period, the VAIC begins to grow, which means a favourable development of value added by intellectual capital.

The yearly VAIC shows higher values for Romanian companies in the examined period, so that value added by intellectual capital is higher in Romanian companies. The range and interquartile range are more significant in Romanian companies, which suggest greater variability in term of VAIC. The high variability also means greater heterogeneity in term of intellectual capital. Excepting one 
year, the VAIC's coefficient of variance shows higher values in Romanian companies, which also indicates greater variability.
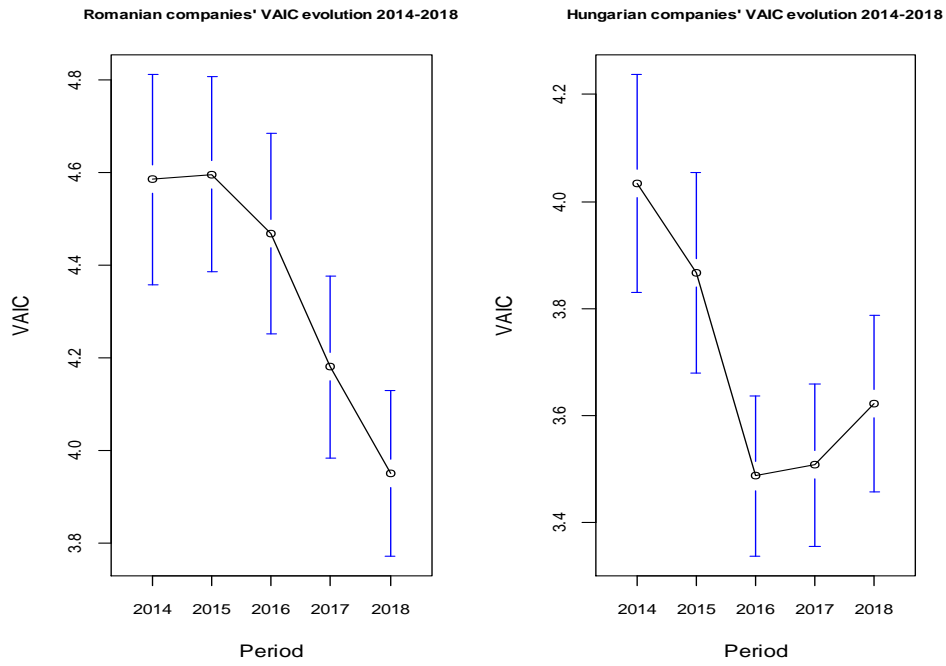

Figure 1: VAIC evolution for Hungarian and Romanian companies (2014 - 2018) Source: own calculations using $\mathrm{R}$ statistical system

After these, we want to deepen the empirical analysis of VAIC, so we grouped the companies from both countries by sectors and decomposed the VAIC coefficient to its components for the last investigated year (2018). Then, we determine the mean and coefficient of variance for VAIC's components: Human Capital Efficiency (HCE), Structural Capital Efficiency (SCE) and Capital Employed Efficiency (CEE) for each group of companies' acting in the sectors mentioned above. The results are disposed in Table 1. and Table 2.

Table 1: The results of VAIC components for firms grouped by sector (2018)

\begin{tabular}{|c|c|c|c|c|c|c|c|}
\hline \multirow[b]{2}{*}{ Indicator name } & \multirow[b]{2}{*}{$\begin{array}{c}\text { Statistical } \\
\text { indicator }\end{array}$} & \multicolumn{2}{|c|}{ Agriculture } & \multicolumn{2}{|c|}{ Construction } & \multicolumn{2}{|c|}{ Manufacturing } \\
\hline & & $\begin{array}{c}\text { Romanian } \\
\text { firms }\end{array}$ & $\begin{array}{l}\text { Hungarian } \\
\text { firms }\end{array}$ & $\begin{array}{l}\text { Romanian } \\
\text { firms }\end{array}$ & $\begin{array}{l}\text { Hungarian } \\
\text { firms }\end{array}$ & $\begin{array}{l}\text { Romanian } \\
\text { firms }\end{array}$ & $\begin{array}{l}\text { Hungarian } \\
\text { firms }\end{array}$ \\
\hline Total firms & & 57 & 61 & 55 & 96 & 188 & 147 \\
\hline \multirow{2}{*}{$\begin{array}{l}\text { Human Capital Efficiency } \\
\text { (HCE) }\end{array}$} & Mean & 3.61 & 2.92 & 2.05 & 3.62 & 1.86 & 1.93 \\
\hline & $\begin{array}{l}\text { Coefficient } \\
\text { of variance }\end{array}$ & $71.97 \%$ & $58.24 \%$ & $50.52 \%$ & $86.98 \%$ & $58.77 \%$ & $48.48 \%$ \\
\hline \multirow{2}{*}{$\begin{array}{l}\text { Structural Capital } \\
\text { Efficiency (SCE) }\end{array}$} & Mean & 0.57 & 0.53 & 0.53 & 0.54 & 0.39 & 0.38 \\
\hline & $\begin{array}{l}\text { Coefficient } \\
\text { of variance }\end{array}$ & $45.12 \%$ & $41.82 \%$ & $138.69 \%$ & $69.76 \%$ & $245.96 \%$ & $63.51 \%$ \\
\hline \multirow{2}{*}{$\begin{array}{l}\text { Capital Employed } \\
\text { Efficiency (CEE) }\end{array}$} & Mean & 0.62 & 0.30 & 0.80 & 0.61 & 1.07 & 0.79 \\
\hline & $\begin{array}{l}\text { Coefficient } \\
\text { of variance }\end{array}$ & $58.22 \%$ & $27.95 \%$ & $69.62 \%$ & $45.94 \%$ & $143.75 \%$ & $91.20 \%$ \\
\hline
\end{tabular}

Source: Own calculation

The firms' acting in agriculture represents 8,30\% from all investigated Romanian companies and $9,34 \%$ from the Hungarian corporate sample. As we can see from 
Table 1., in both case, the greatest part of VAIC is represented by HCE, followed by SCE and CCE. This means that human resources, the employees' knowledge, and skills contribute significantly to increasing agricultural firms' value. Compared with all sectors' VAIC average (Romanian firms 3.95, Hungarian firms 3.62) the firms acting in agriculture takes higher VAIC values for both countries companies, which confirms the essential role of intellectual capital in this sector. The coefficient of variance values shows greater values at Romanian agricultural companies, which also indicates greater variability.

Construction companies represent $8.01 \%$ of the total Romanian sample and $14.70 \%$ of investigated Hungarian enterprises. The Hungarian construction companies' VAIC (4.77) exceeds both Hungarian total sample VAIC results (3.62) and Romanian construction firms' VAIC (3.37). Both countries companies' HCE represents a significant part of VAIC. The higher SCE's coefficient of variance for Romanian companies could be interpreted as a sign of great variability in term of value added by structural capital.

The manufacturing companies represents the second great part of investigated companies sample (Romanian firms $27.37 \%$, Hungarian firms $22.51 \%$ ). The VAIC values of Romanian and Hungarian manufacturing companies are very close to each other. This indicates the same role of intellectual capital for manufacturing firms in both countries. The great part of VAIC is represented by HCE in both countries, followed by CCE. High values of coefficient of variance indicate great heterogeneity and spatial variability in term of SCE and CEE of Romanian manufacturing companies. Large CCE's values mean that compared to other components of VAIC, the value added by the corporate property, the efficiency of assets is relatively high at manufacturing companies. This underlines the key role of physical assets as machines and equipment used in the firm's value creation process.

Table 2: The results of VAIC components for firms grouped by sector (2018)

\begin{tabular}{|c|c|c|c|c|c|c|c|}
\hline \multirow[b]{2}{*}{ Indicator name } & \multirow[b]{2}{*}{$\begin{array}{l}\text { Statistical } \\
\text { indicator }\end{array}$} & \multicolumn{2}{|c|}{ Wholesale trade } & \multicolumn{2}{|c|}{ Retail trade } & \multicolumn{2}{|c|}{ Transportation } \\
\hline & & $\begin{array}{l}\text { Romanian } \\
\text { firms }\end{array}$ & $\begin{array}{l}\text { Hungarian } \\
\text { firms }\end{array}$ & $\begin{array}{c}\text { Romanian } \\
\text { firms }\end{array}$ & $\begin{array}{l}\text { Hungarian } \\
\text { firms } \\
\end{array}$ & $\begin{array}{c}\text { Romanian } \\
\text { firms }\end{array}$ & $\begin{array}{l}\text { Hungarian } \\
\text { firms }\end{array}$ \\
\hline Total firms & & 174 & 165 & 91 & 140 & 122 & 44 \\
\hline \multirow{2}{*}{$\begin{array}{l}\text { Human Capital Efficiency } \\
\text { (HCE) }\end{array}$} & Mean & 3.29 & 2.86 & 2.05 & 2.01 & 2.74 & 2.16 \\
\hline & $\begin{array}{l}\text { Coefficient } \\
\text { of variance }\end{array}$ & $79.33 \%$ & $75.39 \%$ & $51.39 \%$ & $49.67 \%$ & $50.93 \%$ & $51.66 \%$ \\
\hline \multirow{2}{*}{$\begin{array}{l}\text { Structural Capital } \\
\text { Efficiency (SCE) }\end{array}$} & Mean & 0.55 & 0.52 & 0.42 & 0.42 & 0.54 & 0.46 \\
\hline & $\begin{array}{l}\text { Coefficient } \\
\text { of variance }\end{array}$ & $44.15 \%$ & $70.81 \%$ & $52.82 \%$ & $48.72 \%$ & $132.47 \%$ & $40.50 \%$ \\
\hline \multirow{2}{*}{$\begin{array}{l}\text { Capital Employed } \\
\text { Efficiency (CEE) }\end{array}$} & Mean & 0.78 & 0.49 & 0.92 & 0.73 & 0.97 & 0.60 \\
\hline & $\begin{array}{l}\text { Coefficient } \\
\text { of variance }\end{array}$ & $112.57 \%$ & $80.13 \%$ & $88.06 \%$ & $100.89 \%$ & $181.72 \%$ & $57.17 \%$ \\
\hline
\end{tabular}

Source: Own calculation

The trading companies represent the greatest part of whole samples in both countries (Romanian firms $38.57 \%$, Hungarian firms $46.71 \%$ ). Greater VAIC values can be seen in the case of Romanian trading companies (Wholesale trade 4.63, Retail trade 3.39). Compared with the full sample average, the higher VAIC for wholesale trade companies highlights the great contribution of intellectual capital to 
firms' performance. The major part of trading companies VAIC is HCE, in both countries. These indicate that employees' knowledge, skills represents the highest contribution to the company's value creation. The greater coefficient of variance of HCE in both countries shows greater spatial heterogeneity of investigated wholesale trading companies. The Romanian wholesale trading companies' and Hungarian retail trading companies' CCE variability is relatively high compared with other sectors' results, which means that trading companies vary a lot in term of CCE.

The Romanian transportation companies represent $17.76 \%$ of the whole firms' sample. The Hungarian firms acting in transportation means $6.74 \%$ of the examined companies. The VAIC of Romanian transportation firms (4.25) is higher than the Hungarian firms' VAIC mean. The VAIC level also exceeds the average of Romanian companies' VAIC (3.95). The HCE forms the greatest part of VAIC, so this has a great contribution to firms' value creation, followed by CCE. The lower values of SCE means that corporate structures and information systems have small contributions to enterprise value enrichment. The variability within the group is very high, which is equal to relatively high variability.

Comparing the result of VAIC, we can summarize that in Romanian companies, the sectors where the contribution of intellectual capital is dominant mainly in firms' value creation are the following: agriculture, wholesale trade and transportation. In Hungary, the sectors where intellectual capital has key role in corporate value creation are construction and wholesale trade. The higher average VAIC in the case of investigated Romanian companies confirms the indispensable role of intellectual capital on the aspect of corporate value creation.

In the last part of the analysis, we investigate the relationship between firms' performance and value added by intellectual capital. For this, we performed the panel regression analysis. As a measurement of corporate performance, we used two profitability indicators: the Operating Return on Sales (OROS) and Operating Return on Assets (OROA). The difference between Operating Return on Sales (OROS), Operating Return on Assets (OROA) and the regular Return on Sales (ROS), Return on Assets (ROA), consist in the numerators of their formulas. While the first two ratios use the Earnings before interest and taxes or operating income at the numerator of the equation, the second two uses the net income. So, the OROA and OROS do not consider the financial expenses as interests and taxes. These profitability ratios could be used with success in comparative analysis of firms' performance acting in different economic sectors. Corporate performance expressed like these provides a more accurate analysis of performance. Also, by using these profitability ratios, we can eliminate the effects of taxes, which is kindly different for Romanian and Hungarian companies. So, OROA and OROS are much more suitable in our comparative analysis for the reasons mentioned above. We used as explanatory variables the VAIC components: HCE, SCE, CCE. We also run the fixed and random (one-, two-ways panel, and Swamy-Arora-Amemiya's transformation) effect panel regression. Then, we compare the results by using Hausman-Test. We used the coefficient of determination $\left(R^{2}\right)$ to test the goodness of fit of the panel models. In order to avoid multicollinearity, we also calculate the variance inflation factor (VIF). The variance inflation takes values less than 5 for each independent variables, so there is no danger of multicollinearity. Based on Hausman-Test, the two ways fixed effect panel regression model shows better results in Romanian firms. 
The results of panel regression for Romanian companies are disclosed in Table 3. As we can see from the table, all of the coefficients are significant at least $5 \%$ of the significance level, so the VAIC' components could be used with success as independent variables to explain the OROA variable. This is also suggested by' ***' signs, which means the significance level is very close to 0 . The results show that each VAIC components (HCE, SCE and CCE) are positively correlated with OROA.

By analyzing the coefficients of determination $\left(R^{2}\right)$, we can conclude that in Romania companies $(0,2974)$, the dependent variable variance can be explained by the independent variable in a proportion of $29.74 \%$. Based on these, a mediumstrong correlation between OROA and VAIC components is specific for investigated companies. The values of the coefficient of correlation also confirm these.

Table 3. Panel regression for Romanian companies (dependent variable: OROA)

\begin{tabular}{|c|c|c|c|c|}
\hline Independent variables & Estimation & Std. Error & T- value & $\operatorname{Pr}(>|t|)$ \\
\hline Human Capital Efficiency (HCE) & 0.0444 & 0.0014 & 32.4909 & $<2.2 \mathrm{e}-16^{* * *}$ \\
\hline Structural Capital Efficiency (SCE) & 0.0164 & 0.0036 & 4.6208 & $3.999 \mathrm{e}-06^{* * *}$ \\
\hline Capital Employed Efficiency (CEE) & 0.0068 & 0.0017 & 4.1241 & $3.833 e-05^{* \star *}$ \\
\hline $\mathrm{R}$ - squared (R2) & 0.2974 & & & \\
\hline Coefficient of correlation $(\mathrm{R})$ & 0.5453 & & & \\
\hline
\end{tabular}

Using the same independent (HCE, SCE, CEE) and dependent (OROS, OROA) variables, we also performed the panel data regression for Hungarian companies. The results of two ways fixed effect panel regression model are presented in Table 4.

In the case of Hungarian firms, a stronger correlation can find out between OROS and VAIC components. In the case of OROS, the coefficients are significant at least $5 \%$ of the significance level. According to this, the VAIC' components could be used with success as independent variables to explain the OROS variable. This is also suggested by' ${ }^{* * * \prime}$ signs from Table 4. Compared with panel regression results for Romanian companies, the coefficients of determination $\left(R^{2}\right)$ show a higher value $(0.4088)$ in Hungarian companies. This means that the independent variable can explain the dependent variable variance in a proportion of $40.88 \%$. The coefficients of determination $\left(R^{2}\right)$ and coefficient of correlation suggest a medium-strong relationship between investigated firms' intellectual value components and corporate performance.

Table 4. Panel regression for Hungarian companies (dependent variable: OROS)

\begin{tabular}{|l|r|r|r|c|}
\hline \multicolumn{1}{|c|}{ Independent variables } & Estimation & Std. Error & \multicolumn{1}{c|}{ T- value } & $\operatorname{Pr}(>|\mathbf{t}|)$ \\
\hline Human Capital Efficiency (HCE) & 0.0239 & 0.0008 & 31.4051 & $<2.2 \mathrm{e}-16^{* * *}$ \\
\hline Structural Capital Efficiency (SCE) & 0.0699 & 0.0045 & 15.4122 & $<2.2 \mathrm{e}-16^{* * *}$ \\
\hline Capital Employed Efficiency (CEE) & 0.0039 & 0.0013 & 3.1185 & $0.001838^{* *}$ \\
\hline R - squared (R ${ }^{2}$ ) & 0.4088 & \multicolumn{3}{|l}{} \\
\cline { 1 - 2 } Coefficient of correlation (R) & 0.6393 & &
\end{tabular}

Source: Own calculation 
In most of the studied scientific papers dealing with intellectual capital and its positive contribution to corporate value creation, we can read about the relationship between specific profitability ratios (ROA, ROS, ROE) and VAIC components. The results of panel regression analysis also confirmed these for the investigated firms from Romania and Hungary. Based on these, the present empirical analysis supports the fact that intellectual capital is the main determinants of corporate performance.

\section{Conclusion}

With the transition to modern, knowledge-based economies, the constituent elements of intellectual capital, such as knowledge, skills, corporate cultures, methods, are playing an increasingly important role in the process of corporate value creation over physical assets. This study aims to perform a comparative analysis of VAIC and its components for companies acting in different sectors and investigate the relationship between intellectual capital and corporate performance. Based on the higher VAIC average of investigated Romanian companies, we can conclude that the intellectual capital's contribution to corporate value creation is more significant than Hungarian companies' case. The reason for this is that Romania is a developing country, where the role of intellectual capital is much more pronounced. Also, cultural differences and geographical location, organizational features may be other determinants of these differences. For Bihor County, the results show that the contribution of intellectual capital to firms' performance is significant in companies acting in agriculture, wholesale trade, and transportation. In Hungary, intellectual capital plays a crucial role in corporate value creation at construction and wholesale trade companies. A medium-strong correlation can be seen between OROA and VAIC components in the case of investigated Romanian firms. For Hungarian companies, we find out that OROS is medium-strong correlated to VAIC each component. The results of panel data analysis support the finding that there is a direct relationship between value added by intellectual capital and firms' performance.

\section{References}

1. Lev, B. (2004), "Sharpening the intangibles edge", Harvard Business Review, Vol. 82 No. 6, pp. 109-116.

2. Bayraktaroglu, A. E. - Calisir, F: - Baskak, M. (2019) Intellectual capital and firm performance: an extended VAIC model, Journal of Intellectual Capital, Vol. 20 No. 3, 2019, pp. 406-425, Emerald Publishing Limited1 469-1930

Boda Gy. (2008): A tudástőke mérési módszerei és használhatóságuk. CEO magazin, 3. melléklet

4. Bontis, N., Janosevic, S. and Dzenopoljac, V. (2015), "Intellectual capital in Serbia's hotel industry", International Journal of Contemporary Hospitality Management, Vol. 27 No. 6, pp. 1365-1384.

5. Bergeron, B. (2003): Essentials of Knowledge Management. John Wiley \& Sons, Inc., New Jersey.

6. Brennan, N. - Connell, B. (2000): Intellectual Capital: current issues and policy implications. Journal of Intellectual Capital, Vol. 1, No. 3, 206-240. o. 
7. Clarke, M. - Seng, D. - Whiting H. R (2011) Intellectual capital and firm performance in Australia, Journal of Intellectual Capital, Vol. 12 No. 4, 2011, pp. 505-530, Emerald Group Publishing Limited 1469-1930

8. Chen, M.-C., Cheng, S.-J. and Hwang, Y. (2005), An empirical investigation of the relationship between intellectual capital and firms' market value and financial performance, Journal of Intellectual Capital, Vol. 6 No. 2, pp. 159-176.

9. Chan, K.H. (2009), Impact of intellectual capital on organizational performance. An empirical study of companies in the Hang Seng Index (Part 2)", The Learning Organization, Vol. 16 No. 1, pp. 22-39

10. Chang, W.S. and Hsieh, J.J. (2011), "Intellectual capital and value creation is innovation capital a missing link?", International Journal of Business and Management, Vol. 6 No. 2, pp. 3-12.

11. Edwinsson, L., and Malone, M. S. (1999): Intellectual capital: realizing your company's true value by finding its hidden brainpower, Harper-Business, New York.

12. Edvinsson, L. - Kivikas, M. (2007): Intellectual capital or Wissensbilanz process: some German experiences. Journal of Intellectual Capital, 3. pp. 376385.

13. Goebel, V. (2015), "Estimating a measure of intellectual capital value to test its determinants", Journal of Intellectual Capital, Vol. 16 No. 1, pp. 101-120.

14. Gu, F. - Lev, B. (2001): Intangible assets - measurement, drivers, usefulness. Boston University and New York Univerity.

15. Harangozó, T. (2007): Az intellektuális tôke mérése és ennek lehetséges magatartási vonatkozásai Vezetéstudomány, Vol. XXXVIII. No. 12.

16. Hunter, L., Webster, E. and Wyatt, A. (2005), "Measuring intangible capital: a review of current practice", Australian Accounting Review, Vol. 15 No. 2, pp. 4-21.

17. Juhász, P. (2004) A szellemi tõke értékelési problémái, Hitelintézeti szemle, harmadik évfolyam, no. 5.

18. Kamukama, N., Ahiauzu, A. and Ntayi, J.M. (2010), "Intellectual capital and performance: testing interaction effects", Journal of Intellectual Capital, Vol. 11 No. 4, pp. 554-574.

19. Kaufmann, L., and Schneider, Y. (2004): Intangibles - A synthesis of current research. Journal of Intellectual Capital, Vol. 5, No. 3, pp. 52-63.

20. Maditinos, D., Chatzoudes, D., Tsairidis, C. and Theriou, G. (2011), "The impact of intellectual capital on firms' market value and financial performance", Journal of Intellectual Capital, Vol. 12 No. 1, pp. 132-151.

21. Nimtrakoon, S. (2015), "The relationship between intellectual capital, firms' market value and financial performance Empirical evidence from the ASEAN", Journal of Intellectual Capital, Vol. 16 No. 3, pp. 587-618.

22. Pfeil, O.P. (2004): Earnings from Intellectual Capital as a Driver of Shareholder Value. Haupt Verlag AG, Bern

23. Sardo, F. and Serrasquueiro, Z. (2017) European empirical study of the relationship between firms' intellectual capital, financial, Journal of Intellectual Capital Vol. 18 No. 4, 2017 pp. 771-788

24. Sveiby, K.E. (2001): A knowledge-based theory of the firm to guide in strategy formulation. Journal of Intellectual Capital, Vol. 2, No. 4, pp. 344-358.

25. Sveiby, K.E. (2010), "Methods for measuring intangible assets" 
26. Vishnu, S. and Gupta, V.K. (2014), "Intellectual capital and performance of pharmaceutical firms in India", Journal of Intellectual Capital, Vol. 15 No. 1, pp. 8399.

27. Wang, Z., Wang, N. and Liang, H. (2014), "Knowledge sharing, intellectual capital and firm performance", Management Decision, Vol. 52 No. 2, pp. 230-258. 


\title{
THE IMPACT OF BASEL BANKING REGULATION ON FINANCIAL TRANSACTIONS
}

\author{
Margit CSIPKÉS, Rebeka NAGY, Sándor NAGY \\ University of Debrecen Faculty of Economics Institute of Statistics and \\ Methodology, Debrecen, Hungary \\ csipkes.margit@econ.unideb.hu \\ nrebeka96@gmail.com \\ nagysanyi@freemail.hu
}

\begin{abstract}
In our research, we review Basel banking regulation because in our rushed lives, unfortunately, we don't know much about it (even though we live in a world controlled by money). In our research, we aim to present in detail the centuries-old system of the banking system, the role of banks in the economy and society, and the need for banking regulation in the light of the operation of credit institutions. In our research, we review in detail the past of Basel banking regulation and examine its impact on the present. In our material, we have summarized in a separate section the most well-known forms of classification, which can be used in such an analysis due to their complexity. We also present the CAMELS method, which, unlike other methods of analysis, includes the classification of capital adequacy, assets, management, profitability, liquidity and sensitivity to market risks. In our research, we present the CAMELS analysis method (supported by indicators) through a specific example. The CAMELS method was developed in the United States in order to determine a bank's capital adequacy. In addition, the method helps to determine the quality of assets, profitability and liquidity (it is also suitable for determining the sensitivity to market risk). Our aim through this research is to present both the advantages and disadvantages of the CAMELS method through the example of a reputable bank in the last 5 years. Officially available databases were used for the research.
\end{abstract}

Keywords: Basel, Camels, analysis method, research

\section{JEL classification: G21}

\section{Introduction}

Nowadays, people take the existence of banks completely naturally. We can either borrow from banks if necessary or save our money there. A significant part of today's society receives their income in a bank account and we also take care of everyday matters through this account. (purchase of goods, settlement of invoices, repayment of loans, etc.). The existence of credit institutions is essential for the functioning of the economy and society. Depending on the specific impact of credit institutions on a day-to-day basis, the need for banking regulation becomes clear. Until the end of the 20th century, banks were regulated at the nation-state level. However, banking regulation was unequal in terms of branches and international activity. The turning point was the adoption of the Basel Capital Accord, which raised the regulation of credit institutions to an international level and set uniform standards for the regulatory system. 


\section{Literature - A Basel I-IV. brief overview}

The International Convergence of Capital Measurement and Capital Standards was established by representatives of the 12 largest capital market countries (France, Italy, Germany, Sweden; Canada, Japan, Netherlands, Luxembourg, Switzerland, USA, United Kingdom, Belgium) to ensure uniform competition (Tajti, 2011).

The Basel I agreement was issued in 1988. The agreement focused on the capital adequacy of financial institutions. By defining the concept of own funds, this agreement created elements of guarantee capital that provided creditable collateral to credit institutions to cover future losses.

The reason for the development of the new banking regulatory system is the shortcomings of Basel I. (BCBS 2006). On 26 June 2004, the Basel Committee on Banking Supervision established Basel II. This agreement already takes into account banks' operational risk, credit risk and market risk. The new banking regulation also provides for additional capital, which is accepted by national regulators. A major disadvantage of the regulation is that Basel II. capital requirements do not include liquidity risk, banking book interest rate risk, strategic risk and business risk (these risks would be subject to the "supervisory review process"). This regulation requires banks to maintain their capital adequacy requirement at a minimum of $8 \%$ (Tajti, 2011; Fazekas, 2009). Basel II provided banks with more informed approaches to calculating capital requirements based on credit risk. It aims to provide users of financial information with relevant information to make informed trading decisions (Hull, 2015). (Hull, 2015).

Following the economic crisis of 2008, Basel II Convention has been revised. Basel III was developed. agreement. The aim of Basel II is to improve the ability of banks to deal with shocks arising from financial stress, to make the system more transparent and to make them more public. It is important to prevent banks from taking more risk than they can handle (Homolya, 2014; Szombati, 2010). Basel III. the most important principles of Basel I and II. are based on principles. It is important to introduce a minimum capital requirement, a leverage ratio and liquidity in banks. Basel III. its capital requirements focused on reducing customer risk. This risk depended on whether the bank traded through a merchant or with a central clearing partner. If a bank has traded derivatives with the trader, Basel III. created an obligation and imposed a high capital requirement for this trade.

In December 2017, the Governors and Supervision Groups of the Central Bank adopted the Basel IV reform package. The main objectives of the latest reforms are to increase the risk sensitivity of standardized approaches and to increase the comparability of RWA calculations by limiting the use of internal models. Basel IV. package proposes a nine-year implementation timetable, which leaves considerable time for preparation. A five-year "implementation" period will begin on January 1, 2022, with full implementation expected from January 1, 2027. In summary, Basel IV credit risk is a challenge for any financial institution (KPMG, 2013; 2015; Coluccia-Franchini-Quinto, 2020).

\section{Material and methodology - Analysis and components of Camel}

In 1979, the Unified Classification of Financial Institutions (UFIRS) was introduced. The system has become internationally known by the acronym CAMEL, which 
reflects five areas of evaluation: Capital Adequacy (C), Assets Quality (A), Management (M), Earning (E), Liquidity and assets and liability management (L). In 1995, the name CAMEL was changed to CAMELS. The meaning of "S" stands for subjectivity to market risk (Sensitivity). The new rating includes an assessment of exposure to market risk and adds a rating on a scale of 1 to 5 to market risk management. CAMEL is used by banking supervisors to rate financial institutions based on six factors (Sulyok - Pap, 2006; Seregdi, 1993).

Next, let's look at the 5 assessment areas:

1. capital adequacy: Capital adequacy shows the stability of a company when faced with special risks. Capital adequacy shall reflect the effectiveness of the credit institution's investment policy and practices (Szemán, 2015; Rai, 2010). The "capital adequacy ratio", "leverage ratio" and "capital accumulation ratio" can be used for the analysis. Qualitative assessment of capital adequacy: 1 strong capital level, 2 satisfactory capital level, 3 below-satisfactory capital level (but still exceeding the statutory level), 4 incomplete capital level (external financial resources may be required), 5 critical capital level (requires immediate financial assistance) (Szemán, 2015; Rai, 2010).

2. device quality: Asset quality refers to the quality of institutional credit that reflects the income of the institution. This shows the stability of the company when faced with special risks. Indicators that can be used in the analysis are "rated credit ratio", "outstanding loan ratio indicator" and "adjusted credit quality indicator". Asset quality classification in the analysis: 1 excellent asset quality (risk exposure is negligible compared to management ability), 2 satisfactory asset quality (risk exposure is proportional to management skills), 3 asset quality below satisfactory (means deterioration and increased risk), 4 insufficient asset quality, 5 already critically insufficient asset quality (Szemán, 2015; Rai, 2010).

3. management: Management evaluation determines whether an institution is able to respond adequately to financial difficulties. The indicators used in the analysis are "headcount efficiency" and "cost-effectiveness". Quality classification of management in the analysis: 1 strong managerial performance (strength of risk management), 2 adequate managerial performance and well-identified risk, 3 improvement of managerial performance and poorer-than-satisfactory risk management, 4 deficient performance (to maintain stability) management must intervene), 5 means critically deficient managerial performance (requires replacement or strengthening of management) (Szemán, 2015; Rai, 2010).

4. profitability: The ability of a credit institution to generate adequate returns for expansion, maintaining competitiveness and raising capital. The indicators used in the analysis are "return on equity (ROE)" and "return on assets (ROA)". Profitability classification in the analysis: 1 strong profitability (this level has more than enough income for proper operation and adequate level of capital), 2 satisfactory profitability (income is just enough to operate and maintain capital level), 3 means profitability that already needs to be increased (there is not enough income for operation and capital growth), 4 already low level of profitability (net income and loss fluctuate at this level, there is not enough income for operation and capital maintenance), 5 critical illness (credit institution is unprofitable, viability uncertain) (Szemán, 2015; Rai, 2010).

5. liquidity: A credit institution can be considered liquid if it is able to repay the deposits placed with it and the interest thereon and to provide credit to creditworthy customers. Following the 2008 financial crisis, the Basel Convention 
required credit institutions to calculate liquidity ratios. The indicators used in the analysis are "liquidity ratio" and "deposit coverage ratio". Liquidity rating in the analysis: a rating of 1 means strong, a rating of 2 means satisfactory liquidity and advanced funding. For a rating of 3 , both liquidity and funding practices need to be improved. A rating of 4 indicates an insufficient level of liquidity, in which case the funding process is inadequate. A rating of 5 indicates a critical level of illiquidity and an inadequate funding approach where the credit institution is at risk. In such cases, it needs immediate external financial assistance and the mobilization of resources to pay overdue liabilities (Szemán, 2015).

6. Sensitivity to market risks: Sensitivity examines how individual risk exposures can affect institutions. The indicators used in the analysis are "interest rate risk" and "price risk". Classification of sensitivity to market risks in the analysis: 1 the bank's risk management is effective, the income level and capital provide coverage in proportion to the risks taken, 2 the risk management is satisfactory compared to the size of the bank, 3 one or more elements need to be developed, 4 significant market risk exposing the credit institution to liquidity, 5 critical deficiencies are present in the credit institution that threaten operations, management is unable to manage risks, unsuitable for it) (Szemán, 2015). In the following, we present the CAMELS analysis at OTP Bank. The question has arisen in us as to whether it is necessary to obtain the best rating for all factors in order to maintain a market-leading position.

\section{Material and methodology - Analysis and components of Camel}

OTP Bank is at the forefront of the 2019 ranking of domestic credit institutions on the basis of bank balance sheet total and after-tax profit. In the case of the comparative analysis, the average of the banking sector is the average of the 3 market-leading banks (UniCredit Bank, Erste Bank and K\&H Bank) following OTP Bank.

\subsection{Examination of capital adequacy}

In the case of the examination of long-term solvency, it can be stated that OTP Bank's capital adequacy ratio shows a decrease and then an increase in the period under review (Table 1). The average for the banking sector as a whole showed higher result, but also fluctuated in both directions. The increase was due to an increase in own funds.

Table 1: Indicators related to capital adequacy between 2015-2019 (\%)

\begin{tabular}{|l|c|c|c|c|c|c|c|c|c|c|}
\hline \multirow{2}{*}{ Indicators } & \multicolumn{4}{|c|}{ OTP Bank } & \multicolumn{4}{c|}{ Average of the banking sector } \\
\cline { 2 - 13 } & $\mathbf{2 0 1 5}$ & $\mathbf{2 0 1 6}$ & $\mathbf{2 0 1 7}$ & $\mathbf{2 0 1 8}$ & $\mathbf{2 0 1 9}$ & $\mathbf{2 0 1 5}$ & $\mathbf{2 0 1 6}$ & $\mathbf{2 0 1 7}$ & $\mathbf{2 0 1 8}$ & $\mathbf{2 0 1 9}$ \\
\hline Capital adequacy & 16,2 & 16 & 14,6 & 18,3 & 16,3 & 17,9 & 17,8 & 19,8 & 18,7 & 19,2 \\
\hline Leverage & 17,9 & 18,4 & 18,6 & 18,2 & 18,2 & 6,03 & 6,8 & 9,02 & 7,4 & 9,41 \\
\hline Capital accumulation & 5,12 & 14,3 & 17,2 & 17,4 & 18 & 6,29 & 16,1 & 15,6 & 17,1 & 14,1 \\
\hline
\end{tabular}

Source: Own compilation based on the 2015-2019 annual reports of OTP Bank, ERSTE Bank, Unicredit Bank and K\&H Bank

The average indicators of the banking sector proved to be better in the period under review, while the indicators of OTP Bank were lower in the period under 
review. It exceeded the minimum capital adequacy ratio under the Basel Convention in all three years. Based on these, it can be stated that OTP Bank can be considered a capital-intensive bank, there is no risk of insolvency. This capital adequacy is also valid for the other banks of the examined banking system, we can see from the data that the Hungarian banking system has produced strong, good results so far. It received 1 rating for the capital adequacy test.

\subsection{Examination of asset quality}

In order to examine the maintenance of solvency, the indicators in Table 2 were calculated.

Table 2: The examined indicators in the period 2015-2019 (million HUF/person)

\begin{tabular}{|l|c|c|c|c|c|}
\hline \multirow{2}{*}{\multicolumn{1}{|c|}{ Indicators }} & \multicolumn{5}{c|}{ OTP Bank } \\
\cline { 2 - 6 } & $\mathbf{2 0 1 5}$ & $\mathbf{2 0 1 6}$ & $\mathbf{2 0 1 7}$ & $\mathbf{2 0 1 8}$ & $\mathbf{2 0 1 9}$ \\
\hline Qualified loan ratio & 13,5 & 12,5 & 12,3 & 11,6 & \\
Description indicator & 31,4 & 10,8 & 9,98 & 9,75 & $\begin{array}{c}\text { not data } \\
\text { available }\end{array}$ \\
\hline Adjusted credit quality & 6,34 & 9,5 & 8,4 & 6,2 & \\
\hline
\end{tabular}

Source: Own preparation based on OTP Bank's annual reports for 2015-2019

OTP Bank's qualified loan portfolio developed favorably between 2015 and 2018, and the willingness of borrowers to repay was also reflected in the continuous decline in percentages. In 2018, $11 \%$ of repayments will have a repayment problem. Overall, with regard to OTP Bank's average, the share of loans with a capital debt of more than 15 days decreased.

A decrease can also be observed in the "Description ratio". Despite an increase in the number of borrowers, the proportion of those making late payments has decreased. The improvement is small. The adjusted credit quality ratio is low throughout the period under review.

Table 3: Lending data of OTP bank between 2015-2019 (\%)

\begin{tabular}{|l|c|c|c|c|c|}
\hline \multicolumn{1}{|c|}{ Indicators } & $\mathbf{2 0 1 5}$ & $\mathbf{2 0 1 6}$ & $\mathbf{2 0 1 7}$ & $\mathbf{2 0 1 8}$ & $\mathbf{2 0 1 9}$ \\
\hline $\begin{array}{l}\text { Rate of loans overdue for more than } \\
\text { 90 days }\end{array}$ & 17,0 & 14,7 & 9,2 & 6,3 & 4,2 \\
\hline $\begin{array}{l}\text { Coverage of loans overdue for more } \\
\text { than 90 days with all provisions }\end{array}$ & 93,4 & 96,8 & 99,3 & 118,4 & 142,37 \\
\hline
\end{tabular}

Source: Own preparation Based on the 2015-2019 annual reports of OTP Bank

Table 3 shows that the proportion of loans overdue for more than 90 days decreases over the five years examined. Changes in the coverage of loans overdue for more than 90 days with all provisions are also encouraging for the future.

The bank's rated loan composition changed relatively much during the period under review. The receivables to be monitored separately have almost halved in 
the last 3 years. Loans classified as below average brought the same level, while transactions in the doubtful category, ie arrears with a principal of between 3 months and 1 year, showed a high increase. In my opinion, this is due to the fact that in the years following the 2008 crisis, borrowers became more cautious in the post-forint period, but this trend has come to an end in recent years and people by being able to repay loans as general dangers such as job losses and repayment of preferential family support loans in the event of a divorce remain a real problem.

In terms of asset structure, OTP Bank has a variable composition. Most of the loans are loans. Asset quality can be rated 2 for the period under review.

\subsection{Management examination}

The management of the credit institution plays a significant role in the life of all commercial banks, therefore we examined both the staff efficiency and cost efficiency indicators. The headcount of the OTP Bank Group developed as follows in the years under review.

Based on the headcount efficiency indicator 1, the increase in lending can be seen in the period under review. With a few minor exceptions, all commercial banks have increased their staff over the past five years. OTP Bank produced lower indicators compared to the average of the banking sector. Regarding the 2 indicators, the average of OTP Bank and the benchmark also shows a steady improvement.

Table 4: Personnel efficiency indicators (LH) in the period 2015-2019

\begin{tabular}{|c|c|c|c|c|c|c|c|c|c|c|c|}
\hline \multirow{2}{*}{\multicolumn{2}{|c|}{ Indicators }} & \multicolumn{5}{|c|}{ OTP Bank } & \multicolumn{5}{|c|}{ Average of the banking sector } \\
\hline & & 2015 & 2016 & 2017 & 2018 & 2019 & 2015 & 2016 & 2017 & 2018 & 2019 \\
\hline \multirow{2}{*}{$\begin{array}{l}\text { Head- } \\
\text { count }\end{array}$} & 1 & 141,6 & 146,9 & 168,3 & 202 & 306,4 & 477,7 & 498,4 & 471,4 & 526,6 & 579,9 \\
\hline & 2 & 209 & 221,4 & 246,5 & 280,8 & 388,4 & 603,5 & 658,1 & 689,2 & 769,6 & 875,4 \\
\hline
\end{tabular}

Source: Own compilation based on the 2015-2019 annual reports of OTP Bank, ERSTE Bank, Unicredit Bank and K\&H Bank

Cost-effectiveness shows a slight fluctuation in the average of both OTP Bank and the banking sector (Table 5), which is due to the fact that the bank's balance sheet total increased more than the increase in operating expenses in some places and turns in the opposite direction.

Table 5: The cost-effectiveness indicator for the period 2015-2019

\begin{tabular}{|l|c|c|c|c|c|c|c|c|c|c|}
\hline \multirow{2}{*}{ Indicator } & \multicolumn{4}{|c|}{ OTP Bank } & \multicolumn{4}{c|}{ Average of the banking sector } \\
\cline { 2 - 11 } & 2015 & 2016 & 2017 & 2018 & 2019 & 2015 & 2016 & 2017 & 2018 & 2019 \\
\hline CE (\%) & 27,32 & 27,99 & 29,86 & 29,37 & 35,45 & 34,24 & 40,95 & 36,78 & 38,53 & 41,62 \\
\hline
\end{tabular}

CE: Cost-effectiveness

Source: Own compilation based on the 2015-2019 annual reports of OTP Bank, ERSTE Bank, Unicredit Bank and K\&H Bank 
Efficacy indicators were then examined. The branch efficiency indicator 1 shows that more and more loans were received per unit of bank branches, which was due to the rising loan portfolio (Table 6). The provision of family support and preferential loan disbursement by the Hungarian Government in 2018 enabled banks to significantly increase their lending, which results in a huge jump. At the same time, customer deposits have been growing steadily, as provided by the second indicator of account efficiency. There is an increase in the average labor cost. This resulted in a stable positive change in average labor costs. Based on these indicators, it can be stated that the management of OTP Bank operates the credit institution properly (from 2018 to 2019, the network was expanded with 323 branches). The management can be classified as 1 in the period under review.

Table 6: Efficiency indicators at OTP Bank in the period 2015-2019

\begin{tabular}{|l|c|c|c|c|c|}
\hline \multirow{2}{*}{\multicolumn{1}{|c|}{ Indicators }} & \multicolumn{5}{c|}{ OTP Bank } \\
\cline { 2 - 6 } & $\mathbf{2 0 1 5}$ & $\mathbf{2 0 1 6}$ & $\mathbf{2 0 1 7}$ & $\mathbf{2 0 1 8}$ & $\mathbf{2 0 1 9}$ \\
\hline Account efficiency 1 & 4037,29 & 4351,07 & 4696,13 & 5887,11 & 7063,16 \\
\hline Account efficiency 2 & 5989,13 & 6473,39 & 7013,80 & 8183,85 & 8951,93 \\
\hline Average wage cost / person & 3,59 & 3,60 & 3,86 & 4,55 & 5,36 \\
\hline
\end{tabular}

Source: Own preparation Based on the 2015-2019 annual reports of OTP Bank

\subsection{Examination of profitability}

Profitability is a vital issue for all commercial banks, as credit institutions aim to generate income. The most common indicators used to measure profitability are shown in Table 7.

Table 7: Development of profitability indicators between 2015-2019

\begin{tabular}{c|c|c|c|c|c|c|c|c|c|c}
$\begin{array}{c}\text { Indica- } \\
\text { tors }\end{array}$ & \multicolumn{4}{|c|}{ OTP Bank } & \multicolumn{4}{c}{ Average of the banking sector } \\
\cline { 2 - 11 } & 2015 & 2016 & 2017 & 2018 & 2019 & 2015 & 2016 & 2017 & 2018 & 2019 \\
\hline $\begin{array}{c}\text { ROE } \\
(\%)\end{array}$ & 5,1 & 15,3 & 18,5 & 18,7 & 20,3 & 8,93 & 18,6 & 16,6 & 18,4 & 15,2 \\
\hline $\begin{array}{c}\text { ROA } \\
(\%)\end{array}$ & 1,1 & 1,8 & 2,4 & 2,3 & 2,4 & 0,57 & 1,82 & 1,91 & 1,98 & 1,67
\end{tabular}

Source: Own compilation based on the 2015-2019 annual reports of OTP Bank, ERSTE Bank, Unicredit Bank and K\&H Bank

The ROE indicator shows the return on equity for the owners of the bank. The period under review was profitable for both OTP Bank and the average of the banks selected from the banking sector. The increase in the ROE ratio supports the bank's profitability. Comparing the data of OTP Bank with the further data of the banking sector, it can be said that it performed better, but in almost the same way, from the banking sector in the period under review. OTP Bank's results are steadily upwards. There is a slight fluctuation in the banking sector, but it can still be said to be profitable.

The ROA indicator shows the ratio of profit after tax to total assets. In terms of the calculated indicators, there are successful years behind commercial banks, OTP 
Bank's results in this category are also above the average of the banking sector, but along similar values. Profitability is rated 1 in the period under review.

\subsection{Liquidity analysis}

The report shows that the European Central Bank's refinancing resources, amounting to EUR 163 million, are available to the bank. There was no capital raising in 2018 due to the issuance of mortgage bonds due to central regulations. OTP Bank's liquidity reserve is significantly above the safe level. At the end of December 2018, it exceeded the amount of EUR 7.75 billion. This amount is orders of magnitude larger than the stock of maturing capital market debts. Regarding liquidity, it can also be said that in order to comply with the required liquidity ratio, mortgage bonds were issued in the nominal value of HUF 220 billion and repurchased from investors in the amount of HUF 52 billion in 2019 (Table 8).

Table 8: Liquidity ratios in the period 2015-2019 for the examined banks

\begin{tabular}{|l|c|c|c|c|c|c|c|c|c|c|}
\hline \multirow{2}{*}{ Indicators } & \multicolumn{4}{|c|}{ OTP Bank } & \multicolumn{4}{c|}{ Average of the banking sector } \\
\cline { 2 - 12 } & $\mathbf{2 0 1 5}$ & $\mathbf{2 0 1 6}$ & $\mathbf{2 0 1 7}$ & $\mathbf{2 0 1 8}$ & $\mathbf{2 0 1 9}$ & $\mathbf{2 0 1 5}$ & $\mathbf{2 0 1 6}$ & $\mathbf{2 0 1 7}$ & $\mathbf{2 0 1 8}$ & $\mathbf{2 0 1 9}$ \\
\hline Liquidity (\%) & 12,4 & 14,5 & 9,08 & 10,6 & 9,15 & 4,87 & 9,08 & 8,21 & 5,32 & 4,57 \\
\hline Deposit coverage (\%) & 68 & 67,2 & 68,2 & 69,9 & 78,9 & 81 & 76 & 68 & 67 & 65 \\
\hline
\end{tabular}

Source: Own compilation based on the 2015-2019 annual reports of OTP Bank, ERSTE Bank, Unicredit Bank and K\&H Bank

The deposit coverage ratio illustrates the strengthening of lending activity during the period under review. Considering the banking sector as a whole, this trend can be said to have strengthened lending in Hungary. Liquidity also includes the knowledge of the fact that the bond portfolio of households decreased by HUF 2 billion year-on-year, which is a $27 \%$ difference compared to previous years. Liquidity can be rated 1 during the period under review.

\subsection{Sensitivity to market risks}

In commercial banks, interest rate and price risk may arise (Table 9). In the case of OTP Bank, the interest rate risk ratio does not fluctuate much for the given period. The increase in the number of forint loans results in relatively equalized values. The bank's fixed-rate assets exceed the value of fixed-rate liabilities, ie fixed-rate loans are financed with floating-rate deposits. The low value of the deposit rate is affected by inflation and the fact that the central bank keeps the central bank base rate low. Savings are moving in the direction of securities investments and government securities, where there is the potential for higher returns relative to deposit rates. The banking group has an interest rate risk exposure, which is offset by the purchase of long-term, fixed-rate government securities, as the decline in yields has a negative impact on net interest income. In 2018, an interest rate swap was concluded with the Magyar Nemzeti Bank in the amount of HUF 299 billion. 
Table 9: Risk indicators in the period 2015-2019 for OTP Bank

\begin{tabular}{|c|c|c|c|c|c|}
\hline \multirow{2}{*}{ Indicators } & \multicolumn{5}{|c|}{ OTP Bank } \\
\cline { 2 - 6 } & $\mathbf{2 0 1 5}$ & $\mathbf{2 0 1 6}$ & $\mathbf{2 0 1 7}$ & $\mathbf{2 0 1 8}$ & $\mathbf{2 0 1 9}$ \\
\hline Interest rate risk (\%) & 244 & 215 & 196 & 180 & 168 \\
\hline Price risk (\%) & 0,09 & 0,09 & 0,09 & 0,12 & 0,1 \\
\hline
\end{tabular}

Source: Own compilation based on the 2015-2019 annual reports of OTP Bank, ERSTE Bank, Unicredit Bank and K\&H Bank

In terms of investments, the price risk is not significant, all data examined approach 0 percent due to the low investment rate. Sensitivity to market risk is rated 2 .

\subsection{The result of the qualification}

The CAMELS rating approach is seen as an important tool in identifying the financial strengths and weaknesses of a bank. This analysis highlights potential weaknesses and suggests the necessary corrective actions to overcome the weaknesses and thus improve a bank's overall performance.

Table 10: The CAMELS rating system for OTP Bank

\begin{tabular}{|l|c|c|c|}
\hline \multicolumn{1}{|c|}{ Appellation } & Rating & Weighting & Weighted value \\
\hline Capital adequacy (C) & 1 & $25 \%$ & 0,25 \\
\hline Asset quality A) & 2 & $20 \%$ & 0,4 \\
\hline Management (M) & 1 & $10 \%$ & 0,1 \\
\hline Earnings (E) & 1 & $20 \%$ & 0,2 \\
\hline Liquidity (L) & 1 & $15 \%$ & 0,15 \\
\hline Sensitivity (S) & 2 & $10 \%$ & 0,2 \\
\hline Total & & $\mathbf{1 0 0} \%$ & $\mathbf{1 , 3}$ \\
\hline
\end{tabular}

Source: Own editing

In the CAMELS rating system, a rating of 1 means a well-functioning, risk-free bank with appropriate risk management. The bank is shock-resistant and its lending capacity is favorable, and its capital adequacy represents good values. OTP Bank is able to maintain stable operations and carry out its activities smoothly even in a strong, unfavorable economic environment in terms of capital.

- The proportion of qualifying loans with adequate asset quality decreased, but the proportion of doubtful loans increased.

- In terms of liquidity, the bank is performing well.

- The management is suitable for leadership, performs its task well, is competent for this role in all respects.

- The banking group has an interest rate risk exposure, which is offset by the purchase of long-term, fixed-rate government securities.

OTP Bank's strengths: universal financial services through several subsidiaries; Hungary's largest commercial bank; more than 13 million customers; approx. It 
has 1500 branches; global presence in 9 countries; strong financial and brand position; appropriate strategy. Weakness of OTP Bank: strong competition means limited market share; downgrading recent credit ratings; characterized by dispersed ownership by private and institutional (financial) investors; domestic low interest rates; change in asset quality.

Opportunities for OTP Bank: further international expansion; merging banks; growth in demand for MNB credit and investment products.

The threat of OTP Bank: domestic political environment; diversified relations with other countries; strong competition in the region; public distrust of products and credit institutions.

\section{Conclusions and recommendations}

The aim of the research was to measure the stability of OTP Bank using the CAMELS method. In our opinion, a bank can only achieve its current marketleading position if it receives the best rating of all the factors included in the analysis and performs better than the average of the banking sector in all respects. This assumption was not substantiated, as the examined bank did not receive the best rating for several items. Based on the calculations, it can be seen that it did not perform above the average of the banking sector in all analytical factors, but nevertheless it is able to maintain its market-leading position for years due to its long-term strategy and competent management. In our view, efficiency levels remain sustainable with either higher profits or lower operating costs.

Of course, the impact of COVID-19 on the current economic situation must also be examined. It is the responsibility of the institutions concerned to continue to support both the household and corporate sectors, with a special focus on small and medium-sized enterprises, and to prioritize the basic needs of their clients. It is not yet clear what impact the isolation measures taken as a result of the spread of the virus and the damage to the economy, consumer decline due to unemployment and insolvency will have. All the countries of the world, including Hungary, have taken significant economic measures, one of the main participants of which is commercial and credit banks. A moratorium on repayment of loans taken out by individuals and companies to date will be introduced in Hungary by the end of the year, which has been accepted by commercial banks. The maturity of short-term business loans has been extended until June 30, 2021. The maximum APR for consumer loans is set at a maximum of five percentage points relative to the MNB's base rate.

\section{References}

1. BCBS (2006) Basel Committee on Banking Supervision. International Convergence of Capital Measurement and Capital Standards

2. Fazekas, Zs. (2009) A Bázel 2 pénzügyi szabályozási rendszer. Budapesti Gazdasági Főiskola Külkereskedelmi Kar https://docplayer.hu/7018519-A-bazel-2penzugyi-szabalyozasi-rendszer.html (download: 05.02.2021.)

3. John C. Hull (2015): Risk Management and Financial Institutions

4. Kiss, H.J. and Homolya D. (2014): On the optimal design of operational risk data. consortiums, Journal of Operational Risk, 9 (1), pp. 33-55. (download: 
https://www.scopus.com/inward/record.uri?eid=2-s2.0-84973894708\&partner $\mathrm{ID}=40 \& \mathrm{md} 5=4 \mathrm{c} 59824595 \mathrm{c} 35076 \mathrm{a} 1 \mathrm{bde} 8 \mathrm{af0eda} 015 \mathrm{c}$ )

5. KPMG (2013): Basel 4 - Emerging from the mist?

6. Massimiliano Coluccia and Marco Franchini and Elisa Quinto: (2020) Basel 4 and the reduction in RWA variability: capital buffers and capital erosion

7. Rai, E. (2010). A study of Camel analysis of commercial banks.

8. Seregdi, L. (1993) Pénzintézetek komplex elemzési és értékelési rendszere, Bank és tőzsde, 1993

9. Sulyok-Pap, M. (2006) Banküzemtan, Pénzügyi Tanácsadó és Szolgáltató Kft., Budapest.

10. Szemán J. (2015) A magyar bankrendszer CAMELS típusú elemzése

11. Szombati, A. (2010) Bázel III. rendszerszintű hatásai itthon és Európában. MNB szemle https://www.mnb.hu/letoltes/szombati.pdf (download: 04.03.2021) 12. Tajti Zs. (2011) A bázeli ajánlások és a tőkemegfelelési direktíva (CRD) formálódása 


\title{
THE IMPACT OF THE COVID-19 PANDEMICS OVER THE FINANCIAL PERFORMANCE AT THE LEVEL OF THE MAIN PHARMACEUTICAL OPERATING IN CENTRAL AND EASTERN EUROPE
}

\author{
Laurentiu DROJ', Goran KARANOVIC ${ }^{2}$, loan Gheorghe TARA ${ }^{1}$ \\ 'University of Oradea, Faculty of Economics, Finance and Accounting \\ Department, Oradea, Romania \\ 2University of Rijeka, Faculty of Tourism and Hospitality Management, Department \\ of Finance, Rijeka, Croatia \\ Laurentiu.droj@uoradea.ro \\ gorank@fthm.hr \\ itara@uoradea.ro
}

Abstract: The COVID19 pandemic seems to have affected the financial results of the companies operating in Central and Eastern Europe. This paper has as a main goal to analyse the impact of COVID-19 crisis over companies which operate in the pharmaceutical sector. Since two of the authors developed an article in 2018 concentrated on the Early warning indicators and their impact over the medical companies registered in the Bucharest Stock Exchange, the current article analysis the same indicators but extends them at the level of four countries: Romania, Croatia, Slovenia and Hungary. Within the paper the authors will compare the evolution of several financial indicators: liquidity, financial leverage, solvency, annual return, ROE, ROA, so on in context of COVID-19. The main reason for the selection of medical and pharmaceutical sector is constituted by the discussions that these companies benefit from the effects of COVID19.

Keywords: financial analysis, financial indicators, ROE, liquidity, solvency, COVID19, pharmaceutical sector

JEL classification: G34, G11, G32, O16, C58

\section{Introduction}

A large part of the media and also a large part of population consider that the impact of COVID-19 pandemics over the pharmaceutical sector has been a positive one by driving an increase in the consumption of medical equipment, prescription medicine and especially vaccines and therefore the financial results for these companies should be increasing in 2020. Opinions from other specialists are highlighting the fact that most of the investments, M\&A deals and sale were concentrated on COVID-19 products (Robke et all, 2020 and Rickwood \& Harb, 2020, BRK, 2021). 
The study published by BRK (2021) highlighted the fact that Sales of some product categories increased in 2020, such as medicines promoted as protection against COVID-19, those useful in relieving the symptoms of the virus (some painkillers, vitamins and food supplements that stimulate immunity) and those for sleep. This is due to the fact that as the news of the virus spread, consumers began to stock up on medicines that were considered essential.

The same study by BRK(2021) citing a study by Padmanabhan (2020) and published in Euromonitor: https://www.euromonitor.com/article/coronavirus-acceleratesdemand-for-immunity-and-holistic-wellness signals the fact that clients changed their behaviour and are concentrating over Immunity and holistic wellness decreasing the purchases for other type of pharmaceutical products such as weight management and wellbeing.

Figure 1 Consumer health by category

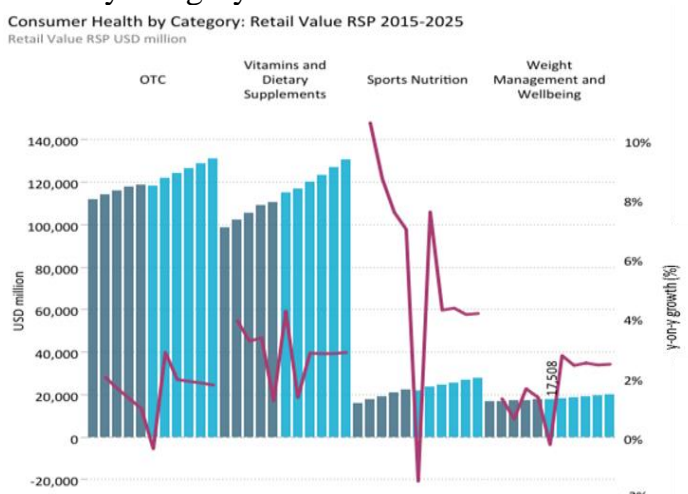

Source Padmanabhan (2020) in Euromonitor

https://www.euromonitor.com/article/coronavirus-accelerates-demand-for-immunity-andholistic-wellness

Since this article follows and can be considered as an extension of an article published by two of the authors Droj and Tara (2018) which is entitled Early warning indicators - evolution for the medical companies registered at BSE and which was published in the same Journal. The previous article intended to identify several early warning bankruptcy indicators and dealt with analyzing several models such as:

- Simple bankruptcy analysis pioneered by Beaver(1966) based on statistical methods

- Z-score model proposed by Altman (1968) a very popular model until now

- Multiple logistic regression models as proposed by Ohlson(1980)

- Neural networks championed by Charitou, Neophytou and Charalambous (2004)

- Econometric/Combined models (Tarnoczi and Fenyves, 2011, Bedenik et al., 2012)

Other complementary studies (Karanovic et all, 2018) are tackling issues such bankruptcy, insolvency or excessive debt at the level of companies and also increase of competitiveness and increase in revenues of the companies. 
In the following chapters the authors will present several financial indicators through which can be assessed the effects of COVID-19 pandemics over the pharmaceutical sector from Romania, Croatia, Hungary and Slovenia. These are indicators including both classical liquidity or solvency indicators (Droj, 2012) and financial or economic efficiency indicators (Droj, 2015).

\section{Selection of the financial indicators suitable for analyzing the impact of COVID 19 pandemics over the pharmaceutical sector}

The financial indicators which will be used to test the companies registered at the Romanian stock market were presented earlier by the author in other studies (Droj and Tara 2018). Several other authors dealt with analysis of financial indicators in the region: Rozsa (2014), Fenyves et all (2018) or Karanovic and Karanovic (2016)

As mentioned earlier the indicators selected are representative for the issues of financial efficiency, liquidity and solvency were selected the following indicators:

\section{Liquidity indicator:}

Current ratio (WCR) is used to analyse the ability of a company to pay its current liabilities its current assets. This ratio is also known as the working capital ratio.

$$
W C R=\frac{\text { Current assets }}{\text { Current Liabilities }}
$$

\section{Solvency ratio}

- shows the extent to which total debts are covered by total assets, and reflects the security enjoyed by creditors, as well as the creditworthiness of the company(Droj, 2012).

$$
\mathrm{Sv}=\frac{\text { Total assets }}{\text { Totaldebts }} \times 100
$$

\section{Return Indicators as presented by Droj (2015) and Rozsa (2012):}

- The Return on Equity (ROE), also known in French economic literature as "financial return rate", and abbreviated in the specialized literature as ROE. This indicator shows the efficiency of the capital invested by shareholders. ROE constitutes one of the most important return indicators, being used by company owners and potential investors in the investment decision-making process.

$$
\mathrm{ROE}=\frac{\text { Net } \text { Profit }}{\text { Equity }}
$$

These indicators were tested by using financial data for companies operating in Tourism industry in Romania, Croatia, Hungary and Slovenia accessed from 
Amadeus databases (https://amadeus.bvdinfo.com/). The collected information is analyzing the Financial Reports of the selected companies in the period 20162020.

\section{Assessing the impact of COVID 19 pandemics over the pharmaceutical sector from central and Eastern Europe in the period 2016-2020}

After a period (2016-2019) of consolidation and fierce competition in the pharmaceutical sector, the COVID-19 pandemics brought new challenges and opportunities for the pharmaceutical sector. The companies selected for the study are having the following key financial information: turnover over 5 million EURO and bellow 50 million EURO.

The selection used a Boolean algorithm in order to select the most representative pharmaceutical companies from Romania, Croatia, Hungary and Slovenia. The first step of analyzing the impact of COVID 19 over these companies was analyzing the evolution in the period 2016-2020 of the turnover, cash flow and number of employees.

As can be seen from the analysis of the Return on Equity this indicator managed to improve significantly in the COVID-19 pandemics from a median of $11 \%$ and an average of $10 \%$ this indicator achieved an average a median of $16 \%$, even if the results in Slovenia were negative.

Table 1 Evolution of Return on Assets (ROA) - 2016-2020

\begin{tabular}{|l|c|c|c|c|c|}
\hline ROE \% & $\mathbf{2 0 1 6}$ & $\mathbf{2 0 1 7}$ & $\mathbf{2 0 1 8}$ & $\mathbf{2 0 1 9}$ & $\mathbf{2 0 2 0}$ \\
\hline Slovenia & 18 & 9 & 14 & -4 & -13 \\
\hline Romania & 24 & 17 & 16 & 15 & 15 \\
\hline Hungary & 13 & 14 & 12 & 8 & 16 \\
\hline Croatia & -5 & 5 & 7 & 20 & 25 \\
\hline TOTAL & $\mathbf{1 5}$ & $\mathbf{1 2}$ & $\mathbf{1 1}$ & $\mathbf{1 1}$ & $\mathbf{1 6}$ \\
\hline Median & $\mathbf{1 5}$ & $\mathbf{1 2}$ & $\mathbf{1 3}$ & $\mathbf{1 2}$ & $\mathbf{1 6}$ \\
\hline Average & $\mathbf{1 2}$ & $\mathbf{1 1}$ & $\mathbf{1 2}$ & $\mathbf{1 0}$ & $\mathbf{1 1}$ \\
\hline
\end{tabular}

Source: Calculation of the authors based on the data from www.bvb.ro

The biggest improvement for this indicator was registered by companies from Hungary and Croatia, while the selected companies from Romania maintained the same level.

Figure 2 Evolution of Return on Assets (ROA) - 2016-2020 


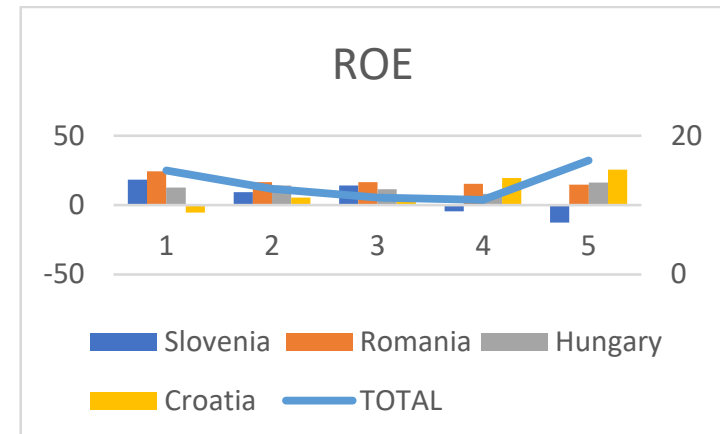

Source: Calculation of the authors based on the data from https://amadeus.bvdinfo.com/).

In which concerns the liquidity indicator we can see that the overall evolution is extremely positive both at the level on the entire sector and at the level of individual country. Even the companies from Slovenia improved their values from the all time low of 2018.

Table 2 Evolution of Liquidity ratio - 2016-2020

\begin{tabular}{|c|l|l|l|l|l|}
\hline Liquidity ratio & $\mathbf{2 0 1 6}$ & $\mathbf{2 0 1 7}$ & $\mathbf{2 0 1 8}$ & $\mathbf{2 0 1 9}$ & $\mathbf{2 0 2 0}$ \\
\hline TOTAL & $\mathbf{2 . 3 3}$ & $\mathbf{2 . 3 5}$ & $\mathbf{2 . 2 1}$ & $\mathbf{2 . 5 6}$ & $\mathbf{2 . 6 4}$ \\
\hline Slovenia & 1.39 & 0.98 & 0.51 & 0.63 & 0.85 \\
\hline Romania & 2.15 & 2.20 & 2.26 & 2.46 & 2.47 \\
\hline Hungary & 2.53 & 2.63 & 1.89 & 3.03 & 3.20 \\
\hline Croatia & 2.12 & 2.29 & 3.00 & 2.19 & 2.32 \\
\hline Median & $\mathbf{2 . 1 3}$ & $\mathbf{2 . 2 5}$ & $\mathbf{2 . 0 7}$ & $\mathbf{2 . 3 2}$ & $\mathbf{2 . 4 0}$ \\
\hline Average & $\mathbf{2 . 0 5}$ & $\mathbf{2 . 0 3}$ & $\mathbf{1 . 9 1}$ & $\mathbf{2 . 0 8}$ & $\mathbf{2 . 2 1}$ \\
\hline
\end{tabular}

Source: Calculation of the authors based on the data from https://amadeus.bvdinfo.com/).

The liquidity indicator shows and extremely healthy sector in Hungary (3.20), Romania (2.47) and Croatia (2.32), in all these countries the values increased comparing with 2019 and in Hungary and Romania these values are at the all-time high. 
Figure 3 Evolution of Liquidity ratio - 2016-2020

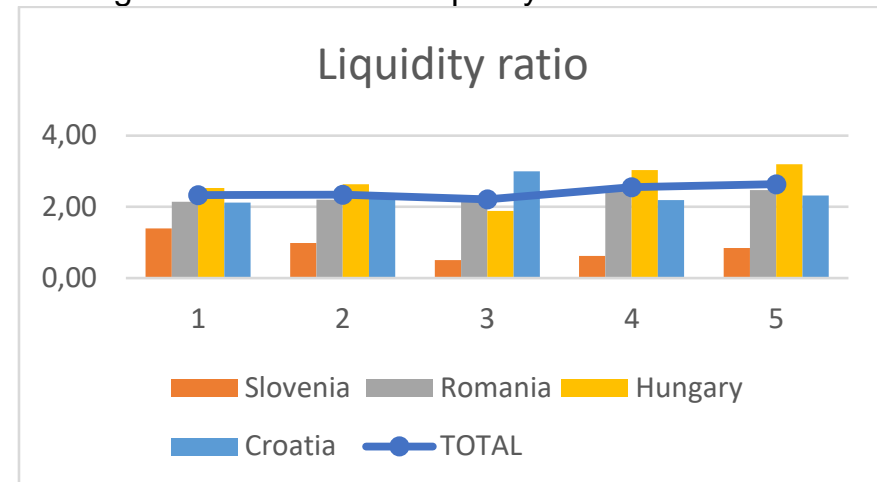

Source: Calculation of the authors based on the data from https://amadeus.bvdinfo.com/).

The solvency follows the evolution of the liquidity indicator, where the results are having an extremely positive tendency in 2020 improving significantly from 2019. The lowest levels for this indicator are registered at the level of the Slovenian companies included in the study $27.95 \%$ in 2020 , increasing from $18.78 \%$ in 2019

Table 3 Evolution of Solvency Ratio - 2016-2020

\begin{tabular}{|c|c|c|c|c|c|}
\hline $\begin{array}{c}\text { Solvency ratio } \\
\text { (Liability based) \% }\end{array}$ & $\mathbf{2 0 1 6}$ & $\mathbf{2 0 1 7}$ & $\mathbf{2 0 1 8}$ & $\mathbf{2 0 1 9}$ & $\mathbf{2 0 2 0}$ \\
\hline TOTAL & $\mathbf{4 3 . 6 0}$ & $\mathbf{5 5 . 7 8}$ & $\mathbf{4 8 . 3 2}$ & $\mathbf{5 0 . 6 1}$ & $\mathbf{5 8 . 9 5}$ \\
\hline Slovenia & 38.98 & 47.86 & 31.45 & 18.78 & 27.95 \\
\hline Romania & 34.68 & 48.74 & 48.42 & 48.05 & 53.99 \\
\hline Hungary & 49.44 & 63.17 & 48.66 & 59.40 & 60.47 \\
\hline Croatia & 61.66 & 58.85 & 61.99 & 55.32 & 67.70 \\
\hline Median & $\mathbf{4 4 . 2 1}$ & $\mathbf{5 3 . 8 0}$ & $\mathbf{4 8 . 5 4}$ & $\mathbf{5 1 . 6 9}$ & $\mathbf{5 7 . 2 3}$ \\
\hline Average & $\mathbf{4 6 . 1 9}$ & $\mathbf{5 4 . 6 6}$ & $\mathbf{4 7 . 6 3}$ & $\mathbf{4 5 . 3 9}$ & $\mathbf{5 2 . 5 3}$ \\
\hline
\end{tabular}

Source: Calculation of the authors based on the data from https://amadeus.bvdinfo.com/).

The biggest achievers are the companies from Croatia which increased their financial stability from $55.32 \%$ in 2019 to $67.70 \%$ solvency in 2020 . Positive evolutions were recorded at the level of Romanian (53.99\%) and Hungarian $(60.47 \%)$ companies. 
Figure 3 Evolution of Solvency ratio - 2016-2020

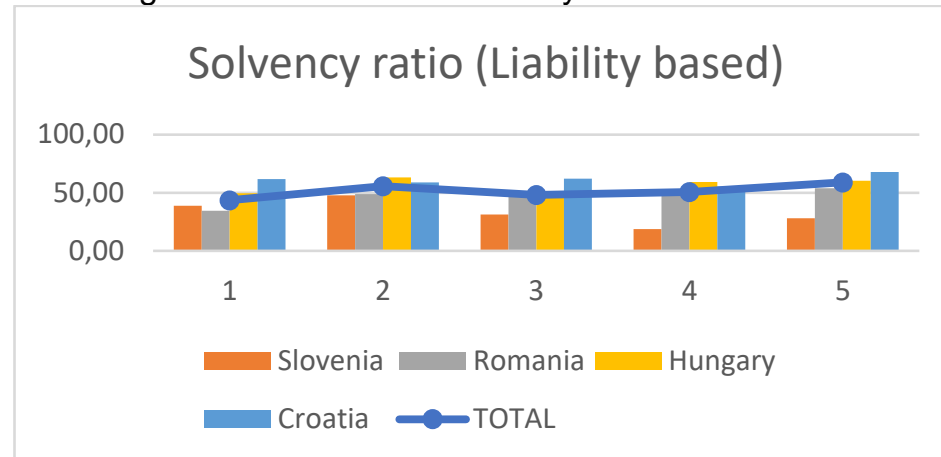

Source: Calculation of the authors based on the data from https://amadeus.bvdinfo.com/).

\section{Conclusions}

After the analysis of the data, it is clear that the financial results of the pharmaceutical companies improved consistently in 2020, the first year where the COVID-19 effects were felt by the pharmaceutical sector. It is clear that the pharmaceutical sector reacted properly to the increasing demand in medicines promoted as protection against COVID-19, those useful in relieving the symptoms of the virus (some painkillers, vitamins and food supplements that stimulate immunity) and those for sleep. A clear view over the positive impact over the financial results, caused in this sector by COVID-19 pandemics, can be realized only after the analysis of the financial information for 2021 and the years postCovid.

As a general conclusion of this paper, we can consider that the indicators used in this study should be accompanied by several other types of indicators both financial, macro-economic, sectorial and also non-financial qualitative or quantitative. This study should be continued on a larger scale and including other indicators in order to establish which elements should be tackled first when dealing with the effects of COVID-19 crisis over the pharmaceutical sector.

\section{References}

1. Altmacharitn, E. I. (1968), "Financial ratios, discriminant analysis and the prediction of corporate bankruptcy", The Journal of Finance, Vol. 23, No. 4, pp. 589-609.

2. Altman, E. I. (1993). Corporate financial distress and bankruptcy. New York: NY, John Wiley and Sons, In.

3. Amadeus, 2021, Amadeus Database - Software version 16.12 - data update 22.11.2021 https://amadeus.bvdinfo.com/ accessed in 26.11.2021

4. Beaver, W. H. (1966), "Financial ratios as predictors of failure", Journal of Accounting Research, Vol. 4, pp. 71-111.

5. Bedenik, N. O., Rausch, Al., Fafaliou, Ir., \& Labaš, D. (2012). Early Warning System - Empirical Evidence. In: TRŽIŠTE, 24 (2), 201-218.

6. Charitou, A., Neophytou, E., and Charalambous, C. (2004). Predicting corporate failure: Empirical evidence for the UK. European Accounting Review 13(3), 465497. 
7. BRK Financial Group, 2021, Raport de Analiza Biofarm, https://www.brk.ro/cotatiisi-analize/rapoarte-de-analiza/raport-de-analiza-biofarm/

8. Droj, L., 2012 Financial Performance Analysis based on the Financial Statements for the Companies Located in the Bihor - Hajdu Bihar Euroregion, Published in Annals of the University of Oradea, Economic Science Series;2012, Vol. 21 Issue 2, p464, Oradea, Romania http://connection.ebscohost.com/c/articles/85948972/financial-performanceanalysis-based-financial-statements-companies-located-bihor-hajdu-bihareuroregion

9. Droj, L. 2015 Study Regarding the Profitability Indicators for the Romanian Companies Operating in the Tourism and Leisure Services Sector in the Period of 2010-2013 available online http://steconomiceuoradea.ro/anale/volume/2015/n1/093.pdf

10. Droj L., Tara I.G., 2018, Early warning indicators - evolution for the medical companies registered at BSE, available online https://ideas.repec.org/a/ora/journl/v1y2018i2p102-108.html

11. Fenyves, Veronika \& Bács, Zoltán \& Zéman, Zoltán \& Böcskei, Elvira \& Tarnoczi, Tibor. (2018). The role of the notes to the financial statements in corporate decision-making. Corporate Ownership \& Control. 15. 138-148. $10.22495 / \operatorname{cocv} 15 i 4 \mathrm{c} 1 \mathrm{p} 1$.

12. Goran Karanovic, Bisera Karanovic, and Martina Gnjidic. 2018. Liquidity Risk Management: Practice Among Croatian Firms. Journal of the Polytechnic of Rijeka, 6(1), 81-98.

13. Karanovic, Goran, and Bisera Karanovic. 2016. IPOs Performance Analysis: Evidence from Emerging Markets in the Balkans. Scientific Annals of Economics and Business 63(3): 381-389. DOI: 10.1515/saeb-2016-0129

14. Ohlson, J. A. (1980). Financial ratios and the probabilistic prediction of bankruptcy. Journal of Accounting Research 18(1), 109-131.

15. Padmanabhan J. (2020) Coronavirus Accelerates Demand for Immunity and Holistic Wellness published in Euromonitor 2020, https://www.euromonitor.com/article/coronavirus-accelerates-demand-forimmunity-and-holistic-wellness

16. Rickwood, S; Harb, N. 2020, Taking stock: An assessment of 2020 for the EU5 pharma market, and the lessons for 2021, webinar Webinar: September 29, 2020, IQWIA available online: https://www.iqvia.com/library/white-papers/monitoring-theimpact-of-covid-19-on-the-pharmaceutical-market-eu5

17. Robke, L; Berghauser Pont, L.; Bongard, J., Wurzer, S; Smietana, K and Moss, R 2020, Impact of COVID-19 on pharmaceutical external innovation sourcing, published in Nature Reviews Drug Discovery 19, 829 (2020)

18. Rozsa, A. (2014), Financial position of building industry in Hajdú-Bihar county ( $E$ Hungary) in the period of 2008-2012: Regional sectoral analysis based on economic performance ratios, published in International Review Of Applied $\begin{array}{llll}\text { Sciences And } \quad \text { Engineering } & \text { 67-77, }\end{array}$ http://www.akademiai.com/doi/abs/10.1556/IRASE.5.2014.1.9

19. Tarnoczi, Tibor \& Fenyves, Veronika. (2011). LIQUIDITY MANAGEMENT AND CORPORATE RISK. Annals of Faculty of Economics. 1. 530-536. 


\title{
CONSIDERATIONS REGARDING THE IMPACT OF THE COVID-19 PANDEMICS OVER THE FINANCIAL PERFORMANCE AT THE LEVEL OF THE TOURISM COMPANIES OPERATING IN CENTRAL AND EASTERN EUROPE
}

\author{
Laurentiu DROJ', Gabriela DROJ ${ }^{2}$ \\ ${ }^{1}$ University of Oradea, Faculty of Economics, Finance and Accounting \\ Department, Oradea, Romania \\ 'University of Oradea, Faculty of Construction, Cadaster and Architecture, \\ Oradea, Romania \\ Laurentiu.droj@uoradea.ro \\ Gdroj@uoradea.ro
}

\begin{abstract}
The tourism sector is one of the most dynamic economic sectors in Romania contributing with $6.3 \%$ in the number of workplaces and reaching $5.3 \%$ from the total GDP. The impact of the COVID-19 pandemic over this sector has been catastrophic. The goal of the proposed article is to perform a brief financial assessment of the companies operating in the tourism sector, located Romania, Croatia, Hungary and Slovenia, by using financial information collected from Amadeus database. The macroeconomic data was collected through Statista and the financial information used in the study is based on the financial reporting data for the years 2016-2020 processed through Amadeus data base. Based on both sets of data the current paper will attempt to analyze the financial information (ROE, ROA, annual return, evolution of cash-flow and number of employees) and determine if a link can be established between the evolution of the financial performance of the selected companies and the COVID-19 pandemics effects over the tourism sector. These companies were selected especially since they are extremely affected by the effects of COVID19 and therefore further research can be performed in the following years.
\end{abstract}

Keywords: financial analysis, financial results, ROE, ROA, Romania, Croatia, Slovenia, Hungary, COVID19, tourism

JEL classification: G32, G17, G34, O16

\section{Introduction}

The impact of the COVID-19 pandemic over the tourism sectors has been catastrophic. In a study published in 29 November 2021 by the United Nations citing UNWTO Barometer the projected lost revenues in 2021 for the tourism industry are in amount of 2 trillion USD (United Nations, 2021).

As it can be seen in a report published in November 2021 by UNWTO (2021) the number of tourist arrivals has collapsed in 2021 comparing with 2019 and in some regions even comparing with 2020 . 
Figure 12021 International Tourist Arrivals

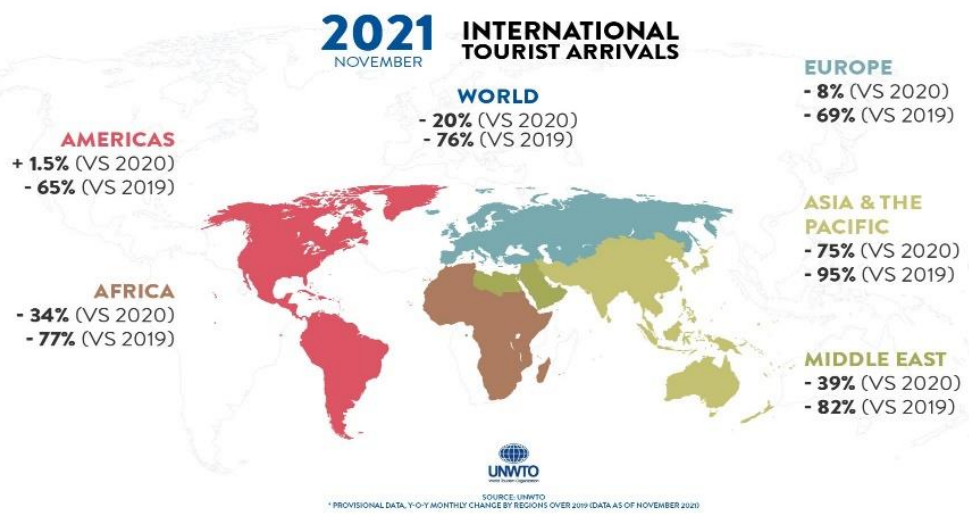

Source: UNWTO (2021) https://www.unwto.org/

For the Central and Eastern European Countries, the tourism sector is considered one of the most important economic sectors. A study published by Statista (2021) highlights the fact that Europe is the global leader in international tourism with a continuous tourism development, accruing over 700 million tourists each year and contributing to the European GDP growth with 2.191,2 billion USD. The total revenues from tourism decreased to $1.064,7$ billion USD in 2020, as an effect of COVID-19 pandemics.

The importance of this sectors is highlighted by the fact that is fastest developing economic sectors in Romania with a contribution of $6.3 \%$ of the total workplaces and a $5.3 \%$ direct contribution towards the GDP.s

Starting from the last financial crisis new elements have been introduced in the analysis since both academic researchers and audit agencies realized that, for a proper measurement of the phenomenon more financial and non-financial factors should be analysed. The results seem to be different from one case study to another and seems to be linked with the financial data at the disposal of the researchers (Droj and Tara, 2018, Ohlson, 1980 and Pierre, 2004).

Figure 2 Total contribution of travel and tourism to GDP in Europe

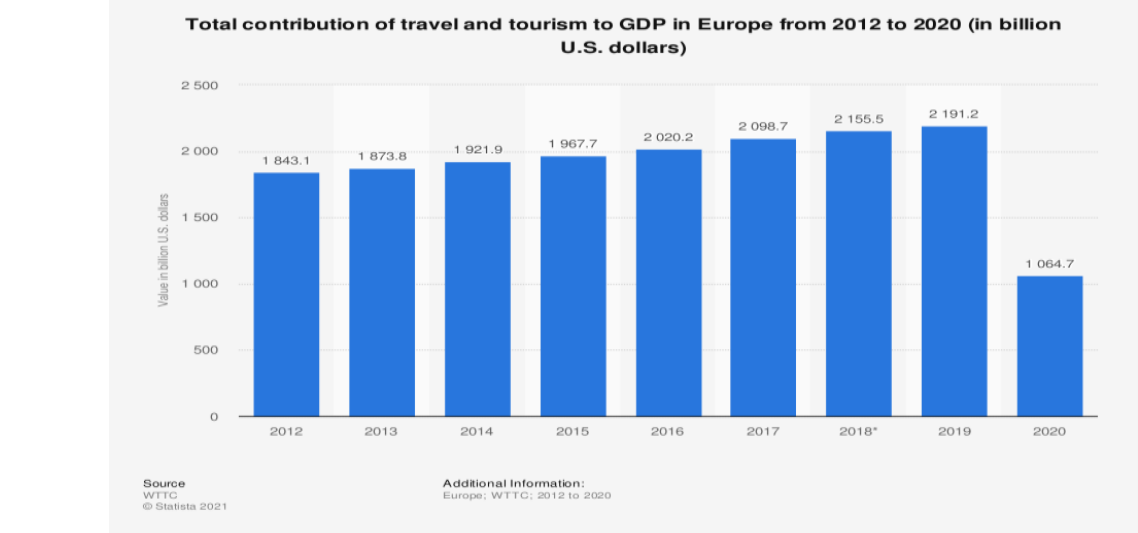

Source: Statista Research department

https://www.statista.com/statistics/617528/travel-tourism-total-gdp-contribution-europe/ 
Taken into consideration the above, the authors of this paper are trying to analyze several indicators, which can be highlight the impact of COVID over the financial performance of the tourism companies operating in Central and Eastern Europe. The authors selected several financial early warning indicators, which can be suitable for the proposed model. These are indicators including both classical liquidity or solvency indicators (Droj, 2012) and financial or economic efficiency indicators (Droj, 2015).

\section{Selection of the financial indicators suitable for analyzing the impact of COVID 19 pandemics over the tourism sector}

The financial indicators which will be used to test the companies registered at the Romanian stock market were presented earlier by the author in other studies (Droj, 2012, Droj 2015). Several other authors dealt with analysis of financial indicators in the region: Rozsa (2014), Fenyves et all (2018) Tarnoczi et all(2011) or Karanovic and Karanovic (2016)

As mentioned earlier the indicators selected are representative for the issues of financial efficiency, liquidity and solvency were selected the following indicators:

- Annual return and cash flow- are critical indicators which reflect the evolution of revenues in this sector in the analysed period since the companies are counting on them in order to achieve their survival in a period of economic crisis.

- Number of employees - since one of the most important elements of the tourism sector is the number of jobs created the evolution in number of employees is considered an important element of analysis during an economic crisis.

- Cash flow - is one of the most important elements for companies in periods where

\section{Return Indicators as presented by Droj (2015) and Fenyves et all (2018):}

The Return of Assets (ROA) reflects the difference between an economic result: net profit, known in specialized literature as EBIT and the assets used for its achievement (Pierre, 2004).

$$
\mathrm{ROA}=\frac{\text { Net } \text { Profit }}{\text { Total assets }}
$$

- The Return on Equity (ROE), also known in French economic literature as "financial return rate", and abbreviated in the specialized literature as ROE. This indicator shows the efficiency of the capital invested by shareholders. ROE constitutes one of the most important return indicators, being used by company owners and potential investors in the investment decision-making process.

$$
\mathrm{ROE}=\frac{\text { Net } \text { Profit }}{\text { Equity }}
$$

These indicators were tested by using financial data for companies operating in Tourism industry in Romania, Croatia, Hungary and Slovenia accessed from Amadeus databases (https://amadeus.bvdinfo.com/). The collected information is 
analyzing the Financial Reports of the selected companies in the period 20162020.

\section{The financial performance at the level of the tourism companies operating in Central and Eastern Europe}

The analyzed period (2016-2020) is period when the tourism sector witnessed both growth (2016-2019) and recession caused by COVID 19 in 2020. The companies selected for the study are having the following key financial information: turnover over 1 million EURO and bellow 50 million EURO. The selection used a Boolean algorithm in order to select the most representative tourism companies from Romania, Croatia, , Hungary and Slovenia. The first step of analyzing the impact of COVID 19 over these companies was analyzing the evolution in the period 20162020 of the turnover, cash flow and number of employees.

Table 1 Evolution of turnover, cash flow and number of employees

\begin{tabular}{|l|c|c|c|c|c|}
\hline & $\mathbf{2 0 1 6}$ & $\mathbf{2 0 1 7}$ & $\mathbf{2 0 1 8}$ & $\mathbf{2 0 1 9}$ & $\mathbf{2 0 2 0}$ \\
\hline Turnover (mil. USD) & 12046.5 & 12894.23 & 13955.33 & 15195.87 & 6861.606 \\
\hline Turnover\% evolution & & $7.04 \%$ & $8.23 \%$ & $8.89 \%$ & $-54.85 \%$ \\
\hline Cash flow (mil USD) & 2683.578 & 3006.263 & 3165.479 & 3889.769 & -153.172 \\
\hline Cash flow\% evolution & & $12.02 \%$ & $5.30 \%$ & $22.88 \%$ & $-103.94 \%$ \\
\hline Employees & 212 & 216 & 224 & 228 & 175 \\
\hline Employees\% evolution & & $1.99 \%$ & $3.71 \%$ & $1.53 \%$ & $-23.04 \%$ \\
\hline
\end{tabular}

Source: Calculation of the authors based on the data from

https://amadeus.bvdinfo.com/).

As observed from the Table above the evolution of these indicators was positive each year of the analysis, with an extremely good year of 2019. The COVID-19 impacted heavily the results of 2020 when the values collapsed with $54.85 \%$ in case of turnover, $103.94 \%$ in case of cash flow and $23.04 \%$ in terms of employees.

Figure 3 Evolution of turnover, cash flow and number of employees

Evolution of turnover, cash flow and employees at the regional level

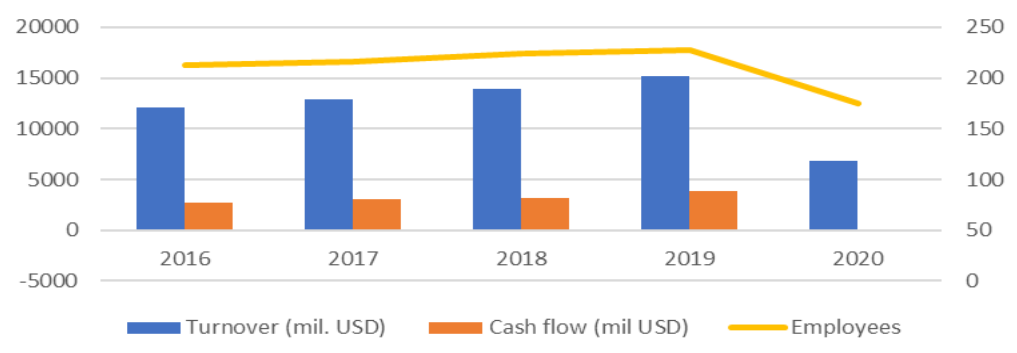

Source: Calculation of the authors based on the data from https://amadeus.bvdinfo.com/). 
The Return on Equity (ROE) was the next indicator which was analyzed for all four countries. As observed from the table bellow, the selected companies from the tourism sector had healthy ROE in the last years. The median of the sector being highest in 2019 at the value of $14.23 \%$ and the average ration of $14.15 \%$, the second highest.

Table 2 Evolution of Return on Equity (ROE) - 2016-2020

\begin{tabular}{|l|r|r|r|r|r|}
\hline ROE(\%) & $\mathbf{2 0 1 6}$ & $\mathbf{2 0 1 7}$ & $\mathbf{2 0 1 8}$ & $\mathbf{2 0 1 9}$ & $\mathbf{2 0 2 0}$ \\
\hline Romania & 31.01 & 18.54 & 20.42 & 20.99 & -2.04 \\
\hline Hungary & 14.90 & 19.61 & 19.33 & 23.23 & -32.17 \\
\hline Slovenia & 10.66 & 8.49 & 0.81 & 4.92 & -3.75 \\
\hline Croatia & 8.31 & 7.44 & 8.79 & 7.46 & -15.30 \\
\hline Median & $\mathbf{1 2 . 7 8}$ & $\mathbf{1 3 . 5 1}$ & $\mathbf{1 4 . 0 6}$ & $\mathbf{1 4 . 2 3}$ & $\mathbf{- 9 . 5 3}$ \\
\hline Mean & $\mathbf{1 6 . 2 2}$ & $\mathbf{1 3 . 5 2}$ & $\mathbf{1 2 . 3 4}$ & $\mathbf{1 4 . 1 5}$ & $\mathbf{- 1 3 . 3 2}$ \\
\hline
\end{tabular}

Source: Calculation of the authors based on the data from https://amadeus.bvdinfo.com/).

The emergence of COVID-19 impacted directly on ROE which plummeted to negative values, the results can be seen clearly in the table bellow. The biggest impact of the COVID-19 over the ROE was registered at the level of Hungarian and Croatian companies, also countries where revenues tourism has an important share in the GDP.

Figure 4 Evolution of Return on Equity (ROE) - 2016-2020

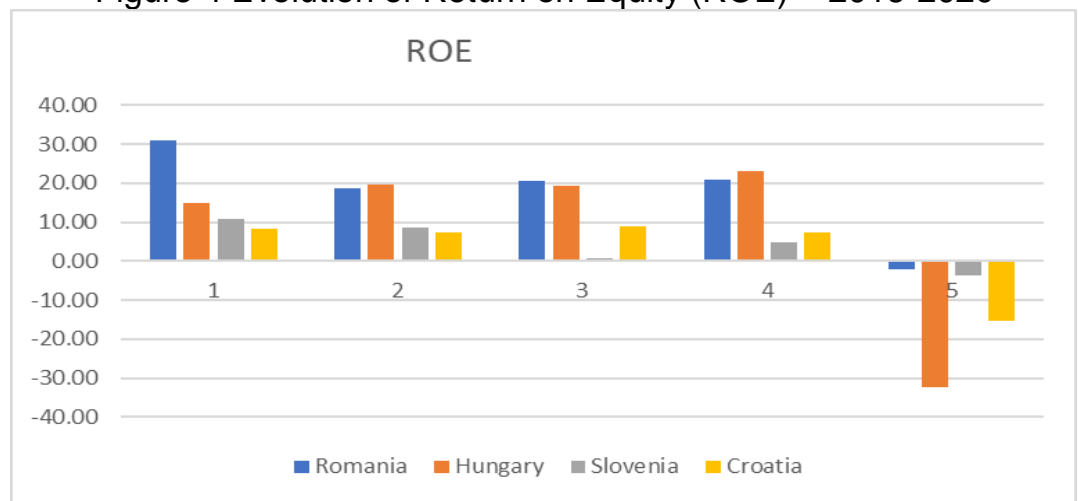

Source: Calculation of the authors based on the data from https://amadeus.bvdinfo.com/).

The evolution of Return of Assets (ROA) was also subjected to negative financial results in 2020 after extremely good years of $2016-2020$ where the results reached from a median of $4.79 \%$ in 2016 to a median of $6.88 \%$ in 2019 . 
Table 3 Evolution of Return on Assets (ROA) - 2016-2020

\begin{tabular}{|l|r|r|r|r|r|}
\hline ROA\% & $\mathbf{2 0 1 6}$ & $\mathbf{2 0 1 7}$ & $\mathbf{2 0 1 8}$ & $\mathbf{2 0 1 9}$ & $\mathbf{2 0 2 0}$ \\
\hline Romania & 5.38 & 7.48 & 8.57 & 10.28 & -1.96 \\
\hline Hungary & 5.98 & 7.37 & 7.43 & 9.66 & -5.49 \\
\hline Slovenia & 4.21 & 3.66 & 1.66 & 1.53 & -4.40 \\
\hline Croatia & 4 & 4 & 4 & 4 & -6 \\
\hline Median & $\mathbf{4 . 7 9}$ & $\mathbf{5 . 6 9}$ & $\mathbf{5 . 5 7}$ & $\mathbf{6 . 8 8}$ & $-\mathbf{4 . 9 4}$ \\
\hline Mean & $\mathbf{4 . 9 4}$ & $\mathbf{5 . 6 3}$ & $\mathbf{5 . 3 4}$ & $\mathbf{6 . 3 9}$ & $\mathbf{- 4 . 4 0}$ \\
\hline
\end{tabular}

Source: Calculation of the authors based on the data from https://amadeus.bvdinfo.com/).

The same as ROE, the evolution of ROA had negative results in 2020 with an median of $-4.94 \%$ and an average of $-4.40 \%$.

Figure 5 Evolution of Return on Assets (ROA) - 2016-2020

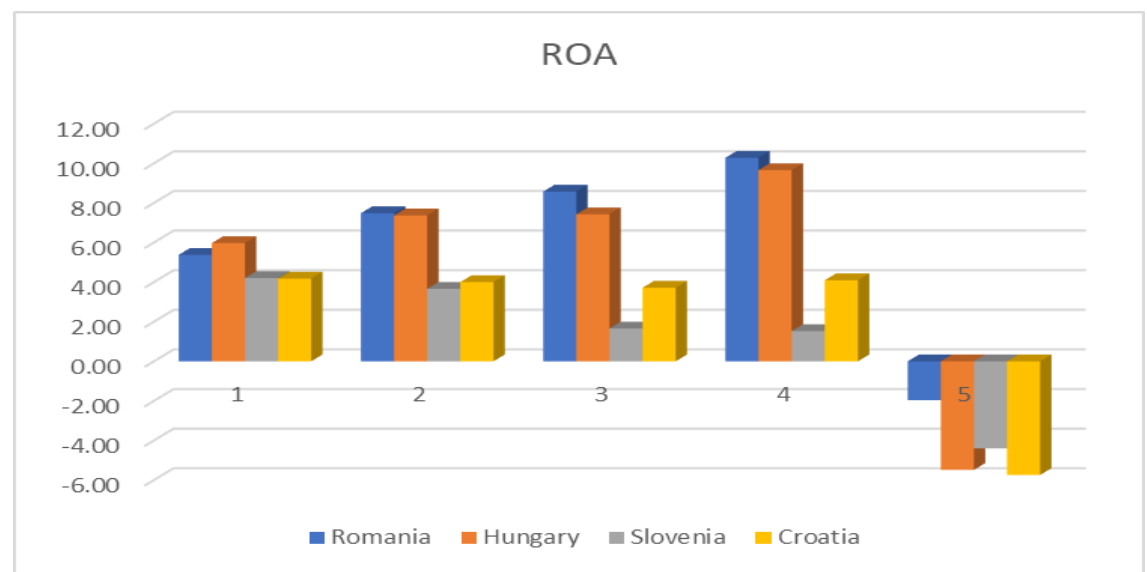

Source: Calculation of the authors based on the data from https://amadeus.bvdinfo.com/).

In 2020, since the effects of COVID-19 were extremely damaging to the revenues, Croatia and Hungary registered the lowest ROA cumulated values in 2020, followed closely by Slovenia.

\section{Conclusions}

As mentioned earlier, the impact of the COVID-19 pandemic over the tourism sectors has been catastrophic both at the level of the financial results (annual return and cash flow), at the level of employed persons in the sector and also at the level the main financial performance indicators. A clear view of the disaster caused in this sector by COVID-19 pandemics can be realized only after the analysis of the financial information for 2021 and the years post-Covid. 
As a general conclusion of the paper we can consider that the indicators used in this study should be accompanied by several other types of indicators both financial, macro-economic, sectorial and also non-financial qualitative or quantitative. This study should be continued on a larger scale and including other indicators in order to establish which elements should be tackled first when dealing with the effects of COVID-19 crisis in order to design the proper measures to revive the tourism sector in Central and Eastern Europe.

\section{References}

1. Amadeus, 2021, Amadeus Database - Software version 16.12 - data update 22.11.2021 https://amadeus.bvdinfo.com/ accessed in 26.11.2021

2. Droj, L., 2012 Financial Performance Analysis based on the Financial Statements for the Companies Located in the Bihor - Hajdu Bihar Euroregion, Published in Annals of the University of Oradea, Economic Science Series;2012, Vol. 21 Issue 2, p464, Oradea, Romania http://connection.ebscohost.com/c/articles/85948972/financial-

performance-analysis-based-financial-statements-companies-located-

bihor-hajdu-bihar-euroregion

3. Droj, L. 2015 Study Regarding the Profitability Indicators for the Romanian Companies Operating in the Tourism and Leisure Services Sector in the Period of 2010-2013 available online at: http://steconomiceuoradea.ro/anale/volume/2015/n1/093.pdf

4. Droj L., Tara I.G., 2018, Early warning indicators - evolution for the medical companies registered at BSE, available online https://ideas.repec.org/a/ora/journl/v1y2018i2p102-108.html

5. Fenyves, Veronika \& Bács, Zoltán \& Zéman, Zoltán \& Böcskei, Elvira \& Tarnoczi, Tibor. (2018). The role of the notes to the financial statements in corporate decision-making. Corporate Ownership \& Control. 15. 138-148. 10.22495/cocv15i4c1p1.

6. Gilbert, L. R., Menon, K., \& Schwartz, K. B. (1990). Predicting bankruptcy firms in financial distress. Journal of Business, Finance \& Accounting, 17(1), 161-171.

7. Goran Karanovic, Bisera Karanovic, and Martina Gnjidic. 2018. Liquidity Risk Management: Practice Among Croatian Firms. Journal of the Polytechnic of Rijeka, 6(1), 81-98.

8. Karanovic, Goran, and Bisera Karanovic. 2016. IPOs Performance Analysis: Evidence from Emerging Markets in the Balkans. Scientific Annals of Economics and Business 63(3): 381-389. DOI: 10.1515/saeb2016-0129

9. Ohlson, J. A. (1980). Financial ratios and the probabilistic prediction of bankruptcy. Journal of Accounting Research 18(1), 109-131. 
10. Pierre F., (2004), Valorisation d'entreprise et theorie financiere, Edition d'Organisation, Paris, p. 25, France

11. Rozsa, A. (2014), Financial position of building industry in Hajdú-Bihar county (E-Hungary) in the period of 2008-2012: Regional sectoral analysis based on economic performance ratios, published in International Review Of Applied Sciences And Engineering 5:(1) pp. 67-77, http://www.akademiai.com/doi/abs/10.1556/IRASE.5.2014.1.9

12. Statista Research Department, 2021, Travel and tourism in Europe statistics \& facts, available online at https://www.statista.com/topics/3848/travel-and-tourism-ineurope/\#dossierKeyfigures

13. Tarnoczi, Tibor \& Fenyves, Veronika. (2011). Liquidity management and corporate risk. Annals of Faculty of Economics. 1. 530-536.

14. United Nations 2021, Coronavirus pandemic could cost global tourism \$2 trillion this year, available online https://news.un.org/en/story/2021/11/1106712

15. UNWTO, 2021, Global Tourism Sees Upturn in Q3 but Recovery Remains Fragile, available online at https://www.unwto.org/news/global-tourismsees-upturn-in-q3-but-recovery-remains-fragile 


\title{
ARIMA vS. MACHINE LEARNING IN TERMS OF EQUITY MARKET FORECASTING
}

\author{
Iulian-Cornel LOLEA ${ }^{1}$, Ioan-Radu PETRARIU², Adriana GIURGIU³
}

\author{
${ }^{1}$ Bucharest University of Economic Studies, Bucharest, Romania \\ ${ }^{2}$ Bucharest University of Economic Studies, Bucharest, Romania \\ ${ }^{2}$ Bucharest University of Economic Studies, Bucharest, Romania; Department of \\ International Business, Faculty of Economic Studies, University of Oradea, \\ Oradea, Romania \\ loleaiulian@gmail.com \\ radu.petrariu@rei.ase.ro \\ adrianagiurgiu@gmail.com
}

\begin{abstract}
Through this paper we aimed to develop a comparison between ARIMA, Prophet, KNN and Neural Networks in terms of stock prices forecasting. After reviewing the literature, we noticed that there is a plethora of studies that address this problem of forecasting, but very few have made comparisons that include ARIMA, machine learning, but also the Prophet forecasting model developed by Facebook, which brought interesting results for certain data series. Based on methodologies validated by other authors, we compared these models in our paper and we sought to obtain promising results regarding performance evaluation. The comparison was made in-sample, the training period being 01/01/2010 $31 / 07 / 2021$, but also out-of-sample (01/08/2021 - 31/10/2021). The study was performed for Societe Generale's stock, using daily observations. Statistical loss functions such as RMSE, MPE, MAPE, MAE, and ME were used for comparison. The results indicated an outperformance of Neural Networks, both in-sample and out-of-sample, this model being on the 1st place according to the aggregated score. It is also noteworthy that the ARIMA model was in second place in-sample, ahead of KNN, but for out of sample these two algorithms changed their positions. On the other hand, the Prophet algorithm performed the weakest, both in-sample and out of sample. Also, we must underlie that all four algorithms had a clear tendency to overestimate the price of Societe Generale, according to the results of the statistical loss functions ME and MPE. Finally, it should be noted that the results were consistent with what other authors found out, especially for the out-ofsample period, where the machine learning models performed best.
\end{abstract}

Keywords: loss functions; machine learning; autoregressive; equity markets.

JEL Classification: G17; G11; C22; C38.

\section{Introduction}

Time series are difficult to model, especially due to time variability and seasonality. However, over time, plenty models and methodologies have been developed aiming to model time series, and here we can include forecasting stock prices. This objective is a very difficult one, but there are different papers that have set out to 
achieve this, obtaining gratifying results, especially when machine learning algorithms are used for the in-sample period.

In the literature there are a plethora of papers that have addressed this issue of stock price forecasting, and some of these articles have been used to substantiate this paper. There are articles that address classical statistical models, machine learning models, but also articles that make comparisons between the two types of approaches. In most cases, the results indicated an over-performance of machine learning models, especially when talking about in-sample evaluation.

In this article we set out to present a comparison on the performance of ARIMA, Prophet, KNN and Neural Networks for estimating the share price of Societe Generale. The comparison will be made based on the statistical loss functions, while the models will be ranked based on an aggregate score for all the criteria. Also, we will use indicators to show whether there is a bias for the models in terms of overestimating or underestimating the share price.

The methodology used in the study is like that used by other authors such as Chan (2020) or Madhuri et al. (2020) in terms of comparisons between models. This methodology has been extended to KNN and Neural Networks. The results obtained were in line with what was observed in the literature, indicating an overperformance of Neural Networks, both in-sample and out-of-sample. On the other hand, during the in-sample period, a good performance of the ARIMA model was also observed, this model ranked second among the four models considered in this paper.

The results of this research are important and can be used as part of a trading strategy, both by retail investors and by institutional investors. Also, there are possibilities to improve and refine the models such as considering an HMM methodology, in addition to machine learning algorithms.

\section{Literature review}

Forecasting the stock prices is a complex activity, which involves a thorough research of the literature. To substantiate this paper, we started from articles that address classical statistical methodologies and we continued with some papers that address various machine problems in terms of use for stock market forecasting. We also tried to identify articles in which a comparison was made between these two generations of models.

The problem of forecasting has been addressed in recent decades in various papers, but among the articles that have added to the area of classical prediction models I can mention the work of Gencay (1996) which addressed the problem of a prediction using different rules of moving averages. This type of analysis is an incipient one, and will then be developed by Gencay and Stengos (1998) who brought an additional analysis in this area of the use of moving averages for prediction. Also, the technique was later significantly improved by Wei et al. (2014), combining several methodologies to achieve significant results compared to a buy and hold strategy.

Classical statistical analysis was further improved by researches based on ARIMA models. Important for substantiating the methodology in this paper are the article published by Banerjee (2014), for the Indian stock market, and Mondal et al. (2014). The authors of the two papers managed to calibrate ARIMA models for the 
analysed data series, used the AIC and BIC informational criteria to choose the most appropriate model and obtained conclusions regarding the performance of these models according to different forecast horizons and for different time periods. At the same time, Mondal et al. (2014) highlighted the need to study ARIMA models for stocks within the same sector of activity, but also within different sectors of activity, being observed different performances depending on the type of company and sector. Other important papers that considered the prediction based on ARIMA are those of Ariyo et al. (2014) or Jarrett and Kyper (2011). The methodologies used in all these papers were the basis for the current study.

In this paper we aimed to make a performance comparison regarding stock prices forecasting between ARIMA, Prophet, KNN regression and Neural Networks. Thus, another important paper that was used to substantiate the methodology is that of Chan (2020) in which he made a comparison between the performance of ARIMA and Prophet for the equity market in Myanmar. Moreover, we should consider the research of Madhuri et al. (2020), which was made in the same sense, but also the article by Satrio et al. (2021) which compared the performance of the two methodologies during the crisis generated by the Covid-19 Pandemic. On the other hand, we considered important the paper of Fang et al. (2019) in which they compare the performance of the Prophet model with that of some machine learning algorithms.

Researches on the use of machine learning algorithms for stock price forecasting are not few, and among them we used as a research base Milosevic's (2016) article, which addresses a prediction problem from the perspective of a long-term investment. Close to our methodology is the research of Ban et al. (2013), but also that of Alkhatib et al. (2013), in which the KNN algorithm is applied in different forms for realizing a forecast regarding the stock market. Also, we considered the article of Vaisla and Bhatt (2010), but also that of Pang et al. (2020), in which the neural networks methodology is applied for forecasting.

\section{Methodology and data}

The methodology for this paper involves the implementation of four stock prices forecasting models: ARIMA, Prophet, KNN regression and Neural Network. These algorithms will be applied for the stock's price of Societe Generale.

For this stock prices we have obtained daily prices from public data sources for the period between: 01/01/2010 - 31/10/2021

This period was divided into two sub-periods:

In-sample (training period): 01/01/2010 - 31/07/2021

Out-of-sample period: - 01/08/2021 - 31/10/2021

For each of these periods, indicators such as RMSE, MAD, MSE or others will be. For each of these periods, indicators such as RMSE, MAD, MSE or others will be calculated for model errors and comparisons will be made. It is important to make a comparison for both the in-sample period and the out-of-sample period, in order to obtain the most relevant conclusions.

To estimate the ARIMA model, the Box-Jenkins methodology will be initially applied. In order to choose the most suitable model, the auto.arima function applied in RStudio will be used, this being based on an iterative selection process. 
The Prophet model is developed by Facebook to make predictions about data series. It will be used for forecasting, taking into consideration its three components: i) $g(t)$ that models the trend ii) $s(t)$ that models the seasonality using Fourier series and iii) $h(t)$ that takes into account the effects days off or extreme events. Thus, the shape of the model is as follows:

$\mathrm{y}(\mathrm{t})=\mathrm{g}(\mathrm{t})+\mathrm{s}(\mathrm{t})+\mathrm{h}(\mathrm{t})+\epsilon_{\mathrm{t}}$

The trend parameter $(\mathrm{g}(\mathrm{t}))$ is responsible for shouldering two other parameters: growth saturation and trend change points. The growth saturation takes into account how consistent the data are (ie if an element that can change their dynamics has appeared)

The third algorithm is KNN. This is an algorithm that can be used both for classification and to solve regression problems, but more often it is used for classification problems. However, I will apply it for regression issues in order to be able to make an estimate regarding the price of the Societe Generale share. For this we will use the tsfknn package from Rstudio. It should be noted that to predict the new values in the data series the algorithm uses the so-called similarity of characteristics.

Another way to predict data is to use a neural network. In this sense, we decided to use the RStudio package called nnetar, and for this study we will use a neural network with a single layer in order to keep things simple. Later, this type of the model can be developed and improvements can be made.

In this model we proposed there is a single layer of nodes with input values that send information to a single layer with docks that contain registration fields. This model will use time series lag values as input data, obtaining a nonlinear autoregressive model.

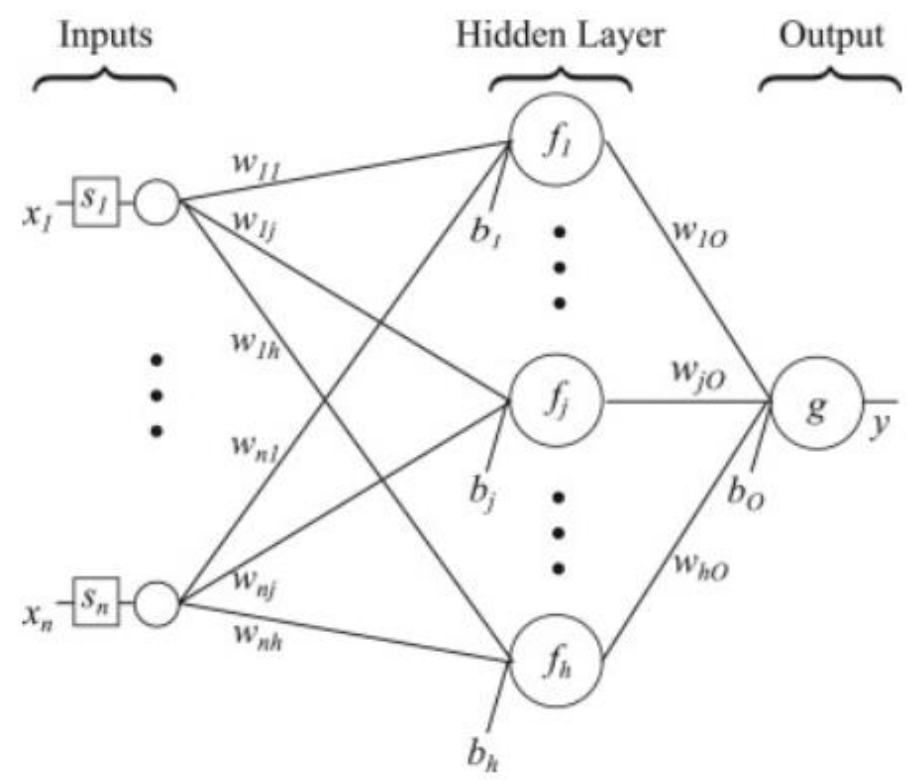

Figure 1: Neural Network with a single hidden layer

Source: Single hidden layer neural network - Nicola Manzini 
The number of hidden nodes was selected according to the following formula:

$$
N_{h}=\frac{N_{s}}{\left(\alpha *\left(N_{i}+N_{o}\right)\right)}
$$

Where,

$\mathrm{Ni}=$ the number of input neurons

$\mathrm{No}=$ the number of output neurons

$\mathrm{Ns}=$ the length of training sample

$\alpha=1.5^{-10}$

\section{Results}

The results of this research will be presented in two stages. In the first, the results that are obtained in terms of forecasting for ARIMA and neural networks, but also for the components of the Prophet model, will be presented in a graphical form. Second, the values obtained for the indicators by which the forecast errors are measured, both in-sample and out-of-sample, will be presented.

Following the estimation, we obtained results for each of the four methodologies. The ARIMA model was first estimated, and the iterative process in $\mathrm{R}$ indicated that an ARIMA model $(0,1,1)$ is the most suitable for the Societe Generale share data series.

The result of the forecast for Societe Generale shares using ARIMA $(0,1,1)$ is presented in graphical form below.

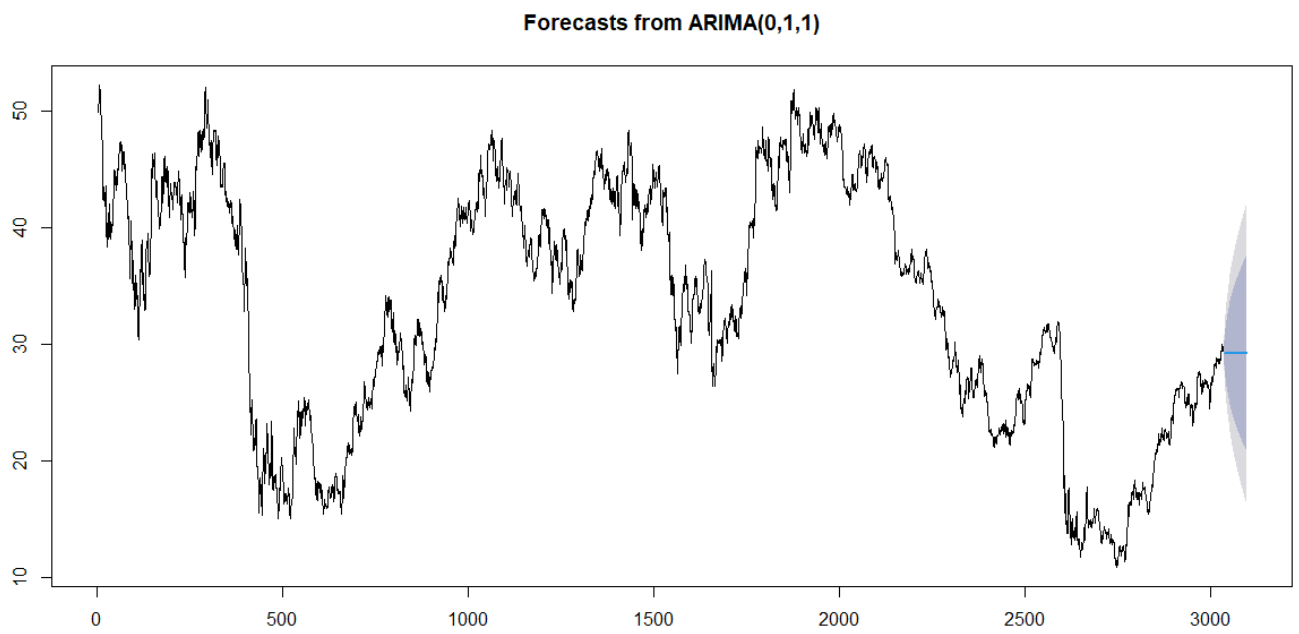

Figure 2: ARIMA forecast

Source: authors' own computation

Also, as we presented in the methodology part, for The Prophet, three components are estimated, and the results are presented below: 

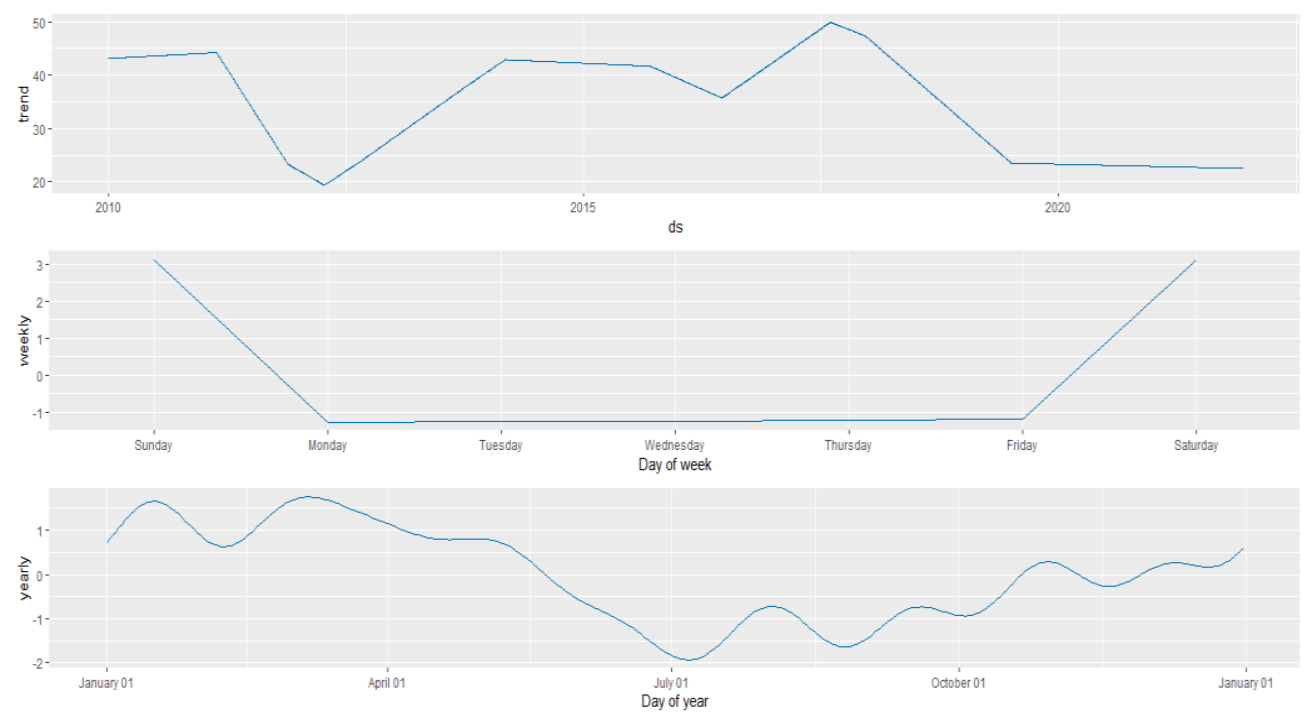

Figure 3. The three components of the Prophet Source: authors' own computations

In the same way as we did in the case of ARIMA, we will present the forecast obtained following the implementation of neural networks.

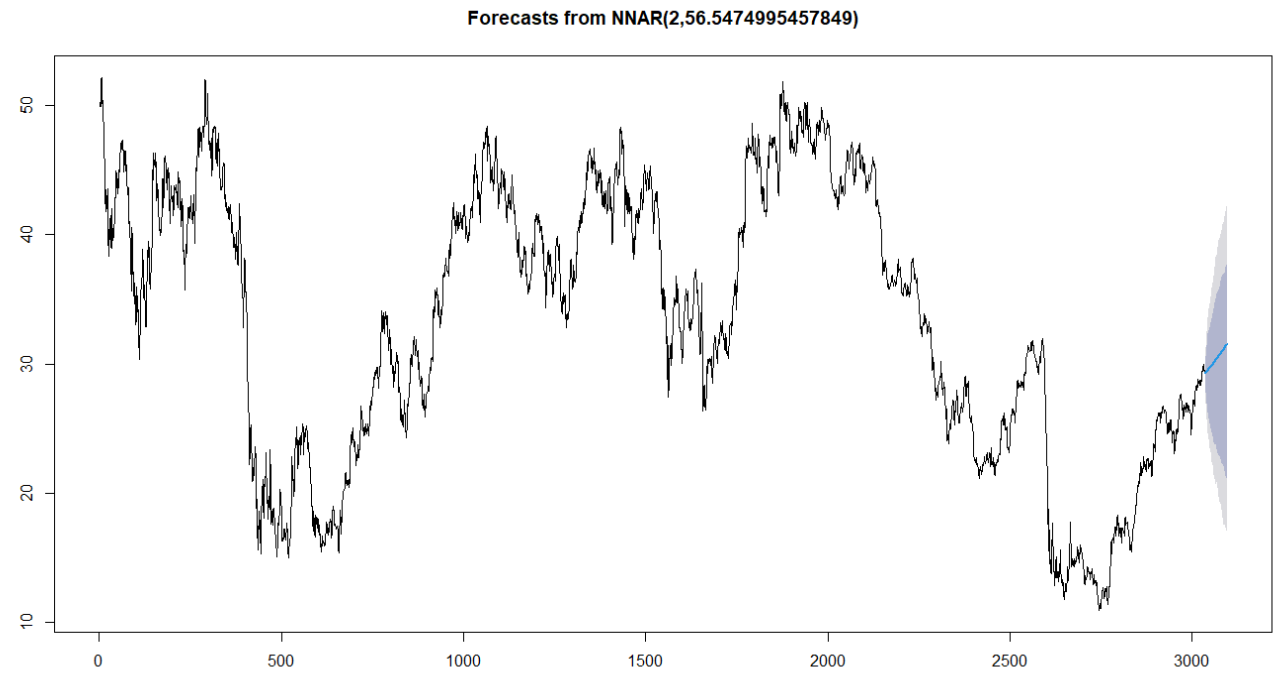

Figure 4: Neural Networks forecast

Source: authors' own computation 
Thus, it is possible to observe on the previous figure the estimated for the Societe Generale stock price, but also the confidence interval which is established with probabilities of $85 \%$ (dark blue) and $95 \%$ (light blue).

Further, we will present the results obtained for the indicators regarding the errors of the models for the training period. A rank was assigned to each indicator, so that an average rank could be calculated later

Table 1: Statistical loss functions - in sample

\begin{tabular}{|l|l|l|l|l|l|l|l|}
\hline \multicolumn{1}{|c|}{ Indicator } & & & & & & & \\
\hline Model & RMSE & RANK & MAE & RANK & MAPE & RANK & Average Rank \\
\hline ARIMA $(0,1,1)$ & 0.773 & 2 & 0.555 & 2 & 1.835 & 2 & 2.00 \\
\hline Prophet & 4.225 & 4 & 3.467 & 4 & 13.166 & 4 & 4.00 \\
\hline KNN regression & 2.751 & 3 & 2.158 & 3 & 7.511 & 3 & 3.00 \\
\hline Neural Network & 0.769 & 1 & 0.553 & 1 & 1.830 & 1 & 1.00 \\
\hline
\end{tabular}

Source: Authors' own computations

Neural network performed best for all indicators, and ARIMA was the second model, highlighting the fact that classical statistical models work well, at least for the in-sample period. On the other hand, the Prophet model performed the weakest, being on the 4th place for all three criteria.

Thus, the ARIMA model was very close to the in-sample performance of the machine learning models and it cannot be said that they strongly over-performed the classic statistical models, at least in-sample.

Below, we presented the values for the ME and PE indicators, which provide information regarding any potential estimation biases.

Table 2: ME si MPE for in-sample

\begin{tabular}{|c|c|c|}
\hline Model Indicator & $\mathrm{ME}$ & MPE \\
\hline ARIMA $(0,1,1)$ & -0.0064 & -0.050 \\
\hline Prophet & -0.0104 & -3.374 \\
\hline KNN regression & -0.0095 & -2.754 \\
\hline Neural Network & -0.009 & -0.075 \\
\hline
\end{tabular}

Source: authors' own computations

The values obtained for ME and MEP were negative for all cases, which shows that the models behave approximately the same in terms of estimation bias. Thus, it is about a systematic overestimation of the values of the Societe Generale stock's prices. The model error was calculated as the difference between the realized value and the estimated value.

After performing the in-sample analysis, we will also present the results obtained for the out-of-sample analysis. 
Table 3: Statistical loss functions - out-of-sample

\begin{tabular}{|l|l|l|l|l|l|l|l|}
\hline \multicolumn{1}{|c|}{ Indicator } & & & & & & $\begin{array}{l}\text { Average } \\
\text { Rank }\end{array}$ \\
\hline & RMSE & RANK & MAE & RANK & MAPE & RANK \\
\hline ARIMA $(0,1,1)$ & 2.981 & 3 & 2.785 & 3 & 8.341 & 2 & 2.67 \\
\hline Prophet & 4.357 & 4 & 4.984 & 4 & 16.050 & 4 & 4.00 \\
\hline KNN regression & 2.743 & 2 & 2.457 & 2 & 8.649 & 3 & 2.33 \\
\hline Neural Network & 1.015 & 1 & 0.984 & 1 & 2.743 & 1 & 1.00 \\
\hline
\end{tabular}

Source: Authors' own computations

The out-of-sample evaluation showed that the models based on machine learning (Neural Network and KNN regression) outperformed the classic ARIMA model, but also the Prophet. It is observed that KNN regression outperformed ARIMA $(0,1,1)$ for RMSE and MAE, while ARIMA $(0,1,1)$ was better for MAPE, but the result was quite close to that of KNN regression. On the other hand, Neural Network continued to be the best model, clearly outperforming the other models.

As was the case with in-sample, The Prophet model performed the poorest in terms of estimating the share price of Societe Generale. Moreover, it should be noted that all models obtained higher errors in the out-of-sample period than in the in-sample case, this result being in line with expectations.

\section{Conclusions}

Through this paper we tried to perform a comparison in terms of performance of classic models that can be used in stock prices forecasting and models based on machine learning algorithms. Also, we noticed that there are comparisons in the literature with the Prophet algorithm developed by Facebook and we considered it interesting to introduce it in the comparison that was made.

An in-sample and out-of-sample estimation was performed for ARIMA, Prophet, KNN regression and Neural Network. The aim was to forecast the price of the Societe Generale stock for the training period January 2010 - July 2021, so that the out-of-sample forecast can be made on a horizon of 3 months. For this scope, indicators such as RMSE, MAE, MAPE, ME or MPE were used, calculated for the models' errors.

The results for the in-sample estimation indicated that Neural Network obtained the best performance, being followed by the ARIMA model $(0,1,1)$. On the other hand, the Prophet model obtained the poorest performance for all the indicators considered. Thus, all these results indicated that in-sample, classical statistical models perform well enough compared to machine learning models. It should also be noted that all four models led to a systematic overestimation of the share price of Societe Generale.

Out-of-sample testing revealed better results for models based on machine learning. Neural Network continued to be the best model, and the Prophet to be the weakest, obtaining the highest values for all calculated loss function functions.

The results obtained in this paper are gratifying and show that the machine learning models add value and lead to better results than the classic statistical models, both in-sample and out-of-sample. On the other hand, it cannot be said that they over-performed by far, with the possibility that if testing is applied on 
another asset class or on other series with different volatility, a different ranking will be obtained. This could also be a way in which the research could expanded, along with the application of deep-learning algorithms.

\section{References:}

1. Alkhatib, K., Najadat, H., Hmeidi, I., \& Shatnawi, M. K. A. (2013) Stock price prediction using k-nearest neighbor (kNN) algorithm, International Journal of Business, Humanities and Technology, 3(3), 32-44.

2. Ariyo, A. A., Adewumi, A. O., \& Ayo, C. K. (2014, March) Stock price prediction using the ARIMA model, In 2014 UKSim-AMSS 16th International Conference on Computer Modelling and Simulation (pp. 106-112), IEEE.

3. Ban, T., Zhang, R., Pang, S., Sarrafzadeh, A., \& Inoue, D. (2013, November) Referential knn regression for financial time series forecasting, In International Conference on Neural Information Processing (pp. 601-608), Springer, Berlin, Heidelberg.

4. Banerjee, D. (2014, January), Forecasting of Indian stock market using timeseries ARIMA model, In 2014 2nd International Conference on Business and Information Management (ICBIM) (pp. 131-135), IEEE.

5. Chan, W. N. (2020) Time Series Data Mining: Comparative Study of ARIMA and Prophet Methods for Forecasting Closing Prices of Myanmar Stock Exchange, J. Comput. Appl. Res., 1, 75-80.

6. Fang, W. X., Lan, P. C., Lin, W. R., Chang, H. C., Chang, H. Y., \& Wang, Y. H. (2019, December) Combine Facebook prophet and LSTM with BPNN forecasting financial markets: the Morgan Taiwan Index, In 2019 International Symposium on Intelligent Signal Processing and Communication Systems (ISPACS) (pp. 1-2). IEEE.

7. Gencay, R. (1998), Non-linear prediction of security returns with moving average rules, Journal of Forecasting 15.3, 165-174.

8. Gencay, R. and Stengos, T. (1998) Moving average rules, volume and the predictability of security returns with feedforward networks, Journal of Forecasting, 17(5-6), 401-414.

9. Jarrett, J. E. and Kyper, E. (2011) ARIMA modeling with intervention to forecast and analyze Chinese stock prices, International Journal of Engineering Business Management, 3(3), 53-58.

10. Madhuri, C. R., Chinta, M. and Kumar, V. P. (2020, July) Stock Market Prediction for Time-series Forecasting using Prophet upon ARIMA, In 2020 7th International Conference on Smart Structures and Systems (ICSSS) (pp. 1-5). IEEE.

11. Milosevic, N. (2016) Equity forecast: Predicting long term stock price movement using machine learning, arXiv preprint arXiv:1603.00751.

12. Mondal, P., Shit, L. and Goswami, S. (2014) Study of effectiveness of time series modelling (ARIMA) in forecasting stock prices, International Journal of Computer Science, Engineering and Applications, 4(2), 13.

13. Pang, X., Zhou, Y., Wang, P., Lin, W. and Chang, V. (2020), An innovative neural network approach for stock market prediction, The Journal of Supercomputing, 76(3), 2098-2118. 
14. Satrio, C. B. A., Darmawan, W., Nadia, B. U. and Hanafiah, N. (2021), Time series analysis and forecasting of coronavirus disease in Indonesia using ARIMA model and PROPHET, Procedia Computer Science, 179, 524-532.

15. Vaisla, K. S. and Bhatt, A. K. (2010), An analysis of the performance of artificial neural network technique for stock market forecasting, International Journal on Computer Science and Engineering, 2(6), 2104-2109.

16. Wei, L. Y., Cheng, C. H. and Wu, H. H. (2014) A hybrid ANFIS based on nperiod moving average model to forecast TAIEX stock, Applied Soft Computing, 19, 86-92. 


\title{
THE DIFFERENCE BETWEEN IFRS AND US GAAP IN FINANCIAL STATEMENT PRESENTATION
}

\author{
Saleh JAWARNEH \\ Department of Finance, Faculty of Economics, University of Miskolc, Hungary \\ Saleh1jaw@gmail.com
}

\begin{abstract}
This paper meticulously studies the main differences between US GAAP and IFRS when it comes to the presentation of financial statements focusing on the balance sheet and income statement more than the cash flow statement. A real-life case study (of a company called Hydro) approach was applied to see the effect of using on the system over the other by numbers, and how far applying one system affect the result of each financial statement, the case study shows a practical conversion of US GAAP results to IFRS and how each system lists the financial statements next to each other. There are multiple similarities between US GAAP and IFRS when it comes to the presentation of financial statements, but there are some differences that affect what financial information is presented, how it is presented, and where it is presented. For example, regarding financial statement presentation, cosmetic differences include the use of the accounting equation $(A=L+S E)$ compared to $(A-S E=L)$, terminology, and order of liquidity. The study is solely based on secondary data collected from different reliable sources like Ernst and Young. The findings of this research indicate that there are some notable differences between US GAAP and IFRS in financial statement presentation, but they are not significant. Finally, bringing together both systems increase the comparability of accounting practices and results to investors, greater investor desire for cross-regional investment, lower capital cost, more efficient resource allocation; And even higher economic growth not only for companies and institutions but also for government, which can be done by setting limits on how much they can vary.
\end{abstract}

Keywords: Accounting Standards, IFRS, US GAAP, Accounting Harmonization

JEL classification: M40; M41; M48; E42

\section{Introduction}

Accounting has been developed since a long time ago, where every country has been interested in developing its own principles which can reflect the industry practices and contributions of accounting bodies established for this purpose, there have been leading countries in this area because of industrial development, including the United States of America, which knew a developed industrial sector in the beginnings of the last century which been reflected on the developing of the accounting profession (Unegbu, 2014).

Convergence of accounting standards has an advantage for listed companies in two respects: on the one hand, there is no need to prepare more financial statements, which saves large amounts, and on the other hand, due to financial comparability. Data is guaranteed. In this regard, under the 2002 Norwalk Agreement, the Financial Accounting Standards Board and the International 
Accounting Standards Board have decided that the U.S. Standards Board has decided that the U.S. Standards are close to the International Standards (Burlaud \& Baker, 2015). However, it seems that it will take many years for the two references to come close.

The main difference between IFRS and US GAAP is that US standards are rulesbased and IFRSs are principles. A rules-based standard does not mean that standards bodies did not apply principles to create them, but that rules play an important role in the implementation of the standard. As part of this debate, there is an important debate about principles-based standards and rules-based standards. Rules-based standards, the dominant approach of the FASB, attempt to anticipate and find solutions to all or most problems, while standards-based standards, the dominant approach of the IASB, are less prescriptive and based on objectives and principles to be followed. As a result, US GAAP consists of approximately 17,000 pages, while IFRS contains approximately 2,500 pages (Gibson, 2009).

Using different accounting frameworks in different areas becomes a problem for both companies and investors. To that end, it was necessary for countries to abandon their accounting frameworks and use one framework to reduce the problem of variation (UNITED NATIONS, 2008).

Both committees are guided by the conceptual framework (IASB for IFRS, U.S. GAAP for FASB) when establishing or revising new standards. As a result, the differences between them can contribute to differences in standards. In 2004, through the convergence of the two repositories (IFRS and US GAAP), the Financial Accounting Standards Board and the International Accounting Standards Board began working together to develop a common and improved conceptual framework that provides a basis for common standards. The project has eight steps, and the two bodies are currently working on the first four, The first phase was completed and resulted in the issuance of a conceptual framework that includes the objective of financial reporting and the qualitative characteristics of useful information, it seems that the harmonization of IFRS and U.S. GAAP is always a work in progress. (Smith, 2011)

\section{Literature Review}

Several papers attempted to determine the level of compliance between various accounting practices and the impact of adopting international standards on accounting harmonization.

Gordon al. (2011) used a large sample of companies reporting under both IFRS and GAAP compared to other studies. Form 156 firms are used, which adapts IFRS to GAAP for three years, 2004-2006. Their study continues the tradition of using numbers in financial statements to assess the adequacy of book quality and value. It is concluded that GAAP continues to differ from IFRS, showing "increasing information" in addition to IFRS numbers and that GAAP is more important in terms of "monetary stability" and value. They suggest that IFRS and GAAP are different, even in the recent past, when convergence was well advanced. They show that there are differences and, in this sense, complement the first of our three research objectives (Gordon, et al., 2011).

According to EY annual book, In terms of financial statement format, US GAAP and IFRS guidelines are quite comparable. A statement of financial position, a statement of profit and loss (income statement), a statement of comprehensive 
income (either a single continuous statement or two consecutive statements), a statement of cash flows, and accompanying notes to the financial statements are all included in a complete set of financial statements under both sets of standards. Both US GAAP and IFRS necessitate the presentation of changes in shareholders' equity. However, US GAAP permits the presentation of changes in shareholders' equity in the notes to the financial statements, but IFRS mandates the presentation of changes in shareholders' equity as a separate statement. Furthermore, unless under exceptional circumstances, both require the financial statements to be prepared on an accrual method of accounting. The ideas of materiality and consistency that companies must examine in producing their financial statements are comparable in IFRS and US GAAP. The degree of detailed instruction offered tends to be where the two sets of criteria differ. (EY, 2021)

Table 1: Financial statement presentation significant differences

\begin{tabular}{|l|l|}
\hline $\begin{array}{l}\text { Financial periods } \\
\text { required }\end{array}$ & $\begin{array}{l}\text { A single year can be presented } \\
\text { in certain circumstances, while } \\
\text { comparative statement are } \\
\text { presented. On the other hand, } \\
\text { public companies must follow } \\
\text { SEC rules, which typically } \\
\text { require two most recent years. }\end{array}$ \\
$\begin{array}{l}\text { Layout of balance } \\
\text { sheet and income } \\
\text { statement }\end{array}$ & $\begin{array}{l}\text { Public companies must follow } \\
\text { the detailed regulations, there is } \\
\text { no general requirements with in } \\
\text { the US GAAP to prepare } \\
\text { balance sheet or income } \\
\text { statement. }\end{array}$ \\
\hline
\end{tabular}

Balance sheet- Debts in which there has been a presentation of covenant violation may be debt as current presented as non-current if versus noncurrent there is agreement by the lender to waive the right to claim payment more than one year before the financial statements are issued or made available for issuance.

Balance sheet All deferred tax assets and classification of liabilities will be classified as deferred tax assets noncurrent.

and liabilities

Income statement- There is no general requirement classification of within the US GAAP to classify expenses the income statement items by function or nature although there are requirements based

\section{IFRS}

Comparative information must be presented to previous period, for all amounts reported in current period's financial statement.

IFRS doesn't require specific layout but includes minimum line items, and these are less than the required by US GAAP for public companies.

Debt related to breach of the covenant violation must be provided as current unless the lender agreement is reached before the balance sheet date.

All amounts classified as noncurrent in the balance sheet.

Entities may present expenses based on either function or nature (e.g., salaries, depreciation). However, if function is 


\begin{tabular}{|c|c|c|}
\hline & $\begin{array}{l}\text { on the specific cost incurred } \\
\text { (e.g. restructuring fees and } \\
\text { freight and handling costs). } \\
\text { However, SEC registrar is } \\
\text { generally required to provide } \\
\text { expenses based on the post } \\
\text { (e.g., cost of sales, } \\
\text { management). }\end{array}$ & $\begin{array}{l}\text { selected, certain } \\
\text { disclosures about the } \\
\text { nature of expenses must } \\
\text { be included in the notes. }\end{array}$ \\
\hline $\begin{array}{l}\text { Income statement- } \\
\text { discontinued } \\
\text { operations criteria }\end{array}$ & $\begin{array}{l}\text { Discontinued operations } \\
\text { classification is for components } \\
\text { that are: Held for sale or } \\
\text { disposed of and represent a } \\
\text { strategic shift that has (or will } \\
\text { have) a major effect on an } \\
\text { entity's operations and financial } \\
\text { results. Also a newly acquired } \\
\text { business or nonprofit activity } \\
\text { that on acquisition is classified } \\
\text { as held for sale qualifies for } \\
\text { reporting as a discontinued } \\
\text { operation. }\end{array}$ & $\begin{array}{l}\text { Discontinued operations } \\
\text { classification is for } \\
\text { components held for sale } \\
\text { or disposed of and the } \\
\text { component represents a } \\
\text { separate major line of } \\
\text { business or geographical } \\
\text { area, is part of a single } \\
\text { coordinated plan to } \\
\text { dispose of a separate } \\
\text { major line of business or } \\
\text { geographical area of or a } \\
\text { subsidiary acquired } \\
\text { exclusively with an } \\
\text { intention to resell. }\end{array}$ \\
\hline $\begin{array}{l}\text { Statement of cash } \\
\text { flows-restricted } \\
\text { cash }\end{array}$ & $\begin{array}{l}\text { Statement of Cash Flows- } \\
\text { Restricted Cash, changes in } \\
\text { restricted cash and restricted } \\
\text { cash equivalents will be shown } \\
\text { in the statement of cash flows. } \\
\text { In addition, when cash, cash } \\
\text { equivalents, restricted cash and } \\
\text { restricted cash equivalents are } \\
\text { presented in more than one-line } \\
\text { item on the balance sheet, also } \\
\text { it requires a reconciliation of the } \\
\text { totals in the statement of cash } \\
\text { flows to the related captions in } \\
\text { the balance sheet. This } \\
\text { reconciliation can be presented } \\
\text { either on the face of the } \\
\text { statement of cash flows or in } \\
\text { the notes to the financial } \\
\text { statements. }\end{array}$ & $\begin{array}{l}\text { There is no specific } \\
\text { guidance about the } \\
\text { presentation of changes } \\
\text { in restricted cash and } \\
\text { restricted cash } \\
\text { equivalents on the } \\
\text { statement of cash flows. }\end{array}$ \\
\hline $\begin{array}{l}\text { Disclosure } \\
\text { performance } \\
\text { measures }\end{array}$ & $\begin{array}{l}\text { There are no general } \\
\text { requirements within US GAAP } \\
\text { address the presentation of } \\
\text { specific performance measures. } \\
\text { SEC regulations define certain } \\
\text { key measures and require the } \\
\text { presentation of certain headings }\end{array}$ & $\begin{array}{lr}\text { Certain } & \text { traditional } \\
\text { concepts such as } & \text { such are not } \\
\text { "operating profit" are not } \\
\text { defined; therefore, } \\
\text { diversity in practice exists } \\
\text { regarding line items, } \\
\text { headings and subtotals }\end{array}$ \\
\hline
\end{tabular}




\begin{tabular}{|c|c|c|}
\hline & $\begin{array}{l}\text { and subtotals. Additionally, } \\
\text { public companies are prohibited } \\
\text { from disclosing non-GAAP } \\
\text { measures in the financial } \\
\text { statements and accompanying } \\
\text { notes. }\end{array}$ & $\begin{array}{l}\text { presented on the income } \\
\text { statement. IFRS permits } \\
\text { the presentation of } \\
\text { additional line items, } \\
\text { headings and subtotals in } \\
\text { the statement of } \\
\text { comprehensive income } \\
\text { when such presentation is } \\
\text { relevant to an } \\
\text { understanding of the } \\
\text { entity's financial } \\
\text { performance. IFRS has } \\
\text { requirements on how the } \\
\text { subtotals should be } \\
\text { presented when they are } \\
\text { provided, }\end{array}$ \\
\hline $\begin{array}{l}\text { Third balance } \\
\text { sheet }\end{array}$ & Not required. & $\begin{array}{l}\text { A third balance sheet is } \\
\text { required as of the } \\
\text { beginning of the earliest } \\
\text { comparative period when } \\
\text { there is a retrospective } \\
\text { application of a new } \\
\text { accounting policy, or a } \\
\text { retrospective restatement } \\
\text { or reclassification, that } \\
\text { have a material effect on } \\
\text { the balances of the third } \\
\text { balance sheet. Related } \\
\text { notes to the third balance } \\
\text { sheet are not required. A } \\
\text { third balance sheet is also } \\
\text { required in the year an } \\
\text { entity first applies IFRS. }\end{array}$ \\
\hline
\end{tabular}

Source: US GAAP versus IFRS The basics January 2021. Available: https://www.ey.com/en us/assurance/accountinglink/us-gaap-versus-ifrs--the-

basics---january-2021

\section{Research Methodology}

In order to keep in mind the reliability and accuracy of the research data, this research method has been selected in a critical manner. Firstly, manner is a qualitative approach, in order to get some reliable and accurate data to be collected, interpreted, and reported in this research paper, the qualitative data will be collected through a practical case study, which will allow us to understand the deep application, results, and consequences of the different standards being adopted by the company. This case study, which is taken from a real company based in Norway and called Hydro. A company was using US GAAP standards in their accounting system, and in 2006 they decided to switch to IFRS standards, this case study helps to collect real data from the company published and shared 
financial statements under IFRS and then compare them to the results of the same financial information under US GAAP standards.

\section{Case Study}

It is critical for the reader to have a thorough grasp of the differences between US GAAP and IFRS. The need to understand both US GAAP and IFRS. This research chooses Hydro 2007 as a case study to explain the differences between both standards. Hydro published enough financial information in public which allows for a full comparison.

The below figures show the difference between both standards in real numbers. When comparing US GAAP to IFRS income statements (Figure 1), there are variations in presentation and categorization. The term "operating revenue" is replaced by the term "revenue." Operating revenues under US GAAP contain several miscellaneous revenue components that are categorized as other income, net under IFRS. The line-item Share of the profit (loss) from equity-accounted investments is now included as part of Total revenue and income. The amount of Share of the profit (loss) from equity-accounted investments is different after the presentation change as discontinued operations are included in the amount; IFRS does not have line-item Discontinued operations in the financial statements. The line-item other income, net, comprises some miscellaneous revenue items and gain or loss on sale of property, plant and equipment, and investments previously reported as part of Other operating expenses.

\begin{tabular}{|l|r|r|}
\hline & US GAAP & IFRS \\
\hline Operating revenues & 196,234 & \\
\hline Revenue & 201,283 \\
\hline Share of the profit (loss) in equity accounted investments & 990 \\
\hline Other income, net & 1,470 \\
\hline Total revenue and income & \\
\hline Raw material and energy expense & 98,961 & 82,810 \\
\hline Employee benefits expense / Payroll and related costs & 19,404 & 19,546 \\
\hline Depreciation and amortization expense & 16,937 & 17,215 \\
\hline Impairment of non-current assets / Impairment losses & 5,228 & 5,492 \\
\hline Other & 3,481 & 23,670 \\
\hline Total expenses / Operating costs and expenses & 144,010 & 148,733 \\
\hline Operating income & 52,224 & \\
\hline Earnings before financial items and tax & 55,010 \\
\hline Financial income (expense), net & 1,785 & \\
\hline Financial income & 1,425 \\
\hline Financial expense & $(43)$ \\
\hline Financial income (expense), net & 1,785 & 1,382 \\
\hline Equity in net income of non-consolidated investees & 962 & \\
\hline Other income (expense), net & 53 & \\
\hline Income before tax / Income from continuing operations before taxes and minority interest & 55,024 & 56,392 \\
\hline Income tax expense & $(37,598)$ & $(38,459)$ \\
\hline Minority interest & $(202)$ \\
\hline Income from continuing operations & 17,224 & 167 \\
\hline Income from discontinued operations & 17,391 & 17,933 \\
\hline Net income & 273 \\
\hline Net income attributable to minority interests & 17,660 \\
\hline Net income attributable to equity holders of the parent & \\
\hline Fla & \\
\hline
\end{tabular}

Figure 1: Consolidated income statement US GAAP to IFRS

Source: www.hydro.com 


\begin{tabular}{|c|c|c|}
\hline & US GAAP & IFRS \\
\hline \multicolumn{3}{|l|}{ Assets } \\
\hline Cash and cash equivalents & 6,760 & 6,760 \\
\hline Short-term investments & 15,020 & 15,020 \\
\hline Accounts receivable & 25,608 & 34,508 \\
\hline Inventories & 16,497 & 16,497 \\
\hline Other current assets / Prepaid expenses and other current assets & 14,025 & 7,980 \\
\hline Current deferred tax assets & 3,099 & \\
\hline Assets held for sale / Current assets held for sale & 1,122 & 3,691 \\
\hline Total current assets & 82,131 & 84,457 \\
\hline Investments accounted for using the equity method/non-consolidated investees & 10,455 & 10,690 \\
\hline Property, plant and equipment & 124,976 & 119,075 \\
\hline Intangible assets & 4,861 & 11,475 \\
\hline Financial assets & & 4,914 \\
\hline Other non-current assets / Prepaid pension, investments and other non-current assets & 7,763 & 303 \\
\hline Deferred tax assets & 1,239 & 2,177 \\
\hline & 2,569 & \\
\hline Total non-current assets & 151,862 & 148,635 \\
\hline Total assets & 233,993 & 233,092 \\
\hline \multicolumn{3}{|l|}{ Liabilities and equity } \\
\hline Trade and other payables & & 29,785 \\
\hline Bank loans and other interest-bearing short-term debt & 3,213 & 3,655 \\
\hline Current portion of long-term debt & 441 & \\
\hline Provisions & & 2,197 \\
\hline Taxes payable & & 18,995 \\
\hline Other current liabilities & 55,550 & 7,949 \\
\hline Current deferred tax liabilities & 1,134 & - \\
\hline Liabilities included in disposal groups / Current liabilities in disposal groups & 738 & 1,011 \\
\hline Total current liabilities & 61,076 & 63,591 \\
\hline Long-term debt & 19,619 & 19,619 \\
\hline Provisions & & 14,357 \\
\hline Pension obligation & 12,391 & 12,605 \\
\hline Other financial liabilities & & 353 \\
\hline Other liabilities & 16,126 & 2,702 \\
\hline Deferred tax liabilities & 27,307 & 23,265 \\
\hline Long-term liabilities in disposal groups & 273 & \\
\hline Total non-current liabilities & 75,715 & 72,900 \\
\hline Total liabilities & & 136,491 \\
\hline Minority shareholders' interest in consolidated subsidiaries & 707 & \\
\hline Share capital & 4,708 & 4,708 \\
\hline Additional paid-in capital & 9,736 & 9,736 \\
\hline Other reserves / Accumulated other comprehensive income (loss) & $(9,135)$ & $(1,533)$ \\
\hline Retained earnings & 97,811 & 89,544 \\
\hline Treasury shares & $(6,624)$ & $(6,624)$ \\
\hline Equity attributable to equity holders of the parent / Shareholders' equity & 96,496 & 95,831 \\
\hline Minority interest & & 771 \\
\hline Total equity & & 96,601 \\
\hline Total liabilities and equity / shareholders' equity & 233,993 & 233,092 \\
\hline
\end{tabular}

Figure 2: Consolidated balance sheet US GAAP to IFRS

Source: www.hydro.com

When comparing US GAAP to IFRS income statements (Figure 1), there are variations in presentation and categorization. The term "operating revenue" is replaced by the term "revenue." Operating revenues under US GAAP contain several miscellaneous revenue components that are categorized as other income, net under IFRS. The line item Share of the profit (loss) from equity accounted investments is now included as part of Total revenue and income. The amount of Share of the profit (loss) from equity accounted investments is different after the presentation change as discontinued operations are included in the amount; IFRS does not have a line item Discontinued operations in the financial statements. The 
line item Other income, net, comprises some miscellaneous revenue items and gain or loss on sale of property, plant and equipment and investments previously reported as part of Other operating expenses.

When it comes to Balance Sheet (Figure 2), short-term receivables that were formerly categorized as part of other current assets under US GAAP are now classified as Accounts Receivable. VAT receivables and other external prepaid goods make up most of these short-term receivables. Under US GAAP, capitalized exploration costs were classed as part of Property, plant, and equipment, but are now classified as intangible assets. Non-current financial assets have been reclassified from other non-current assets and are now shown on the face of the balance sheet. Shares held for trading are classified as part of Short-term investments with a fair value. Non-marketable shares previously classified under US GAAP as not held for trading are classified as available-for-sale under IFRS with changes in fair value booked against equity. The shares are presented in the balance sheet as part of Financial Assets. Non-marketable shares in the US GAAP balance sheet were classified as prepaid pension, investment and other noncurrent assets, and measured at cost.

The IFRS statement of cash flows is very similar in presentation and format to the US GAAP statement of cash flows, with only four presentation, classification or measurement differences related to them measurement of cash, Classification of capitalized interest, presentation of capitalized capital maintenance and presentation related to Assets held for sale.

\section{Conclusion}

This study aimed to study the main differences between US GAAP and IFRS when it comes to financial statement presentation. The study used a real-life case study to compare both standards applications. Findings of the study comprised that there are many similarities between US GAAP and IFRS when it comes to the presentation of financial statements. Even with these similarities, the differences are still recognizable and effective to the results of the financial statements. This study examined the main differences between US GAAP and IFRS in financial statements presentation. The finding of this research concluded that there is a significant difference in presenting financial data between US GAAP and IFRS, the main differences were in the income statement and balance sheet. For example, US GAAP doesn't require a third balance sheet while IFRS requires it in specific conditions. While the statement of cash flows is very similar in presentation and format in IFRS to the US GAAP. Finally, In the case study, coverage of IFRS methodology is addressed, and the most likely financial statement differences between US GAAP and IFRS are examined and listed which approves the differences between both accounting systems.

\section{References:}

1. AICPA, 2021. History of the AICPA. [Online] Available at: https://www.aicpa.org/about/missionandhistory/history-of-the-aicpa.html [Accessed 2021].

2. Burlaud, A. \& Baker, R., 2015. Epistemology of accounting: from doctrine to consequentialism. French Accounting Review,.

3. EY, 2021. US GAAP versus IFRS The basics, s.I.: s.n. 
4. FASB, 2021. Financial Accounting Standards Board. [Online] Available at: https://www.fasb.org/facts/

5. Gibson, C. H., 2009. Financial Reporting \&Analysis: Using Financial Accounting Information. s.l.: The University of Toledo, Emeritus.

6. Gordon, E. A., Jorgensen, B. N. \& Linthicum, C. L., 2011. Could IFRS Replace US GAAP? A Comparison of Earnings Attributes and Informativeness in the US Market. Working Papers 0028.

7. Hydro, 2007. Norsk Hydro ASA, Oslo: s.n.

8. IASB, 2021. [Online] Available at: https://www.ifrs.org/about-us/who-weare/\#history

9. Pierre, D. \& Guillaume, O., 2016. The Convergence of U.S. GAAP with IFRS: A Comparative Analysis of Principles-based and Rules-based Accounting Standards, s.I.: Scholedge International Journal of Business Policy and Governance.

10. Smith, M., 2011. IFRS and U.S. GAAP: Some key differences accountants should know.

11. Smith, M., 2012. IFRS and U.S. GAAP: Some Key Differences Accountants Should Know. Management Accounting Quarterly, 14(1), pp. 19-26.

12. U. N., 2008. INTERNATIONAL ACCOUNTING and REPORTING ISSUES. New York and Geneva, UNITED NATIONS.

13. Unegbu, A. O., 2014. Theories of Accounting: Evolution \& Developments, IncomeDetermination and Diversities in Use. Research Journal of Finance and Accounting, 15(19). 


\section{SECTION: MANAGEMENT, MARKETING, ECONOMIC INFORMATICS AND CYBERNETICS}




\title{
DEMOGRAPHIC AND ECONOMIC FACTORS INFLUENCING THE REAL-ESTATE MARKET IN ROMANIA
}

\author{
Remus Dorel ROȘCA, Sebastian ȘIPOȘ-GUG \\ University of Oradea, Faculty of Economics, Oradea, Romania \\ roscaremus10@gmail.com \\ sebastian.siposgug@gmail.com
}

\begin{abstract}
Forecasting the evolution of the residential real-estate market on the longer term is a daunting task that we aim to improve by looking into the relationship between home prices and real-estate transactions and several demographic indicators: number of marriages, divorces, birth-rates and deathrates, as well as several other factors, including income, employment and interestrates. By looking at the monthly data for Romania between April 2009 and September 2016, and using a path analysis approach, we tested our proposed model and, after making several adjustments to it in order to increase its power, we found a way to relate the demographic indicators, prices and transactions that could provide assistance both in explaining the dynamics of the real-estate market and aid in making forecasts that related to these indicators. Our main results point to a negative relationship between prices and transactions, which is in line with our expectations and current economic theory. We also find that income has a positive relationship with the number of transactions and a negative one with home prices. However, the latter can be fully explained by a mediation effect though the former, and thus there is a strong possibility that changes in income have an indirect effect on prices, by their effect on transactions. In terms of demographics indicators, divorces are positively related to prices, births are positively related with transactions, while marriages have an inverse relationship with the number of transactions and we failed to find any indicators that deaths have a strong relationship to either prices or transactions. These effects are relatively smaller than those of income or employment, but nonetheless on the longer term they add up and, after all, demographic trends change slower. We conclude that marriages, divorces and births are related to changes in home prices and number of transactions in the Romanian real-estate market and that their long-term trends could be important in assessing the future of this market.
\end{abstract}

Keywords: home prices; real-estate transactions; demographics;

JEL Classification: R31; R21; J11.

\section{Introduction}

The real estate market has a relatively big impact on the lives of people, with prices and transaction activity being closely tied to the living conditions one can afford, where we live and, often, what work opportunities are available for adults and educational options for children. Not to mention that, for a large portion of the population, their house will be the single most valuable asset they own and will be the biggest contributor to their net worth. For those with above average income, a second house or apartment to lease might be a big part of their retirement plan. 
There are also cultural aspects to consider, as the home ownership rate in Romania in 2019 was $95.8 \%$, the biggest in the EU, which averages just $69.8 \%$ (Eurostat, 2021a), thus pointing towards the high desire of Romanians to own a home. Thus, when looking at the overall demographic changes that Romania is currently going through, one must wonder how all this will change in the future.

Table 1. Evolution of births, marriage and divorce between 1990 and 2019

\begin{tabular}{|l|l|l|l|l|}
\hline Year & $\mathbf{1 9 9 0}$ & $\mathbf{1 9 9 9}$ & $\mathbf{2 0 0 9}$ & $\mathbf{2 0 1 9}$ \\
\hline Mean age of women at birth & 22,3 & 23,5 & 25,5 & 27,6 \\
\hline Fertility rate per 1000 inhabitants & 13,6 & 10,3 & 9,9 & 9,2 \\
\hline Mortality rate per 1000 inhabitants & 10,6 & 11,6 & 11,4 & 11,7 \\
\hline Marriage rate per 1000 inhabitants & 8,3 & 6,1 & 6 & 5,8 \\
\hline Median age at first marriage & 25 & 26,5 & 29,1 & 31,6 \\
\hline Divorce rate per 1000 inhabitants & 1,42 & 1,51 & 1,44 & 1,36 \\
\hline
\end{tabular}

Source: National Statistics Institute

We are noticing demographic decline (from 19.281 million in 2020 to an forecasted 15.5 million by 2050, source: Eurostat, 2021b), with lower birth rates, declining rates of marriage, higher age at birth and marriage (source: National Statistics Institute), and all these might have a negative impact on the residential real estate market on the longer term. On the other hand, average income has been rising faster than inflation, and interest rates are at a historical low. This might sound like good news for the market at the moment, but on the longer term the interaction of all these variables is complex, and predicting how the market might look like in few decades might be dependent on all of them.

The impact of demographic factors on the real estate market has been investigated across the globe, and results seem to be different between countries. Developing economies often find a positive relationship between demography and real estate indicators, like in Kenya (Karoki, 2013) or Ghana (Obeng-Odoom, 2010), while some developed nations expect the impact to be a negative one and are preparing mitigation measures to prevent market decline, like in Germany (Berndgen-Kaiser et al., 2014)

When it comes to the Romanian market, several studies found relationships between demographics and home prices (Anghel \& Hristea, 2013; Șipoș, 2018) or the number of transactions (Enăchescu \& Bănică, 2019). Sorcaru (2020) also points towards internal migration of the elderly towards rural areas as a factor of urban depopulation, which would also lead to increased number of transactions. Looking at economic indicators influencing the real-estate market, Anica-Popa (2013) and Simionescu (2014) conclude that increases in interest rates have a negative impact on it. In addition to interest rates, other measures by the National Bank, like loan-to-value restrictions, seem to be more reactionary, rather than causal in nature, when it comes to their impact on the market (Neagu, Tatarici \& Mihai, 2015). Popescu \& Ciora (2015) also suggest that GDP, unemployment, interest rates, income and government programs can all influence the real-estate market. The relationship is not clear-cut however, since Enăchescu \& Bănică (2019) didn't find a strong indicator that GDP, income and transactions are related. The current paper aims to continue their work, and to explore the relationship between all these potential indicators and the changes in home prices and number 
of transactions, in order to improve both our theoretical understanding of the markets and our ability to effectively provide long term forecasts for it.

\section{Proposed model}

Based on our literature review and personal experience, we created a theoretical model of housing prices and real estate transaction, based on social, economic and demographic variables. The model is succinctly presented in the neighboring graph, with arrows indicating directional or bi-directional relationships. Full lines symbolize direct relationships and dotted lines reverse relationships.

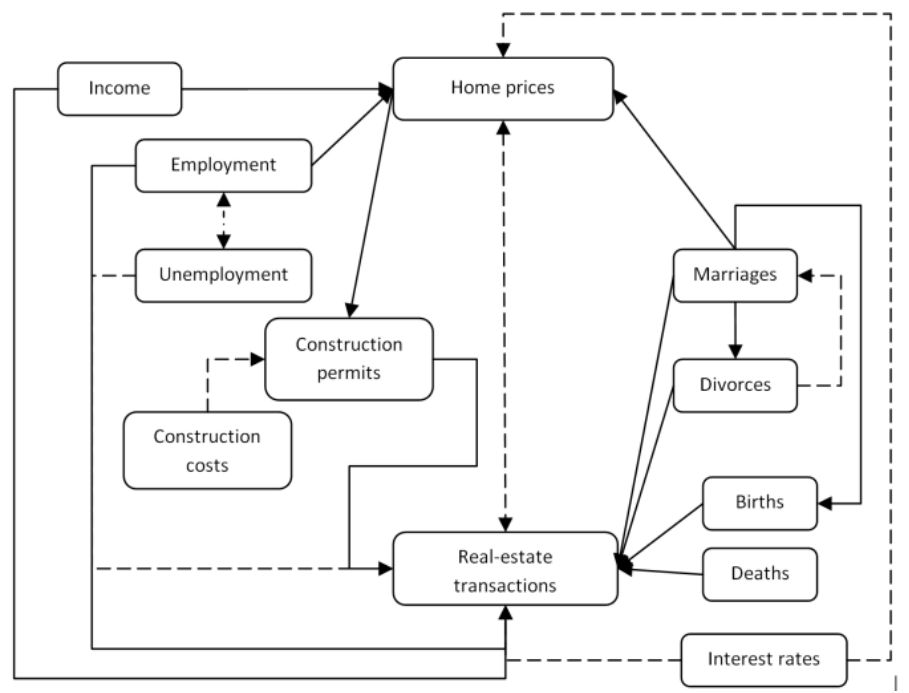

Figure 1: The proposed model of home prices and real-estate transactions

Testing a model of this complexity can be difficult, requiring time series long enough to provide a reasonable statistical power. For this purpose we chose the finest-grained time series available, that of monthly data and we used this as a main criterion for indicator selection. In order to control some of the downsides of monthly data, we further looked at seasonality and potential breaks in the time series for each indicator, that might influence the testing of our model.

\section{Indicators}

\subsection{Real estate transactions}

The data regarding real estate transactions was collected from the National Agency for Cadastre and Land Registration (ANCPI), and was available starting with January 2009. A potential issue with this data source is that it tracks total transactions, not only residential ones. However, since 2017, they do provide a break-down of the series,

In order to see if there are any structural changes in the time series, as it might have been collected or reported differently over the years, we used the breakpoints function of the strucchange $R$ package, version 1.5-2. The test pointed to three potential breakpoints, April 2012, February 2015 and September 2016. The 2012 
and 2015 points might point to market changes (by 2012 the market had stabilized after the 2008 crisis and starting with 2015 it returned to a growth trend). However, since ANCPI also changed its data reporting structure in 2016, this will have to be taken into account in the further analyses.

Seasonality is also of concern, especially when dealing with construction related data. To test for seasonality we used the WO test, from the seastests R package, version 0.14.2, which rejected the lack of a seasonal component. In order to decompose the time series, we used the STL function from the stats R package, version 3.6.3. After eliminating the seasonal component, the WO test failed to reject the lack of a seasonal component $(p=0.747)$, thus we concluded that our real estate transaction time series has a 12 - month (additive) period.

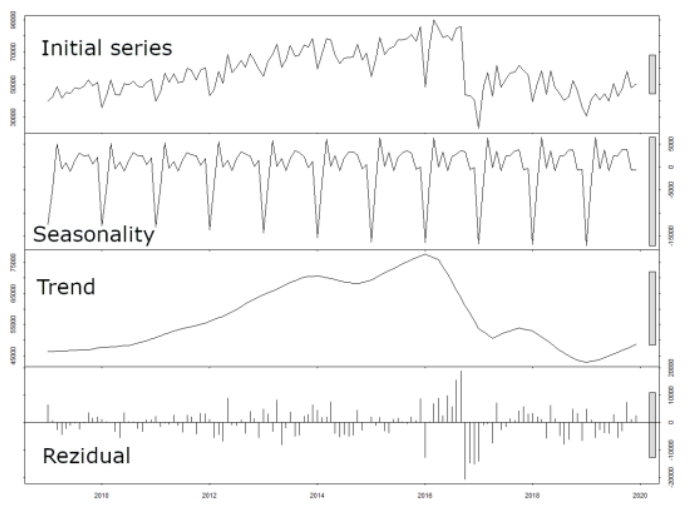

Figure 2. Seasonal decomposition of the number of real-estate transactions Source: Author's calculations based on data from the National Agency for Cadastre and Land Registration

Another concern is that of stationarity. In order verify this, we used the $A D F$ (Augmented Dickey-Fuller) and KPSS (Kwiatkowski-Phillips-Schmidt-Shin) test, of the $\mathrm{R}$ package tseries, version $0.10-47$. This approach is often recommended, since each of the alone can be prone to Type I errors (Charemza and Syczewska, 1998, Kębłowski and Welfe, 2004). Both tests pointed to a lack of stationarity of the initial time series, but not so after a level 1 differentiation and so we concluded that a single differentiation can make the time series stationary.

\subsection{Home prices}

Data regarding home prices is available from multiple sources. The National Statistics Institute (INS) publishes a quarterly index, that is also the source for the Eurostat database. This is however a poor choice for our study, since it's availability is limited in time, and the reporting period is a quarterly one. Instead, we used as a proxy for home prices the IMO index, published by the imobiliare.ro website. This is the average asking price in Euro per square meter of an apartment on the website and is has a monthly reporting frequency. While there can be a difference between asking prices and real prices and the website is only a sample of the entire market, the fact that the data is available since March 2008 and the reporting frequency makes it a better suited choice for our study. Moreover, we compared the trends of the two indices (by converting both to annual rate of 
change) and they strongly overlap, with an $r=0.93$, thus it would seem that they both change very similarly from year to year.

We performed the same tests regarding continuity, seasonality and stationarity as we did previously for home transactions. We identified four potential breakpoints, that correspond to changes in the trend of the indicator: an accelerated drop in prices starting with July 2010 , followed by stabilization after June 2012, fast growth starting with January 2016 and a slower growth from August 2017 onwards.

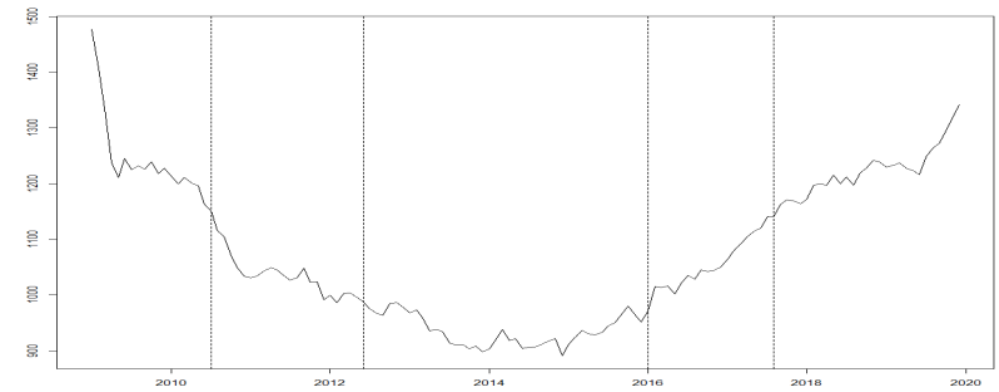

Figure 3. Breakpoint analysis of home prices

Source: Author's calculation based on data from imobiliare.ro

The WO test failed to reject the lack of a seasonal component $(\mathrm{p} 1=0.118, \mathrm{p} 2=$ 0.47 ), and thus we continued our work on the assumption that our home price indicator is not subject to seasonal variation. This would be in contrast with studies on other markets, that did find seasonality in the variation of home prices in USA (Miller et al., 2013), UK (Kajuh \& Schmidt, 2016), or Poland (Trojanek, 2013)

Regarding stationarity, both the ADF and KPSS tests pointed to a high chance of the time series not being stationary $(p=0.934$ and $p<0.01$, respectively), but this changed after an order 1 differentiation both tests $(p<0.01$ and $p>0.1$, respectively). Thus, where stationarity is important, we recommend using the first order differential of this time series.

\subsection{Demographic indicators}

We looked at several demographic indicators, all reported publicly by the National Statistics Institute: births, deaths, number of marriages and number of divorces. We collected the monthly data from the January 2009 - December 2019 interval, as to match the available time frame for the other indicators.

All four indicators showed signs of seasonality, with the WO test failing to reject this hypothesis, and we found that they have an additive seasonal component.

Regarding stationarity, with the exception of birth rates, the other time series didn't raise any concerns, with both the ADF and KPSS tests pointing to a very low chance that they are not stationary. In the case of birth rates, a declining trend was indentified and the series was found to be stationary around this trend.

\subsection{Economic indicators}

We also wanted to include in our model several key economic indicators that have been traditionally related to the real-estate market, namely income, employment, interest rates. We also included the number of building permits issued and construction costs, as potential factors in our model. 
The majority of this data was collected from the INS, using the following data series:

- "Monthly average net earnings in the economy" in the case of income

- "Number of employees at the end of the month" for employment

- "Registered unemployed at the end of the month"

- "Building permits by type of construction"

- "Construction cost indices - base year 2015" for construction costs

Our source for interest rates for housing loans was the National Bank of Romania, and we used as an indicator the average interest rate for loans as a weighted mean of interest rates for various currencies and using volume of loans as weights. We performed the same tests for stationarity and seasonality as previously, and there were only two potential issues: income showed signs of seasonality (WO test $\mathrm{p}<0.001$ ) and unemployment requires an first order differentiation to be stationary.

\section{Testing the model}

In order to test the model using the previously mentioned data sources, we resorted to a path analysis, conducted by applying the sem function from the lavaan $\mathrm{R}$ package, version 0.6-7. Time series were shortened to the interval April 2009 - September 2016 in order to minimize the impact of breaks in data.

The function call used the following model parameters:

\{ Prices $\sim$ Income + Marriages + Divorces + Births + Deaths + Interest rates + Persons Employed + Persons Unemployed + Construction Permits

Transactions $\sim$ Income + Marriages + Divorces + Births + Deaths + Interest

rates + Persons Employed + Persons Unemployed + Construction Permits

Births Income + Marriages

Persons Employed Persons Unemployed \}

The initial model failed our chi-squared fit test $(p<0.001)$, thus we looked into what might cause this result. Since our sample size was relatively low (85 time points), the chi-squared test would be a reasonable measure (Kenny, 2020), however we would normally want at least 200 cases for the SEM model to achieve sufficient statistical power. Since collecting more data is not practical in this case, we decided to strip down the model and reduce its complexity. The final version of our model had a adequate chi-squared fit $(p=0.771)$ and all coefficients were significantly different from $0(p<0.05)$.

The revised model had the following parameters:

\{ Prices $\sim$ Income + Divorces + Persons Employed + Persons Unemployed

Transactions $\sim$ Income + Marriages + Births + Interest rates + Persons Unemployed + Construction Permits \}

In order to simplify the interpretation of our results, we resorted to a graphical representation of the data, using green arrows to point to a direct relation and red arrows to point to indirect relations. Arrow thickness is proportional to the size of the relationship. We also removed auto-correlation terms from this representation, as to keep the image as simple as possible. We decided to leave in significant correlations between other variables (outside of our model) and they are marked with a dotted line, in this case not proportional to effect sizes. 


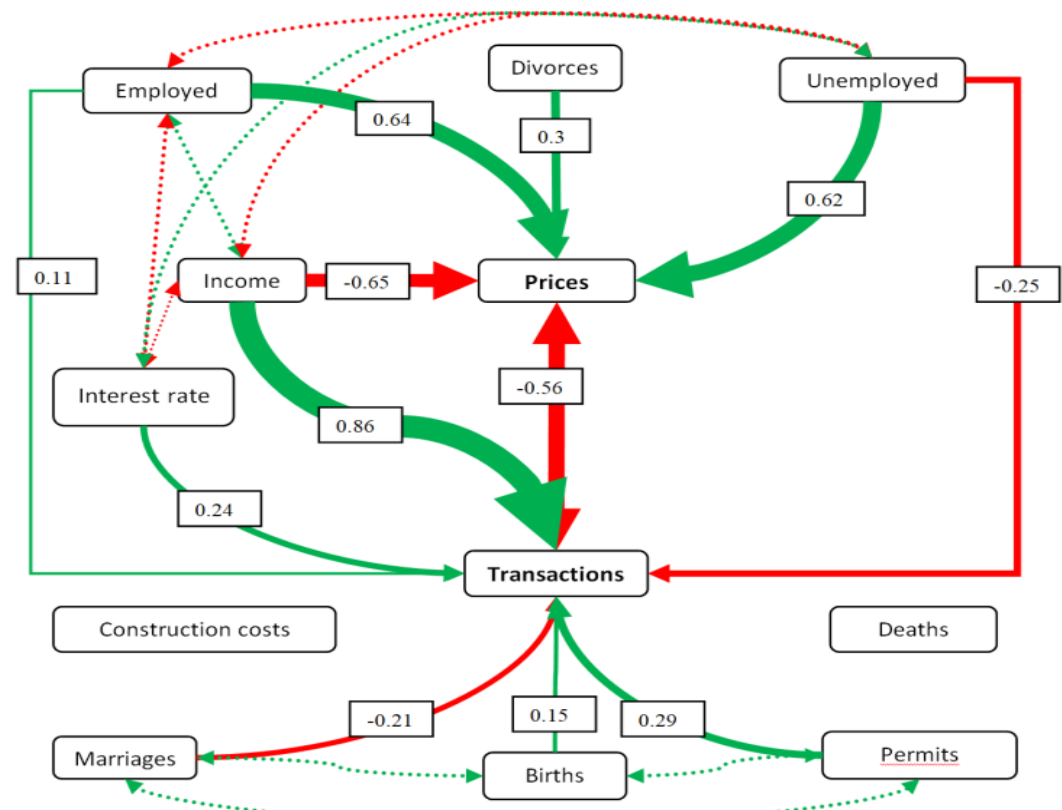

Figure 4. Tree graph of the revised model Source: Author's calculations

\section{Results}

Our model shows that the main factors helping to predict apartment prices are the number of employed and unemployed persons, divorces, income and the number of real estate transactions, with the latter two having a negative relation with prices. Some of these results are in line with our expectation. In fact, the relationship between price and number of transactions is but a confirmation of the long established relationship between supply and price, in general.

At a first glance, we were taken aback by the negative relation between income and prices, since common sense would have predicted that an increase in average income would translate to an increase in average home prices. Thus, we decided to look a bit further into this relationship. We looked at transactions as a potential mediator between income and prices. We used the mediate function of the $\mathrm{R}$ package mediation, version 4.5.0, and the results were in favor of our hypothesis. That is, they showed that the number of transactions completely mediates the relationship between income and apartment prices. We can conclude, then, that an increase in income is indeed related with a decrease in apartment prices, potentially due to the indirect effects of increased real estate transactions. This relationship will require further study, as it has not been the focus of our paper.

Employment/unemployment and their relation to prices also seems rather complex, with them having a reversed correlation to each other, but both having a positive relation to apartment prices. Unfortunately, we could not look at more macro economical indicators related to employment, since they are reported quarterly or yearly, and would not have fitted our study's design. Most likely unemployment and prices rise together in periods of economic unease, when interest rates also 
increase (we also found a positive relationship between unemployment and interest rates). An increase in unemployment might mean fewer lower income persons that can buy apartments, and thus fewer transactions. The remaining transactions would be those involving homes that are more expensive and thus average prices go up. Anecdotally, we can see this in the current (Q1 2021) real estate market. Since there are so few investment opportunities for those with excess income, many choose to invest in apartments, pushing the prices upwards, despite an overall less optimistic forecast regarding employment.

The demographic factors were related to transactions, with marriages having a negative impact on them, while births having a positive one. While we expected births to lead to more transactions, since an expanding family would often require more room and/or parents would change their housing preferences to better accommodate children (having a yard, proximity to schools, etc.), the negative relation to marriages was in opposition with that proposed by our model. We cannot eliminate the probability that this is an artifact of both variables being nonstationary, there might actually be an economic explanation: many young couples move in to a home one of them already owns, and then buy a new home at a later date, perhaps once a child is born. Supporting this hypothesis is the fact that the median age of marriage is rising, and with the high rates of home ownerships in Romania there are good odds that one, or both partners, already own a home at 31 years (the median age of first marriage in 2019). We also found that divorces have a positive relationship with prices, while we initially expected them to be related to transactions (since a divorce would likely mean one of the partners moves out). For now, our best explanation is that separation and divorce might occur at different moments in time, and a couple would file for divorce when they try to divide their assets, and this would take place when they get a good price for them. This relationship would be interesting to investigate in more detail, as there could be other intervening factors that we missed.

\section{Conclusions}

We proposed a model of demographic and economic factors influencing the real estate market in Romania. While our proposed model proved to be too complex to test with adequate statistical power using the data at hand, we have revised and simplified it as much as possibly, without losing it's core ideas.

We found that income was the strongest factor related to both asking prices for homes and the number of total real estate transactions. Furthermore, we found that its impact on prices can be fully mediated by its relation to transactions. Thus, measures aimed at increasing wages could be used to, paradoxically, lower home prices, via their strong impact on the number of transactions.

At the same time, employment and unemployment both have a positive impact on prices, but a different impact on transactions, with employment leading to more transactions, while unemployment to fewer. This points to a complex relation between the four indicators, and shows that increases in employment can have a positive impact on the real-estate market, while unemployment leads to fewer, but more valuable on average, transactions.

Not the least, demographic indicators also play a role, with divorces positively tied to home prices, while births seem to lead to more transactions. Marriages are, 
contrary to our expectations, a negative factor of real-estate transactions, despite their positive relationships with births and home permits. While their impact is relatively smaller than that of the economic indicators we looked it, nonetheless forecasters and policy makers alike should try to factor them in their models, as they can provide valuable insights of the longer term trends.

\section{References}

1. Anica-Popa, A, (2013) Piaţa imobiliară şi evoluţia dobânzii, Economie teoretică şi aplicată, XX, Supliment, 53-64.

2. Anghel, I., \& Hristea, A. M. (2013). Evoluţia demografică, dinamica fondului de locuinţe în România și evoluția prețurilor proprietăților imobiliare din România. Economie teoretică şi aplicată, XX, 5-12.

3. Berndgen-Kaiser, A., Bläser, K., Fox-Kämper, R., Siedentop, S., \& Zakrzewski, P. (2014). Demography-driven suburban decline? At the crossroads: mature singlefamily housing estates in Germany. Journal of Urbanism, 7(3), 286-306.

4. Charemza, W., \& Syczewska, E. (1998). Joint application of the Dickey-Fuller and KPSS tests. Economics Letters, 61(1), 17-21.

5. Enachescu, P. C., \& Bănică, C. (2019). Analysis Of The Real Estate Market In Romania From The Point Of View Of The Number Of Transactions During 20092018. Scientific Bulletin-Economic Sciences, 39-46.

6. Eurostat (2021a), Distribution of population by tenure status, type of household and income group - EU-SILC survey [Online] https://ec.europa.eu/eurostat/databrowser/view/ilc_Ivho02/default/table?lang=en [31.03.2021]

7. Eurostat (2021b), Population on 1st January by age, sex and type of projection [Online]https://appsso.eurostat.ec.europa.eu/nui/show.do?dataset=proj_19np\&lang $=$ en [31.03.2021]

8.Imobiliare ro (2021) Indicele

https://www.imobiliare.ro/indicele-imobiliare-ro [31.03.2021]

9. Kajuth, Florian and Schmidt, Tobias, (2011). Seasonality in House Prices Bundesbank Series 1 Discussion Paper No. 2011,08.

10. Karoki, R. W. (2013). Determinants of residential real estate prices in Kenya (Doctoral dissertation, University of Nairobi).

11. Kębłowski, P., \& Welfe, A. (2004). The ADF-KPSS test of the joint confirmation hypothesis of unit. Economics Letters, 85(2), , 257-263.

12.Kenny, D.A. (2020) Measuring Model Fit [Online] http://www.davidakenny.net/cm/fit.htm [01.09.2020]

13. Miller, Norman G., Vivek Sah, Michael Sklarz, and Stefan Pampulov. (2013). Is There Seasonality in Home Prices-Evidence from CBSAs. Journal of Housing Research 22, no. 1: 1-16.

14. Neagu, F., Tatarici, L., \& Mihai, I. (2015), Implementing Loan-to-Value and Debt Service-To-Income measures: A decade of Romanian experience. Munich Personal RePEc Archive: https://mpra.ub.uni-muenchen.de/65988/

15. Obeng-Odoom, F. (2010). Urban real estate in Ghana: A study of housingrelated remittances from Australia. Housing Studies, 25(3), 357-373. https://doi.org/10.1080/02673031003711568

16. Popescu, D. D., \& Ciora, C., (2015) Determinants of the real estate market: the Romanian case, "Theoretical and Applied Economics", XXII, 21-34. 
17. Simionescu, M., (2014) Un model quantilic autoregresiv cu lag distribuit pentru prețul locuințelor în România, Studii Şi Cercetări De Calcul Economic Şi Cibernetică Economică

18. Sorcaru, I. A. (2020). Urban Depopulation in Romania. Annals of "Dunarea de Jos" University of Galati, 39-48.

19. Șipoș, C. (2018). Are correlated the real estate prices in Romanian cities to the living conditions offered? The Valuation Journal, 13(1), 5-21.

20. Trojanek, R. (2013). An attempt to identify the seasonality of housing prices in selected polish cities in 1996-2012. Real Estate Management and Valuation, 21(4), 96-109. 


\title{
PARTICULARITIES OF CSR PROGRAMS DURING THE COVID-19 PANDEMIC
}

\author{
Simona Aurelia BODOG ${ }^{1}$, Nicoleta Alina ANDREESCU ${ }^{2}$ \\ ${ }^{1}$ Department of Management-Marketing, Faculty of Ecomonic Sciences, University \\ of Oradea, Oradea, Romania \\ ${ }^{2}$ Department Textiles-Leatherwork and Industrial Management, Faculty of Energy \\ Engineering and Industrial Management, University of Oradea, Oradea, Romania \\ simonabodog@gmail.com \\ nandreescu@uoradea.ro
}

\begin{abstract}
In 2020, the COVID-19 pandemic transformed the lives of all people. The most affected sectors were the medical, educational and disadvantaged communities. The purpose of this paper is to analyze the way in which Romanian companies have adapted their CSR programs to the new conditions of the social and economic environment. The health crisis of 2020 highlighted the deficiencies in the health system and stressed the need for collaboration between the state and the private sector to overcome it. The increase in the demand for protective equipment, medical equipment has accelerated the collaboration between private companies and hospitals, which intervene by donating the necessary materials to those in the front line. The educational system was severely affected: the school had to run online, but many students and teachers did not have the necessary equipment and knowledge and in these conditions the risk of dropping out of school was very high, especially in disadvantaged communities. The CSR programs of Romanian companies also focused to this field, donating equipment: laptops, tablets or free internet connection for schools and for students with limited financial resources. The priorities of the CSR programs were directed in 2020, especially towards these fields in response to the needs of society.
\end{abstract}

Keywords: COVID-19, CSR, health services, education.

JEL Classification: 100, 118, 124, M14.

\section{Introduction}

With the increasing impact of the COVID-19 pandemic on society, the business environment, companies need to develop corporate social responsibility programs so that the benefits are mutual, a situation that involves adapting to the global pandemic.

The effect of the COVID-19 pandemic accentuated the inequalities in the society: unemployment, social crises (education, health), economic problems even the developed world and determined the increase of the vulnerabilities of the society in front of the appeared problems. Human health, income, shelter and other goals of life are now caused by many more risks and uncertainties arising from COVID-19 attacks. The only lever that can link business interests to social interests is community trust, and empathy is an important indicator for building trust (Boadi et 
al., 2019). Thus, in this critical period, the moral duty of companies is to support society.

In all countries there have been and still are concerns for studying the possibilities of adapting social responsibility programs in times of crisis and identifying the effects of this adaptation on society.

\section{Literature review}

A group of Spanish researchers (Raimo, N., Rella, A., Vitolla, F., Sánchez-Vicente, M-I., García-Sánchez, M-I., 2021) examines how Spanish companies have supported society and vulnerable individuals through partnerships with non-governmental organizations (NGOs). The results of this study indicate that these partnerships are mainly aimed at providing food, health, social and technological support to society and vulnerable individuals. The authors (Raimo, N., Rella, A., Vitolla, F., SánchezVicente, M-I., García-Sánchez, M-I., 2021) report that this is the first study that examines the support provided by companies to society during the COVID-19 pandemic in the European context.

Another study (Mahmud, Ding, Hasan, 2021) explores business responses to the COVID-19 pandemic to support employees, customers, communities, and society as a whole through CSR initiatives. Results of this research report that companies show respect to their employees and focus on stewardship relations between corporations and customers and communities during the COVID-19 pandemic.

Hongwei He and Lloyd Harris (2020), (Hongwei and Lloyd, 2020), examine how the Covid-19 pandemic may influence CSR developments and highlights how consumer decision-making will be affected by the pandemic.

Another study by Italian researchers (Patuelli et al. 2021) provides information on the major problems and challenges facing companies in the Covid-19 pandemic and their concerns about corporate social responsibility (CSR) following an investigation into Twitter discussions of major Italian companies in the first months of the pandemic. The results of the study highlight the contribution of online social networks and the role of online social networks in understanding the problems, challenges and responsibilities of companies, with common narratives that flow naturally from the data.

In Romania, too, several studies have been conducted that analyze how the pandemic affects society and the economy and assess the impact of the effects of the COVID-19 pandemic on society. The purpose of these studies is related to the need to change the attitude of citizens and assume the social responsibility of companies (Zamfir and Zamfir, 2020).

\section{CSR programs of companies during the COVID-19 Pandemic}

The COVID-19 pandemic has, in addition to its effects on the population's health, multiple social implications: social relations have undergone significant changes (social distancing), the way people relate to themselves and other members of society, lifestyle changes through by restricting access to public space, online education, and encouraging companies to promote homework for their employees. 
The economic impact was obvious: many companies restricted their activity, employees went on unpaid leave or unemployment and others lost their jobs.

In this context, the CSR programs of the companies have been adapted to the new needs of the society and the communities in which they operate.

The purpose of this paper is to analyze the way in which Romanian companies have adapted their CSR programs to the new conditions of the social and economic environment and in these conditions we have analyzed the CSR programs of some companies in Romania that were involved in the crisis caused by Covid -19 .

The criteria by which these companies were chosen are:

-the amount of money invested in the program,

-visibility, the way in which stakeholders were informed about the adaptation of the CSR program to the new conditions imposed by the pandemic,

-the speed with which the CSR program adapted to the new realities, -the domains in which they were active.

Table 1: Representative CSR activities by Romanian companies during the COVID-19 Pandemic

\begin{tabular}{|c|c|c|c|}
\hline Activity sector & Company & Ways to get involved & $\begin{array}{c}\text { The } \\
\text { amount } \\
\text { invested }\end{array}$ \\
\hline Financial & $\begin{array}{l}\text { Banca } \\
\text { Transilvania }\end{array}$ & $\begin{array}{l}\text { Money and equipment for } \\
\text { hospitals and for } 30 \\
\text { communities. } \\
\text { Accelerate the launch of online } \\
\text { banking solutions to allow } \\
\text { permanent access to products } \\
\text { and services. } \\
\text { Measures to support } \\
\text { customers with loans affected } \\
\text { by the pandemic } \\
\text { Continuing the business by } \\
\text { continuing all operations. }\end{array}$ & $\begin{array}{l}2.000 .000 . \\
\text { Euro }\end{array}$ \\
\hline Financial & $\begin{array}{l}\text { BRD } \\
\text { Groupe } \\
\text { Société } \\
\text { Générale }\end{array}$ & $\begin{array}{l}\text { Donation for the medical } \\
\text { sector }\end{array}$ & $\begin{array}{l}1.700 .000 \\
\text { Lei }\end{array}$ \\
\hline Financial & CEC Bank & $\begin{array}{l}\text { Sponsorships to nine frontline } \\
\text { hospitals in the fight against } \\
\text { COVID-19 }\end{array}$ & $\begin{array}{l}1.000 .000 \\
\text { Lei }\end{array}$ \\
\hline Financial & $\begin{array}{l}\text { OTP Bank } \\
\text { România }\end{array}$ & $\begin{array}{l}\text { Donation for the purchase of } \\
\text { equipment and materials } \\
\text { necessary for medical staff. }\end{array}$ & $\begin{array}{l}500.000 \\
\text { Lei }\end{array}$ \\
\hline Telecomunications & RCS RDS & $\begin{array}{l}\text { Donations of medical } \\
\text { equipment for } \\
\text { departments. } \\
\text { Donations of medical } \\
\text { equipment and connectivity } \\
\text { services for children from }\end{array}$ & $\begin{array}{l}\text { No info } \\
\text { provided }\end{array}$ \\
\hline
\end{tabular}




\begin{tabular}{|c|c|c|c|}
\hline & & $\begin{array}{l}\text { disadvantaged areas or } \\
\text { isolated communities. }\end{array}$ & \\
\hline Telecomunications & Orange & $\begin{array}{l}\text { Health projects: eight public } \\
\text { hospitals were equipped with } \\
\text { artificial ventilation devices and } \\
\text { protection equipment. } \\
\text { Digital education } \\
\text { Social inclusion and } \\
\text { community support projects. }\end{array}$ & $\begin{array}{l}400.000 \\
\text { Euro } \\
\\
550.000 \\
\text { Euro } \\
380.000 \\
\text { Euro }\end{array}$ \\
\hline Retail & LIDL & $\begin{array}{l}50.000 \text { collection kits for nasal } \\
\text { and pharyngeal exudate, } \\
\text { needed to perform molecular } \\
\text { diagnostic tests in the } \\
\text { beginning of the pandemic. } \\
\text { Donations for the SMURD } \\
\text { Foundation and DSU to } \\
\text { purchase the first mobile } \\
\text { therapy unit, intended for the } \\
\text { treatment of patients with } \\
\text { SARS-CoV } 2 \text { infected and in } \\
\text { critical condition. } \\
20 \text { oxygen concentrators for } \\
\text { the Botosani Emergency } \\
\text { Hospital. Donations in the } \\
\text { "Românii Împreună pentru } \\
\text { dotarea sectiilor de Terapie } \\
\text { Intensivă" Campaign. }\end{array}$ & $\begin{array}{l}1.208 .000 \\
\text { Lei }\end{array}$ \\
\hline Beverage & $\begin{array}{l}\text { Coca Cola } \\
\text { România }\end{array}$ & $\begin{array}{l}\text { Donations to the Red Cross for } \\
\text { the purchase of necessary } \\
\text { medical equipment. } \\
\text { Drinks covering one month's } \\
\text { supply of Covid-19 infectious } \\
\text { disease hospitals and } \\
\text { quarantine centers in the } \\
\text { country. }\end{array}$ & $\begin{array}{l}100.000 \\
\text { Euro } \\
100.000 \\
\text { Euro }\end{array}$ \\
\hline Energy & $\begin{array}{l}\text { OMV } \\
\text { Petrom }\end{array}$ & $\begin{array}{l}\text { Donation for the purchase of } \\
\text { COVID19 rapid diagnostic test } \\
\text { equipment. }\end{array}$ & $\begin{array}{l}1.000 .000 \\
\text { Euro }\end{array}$ \\
\hline Energy & $\begin{array}{l}\text { ENGIE } \\
\text { România }\end{array}$ & $\begin{array}{l}\text { Purchase of medical } \\
\text { equipment for the endowment } \\
\text { of three medical units in } \\
\text { Bucharest and Brassov. } \\
\text { Financial contribution directed } \\
\text { to several NGOs. }\end{array}$ & $\begin{array}{l}110.000 \\
\text { Euro }\end{array}$ \\
\hline Pharmaceutical & Sanofi & $\begin{array}{l}\text { Donations of drugs used in the } \\
\text { treatment of patients infected } \\
\text { with the SARS-CoV-2 virus }\end{array}$ & $\begin{array}{l}\text { No info } \\
\text { provided }\end{array}$ \\
\hline
\end{tabular}




\begin{tabular}{|l|l|l|l|}
\hline & & $\begin{array}{l}\text { (Hidroxiclorochine) have been } \\
\text { donated to the Ministry of } \\
\text { Health, }\end{array}$ & \\
\hline Insurance & Allianz- & $\begin{array}{l}\text { Equipping with five ATI } \\
\text { devices the modular hospital in } \\
\text { the yard of Elias Hospital in } \\
\text { Bucharest for the treatment of } \\
\text { serious cases of COVID-19. }\end{array}$ & \\
\hline
\end{tabular}

Source: made by the authors based on data collected from the companies' sites

By analyzing the way in which companies have adapted their CSR programs to the new social realities, we can see some common points of them:

- all the analyzed companies directed their CSR campaigns to hospitals, schools and disadvantaged people,

- the donation was the main CSR tactic that the companies adopted,

- the companies collaborated with each other to support projects and NGOs that carried out their activity in these fields (eg. the campaign Dăruieste viață!),

- the companies analyzed and published through the media the actions of CSR in order to become a good example for other companies but also to be close to people to prove to them that they are together in this crisis.

\section{Conclusions}

The health crisis has affected the lives of all people but also the way companies do business. Both people and companies have had to adapt to new social and economic realities in a very short time.

Under these conditions, the companies turned their attention to the employees, understanding that only by protecting them and the community can they continue to carry out their activity.

CSR programs have been adapted to new realities and the priority has been a donation to hospitals to provide protective materials and medical equipment; most CSR actions have been directed in this direction.

Companies whose field of activity is telecommunications, in addition to donations to hospitals, have also targeted schools and students. Through their programs, the companies have equipped students with reduced possibilities, with laptops or tablets and with an internet connection in order to be able to participate in online classes and to continue their education.

We can see that the CSR programs of the companies have seen an increase in the pandemic, although they have been directed in only two or three areas of interest: health, education and the environment, in some cases.

As a result, companies have moved closer to the community and have been perceived as a "good citizen", an integral part of the community, responding to its needs in crisis situations and adapting its CSR strategy to the needs of stakeholders.

We believe that the CSR policy of companies has become stronger and more visible in the new economic and social conditions. 


\section{References}

1. Allianz-Tiriac Asigurari sustine lupta impotriva noului coronavirus si doneaza 80.000 de euro, available at https://www.allianztiriac.ro/ro_RO/comunicate-depresa/comunicate-de-presa/allianz-tiriac-doneaza-pentru-tratarea-pacientilor-in-starecritica.html, accessed June 2021

2. Banca Transilvania si eMAG continua implicarea in lupta cu COVID-19 si doneaza inca 2 milioane de lei (2020, 29 aprilie, INFO-COVID), available at https://www.bancatransilvania.ro/bt-social-media-newsroom/stiri/banca-transilvania-siemag-continua-implicarea-in-lupta-cu-covid-19, accessed June 2021

3. BRD donează 2 milioane de lei pentru a susține sectorul medical și ecosistemul cultural independent (2020, 19 martie), available at https://www.brd.ro/brd-doneaza-2milioane-de-lei-pentru-sustine-sectorul-medical-si-ecosistemul-cultural-independent, accessed June 2021

4. Boadi, E. A., He, Z., Bosompem, J., Say, J., Boadi, E. K. (2019), Let the talk count: Attributes of stakeholder engagement, trust, perceive environmental protection and CSR, SAGE Open, 9(1), 1-15, https://doi.org/10.1177/2158244019825920

5. CEC Bank, available at https://www.cec.ro/noutati, accessed September 2021

6. Coca-Cola România, Doar împreună, de la distanță, putem depăși mai ușor acest impas! (2020, 26 martie), available at https://www.coca- cola.ro/desprenoi/actiunile-noastre/initiativele-coca-cola-coronavirus/sistemul-coca-cola-donatie-covid,

accessed September 2021

7. Donație de la SANOFI de peste un milion de doze de Hidroxiclorochinină, un medicament vital în lupta împotriva pandemiei COVID-19 (2020, 03 aprilie), available at http://www.ms.ro/2020/04/03/donatie-de-la-sanofi-de-peste-un-milion-dedoze-de-hidroxiclorochinina-un-medicamente-vital-in-lupta-impotriva-pandemiei-covid-

19/, accessed August 2021

8. ENGIE Romania continuă sprijinul în lupta împotriva COVID-19 și donează 110.000 euro către Dăruiește Viată pentru achiziția de echipamente medicale (2021, 19 aprilie), available at https://www.engie.ro/engie-romania-continua-sprijinulin-lupta-impotriva-covid-19-si-doneaza-110-000-euro-catre-daruieste-viata-pentru-

achizitia-de-echipamente-medicale/, accessed September 2021

9. Hongwei, H., Lloyd, H., (2020), The impact of Covid-19 pandemic on corporate social responsibility and marketing philosophy, Elsevier Public Health Emergency Collection, doi: 10.1016/j.jbusres.2020.05.030

10. Lidl Romania, available at https://corporate.lidl.ro/, accessed June 2021

11. Mahmud, A., Donghong, D., Hasan, MM., Corporate Social Responsibility: Business Responses to Coronavirus (COVID-19) Pandemic (2021), SAGE Open, https://www.mottmac.com/views/adapting-corporate-social-responsibility-to-covid-19, https://doi.org/10.1177/2158244020988710

12. Patuelli A, Caldarelli G, Lattanzi N, Saracco F (2021), Firms' challenges and social responsibilities during Covid-19: A Twitter analysis, PLoS ONE 16(7): e0254748. https://doi.org/10.1371/journal.pone.0254748

13. Panagiotopoulos, I. Novel CSR \& novel coronavirus: Corporate Social Responsibility inside the frame of coronavirus pandemic in Greece. Int J Corporate Soc Responsibility 6, 10 (2021). https://doi.org/10.1186/s40991-021-00065-7

14. Prima tranșă de echipamente ATI donate de grupul DIGI a ajuns la spitalele din țară (2020, 25 mai), available at https://www.digi.ro/anunturi/prima-transa-de- 
echipamente-ati-donate-de-grupul-digi-a-ajuns-la-spitalele-din-tara-18217,

accessed

September 2021

15. Orange, Responsabilitate socială, Comunicate de presă, preluat de pe https://www.orange.ro/newsroom/comunicate-de-presa/responsabilitate-sociala-3

accessed June 2021

16. OMV Petrom, Rapoarte de sustenabilitate, available at https://www.omvpetrom.com/ro/sustenabilitate/rapoarte-de-sustenabilitate, accesesed September 2021

17. OTP Bank, available at https://www.otpbank.ro/ro, accessed September 2021

18. Raimo, N., Rella, A., Vitolla, F., Sánchez-Vicente, M-I., García-Sánchez, M-I. (2021), Corporate Social Responsibility in the COVID-19 Pandemic Period: A Traditional Way to Address New Social Issues, Sustainability, 13(12), 6561; https://doi.org/10.3390/su13126561

19. Zamfir C. and Zamfir E. (2020), Calitatea vietii in timpul pandemiei: probleme si politici de raspuns, Raport social al ICCV 2020, ICCV, Academia Romana, available at https://acad.ro/SARS-CoV-2/doc/d01-CalitateaVietii.pdf 


\title{
GLOBALIZATION AND INTERNATIONALIZATION OF THE EDUCATION MANAGEMENT
}

\section{Luminița ANDONE}

Doctoral School, Faculty of Economic Sciences, University of Oradea, Romania andoneluminita@yahoo.com

\begin{abstract}
Recently, the internationalization of higher education has been one of the topics on the agenda of researchers and representatives of educational institutions. Thus, I also approached this aspect in my research for my doctoral thesis. In the context of internationalization, education is considered a "strategic partner" that can decisively influence the development of the national economy. The management of educational institutions plays a strategic role at the branch level. The process of internationalization of the educational activity of institutions to obtain the competitive advantage is encouraged and supported by various means (market entry facilities, specialized assistance in the process of implementing investment projects) by the host countries governments. Globalization is seen as a continuous process, characterized by the particularities like the development of foreign investments, the amplification of export activities and the development of strategic alliances at the international level. Due to globalization, higher education has become more receptive to the forces of the international market by accentuating the cross-border movement not only of students, professors and researchers in universities but also by the extent of international cooperation, through the development of branches and extensions of universities in countries other than the host country of the institution. Higher education is no longer a sector dominated by the state monopoly but is increasingly targeted by the private sector, following the corporate model, with profit-loss balances and high rates of return on investment. The level of research funding in universities is an important factor in motivating the internationalization of higher education, especially for students in master and doctoral cycles. Many World Bank officials tend to see strengthening higher education as a key strategy for poverty reduction.
\end{abstract}

Keywords: globalization, internationalization, education, investment, development

JEL classification I21, I25, I29

\section{Introduction}

Globalization removes national borders. People are the main factor that gives organizations the adaptability and flexibility they need to succeed. In the opinion of human resources specialists, the level of competence of human resources managers has a major influence in the process of integrating the human resources strategy into the overall strategy of the organization. In the context of globalization, human resource management is becoming the main tool and means by which organizations can ensure their competitive advantage, and managers' strategic 
decisions must increasingly reflect their commitment to people. The absence at the organizational level of coherent human resources strategies makes it impossible for organizations to adapt to changes in the international environment. Human resources activities must be understood in interdependence with all other processes carried out at the level of an organization. This is because, in the global era, people, not firms, form the adaptive mechanism that determines how organizations respond to environmental challenges. Human resource management, as a strategic management process, is much more difficult compared to promoting technical progress or lack of financial resources. Organizations that have learned how to lead their people, applying efficient human resource management, have gone one step further than others because ensuring and maintaining the quality of human resources are long-term strategic processes. In the context of business internationalization, human resources have acquired a key role, being considered a "strategic partner" that can decisively influence the development and expansion strategy of multinational companies, both at the central level and the level of subsidiaries. Globalization is a frequently used word but at the same time a modern and rarely defined word. Globalization predicts current changes in society, the global economic branch (Beck, 1999).

Research methods used in this article are techniques such as scientific observation, documentary analysis, data analysis and conclusions.

\section{Globalization}

Globalization, as a phenomenon is perceived worldwide as a process of integration of economic, cultural, political, religious and social systems leading to equalization and acceleration of global interconnection. From ancient times, learning strategies have been applied in various environments to accommodate the place. The learning process needs to be rethought and focused on themes from the previous system. The international strategy transforms learning into lifelong learning, and it is perceived to be a key competence for future generations. The process of globalization has changed the perception of learning: lifelong learning has become a new strategy - learning focused on skills training. Globalization is the process that embodies a transformation in the organization of social relations and transactions analyzed in terms of their extent, intensity, speed and impact - generating transcontinental or inter-regional flows and networks of activity, interaction and power (Held, 2004).

Globalization and regionalization are two complementary processes, which support each other in a unitary effort to build new world order, based on the principles of market economy and democratic political leadership and organization. Economic globalization is not complete in scope, but it is the most widespread form of globalization, which involves states with financial and productive capital, but also those in development, but with material and human resources. (www.armyacademy.ro) .

In the field of strategic management, globalization is analyzed by specialists in the form of the competitive advantage that can be obtained by a company expanding its activity globally. Analyzing the content of this definition can be seen that specialists in strategic management emphasize that the competitive advantage can be obtained by a provided educational unit that meets the criteria of efficiency and low labour costs. In the context of rapid change, the European Union countries 
have reacted in various ways to rethinking the transformation of governance structures and policies for the coordination of educational institutions.

The responsibilities of educational institutions are regulated by the government through the line ministries, although they assume some responsibilities. Educational institutions must show that they meet the needs of society, that the use of funds received is managed responsibly. Autonomy has brought major changes, changes that remove traditional methods. (Creciun, 2016).

In the structure of the education sector, new models of coordination, control, responsibility and decision-making power are applied. These are regulated by the involved internal and external actors. The state authority that establishes the rules for the organization and functioning of educational units, represents the external regulation. At the national level, the Ministry of Education regulates educational policies and is responsible for developing plans and strategies for the development of educational institutions. Managerial self-government refers to the management staff of educational units that make decisions in carrying out the activities of the institution.

\section{Globalization and internationalization of the education system}

The education system has undergone changes in terms of policy, economics, and institutions due to globalization that is accelerating global interconnections. (Held, 1999) ${ }^{5}$.

The opinion of (Knight, 1997) Jane Knight and Hans de Wit (1997) was the following: in higher education "globalization represents the technological, economic, informational flow of people, values, ideas ... beyond borders. Globalization affects all countries differently, due to the diversity of national history, traditions, culture and priorities of each nation. "And" the internationalization of higher education is one of how a country responds to the impact of globalization but at the same time of the nation ". As such, internationalization and globalization are two different dynamically linked concepts, in which globalization is a catalytic phenomenon, and internationalization is a proactive response to it.

The important goal of education in the third millennium is the fundamental religion oscillates between globalization and sustainable development in the context of internationalization, being permanently shaped by competition, efficiency and performance. Globalization, from a philosophical point of view, is a phenomenon. The phenomenon is the interconnected structure made up of: physical shape, appearance and highlighting (wwwplato.stanford.edu, 2005). The influences of the globalization of education show the material and immaterial effects on the educational process. Globalization and internationalization are the puzzle pieces of education reforms at an institutional, regional, national, and branch level. The factors of the consequences of globalization are elements with a major impact that reflect the result of the internationalization of education. Elements of globalization with influence in higher education are represented in table 1. 
Table 1. Elements of globalization with influence in education

\begin{tabular}{|c|c|c|}
\hline $\begin{array}{l}\text { (Integrated) Element of } \\
\text { globalization }\end{array}$ & $\begin{array}{l}\text { Impact on higher } \\
\text { education }\end{array}$ & $\begin{array}{l}\text { Implications for the } \\
\text { international dimension } \\
\text { of higher education }\end{array}$ \\
\hline $\begin{array}{l}\text { The growing importance } \\
\text { of the production and } \\
\text { use of knowledge to } \\
\text { create wealth for nations }\end{array}$ & $\begin{array}{l}\text { Increasing emphasis on } \\
\text { lifelong learning and } \\
\text { continuing professional } \\
\text { development creates a } \\
\text { demand for higher } \\
\text { education. } \\
\text { The need to develop new } \\
\text { skills and knowledge that } \\
\text { results in new types of } \\
\text { programs and } \\
\text { qualifications a r aniversities in } \\
\text { The role of univerch and } \\
\text { scientific research } \\
\text { knowledge production is } \\
\text { changing and becoming } \\
\text { more and more } \\
\text { commercial. }\end{array}$ & $\begin{array}{l}\text { New types of private and } \\
\text { public providers deliver } \\
\text { training and education } \\
\text { programs abroad. For } \\
\text { example, private media } \\
\text { companies, networks of } \\
\text { public/private institutions, } \\
\text { university corporations, } \\
\text { multinational companies } \\
\text { More programs to meet the } \\
\text { demands of the labour } \\
\text { market. Specialized } \\
\text { training programs } \\
\text { developed for the niche } \\
\text { market, with the aim of } \\
\text { professional development } \\
\text { and worldwide distribution } \\
\text { International increase in } \\
\text { (1) mobility of students and } \\
\text { academic staff; (2) } \\
\text { vocational training and } \\
\text { education programs; (3) } \\
\text { scientific research; (4) } \\
\text { suppliers and projects. } \\
\text { Mobility can be physical, } \\
\text { but also virtual. }\end{array}$ \\
\hline $\begin{array}{l}\text { ICTs } \\
\text { New developments in } \\
\text { information and } \\
\text { communication } \\
\text { technology. }\end{array}$ & $\begin{array}{l}\text { New delivery methods } \\
\text { used in education at } \\
\text { national or cross-border } \\
\text { level, via satellite or } \\
\text { online }\end{array}$ & $\begin{array}{l}\text { Innovative methods of } \\
\text { delivering education } \\
\text { internationally such as e- } \\
\text { learning and franchising } \\
\text { require increased attention } \\
\text { to program/provider } \\
\text { accreditation and } \\
\text { recognition of qualifications }\end{array}$ \\
\hline $\begin{array}{l}\text { Market economy } \\
\text { Increasing the number } \\
\text { and influence of market- } \\
\text { based economies } \\
\text { around the world }\end{array}$ & $\begin{array}{l}\text { Intensifying the } \\
\text { commercialization and } \\
\text { modification of higher } \\
\text { education and vocational } \\
\text { training programs at the } \\
\text { national and international } \\
\text { level }\end{array}$ & $\begin{array}{l}\text { New concerns related to } \\
\text { the adequacy of curriculum } \\
\text { and teaching materials in } \\
\text { different countries and } \\
\text { cultures, increasing the } \\
\text { potential for } \\
\text { homogenization, as well as } \\
\text { new opportunities for } \\
\text { hybridization }\end{array}$ \\
\hline Trade li & $\begin{array}{l}\text { Increasing the import and } \\
\text { export of educational }\end{array}$ & $\begin{array}{l}\text { Intensifying trade that } \\
\text { exports/imports }\end{array}$ \\
\hline
\end{tabular}




\begin{tabular}{|c|c|c|}
\hline $\begin{array}{l}\text { Development of new } \\
\text { international and } \\
\text { regional agreements to } \\
\text { reduce trade barriers }\end{array}$ & $\begin{array}{l}\text { services and products } \\
\text { after removing barriers }\end{array}$ & $\begin{array}{l}\text { programs and diminishing } \\
\text { the importance of } \\
\text { international development } \\
\text { projects }\end{array}$ \\
\hline $\begin{array}{l}\text { Governance } \\
\text { Creating new regional } \\
\text { and international } \\
\text { governance structures } \\
\text { and systems }\end{array}$ & $\begin{array}{l}\text { The role of national, } \\
\text { governmental and non- } \\
\text { governmental actors in } \\
\text { education is changing. } \\
\text { New policies and } \\
\text { regulatory frameworks } \\
\text { are being considered at } \\
\text { all levels }\end{array}$ & $\begin{array}{l}\text { New international/regional } \\
\text { frameworks are being } \\
\text { considered that } \\
\text { complement national and } \\
\text { regional policies and, in } \\
\text { particular, practices related } \\
\text { to quality assurance, } \\
\text { accreditation, credit } \\
\text { transfer, recognition of } \\
\text { qualifications, and student } \\
\text { mobility. }\end{array}$ \\
\hline
\end{tabular}

Source: (Knight, 2004a) ${ }^{7}$ (Knight, 2006)

\section{The influences of globalization on management}

Globalization, in management, is a strategy or even marketing that relates to the emergence of international markets, so globalization and internationalization came with new challenges to society, being visible both benefits and side effects and destructive in almost all environments (economic, religious, social, political, educational, cultural, demographic, etc.). In the opinion of specialists in the field of strategic management, globalization is analyzed in the form of the competitive advantage that can be obtained by a company by expanding its activity globally. Analyzing the content of this definition, it can be seen that the specialists in strategic management emphasize the fact that the competitive advantage can be obtained by a company in the conditions in which its activity meets the efficiency criteria.

In the opinion of specialists in the field of strategic management, globalization is analyzed in the form of the competitive advantage that can be obtained by a company by expanding its activity globally. Analyzing the content of this definition, it can be seen that specialists in strategic management emphasize that the competitive advantage can be obtained by a company provided that its activity meets the criteria of efficiency and labour costs are low. Beyond the action of factors such as the free movement of labour and goods, these are, in fact, the main criteria that multinational companies take into account in the process of widening the range of activities globally. In the education system, globalization has a major impact, which can be negative, positive or zero. We mention, from an economic point of view, as a positive impact the "European Program for Lifelong Learning". Lifelong learning, as opposed to teacher training, can be achieved in different settings based on a personal goal. The specificity of lifelong learning is inclusion in non-formal, informal learning and formal education. From the point of view of knowledge accumulation management, the risk of globalization must be assessed in terms of negative impact. Through the lifelong learning programs teachers and students interested in academic mobility increases, especially learning a language of international circulation. Education involves influences that cause changes in intellectual, moral, aesthetic, religious, physical education, etc., due to its 
complexity. Globalization is seen as a continuous process, characterized by the following particularities: the development of foreign investments, the amplification of export activities and the development of strategic alliances at the international level, to expand the activities of companies in new markets. (www.sfin.ro, fără an).

Table 2. The advantages and disadvantages of globalizing human resources

\begin{tabular}{|c|c|}
\hline Advantages & Disadvantages \\
\hline 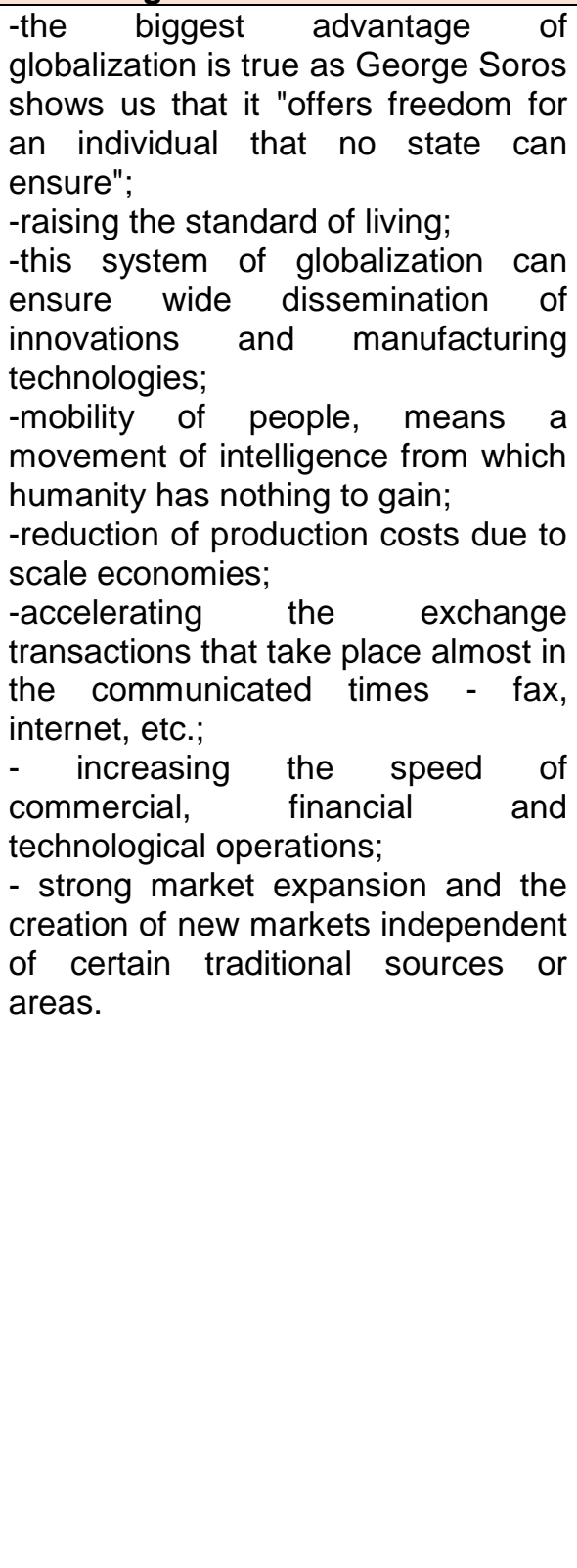 & $\begin{array}{l}\text {-produces global inequalities between } \\
\text { states. Being mostly an economic } \\
\text { phenomenon, it produces prosperity in } \\
\text { "globalized" countries, namely in those } \\
\text { countries where markets grow healthily and } \\
\text { poverty in states marginalized by global } \\
\text { markets; } \\
\text { - labour migration (cheap labour from } \\
\text { developing countries migrates to developed } \\
\text { countries, which leads to a decrease in the } \\
\text { wage level, which is good for the employer, } \\
\text { but unsatisfactory for the domestic labour } \\
\text { force) } \\
\text {-access to cheap labour countries (unlike } \\
\text { the above case, multinationals close their } \\
\text { production subsidiaries in those developed } \\
\text { countries that had the advantage of a good } \\
\text { sales market but with high production costs } \\
\text { due to expensive labour, and open } \\
\text { production subsidiaries in developing } \\
\text { countries with cheap labour, produce } \\
\text { products in these countries and, where } \\
\text { appropriate, sell them where they have } \\
\text { markets. The result: in developed countries } \\
\text { the number of unemployed increases, and } \\
\text { they are the ones who protest quite } \\
\text { violently); } \\
\text { - the abolition of the nation and the nation- } \\
\text { state; } \\
\text { - reducing jobs in developing countries or } \\
\text { with a lower level of labour productivity; } \\
\text { - the specialization of some states in } \\
\text { production activities that generate pollution } \\
\text { and that require high consumption of } \\
\text { labour, raw materials and energy; } \\
\text { - deepening the economic gaps; } \\
\text { - the dangers regarding the abolition of } \\
\text { some branches, the bankruptcy of some } \\
\text { banks, the destabilization of economic life, } \\
\text { including some states. }\end{array}$ \\
\hline
\end{tabular}

Source: author processing after: (Soros, 2002) 


\section{Conclusions}

Like all other areas of socio-economic activity, higher education could not remain immune to the effects of globalization. This appreciation is unanimously accepted, even by those who continue to claim that, because education is a public good, it must be provided free of charge by the state. Management emphasizes the results, through which the success of institutions in the future will be evaluated. The process of globalization continues the internationalization of education in the greed of diversification and flexibility of education. Extending cooperation on the development of teaching quality assessment methods (teaching, learning, research). The globalization and internationalization of education are facing the outsourcing of benefits and the internalization of costs generated due to the exodus of grey matter. From the point of view of the scope of the labour market, we distinguish the internal labour market and, respectively, the external market, the international one. The free movement of persons implies implicitly the mobility/movement of the labour force, both on the internal labour market and the European Union market. The fundamental motivation for the priority support of higher education from both the public and private sources is that it produces the educated workforce needed in the economy and society, drives fundamental and applied research, the results of which, once commercialized, create new industries and new jobs and contributes to the development of the economy and social welfare. The strategic direction in the design and implementation of the educational activities of training development of the human personality in the knowledge-based society provides for the transformation of the current society into a learning society.

\section{References:}

1. Ulrich Beck, What is Globalization?, Polity Press, 1999, p. 37

2. Held, David, McGrew, Antony, Goldblatt, David, Perraton, Jonathan, Transformări globale. Politică, economie şi cultură, laşi, Editura Polirom, 2004, p. 40

3. https://www.armyacademy.ro/reviste/3 2005/a26.pdf, 13.04.2021

4. Creciun, Ala, Particularitățile managementului financiar al instituțiilor de învățământ superior în țările Europene în condițiile globalizării financiare, Editura ASEM, Chișinău, 2016, http://irek.ase.md:8080/xmlui/handle/123456789/348, 12.04.2021

5. Held, D., McGrew, A., Goldblatt, D., Perraton, J. (1999). Global Transformations: Politics, Economics and Culture. Stanford, California: Stanford University Press http://cdu.centre.ubbcluj.ro/sinteze/Globalizarea\%20si\%20Internationalizarea\%20i nvatamantului\%20superior.pdf, 11.04.2021

6. Knight, J., de Wit, H. (Eds.) (1997). Internationalization of higher education in Asia Pacific countries. Amsterdam: European Association for International Education

http://cdu.centre.ubbcluj.ro/sinteze/Globalizarea\%20si\%20Internationalizarea\%20i nvatamantului\%20superior.pdf, 11.04.2021

7. Knight, J. (2004a). Internationalization Remodeled: Definition, Approaches, and Rationales. Journal of Studies in International Education, Vol. 8, No. 1, pp. 5-31, Online: http://isi.sagepub.com/content/8/1/5.full.pdf+html 
8. Knight, J. (2006). Internationalization: Concepts, Complexities and Challenges în International Handbook of Higher Education, Vol. I, edited by J.J.F. Forest and P. G. Altbach, pp. 207-227. Dordrecht, The Netherlands: Springer.

9. Ioan Ciobanu, Facultatea de Economie si Administrarea Afacerilor, lasi, http://www.sfin.ro/articol 7977/influentele globalizarii asupra managementului re surselor umane.html, 14.04.2021

10. Soros, G., Despre globalizare, ed. Polirom, laşi, 2002, p. 25

11.http://cdu.centre.ubbcluj.ro/sinteze/Globalizarea\%20si\%20Internationalizarea\% 20invatamantului\%20superior.pdf 


\title{
A THEORETICAL VIEW ABOUT AGILE MANAGEMENT IN BANK SECTOR
}

\author{
Valentin Partenie MUNTEANU', Paul DRAGOS ${ }^{1}$ \\ ${ }^{1}$ Department of Management, Faculty of Economics and Administrative Affairs, \\ West University, Timisoara, Romania \\ valentin.munteanu@e-uvt.ro \\ paul.dragos90@e-uvt.ro
}

\begin{abstract}
The adoption of Agile methodologies is one of the biggest topics in large organisations and many IT departments nowadays. Banks must introduce new flexible approaches to keep up with the changes in the market, especially regarding the new digital technologies. Large enterprises in all information system programs have implemented Agile approaches because of the widespread benefits. Unlike traditional development model, agile guidelines encourage businesses to follow a straightforward and data-oriented procedure and continually test and learn, rather than producing a final product before testing. This research aims to explore the benefits of Agile approaches in the banking industry and the problems with implementing such methods in product development processes. This study also leads to speedy marketing by offering a minimum viable product (MVP) that satisfies consumers' needs and can be easily adapted. Although various studies explored the implementation of agile principles in multiple contexts, this research is based primarily on the banking software industry. The banking sector must transform itself, to become more digital. However, digital processes are not as simple as in other sectors because banks operate on regulated markets, making it even more challenging to adopt Agile methods. In conjunction with the Agile approaches, this study also illustrates the current management practices. This research is mostly theoretical and qualitative, attempting to complete an existing gap by thoroughly reviewing the existing literature on Agile methodologies for software development and reviewing the standards for banks' software development life cycles. Managing the regulatory climate in which banks work is an essential challenge in optimizing agility. This paper's findings contribute to the field by offering an insight into how Agile approaches can be implemented on the banking setting by analysing the existing literature, with a focus on financial software development.
\end{abstract}

Keywords: Agile Methodology; Agile Banking; Agile development; Iterative approach; Testing approach

\section{JEL Classification: $\mathrm{O} 3$}

\section{Introduction}

The activities of financial services companies are becoming increasingly critical of information technology (IT). Banks are now spending up to $15 \%$ of non-interest expenditure on IT, the bulk of the IT spending in the US economy being made up of financial institutions. Nowadays, banks are more vulnerable to the challenges on the environmental and social level (Carnevale et al., 2012). They have a broader 
role in society and need an Agile framework, probably even more than any other institution. Traditional software development like Waterfall cannot cope with the rapid changes nowadays, and a high rate of systems development (SD) failures are attributed to the conventional methods. Also, the banking sector is a particular sector for using large, monolithic, legacy systems. The fast progress in software development could be more difficult for them to achieve.

The financial services sector seems to be a very complicated business environment that deals with a great deal of knowledge. Even minor gaps in the flow of information have much-reaching effects (Sternkopf, 2018). Consequently, it appears challenging to measure the expenses, challenges, and intensity of a digitalisation project. For this cause, multiple banks are eager to make a move into critically necessary digital transformation.

Major financial entities have traditionally focused on software innovation approaches influenced by the Waterfall method. But even the slightest error in banking and finance systems can lead to the loss of thousands or even millions, particularly when account waves and transfers have to be coordinated with incredible accuracy (Hajrizi and Bytyci, 2015). The system can't fail, or vulnerability to danger is unreasonable. Proper research provisions have prompted many banking and finance companies to remain with the construction of Waterfalls, where the paperwork is incredibly comprehensive, by auditory as well as other regulatory requirements. Therefore, Agile and conventional approaches remain intertwined in the banking sector.

Boehm and Turner (2003) recommended that professionals should go to Agile according to the venture. Organisations are likely to adopt Agile principles if their projects need constant change. If the venture is reasonably stable, standardised methods should be used. Flipping among Agile and formal methods cannot be that fast. If companies want to move between a strictly structured approach and a fully Agile approach, systems engineering companies may be hindered by other powers, which are harder to change.

\section{Literature Review}

The adaptability in the service sector is highly relevant because of the product's intangible nature and the need to create trust amongst stakeholders (Perez et al., 2013). The stakeholder engagement activities must be visible; the project information should be visual to support transparency. Engaging the stakeholders in the agile project is the first step to ensure that the team builds precisely what the customer expects and that the delivered product is of high quality and meets or exceeds expectations (Canty, 2015). The PMI (2013) suggests a number of mechanisms for the stakeholder management of a project, illustrated in Figure 1. 


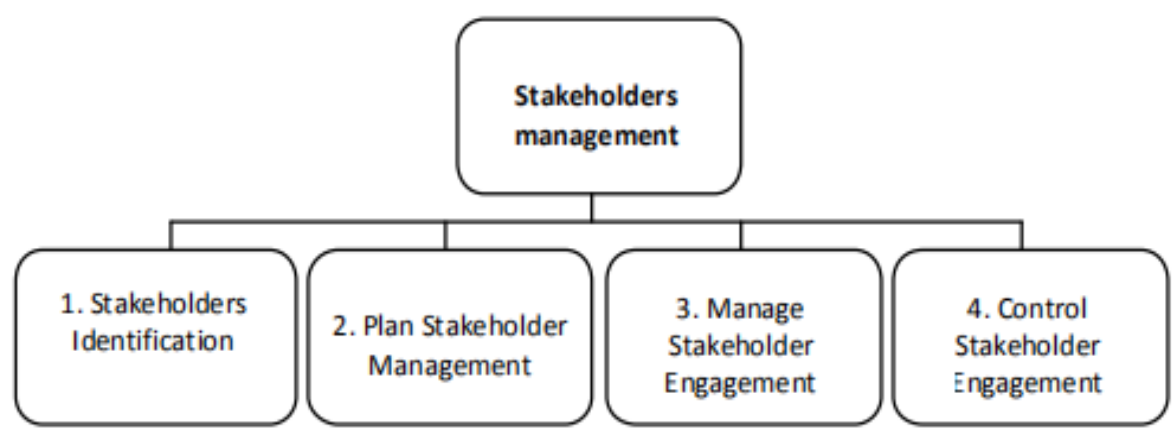

Figure 1: Stakeholders management processes

Source: PMI (2013)

The key stakeholders in the banking industry are: the customers, the investors, the bank clerks, the risk managers, the audit, the IT staff (Murmann, 2018).

In many areas of life, customers have grown used to digital processes over the years and now expect it in all sectors. According to Murrmann (2018), today, with regard to current practise, the customers' standards go far beyond the common practises, such as user-friendliness and accessibility of information, and the availability of information in the 24/7 manner. These subjects like openness of processes, differences between products, and a more established partnership with suppliers and customers are getting increasingly important.

The customer's needs, desires, hopes, and concerns often align with the employee's interests. The employee cares about both the speed and how quickly and how accessible is the data to his customers. By putting together knowledge through systems, he aims to save time and avoid mistakes (Murrmann, 2018).

The organisations test the worthiness of investments in emerging technologies on a case-by-by-case basis, all the way down to the micro stage. The managers and investors aren't expected to be impressed by features, but instead should be persuaded by the facts. They want in particular to see how the digitalization initiative impacts the company's profitability. Questions about the expected productivity improvement, the projected project time and necessary staff are compulsory (Murrmann, 2018).

The modern stakeholders (managers, employees, customers, business partners, local governments, shareholders) work with the organisation (in this case, the bank) to enhance corporate profitability. However, they are not just a way to make money. According to Halal (2001), if the theory that the wealth creation arises directly from integrating stakeholders into a productive whole, a "collaborative enterprise," the companies can claim then legitimate status as dedicated corporate citizens, serving both the economic and social functions of society. Bruyn (1977) even concluded that stakeholders' resources are more significant than shareholders' financial investments by roughly a factor of ten. According to Flavian et al. (2005), maintaining the confidence of stakeholders is vital to the banking sector.

Crosman (2016) found that the Agile development benefits are well-known, not only in one big, long-run "waterfall," but as a way to create applications for small chunks and short spurts: Agile projects are fast-moving, adaptable projects, 
involving working parties, input from end users (continuous tests) and faster outcomes and errors in the process (agility).

Singla (2016) states that the justification for Agile methodology's success in designing financial services, especially in bank applications, is its effective handling of changes in specifications and timelines. The Agile system is agile and versatile. These agile traits become important especially in a climate when the rules of the game can change from one day to another. If regulatory bodies make adjustments to the rules, there will always be possibilities of a sudden shift in specifications and standards. In an Agile environment, it can be easier for the development teams to understand the new criteria (in the sense of the current specifications) and make adjustments to the test situations accordingly.

Agile methodologies don't mean the same thing for every stakeholder, and the concept of Agile differs from one industry to another (Decker, 2004). Often, it is not sufficiently clear which Agile characteristics are likely to trigger a positive stakeholder response. There is a need for a specific model to understand how the stakeholders' project management is performed in an Agile context.

There are some criticisms regarding Agile, especially regarding the boundary conditions. Boehm and Turner (2003) criticised the excuse that agility leads to cowboy-style hacking and limited architectural pre-planning. Fruhling (2006) highlighted the over-reliance on developers' capabilities. It is considered that the tight coordination needed for agility might break down in large teams, that Agile is inappropriate for safety-critical systems, that it risks over-responding to change, rely too much on customer involvement and commitment, and that re-factoring efforts can escalate (DeMarco and Boehm, 2002).

There is not enough research regarding the stakeholders' response in implementing an Agile methodology and the banking industry context. Given that empirical research into agile modelling is not sufficient (Capiluppi, 2007) and the above criticisms of Agile, a research model linking Agile's upsides and downsides with the stakeholders' satisfaction is needed. Like any other method or tool, the Agile methodologies must be finely tuned to a given institution's specifics, in this paper, the institutions being the banks.

\section{Agile Approach for Software Development in Banking}

The consumer experience, in the banking environment, can be controlled by the agile supplier. The organisation makes judgments based first on what is most appropriate for the customer and then on what is most suitable for the financial system. Banking has a robust competitive choice regarding consumer data, opportunities, and personal levels. By applying strong analytics and an agile approach, an appropriate treatment is developed quickly and resiliently. An Agile system helps to engage customers with more innovative results. The continuous development and improvement of customer-oriented products can encourage banks to demonstrate their customer knowledge (Keita, 2020). Figure 2 represents the procedure of a true Agile approach. 


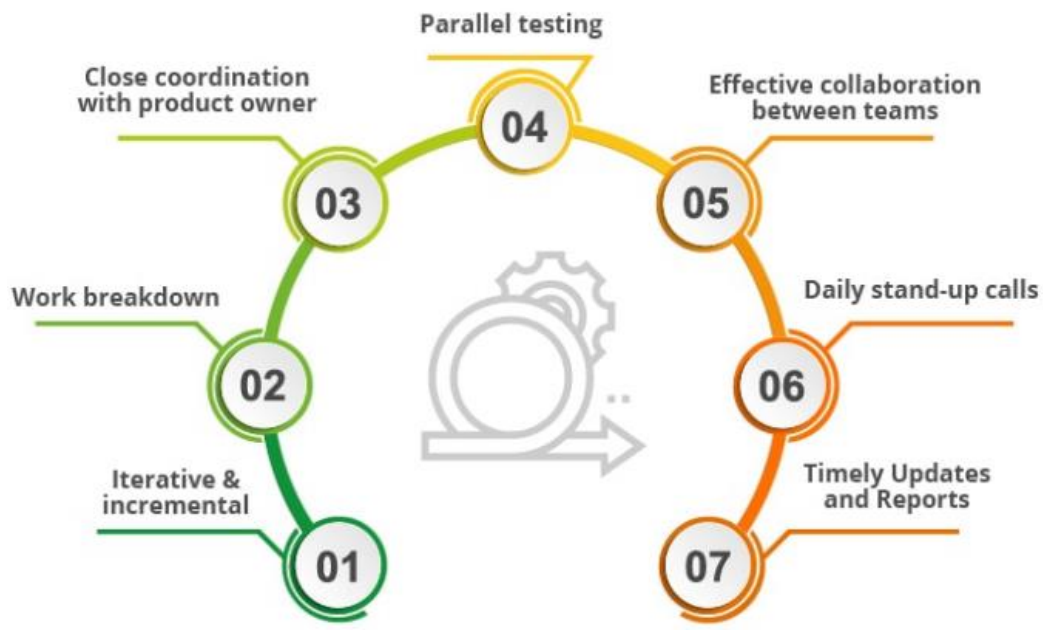

Figure 2: Agile Methodology Framework

Source: (TestingXperts, 2021)

According to Chintala (2015), there are some critical areas which must be carefully considered when it comes to software development and they are: continuous Testing, Omni-channel testing (e.g. assure consistent customer experience across channels), customer experience, analytics validations (validate structured and unstructured data, test the accuracy of data etc.), Cyber Security QA.

Financial services firms must take three paths to conquer the agility obstacles and they are presented below.

Assessment and Preparation of the Company: they need to recognise the internal impediments to agility and build a path to resolve them. They need to describe their vision.

Preparations for deployment: the goal of agile change is to develop consumer value rapidly. Companies can then build teams based on distinct customer experiences. These teams operate better when managers exhibit 'servant leadership'-that is, they often eliminate obstacles that can slow down the work of digital product teams instead of working in conventional control and command mode.

Community and technology network support: financial services firms must use advanced information and design architectures such as microservices and application programming interfaces (APIs), which benefit from the latest technologies in infrastructure and cloud-based systems to support new products' agile development. Product developers must also follow an automated system culture - wherever possible manual labour is transformed into automated work.

When it refers to the implications of adopting Agile toward conventional workplace and administration models, the most important benefit provided by Agile is that it reveals corporate dysfunctions (Javanmard and Alian, 2015). If any significant adjustments are made in an Agile approach, the group will not suspend the working mechanism; instead, it will decide how and where to effectively manage 
the adjustments that arise across the project. In development, the evaluation process throughout an Agile approach often arises quicker (Bhattacharjee, 2012). Agile software projects thrive at a set longitudinal rhythm or pulse. The constant flow of new, tested features each time offers feedback that keeps the project and the system on track. The agile software development procedure can be seen in Figure 3.

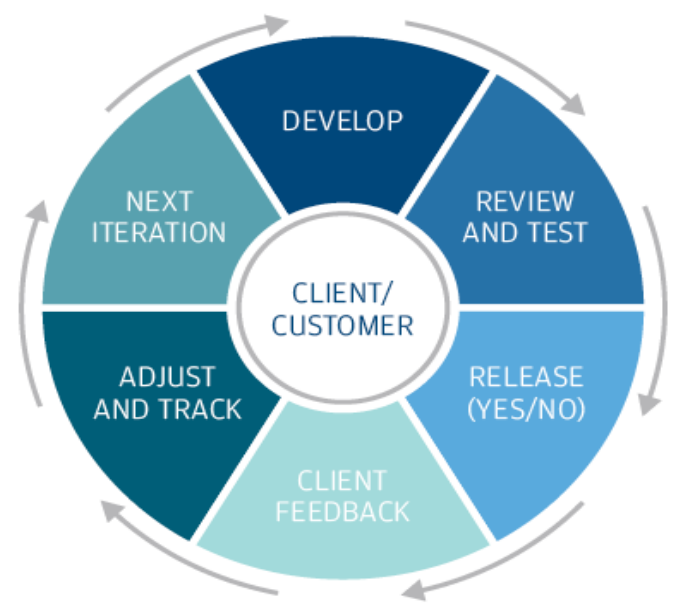

Figure 3: Agile Development

Source: (Rodrigues, 2018)

The fundamental positive characteristics of the Agile approach are presented in Table 1.

Table 1: Agile Modelling (AM) characteristics

\begin{tabular}{|l|l|}
\hline AM characteristics & Description \\
\hline Iterative Development & $\begin{array}{l}\text { Quick delivery of small working (and tested) software } \\
\text { releases at regular intervals or cycles. }\end{array}$ \\
\hline Continuous Integration & $\begin{array}{l}\text { After every task (in the ideal case), the last version of } \\
\text { the code is added to the production base code. }\end{array}$ \\
\hline Collective Ownership & $\begin{array}{l}\text { Any developer has the right to add or maintain the } \\
\text { code anywhere in the system at any time. }\end{array}$ \\
\hline Test-Driven Design & $\begin{array}{l}\text { Developers write tests before they do code. This can } \\
\text { motivate developers to plan better before starting to } \\
\text { code. }\end{array}$ \\
\hline Feedback & $\begin{array}{l}\text { Frequent feedback loops with customers allow } \\
\text { developers to ascertain the functionality's accuracy. }\end{array}$ \\
\hline
\end{tabular}

Source: (Ferreira and Cohen, 2008)

However, there are some things to consider when adopting an Agile methodology. The first negative factor is the limited architectural pre-planning. Even though Agile permits constant changes, solid initial requirements are highly essential to have clear initial visions. The developers should consider this step of pre-planning as one of the most critical steps in the project. Agile works better on solid ground.

The second negative factor is the over-reliance on the capabilities of developers. In an Agile environment, the developers have higher ownership over the project. 
However, the lack of central leadership might be an issue, especially when facing a critical problem.

The third negative factor is the risk of over-responding to change. Trying to satisfy the stakeholders by answering every one of their requirements is detrimental to the business. There are legitimate requests and non-legitimate requests for change, and an Agile team must know how to differentiate between them.

The fourth negative factor is relying too much on customer involvement and commitment. The customer might be the king, but even the king sometimes is not sure of what he desires from a product. Often, the sellers (the bank's employees) can guide the customers effectively to the best solution for their case.

Also, suppose the customers are not as involved or committed as expected. In that case, the banks might not get enough feedback from them to make the necessary iterations, characteristics to an Agile process. In this case, they better get creative in attracting more customers or getting ahead without too much customer involvement while maintaining the Agile methodologies for other aspects of the development process.

The nine factors of Agile (5 positives and 4 negatives) are linked to the stakeholder's satisfaction, which has two divisions: process satisfaction and outcome satisfaction. In the development process, the stakeholders will be negatively influenced by any perceived problem (Kim et al., 2006). To avoid this, the development process should go smoothly, with an excellent way to tackle the eventual problems which might arise. According to (McKeen 2004), the more satisfied are the stakeholders with the development process, the more likely the system will reflect their requirements and meet their expectations. Consequently, the more likely they will accept the system and take ownership. In other words, the more they are satisfied with the development process, the more they will be satisfied with the development outcome. Figure 4 compiled all the factors and their impact on stakeholders' satisfaction.

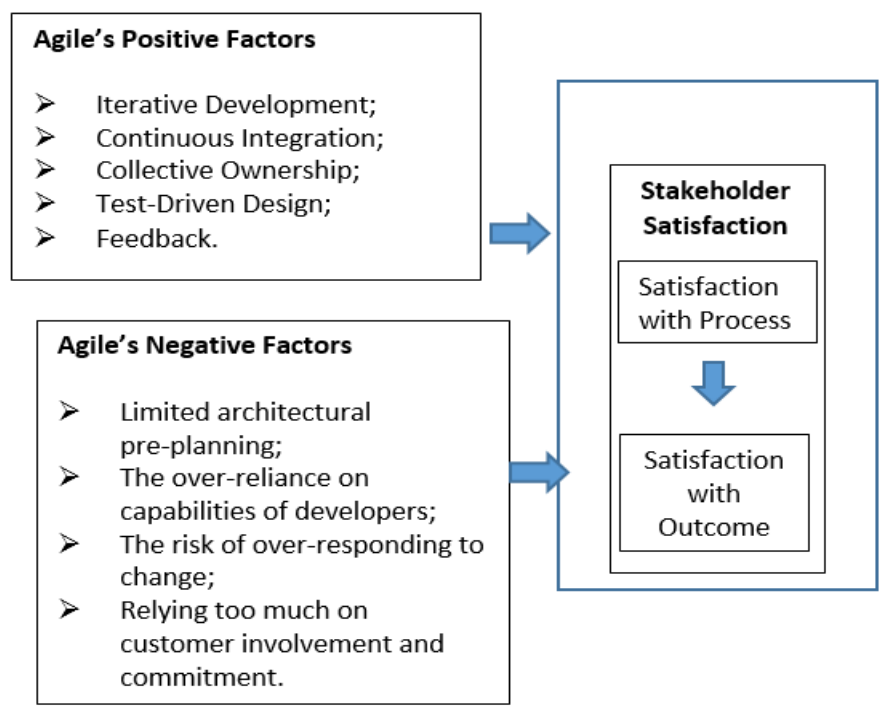

Figure 4: Conceptual Model

Source: Adapted from Ferreira and Cohen (2008) 


\section{Conclusion}

Agile requires connecting all the stakeholders and, as a concept, Agile is still a work in progress, just like the applications developed under Agile concepts. As such, it might be the time to reassess the progress and see what worked, what did not work, what could be done better, and how Agile could improve. Several businesses continue to work in their old-fashioned way, but this way of doing business is not sustainable in the long run. A company cannot expect the same thing over and above to yield exponentially, unbelievably impossible performance. Under the Agile methodology, the job has only started after a sprint has been completed. The Agile team needs to have a sprint summary meeting at the end of each sprint where the team addresses successes and weaknesses and how to refine the strategy continuously. This is the ticket for a team that expands, goes quicker, and creates better financial software.

\section{References:}

1.Bhattacharjee, V. (2012), "Comparison Between Agile and Traditional Software Development Methodologies", EzineArticles, available at: https://ezinearticles.com/?Comparison-Between-Agile-and-Traditional-SoftwareDevelopment-Methodologies\&id=7162906 (accessed on March 2021)

2.Boehm, B. and Turner, R. (2003), Balancing Agility and Discipline: A Guide for the Perplexed, Addison-Wesley Professional.

3.Bruyn, S. (1977) The Social Economy (New York: Wiley).

4.Canty, D. (2015). Agile for project managers. CRC Press.

5.Carnevale, C., Mazzuca, M., \& Venturini, S. (2012). Corporate social reporting in European banks: the effects on firm market value, Corporate Social Responsibility and Environmental Management, 19, 159-177.

6.Capiluppi, A., Fernandez-Ramil, J., Higman, J., Sharp, H.C., and Smith, N. 2007. An empirical study of the evolution of an agile-developed software system. Proceedings of the 29th International Conference on Software Engineering (Minneapolis, MN, USA, 2007).

7.Chintala, S. and Mohan, N. (2015), "The intricacies of software testing", available at: https://bankingfrontiers.com/the-intricacies-of-software-testing/ (accessed on March 2021).

8.Crosman, P. (2016), "Agile Development Is Reshaping Tech at Banks Like Chase and BBVA", American Banker, available at: https://www.americanbanker.com/news/agile-development-is-reshaping-tech-atbanks-like-chase-and-bbva (accessed on March 2021).

9.Decker, O.S. (2004). Corporate social responsibility and structural change in financial services. Managerial Auditing Journal, 19, 712-728.

10. DeMarco, T. and Boehm, B. (2002) 'The agile methods fray', Computer, 35(6), pp. 90-92. doi: 10.1109/MC.2002.1009175.

11. Ferreira, C., \& Cohen, J. (2008, October). Agile systems development and stakeholder satisfaction: a South African empirical study. In Proceedings of the 2008 annual research conference of the South African Institute of Computer Scientists and Information Technologists on IT research in developing countries: riding the wave of technology (pp. 48-55). 
12. Flavian, C., Guinaliu, M., Torres, E. (2005). The influence of corporate image on consumer trust :a comparative analysis in traditional versus internet banking, Internet Research, 15, 447-470.

13. Fruhling, A. and De Vreede, G-J. (2006). Field experiences with eXtreme programming: developing an emergency response system. J. Manage. Inform. Syst. 22,4 (2006), 39-68.

14. Hajrizi, E. and Bytyci, F. (2015), "Agile Software Development Process at Financial Institution in Kosovo", IFAC-PapersOnLine, Vol. 48 No. 24, pp. 153156.

15. Halal, W. E. (2001). The collaborative enterprise: A stakeholder model uniting profitability and responsibility. Journal of corporate citizenship, (2), 27-42.

16. Javanmard, M. and Alian, M. (2015), "Comparison between Agile and Traditional software development methodologies", Vol. 36 No. 3, p. 9.

17. Keita, B. (2020). Why Agile Is Extremely Essential for Banking | Invensis Learning. [online] Invensis Learning Blog. Available at: https://www.invensislearning.com/blog/agile-is-essential-for-banking/ (accessed on March 2021).

18. Kim, H. and Pan, S.L. (2006). Towards a process model of information systems implementation : the case of customer relationship management (CRM). The DATA BASE for Advances in Information Systems. 37, 1 (Winter 2006), 5976. (accessed on March 2021)

19. Murmann, S. (2018), "The Most Important Stakeholders in the Digital Transformation of Finance", available at: https://www.knowis.com/blog/the-mostimportant-stakeholders-in-the-digital-transformation-of-finance (accessed on March 2021)

20. Perez, A., Garcia de los Salmones, M.M., \& Rodriguez del Bosque, I. (2013). The effect of corporate association on consumer behavior. European Journal of Marketing, 47, 218-238.

21. PMI (2013), "A guide to the project management body of knowledge", 5th Edition, Newton Square: Pennsylvania.

22. Rodrigues, K., 2018. Building an Agile Business. Available at: https://www.jpmorgan.com/commercial-banking/insights/building-agile-business (accessed on March 2021).

23. Singla, G. (2016), "Agile and testing: What banks need to know", Finextra Research, 27 August, available at: https://www.finextra.com/blogposting/13021/agile-and-testing-what-banks-needto-know (accessed on March 2021).

24. Sternkopf, C. (2018), Software Testing Help, "The Implementation of a Banking Software for the Lending Sector in Practice", available at https://www.knowis.com/blog/implementation-of-a-banking-software-for-thelending-sector-in-practice (accessed on March 2021).

25. TestingXperts. 2021. Agile Methodology - An Effective Guide for Businesses. Available at: https://www.testingxperts.com/blog/agile-methodology (accessed on March 2021). 


\title{
THE IMPACT OF STAKEHOLDERS IN AGILE SOFTWARE DEVELOPMENT
}

\author{
Paul Dragos \\ Department of Management, Faculty of Economics and Administrative Affairs, \\ West University, Timisoara, Romania \\ paul.dragos90@e-uvt.ro
}

\begin{abstract}
The market for software development projects is dynamic and complex. The stakeholders involved in the software development process come from different organisational positions and therefore have varying interests and expectations from the product. Effective project management practices enable successful on-time delivery of high-quality product. It is essential to identify the stakeholder roles and responsibilities to effectively manage the development practices within the organisation. Elucidating the stakeholder roles will enable stakeholder management via effective communication and sustainable practices that reflect stakeholder interests. This study elucidates the roles and responsibilities of the stakeholders associated with Agile software development projects. The study identifies that for effective stakeholder management practices understanding of the stakeholder roles and interests is vital. Additionally, application of Agile software development methodology would result in successful development of high-quality software solutions.
\end{abstract}

Keywords: Agile; software development; stakeholders; management; roles

JEL classification: O32; M11; M15; C88; D24

\section{Research Background}

Current business environment is complex and evolving as per the market requirements. Owing to this dynamic nature, the providers are compelled to hasten the launch of their new and innovative products into the market. The primary objective of Agile Software Development (ASD) is to help deliver the product on-time and ensure customer satisfaction (Ferreira and Cohen, 2008). With the help of ASD, the product development process has shifted to a more incremental and empirical approach which allows for an easy and immediate change in product development direction (Raharjo and Purwandari, 2020). ASD methodologies such as Scrum, Kanban, and Extreme Programming offer the necessary processes for product development. Several studies indicate that Agile practices help with improving team productivity as well as their contextual understanding of the product. Studies have reported that $71 \%$ of the organizations adopt Agile practices for project management and software development (PMI, 2017; Padalkar and Gopinath, 2016; Raharjo and Purwandari, 2020). The most important factor for effective work in ASD is the stakeholder interaction. Proactive stakeholders are necessary for overall success of agile software development projects. This study discusses the stakeholders involved in software development projects and their role in project success. 


\section{Literature Review}

This chapter investigates the existing literature to examine the researches on software engineering, software development, agile software development, etc. Specifically, it traces the impact of stakeholders on agile software development. This section will explore the roles and responsibilities of the stakeholders involved in software development projects.

\subsection{Software Engineering}

Software engineering is a subject that has experienced much advancement in an attempt to continue up with new technological breakthroughs and current business needs by developing efficient methods to the end software package (Stol \& Fitzgerald, 2018). One of these milestones is the development of an agile software. The agile software development model was presented to surpass the limitations of the traditional development approaches. It was also proposed to reduce the cost of the project. It also offers the support to make any changes if and when required (Braude \& Bernstein, 2016).

\subsection{Software Development}

Software development is an evolving stream of science with extensive knowledge and research of the practices and theories involved (Raharjo \& Purwandari, 2020). The process of conceptualizing, defining, designing, programming, researching, evaluating, and problem fixing that goes into developing and managing applications, systems, or other software modules is known as software development. Being a specialist in certain tasks necessitates specific capabilities, information, and experience. Introducing innovative functionalities, assessing constraints, and addressing defects are all part of the software development process (Hoda, Salleh, \& Grund, 2018).

\subsection{Project Management}

The project management practices adopted to handle such projects also require similar adaptability (Hitt, et al 2001). The project manager is someone who supervises a team of experts, for whom the role is defined in length, who hires the team members, performs project management plans, and can market the venture to clients. The project management body of knowledge has defined the project manager as the one who is assigned with the task to lead the team with proper planning and coordination in a way to achieve the aims and goals of the organization effectively (PMBOK, 2018).

\subsection{Traditional Software Development}

A conventional software development module, commonly known as Waterfall, is marked by some significant qualities. These features include thorough research, proper planning, prior data collection, comprehensive communication, and an emphasis on efficient workflow. It has been observed that many significantly 
important principles of conventional project management have been included in the Waterfall. These characteristics include the arrangement of the important developmental processes in an orderly form, a concentrate on substantial preplanning, and a sequenced approach (Kusters, Rutten \& Trienekens, 2017).

One of the biggest critiques leveled against the waterfall technique is its inability to adapt to changes in the project circumstances. The aspect that the progressive waterfall model does not work effectively in a dynamic design was noticed early on, prompting Boehm to suggest an alternative spiral model. This strategy emphasized risk management and involvement of the client in the project development. Boehm and Ross formulated a people-oriented approach to software project management. It argued that the project would only be effective if the project coordinator was responsible for formulating a bid contract for clients, investors, staff members, and relevant stakeholders (Boehm \& Ross, 1989).

Waterfall modules are comparatively slow and time taking whereas the agile software technology is rapid and involves short and quick cycles. This feature attracts more and more stakeholders to invest in the projects related to software development. The agile software development offers more details and more involvement in the development process that makes the stakeholders clear about the process. They are also provided with the option to set their preferences at any stage of development.

\subsection{Agile Modeling for Software Development}

The agile modeling for software development practices requires active stakeholder participation to gain information and feedback on the product being developed and help decide the direction of the development process as well as its prioritization. Studies have reported that the level of understanding among the stakeholders directly impacts the project's success. Survey studies by the Standish group have reported that less than $50 \%$ of the software development projects are successfully delivered within the set time, budget, and scope. The outcome of any project is determined by the individuals associated with its development process. Along with poor management practices, poor stakeholder management could result in project failure. The complete software development project depends entirely on the stakeholder's vision and requirements. Therefore, the direction of the project and the process prioritization is solely driven by the stakeholders. PMI defines the stakeholder as a "group of individuals or organizations that are actively involved in the project and whose interests directly influence the project's success" (PMI, 2011). The importance of stakeholder management was illustrated by Freeman (2010) through the "Strategic Management: A Stakeholder Approach".

\subsection{Agile Software-People Oriented}

A significant feature of agile software development is that it focuses significant importance on human aspects in the project like friendliness, creativity, competence, and interaction. These characteristics become a top priority for the aspiring agile team. Skill development is essential so that each individual may 
produce more value with less time. The focus on human concerns lends a distinction to agile initiatives (Cockburn, 2001).

\subsection{Stakeholders}

According to Nothaft and Wiesche (2021), stakeholders are individuals or workgroups who often interact with the product owner, project leader, and project manager to offer assistance in the development of the project's items \& services. They have a strong influence on the overall project as they are the major contributors to the whole process. They may be customers, employees, investors, and suppliers, etc.

Stakeholders are the ones who determine the specifications for the products to be designed and can therefore effectively assess if they are satisfied with the output or not. And also whether their demands have been effectively fulfilled or not. Other stakeholders may not have defined requirements about the products, but they may have a revenue target for the corporation (Koch, 2005).

\subsection{Stakeholders in Agile Software Development}

In a given scenario, the response of any system is determined by the specifications marked at the start. The responses are determined by the demands and aims of different stakeholders. All the approaches involve one or more stakeholders at one or another level of the project management. These are involved in the project in separate phases. But on the other hand, agile practices in software development involve the engagement of stakeholders at all levels. They are actively concerned throughout the process and are consulted for their opinion. Agile software development revolves around the indulgence of all stakeholders to the possible extent so that any change can be assessed timely. These changes may include the changing demands of the stakeholders, innovative technological aspects, or other factors affecting the software development process (Cao, et al., 2009).

\subsection{Involvement of the Stakeholders in Agile Software Development}

Over the years, the changes in the business sector shifted the focus on incorporating the stakeholder needs and interests from a social perspective (Waddock \& Mcintosh, 2009). An increasing number of studies have reported the advantages of stakeholder engagement and the importance of cooperation for achieving a competitive edge on the global business platform (Sudevan et al, 2014). Stakeholder engagement targets, that also include the involvement of the different stakeholders in the decision-making process, improve the competency of the (Sudevan et al., 2014). The stakeholders should be engaged to collect the relevant information from them. The collected information should be compared to frame any strategy. The involvement of stakeholders is highly effective in planning and framework (Cheng \& Lui, 2008).

Effective communication between stakeholders associated with the project paves the path to sustainable practices that reflect the stakeholders' interest (Sudevan et 
al, 2014). Thus, with proper stakeholder management practices, the direction and progress of the project would improve significantly and result in success. In software development projects its success is based on product quality and meeting stakeholder expectations. The stakeholders in a software development project range from different corporate positions and thus have different interests in the project.

\subsection{Stakeholders' Job Satisfaction}

Development teams must satisfy the demands of multiple stakeholders in order to thrive and go ahead (Leffingwell, 2011). The review of the literature has suggested that there is a direct link is found between the standard of information and the job satisfaction of stakeholders. The work satisfaction of clients is also determined by a system's technological capabilities. The techno-stress and its influence on users' work satisfaction, commitment, and determination to the organization have been studied and evaluated. The most important findings described are as follows: stress issues lower work satisfaction, resulting in diminished organizational and individual dedication (Joshi \& Rai, 2000).

On the other hand, the stress-reduction factors have a reverse impact (Nathan et al., 2008). Wamba \& Bhattacharya (2015) has suggested that the factors that affect the job satisfaction of the stakeholders should be considered and dealt with accordingly. According to Neteller, et al., 2017, the success of any firm lies in job satisfaction. So the corporate should focus on this factor and try to improve this aspect.

Stakeholder satisfaction is important. They should be engaged in agility assessments. The studies have suggested that the involvement of stakeholders in the project development, obtaining their critical feedback, reassures stakeholders that their input is significant and acknowledged. Stakeholders are critical to the project's success. Their desires and requirements drive the product, and their input assists in advancing both the product and the process, concluding in a positive end.

\subsection{Impact of Stakeholders on Software Development}

The number of stakeholders involved in a specific project may vary depending on the nature of the project. The large projects may involve more stakeholders to assist the execution of the objectives. All the stakeholders involved vary in their views and opinions. They may have different aims and interests regarding the projects. They should be given detailed attention to enhance the effectiveness of the project. As their involvement in agile software development supports the development and execution of the project. All these interests and concerns should be merged into a single comprehensive framework to ensure the efficiency of the process (Khan, Khalid \& Haq, 2013).

The stakeholders are the ones who have an interest in some specific software development and they involve in the project with some aims. Their views should be respected and their interests should be safeguarded. Their contribution is very significant for the execution of the project (Sommorville \& Kotonya, 2000). While involving the stakeholders in the project, the relevant stakeholders should be 
approached to avoid any sort of incompetency in the task. They should be questioned about their goals, risk factors, investment interest prior to their engagement in the project (Lausean, 2002).

\subsection{Collaboration and Interaction with the Stakeholders}

Stakeholders are the driving force behind product development. They have certain demands and needs that the development team must meet. Their goals and requirements, on the other hand, are not always apparent; in fact, the Stakeholder might not always know precisely what they really want, and as a consequence, frequent meetings are usually required to obtain a clear understanding for both sides. The collaboration of stakeholders is an important part of project management. To enable successful cooperation and a higher possibility of project success, effective communication should be maintained (Buchan, MacDonell \& Shinde, 2017).

Stakeholders should be brought in as early as feasible in the process. Involvement in talks about requirements and narrative mapping will help them sound participated in the process and appreciated (Ram, Rodriguez \& Oivo, 2018). Establishing this approach in the initial stages helps Stakeholders realize that their participation in the project is valued and anticipated, establishing a precedent for their future involvement. Stakeholders should be employed early in the process as feasible to acquire knowledge of project worth and the utilization of the finished product.

The key to effective engagement is the proper communication and coordination with the stakeholders of the project. The major obstacles in coordinating an agile project have been maintaining interactions between different major stakeholders who were previously used to collaborating in a traditional approach and a lack of relevant technical expertise on the client's perspective, which may require substantial education programs. A comprehensive communication approach is required to overcome this barrier and prevent any loss in the project (Chen \& Lvova, 2011).

Stakeholders may find it challenging to comprehend how they will be benefited from a product, especially if they are not the final consumer. This inadequate knowledge might have an impact on Stakeholders' active participation. For that, the significance of the project should be explained to them to promote their participation in the project (Avikainen \& Leppänen, 2017).

Involving stakeholders in decision taking practices will encourage them. Despite the fact that the product manager makes the ultimate decision, Stakeholders play a significant role in the context. Product owners make judgments based on a variety of criteria and take decisions conveyed to them by stakeholders. It is consequently critical that both entities maintain consistent interaction.

\subsection{Identification of stakeholders for Agile Software Development}

The agile software development must involve multiple but relevant stakeholders to ensure the successful completion of the project. A study of the literature has revealed a significantly positive link between agility and stakeholder support 
(Juhole et al., 2014). Power has devised a model to investigate the appropriate stakeholders for the projects and their impact on output. The model suggests that effective communication and interaction with the stakeholders help the corporation in achieving its goals (Power, 2010).

Identifying people with relevant competence, taking time, and being consistent are all concerns for working with stakeholders, according to Hanssen and Fgri (2006). Matook and Maruping (2014) studied the importance of finance, social aspects, and systems capabilities in agile projects. The involvement of stakeholders in an agile environment in a comprehensive approach has been effective by Conboy and Morgan (2011).

A stakeholder management approach typically includes the identification of the appropriate stakeholders, planning a strategic management approach to engage the stakeholders, organizing the communication channels, and meeting their expectations and demands. Projects that employ an agile approach are aimed at people, iterations, and implementation of the aims (Adjeii \& Rwakatiwana, 2009). A distinct project purpose, effective stakeholder involvement throughout the initiative, the interaction of stakeholders, progressive output are the features associated with the agile approach in the development (Haas, 2007).

\subsection{Stakeholder Management}

According to Fitsilis (2008), stakeholder management involves management skills, human resource management strategies, and the quality management approach. The management skills involve managing and organizing the whole developmental procedure, human resource management expertise is concerned with the human aspects of the project while quality management ensures the frequent assessment and review of the project (Fitsilis, 2008).

The specifications and requirements of the stakeholders should be given prime importance in the project. As the agile software development success is backed by the strong interaction and communication between the stakeholders. The understanding and fulfillment of the interests and concerns of the stakeholders help in the advancement of the project (Chen \& Lvova, 2011.

\section{Research Methodology}

This section describes the research methodology that is used for the study. Content analysis of the articles was conducted to identify the myriad roles of stakeholders in Agile software development projects. The study aims to answer: What are the roles of stakeholders in Agile software development projects? The studies that explored the importance of stakeholders in Agile software development projects were chosen for content analysis. The publication date for the selected studies ranged from the year 2001 to 2020. The 19-year timeline chosen was appropriate for analysing the variables (Shaffril et al., 2018). The study only considered articles written in English language, publishedpeer-reviewed journals, between 2001 and 2020. All articles which did not fit the selection criteria were excluded. The studies associated with keywords such as "Agile", "Software Development", "Stakeholder", and "Stakeholder Roles" were selected. 


\section{Results}

Stakeholder in software development projects is directly associated with the product outcome. A stakeholder could be the direct or indirect product user, managers, in charge of operations, product sponsor, developer, or support staff. The stakeholder interests are therefore as diverse as the organisational background of the people involved. Thus, to achieve project success it is necessary to understand the stakeholder requirements to form a cohesive vision for project direction and priorities. If we consider arranging the stakeholders involved in an Agile Software development project in an onion diagram, the product makes up the core of the onion being the most crucial aspect of the project and the stakeholders in layers closest to farthest represent their roles in the product development process. The Users, Support staff and System administrators are primary stakeholders. While, the Technical and User management groups, sales and purchasing group, and the legal group are secondary stakeholders. The sponsors, client, suppliers, regulators, developers, public, and media are the tertiary stakeholders (Caprano, n.d.; Power, 2010). The most involved group of stakeholders are Project Sponsors, Product owner, Product Developers, Project Managers, and Product User. The project sponsors are the external stakeholders as they are mainly interested in the project success. Their role is to organise the financial help necessary for the project. To find out the alternatives for project cost overruns is also included in their tasks. The project owner is the primary stakeholder responsible for setting the goals and business strategy for the project. Additionally, the owner also plays an important role in clearing backlogs to help the team with project direction and prioritization. Developers among other stakeholders are involved in the actual software development process. The development team includes the software designers, product testers and team leaders. Their role is to successfully deliver the software on time and quality estimation of the product. The project managers handle the complete planning and organization so the project is completed within the estimated time, scope and requirements. In Agile software development, the project manager is an integral part of the development process and is responsible for communicating with the other stakeholders regarding the requirements, budget and deadlines of the project. The end user is the target audience for the product. If engaged in a proper manner, the end user can support the development process by testing the product and provide feedback for improvements to the final product (Buchan et al., 2017).

\section{Conclusion}

Development of high-quality software solutions requires identification and categorization of stakeholders' roles and responsibilities as they wield influence on the project process and its outcome. In an Agile software development project, the sponsor has a high influence on the project since they can withdraw the funding if the outcome is not to their liking. The technical and administrative staff on the other hand have minimal influence in terms of project outcome. However, they can significantly influence the project process which aid in achieving said outcome. Hence, for efficient project management, it is very essential to trace the relevant stakeholders and develop interaction with them. It would help in estimating the 
stakeholders' perception towards project decisions. Thus, making it easier to determine their interest and requirements from the product. Effective and cohesive communication among the stakeholders can set the project direction and help in proper prioritization of the product development processes. Application of Agile methodology enables a productive collaboration of stakeholders for development of specific high quality software solutions.

\section{References}

1.Abid, M.A., Din, Z.U., Khan, M.I. and Naeem, T., 2020. FACTORS AFFECTING REQUIREMENTS ENGINEERING IN AGILE SOFTWARE DEVELOPMENT: A SYSTEMATIC ANALYSIS.

2.Buchan, J., Bano, M., Zowghi, D., MacDonell, S. and Shinde, A., 2017, June. Alignment of stakeholder expectations about user involvement in agile software development. In Proceedings of the 21st International Conference on Evaluation and Assessment in Software Engineering (pp. 334-343).

3.Braude, E.J. and Bernstein, M.E., 2016. Software engineering: modern approaches. Waveland Press.

4.Caprano, C., Identifying and Structuring Challenges in Adopting Agile and Lean Practices in Large Organizations based on a Literature Analysis.

5.Cao, L., Ramesh, B. and Abdel-Hamid, T., 2010. Modeling dynamics in agile software development. ACM Transactions on Management Information Systems (TMIS), 1(1), pp.1-26.

6.Ciric, D., Lalic, B., Gracanin, D., Tasic, N., Delic, M. and Medic, N., 2019. Agile vs. Traditional approach in project management: Strategies, challenges and reasons to introduce agile. Procedia Manufacturing, 39, pp.1407-1414.

7.Conboy, K. and Morgan, L., 2011. Beyond the customer: Opening the agile systems development process. Information and Software Technology, 53(5), pp.535-542.

8.Cockburn, A. and Highsmith, J., 2001. Agile software development, the people factor. Computer, 34(11), pp.131-133.

9.Fitsilis, P., 2008. Comparing PMBOK and Agile Project Management software development processes. In Advances in Computer and Information Sciences and Engineering (pp. 378-383). Springer, Dordrecht.

10. Freeman, R.E., 2010. Strategic management: A stakeholder approach. Cambridge university press.

11. Hoda, R., Salleh, N. and Grundy, J., 2018. The rise and evolution of agile software development. IEEE software, 35(5), pp.58-63.

12. Huck-Fries, V., Nothaft, F. and Wiesche, M., 2021, January. Investigating the Role of Stakeholders in Agile Information Systems Development Projects: A Mixed Methods Approach. In Proceedings of the 54th Hawaii International Conference on System Sciences (p. 6806).

13. Chen, H. and Lvova, L., 2011. Stakeholder Management in Agile Public Projects Case Study of municipal project" Innoveta KC".

14. Khan, M.N.A., Khalid, M. and ul Haq, S., 2013. Review of requirements management issues in software development. International Journal of Modern Education and Computer Science, 5(1), p.21. 
15. Kulkarni, R.H., Padmanabham, P., Harshe, M., Baseer, K.K. and Patil, P., 2017. Investigating Agile Adaptation for Project Development. International Journal of Electrical \& Computer Engineering (2088-8708), 7(3).

16. Kusters, R.J., van de Leur, Y., Rutten, W.G. and Trienekens, J.J., 2017, April. When agile meets waterfall-investigating risks and problems on the interface between agile and traditional software development in a hybrid development organization. In International Conference on Enterprise Information Systems (Vol. 2, pp. 271-278). SCITEPRESS.

17. Koch, A.S., 2005. Agile software development: evaluating the methods for your organization. Artech house.

18. Leffingwell, D., 2010. Agile software requirements: lean requirements practices for teams, programs, and the enterprise. Addison-Wesley Professional.

19. Majanoja, A.M., Avikainen, P. and Leppänen, V., 2017, April. The impact of agile software development approach on software developers' responsibilities. In World Conference on Information Systems and Technologies (pp. 581-591).

20. Springer, Cham.Matook, S. and Maruping, L.M., 2014. A competency model for customer representatives in agile software development projects. MIS Quarterly Executive, 13(2).

21. Nguyen, T.S. and Mohamed, S., 2021. Mediation Effect of Stakeholder Management between Stakeholder Characteristics and Project Performance. Journal of Engineering, Project \& Production Management, 11(2).

22. Padalkar, M. and Gopinath, S., 2016. Six decades of project management research: Thematic trends and future opportunities. International Journal of Project Management, 34(7), pp.1305-1321.

23. Richardson, G.L. and Jackson, B.M., 2018. Project management theory and practice. Auerbach Publications.

24. Raharjo, T. and Purwandari, B., 2020, January. Agile project management challenges and mapping solutions: a systematic literature review. In Proceedings of the 3rd International Conference on Software Engineering and Information Management (pp. 123-129).

25. Ram, P., Rodriguez, P. and Oivo, M., 2018, November. Software process measurement and related challenges in agile software development: A multiple case study. In International Conference on Product-Focused Software Process Improvement (pp. 272-287).

26. Springer, Cham.Sudevan, S., Bhasi, M. and Pramod, K.V., 2014. Existing Software Stakeholder Practices an Overview. International Journal of Computer Applications, 102(3).

27. Shaffril, H.A.M., Krauss, S.E. and Samsuddin, S.F., 2018. A systematic review on Asian's farmers' adaptation practices towards climate change. Science of the Total Environment, 644, pp.683-695.

28. Stol, K.J. and Fitzgerald, B., 2018. The ABC of software engineering research. ACM Transactions on Software Engineering and Methodology (TOSEM), 27(3), pp.1-51.

29. Waddock, S. and Mclntosh, M., 2009. Beyond corporate responsibility: Implications for management development. Business and Society Review, 114(3), pp.295-325. 


\title{
WORKING FROM HOME - A COMPARATIVE STUDY BETWEEN THE BEGINNING OF THE PANDEMIC PERIOD AND A YEAR LATER
}

\author{
Mirela BUCUREAN \\ Management and Marketing Department, Faculty of Economics, University of \\ Oradea, Oradea, Romania \\ mbucurean@gmail.com
}

\begin{abstract}
The study on working from home has received growing interest from researchers over the last year, when the coronavirus pandemic turned many people into remote workers overnight. Romanians used teleworking much less than other Europeans before the pandemic, but now that they have been forced to work from home, their numbers have increased. Nevertheless, the crisis caused by the pandemic accelerates teleworking and reduces the digital differences between European countries. In Romania, many of the employees who work from home today have never had this experience before. They started this way of working without any prior training or preparation. The current study aims to find how working from home has evolved in terms of productivity in the last year, how employees' perceptions of the advantages and disadvantages have changed, but also which are the long-term consequences of working from home. For this purpose, we analyzed the answers received after administering a questionnaire to the employees from three private companies in Bihor county at the beginning of the pandemic and a year later. The final results indicate a significant difference in how employees perceive this way of working after a year. If at the beginning of the pandemic the results indicated a negative effect of working from home on productivity, now, after a year, the results indicated a positive effect. Their answers referring to the advantages and challenges of working from home have changed after a year's experience of working from home. While the main benefits have remained the same, the biggest challenges have changed.
\end{abstract}

Keywords: working from home; remote worker; productivity; coronavirus pandemic; benefits; challenges.

JEL classification: M50; M54.

\section{Introduction}

The beginning of 2020 was the beginning of the pandemic and nothing has been the same as before. Everything has moved online, including work. Working from home was common even before the pandemic in some countries, but not in Romania. Moving office work online found Romanian employees unprepared; they were not familiar at all with this type of work. In some companies, employees occasionally worked from home, but that does not mean that they were prepared to work from home full time and for so long.

First of all, working from home requires adequate technical means that some of the employees did not have. Indeed, sometimes working from home requires only a 
laptop and a good internet connection, but other times other technical means are needed.

Moreover, an appropriate atmosphere is required, in which the employees can concentrate on solving their tasks. When the whole family is at home, carrying out their activities in the online environment (online school, online job), the employees often face disturbances from the family members. Indeed, when being at the office there are disturbances from colleagues, but being surrounded by them also means an easier collaboration.

Not least, working from home requires a separate workspace; when this cannot be done, there are many more disruptive factors both from the inside (children making noise, the spouse interrupting voluntarily or not), or from the outside (a package delivery, a neighbour).

All these were problems which the Romanian employees that were moved overnight online faced, and which they had to learn to manage as soon as possible. Unlike office work, each employee faced a different level of noise around them, a different system of organizing the home office and, in some cases, the presence of family members or roommates. This made everyone's work experience at home different and could have a positive or negative impact on productivity. Of course, at the beginning of the period it was very difficult, given the unexpected situation, but gradually, during the year, the employees adapted to this way of working. Many of the employees adapted very quickly and became more productive when working from home. For others, the adjustment period was longer, but given that working from home continued in most cases throughout the year, they succeeded to adapt and found ways to be productive.

Both employees and employers have sought and found ways to increase productivity when working from home. (Jernegan, 2020) Therefore, many employers consider continuing this way of working even when the pandemic situation will no longer require it.

As for employees, while some may be eager to meet their colleagues and leave home every day, others may be concerned about the prospect of resuming social life and may need encouragement. Some employees have found that they have more time for their hobbies or family while working from home; they may not be very interested in returning to the office. If the employees did not find too many differences in work-life balance, they will be more willing to return to work.

However, going back to the office will not be an easy process, just as going online has not been easy. (Guide Covid-19 Returning to the workplace, 2021)

\section{Returning to the Workplace after the Pandemic}

Immediately after the onset of the pandemic, working from home received special attention, with many researchers looking to find ways to increase productivity. After a long period of working from home, researchers' attention is now focused on returning to the office. (Guide Covid-19 Returning to the workplace, 2021) According to research conducted during this period, there are both advantages and disadvantages of working from home. (Catton, 2020)

The main advantages when working from home are:

Balance between personal and professional life - Employees who work from home have a much better balance between personal and professional life. 
No time wasted in traffic - Employees use the time they would have wasted in traffic to work. In addition, there is no fatigue caused by hours spent in traffic.

Flexibility - Employees working from home can organize their own programme, with the consent of the employer.

Increased productivity - Numerous studies have shown that working from home is more productive. Even though the beginning of the pandemic was a difficult period, especially for employees who had not worked from home before, studies have shown that working from home is/has become more productive.

The main disadvantages when working from home are:

Lack of organization - Employees who work from home must be organized and have a schedule to follow. A manager must organize and coordinate a team and that's harder when employees aren't in the office.

Social isolation - The employees are used to communicate face-to-face with managers and colleagues. When working from home, communication takes place on social networks, is lower and that could make them feel isolated. All employees can be affected by the consequences of isolation.

Studies show that after a period of isolation, people are more likely to face problems such as anxiety, insomnia or difficulty coping with stress. It was also found that there are no differences in this regard between young or old people, between men and women.

Distractions at home - Children can distract their parents from work. The involvement in household chores can also be a distraction.

Separate workplace is needed - Employees who work from home must have a separate space. They can concentrate better when they have an adequate space, with the necessary technical means, where children and spouse do not bother him/her during the work schedule.

The longer the period of isolation, the more social isolation stands out as the main disadvantage of working from home. Social networks are obviously a way to keep in touch with others, but of course, they cannot replace face-to-face communication. Personally, social isolation opens the list of negative consequences and can generate negative repercussions over time, both on mental and physical health. Of course, there are e-mails, video calls and applications meant to bring individuals closer, but some things are easier and faster to explain when one person is right next to the other. Limited communication options can make collaboration more difficult.

A serious consequence is the appearance of depression or a sedentary lifestyle, given that for some people the only form of exercise is to go to the office.

But anxiety and depression can also set in when returning to the office. After a period of crisis that lasted long enough to create an adaptation to the new conditions, employees now need a period of time to readjust to the old conditions. (Mangia, 2020) Adaptation involved a new routine and new relationship systems. Change can make room for new acquisitions in the comfort and development of the individual, but it can also create anxiety and resilience out of a desire to maintain the comfort and predictability zone prior to the pandemic. (Spitzer, 2020)

For anxious or depressed people during this period, adaptation is difficult and they need support. It is important not to ignore their subjective and emotional needs, because otherwise the defense mechanisms will be triggered and the adaptation time will be increased. 


\section{Research Methodology, Results and Discussions}

The objective of the current study was to compare employees' perceptions of productivity, the advantages and disadvantages of working from home in two important time periods - at the beginning of the pandemic and a year later. A questionnaire was sent by e-mail to 150 employees of three large companies in Bihor County at the beginning of the pandemic (April, 2020). 57 people completed the questionnaire, which means that the response rate was $38 \%$. The same questionnaire was sent to the same employees a year later. The response rate was 34\%; 51 people completed the questionnaire in April 2021. The target group was not significant, but we were able to get a general idea of changing employees' perception of productivity, benefits and disadvantages of working from home in the first year of the pandemic.

The questionnaire consisted of 10 questions:

1. How often did you work from home before the pandemic period?

2. How satisfied are you with your current work from home arrangement?

3. How full-time work from home arrangement influences your productivity?

4. What work from home arrangement would you like?

5. Do you have all the equipment you need in order to do your work from home?

6 . Do you have a dedicated workspace where you can work at home?

7. Do you keep to a regular working schedule at home?

8. Do you consider you have more distractions at home or at work?

9. What is the biggest benefit when working from home?

10. What is the biggest struggle when working from home?

To these questions were added the socio-demographic questions regarding age, gender, number of family members in the household.

Table 1: Age distribution

\begin{tabular}{|l|l|l|l|l|}
\hline Below 25 & $25-34$ & $35-44$ & $45-54$ & Above 54 \\
\hline- & $6 \%$ & $41 \%$ & $51 \%$ & $2 \%$ \\
\hline
\end{tabular}

Table 2: Gender distribution

\begin{tabular}{|l|l|}
\hline Men & Women \\
\hline $63 \%$ & $33 \%$ \\
\hline
\end{tabular}

Table 3: Distribution according to household members

\begin{tabular}{|l|l|l|l|}
\hline 1 member & 2 members & $\begin{array}{l}3-5 \\
\text { members }\end{array}$ & $\begin{array}{l}\text { More than } \\
5 \text { members }\end{array}$ \\
\hline $21 \%$ & $14 \%$ & $65 \%$ & - \\
\hline
\end{tabular}

When asked about their satisfaction related to the current work from home arrangement in April 2020, the percentage of those who claimed to be very satisfied was 13, while in April 2021 the percentage was 24. 27 percent claimed in 2020 they were very dissatisfied, but in 2021 the percent has decreased to 16 . In both 2020 and 2021, the percentage of women who claimed they were satisfied and very satisfied with working from home arrangement was higher than that of men. 


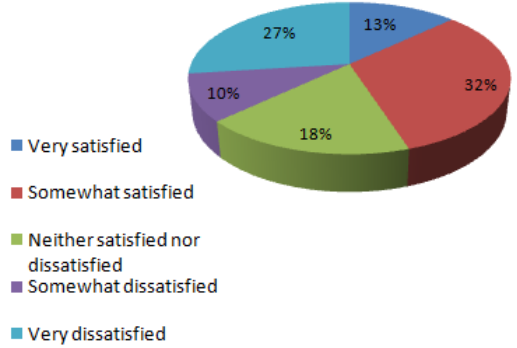

Figure 1: Level of satisfaction with WFH Figure 2: Level of satisfaction with WFH in 2020

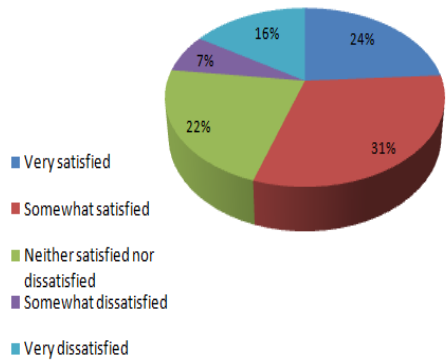

in 2021

A large percentage of employees who worked from home in April 2020, 57 percent, consider that this way of work negatively influenced their productivity, while 43 percent consider that their productivity was positively affected. In April 2021 the perception of employees working from home has changed: 67 percent consider that this way of work positively influenced their productivity, while 33 percent consider that their productivity was negatively affected.

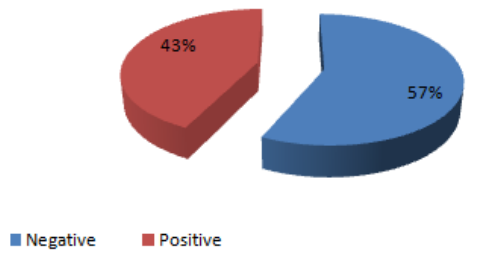

Figure 3: Perceived influence of work from home on productivity in 2020

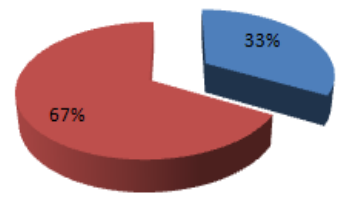

negative $\quad$ Positive

Figure 4: Perceived influence of work home on productivity in 2021

Regarding the equipment they needed in order to do the work from home, in 2020, a percentage of $23 \%$ of the respondents did not have all the equipment they needed, but in 2021 this percent was much lower, 4\%. At the begining of the pandemic period they were not prepared, but after a year they had the technical means necessary to carry out the activity. The $4 \%$ could mean that there were probably situations when the internet connection was not good or they would have needed a better copy machine.

Considering the workspace, we learned that 38 percent did not have a dedicated workspace in 2020, but in 2021 only $17 \%$ claimed they did not have a space only to work.

If we refer to maintaining a regular work schedule at home, the difference between April 2020 and April 2021 is not too big, 43 versus 32. The employees are tempted to interrupt their work for some household chores.

Regarding the biggest benefit, the hierarchy remains the same in 2021, the percentages being slightly different. 


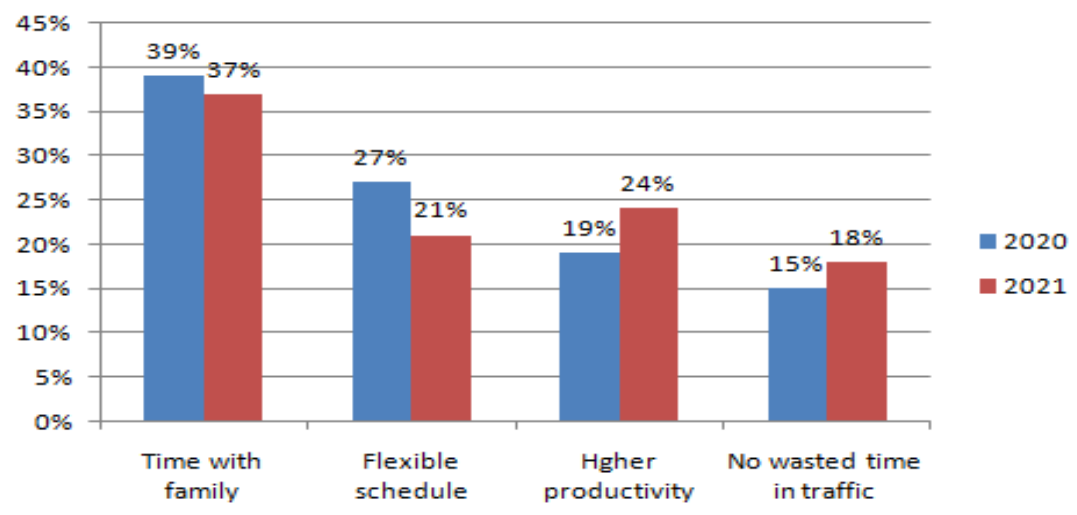

Figure 5: The biggest benefit when working from home in 2020/2021

Referring to the biggest challenge, the percentage of those who said that this is social isolation is almost double (67\% compared to $39 \%)$.

Figure 8 shows that the hierarchy of the biggest challenge changed in 2021. If social isolation remained on the first place, the other challenges are on different positions. During the year, the employees managed the disturbances at home better, they organized their work better, but it was more difficult in terms of arranging a separate space. It was more difficult for the employees to have a separate space dedicated to work; they probably needed a bigger house and this change was not taken into account by the employees.

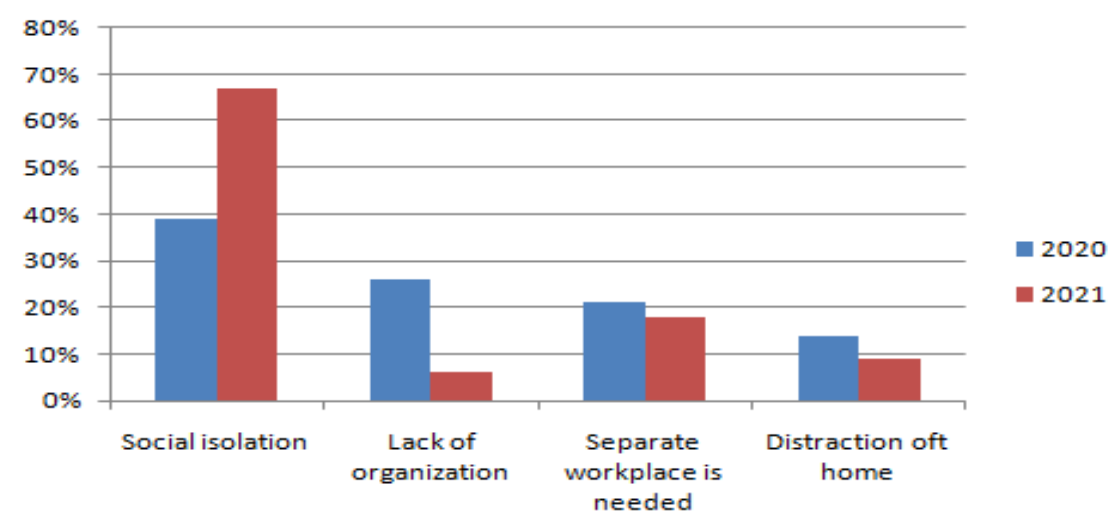

Figure 6: The bigest struggle when working from home in 2020/2021

\section{Conclusions}

Working from home has demonstrated its advantages in the pandemic period, but the office cannot be completely eliminated, as it has the role of supporting collaboration, strengthening relationships between colleagues and stimulating the feeling of belonging to the team. Before the pandemic, working from home was 
considered to be a benefit that some employees could enjoy. Many of them proved to be more dedicated and productive, taking on more roles. After the pandemic, working from home will probably be integrated into employment conditions. But those who will continue to work from home will probably also carry out certain activities in the office.

The results of our research indicate:

The employees' perception of productivity has changed after a year. Unlike the beginning of the pandemic, when the employees perceived working from home as having a negative impact, after a year, they claimed that the impact of working from home on productivity was positive.

Women are more satisfied than man with working from home arrangement.

The biggest benefit identified by our respondents was the same in 2020 and 2021 the time spent with the family; the same hierarchy was maintained for the other advantages: a flexible schedule, higher productivity and no time lost in traffic.

The main challenge was social isolation; our respondents indicated that both, at the beginning of the pandemic, but to a greater extent after a year.

Social isolation was indicated as the main struggle to a greater extent by those who had one family member. In fact, the number of those who indicated social isolation as the main disadvantage was inversely proportional to the number of household members.

However, there are many psychological studies (Akitude, 2020) which sustain that for periods longer than 9-12 months the psychological impact of working from home is negative. Lack of interaction, lack of relationships between people and lack of office dynamics affect certain categories of people and decrease productivity.

Numerous studies (Chery, 2020, Sarner,2020) have shown that the most common post-isolation symptoms caused by the Covid-19 pandemic were: anxiety; sadness; insomnia; confusion; anger; depressive mood; stress; emotional disorders; irritability; emotional exhaustion. The biggest challenge in the next period of time will certainly be managing these negative effects of social isolation.

\section{References}

1. Akitunde, T. (2020) How remote workers are creatively battling social isolation Available: https://blog.dropbox.com/topics/work-culture/how-remote-workers-arecreatively-battling-social-isolation.

2. Catton, A. (2020) Working from Home During Covid-19: Tips, Tricks And Best Practices (online)

Available:

https://www.lexology.com/library/detail.aspx?g=3a870cf0-815c-489a-85726c554befa6e7.

3. Cherry, K. (2020). How to Cope With Quarantine. Available: https://www.verywellmind.com/protect-your-mental-health-duringquarantine-4799766

3. Douglas, T., Gordon, H., Webber, M. (2020) Working Remotely: Secrets To Success For Employees On Distribute Teams.

4. Guide Covid-19 Returning to the workplace (online) Available: https://www.cipd.co.uk/knowledge/fundamentals/emp-law/employees/workplaceguide-returning-after-coronavirus\#gref. 
5. Jernegan, C. (2020) Working from a Home Office Successfully: Best Practice Tips.

6. Mangia, K. (2020) Working from home - making the new normal work for you, Wiley.

7. Neeley, T. (2021) Remote Work Revolution: Succeeding from Anywhere, Harvard Business School.

8. Neeley, T. 15 Questions About Remote Work, (online) Available: https://hbr.org/2020/03/15-questions-about-remote-work-answered

9. Sarner, M., (2020) Maintaining mental health in the time of coronavirusAvailable: https://www.ncbi.nlm.nih.gov/pmc/articles/PMC7194563/

10. Spitzer M., (2020) Pandemic and quarantine: Loneliness is contagious,(online) Available:https://www.dw.com/ro/pandemie-\%C5\%9Fi-carantin\%C4\%83singur\%C4\%83tatea-e-contagioas\%C4\%83/a-52966096.

11. Sutherland, L. and Nelson, C.J., (2020) Work together anywhere, John Wiley And Sons Ltd.

12. Weed, J. How to Succeed in Your Office Job When There is no Office (online) Available:https://www.nytimes.com/2020/06/21/business/work-homecoronavirus.html.

13. Young B., Leigh E., (2021) How to own working from home, Boss on Purpose LLC. 


\title{
THE ECONOMIC AND SOCIAL IMPACT OF TELEWORK. THE CASE OF ROMANIA
}

\author{
Elena-Florentina MATEI ${ }^{1}$, loana Manuela MINDRICAN ${ }^{1}$ \\ ${ }^{1}$ Doctoral School Economy I, Academy of Economic Studies, Bucharest, Romania \\ matei.elena96@gmail.com \\ mindrican.ioanamanuela@gmail.com
}

\begin{abstract}
In the current context, the phenomenon of teleworking has major implications for both individuals, organizations and society. It is well known that the relative ease of identification and use of information has led to significant changes in organizational structures, but also in the working methods of employees. Among the new working arrangements considered flexible, is, more precisely, telework, work from home, which has been implemented considerably, with the emergence of the crisis caused by the Covid-19 pandemic. The purpose of this paper is to examine the main advantages and disadvantages of this "technological revolution", but also how the authorities have intervened through fiscal measures. Regarding the main advantages of telework, they are represented by the increasing autonomy and flexibility, the reduction of damage to the environment, as well as the development of optimal solutions for populations with special needs. However, the advantages are weighed against the disadvantages, as some employees believe that they are affected by the feeling of isolation and social distancing, and in terms of organization, they feel negative effects in terms of increased costs of the transition process and new working methods.

The motivation for choosing this theme is to identify the economic and social impact that this change had on employees in Romania during Covid-19. Furthermore, in the light of the case study, it is desired to establish the level of satisfaction among remote workers and why they are satisfied, respectively dissatisfied with this measure. More precisely, this article captures the way in which telework is perceived by employees in Romania, and highlights the possible benefits and pitfalls resulting from this process and the impact of the measures taken by the authorities. Regarding the research method used, it is represented by the descriptive analysis, the dynamic macroeconomic analysis by using graphs, as well as the comparative analysis according to the objectives pursued during the research. Compared to the way of presenting the information from the bibliography used and found at the end of the paper, in this paper are found only the essential aspects, the particularities of the chosen research topic, which finally provides an overview.
\end{abstract}

Keywords: telework; impact; transition; costs; measures.

JEL Classification: J81; O33;

\section{Introduction}

At the time of the emergence of this concept, the practice of teleworking was known in the literature as "telecommuting". At the time, the telecommunications arrangements concerned the existence of an agreement whereby the employee 
operated from his own home, using telecommunications links to have virtual access to the office. More specifically, the term "telecommute" refers to the work performed by an employee with the help of these telecommunications links. Telework is an alternative way of organizing and managing work. It encompasses two sources of competitive advantage in the market, namely, the human resources of each company, namely, the workforce, and new telecommunications and information technologies. From an economic point of view, telework is an arrangement that gives the employee the opportunity to work in another alternative place, but approved by the company, such as at home or in a telework center.

Information processing and telecommunications technology, more precisely, technological progress, is what has facilitated the availability of telework for employees. The main technological innovations that have gradually led to the expansion of this phenomenon are related to the increasing portability of computers, but also data files, the ability of employees to participate in online sessions with colleagues or customers, video applications that offer the possibility of virtual meetings, which occur in real time and without the physical presence of the meeting participants. The concept of telework has grown considerably over the years, but in the context of the onset of the coronavirus crisis, it has left deep imprints on each area of activity. The Covid-19 pandemic was a major blow to the entire global population, and in response to the effects of this situation, most private companies have made the process of transitioning employees into telework conditions. In other words, this phenomenon has caused a number of positive and negative effects for both employees and employers. An example is that working from home can significantly affect relationships between family members and can reduce labor productivity to some extent, as it is difficult for a parent to pay attention to the child during work hours, and in at the same time, to perform their tasks in optimal conditions. However, according to specialized studies, there are people who affirm the need and desire to continue teleworking, even after overcoming this crisis, because they claim that in this way a balance between family life and life can be reached much faster than professional.

This paper aims to study and analyze the economic and social impact of telework on the employed population in Romania as a result of the outbreak of the Cobvid19 pandemic, but also the measures implemented by the authorities. This paper is structured in several distinct parts, as follows: (i) in the first part is the introduction, (ii) in the second part the stage of knowledge, (iii) in the third part the research methodology, (iv) in the part the fourth case study, (v) and in the last part the conclusions are found.

\section{The stage of knowledge}

The term telecommunications was first encountered around the 1970s in the United States as a result of the effects of the oil crisis. Consistent with studies by Avery and Zabel (2001), the term was first introduced by Jack Nilles, who was a recognized engineer due to extensive projects for the National Aeronautics and Space Administration. At the time, this idea was to move work to workers, rather than moving workers to work, to reduce energy consumption and alleviate traffic problems. Subsequently, the federal and state governments began to financially support demonstration projects to analyze the feasibility and effectiveness of telecommunications. Thus, "by 1997, approximately 10,000 U.S. government employees worked from home or other remote locations", Avery and Zabel (2001). 
At the same time, in 1970, private companies came to the conclusion that the telecommunications service could be used to solve labor problems. Companies such as IBM and Control Data Corporation have recognized that teleworking can help people to some extent in managing work-related and family responsibilities. It should be noted that the evolution of telework is closely in line with technological progress and economic change.

According to a study by Nilles (1994), telework requires more than an employee to work from home and keep in touch with the office through telecommunications tools, because it involves both working in work centers, which is actually an area office space for employees of various companies, as well as working in satellite offices. The satellite office is known in the literature as the company's office located in a certain area where there are a concentrated number of teleworkers. Thus, in this context of large-scale use of telecommunications, it is particularly important to understand initially the adaptation of users, but also the background of the implementation of this type of work. In 2002, Tremblay conducted a survey in Quebec (Canada) to identify the advantages and disadvantages of teleworks perceived by workers in the region. It should be noted that the study was conducted in both the public and private sectors. The authors concluded that there are major gender differences in the perception of employees, but nevertheless, both women and men stated that the main benefit is the flexibility of the work schedule. At the same time, another positive effect perceived by them is the decrease of time in traffic.

Authors Troup and Rose (2012) conducted comparative research on formal and informal teleworking. This study was conducted in the public sector in Queensland (Australia), and the result was negative, as differences were identified between job satisfaction and the distribution of tasks between men and women with children. This aspect highlights the idea that telework can significantly affect work relationships, but also family. However, there is research that has captured the positive effects of teleworking. Authors Mello et al. (2014) demonstrated that in the long run, teleworking aims to reduce costs, increase productivity, and improve the quality of life of teleworkers by reducing travel time, social and digital inclusion of all people. Furthermore, according to a study by Gaspar et al. (2014), there are many factors that increase the chances of adopting and implementing this form of work globally, among them being the incentive for spontaneous telework, continuous employee training, promoting social activities, stimulating creativity, proactivity and innovation, as well as their gradual implementation. However, in the current period, there are still a number of challenges regarding the implementation of telework, among them the difficulty of evaluating the performance, but also of controlling the objectives and results obtained. Another challenge is to define the profile of the employee, because in reality, not all employees are compatible with this form of work, Stavrou (2005). Telework is the form in which work can be organized and carried out, and the employee can perform duties specific to the position held at least one day a month in a place not arranged by the employer and using information and communication technology, in accordance with Law 81/2018 on regulation telework activity, National Institute of Administration (2020). At the same time, in Romania, the telework regime has been regulated since 2018, but employers have been reluctant with this new regime. The onset of the Covid-19 pandemic led to a change in the attitude of employers towards this new work regime, as they were constrained by the new economic context, in which they had 
to choose between significantly reducing their workload or continuing on a regular basis telework. Most employers have decided to continue their telework activities and even support their employees by providing the necessary equipment.

According to specialized studies, telework is a form of savings for employers, which can save up to $\$ 11,000$ per employee, Global Workplace Analytics (2020). In addition to these results, teleworking increases the working time by 1.4 days for the employee and reduces by 408 hours the time from home to the office, which leads to a gain of 17 days per year. The study conducted by Eurofound (2020) shows that in Romania less than $20 \%$ of employees have made the transition to telework, even if there has been extensive progress on work and digitization. Finally, to support the employees in the fields affected by the Covid-19 pandemic, who carried out their activities in telework during the state of emergency, the Romanian authorities, more precisely the Government issued several normative acts, such as "Law 296/2020 on amending and supplementing Law 227/2015 on the tax code", while the local authorities supported the German Kurzarbeit model, which consists in subsidizing reduced working time by the state, Deloitte (2020).

\section{Research methodology}

This paper is based on a mixed research methodology, as it includes both the method of descriptive analysis, used to identify studies and introduction to the literature, and a dynamic macroeconomic analysis used to conduct the case study on the impact identification pandemic on the economy, more precisely how the budget deficit and public debt have evolved in the context of Covid-19, which are highlighted in the form of time series, more precisely the graphs. At the same time, this paper includes an analysis of the measures taken by the Romanian authorities to support employees and employers in the context of the Covid-19 pandemic, but also a table summarizing the advantages and disadvantages of telework from the perspective of employers and employees in Romania.

To carry out this work, more precisely the chart of the quarterly evolution of public debt and budget deficit in Romania, we used the database taken from the Eurostat website for the period 2019Q1 - 2020Q1, to highlight the evolution of the impact of the pandemic and the intervention of the authorities. The chart was created using Microsoft Excel software, which is a powerful tool for viewing and analyzing data.

\section{Case Study}

\subsection{Ensuring the continuity of labor productivity in the context of the COVID- 19 pandemic}

Given the general framework that affects the well-being of employees and the economic performance of organizations, most companies globally have considered teleworking during the COVID-19 pandemic. This measure was considered on the one hand to protect workers from the spread of the virus, and on the other hand to contribute to the government's efforts to flatten the curve of new cases. Moreover, the concept of telework has been and is seen from many perspectives by every organization, especially in view of the fact that ensuring adequate working conditions for remote workers raises major issues. At the same time, traditional management or the methods that are applied in the current context at work may not be suitable for telework, a measure that brings with it a number of challenges, 
advantages and disadvantages for employees and employers. An important aspect to note is that the way in which this challenge is addressed has a significant impact on the labor market, in particular on the workplace schedule, rest periods, employee performance and productivity, and the well-being of teleworkers.

According to a study conducted by Eurofound in 2020 on the background of the current pandemic, one of the strengths of telework is that it ensures the flexibility of working time for each employee, thus allowing a balance between work and family life. Since the outbreak of the COVID-19 crisis, the house has become the office for millions of workers both in the European Union and around the world. In line with Eurofound's estimates for 2020 , they show that around $40 \%$ of all people currently working in the European Union have started working full-time in telework as a result of the effects of the pandemic. A recent study by the European Commission in 2020 supports the idea that $25 \%$ of employment in the European Union is in telework, but given that the current pandemic is ongoing it is estimated that by the end of 2021 the percentage this indicator to double. It is important to note that before the pandemic broke out, only $15 \%$ of EU employees had the opportunity to be employed in telework, and the others faced major challenges in the sudden transition from physical work to office to telework. Of course, the magnitude of this phenomenon can vary considerably depending on other external factors, so in this paper we will highlight both the impact of telework socially and economically. According to the latest studies carried out by the European Commission, it is still desired to maintain telework, especially in companies that agree with this measure and can operate in optimal conditions and in real time, because the importance of telework is necessary in maintaining jobs current employment and maintaining productivity in the context of the COVID-19 crisis.

Table no.1: Advantages and disadvantages of employers / employees in the context of telework

\begin{tabular}{|c|c|c|}
\hline & Advantages & Disadvantages \\
\hline \multirow{5}{*}{$\begin{array}{l}\text { Advantages } \\
\text { and } \\
\text { disadvantages } \\
\text { borne by } \\
\text { employers }\end{array}$} & Flexibility & $\begin{array}{l}\text { Equipment necessary for the } \\
\text { continuation of the telework activity }\end{array}$ \\
\hline & More services & $\begin{array}{l}\text { Lack of involvement in the } \\
\text { company }\end{array}$ \\
\hline & Productivity & Loss of informal communication \\
\hline & More motivated staff & Staff training and guidance \\
\hline & $\begin{array}{lr}\text { Contacting } & \text { the } \\
\text { organization easier } & \text { or } \\
\text { even outside of office } \\
\text { hours }\end{array}$ & $\begin{array}{l}\text { Adapting the organization to the } \\
\text { new economic context }\end{array}$ \\
\hline \multirow{5}{*}{$\begin{array}{l}\text { Advantages } \\
\text { and } \\
\text { disadvantages } \\
\text { borne by } \\
\text { employees }\end{array}$} & Flexibility & Isolation \\
\hline & Autonomy & Arranging the new job \\
\hline & Productivity & Income and job insecurity \\
\hline & $\begin{array}{l}\text { Lower costs and reduced } \\
\text { travel time }\end{array}$ & Deteriorating working conditions \\
\hline & $\begin{array}{l}\text { Greater opportunities to } \\
\text { get or keep a job }\end{array}$ & $\begin{array}{l}\text { Mixing family responsibilities with } \\
\text { professional ones }\end{array}$ \\
\hline
\end{tabular}




\subsection{The social impact of telework}

Although technology has evolved considerably, the concept of telework is not as recent as we think. The notion dates back to the nineteenth century, when working from home was the norm for craftsmen and peasants, who carried out part or all of their occupation in a reserved area, more precisely in their homes. At the time of the outbreak of the Industrial Revolution, the factory and office gradually replaced the internal workshop and later became the dominant working environment. However, the notion of telework was brought to the fore much more recently, specifically in 1973, when Jack Nilles, known in the literature as the "father of telework" argued the importance of telework in a world without internet, for the companies of that time in order to compensate for the economic losses due to the oil crisis. In short, we can summarize that this concept has its origins long before the outbreak of the COVID-19 pandemic. Currently, the harmful effects of the SARS-VOC-2 virus have brought back to work the remote operation of work and have considerably fueled the debate on the social impact and way of life of people, taking into account these major changes that have taken place. One of the greatest benefits felt socially after the application of telework is the existence of a better reconciliation between the professional and personal life of individuals, known in the economic literature as the "work-life balance". At present, amid the pandemic, this topic has become of great interest to both European and global societies, especially in view of the fact that household and childcare tasks are no longer exclusively the responsibility of to a single parent, this time both are involved, and given that working from home has become part of everyday life and facilitated this. Consistent with the meta-analysis by Allen et al. (2015), telework is associated with a much better balance between personal and professional life. However, statistically the relationship is quantitatively weaker. The study highlights the fact that if we asked 100 employees who are in telework, if they see this measure as a benefit, on average only 16 affirmative answers will be obtained.

There is other research that emphasizes the importance of this measure. An example can be represented by the study conducted by Golden et al. (2006), through which the positive relationship between telework and work-life balance gradually increases with its intensity. More precisely, the more an individual works from a distance, the greater the benefits of teleworking in order to achieve a better work-life balance. Furthermore, people who work from a distance of more than one succeed without fail and can get much higher earnings in the balance between work and family life compared to those who work less time. Taking into account the above information, the ratio of 16 positive responses per 100 respondents will increase to 25, which is an important figure, but not statistically overwhelming. Although telework is a well-known form of work at home, its use has been fueled by the COVID-19 pandemic, where more than a third of all employees have been forced to make the switch from physical work to office work from home, the share of women being higher than that of men, Eurofound (2020). However, telework involves social isolation in order to reduce the spread of the virus, and from a social point of view, this has a number of negative consequences and can generate major repercussions over time on both mental and physical health. Of course, due to technological developments, there are emails, video calls and many applications through which you are closer to the person you are communicating with, but this 
does not replace the physical existence of that person. Sometimes, simple communication through a device brings people into a state of immeasurable sadness by reminding them of the pandemic context in which we have been for so long and the distance that continues to occupy an important place in our lives. At the same time, rather limited communication options can make collaborations between organizations much more difficult, requiring much greater involvement. An important aspect to emphasize about telework is the installation of depression or sedentary lifestyle, because according to specialized studies for many people the only way to move is to physically go to the office. Moreover, one of the most harmful effects resulting from the COVID-19 pandemic triggered in 2020 is the increase in the number of people suffering from depression due to job loss, inability to adapt to work at home, isolation, stagnation of economic and social activity, as well as fear of infection. In short, measures taken to reduce the spread of the virus are seen as actions that isolate and deprive people of the necessary treatments. At the same time, what is difficult to bear for most people, is particularly stressful for people suffering from depression, they are not more afraid of contracting the virus compared to the general population, the statistics being $43 \%$ versus $42 \%$. An important aspect to emphasize is the fact that they feel the stagnation of economic and social activity more acutely than other people, specialized studies highlight the proportion by the following data: $74 \%$ versus $59 \%$. Specifically, those affected suffer almost twice as much due to the lack of daily structure, the share being $75 \%$ compared to $39 \%$. Therefore, it can be stated that teleworking for people suffering from depression and anxiety is not a beneficial solution especially in the long run, on the contrary sedentary lifestyle aggravates this disease.

Another impact of teleworking today is the existence of an increasing number of overtime hours worked by employees of various organizations, which are mostly unpaid. It is important to emphasize the idea that, from a legal point of view, the improper implementation of telework at the level of employers disadvantages especially employees who have a flexible work schedule. The advantages of the flexible work schedule gradually tend to turn into the major disadvantage resulting from the provision of a number of overtime hours, which are not significantly met by the company and which can generate major conflicts related to their compensation. For a large part of the employees, the lack of productivity in the case of telework is a negative factor and with a rather large economic impact, because it can gradually lead to a decrease in the company's efficiency. Many employees have stated that they lack the intrinsic motivation to work in a context where they do not have the necessary resources or space to approach their office colleagues. Another fundamental aspect of remote work, which should not normally affect employees, is the generation of additional costs for a home office. In accordance with the law in force, costs should be reimbursed by employers, but in practice there are quite a few companies that have subsequently developed and implemented internal measures and policies through which to regulate all these aspects related to the concept of telework. Therefore, the existence of additional costs resulting from telework disadvantages employees both economically and socially, as they are demoralized to continue working in these conditions. At the same time, according to a study carried out by Eurofound, teleworking brings with it many opportunities from the perspective of gender equality, including better participation in the labor market, greater flexibility in managing working time while combining responsibilities associated with personal life, increase productivity by improving performance, a 
much more accurate correlation in terms of spatial demand and labor supply, thus not requiring physical travel, low costs in terms of eliminating travel and last but not least row, time saving.

\section{Câștigul salarial real}

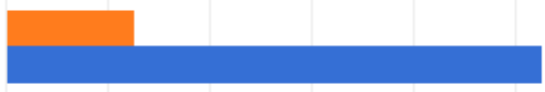

Câștigul salarial mediu net lunar

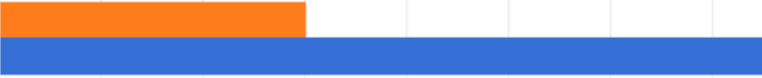

Populația ocupată total

Rata șomajului

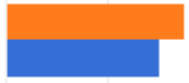

Numărul mediu de salariați

Figure no. 1: Evolution of earnings and employment compared to the previous year (\%)

Source: Graphic representation of the authors, according to the data taken from the National Commission for Strategy and Forecast, www.cnp.ro

\subsection{The economic impact of telework}

Since the outbreak of the COVID-19 pandemic and to date, numerous studies have been developed that highlight the impact of telework from an economic point of view, but there is no consensus in the economic literature to refer to this fact. The recession resulting from the health crisis of 2020 is generally not a novelty in the history of the economy, given that over the years various bottlenecks of economic activity have been identified, they are recorded from the Middle Ages and continuing until Modern Ages. The novelty and difference of the current context is given by the manifestation of this recession in a service economy, which has a high level of globalization and at the same time the penetration of information and communication technologies in the development of socio-economic activities.

The COVID-19 pandemic triggered in 2020 brought major effects on both labor supply and demand. An important aspect to emphasize is the fact that in the acute periods of the epidemic crisis there was a segmentation of the labor supply, in accordance with the role it played in combating the effects of the pandemic, the possibilities of access to current information and communication technologies. lastly, the level of exposure to pathogens. Furthermore, the possibility of teleworking in Romania is closely correlated with the characteristics of socioeconomic activities, but also with the professional skills of employees in those activities. In terms of labor demand, the most important and significant recessionary effects were recorded at the level of consumer support services, 
administrative and business support services, as well as in the manufacturing industry. At the same time, it was a consequence and a result of both the decrease of revenues and the appearance of significant blockages at the level of international supply chains with raw materials and products essential to the daily activity. As a result of the experience of the functioning of the business environment in Romania during March-April 2020, this aspect highlighted the idea that the negative effects exerted by the COVID-19 pandemic were mainly more prominent in the case of self-employed workers small employers in contrast to people employed in the informal economy.

The main measures that were adopted both in Romania and globally aimed to combat the effects of the recession in order to increase the duration and level of social assistance, as well as active labor market policy measures, such as this is the case for part-time employment. An example can be represented by the case of Romania, where a series of social protection measures and policies specific to social categories were implemented, which were affected by the external shock propagated by COVID-19. The measures applied were in line with the practices of the European Union and were mainly based on a series of innovations related to the expansion of the use of information technologies for the transmission of social assistance, but also to the organization of forms of vocational training, which materialized through -forced digitization in order to reduce the negative impact exerted by the COVID-19 pandemic. At the same time, the onset of the COVID-19 pandemic placed particular emphasis on the expansion of telework, being considered one of the essential methods of organizing the production and performance of companies, and implicitly employment. The degree and level of expansion of telework is in a relationship of dependence with several factors, the most important of which is the agreement between employees and employers. Undoubtedly, in the context of the current pandemic, telework was considered a means of maintaining a large part of human capital, but also of continuity of the implementation of new communication-information technologies.

\subsection{Measures implemented by the authorities to support employees and employers}

The onset of the health crisis caused by the Covid-19 pandemic put unprecedented pressure on world governments, which had to implement unprecedented measures to support the economy at the same time as the population and businesses. All these measures have led to a sharp increase in government spending while declining government revenues, which has led to a deepening of macroeconomic imbalances, more of the budget deficit and public debt.

Among the measures taken in the context of the Covid-19 pandemic in Romania, we can see the Emergency Ordinance no. 132/2020, measures to support employers and employees, measures of social distance, but also measures to stimulate employment, which led to the regulation of the Kurzarbeit model in the private sector. By Emergency Ordinance no. 132/2020 the authorities decided the possibility of reducing the working time of employees up to $80 \%$ by decision of employers for a period of at least 5 working days, the possibility of changing the work schedule by decision of employers, but also granting employees affected by reduced working time an allowance of $75 \%$ of the gross monthly basic salary. This allowance is borne by the employer and can be reimbursed from the unemployment insurance budget, insofar as the employers fulfill the declaratory 
and payment obligations in accordance with Law 227/2015 on the Fiscal Code. An important aspect to mention is that in the event that employers fail to recover this benefit from the unemployment insurance budget, they do not have the right to charge this amount to employees.

Other measures implemented by the authorities in response to the Covid-19 pandemic and supporting employees and employers include:

- measures to support enterprises;

- granting the possibility for employees to stay at home with children and receiving an indemnity paid by employers and recovered by them from the employment agencies by submitting the supporting documents under the conditions provided by law;

- granting bonuses for the payment of profit taxes;

- granting subsidies to enterprises;

- the possibility of rescheduling payments for certain taxes due by companies facing various difficulties;

- granting loan guarantees and subsidized interest for investments;

- accelerated VAT refund;

- suspension of controls performed by tax authorities;

- postponement of property taxes.

The graphical representation shows the economic impact of the fiscal measures implemented by the authorities in response to the Covid-19 pandemic, which determined the increase of the public debt and the deepening of the budget deficit. For example, public debt grew from 33.8\% of GDP in the first quarter of 2019 to $37.3 \%$ of GDP in the first quarter of 2020 and $47.6 \%$ of GDP in the first quarter of 2021 , while the deficit The budget deepened from $-4.4 \%$ of GDP in the first quarter of 2019 to $-7.5 \%$ of GDP in the first quarter of 2020 and $-8.3 \%$ of GDP in the first quarter of 2021.

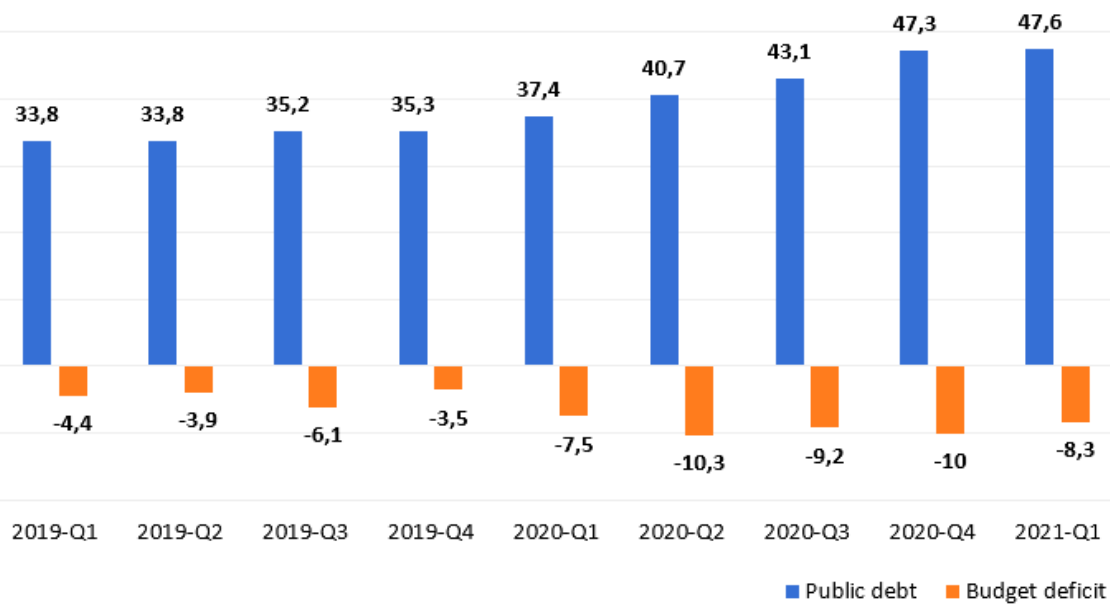

Figure no. 1: The evolution of the budget deficit and public debt in the period 2019Q1 - 2021Q1

Source: Graphic representation of the authors, according to data taken from Eurostat 


\section{Conclusions}

The health crisis generated by the Covid-19 pandemic has had and still has a strong impact on the entire socio-economic system of countries worldwide, which has led to a change in professional and personal activities. Global companies were also severely affected, and the measures implemented by the authorities led to a deepening of macroeconomic imbalances and a sharp increase in government debt while widening budget deficits. In the new economic context, there was a strong emphasis on digitalization and telework, which until the onset of the crisis were used by only a small percentage of the population and businesses. Thus, resilience, flexibility and agility have become key elements of public and private sector work activities.

The purpose of this paper is to identify the economic and social impact of telework, and following this research it can be said that telework has both positive and negative aspects. For example, a positive impact is the continuation of the economic activities of businesses and the population, which risk losing their jobs and thus increasing the unemployment rate which would have put increasing pressure on the authorities. Regarding the negative impact of telework, it is related to social distancing measures, namely the fact that there is no more physical interaction between employees, which can lead to depression that strongly affects a large part of the population. For businesses, the negative impact of telework is related to increased costs by providing the equipment needed to continue working from home. At the same time, telework involves the possession of computer knowledge and access to the equipment necessary to carry out activities, but also housing conditions, which can lead to economic and social inequalities. Finally, teleworking can facilitate the inclusion in the labor market of the disadvantaged population, namely people with disabilities, pregnant women and members of single-parent families, which can lead to improved living conditions for these categories.

Finally, the budgetary impact of the measures taken by the authorities in the fight against the Covid-19 pandemic and in order to support the population and businesses is unprecedented, which has led to a widening of macroeconomic imbalances, and thus an increase in public debt from $35.3 \%$ of GDP in 2019 , up to $47.3 \%$ of GDP in 2020 , while the budget deficit deepened from $-4.4 \%$ of GDP in 2019 , to $-9.2 \%$ in 2020 . For 2021 , it is anticipated that both the budget deficit and the public debt will increase considerably, amid the measures implemented in the fight for survival and economic recovery.

\section{Acknowledgements}

This paper is the result of the research within the Institutional Project 932/16.06.2021: 'Economic and social security in Euro-Atlantic space: actors, tools, trends', Funder: Bucharest University of Economic Studies, Romania.

\section{References}

1. Airtasker (2020). The Benefits of Working From Home. https://www.airtasker.com/blog/the-benefits-of-working-from-home/. 
2. Avery, C. and Zabel, D. (2001). The flexible workplace: a sourcebook of information and research. Westport, CT: Quorum Books. https://www.worldcat.org/title/flexible-workplace-a-sourcebook-of-information-andresearch/oclc/646856758.

3. Bellmann, L. and Hübler, O. (2020). Working from home, job satisfaction and work-life balance - robust or heterogeneous links?. International Journal of Manpower, pp.424-441. https://www.emerald.com/insight/publication/issn/01437720.

4. Brunelle, E. and Fortin, J.A. (2021). Distance Makes the Heart Grow Fonder: An Examination of Teleworkers' and Office Workers' Job Satisfaction Through the Lens of Self-Determination Theory. SAGE Open, 11(1), 215824402098551. https://doi.org/10.1177/2158244020985516.

5. Chung, H. and van der Lippe, T. (2020). Flexible Working, Work-Life Balance, and Gender Equality: Introduction. Soc. Indic. Res, 151(2): 365-381. https://pubmed.ncbi.nlm.nih.gov/33029036/.

6. Labor Code (2021). Home Work. https://legeaz.net/legea-53-2003-codulmuncii/art-108.

7. Dang, T.K.P. and Hong, T.N. (2020). Teleworking and job satisfaction: How the COVID-19 outbreak shapes the new working pattern in Vietnam?. Proceedings of the 6th International Conference on Finance and Economics, pp.38-53.

8. Davidescu, A.A., Apostu, S.A., Paul, A. and Casuneanu, I., (2020). Work Flexibility, Job Satisfaction, and Job Performance among Romanian EmployeesImplications for Sustainable Human Resource Management. Sustainability, 12(15), 6086. https://doi.org/10.3390/su12156086.

9. Deloitte (2020). The Kurzarbeit model in Romania - advantages and vulnerabilities. $\quad$ https://www2.deloitte.com/ro/en/pages/businesscontinuity/articles/modelul-kurzarbeit-in-romania-avantaje-si-vulnerabilitati.html

10. Dima, A.M., Tuclea, C.E., Vrânceanu, D.M. and Tigu, G. (2019). Sustainable Social and Individual Implications of Telework: A New Insight into the Romanian Labor Market. Sustainability, 11(13), 3506. https://doi.org/10.3390/su11133506.

11. Eurofound (2020). Life, work and Covid-19: The first findings. https://www.eurofound.europa.eu/ro/publications/report/2020/living-working-andcovid-19-first-findings-april-2020.

12. EY Romania (2020). Return to work. The new conditions. https://www.ey.com/ro ro/news/2020/10/studiul-ey--revenirea-la-munca--noile-

conditii---60--dintre-anga.

13. Government of Romania (2020). Emergency Ordinance no. 132/2020 on support measures for employees and employers in the context of the epidemiological situation caused by the spread of coronavirus, as well as to stimulate employment growth. Official Gazette no. 720 of August 10, 2020. http://legislatie.just.ro/Public/DetaliiDocument/229026.

14. National Institute of Administration (2020). Telework - a work option implemented in the public sector as well. http://ina.gov.ro/telemunca-o-optiune-demunca-implementata-si-in-sectorul-public/.

15. Nilles, J. M. (1994). Making telecommuting happen. A guide for tele managers and telecommuters. New York: Van Nostrand Reinhold. https://www.worldcat.org/title/making-telecommuting-happen-a-guide-fortelemanagers-and-telecommuters/oclc/473628519. 
16. Romanian Parliament (2020). Law no. $296 / 2020$ for the amendment and completion of Law no. 227/2015 regarding the Fiscal Code. http://legislatie.just.ro/Public/DetaliiDocument/235513.

17. Romanian Parliament (2018). Law no. 81/2018 regarding the regulation of the telework activity. Official Gazette no. 296 of April 2, 2018. http://legislatie.just.ro/Public/DetaliiDocument/199418

18. Stavrou, E. T. (2005). Flexible work bundles and organizational competitiveness: a cross-national study of the European work context. Journal of Organizational Behavior, Volume 26, Issue 8, p. 923-947. https://onlinelibrary.wiley.com/doi/abs/10.1002/job.356. 


\title{
THE TRUSTEE'S OBLIGATION TO INFORM THE PRINCIPAL ON THE PROGRESS OF THE MANDATE. THE ACCOUNTING MANAGEMENT AND THE REPORT
}

\author{
Dana TULAI ${ }^{1}$ \\ 1 Political Economy Department, Faculty of Economical Sciences and Business \\ Administration, Babeș-Bolyai University, Cluj-Napoca, România \\ dana.tulai@econ.ubbcluj.ro
}

\begin{abstract}
This paper aims to bring to attention an issue which involves both economical and juridical aspects: agents' obligation to give an account to principals, derived from mandate contracts. The legal doctrine, both Romanian and European, has largely debated upon this aspect, particularly the form in which the accounting report must be given, as well as the possibility of tacit extempt from the obligation of the trustee to hand over the management account, in cases in which the contractual relations of the parties are based upon a high degree of trust. As shown in this paper, we believe that a genuine accounting report is required from agents only if the principals explicitly demand it. Also, since the legal provisions on the matter do not expressly impose any formalities for the completion of this report, we believe that it is the principals' decision to establish the form in which the trustees must hand over the accounts.
\end{abstract}

Keywords: mandate; accounting; report; management

JEL Classification: $K 11 ; K 12 ; K 15 ; K 22$

As it appears from the legal regulations in force, in a mandate contract, the agent's obligation to "give an account" to the principal is a complex one, since it involves various duties. First of all, the trustee must inform the principal about the execution of his mission and to present a report to him. Secondly, he is legally bound to hand over to the principal all that he has received by virtue of the mandate and pay him interest for the sums owed to the principal. Finally, the agent must prove his loyalty to the principal, as well as show the diligence with which he takes care of his interests, by taking all the necessary measures to preserve the assets held for the principal.

Therefore, first of all, the agent's accounting obligation has a legal aspect, embodied in his duty to inform the principal about the execution of the mandate, referred to as the "reporting obligation". Since the trustee concludes legal acts on behalf of the principal, it is only fair that he keeps the principal up to date with the completion of the duties entrusted to him. The old Romanian Civil Code (art. 382) regulated this duty in a distinct and explicit manner. According to the new Civil Code, it derives from the general obligation to give an account.

Secondly, the agent's duty also has an accounting aspect: the trustee must provide the principal with an account of his management. As the legal doctrine has showed, this obligation "is not subject to any particular formal requirements, but still, it is not a mere arithmetic framework; it is a contract subject to the common law in question. It must include both assets and liabilities." (Dutilleul, Delebecque, 1998: 493). An author (Dănișor, 2006) stated that the principal may exempt the 
agent for the use of the legal forms in giving accounts; however, the law does not establish any special formal conditions for the agent's management report.

Therefore, the trustee's duty to be accountable to the principal primarily involves the obligation to inform him about the performance of the task entrusted to the agent.

The principal is entitled at any time during the term of office to know the status of the operations with which he has empowered the agent, as well as the accounting situation arising therefrom. Therefore, we believe that the trustee will have to justify the management whenever the principal so requests, not only at the end of his term of office.

The doctrine has considered that the principal who has dismissed his agent, without having received the management report, can no longer request it, as it is presumed that he has appropriated the statements of the trustee (BaudryLacantinerie, Wahl, 1907: 359). In the light of the regulations contained by art. 2037 of the new Romanian Civil Code ("Upon termination of the mandate by any means, the agent is bound to complete his obligations provided by art. 2019 and 2020"; art. 2019 regulates the duty to give account, whereas art. 2020 states that the agent must pay interest for the amounts owed to the principal), we believe that the duty to report and implicitly the principal's correspondent right to require the handing over of the accounts subsists even after the termination of the mandate, however it might have occurred.

In order to evade his obligation of accountability, the agent cannot rely on the fact that he acted in reality as a prête-nom representative for a third party, unless the principal himself knew and accepted this situation.

The agent must justify his conduct and inform the principal about the status of the operations with which he was enstrusted.

The legal doctrine (Dutilleul, Delebecque, 1998: 492) pointed out the difference between this obligation to inform that the trustee has towards the principal and the duty of advice, that jurisprudence sometimes assigns to the agent, especially the professional one, such as the real estate agent or the legal adviser. The obligation to inform is a direct and necessary consequence of the intuitu personae character of the mandate contract, and therefore it is a duty of all agents; the obligation to advise, on the other hand, is determined by the proffesional nature of certain mandates. For example, the lawyer "shall explain to his client the circumstances of the case, the current situation, possible future developments and results, in a reasonable manner, according to the specific circumstances of the case" (art. 140 paragraph 2 of the Decision of the Council of the National Union of the Romanian Bar-Associations no. 64/2011 for the coming into force of the Status of the Lawyer Profession).

But what exactly does the agent's obligation to inform involve? It comes in the form of a report on the development of the trustee's mission, indicating both the difficulties and its results. This duty of the agent can undoubtedly be qualified as a result obligation.

Therefore, the agent is bound to inform the principal of the diligences submitted for the execution of the mandate; the mere completion of the mandate is not sufficient, as it must also be communicated to the principal, this obligation to inform being accesory to the duty to carry out the mandate in a diligent manner.

The obligation to give an account is not a purely accounting one. It not only requires the trustee to be held responsable for what he has received and what he 
has given upon the execution of his mandate, but it also involves the completion of a report on the measures taken to carry out the contract (Pétel, 1988: 367-440). Jurisprudence has established that exceptionally, in situations in which the specific relations between the contracting parties implies a very high degree of trust (the typical case being that of family relations), the possibility of tacit exemption of the trustee from the obligation to give an account may be accepted (Cass. civ., the $16^{\text {th }}$ of March 1892, D.P. 1892; Cass. 1re civ., the $7^{\text {th }}$ of January 1982, D. 1982).

The handing over of the account normally happens at the end of the contract, but the particularities of the mission entrusted to the agent may also require a presentation of the report during the execution of the mandate, so that the principal is kept up to date with the progress of the operations and that he could, if necessary, act himself for the successful completion of the business (obligation which also arises from the provisions of art. 2018 paragraph 2 of the Civil Code).

In a 2006 ruling of the French case-law (C. Ap. Aix-en-Provence, 1re ch., sect. A, the $7^{\text {th }}$ of March 2006), the Aix Court stated that, in the case of any mandate in common interest, the agent must regularly inform the principal of the preceedings undertaken, under the penalty that the principal, deprived of information, may revoke the mandate conferred. In this particular case, a woman died, leaving her inheritance to her three children and her husband. The husband received a mandate from the sons to make all the necessary steps on their behalf in order to obtain permission to devide a piece of land that was part of the succession and to carry out its division. A subdivision permit was issued, subject to the commencement of the works within 18 months of notification, under penalty of expiry of the permit. Two of the sons rewoked the mandate shortly before 18 months after receiving the permit. The father and the other son claim that the term of office has been revoked in an abusive manner, and that an appropriate compensation should be granted, corresponding to the value that would have been gained by the division of the land into lots. The Court pointed out that the power of attorney entrusted by several co-owners to one of them, in order to carry out an operation on a plot of land part of the succession, constitutes a mandate in common interest. In the absence of mutual consent of the parties, such a mandate may only be revoked for a legitimate cause recognized in court, such as the fault of the agent.

However, the agent did not inform the principals of the measures taken after the authorization was issued. Furthermore, he cannot show that, at the time of the revocation of the mandate, the works had begun, nor that he had concluded a contract with an undertaker to start them before the expiry of the permit. Therefore, the negligence of the trustee justifies the revocation of the mandate and excludes his right to compensation. Going even further, it can be said that a mandate in common interest, even if correctly carried out, may be legitimately revoked by the principal on the grounds that he has not been informed by the agent of the diligences undertaken and he has not been aware of them from elsewhere.

The duty to give an account obliges the agent to also keep the accounts for the operations carried out and to return the ammounts received from third parties, otherwise making himself liable even to a criminal sanction. For example, art. 243 of the Penal Code sanctions "the misappropriation of another's movable property, [...], or the non-delivery within 10 days from the moment he learned that the property did not belong to him." Art. 242 also criminalizes fraudulent management, 
consisting in "causing damage to a person, on the occasion of the administration or preservation of their assets, by the one who does or must take care of the administration or preservation of such assets." In a court case from 1985 (Cass. crim., the $12^{\text {th }}$ of November 1985), the administrator of a condominium received premiums from certain companies entrusted with the maintenance of the estate; because he did not include these ammounts in the accounts he gave to the coowners, he was convicted of breach of trust.

An important issue that had to be resolved by the courts was to decide whether the trustee's creditors could pursue his professional accounts.

The French courts (Cass. 1re civ., the $20^{\text {th }}$ of April 1983) have ruled that if the sums received from third parties have been placed into an ordinary account, they are part of the trustee's assets and therefore they are likely to be pursued by his personal creditors. The respective amounts, regardless of their origin, as long as a specially-designated account (or sub-account) was not set up for them, in order to allow their individualization, they could not be separated from the patrimony and the "bankruptcy" of the agent. However, if the amounts have been transferred to a special account, they are individualized and do not belong to the trustee, but to the principal, and can only be claimed by the creditors of the latter.

Of course, everything that the trustee receives for the principal enters directly into the principal's patrimony, the agent having only the quality of a holder of those assets; therefore, not being part of his patrimony, these ammounts cannot be pursued by his creditors; it is true, on the other hand, that if the sums received for the principal do not enter into a separate account, they cannot be differentiated from the other sums belonging to the agent, therefore the personal creditors of the trustee, having a right of general pledge over all his patrimonial assets, could pursue these ammounts. Therefore, the problem is to be able to individualize the goods belonging to the principal, as long as they are in the custody of the agent. Here, however, comes the obligation of the trustee to keep accounts of the operations carried out in the execution of the mandate, which also involves the opening of a special account for these amounts.

Thus, some professionals are required to keep separate accounts, such as lawyers, notaries, administrators of co-owners' associations. The file must be sent to the successor to the person in charge of the business. For example, jointlyowned property managers must open a separate account for each co-ownership association they manage, so that, in absence of the principals' agreement, the accounts cannot merge for debt settllement; this ensures the protection of the funds of each principal against the others' creditors, as well as against the agent's creditors.

In the case of the lawyer, the Council of the National Union of Romanian BarAssociations has established strict rules in this regard, in order to avoid the possibility of confusion of the assets held by the lawyer for his clients, either among each other, or between them and the lawyer's personal assets. This also diminishes the risk for the lawyer to use the assets of his clients for his personal benefit.

A matter of doctrinal discussion is the form in which this report must be delivered.

The French doctrine has stated that the trustee should be required to provide the principal with a true accounting, in accordance with the rules of the common law on the matter, and that the principal could demand his agent to provide detailed records of receipts and expenditure. It is therefore a question of keeping regular 
accounts, as it is not sufficient for the trustee to state as a whole what he has received and what he has spent, since that would only have the value of a statement and not that of an account. The trustee will be required to keep a management account, as well as send the principal the balance sheet periodically or at least at the end of his term of office. The agent will have to keep records and justify every single collection and expenditure made on behalf of the principal.

The French doctrine (Baudry-Lacantinerie, Wahl, 1907: 360) has shown that the agent will have to mention in the account both the receipts and the expenses, accompanied by supporting documents, which are necessary for the principal to be able to check the truthfulness of his statements. Also, if the agent is a trade professional, the principal may ask him to present the records; he may claim this even if the agent does not have the above-mentioned quality, if he has kept accounting records.

In the assets column, the agent must mention first of all the necessary advances and expenses that he has made in order to execute the mandate, according to art. 2025 paragraph 2 of the Civil Code: "The principal shall reimburse to the agent the reasonable expenses advanced by the latter for the completion of the mandate, together with the appropriate legal interests, calculated from the date when those expenses were made." Therefore, the assets will also include the interests on the amounts that the agent paid as an advance from the day that these expenses were made, as well as the fees, if applicable, according to art. 2027 of the Civil Code: "If the mandate is executed for a fee, the principal is obliged to pay the trustee the remuneration, even if, through no fault of the agent, the mandate could not be executed."

In the liabilities column, the agent must write all that he has received as such, regardless of whether what he has received was not actually due to the principal; this is normal, if we consider that the trustee received those goods for the principal, and not for himself. If those amounts or other received goods are not rightfully owed to the principal, the injured third parties will act against the principal for the refund of the undue payment and not against the trustee.

An author of the classical French legal doctrine (Laurent, 1887: 553) stated that the principal could not exempt the agent from the duty to give account, as this would be the very essence, not only the nature of the mandate: the obligation to manage the principal's affairs cannot exist without the duty to hand over the report of the management. Moreover, keeping the accounts would be the basis of the principal's claim against the agent, concerning the non-execution of the mandate or his fault committed in the performance of the tasks received. Therefore, to exempt the trustee from accountability to the principal implies to exonerate him from any liability, including fraud or gross negligence; such an agreement of the parties would be absolutely null and void, since it would violate public order and morals. However, according to the quoted author, the clause by which the trustee is exempted from liability could be valid, if the intention of the parties was not to conclude a mandate (which is a contract for the benefit of the principal -the free mandate- or of both contracting parties -the remunerated mandate-), but a liberality in the form of a mandate. The case-law has admitted exemptions from the obligation established by art. 1993 of the French Civil Code (art. 2019 of the Romanian Civil Code), justified by the intention of the contracting parties.

Thus, it mentions the case of a farmer from Santo Domingo who, having been in France for a long period of time, entrusted his father with a mandate empowering 
him to exploit the principal's agricultural estate, including selling or alienating any goods or civil fruits belonging to him, as if he were the owner of those assets, without being bound to any obligation to give an account. After the death of both contracting parties, the heirs of the principal requested from the heir of the trustee a report of management of the estatte, which the court of first instance also ordered. However, the Court of Appeal considered that the express waiver clause of the agent regarding the obligation to give an account was valid, taking into account the particular circumstances of the case: it was the intention of the wealthy son to make a donation for his poor father, which would provide him with the financial means to survive, by granting him the right to manage the farm without the obligation to hand over the management account. Therefore, the contract was declared valid, not as a mandate, but as a disguised donation, the jurisprudence admitting the validity of certain liberalities made in form of onerous acts.

In another case, the court stated that, as a general rule, all agents are bound to hand over the management account to the principal, but in order for this rule to apply, first of all, one must talk about a genuine mandate, not a liberal act disguised as a mandate, and secondly, the agent must have possessed those elements necessary for the execution of his mandate, which are needed to write and justify the management report.

As far as we are concerned, we are in favor of another approach of the French doctrine on the matter, which considers that the mandate is a contract essentially based on trust, therefore the obligation to give an account only characterizes its nature, without being essential (unlike the case of legal guardianship, for example, where the account due by the guardian is the essence of this institution); therefore, the principal may relieve the agent completely of this obligation, if the nature of the relationship between the parties implies such a degree of trust.

Both Romanian (Safta-Romano, 1999: 243) and French doctrine sugest the idea that, being in fact a matter of an act free of charge, the principal must have legal capacity to make the liberality, and the trustee to receive it. Attention was also drawn to the fact that some trustees cannot be relieved of this obligation to be held accountable, precisely the professional agents.

Therefore, we consider that a genuine account will have to be kept by the trustee only if the principal expressly requests so; since the law does not explicitly impose any form of this management, it is up to the principal to decide the form in which the accounts of the mandate will have to be highlighted and handed over.

This opinion has also been shared by courts repeatedly.

Thus, a decision of the French Court of Cassation (Cass. 1re civ., the $18^{\text {th }}$ of January 1989) established that it complied with the requirements of the Civil Code concerning the agents' report of accounting, "a private signature act by which the principals acknowledge that they have received in full amount the sums derived from the sale made the same day, for which they had given a mandate, and therefore give full discharge to their trustee."

Moreover, the French Court of Cassation (Cass. 1re civ., the $12^{\text {th }}$ of November 1957) ruled that the trustee's exemption from the obligation to hand over the accounts could be given by the principal even tacitly, as a result of the special nature of the parties' relations or other circumstances, which would make it 
impossible or unnecessary to perform this obligation. For example, handing over the management account is unnecessary when the principal exercises constant control over the agent, in which case the accounts are being presented to the principal as the trustee performs the operations undertaken. In one case, French case-law stated that a notary's assistant is not required to disclose to the notary the account of the transactions which he has carried out in pursuance of his immediate orders. This ruling is debatable: indeed, the obligation to hand over the account does not operate in this case, by virtue of the fact that it is difficult to identify the assistant as a trustee, since he has rather the position of an employee. For the same reason, jurisprudence has sometimes ruled that there is no obligation to hand over the accounts in the case of sons who act as trustees for their parents (Cass., the $12^{\text {th }}$ of January 1830), or in the case of the wife acting as trusttee of her spouse (Orléans, the $5^{\text {th }}$ of January 1859), in respect of those operations which the principals used to entrust to the respective agents. However, in all these cases, it was stated that these persons had the obligation to keep accounts of the acts concluded on behalf of their principals beyond the limits of their usual duties.

We believe that, despite the existence of close family relations between these contractors, the presence of an obligation to report cannot be excluded. It is true that in practice such a duty is rarely agreed upon by close relatives, the mandate being given to them precisely because of the trust they inspire, but this does not mean that its existence must be ruled out from the start. Even if the obligation had not been verbally agreed, the presumption of such a tacit agreement between the parties could derive from the specific circumstances of the case. We feel that moral rather than legal considerations made the judges dismiss this presumption: it is indeed uncomfortable to identify a son as his mother's agent or a wife being in the position to present her husband with an accounting report. However, such an obligation is not inconceivable, especially under the provisions of the new Civil Code, which regulates the relations between spouses in a much more pragmatic manner, no longer starting on the presumption that there is always complete mutual trust between spouses, as the old Civil Code did. Presently, since there is the possibility for the spouses to choose the separation of patrimonies, it is not unimaginable that they would expect an accounting report in case of a management mandate.

Nevertheless, the issue of the existence of a tacit relief by which the trustee is exempted from the obligation to give an account must be looked upon in a particular manner if the spouses opt for the legal or conventional community of property regime, due to the special nature of the principal-agent relationship.

In case of the legal community of property, the spouses voluntarily agree with a legal framework which is extremely permissive in relation to the freedom that they have in managing jointly-owned goods. Thus, under the presumption of a mutual mandate of representation, any of the co-owners has the right to use the jointlyowned property by himself, without the express consent of the other, with the only limitation of not changing its destination. Also, each spouse has the right to conclude acts of preservation or administration of the jointly-owned property by himself, as well as to acquire such goods. To the extent that his interests in the community of property have been harmed, the spouse who has not participated in the completion of those acts may only claim damages from the other, without causing prejudice to the rights of bona fide third parties. Moreover, any of the 
spouses may dispose by himself of the movable property for which the law does not require specific publicity formalities. Under these legal regulations, which provide for a very permissive regime and for extended rights of the spouses in managing and even alienating certain jointly-owned assets, it is obvious that any of the spouses may exempt the other, even tacitly, from any duty of report; however, the Civil Code (art. 345 paragraph 4) explicitly regulates the right that the injured spouse has to claim damages, if his patrimonial interests were harmed. Still, this does not imply that it is inconcievable for the spouses not to have waived the obligation to report, but only that the court must take into consideration the nature of the contracting parties relation when assessing the probability of a tacit dispensation.

As regards the situation of the conventional community of property, the presumption that there is a tacit exemption between spouses regardind the holding and delivery of accounts will be assessed according to the intention of the spouses when they opted for this marital regime. If the spouses wanted to put even more trust and freedom into their patrimonial relations, by including personal assets and debts in the community, then it is very likely that there is a tacit exemption from accounting or handing over a report. However, if, on the contrary, the spouses' intention was to restrict the specific freedoms of the legal community of property, then the court will have to assess more reluctantly the possibility of a tacit waiver of the right to claim a report on the management of jointly-owned property.

The agent is held accountable to the principal, as well as to his successors or representatives. Art. 2037 of the Civil Code establishes the existence of certain obligations of the agent even after the termination of the mandate in any way, such as the duty to hand over the accounts of the mandate and to pay the interests due for the amounts he used for his personal benefit or with which he remained indebted towards the principal; these duties will be performed towards the successors/representatives of the principal. Moreover, art. 2030 of the Civil Code stipulates that, if the mandate implies the conclusion of successive acts within an activity that is continuous and in progress, it will continue, despite the occurrence of a cause for termination, except for the situation in which the contracting parties or their successors want to revoke it.

It is possible that the person who gave the mandate does not have any qualifications to receive the handover of the management accounts. For example, if the legal representative of an incapacitated individual gave the mandate and that person has regained legal capacity in the meantime, the report will have to be handed over to the person on whose behalf the mandate was given. The legal doctrine (Laurent, 1887: 575) has discussed an interesting issue, related to the situation in which the mandate was given by the apparent heir, who was later removed from the succession by means of a petition for inheritance, before the accounts of the mandate were handed over; it is obvious that the report will not be handed over to the apparent heir, who has lost their quality in relation to the succession, by virtue of which he had conferred the mandate; the trustee actually worked for the real heir, to whom he will therefore have to hand over the management account. 


\section{References:}

1. Baudry-Lacantinerie, G., Wahl, A. (1907) Traité théorique et pratique de droit civil, tome 24, Des contrats aléatoires. Du mandat, du cautionnement, de la transaction, 3ième èd., Librairie S.R.S.J.P., Paris, pp. 359-360

2. Dănișor, D. C. (2006) Considerații privind contractul de mandat: accepțiuni și evoluții ale termenului în drept, Revista de științe juridice 2/2006

3. Dutilleul, F. C., Delebecque, Ph. (1998) Contrats civils et commerciaux, 4e ed., Dalloz, Paris, pp. 492-493

4. Laurent, F. (1887) Principes de droit civil français, tome XXVII, Librairie A. Marescq, Paris, pp. 553-575

5. Pétel, Ph. (1988) Les obligations du mandataire, Litec, pp. 367-440

6. Safta-Romano, E. (1999) Contracte civile. Încheiere. Executare. Încetare, Ed. Polirom, lași, pp. 243 


\title{
NON-PROFIT ORGANIZATIONS DENSITY, SOCIALLY VULNERABLE CATEGORIES AND ECONOMICAL DEVELOPMENT FROM VOLUNTARY AND GOVERNMENT FAILURE THEORIES PERSPECTIVE
}

\author{
Nemțeanu Marcela-Sefora1, Coita Dorin-Cristian², Tarcza Mihaela-Teodora ${ }^{3}$ \\ ${ }^{1}$ Marketing Department, Faculty of Economics and Business Administration; \\ Babeș Bolyai University, Cluj-Napoca, Romania. \\ 2,3. Management and Marketing Department, Faculty of Economic Sciences, \\ University of Oradea, Oradea, Romania \\ seforanemteanu@gmail.com
}

\begin{abstract}
Non-profit organizations have an important role in democracy development, volunteering and in providing support for disadvantaged social categories whose access to social and medical services or to goods of current necessity is reduced. Recent studies prove that local social sustainability correlates to non-profit organizations density at a local or regional level. Previous research encompasses two directions for the study of the role of non-profit organization the first is supported by the Theory of Government and Market Failure, and the second by the Theory of Voluntary Failure. The Theory of Government and Market Failure starts from the assumption that non-profit sector developed as a result of the need for social services provided to categories of population for whom government and market failed to provide to an affordable price or constantly. The Theory of Voluntary Failure starts from the assumption that non-profit sector plays the most important role in case of socio-economic crises or catastrophes but for organizations to perform well the support of the state is needed. This research aim is the assessment of non-profit density correlation to economic development and percentage of the social vulnerable population in Romania. This paper brings theoretical contribution to the study of the non-profit density, to the Theory of Government and Market Failure and to the Theory of Voluntary Failure and practical implications to an emerging economy.
\end{abstract}

Keywords: non-profit organizations density, social vulnerable categories, economic development, GDP per capita, Voluntary Failure Theory, Government Failure Theory.

JEL Classification: 131, 138, L31.

\section{Introduction}

The non-profit sector in Romania in its current form has developed mainly after 1989, since then experiencing an exponential development (Sana, 2014; Nemțeanu \& Tarcza, 2016). However, non-profit organizations in Romania are not yet uniformly developed, their development being facilitated or limited depending on the local policies and the degree of development (Andersen et al., 2017) but also on the possibility of correlating the demand for social support of vulnerable categories with the supply of these entities that take over managerial models and methods to create a social impact (Ballestros \& Gatignon, 2019). In this context, the study of non-profit organizations, their development and how they meet the 
needs of the society, is still at an exploratory level, requiring much more research to contribute to the clear dimensioning of the non-profit sector but also in terms of the factors that contribute to its development (Andersen et al., 2017).

Previous academic research highlights two broad directions in assessing the role of non-profit organizations, namely an approach to the Government and Market Failure Theories (Salamon, 1987) that start from the assumption that the non-profit organizations meet the needs of social categories that cannot afford services or for that there is no acceptable supply of services and goods. The second approach is the Voluntary Failure Theory (Salamon, 1987), or interdependence (Săveanu, 2011) which starts from the presumption that the non-profit organizations develop only when they are supported, their development being directly proportional to the support from part of the state. Through this paper we aim to analyze the premises for the development of non-profit organizations in the context of an emerging economy such as Romania, through this objective covering a gap in the research on exploring the theoretical implications of nonprofit organizations based on data covering the entire situation of the non-profit sector. The paper includes a review of the literature, a development of the research methodology, based on the Correlation Analysis by Pearson's coefficient and a section of discussions and conclusions of the research.

\section{Literature review}

\subsection{Government and Market Failure Theories and non-profit sector development}

The concept of non-profit density has received widespread interest in the last decade, being calculated as the percentage of non-profit organizations in terms of population (Kim, 2013; Lecy \& Van Slyke, 2013; Van Puyvelde \& Brown, 2016; Witesman, 2016). However, the increase in non-profit density is influenced by a wide variety of stakeholders (Van Puyvelde \& Brown, 2016). Previous research conducted between different regions in the United States shows that potential beneficiaries play a key role in increasing the density of the non-profit organizations, which is higher where social disparities are high and social inequalities and problems are pronounced in the community, and the need for social services is high (Kim, 2013). Community heterogeneity is positively associated with the development of the density of non-profit organizations being associated with fragmented and decentralized government leadership in another study conducted in the US regions (Jeong \& Cui, 2020). Thus, we can conclude that the role of the non-profit organizations is to meet the precarious social needs covered by the government or the market, which confirms Government and Market Failure Theory assumptions.

The research at the EU level highlights an indicator in the analysis of vulnerable categories of the population, namely the population at risk of social exclusion (Eurostat, 2020a). This risk can be due to a high degree of poverty, lack of employment opportunities, access to basic services and goods and includes various demographic categories (Kwilinski et al., 2020). Social exclusion population is represented of people found at risk of poverty (Eurostat, 2020b). Different countries have different politics on combatting social exclusion, one of the interventions consisting in providing social aid for guaranteed minimum wage (Stroe \& Cojanu, 2017). State intervention is often associated to non-profit organizations aid providing with services and products, donations and help for 
persons at risk of poverty (Schinnerl \& Greiling, 2019). Based on the previous arguments we conclude that:

H1: Non-profit density growth is correlated to social aid for guaranteed minimum wage.

\subsection{Voluntary Failure Theory and non-profit sector development}

Voluntary Failure Theory or Interdependence Theory (starts from the premise that the non-profit organizations are more developed where there is higher economic development and they receive support from the government through funding or other leverage (Lecy \& Van Slyke, 2013).

From Voluntary Failure perspective, non-profit organizations play the most important role in cases of disasters and socio - economic crises (O'Donovan, 2015) but in order to achieve their objective they depend on the support of state institutions and companies (Săveanu, 2011). The non-profit density is according to previous results (Lecy \& Van Slyke, 2013) positively influenced by the government support that can come through funding. Starting from the highlighted results of the research, we suggest the following hypothesis:

H2: Non-profit density is correlated with economic development.

\subsection{Economic development and social exclusion risk}

The gross domestic product is an internationally relevant indicator in measuring the economic development and the population welfare (Clarke \& Islam, 2003). On the other hand, the risk of social exclusion is an indicator of the estimation of the lack of welfare and impoverishment of the population in an analyzed region (Kwilinski et al., 2020).

The economic development contributes to the reduction and even eradication of poverty among the population over time and, respectively, to the reduction of the number of people in social exclusion (Sinding, 2009; Cremin \& Nakabugo, 2012). A recent concept that aims to reduce the percentage of the population in social exclusion being the Sustainable Development Goals (UN, 2014; Hák et al., 2016), taken over internationally based on the orientation towards efforts for economic development in different sectors (Cremin \& Nakabugo, 2013). In European Union social exclusion is defined as people at risk of poverty if they have a disposable income below the $60 \%$ of the national medial equivalized disposable income (Eurostat, 2020b). In Romania people with below guaranteed income benefit of social aid for guaranteed minimum wage the number of beneficiaries differing from county to county according to National Agency for Payments and Social Inspection (2019) data. Based on the presented arguments we propose the hypothesis:

H3: Economic development is correlated with social aid for minimum wage.

\section{Research Methodology}

\subsection{Research Context}

Romania is a developing economy (Dabija \& Bejan, 2018), with a past in the communist regime (Nemțeanu \& Dabija, 2020b), in which, democracy and in aftermath non-profit organizations have developed significantly in recent decades (Coita, 2008; Andersen et al., 2017). Non-profit organizations became providers for social services, services for youth, educational, medical, civic, entertainment, consumer protection, animal protection, religious and other services contributing to community development and civic engagement (Andersen et al., 2017). 


\subsection{Research methodology}

This research was conducted starting from secondary Eurostat databases (2020a; 2020b), the Register of Non-profit Organizations (MJR, 2019) and the Statistical Yearbook of Romania (National Institute of Statistics, 2019). Statistical analyzes were performed based on the distribution of indicators: non-profit organizations density, GDP / capita and Social Exclusion Risk population in the 8 regions of Romania as defined by the European Commission (Eurostat, 2020a). In Romania there are currently over 100,000 non-profit organizations; at the time of the analysis there are at national level a number of 119,430 entities in this sector.

\section{Figure no. 1. Non-profit organizations Density at 1000 inhabitants Romania} $(\mathrm{N}=119.430)$

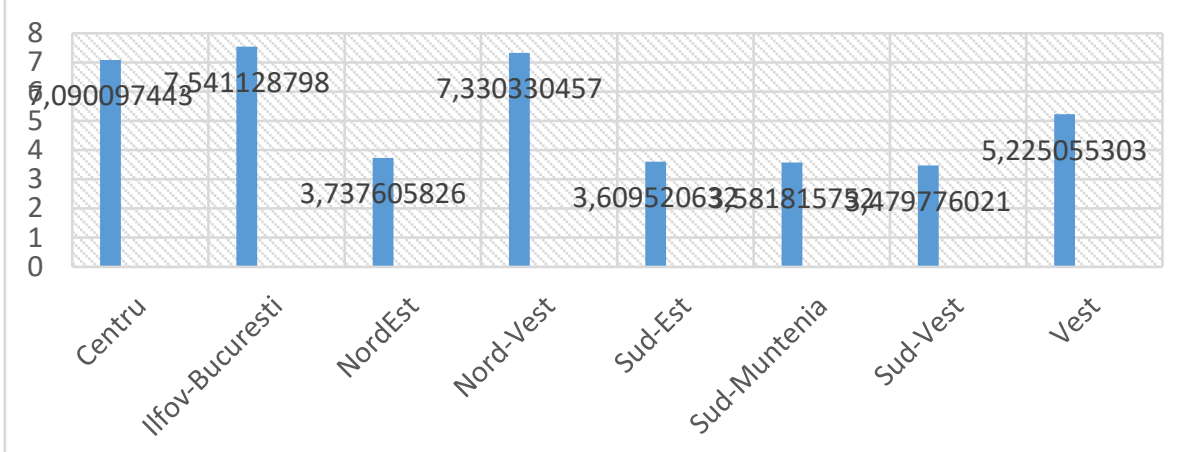

Source: Data processed by the authors of the research taken from the Register of non-profit organizations (MJR, 2019), and the Statistical Yearbook (2020) for the data regarding the Romanian population in 2019.

Based on the processed data. As can be seen in figure no. 1, the llfov-Bucharest region, North-West and Center region have a number of over 7 non-profit organizations per 1000 inhabitants. At the opposite pole there is the Southeast region with only 3.6 non-profit organizations per 1.000 inhabitants.

Figure no. 2. Non-profit organizations at 1000 inhabitants per county, $\mathbf{N}=42$

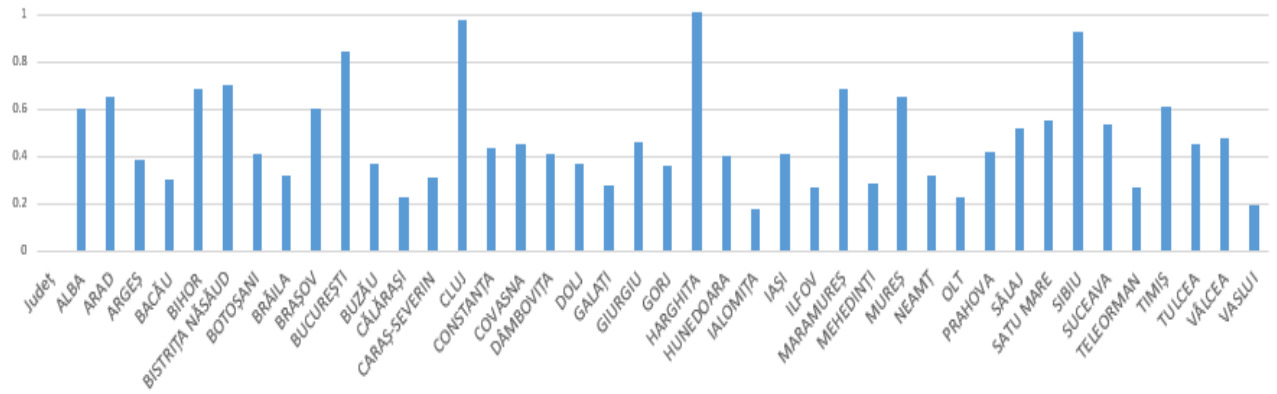

Source: Data processed by the authors of the research taken from the Register of non-profit organizations (MJR, 2019), and the Statistical Yearbook (2020) for the data regarding the

Romanian population in 2019. 
As it is presented in Figure no. 2 counties with highest density at 1.000 inhabitants are Cluj and Harghita, followed by Sibiu, these counties having close to one organization at 1.000 inhabitants. The lowest non-profit organizations density is found in lalomița and Vaslui with 2 organizations at 10.000 inhabitants.

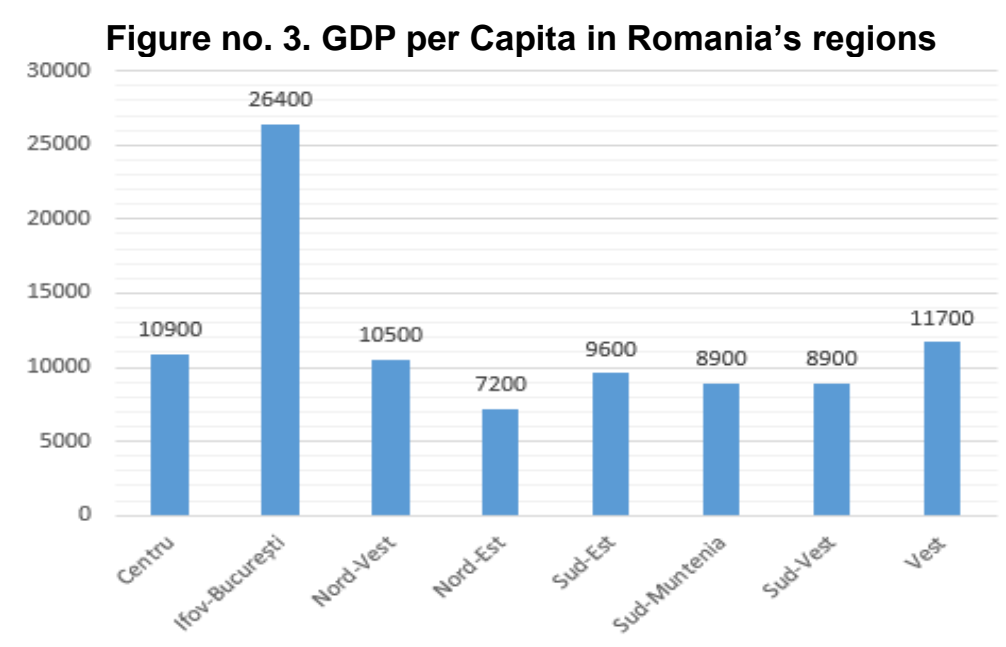

Source: Eurostat (2020a) Regions and Cities Illustrated (RCl). Gross domestic product (PPS per inhabitant), 2019.

https://ec.europa.eu/eurostat/cache/RCI/\#?vis=nuts2.economy\&lang=en accessed 03.03.2020

A relevant indicator in this research related to non-profit organizations density is GDP / capita understood as an indicator of regional economic development (Eurostat, 2020b), As can be seen in figure no. 3, the Ilfov-Bucharest region shows a significantly more alert economic development compared to other regions, being followed by the North-West region, respectively by the Western region.

Figure no. 4. GDP per Capita in Romania's counties, $\mathrm{N}=42$

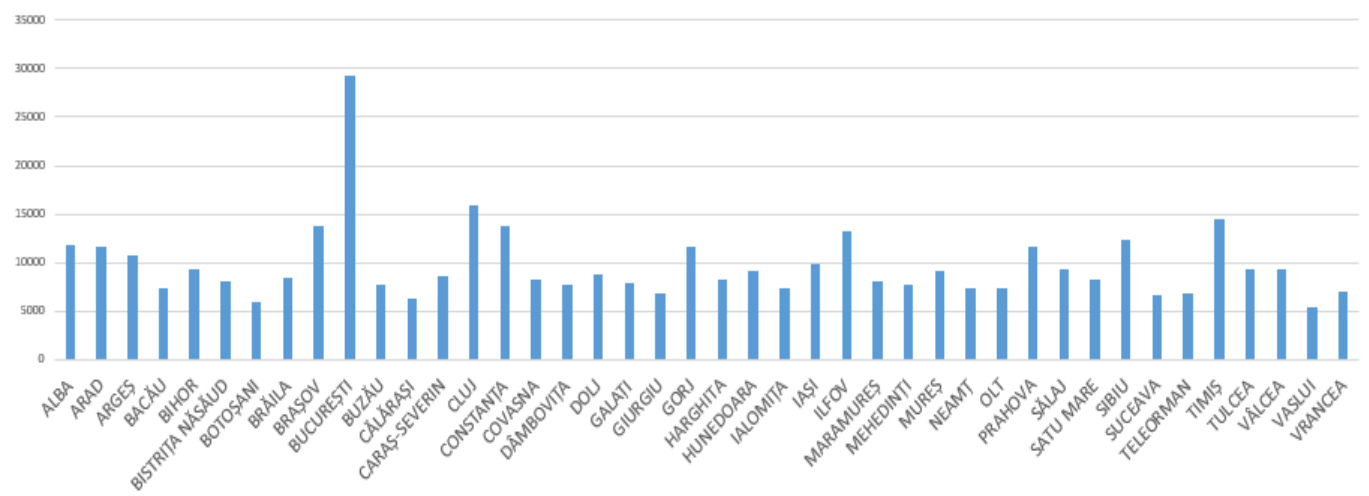

Source: National Commision for Strategy and Prognosis, 2021.Prognosis 2020-2024 in teritory, GDP per Capita 2019.

https://cnp.ro/wp-content/uploads/2021/07/PROGNOZA_2020_2024_in_profil_teritorial.pdf 
According to figure no. 4 GDP per capita is highest in Bucharest (29.175 Euro/inhabitant) followed by Cluj (15.890 Euro/inhabitant), Brașov (13.826 Euro/inhabitant) and Constanța (13.741 Euro/inhabitant). The lowest value for GDP per capita is found in Vaslui (5.462 Euro/inhabitant) followed by Botoșani (5.972 Euro/inhabitant) and Călărași (6.300 Euro/inhabitant).

\section{Figure no. 5. People at risk of poverty or social exclusion in European Union}

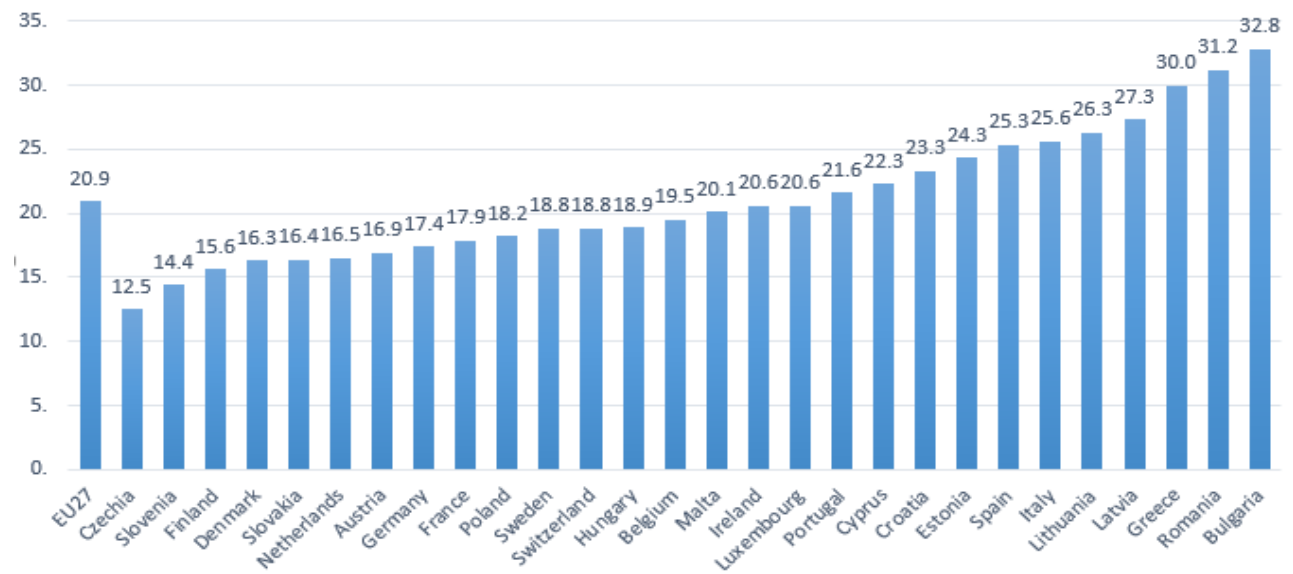

Source: Eurostat (2020b),

https://ec.europa.eu/eurostat/databrowser/view/sdg_01_10/default/table?lang=en

According to Eurostat (2020b) data, as it can be observed in figure no. 5, Romania has the second highest rate of people at risk of poverty or social exclusion with a rate of $31.2 \%$ in European Union, Bulgaria representing the country in UE with the highest rate of $31.8 \%$. The two countries have with more than $10 \%$ more population in risk of poverty and social exclusion than the average of European Union that is of $20.9 \%$.

Figure no. 6. People at risk of poverty or social exclusion at $\mathbf{1 . 0 0 0}$ inhabitants

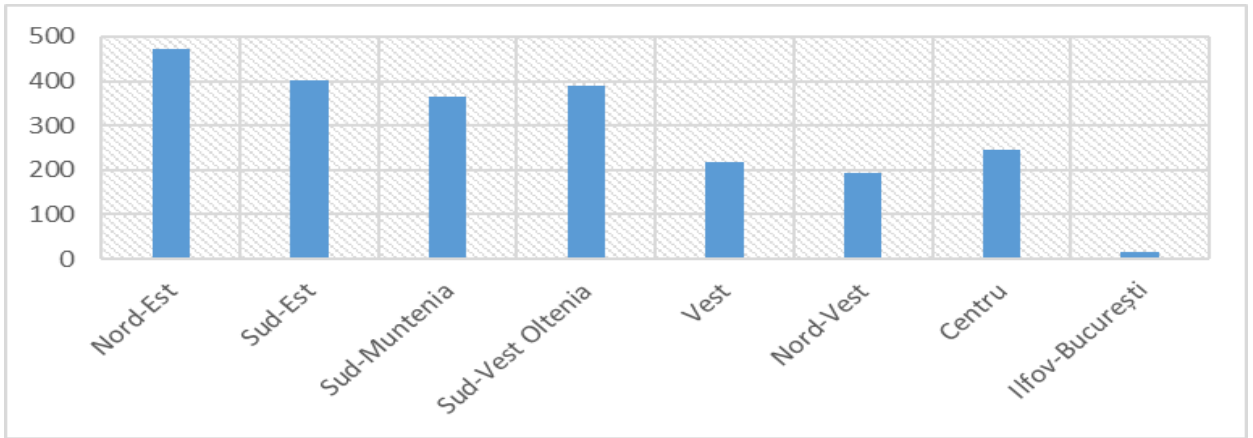

Source: Eurostat (2020b) . People at risk of poverty or social exclusion by NUTS 2 regions, 2019 https://ec.europa.eu/eurostat/databrowser/view/tgs00107/default/table?lang=en 
As can be seen in figure no. 6, in the North-East Region the percentage of the population at risk of social exclusion is over $47 \%$. At the opposite pole, the llfovBucharest region includes the smallest population rate at risk of social exclusion.

\section{Figure no. 7. Number of beneficiaries of Social Aid for Guaranteed Minimum} Income, $\mathrm{N}=42$

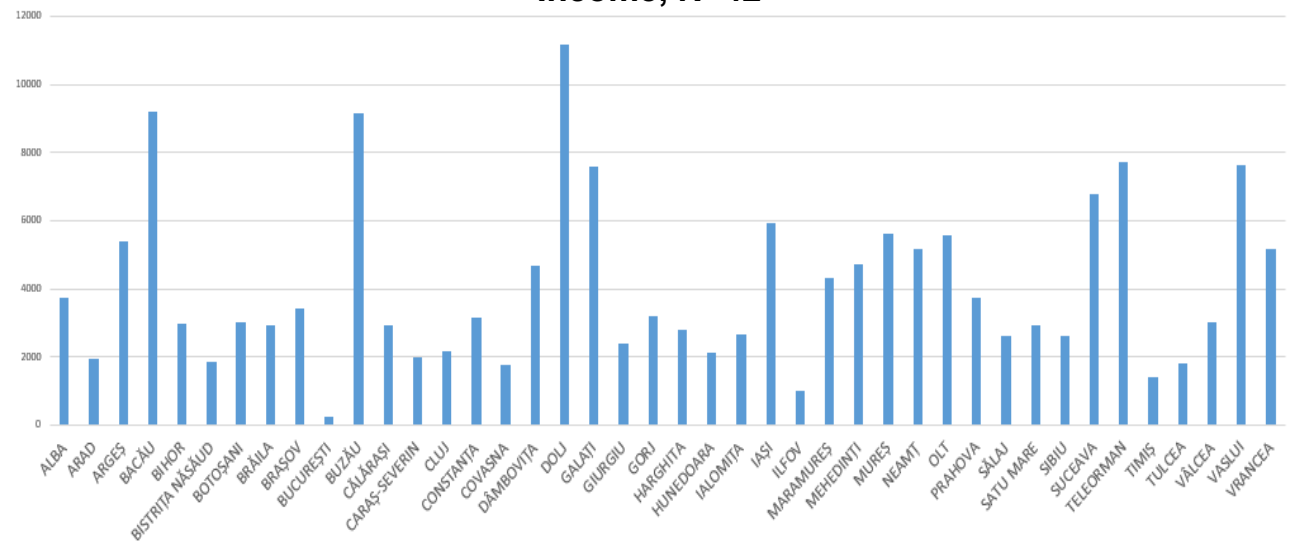

Source: National Agency for Payments and Social Inspection. 2019. Report on Social Aid (Guaranteed Minimum Income) December 2019. file://IC:NMG_Decembrie_2019.pdf

In combatting social exclusion, social aid is provided to personas that are resident in Romania and have the net monthly income is lower than guaranteed minimum income (Stroe \& Cojanu, 2017). According to the public data of National Agency for Payments and Social Inspection (2019) presented in figure no. 7 the counties with highest number of beneficiaries of social aid are Dolj with 11.188 beneficiaries followed by Bacău with 9.176 beneficiaries and Buzău with 9.164. Counties with the lowest number of social aids for guaranteed minimum income are Bucharest with 240 beneficiaries followed by llfov with 1.023 beneficiaries and Timiș with 1.414 beneficiaries.

\subsection{Correlation Analysis results}

The purpose of the research consists in the emphasizing of the linkage between non-profit organizations density to economic development and social exclusion. The research methodology is secondary data analysis.

Selected data was the number of non-profit organizations per county according to the Register of Non-profit Organizations (MJR, 2019), GDP per capita according to National Commission for Strategy and Prognosis, (2021) and social aid for guaranteed minimum wage per counties for December 2019 according to National Agency for Payments and Social Inspection, (2019).

Selected data were processed using the SPSS20 program to test the hypotheses by parametric Correlation analysis based on Pearson's coefficient (Malhotra \& Birks, 2006). Pearson Correlations has been previously used in analysis of the linkage of GDP per capita and other indicators (Peck \& Pressman, 2013). 
Table. no. 1. Correlations analysis results $\mathrm{N}=42$

\begin{tabular}{llrrr}
\hline Variables & & NPODensity & GDPperCapita & \multicolumn{1}{c}{ SAGMIB } \\
\hline \multirow{5}{*}{ NPODensity } & Pearson Correlation & 1 & $.504^{* *}$ & $-.400^{* *}$ \\
& Sig. (2-tailed) & & .001 & .009 \\
& $\mathrm{~N}$ & 42 & 42 & 42 \\
& Pearson Correlation & $.504^{* *}$ & 1 & $-.437^{* *}$ \\
GDPperCapita & Sig. (2-tailed) & .001 & & .004 \\
& $\mathrm{~N}$ & 42 & 42 & 42 \\
& Pearson Correlation & $-.400^{* *}$ & $-.437^{* *}$ & 1 \\
SAGMIB & Sig. (2-tailed) & .009 & .004 & \\
& $\mathrm{~N}$ & 42 & 42 & 42 \\
\hline
\end{tabular}

Note: **. Correlation is significant at the 0.01 level (2-tailed). NPODensity - Non-profit organizations density; GDP per Capita - Gross Domestic Product per capita; SAGMIB Social ai for Guaranteed minimum Income Beneficiaries.

The results of the correlation analysis show that non-profit organization density is inverse proportional correlated with social aid for guaranteed minimum income number of beneficiaries $(0.400 ; p$-value $<0.01)$ Hypothesis 1 being accepted of negative values. We can say that where the need for social aid is higher and social exclusion is higher, the development of the sector is lower, the link between the two variables being inversely proportional. These results lead to the acceptance of the $\mathrm{H} 1$ hypothesis, stating that the results regarding the meaning of influence are surprising and in opposition to the assumptions of the Market and Government Failure Theory. Regarding the link with GPD per Capita, the regional economic development is positively correlated with the density of non-profit organizations (proportional $(0.504 ; p$-value $<0.01)$, so we can conclude that the $\mathrm{H} 2$ hypothesis is accepted. At the county level there is a strong interdependence between the economic development and the growth of the non-profit sector, the results confirming theoretical assumptions of previous research (Salamon, 1987; Săveanu, 2011; Nemțeanu \& Dabija, 2020a). The linkage of GDP per Capita and social aid for guaranteed minimum income is inverse proportional $(-0.436 ; p$-value $<0.01)$ which leads to the acceptance of hypothesis $\mathrm{H} 3$ confirming similar research results that underline the negative linkage between economic development and social exclusion (Sinding, 2009; Cremin \& Nakabugo, 2012).

\section{Conclusions}

The present paper brings contributions on Government and Market Failure Theory respectively Voluntary Failure Theory, contributing to the understanding of the implications of these theories in terms of non-profit organizations density in relation to the economic development through GDP / capita and social aid for guaranteed minimum wage number of beneficiaries.

The practical implications of the paper are to emphasize the importance of the non-profit organization density indicator in relation to other national indicators in 
order to correlate the development need of the non-profit sector to fight against social problems such as the risk of social exclusion that may manifest in various forms. The results show that non-profit organizations are positively correlated to economic development measured by GDP per capita which is a confirmation to previous research on the interdependence of non-profit sector to economic and state institutes.

The problem of social exclusion is more prominent in Romania, the percentage of population affected by poverty being higher that European Union average. The development of non-profit sector is indirect proportional to the number of people that need financial support from state institutions as being in poverty risk and social exclusion. The solution for the regions and counties more affected by poverty in Romania could be the development of non-profit organizations and raise of non-profit density with the support of state institutions and business entities.

The limits of the research consist in the strictly local approach to the issue, and the evaluation of a small number of indicators. Future directions of research may complement the research in order to assess other factors that generate such an acute shortage of non-profit organizations in regions with a significant percentage of social aid for guaranteed minimum income beneficiaries as an indicator of social exclusion.

\section{References:}

1. Andersen, S., Angi, D., Barna, C., Burada, V., Burean, T., Constantinescu, S., Dumitrescu, V., Kivu, M., Nicovescu A., Opincaru, S.I., Pop, A., Radu, B., 2017. România 2017 Sectorul Neguvernamental. Profil, Tendințe, Provocări. București: Fundația pentru Dezvoltarea societății Civile.

2. Ballestros, L. and Gatignon, A., 2019. The relative value of firm and nonprofit experience: Tackling large-scale social issues across institutional contexts. Strategic Management Journal, 40(4) pp.631-657.

3. Clarke, M., Islam, S. M., 2003. Measuring social welfare: application of social choice theory. The Journal of Socio - Economics, 32(1), 115. doi:10.1016/s1053-5357(03)00010-6.

4. Cremin, P., Nakabugo, M. G., 2012. Education, development and poverty reduction: A literature critique. International Journal of Educational Development, 32(4), 499-506. doi:10.1016/j.ijedudev.2012.02.0

5. Coita, D.C., 2008. Marketingul organizațiilor nonprofit. București: Editura Academiei Române.

6. Dabija, D.C. and Bejan, B.M., 2018. Sustainability reporting of grocery retailers on an emerging market. In: Pleșea, D., Vasiliu, C., Murswieck, A., Pamfilie, R., Dinu, V., Tăchiciu, L., Olaru, M. (Eds.). Fourth BASIQ International Conference on New Trends in Sustainable Business and Consumption. Heidelberg, Germany, 11-13 June 2018. Bucharest: Editura ASE. (pp.611-619).

7. Eurostat, 2020a. Regions and Cities Illustrated (RCl). Gross domestic product (PPS per inhabitant), 2019. [online] Available at <https://ec.europa.eu/eurostat/cache/RCl/\#?vis=nuts2.economy\&lang=en> [Accessed in 30.03.2020]. 
8. Eurostat, 2020b. People at risk of poverty or social exclusion [online] Available at <https://ec.europa.eu/eurostat/databrowser/view/tgs00107/default/table?la $\mathrm{ng}=\mathrm{en}>$ [Accessed in 30.03.2020].

9. Hák, T., Janoušková, S., Moldan, B., 2016. Sustainable Development Goals: A need for relevant indicators. Ecological Indicators, 60, 565573. doi:10.1016/j.ecolind.2015.08.003.

10. Jeong, J., Cui, T.S., 2020. The Density of Non-profit Organizations: Beyond Community Diversity and Resource Availability. Voluntas, 31, 213226. https://doi.org/10.1007/s11266-019-00175-8.

11. Kim, M., 2013. Socioeconomic Diversity, Political Engagement, and the Density of Non-profit Organizations in U.S. Counties. The American Review of Public Administration, 45(4), pp. 402416. doi:10.1177/0275074013504616.

12. Kwilinski, A., Vyshnevskyi, O., Dzwigol, H., 2020. Digitalization of the EU Economies and People at Risk of Poverty or Social Exclusion. Journal of Risk and Financial Management. 13(7):142. https://doi.org/10.3390/jrfm13070142.

13. Lecy, J.D., Van Slyke, D.M., 2013. Non-profit Sector Growth and Density: Testing Theories of Government Support, Journal of Public Administration Research and Theory, 23(1), pp. 189214, https://doi.org/10.1093/jopart/mus010.

14. MJR, 2019. Register of nongovernmental organizations. Ministerul Justiției. [online] Available at <http://www.just.ro/registrul-national-ong/> [Accessed 12 Decembrie 2019].

15. Malhotra, N. K., Birks, D. F., 2007. Marketing Research. An Applied Approach, Third Edition. London: Prentice Hall.

16. National Institute of Statistics. 2019. Romanian Statistical Yearbook.

17. National Agency for Payments and Social Inspection, 2019. Report on Social Help (Guaranteed Minimum Income) December 2019. [online] $<$ file:///C:/VMG_Decembrie 2019.pdf> [Accessed in 03.02.2021].

18. Nemțeanu, M.S., Dabija, D.C., 2020a. Best practices of nongovernmental organisations in combatting Covid-19. In: R. Pamfilie, V. Dinu, L. Tăchiciu, D. Pleșea, C. Vasiliu eds. 6th BASIQ International Conference on New Trends in Sustainable Business and Consumption. Messina, Italy, 4-6 June 2020. Bucharest: ASE.

19. Nemteanu, M.S., Dabija, D.C., 2020b. The Influence of Heavy Work Investment on Job Satisfaction and Turnover Intention in Romania. Amfiteatru Economic, 22(14), pp. 993-1013.

20. Nemteanu, S.M., Tarcza, T.M., 2016. Volunteers Trust in Organizational Mission, Leadership and Activities Efficiency", Analele Universităţii din Oradea, 25(1), pag. 995-1002; ISSN 1222 - 569X, ISSN 1582 - 5450.

21. O'Donovan, K., 2015. Disaster Recovery Service Delivery. Administration \& Society, 009539971562223. doi:10.1177/0095399715622231.

22. Peck, M., Pressman, M. A., 2013. The correlation between burn mortality rates from fire and flame and economic status of countries. Burns, 39(6), 1054-1059. doi:10.1016/j.burns.2013.04.010

23. Sana M.S., 2014. Donating Behaviour in the Nonprofit Marketing Context: An Empirical Study Based on the Identity Theory Model. In: Marketing - 
from information to decision $7^{\text {th }}$ International Conference Proceedings, Cluj-Napoca: Risoprint (pp.230-247), ISSN-L: 2067-0338.

24. Săveanu, T.G., 2011. Forme de participare la viața comunității, complementaritate sau opoziție? Cluj-Napoca: Presa Universitară Clujeană, ISBN: 978-973-595-662-2.

25. Salamon, L.M., 1987. Of Market Failure, Voluntary Failure, and Third-Party Government: toward a Theory of Government-Non-profit Relations in the Modern Welfare State. Journal of Voluntary Action Research, 16, pp.29-49.

26. Schinnerl, M., Greiling, D., 2019. Urban Poverty in Europe - Poverty Reduction Policies and Measures. Review of Applied Socio-Economic Research, 18(2), 118-128.

27. Sinding, S. W., 2009. Population, poverty and economic development Philosophical Transactions B, 364, pp. 3023-3030.

28. Stroe, C., Cojanu, S.-F., 2017. Incidence of Poverty among Large Households and the Alleviating Effects of the Guaranteed Minimum Income in Romania. LUMEN Proceedings, 1, pp. 864-875. https://doi.org/10.18662/lumproc.rsacvp2017.79

29. UN, 2014. Millennium Development Goals Report 2014. United Nations, New York.

30. Van Puyvelde, S., Brown, W.A. 2016. Determinants of Nonprofit Sector Density: A Stakeholder Approach. Voluntas 27, pp. 1045-1063 https://doi.org/10.1007/s11266-015-9656-1.

31. Witesman E. M., 2016. An Institutional Theory of the Nonprofit: Toll Goods and Voluntary Action. Non-profit and Voluntary Sector Quarterly. 45(4):97S-115S. doi:10.1177/0899764016651729. 


\title{
THE WAY IN WHICH BIHOR COUNTY'S MOUNTAIN GUESTHOUSES ARE USING SOCIAL MEDIA TO ATTRACT CUSTOMERS
}

\author{
Naiana TुARCĂ \\ Faculty of Economics, University of Oradea, Oradea, Romania \\ ntarca@uoradea.ro
}

\begin{abstract}
The owners of the guesthouses in the mountain areas of Bihor County trying to attract guests using more and more social media channels. Their presence on social media channels plays an important role due to the fact that an increasing number of tourists are searching for information by the means of these channels. In this study, we analyzed the presence of the mountain area Bihor County guesthouses on social media channels. We also studied the way in which different social media channels are used by the owners of the guesthouses to attract guests and also the attention paid to each of them.
\end{abstract}

Keywords: online marketing, social media, touristic guesthouses

JEL classification: M31, C83

\section{Introduction}

It is well known that the number of social media users is constantly growing, both globally and in our country.

According to (Tankovska, Jan 28, 2021) in 2020 the number of social media users worldwide was more than 3.6 billion, expected to reach more than 4.41 billion in 2025.

The presence of tourist guesthouses on social media channels is important because the number of tourists who inform themselves about tourist destinations using social media channels is increasing.

It has also been found that tourists are increasingly influenced by social media in choosing their tourist destination. According to (Tussyadiah and Fesenmaier, 2009) social media increasingly influence decisions on destination selection.

According to (Jorge et al. , 2020) there is a growing interest in the use of social media in the tourism industry.

According to (Dehghani and Tumar, 2015) the use of social media in service promoting activities "attract consumers' attention and address customization of their needs".

The diversity of social media channels is vast and constantly changing.

Among the multitude of available social media channels, tourist guesthouses are increasingly using social networks to attract their guests. This is because the number of people who are getting information on social networks about tourist destinations is increasing.

According to (Tankovska, Feb 9, 2021), worldwide "social networking sites are now estimated to have 3.6 billion users".

The most popular social networks worldwide are shown in Figure 1. 


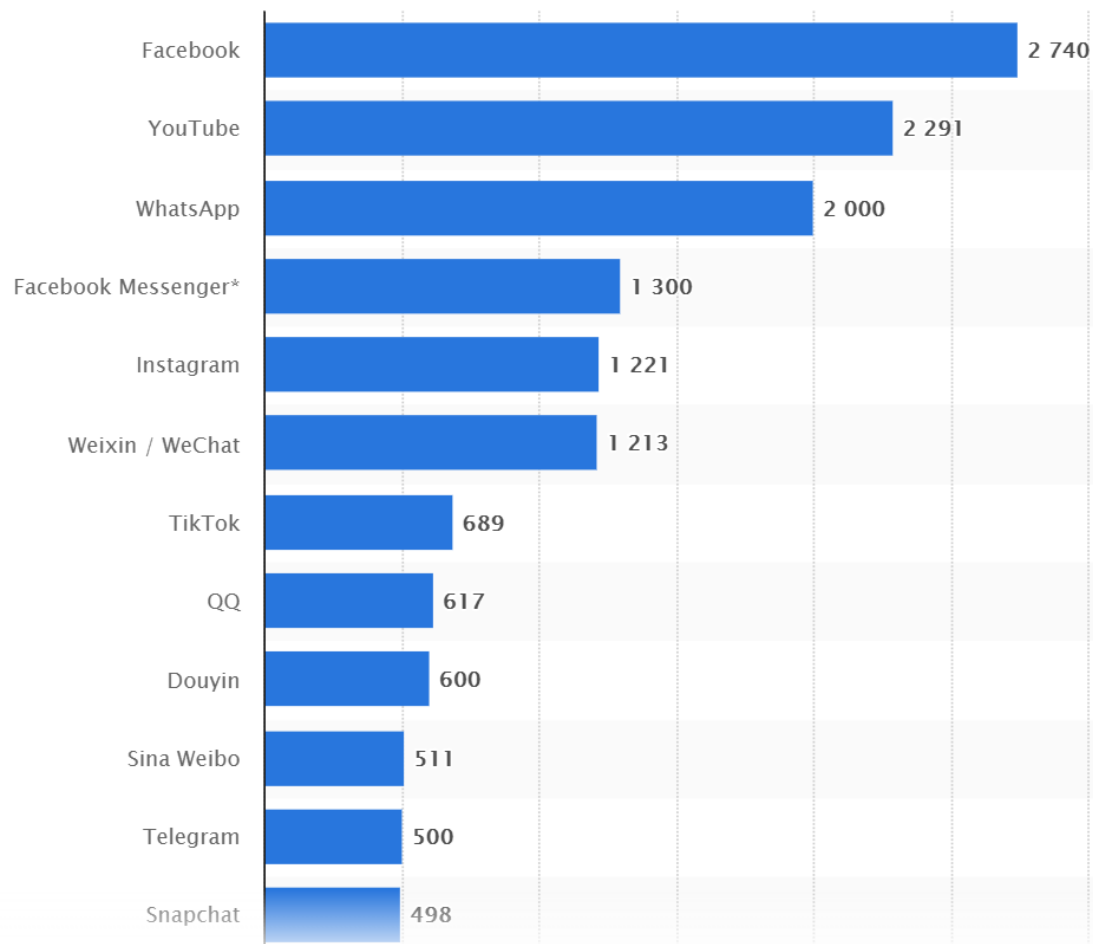

Figure 1: Most popular social networks worldwide as of January 2021, ranked by number of active users (in millions)

Source: Statista 2021, https://www.statista.com/statistics/272014/global-socialnetworks-ranked-by-number-of-users// accesed in April 2021

The rise in popularity of social media channels and the expanding use of increasingly user-friendly computer technologies have led:

- Increasing the number of tourist guesthouses that are present on social media channels;

- The increasing use of social networks by tourist guesthouses to attract guests;

- Expanding the presence of tourist guesthouses from one social network to several, so that they are visible to as many tourists as possible;

- Increase in the number of tourists who inform themselves on social media channels, and especially on social networks before choosing the destination, location for accommodation.

Also, according to (Dehghani and Tumar, 2015) social media such as Facebook act as a check on the credibility of brands.

According to (Tankovska, Feb 9, 2021) the most used social network worldwide is Facebook, which has surpassed one billion registered accounts and currently has about 2.6 billion active users each month.

Also, the most used social network in Romania is, by far, Facebook, as can be seen in Figure 2. 


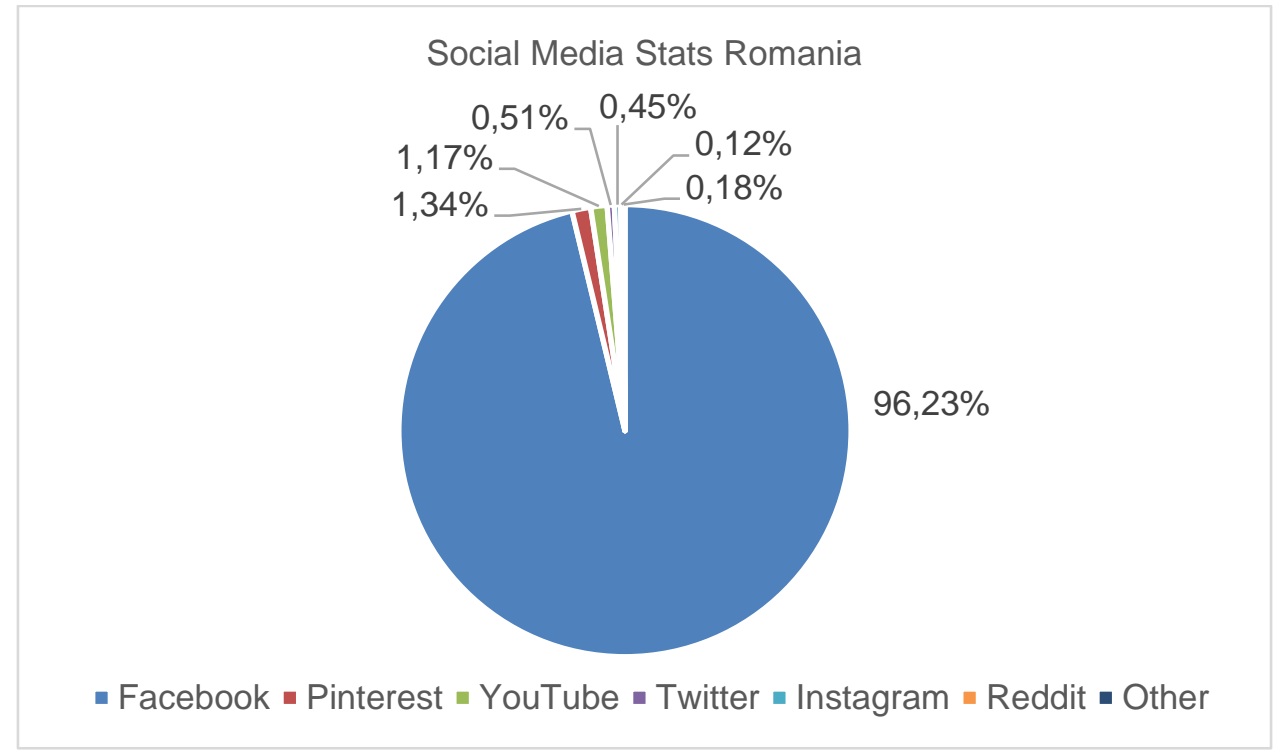

Figure 2: Social Media Stats Romania in April 2021

Source: StatCounter, Globalstats, https://gs.statcounter.com/social-mediastats/all/romania/ accessed in April 2021

\section{The premises and research methodology}

In the research we analyzed the presence of tourist guesthouses in the mountain area of Bihor County on social media channels.

The research objectives are:

- Identification of the social media channels most used by the tourist guesthouses in the mountain area of Bihor County;

- Identification of the social networks most used by the tourist guesthouses in the mountain area of Bihor County.

The research methodology consisted in analyzing the presence on social media channels of the tourist guesthouses from the mountain area of Bihor County. The data were collected from the Internet during January 2021-March 2021.

We started from the following hypotheses:

- Among the existing social media channels, tourist guesthouses use social networks the most;

- Among the existing social networks, tourist guesthouses use Facebook the most;

- Among the tourist guesthouses which are present on social networks, over $80 \%$ are present on Facebook;

- Among the tourist guesthouses which are present on social networks, less than $50 \%$ are present on social networks other than Facebook.

Research stages:

- Identification of tourist guesthouses in the mountain area of Bihor county present on social media channels;

- Identification of tourist guesthouses in the mountain area of Bihor county present on social networks; 
- Identification of tourist guesthouses in the mountain area of Bihor county that are present only on social networks, without having a website;

- Identification of the tourist guesthouses in the mountain area of Bihor county that have a web page and a link to social networks.

\section{Data analysis and interpretation}

For the research we analyzed 90 tourist guesthouses out of the total number of tourist guesthouses in the mountain area of Bihor county which are present on social media channels, (Table 1 ).

Table 1: Number of tourist guesthouses present on social media channels

\begin{tabular}{|l|c|}
\hline & $\begin{array}{c}\text { Number of tourist } \\
\text { guesthouses }\end{array}$ \\
\hline $\begin{array}{l}\text { Tourist guesthouses present on } \\
\text { social media channels }\end{array}$ & 90 \\
\hline $\begin{array}{l}\text { Tourist guesthouses present on } \\
\text { social networks }\end{array}$ & 90 \\
\hline $\begin{array}{l}\text { Tourist guesthouses present on other } \\
\text { social media channels }\end{array}$ & 7 \\
\hline
\end{tabular}

Out of the 90 tourist guesthouses surveyed, only $7.77 \%$ are being present on social media channels other than social networks (Figure 2). Therefore, the first hypothesis that among the existing social media channels tourist guesthouses use social networks the most is confirmed.

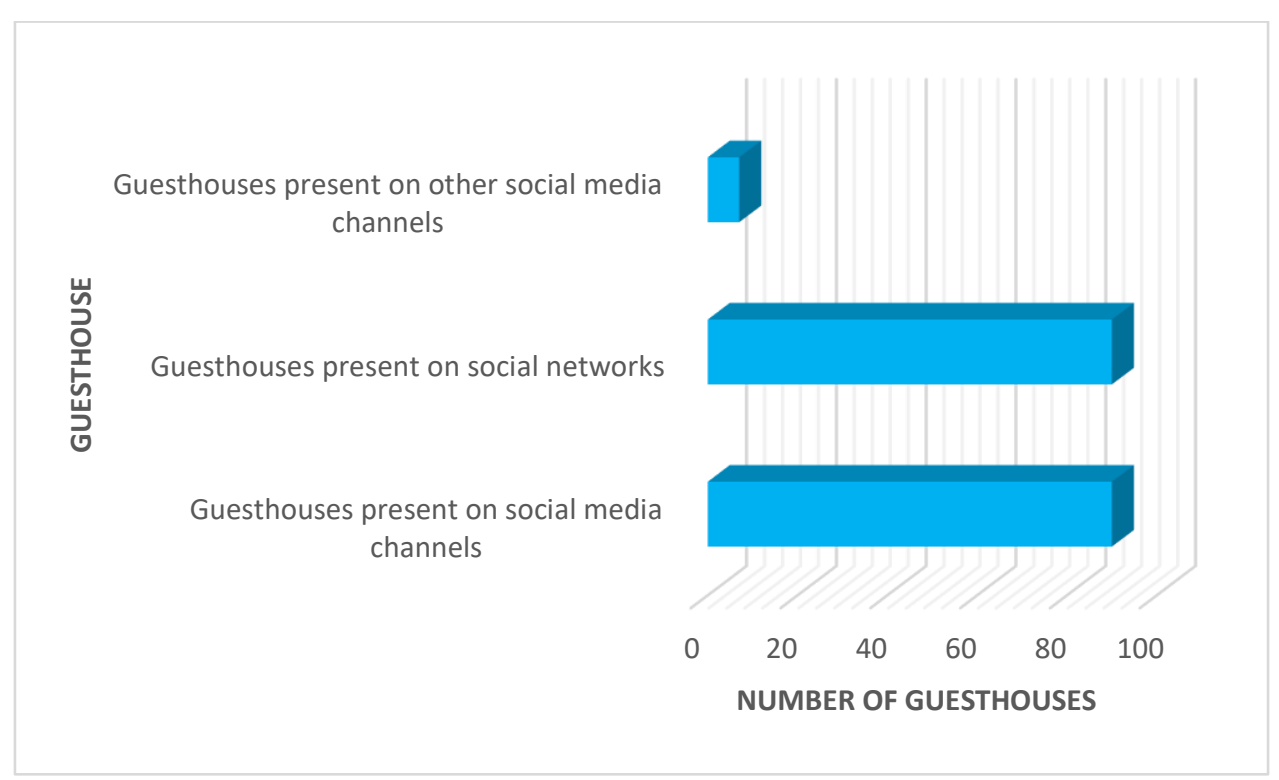

Figure 2: The presence of tourist guesthouses on social media channels 
A large number of the tourist guesthouses present on social networks, also have their own web page, from which they link to Facebook or other social networks (Table 2).

Table 2: Number of tourist guesthouses present on social networks

\begin{tabular}{|l|c|}
\hline $\begin{array}{l}\text { Tourist guesthouses present on social } \\
\text { networks }\end{array}$ & $\begin{array}{c}\text { Number of tourist } \\
\text { guesthouses }\end{array}$ \\
\hline $\begin{array}{l}\text { Tourist guesthouses that have their own } \\
\text { website with links to social networks }\end{array}$ & 90 \\
\hline $\begin{array}{l}\text { Tourist guesthouses present on } \\
\text { Facebook }\end{array}$ & 90 \\
\hline $\begin{array}{l}\text { Tourist guesthouses present on other } \\
\text { social networks }\end{array}$ & 14 \\
\hline
\end{tabular}

Of the tourist guesthouses studied, $81.11 \%$ have their own website, with links to social networks (Figure 3). Perhaps they consider that the presence on social networks could make them more visible online and bring them new customers, while retaining their existing ones.

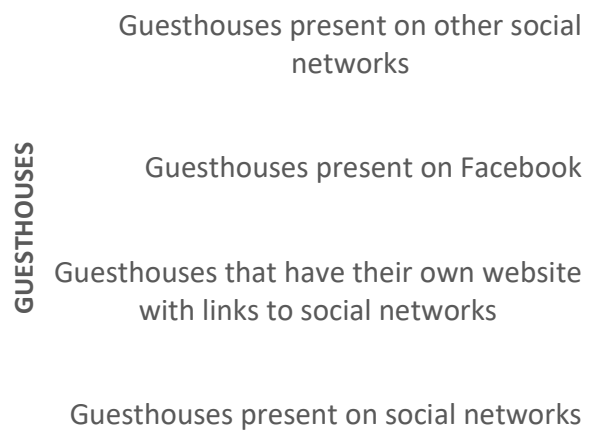

$$
\begin{array}{llllll}
0 & 20 & 40 & 60 & 80 & 100
\end{array}
$$

Figure 3: The presence of tourist guesthouses on social networks

Tourist guesthouses are primarily present on Facebook, but some of them have started to announce their presence on other social networks. Therefore, the second hypothesis that among the existing social networks, tourist guesthouses use Facebook the most is confirmed.

The tourist guesthouses analysed in the research are present on Facebook. This means that the tourist guesthouses have taken into account the fact that the most used social network in our country, is by far, Facebook. 
Of the tourist guesthouses analysed, $15.55 \%$ (Figure 3) are present on social networks other than Facebook. In the last period of time there has been a slight increase of users on social networks other than Facebook. Some of the guesthouses have noticed this and have announced their presence on these social networks as well.

Therefore, the third and fourth hypotheses, according to which more than $80 \%$ of tourist guesthouses are present on Facebook and less than $50 \%$ of tourist guesthouses are present on social networks other than Facebook, are also confirmed.

\section{Conclusion}

To attract customers, the tourist guesthouses in the Apuseni Mountains area have understood that it is very important to be accessible to as many users of the online environment as possible. Therefore, they are present, to an increasing extent, on social media channels. Social media channels can make them more visible in the online environment and can bring them new customers, respectively can make them loyal to the existing ones.

The study shows that among the existing social media channels, tourist guesthouses in the Apuseni Mountains area use social networks the most.

Tourist guesthouses, following the trend of Internet users to be primarily present on Facebook, are also primarily present on this social network.

Considering the fact that lately, people of certain age groups are migrating to other social networks, some tourist guesthouses, in order to stay in the attention of these potential customers, have started to make their presence felt on social networks other than Facebook.

\section{References:}

1. Dehghani, M., \& Tumer, M. (2015). A research on effectiveness of Facebook advertising on enhancing purchase intention of consumers. Computers in Human Behavior, 49, 597-600.

2. Jorge, F., Teixeira, M. S., Fonseca, C., Correia, R. J., \& Gonçalves, R. (2020). Social Media Usage Among Wine Tourism DMOs. In Marketing and Smart Technologies (pp. 78-87). Springer, Singapore.

3. StatCounter, Globalstats, https://gs.statcounter.com/social-mediastats/all/romania/ accessed in April 2021

4. Statista 2021, https://www.statista.com/statistics/272014/global-social-networksranked-by-number-of-users// accesed in April 2021

5. Tankovska, H. (Jan 28, 2021). Number of global social network users 20172025, Statista 2021, https://www.statista.com/statistics/278414/number-ofworldwide-social-network-users/ accesed in April 2021

6. Tankovska, H. (Feb 9, 2021). Global social networks ranked by number of users 2021, Statista 2021, https://www.statista.com/statistics/272014/global-socialnetworks-ranked-by-number-of-users/ accesed in April 2021

7. Tussyadiah, I. P., \& Fesenmaier, D. R. (2009). Mediating tourist experiences: Access to places via shared videos. Annals of Tourism Research, 36(1), 24-40 


\title{
INVESTIGATING THE IMPORTANCE OF CUSTOMER LIFETIME VALUE IN MODERN MARKETING - A LITERATURE REVIEW
}

\author{
Adela-Laura POPA ${ }^{1}$, Dinu Vlad SASU', Teodora Mihaela TARCZA ${ }^{1}$, \\ ${ }^{1}$ Department of Management Marketing, Faculty of Economic Sciences, University \\ of Oradea, Oradea, Romania \\ apopa@uoradea.ro \\ dinusasu@gmail.com \\ teodoratarcza@gmail.com
}

\begin{abstract}
In this paper, we investigate the importance of Customer Lifetime Value $(C L V)$ as part of the modern marketing strategy. There is no doubt that CLV is one of the most important metrics to be considered in Customer Relationship Management and Relationship Marketing. It represents an instrument meant to enhance the client's loyalty and to bring some clearance for the marketing strategies regarding the customer segmentation. At the same time, it is one of the most difficult to calculate. As part of this study, we explore how the concept is approached in the academic literature, the notoriety of the concept, the areas, and the topics with which it is associated. In this investigation, we are using WordStat and QDA Miner software applications for content analysis and text mining aiming to extract themes and trends regarding the approached topic from a significant number of academic articles.
\end{abstract}

Keywords: Customer Lifetime Value; CLV; Customer Relationship Management; CRM; valuable customers; content analysis.

JEL Classification: M31

\section{Introduction. Context. Importance. Vision}

Customers are the lifeblood (Gupta and Zeithaml, 2006), the alma mater (EstrellaRamón et al., 2013) of any organization. There are many other ways to highlight the essence of what customers represent for any organization.

Modern marketing starts from premises like the importance of customers as the most valuable assets the companies own (Mosaddegh et al., 2021), customer centricity, the fact that different customers deserve different treatment, and not all customers are the same value (Gupta and Zeithaml, 2006; Estrella-Ramón et al., 2013). Customer metrics and greater measurability are also prerequisites without which modern marketing could not exist. Due to the many ways in which customer value could be understood and analyzed, estimating customer lifetime value is one of the most challenging metrics marketers are facing.

When approaching the concept of valuable customers, specialists often refer to the 80/20 rule (Pareto Principle) for highlighting the importance of identifying the valuable customers a company has (Dong et al., 2021; Benoit and Van den Poel, 2009; Cooper and Kaplan, 1991). According to the Pareto Principle (also known as the $80 / 20$ rule), attributed to the Italian economist Vilfredo Pareto in $1897,80 \%$ of the results/output are generated by $20 \%$ of the effort/input (Wang et al., 2020; Koch, 2007). Transposing this idea in the area of customer relationship 
management, a percentage of $20 \%$ of customers is expected to generate $80 \%$ of revenue. Even more, new research suggests that the revenue generated by valuable customers exceeds by far $80 \%$ (Morisada et al., 2019; Cooper and Kaplan, 1991).

According to a statement attributed to Peter Drucker, if you want to manage something, you have to measure it. It should be the same when it comes to the value of a customer. Not only customer lifetime value is an essential marketing measure, but some studies show the link between CLV and the improved financial performance of a company (Gupta and Zeithaml, 2006; Hyun, 2009). As a result, CLV is considered a fundamental metric in modern marketing, in general, and Customer Relationship Management (CRM) in particular, as it helps companies identify the valuable customers. CLV thus becomes a key segmentation criterion for companies as part of their strategic approach to the market. On the other side, although the assessment of customer value has been greatly facilitated by information technology and the abundance of customer data (Matsuoka, 2020; Estrella-Ramón et al., 2013), the literature highlights the difficulty in calculating CLV, indicating the idea that it is perceived differently across industries (Mosaddegh et al., 2021; Binh et al., 2021).

The first idea of the concept seems to have been suggested by Kotler in 1974, however the concept began to gain real interest in the context of marketing theory in the 1990s (Matsuoka, 2020).

The literature covers a significant number of domains that tend to manifest great importance towards understanding and measuring the CLV: banking / financial services (Armelini et al., 2015; Estrella-Ramón et al., 2017; Donkers et al., 2007; Méndez-Suárez and Crespo-Tejero, 2021), fashion (Kim et al., 2012; Dahana et al., 2019), telecommunication (Binh et al., 2021; Dandis et al., 2021), airline business (Çavdar and Ferhatosmanoğlu, 2018), online shopping (Jasek et al., 2019), insurance (Farzanfar and Delafrooz, 2016), health (Khajvand et al., 2011; Tarokh and EsmaeiliGookeh, 2019), tourism and hospitality (Kim et al., 2018; Hyun, 2009).

In opening the discussion on the inflectional forms of the definitions given to the lifetime value of the client, it is required to mention the acronym paradigms used in its specialty literature from CLV or CLTV (customer lifetime value) to LCV (lifetime customer value) or LVT (lifetime value), we will establish as CLV positioning term.

The concept is defined as "the present value of all future profits obtained from a customer over the life of his relationship with a firm" by Gupta and Zeithaml (2006) or as "the present value of the future cash flows attributed to the customer relationship" by Pfeifer, Haskins and Conroy (2005). More general, CLV is "the present value of a customer's future benefits to a firm" (Zhang, 2016). So, the present estimation of CLV is related to what we predict the customer will do in the future.

Literature also mentions a significant number of benefits associated with CLV measurement: customer segmentation / help in the process of selection of profitable customers, using CLV in marketing decisions positively influences the financial performance of the company, improves the ability to allocate the marketing resources (Gupta and Zeithaml, 2006; Kumar et al., 2006).

Also, as a root to all these benefits, it is worth to be mentioned the possibility to identify the profile of the valuable customer based on CLV estimation and use it as 
the template for targeting prospects with an increased potential to become valuable customers.

\section{Research methodology}

To achieve the purpose of this study, an exploratory research was conducted. We approached qualitative data analysis based on content analysis. We investigated a number of 130 scientific articles published between 2000 and 2021 and selected from academic databases. The selected articles were the ones that had the keywords "Customer Lifetime Value" in the title, abstract or author-specified keywords. Content analysis was performed using the QDA Miner / WordStat application set (Provalis Research).

\section{Data analysis and results}

At this stage of the study that aims to investigate the interest on the subject of Customer Lifetime Value in the academic literature, we established the following topics of interest: the association with the Pareto principle (the 80/20 rule), the identification of the main themes and of the industries / domains with which CLV is most associated in the academic literature.

The analysis started by investigating the distribution of phrases with the highest incidence in the investigated articles (Figure 1). According to the results, we can see that general concepts such as "customer-centricity" or "customer segmentation" appear only in about half of the investigated articles. We expected these topics to be of higher incidence. On the other hand, "customer retention", "customer loyalty", "customer profitability / profitable customers / valuable customers" and "customer satisfaction" appear in about $70 \%$ of the articles.

As domains / areas to which the concept of Customer Lifetime Value is associated in the case studies of the articles we noticed that the "financial services / banking" is the most approached, but also "luxury brand" appear in the results even if with a much lower frequency. "Behavioral loyalty" and "Attitudinal loyalty" as dimensions of customer loyalty are also mentioned in the results. As calculation methods, our results indicate that the ones with the highest frequencies are those related to the Markov chain model, regression models, RFM model, Pareto NBD. 


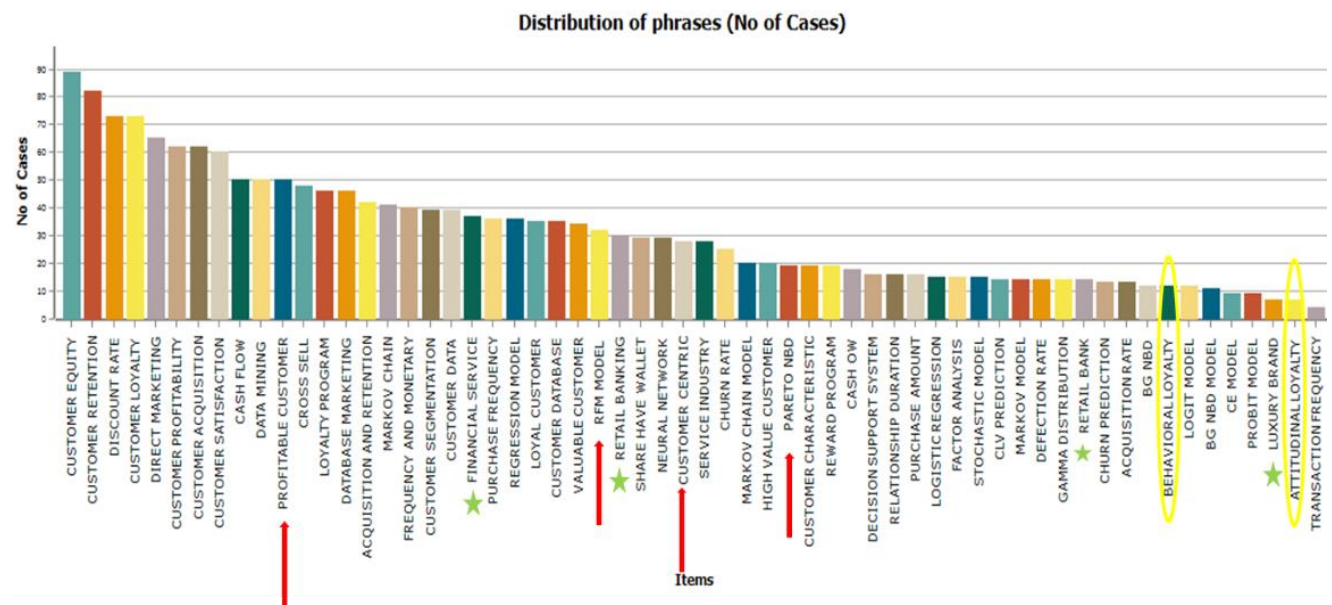

Figure 1: Distribution of phrases with the highest frequencies

Source: authors' own representation

The previous results are also reflected by the analysis of the general topics behind the keywords of these articles (Figure 2). According to our research, the topic of "customer satisfaction" (including also loyalty and customer profitability) and the calculation models are the topics most addressed in the articles analyzed.

\begin{tabular}{|c|c|c|c|c|c|c|c|}
\hline NO & TOPIC & KEYWORDS & COHERENCE & EIGENVALUE & FREQ & CASES & $\%$ CASES \\
\hline 1 & CUSTOMER SATISFACTION & $\begin{array}{l}\text { BRAND; SATISFACTION; LOYALTY; RELATIONSHIP; ROLE; } \\
\text { INFLUENCE; CUSTOMER; CONSUMER; } \\
\text { CUSTOMER EQUITY; CUSTOMER SATISFACTION; CUSTOMER } \\
\text { LOYALTY; CUSTOMER PROFITABILITY; CUSTOMER } \\
\text { RELATIONSHIPS; }\end{array}$ & 0,358 & 5,30 & 9103 & 129 & $99,23 \%$ \\
\hline 2 & PROPOSED MODEL & $\begin{array}{l}\text { MODEL; DATA; SECTION; METHOD; PREDICTION; PROPOSE; } \\
\text { APPROACH; REGRESSION; RESULT; PRESENT; } \\
\text { PROPOSED MODEL; }\end{array}$ & 0,354 & 2,27 & 7495 & 129 & $99,23 \%$ \\
\hline 3 & CASH FLOW & $\begin{array}{l}\text { CASH; FLOW; } \\
\text { CASH FLOW; CASH FLOWS; DISCOUNTED CASH FLOW; FUTURE } \\
\text { CASH FLOWS; }\end{array}$ & 0,272 & 2,08 & 1049 & 61 & $46,92 \%$ \\
\hline 4 & $\begin{array}{l}\text { FREQUENCY AND MONETARY } \\
\text { RECENCY }\end{array}$ & $\begin{array}{l}\text { RECENCY; MONETARY; FREQUENCY; RFM; } \\
\text { FREQUENCY AND MONETARY; PURCHASE FREQUENCY; RFM } \\
\text { MODEL; PURCHASE FREQUENCY AND MONETARY; } \\
\text { TRANSACTION FREQUENCY; RFM VARIABLES; WEIGHTED RFM; }\end{array}$ & 0,374 & 2,04 & 1460 & 93 & $71,54 \%$ \\
\hline 5 & $\begin{array}{l}\text { CUSTOMER RETENTION } \\
\text { ACQUISIMION }\end{array}$ & $\begin{array}{l}\text { ACQUISITION; RETENTION; RESOURCE; ALLOCATE; FIRM; } \\
\text { ACQUIRE; CUSTOMER; } \\
\text { CUSTOMER RETENTION; CUSTOMER ACQUISITION; CUSTOMER } \\
\text { EQUIY; ACQUUSITION AND RETENTION; CUSTOMER } \\
\text { PROFITABIITY; CUSTOMER SATISFACTION; CUSTOOMER } \\
\text { RELATIONSHIPS; }\end{array}$ & 0,379 & 1,69 & 8024 & 128 & $98,46 \%$ \\
\hline 6 & RETAIL BANKING & $\begin{array}{l}\text { BANKING; RETAIL; BANK; INDUSTRY; } \\
\text { RETAIL BANKING; BANKING INDUSTRY; RETAIL BANK; RETAIL } \\
\text { BANKTING CONTEXT; TARGET BANN; MODEL TO DETERMINE } \\
\text { CUSTOMER LIFETIME; BANKING SECTOR; RETAIL BANKING } \\
\text { INDUSTRY; DETERMINE CUSTOMER; }\end{array}$ & 0,317 & 1,66 & 1193 & 105 & $80,77 \%$ \\
\hline 7 & $\begin{array}{l}\text { LOW CLV } \\
\text { NEGATIVE }\end{array}$ & $\begin{array}{l}\text { NEGATIVE; HIGH; POSITIVE; LOW; DECREASE; INCREASE; } \\
\text { LOW CVV; CLV CUSTOMERS; HIGH CLV CUSTOMERS; POSITIVE } \\
\text { IMPACT; }\end{array}$ & 0,346 & 1,62 & 1812 & 126 & $96,92 \%$ \\
\hline 8 & $\begin{array}{l}\text { RECOMMENDATION RULES } \\
\text { QUALTY }\end{array}$ & $\begin{array}{l}\text { RECOMMENDATION; QUALITY; PREFERENCE; ITEM; } \\
\text { RECOMMENDATION RULES; RECOMMENDATION QUALITY; } \\
\text { IMPROVE THE QUALITY; EXTRACT RECOMMENDATION RULLS; } \\
\text { QUALTY OF RECOMMENDATION; BASED RECOMMENDATION; } \\
\text { PROPOSEED HYBRID; BASED METHOD; PURCHASE PREFERENCE; } \\
\text { ASSOCIATION RULE MINING; CANDIDATE PRODUCTS; QUALITY } \\
\text { OF RECOMMENDATIONS; RECOMMENDATION RULE SET; CF } \\
\text { METHOD; BASED CF METHOD; }\end{array}$ & 0,317 & 1,56 & 607 & 78 & $60,00 \%$ \\
\hline 9 & $\begin{array}{l}\text { RECEIVE SPECIAL TREATMENT } \\
\text { REVISE }\end{array}$ & $\begin{array}{l}\text { REVISE; ACCEPT; RECEIVE; FORM; } \\
\text { RECEIVE SPECIAL TREATMENT; SPECIAL TREATMENT; }\end{array}$ & 0,291 & 1,52 & 505 & 114 & $87,69 \%$ \\
\hline 10 & CROSS BUYING & $\begin{array}{l}\text { SELL; CROSS; } \\
\text { CROSS BUYING; }\end{array}$ & 0,296 & 1,46 & 808 & 83 & $63,85 \%$ \\
\hline 11 & DISCOUNT RATE & $\begin{array}{l}\text { RATE; DISCOUNT; ASSUME; TIME; PERIOD; CONSTANT; } \\
\text { ASSUMPTION; PROBABILITY; PURCHASE; } \\
\text { DISCOUNT RATE; }\end{array}$ & 0,363 & 1,43 & 4015 & 128 & $98,46 \%$ \\
\hline 12 & $\begin{array}{l}\text { DATA MINING } \\
\text { AMOUNT }\end{array}$ & $\begin{array}{l}\text { DATA; AMOUNT; INFORMATION; } \\
\text { DATA MINING; CUSTOMER DATA; DATA SETS; }\end{array}$ & 0,283 & 1,39 & 1429 & 126 & $96,92 \%$ \\
\hline
\end{tabular}

Figure 2: The general topics behind the keywords of the investigated articles Source: authors' own representation 


\section{Conclusion}

The importance of understanding the concept of Customer Lifetime Value is of increasing interest in the academic literature, as reflected in the number of papers included in scientific databases in recent years. The dynamics of information technology and the possibility to collect in-depth information about customers will accelerate the interest in finding new ways to assess the lifetime value of customers and use it to develop specific marketing strategies focused on valuable customers.

As expected, concepts like "customer retention", "customer loyalty", "customer profitability / profitable customers / valuable customers", and "customer satisfaction" were frequently mentioned among the investigated articles. But, on the other hand, concepts like "customer-centricity" or "customer segmentation", and the correlation with the Pareto principle (the 80/20 rule) had lower frequencies than we expected.

According to the results of our study, banking / financial services is the most approached domain in the case studies of the articles related to the topic "customer lifetime value".

Perhaps it is time to reconsider the statement that customers are a organization's most valuable asset to the idea that valuable customers are the organization's genuinely most valuable asset. The academic literature also provides a significant number of reasons why CLV should be considered an important segmentation criterion for developing a companies' marketing strategy.

As further research directions, we intend to continue the study by investigating articles written by practitioners to compare the ways in which the concept is approached by both academics and company practitioners.

\section{References}

1. Armelini, G., Barrot, C. and Becker, J. U. (2015). 'Referral programs, customer value, and the relevance of dyadic characteristics', International Journal of Research in Marketing, 32(4), pp. 449-452.

2. Benoit D. and Van den Poel, D. (2009). 'Benefits of quantile regression for the analysis of customer lifetime value in a contractual setting: An application in financial services', Expert Systems with Applications, 36(7), pp.10475-10484.

3. Binh, T. V., Thy, N. G. and Phuong, H. T. N. (2021). 'Measure of CLV Toward Market Segmentation Approach in the Telecommunication Sector (Vietnam)', SAGE Open, 11(2).

4. Çavdar, A. B. and Ferhatosmanoğlu, N. (2018). 'Airline customer lifetime value estimation using data analytics supported by social network information', Journal of Air Transport Management, vol. 67, pp. 19-33.

5. Cooper, R. and Kaplan, R.S. (1991). 'Profit priorities from activity-based costing'. Harvard Business Rev., 69 (3), pp.130-135.

6. Dahana, W. D., Miwa, Y. and Morisada, M. (2019). 'Linking lifestyle to customer lifetime value: An exploratory study in an online fashion retail market', Journal of Business Research, Volume 99, pp. 319-331.

7. Dandis, A. O., Al Haj Eid, M. B., Robin, R. and Wierdak, N. (2021). 'An empirical investigation of the factors affecting customer lifetime value', International Journal 
of Quality and Reliability Management, ahead-of-print. 10.1108/IJQRM-12-20200412.

8. Dong, Y., Li, C.and $\mathrm{Li}, \mathrm{H}$. (2021). 'Customer concentration and M\&A performance', Journal of Corporate Finance, Volume 69, 102021.

9. Donkers, B., Verhoef, P. C. and de Jong, M. G. (2007). 'Modeling CLV: A test of competing models in the insurance industry', Quantitative Marketing and Economics, 5(2), pp. 163-190.

10. Estrella-Ramón, A., Sánchez-Pérez, M., Swinnen, G. and Vanhoof, K. (2013). 'A marketing view of customer value: Customer lifetime value and customer equity', South African Journal of Business Management, 44, pp. 47-64.

11. Estrella-Ramón, A., Sánchez-Pérez, M., Swinnen, G. and VanHoof, K. (2017). 'A model to improve management of banking customers', Industrial Management and Data Systems, 117(2), pp. 250-266.

12. Farzanfar, E. and Delafrooz, N. (2016). 'Determining the customer lifetime value based on the benefit clustering in the insurance industry'. Indian Journal of Science and Technology, 9(1).

13. Gupta, S. and Zeithaml, V. (2006). 'Customer Metrics and Their Impact on Financial Performance', Special 25th Anniversary Issue. Marketing Science, 25(6), pp.718-739.

14. Hyun, S. S. (2009). 'Creating a model of customer equity for chain restaurant brand formation', International Journal of Hospitality Management - INT J HOSP MANAG., Volume 28, Issue 4, pp. 529-539.

15. Jasek, P., Vrana, L., Sperkova, L., Smutny, Z. and Kobulsky, M. (2019). 'Comparative analysis of selected probabilistic customer lifetime value models in online shopping', Journal of Business Economics and Management, 20(3), pp. 398-423.

16. Khajvand, M., Zolfaghar, K., Ashoori, S. and Alizadeh, S. (2011). 'Estimating customer lifetime value based on RFM analysis of customer purchase behavior: Case study', Paper presented at the Procedia Computer Science, 3, pp. 57-63.

17. Kim, K. H., Ko, E., Xu, B. and Han, Y. (2012). 'Increasing customer equity of luxury fashion brands through nurturing consumer attitude', Journal of Business Research, 65(10), pp. 1495-1499.

18. Kim, Y. P., Boo, S and Qu, H. (2018). 'Calculating tourists' customer equity and maximizing the hotel's ROI', Tourism Management, vol. 69, pp. 408-421.

19. Koch, R. (2007). The 80/20 Principle: The secret to achieving more with less, London: Nicholas Brealey Publishing.

20. Kumar, V., Lemon, K. N. and Parasuraman, A. (2006). 'Managing customers for value: An overview and research agenda', Journal of Service Research, 9(2), pp. 87-94.

21. Matsuoka, K. (2020). 'Exploring the interface between management accounting and marketing: a literature review of customer accounting', Journal of Management Control: Zeitschrift für Planung und Unternehmenssteuerung, Springer, vol. 31(3), pp. 157-208.

22. Méndez-Suárez, M. and Crespo-Tejero, N. (2021). 'Why do banks retain unprofitable customers? A customer lifetime value real options approach', Journal of Business Research, Volume 122, pp. 621-626.

23. Morisada, M., Miwa, Y. and Dahana, W. D. (2019). 'Identifying valuable customer segments in online fashion markets: An implication for customer tier programs', Electronic Commerce Research and Applications, Volume 33, 100822. 
24. Mosaddegh, A., Albadvi, A., Sepehri, M. M. and Teimourpour, B. (2021). 'Dynamics of customer segments: A predictor of customer lifetime value', Expert Systems with Applications, 172, 114606.

25. Pfeifer, P. E., Haskins, M. E. and Conroy, R. M. (2005). ' Customer Lifetime Value, Customer Profitability, and the Treatment of Acquisition Spending', Journal of Managerial Issues, 17(1), pp. 11-25.

26. Provalis Research (2019). -QDA Miner - qualitative data analysis softwarell, [Online], available at: www. provalisresearch.com.

27. Tarokh, M. J. and EsmaeiliGookeh, M. (2019). 'Modeling patient's value using a stochastic approach: An empirical study in the medical industry', Computer Methods and Programs in Biomedicine, Volume 176, pp. 51-59.

28. Wang, Y., Wang, B. and Huang, Y. (2020). 'Comprehensive analysis and mining big data on smart E-commerce user behavior', Paper presented at the Journal of Physics: Conference Series, 1616(1).

29. Zhang, S.T. (2016). 'Firm valuation from customer equity: When does it work and when does it fail?', International Journal of Research in Marketing, Volume 33, Issue 4, pp. 966-970. 


\section{SECTION: INTERNATIONAL BUSINESS, EUROPEAN INTEGRATION, FOREIGN LANGUAGES AND BUSINESS ENVIRONMENT}




\title{
ICSID CASES IN 2020, AFFECTED OR NOT BY COVID 19
}

\author{
Mihai BERINDE, Dana Maria PETRICA, Liana-Eugenia MESTER \\ Faculty of Economic Sciences, University of Oradea, Oradea, Romania \\ mihai.berinde@yahoo.com \\ danamester@yahoo.com \\ Imester@uoradea.ro
}

\begin{abstract}
The present paper intends to present the evolution registered in the ICSID - International Centre for Settlement of Investment Disputes - cases during FY2020, comparing with the historical evolution, in order to identify the possible effect of COVID 19 on the dynamics of registering and administrating cases and also in the hearings, if any. Many economic sectors had been deeply affected by the pandemic, and they have shown a real capability to adapt their way of acting and doing things. International arbitration made no difference, and it showed a real adaptive capacity, allowing the existing cases to follow their path and also registering new cases without delays. In 16 April 2020 the leading organisation of arbitration (the CRCICA, DIS, ICC, ICDR/AAA, ICSID, KCAB, LCIA, MCA, HKIAC, SCC, SIAC, VIAC and the International Federation of Commercial Arbitration Institutions) released a common statement on COVID 19: "Collaboration is particularly important as each of our institutions looks to ensure that we make the best use of digital technologies for working remotely." The first element to be notice in the 2020 ICSID Statistics is the fact that the number of the cases registered during 2020 had touched a new record, 58 new cases. The previous record was of 56 , and was registered in 2018, meanwhile in 2019 there were registered 39 new cases. One big difference occurred in the way of holding the hearings, in the last 9 months of the year 2020 , all the hearings were held remotely, $78 \%$ by video and $22 \%$ by phone. ICSID had developed and used their one video conferencing platform. In terms of industry, States parties involved, proceedings outcomes, nationality of arbitrators appointed there were some evolutions but with no significant changes.
\end{abstract}

Keywords: ICSID, damages, foreign direct investment, international disputes

JEL classification: F51; F37; K22

\section{Introduction}

The International Centre for Settlement of Investment Disputes Convention was established in October 1966 by the Convention on the Settlement of Investment Disputes between States and Nationals of Other States (the ICSID Convention).

Arbitration under International Investment Agreements. A Guide to the Key Issues (Yannaca-Small K., 2010) provides, in a logical and accessible manner, the procedural aspects of arbitration and describes the conflicts and challenges that arbitrators face from a practical perspective. The second edition of this guide (Yannaca-Small K., 2018) presents, from an intelligent perspective, a complete update of all procedural issues. 
Disputes are often the result of the use of incentives, which is why their use is rarely a good policy, especially for countries without adequate education and infrastructure (Kenneth Th., 2010). Given that disputes and cooperation between states are the result of economic problems, the legal foundations of the international economy are examined and political tensions and generated results are explored (Lowenfeld, A.F., 2002).

Findings and perspectives on how the benefits of FDI can be improved, but also the limitation or elimination of potential damages as a result of disputes between states or investor and state, are examined in extensive analyzes (Moran Th. M., 2011).

The present study is a continuation of previous studies published by the same authors.

Since 1972, when the first case of arbitration was registered at ICSID, the majority disputes between foreign investors and States were arbitrated by ICSID. Year by year the number of cases had increased significantly.

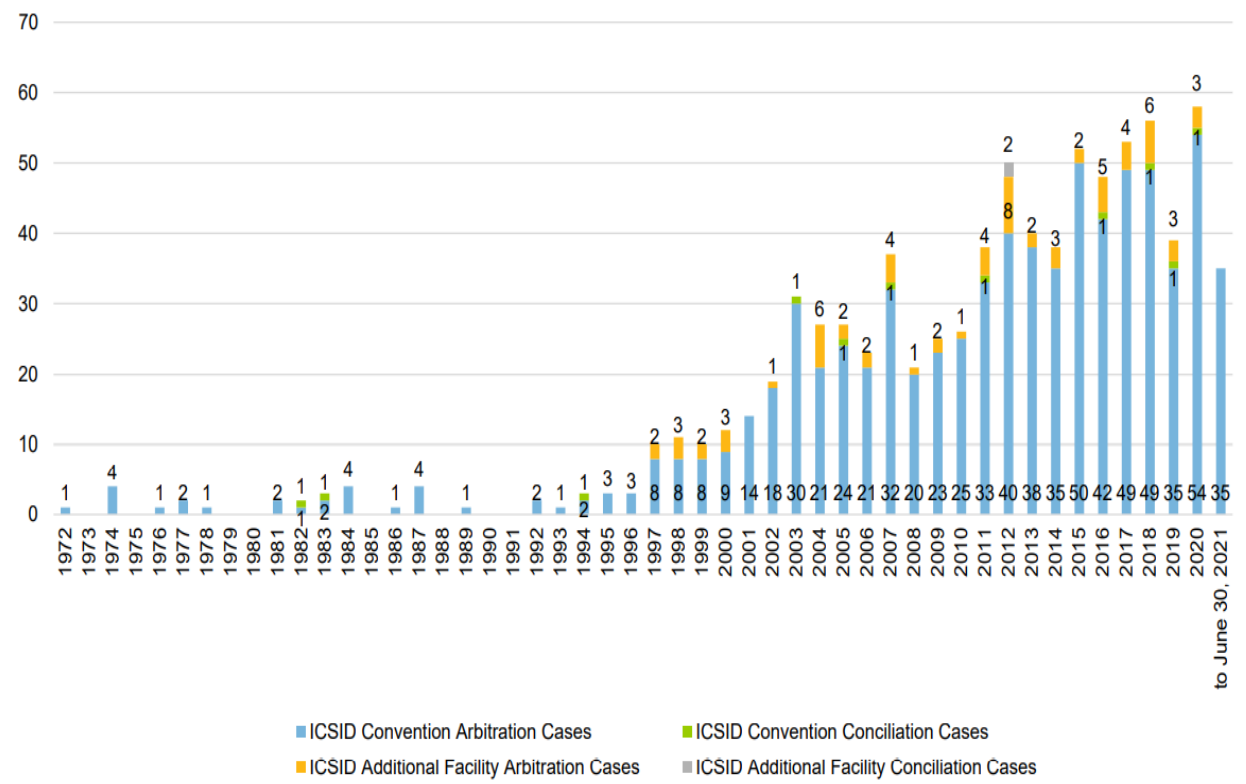

Figure 1: Number of ICSID Cases Registered, by Calendar Year Source: https://icsid.worldbank.org, date: 01.11 .2021

ICSID cases can be split between: ICSID Convention Arbitration Cases, ICSID Convention Conciliation Cases, ICSID Additional Facility Arbitration Cases or ICSID Additional Facility Conciliation Cases. Over $90 \%$ of the cases are ICSID Convention Arbitration Cases.

The resolution for a case needs a period of several years, that is the reason why the Secretariat of ICSID is administrating a high number of cases each year. 


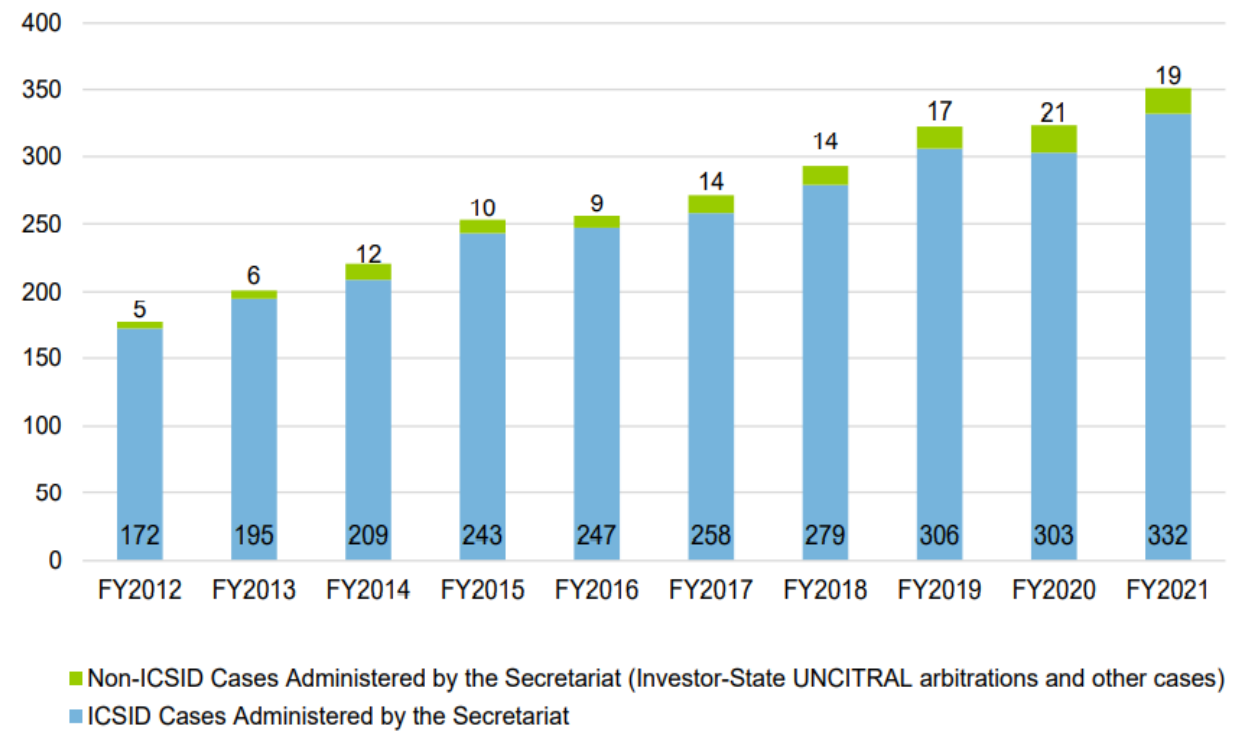

Figure 2: Total Cases Administered by the ICSID Secretariat, under ICSID and Non-ICSID Rules

Source: https://icsid.worldbank.org, date: 01.11.2021

\section{ICSID Cases in FY 2020 2.1. Concluded cases}

In 2020, 303 ICSID cases were administered (40 new ICSID cases) - the second highest number of cases ever administered at ICSID in a single fiscal year (FY). Since 1972 when the first ICSID case was registered, have been administered 768 cases under the ICSID Convention and Additional Facility Rules. In 2020, 37 cases were arbitrations instituted under the ICSID Convention and 3 cases were arbitrations invoking the Additional Facility Rules. (ICSID Annual Report, 2020).

As we can see from the above figures the number of registered cases in 2020 was higher than any of the number of cases registered in previous years, and in terms of cases administrated by the ICSID Secretariat the number of the cases did not increase in the same proportion, that give as a first clue about the numbers of cases that were concluded or terminated during FY2020. BY the end of FY 5168 cases had been concluded. In FY 2020 a number of 68 cases were concluded and in 2019 a number of 59 cases. The economic sectors involved in ICSID proceedings are also diverse. As in previous years, in 2020 most cases come from the extractive and energy industries: $30 \%$ of cases are from the oil, gas and mining industry, $20 \%$ are cases related to energy sources (electricity and other energy sources), $17 \%$ are cases involving construction and the other cases are from information and communication, finances, transportation, agriculture, fishing and forestry, services and trade. Most disputes were decided by the courts $(74 \%)$; the others disputes (26\%) have been resolved or are being resolved, their discussion being interrupted. 


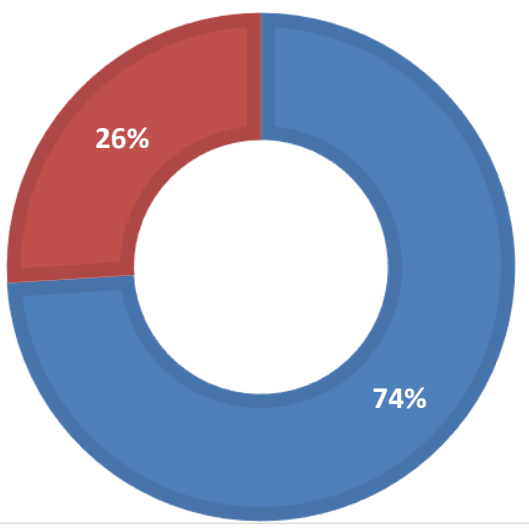

-Dispute decided by Tribunal

-Dispute settled or proceeding otherwise discontinued

Figure 3: Arbitration Proceedings under the ICSID Convention and Additional Facility Rules - Outcomes 2020

Source: https://icsid.worldbank.org, date: 01.11 .2021

From the disputes decided by the Tribunal the main majority were keeping the claims in part or in total:

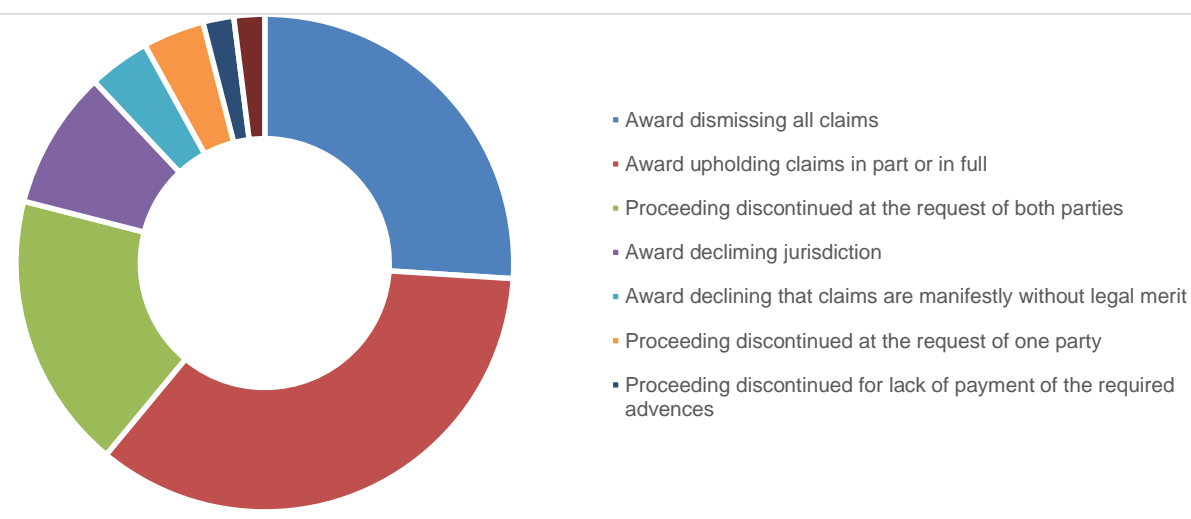

Figure 4: Arbitration Proceedings under the ICSID Convention and Additional Facility Rules - Tribunal Rulings, Settlement \& Discontinuances

Source: https://icsid.worldbank.org, date: 01.11.2021

\subsection{Jurisdiction and regions and economic sectors in 2020 vs. 2019}

In 2019, 306 ICSID cases were administered (52 new ICSID cases). Since 1972 when the first ICSID case was registered, have been administered 728 cases under the ICSID Convention and Additional Facility Rules. In 2019, 47 cases were arbitrations instituted under the ICSID Convention and 4 cases were arbitrations 
invoking the Additional Facility Rules, also one conciliation was registered under the ICSID Convention. (ICSID Annual Report, 2019).

In terms of jurisdiction, regions and economic sectors, in the figures below we can see the evolution from 2019 to 2020.

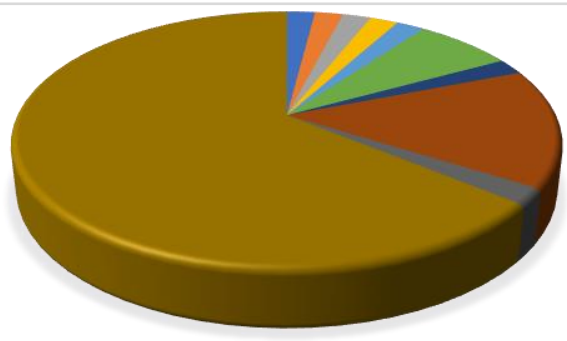

aUS - Columbia Trade Promotio Agreement $2 \%$

aCanada-Columbia Free Trade Agreement 2\%

Aentral America - Panama Free Trade Agreement 2\%

aPeru-Singapore Free Trade Agreement $2 \%$

aUS-Morocco Free Trade Agreement 2\%

aEnergy Charter Treaty $7 \%$

aNorth America Free Trade Agreement 2\%

alnvestment Contract between the Investor and the Host-State 15\%

aDominican Republic-United States-Central America Free Trade Agreement 2\%

Bilateral Investment Treaty 64\%

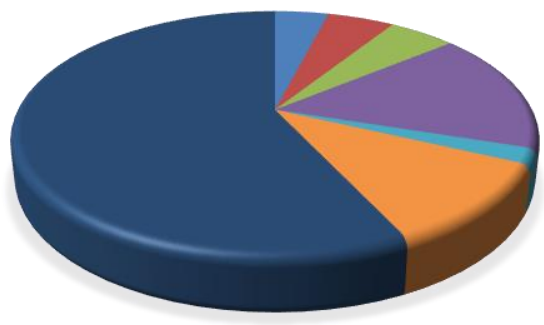

QUS - Columbia Trade Promotio Agreement $2 \%$

aUS - Peru Trade Promotion Agreement 5\%

alnvestment Law of the Host-State $5 \%$

Energy Charter Treaty 16\%

ANorth America Free Trade Agreement 2\%

a Investment Contract between the Investor and the Host-State 11\%

ailateral Investment Treaty 57\%

2020

Figure 5: Basis for deciding jurisdiction in 2019 vs 2020

Source: https://icsid.worldbank.org, date: 01.11.2021

We can see from the figure 5 that most of the cases registered at ICSID were under the jurisdiction of BITs - Bilateral Investment Treaties, in 2019 and also 2020 the percentage of the cases under this section was more than $50 \%$. There is a little decrease in the percentage, and we can see the increase in the jurisdiction of 
Energy Charter Treaty, but this has also been seen in some of the previous years, so without a direct link to the pandemic situation.

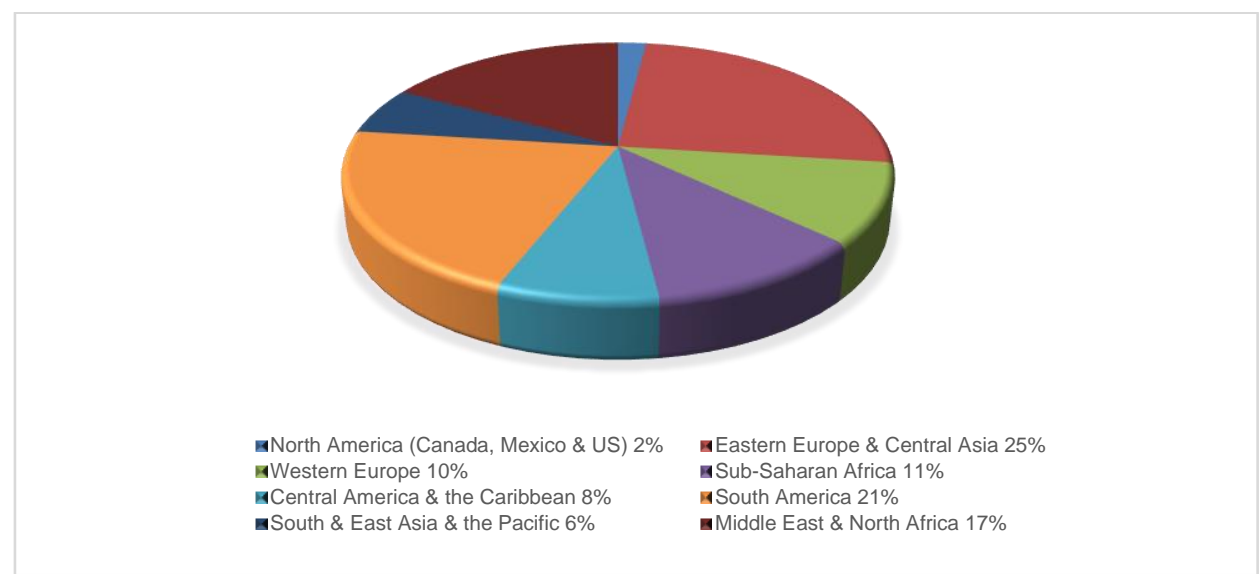

\section{9}

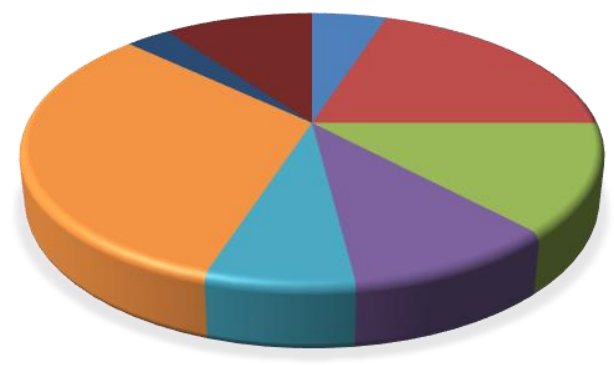

aNorth America (Canada, Mexico \& US) 5\% QWestern Europe 13\%

aCentral America \& the Caribbean 7\% atern Europe \& Central Asia 20\%

aSouth \& East Asia \& the Pacific 3\% Sub-Saharan Africa 10\% ASouth America 32\% Middle East \& North Africa 10\%

\section{0}

Figure 6: Regions in 2019 vs 2020

Source: https://icsid.worldbank.org,date: 01.11 .2021

The figure 6 indicates that Europe had in 2019 35\% of the cases and in 2020,32\%, mainly with a stability from year to year. The change can be seen between America and Africa, Africa dropping with 8 percentage's points and America increasing with $13 \%$, in total America being in 2020 on the first place with a total of $44 \%$ from the cases number, in 2019 Europe had registered the higher percentage from the number of cases, 35\%, America having 31\%. America and Europe were switching between them the first 2 places in the previous years as well. 
IInformation \& Communication 6\% Oil, Gas \& Mining $21 \%$

aTransportation 6\%

aConstruction $15 \%$
Agriculture, Fishing \& Forestry $4 \%$ Ginance $11.5 \%$

OOther Industry $11.5 \%$

Water, Sanitation \& Flood Protection 4\%

2019

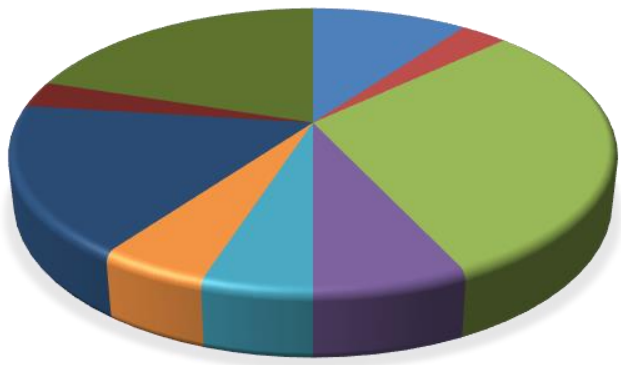

a Information \& Communication 10\% Oil, Gas \& Mining 30\%

QTransportation $5 \%$

aConstruction $17 \%$
Agriculture, Fishing \& Forestry 3\% AFinance $7 \%$

BOther Industry 5\%

QServices and Trade 3\%

\section{0}

Figure 7: Economic sectors in 2019 vs 2020

Source: https://icsid.worldbank.org,date: 01.11 .2021

In terms of economic sectors the first three places are being covered by Oil, Gas \& Mining, Electric Power \& Other Energy and Construction. In 2019, these three industries were covering $57 \%$ of all the cases and in 2020 they were covering $67 \%$

\subsection{Hearing, proceedings and other differences in 2020 compared to 2019}

ICSID sessions and hearings had moved their activity in online, over $70 \%$ being held remotely, in the last 9 months of the year 2020, all the hearings were held remotely, $78 \%$ by video and $22 \%$ by phone.

In 16 April 2020 the leading organisation of arbitration (the CRCICA, DIS, ICC, ICDR/AAA, ICSID, KCAB, LCIA, MCA, HKIAC, SCC, SIAC, VIAC and the International Federation of Commercial Arbitration Institutions) released a common statement on COVID 19: "Collaboration is particularly important as each of our institutions looks to ensure that we make the best use of digital technologies for working remotely." 
Due to high investments in IT structure that ICSID had made during the years they were able to switch from IN PERSON scenario to HYBRID and then to VIRTUAL scenario with a speed that ensure all the cases respected their timeframe.

In IN PERSON scenario all the participants are in the same room on one of the 138th offices of World Bank or in the facilities of other arbitration institutions with which ICSID had signed agreements.

In HYBRID scenario the Tribunal is meeting in one location, the respondent team in other location and the claimant team in a third one, in the locations of World Bank or other arbitration institutions with which ICSID had signed agreements. Hybrid models were expected to be increasingly favored.

The third scenario, the VIRTUAL one, was the one most used during FY2020. This allows hundreds of participants to connect individually from their locations and each of them can share audio and video, documents, power point presentation, or any other type of files that they may need.

Court reporters and interpreters can also provide transcription and interpretation via dedicated text feeds and audio channels in the online conference and all the participants cand chat between them or with the entire group.

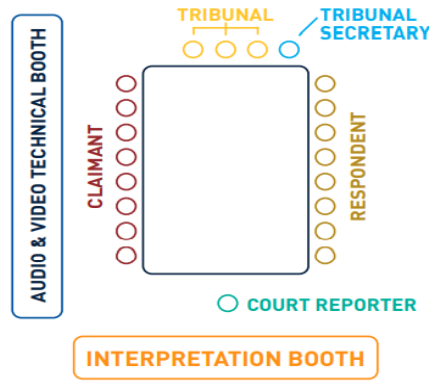

a

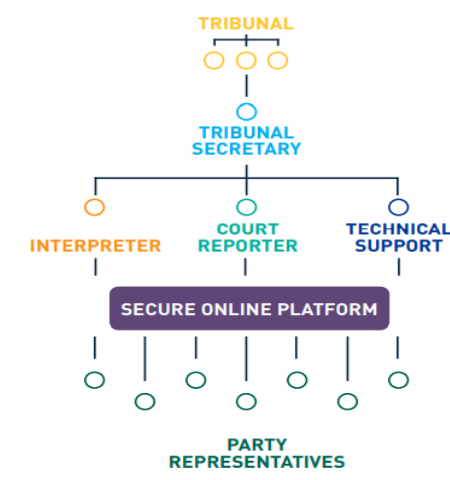

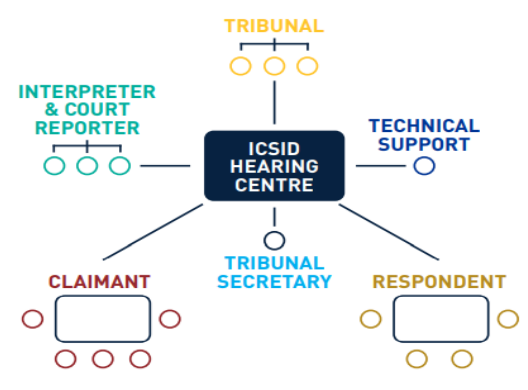

b

C

Figure 8: Scenarios
a: IN PERSON scenario
b: HYBRID scenario
c: VIRTUAL scenario

Source: https://icsid.worldbank.org,date: 01.11.2021 


\section{In conclusion}

TOM XXX, $2^{\text {nd }}$ Issue, December 2021

COVID-19 caused an unprecedented situation, generating a health crisis economic crisis and social crisis.

With all the problems that the pandemic brought, ICSID was following the path they had in the previous years, being able to switch to online with a speed they could not imagine before. It showed a very high capacity to adapt to all the new conditions and registering an increase in number of cases and even an increase in the number of state members, Dijibouti signed the ICSID Convention during 2020, becoming the $155^{\text {th }}$ member.

In terms of industry, States parties involved, proceedings outcomes, nationality of arbitrators appointed there were some evolutions but with no significant changes. An important increase of percentage of women appointed as arbitrators was also registered as compared whit the historical data, from $12 \%$ to $23 \%$.

Beside the way of holding sessions and hearings nothing looks like being affected by the COVID 19 pandemic.

\section{References:}

1. Berinde Mihai, Petrica Dana, Mester Liana, ICSID Cases in which damages were awarded based on market approach, Annals of University of Oradea, Economic Science, TOM XXVII 2018, Issue no 1 http://anale.steconomiceuoradea.ro/volume/ 2018/AUOES-1-2018.pdf.

2. Yannaca-Small, K. (2010), Arbitration under International Investment Agreements. A Guide to the Key Issues, New York: Oxford University Press.

3. Yannaca-Small, K. (2018), Arbitration under International Investment Agreements. A Guide to the Key Issues, Second Edition, New York: Oxford University Press.

4. Kenneth, Th. (2011), Investment Incentives and the Global Competition for Capital

(International Political Economy Series), Kindle Edition, Palgrave Macmillan, London.

5. Lowenfeld, A.F. (2002), International Economic Law, Oxford: Oxford University.

6. Moran, Th.M. (2011), Foreign Direct Investment and Development: Launching a Second Generation of Policy Research, Avoiding the Mistakes of the First, ReEvaluation developed and Developing Country, Washington, DC: Peterson Institute of International Economics.

7. Petrica, Dana (2017), The International Center for Settlement of Investment Disputes - Establishment, Role and Impact on Foreign Direct Investment, 23 November 2017 Emerging Markets Economics and Business. Contributions of Young Researchers. Proceedings of the Conference of Doctoral Students in Economic Sciences No. 5, University of Oradea Publishing, Oradea.

8. Ripinsky, S. and Kevin, W. (2008), Damages in International Investment Law, London: British Institute of International and Comparative Law.

9. ICSID Annual Report (2020), https://icsid.worldbank.org/sites/default/files/ publications/annual-report/en/ICSID AR20 CRA Web.pdf

10. ICSID Annual Report (2021), https://icsid.worldbank.org/sites/default/files/ publications/annual-report/en/ICSID AR21 CRA Web.pdf 


\title{
THE PRINCIPAL FACTORS THAT DRIVE THE ECONOMIC COMPETITIVENESS
}

\author{
Dana-Teodora MIERLUȚ ${ }^{1}$, Adriana GIURGIU ${ }^{2}$ \\ ${ }^{1}$ Doctoral School of Economics and International Business, The Bucharest \\ University of Economic Studies (ASE București), Bucharest, Romania \\ ${ }^{2}$ Doctoral School of Economics and International Business, The Bucharest \\ University of Economic Studies (ASE București), Bucharest, Romania; \\ Department of International Business, Faculty of Economic Sciences, University of \\ Oradea, Oradea, Romania \\ dana.mierlut@gmail.com \\ adrianagiurgiu@gmail.com
}

Abstract: The Economic Competitiveness is a term which has a significant importance in the welfare of a country and also in the development of a company. A simple definition says that competitiveness is the ability of a state or even a firm to put in the market products and services that have a high quality and, in addition, are competitive with others in terms of price; being able to bring some profit after covering all the expenses appeared in the production process. The main objective of this paperwork is to emphasize which factors drive the evolution of the economic competitiveness. It is influenced by internal factors - in a microeconomic perspective -, as well as external factors - in a macroeconomic point of view, factors such as: division of labour, specialization, assets (resources), processes and institutions and government policies. The study is based on the specialized literature in the economic field, precisely the one which influence the economic competitiveness. Economic competitiveness is a complicated notion shaped by a multitude of factors, it appears that utilizing multiple or mixed indicators (indexes) of competitiveness is the most relevant technique to estimate its level. Although the traditional theory of comparative advantage controlled global trade thinking for a long time, it is now regarded as an insufficient justification for firms' competitive advantage in today's business climate. Advances in technology and innovation, as well as some environmental resource limitation issues, have generated new options for obtaining, preserving, and also enhancing productivity versus opponents in an incredibly challenging, worldwide economy.

Keywords: driven factors of the economic competitiveness; economic competitiveness; international competitiveness; determinants of competitiveness; competitiveness.

JEL classification: B27; F14; $O 47$.

\section{Introduction}

We live in a world that promotes globalization and day by day more companies extend their reach beyond the borders of their own national countries. However, there are still many cultural differences from a nation to another and the competition is strong, so a firm must adapt to multiple changes in order to survive in the market or expand its reach to new ones. 
The Economic Competitiveness is a term which has a significant importance in the welfare of a country and also in the evolution of a company. Competitiveness is a word which has its origins in the Classical Latin, "petere" being the meaning of desire, to attack, seek etc, while "con" (the prefix) means together (Siudek and Zawojska, 2014).

A simple definition says that competitiveness is the ability of a state or even a firm to put in the market products and services that have a high quality and, in addition, are competitive with others in terms of price; being able to bring some profit after covering all the expenses appeared in the production process.

In other words, according to the Economic Point's definition, "Competitiveness is the capability a country or company has to achieve profitability in the market in relation to its competitors. Competitiveness depends on the relationship between the value and quantity of the outputs offered and the inputs needed to obtain profitability (productivity), as well as the productivity of the other bidders that exist in the market. The concept of competitiveness can be applied to both a company and a country."

Taking into account the above considerations, the aim of the present paper is to identify and analyze the main factors that drive the economic competitiveness across the globe.

The paper is organised as follows: general literature review on the subject of driven factors of the economic competitiveness, the explanation of some of the most common and important factors, and, in the end, a series of conclusions regarding the driven factors of the economic competitiveness.

\section{The Driven Factors of the Economic Competitiveness}

The factors which influence the level of competitiveness mostly consist of price, quality, logistics and image. Furthermore, the machineries and other technologies, as well as the human know-how, represents the competitive advantages.

Another perspective points out the fact that competitiveness is the one that really sustain the location economy, having the power to improve or decrease the standard of living of the population.

"From a macroeconomic perspective it looks at the drivers of a location's rate of underlying trend growth. The perspective taken is focused on the medium-to longterm: how strong are the underlying fundamentals, and how can they be improved? Wages and costs are in this view assumed to revert 'automatically' to their equilibrium levels. This definition is important for organizations like competitiveness councils that are supposed to focus on long-term growth and prosperity rates. Countries that are losing competitiveness in the sense of slowing productivity dynamics are seen to be exposed to a deteriorating prosperity performance. The literature on growth spurts has shown that the level of sustained productivity growth is what ultimately matters, not the stability or variability of growth rates itself." (Ketels, 2016). 
As we can see in Table 1, the Economic Competitiveness is influenced by internal factors - in a microeconomic perspective -, as well as significant external factors - from a macroeconomic point of view. There are many theorists who strongly agree with each option, usually considering one of them to be the only source of power that keeps the economic competitiveness alive, respectively the actual market still working.

The history proved once and again that none of these apparently solutions are perfect and, in fact, the situation is more nuanced that it may seem. In order for everything to go smoothly in the economy and to have a real growth, there is always some kind of a mix of microeconomic and macroeconomic elements present on the market.

The specialists in this domain developed multiple interesting concepts and theories regarding the determinants of the Economic Competitiveness which combined are really useful and some of them continue to have an impact even after several centuries.

We can identify here the work of Adam Smith - division of labour, specialization, and also the theory of Michael Porter about the importance of the firms within the international markets, how they are the only meaningful actors competing in this considered "game", and also his well known theory of the five forces (supplier power, buyer power, barriers to enter the market, threat of substitutes and rivalry), which is still pretty accurate in the nowadays' economic competitiveness.

From a macroeconomic perspective, the law, political institutions and the monetary and fiscal policy are the agents which really have an impact on the economy, minimizing the influence of the companies.

We are going to analyze in the following pages some elements of each point of view and demonstrate that they are actually strong just when their powers are combined. It is impossible to increase a nation's welfare through the economic competitiveness only using to invest in physical capital or with the help of state institutions and government policies / regulations.

Table 1: Determinants of competitiveness found in empirical research

\begin{tabular}{|c|c|}
\hline Determinants & Authors \\
\hline Division of labour, specialization & Classical economics: Smith (1776) \\
\hline & Neoclassical theories: Schumpeter \\
Investment in physical capital & (1950) \\
& Swan (1956) \\
\hline & Horne et al. (1992) \\
& Barney, Hansen (1994) \\
Carney (1998) & Khalil (2000) \\
& Barney et al. (2001) \\
& Nivievskyi, von Cramon-Taubadel \\
& Zho08) \\
& Zhang (2013) \\
\hline & O'Farrell, Hitchens (1988) \\
& Porter (1990) \\
& Kanter (1993) \\
& Chaharbaghi, Feurer (1994) \\
\hline
\end{tabular}


TOM XXX, 2 ${ }^{\text {nd }}$ Issue, December 2021

\begin{tabular}{||c|c|}
\hline Determinants & Authors \\
\hline & Sushil, Kak (1997) \\
& Notta, Vlachvei (2010) \\
& Atkinson, Andes (2011) \\
& Reeves, Deimler (2011) \\
& Altomonte, Ottaviano (2011) \\
& Buga, Meyer (2012) \\
& Ollo-López, Aramendía- \\
& -Muneta (2012) \\
& Forsman et al. (2013) \\
\hline & Scott, Lodge (1985) \\
& Buckley et al. (1988) \\
& Schwalbach (1991) \\
& Dou, Hardwick (1998) \\
& Man et al. (2002) \\
& Dangelico, Pujari (2010) \\
& Bosma et al. (2011) \\
& Mullen, Keogh (2013) \\
\hline \multirow{3}{*}{ Fupporting and related industries and } & Boonzaaier, von Leipzig (2009) \\
clusters & Altomonte, Ottaviano (2011) \\
& Ketels et al. (2012) \\
& Delago et al. (2013) \\
\hline & Andrén, Oxelheim (2002) \\
& Nivievskyi, von Cramon-Taubadel \\
& (2008) \\
& Gulev, Dukaric (2010) \\
& Brunet (2012) \\
& Gulati et al. (2013) \\
\hline &
\end{tabular}

Source: Siudek, T., Zawojska, A. (2014), p. 101-102

\section{Division of labour, specialization}

The Specialization refers to the concentration of resources and work in a specific area or field, which gives the best results. It is a very profitable technique not only in terms of money, but also when we talk about the time invested in the process and the expertise of different workers.

Taking the last element into consideration, the expertise, we have the Division of Labour. This strategy is going hand in hand with Specialization, because, after we choose the area in which to put all of our financial and physical efforts, it is important to break down the actual work in multiple tasks. This way, every worker does whatever is good at.

While Specialization may be used in all kinds of activities, Division of Labour is mostly known for its contribution to the sectors with mass-production - assembly lines. In this concept is perfect if everyone does a simple job, being considered that there is no need to complicate things. Being capable of understanding a part of the total work may reduce costs in a long run, because the work becomes more efficient. 


\section{Investment in physical capital}

The investment in physical capital is one of the main three factors of production, together with land and labour. It consists of assets, such as the building of a company or the vehicles and machineries used to facilitate the process of production. Their principal characteristic is that assets are fixed capital, which means they cannot be consumed during the production of the merchandise (goods and services).

This is one of the first aspects a new company should focus on, way before orders start to appear. Usually, physical capital requires a huge amount of money, which is invested at the beginning of the business. It depreciates among the time if the selling process proves to be profitable.

Also, it is very important to mention that the value of the physical capital may vary over time, because it tends to depend on every change that happens within the organization (not necessarily big ones) and even on the fluctuations of the prices in the market.

\section{Assets (resources)}

According to some specialists in the economic field, the assets of a country or even a company are those which influence the output and, furthermore, the level of competitiveness of that particular entity in relation to others.

We have to agree with them at least in a partial way, because we cannot really produce anything if we do not have resources. In order to have an output, it is necessary to provide an input.

As simple as the definition from above may seem, it represents in fact the whole idea that Horne, Barney, Khalil and many others like them tried to explain through all kinds of complex theories. The assets or resources are: size of agricultural holding, human resources, technology, social responsibility and trust and trustworthiness.

This is how we get to a simple and logical conclusion: it is impossible for a country (or anyone) to compete in the international market without having anything to offer for sale.

\section{Processes}

As the definition says, a process is „a systematic series of actions directed to some end”; ,a continuous action, operation, or series of changes taking place in a definite manner". (Online Dictionary). This is what many economists, such as Michael Porter, Tony Atkinson and Aspasia Vlachvei, believed to be the essential determinant of the Economic Competitiveness.

It is true in some way, exactly as in the case with the resources. We cannot sell a product if we do not put the resources (assets) through a complex process of production and other stages. Sometimes it is an entire procedure and other times everything happens quite easy, it depends on the products or services involved. However, regardless of the details of production, there is always a process involved. 
The processes may be: strategic management (for example, competencies and quality, flexibility and adaptability), human resources - from workforce mobilization to brain drain and brain gain, technological innovations, actual manufacturing and even marketing campaigns. (Siudek and Zawojska, 2014).

In other words, the processes represent a simple link in the chain. A market can function only when all the aspects are in order and respect their own place, which means they value each other and understand the importance of each factor.

\section{Firm's performance}

Profitable companies are an important component for developing countries. Many economists compare them to a machine in terms of determining their economic, sociological, and political growth. To thrive in a highly competitive marketplace, every company should perform under performance-based conditions.

Firm performance has recently become a popular topic in strategic management research, and it is regularly employed as a dependent variable. Despite the fact that it is a widely held concept in academia, there is little agreement on how to define and quantify it. (Taouab and Issor, 2019)

Anyway, some authors accentuate the elements of the firm's performance. Siudek and Zawojska (2014) mention, for example, Bosma et al. (2011) and Mullen (2013) having the attention on productivity, while Buckley et al. (1988), Dou (1998) and Dangelico (2010) paying tribute to product differentiation and range. Also, there are others, like Porter (1990), Pace (1996) and Scott (1985) focusing on prices and costs or like Mehra (1998), pointing out the importance of the share of the market.

\section{Supporting and related industries and clusters}

Clusters are geographically concentrated groups of interconnected businesses and organizations in a specific industry. Clusters are made up of a variety of interconnected industries and other competitive organizations. Suppliers of specialist inputs such as parts, machines, and services, as well as providers of specialized infrastructure, are among them. Clusters frequently extend downstream to distributors and consumers, as well as laterally to complementary product manufacturers and organizations in industries with similar talents, technology, or inputs.

Clusters can be found in almost every national, regional, state, and even urban economy, especially in more developed countries. Silicon Valley and Hollywood are two of the most well-known clusters in the world. Clusters are not exactly unusual; they are extremely common, and here lies a dilemma: in a global market, the durable competitive advantages largely lay in local activities, relationships, and motivation that foreign competitors cannot replicate.

It's crucial what occurs within organizations, but clusters show that the immediate business environment beyond the companies is just as significant. Despite compelling evidence that innovation and market dominance in so many areas are strongly represented-whether it's entertainment in Hollywood, finance on Wall Street, or consumer electronics in Japan-this importance of locations has long been disregarded. 
Clusters have an impact on competitiveness both within the countries, including across national frontiers. As a result, new objectives emerge for all company leaders, not only those that usually compete on a worldwide scale. Clusters provide a new mindset about place in general, questioning much of the common interpretation on how businesses should be organized, how academics may lead to competitive performance, and how governments can support economic growth. (Porter, 1998)

\section{Institutions and government policies}

The institutions and government policies are a sensitive point in the Economic Competitiveness sphere. This happens because the government of a country has permanently the power to introduce some policies or regulations that may affect the companies.

Of course, there are two possible outcomes when the government and other influential institutions apply policies which impact the economy: they could add taxes or some regulations in order to favour the national production or break them down in order to increase competition (between local businesses or international players). Considering the fact that most of the countries have an important tendency toward globalization nowadays, the second option is more applicable and viable.

However, taking into account this information, we can affirm without any doubt that the state institutions and government policies are directly involved in Economic Competitiveness.

\section{In conclusion}

The study highlights that economic competitiveness is influenced by many factors, such as division of labour, investment in physical capital and institutions and government policies. There are involved both microeconomic and macroeconomic factors.

Although the traditional theory of comparative advantage controlled global trade thinking for a long time, it is now regarded as an insufficient justification for firms' competitive advantage in today's business climate. Advances in technology and innovation, as well as environmental resource limitation issues, have generated new options for obtaining, preserving, and enhancing productivity versus opponents in an incredibly challenging, worldwide economy.

Recognizing the major elements that support or restrict enterprises' capacity to compete is necessary, even the first step of the process, for developing government actions to increase business competition. However, these criteria can vary based on the country, area, or sector. According to the research, one of the biggest barriers to gaining competitiveness for the least-developed nations is the difficulties in setting up their economic environments to the global competitiveness factors.

Because competitiveness is a complicated notion shaped by a multitude of factors, it appears that utilizing multiple or mixed indicators (indexes) of competitiveness is the most relevant technique to estimate its level. 


\section{References}

1. Ketels, C. (2016), Review of Competitiveness Frameworks, Dublin, National Competitiveness Council, [Online]: https://www.hbs.edu/faculty/Publication\%20Files/Review\%200f\%20Competitivenes s\%20Frameworks\%20 3905ca5f-c5e6-419b-8915-5770a2494381.pdf.

2. MindTools (2016), Analyzing Competitiveness Using Porter's Five Forces Model, [Online]: https://www.mindtools.com/pages/article/newTMC 08.htm.

3. Online Dictionary: https://www.dictionary.com/browse/processes.

4. Porter, M. (1998), Clusters and the New Economics of Competition, Harvard Business Review, [Online]: https://hbr.org/1998/11/clusters-and-the-neweconomics-of-competition.

5. Siudek, T., Zawojska, A. (2014). Competitiveness In The Economic Concepts, Theories And Empirical Research, Warsaw, Oeconomia 13 (1), [Online]: http://www.oeconomia.actapol.net/pub/13 1 91.pdf.

6. Taouab, O., Issor, Z. (2019), Firm Performance: Definition and Measurement Models, Morocco, ENCG

Kenitra,

[Online]: http://dx.doi.org/10.19044/esj.2019.v15n1p93. 


\title{
TRADE BETWEEN CENTRAL AND EASTERN EUROPEAN COUNTRIES AND THE RUSSIAN FEDERATION IN THE CONTEXT OF SANCTIONS AND COUNTER-SANCTIONS
}

\section{Livia CEBOTARI}

Economics and International Affairs Doctoral School, Bucharest University of Economic Studies, Bucharest, Romania

cebotari.livia.2014@gmail.com

\begin{abstract}
The year 2014 marked the deepest crisis in EU-Russia relations since the dissolution of the Soviet Union. The bilateral relations cooled down because of the Ukrainian conflict. The EU started to impose restrictive measures on Russian Federation and Russia has responded by imposing counter-sanctions. The sanctions imposed by European Union in conjunction with the counter-sanctions adopted by the Russian Federation on EU food imports had massive consequences on the bilateral trade. The main purpose of this research is to identify and evaluate the impact of sanctions and counter-sanctions on trade in goods between eleven Central and Eastern European Countries and the Russian Federation. This paper tries to determine the factors that can explain why, after the adoption of economic sanctions, some Central and Eastern European Countries recorded losses higher than others. The research methodology combines tools of both quantitative analysis and qualitative analysis.
\end{abstract}

Keywords: European Union, Russian Federation, economic relations, economic sanctions

JEL classification: F10, F50, F51

\section{Introduction}

The year 2014 marked the deepest crisis of the relations between the EU and Russia since the dissolution of the Soviet Union. The bilateral relations cooled down as the conflict in Ukraine evolved. The factor triggering the political crisis was the suspension by the Ukrainian government of the preparation process for signing the Association Agreement between Ukraine and the European Union in November 2013. It followed the Vilnius Eastern Partnership Summit, where the Ukrainian president at that time, Viktor Yanukovych, refused to sign the partnership agreement with Brussels. The decision of the Ukrainian government and the refusal of the president generated protests in the centre of Kyiv. Though at first considered as insignificant, the demonstrations turned into mass manifestations and extended in several towns of Ukraine. The situation further escalated and the following events: the removal of the Ukrainian government from power, the referendum in Crimea and the annexation of the peninsula to the Russian Federation, the military conflict in the Donbas region have increased even more the tension between the Russian Federation and Occident. 
In March 2014, the European Union condemned the actions of Russia in Ukraine and imposed the first wave of sanctions against the Russian Federation. The EU imposed diplomatic measures, individual restrictive measures (asset freeze and travel restrictions), restrictions on economic relations with Crimea and Sevastopol, economic sanctions and restrictions on economic cooperation. The economic sanctions imposed by the European Union targeted the exchanges between the EU and Russia in various sectors. These restrictive measures limited the access for certain Russian banks and companies to EU primary and secondary capital markets and did not allow any forms of financial support and intermediation in favour of the Russian financial institutions. Restrictive measures also prohibited the import, export and direct or indirect transfer of all defense-related materials, as well as dual-use items that could be used for military purposes or used by Russian military end-users. The sanctions curtailed the access of Russia to certain sensitive technologies and services that can be used in the Russian energetic sector, for instance, in oil production and exploration. (European Council, EU restrictive measures in response to the crisis in Ukraine). In response, the Russian Federation introduced an embargo on agricultural and food exports from the European Union. There was a ban on the imports of fruits and vegetables, meat and meat products, certain kinds of fish, milk and dairy products from the EU. All restrictive measures, both those applied by the EU and the counter-sanctions adopted by Russia, are constantly reviewed and are subject to periodical renewals.

\section{Literature review}

Studying the specialised literature that approaches the topic of restrictive measures imposed by the European Union against the Russian Federation, it has been determined that, up to the present, two research direction have been identified. Some authors (Gurvich, E., Prilepskiy, I., (2015); Ilina E. (2015); Russell M. (2018), analysed the efficacy of the sanctions imposed by the EU, referring only to the impact they had on the economy of Russia. Others (Dolidze T. (2015); Bond I., Odendahl C., Rankin J. (2015); Giumelli (2017); Oxenstierna (2018)) preferred to build a clearer picture, examining the costs borne by the EU following the adoption of sanctions.

The report prepared at the request of the European Parliament's Committee on International Trade (DG EPPD (2017)) presented the effects of the restrictive measures on Russia's economy, as well as the way in which sanctions have affected the EU Member States. Dolidze (2015) declared that the restrictive measures had a boomerang effect, thus the sanctions adopted by the EU combined with Russia's embargo on food imported from European Union created a situation of loss for all economic participants involved. Giumelli (2017) studied the effects of the sanctions applied referring to each country separately, not on the level of the entire European Union. The researcher stated that after the adoption of restrictive measures, all EU countries saw a reduction in their exports to the Russian Federation, but not all EU Member States felt the negative effects equally. Oxenstierna (2018) pointed out that the European Union is a multilateral sender, acting uniformly when it comes to imposing restrictive measures, but the consequences of these sanctions and counter-sanctions vary considerably from 
one Member State to another. Bali (2018) brought attention to the distributive impact of restrictive measures, emphasizing that some EU countries were more affected than others. Havlik (2019) found that the economic effects on EU Member States differ according to their level of exposure to the Russian market.

\section{Research objectives and methodology}

The aim of this paper is to evaluate the impact of sanctions and counter-sanctions on bilateral trade between EU Member States from the Central and Eastern European region and the Russian Federation in the period 2014-2019. The practical purpose of the investigation consists in determining the factors that can explain why the restrictive measures had an uneven impact on the countries in this region and on their interaction with Russian Federation.

The term Central and Eastern European Countries (CEECs) has several definitions. That's why it is important to clarify that in the context of this paper, the term Central and Eastern European Countries refers to the definition given by the Organization for Economic Cooperation and Development, except Albania which is not an EU member state. Therefore, in this research, the term Central and Eastern European Countries refers to the group of countries including Bulgaria, Croatia, the Czech Republic, Hungary, Poland, Romania, the Slovak Republic, Slovenia and the three Baltic states: Estonia, Latvia and Lithuania.

The research methodology combines the specific tools of quantitative analysis with that of qualitative analysis. The information collected from official documents of the European Parliament and the European Commission, academic articles and studies conducted by several think-tanks (European Parliamentary Research Service (EPRS), Centre for European Policy Studies (CEPS), Centre for European Reform (CER), The Vienna Institute for International Economic Studies (wiiw), etc.) were analysed. Also, the research relies on database disseminated by Eurostat. Statistical data on trade in goods between Central and Eastern European Countries and Russia for the period 2010-2019 (quantity, value of imports and exports) were collected and processed. The structure of imports and exports of goods was also analysed by using the Standard International Trade Classification (SITC). The main sectors of this classification system are: food and live animals; beverages and tobacco; crude materials, inedible (except fuels); mineral fuels, lubricants and related materials; animal and vegetable oils, fats, waxes; chemicals and related products; manufactured goods classified chiefly by material; machinery and transport equipment; miscellaneous manufactured articles; commodities and transactions not classified elsewhere (Eurostat).

\section{Trade between Central and Eastern European Countries and Russia}

Analyzing the historical data, it can be stated that the economic sanctions have negatively influenced the trade between the EU and Russia, but have not changed its structure. The EU's exports to the Russian Federation were and remain dominated by finished products (machinery and transport equipment, chemicals and medicines, and other manufactured products), while the imports are led by raw materials (oil, natural gas, fuels and coal). The same structure is also present in the 
trade of products between the Russian Federation and the EU Member States from Central and Eastern European region.

In 2013, the structure of EU Member States from Central and Eastern Europe exports to the Russian Federation showed that four product groups concentrated $84,94 \%$ of deliveries, respectively: machinery and transport equipment $(46,41 \%)$, chemicals and related products $(14,79 \%)$, manufactured goods classified chiefly by material (12,40\%) and miscellaneous manufactured articles $(11,34 \%)$. In the same year, the structure of EU Member States from Central and Eastern Europe imports from Russia showed that four product groups represented $95,29 \%$ of total purchases: mineral fuels, lubricants and related materials $(83,30 \%)$, commodities and transactions not classified elsewhere $(5,52 \%)$, chemicals and related products $(3,35 \%)$ and manufactured goods classified chiefly by material $(3,12 \%)$.

In 2019, the same four product groups concentrated $88,92 \%$ of exports from the CEECs' to Russia (machinery and transport equipment $(45,17 \%)$, chemicals and related products $(19,13 \%)$, manufactured goods classified chiefly by material $(12,67 \%)$ and miscellaneous manufactured articles $(11,95 \%)$ ) and $91,99 \%$ of CEECs total imports from Russia (mineral fuels, lubricants and related materials $(72,85 \%)$, manufactured goods classified chiefly by material $(8,10 \%)$, chemicals and related products $(5,84 \%)$ and commodities and transactions not classified elsewhere (5.20\%)).

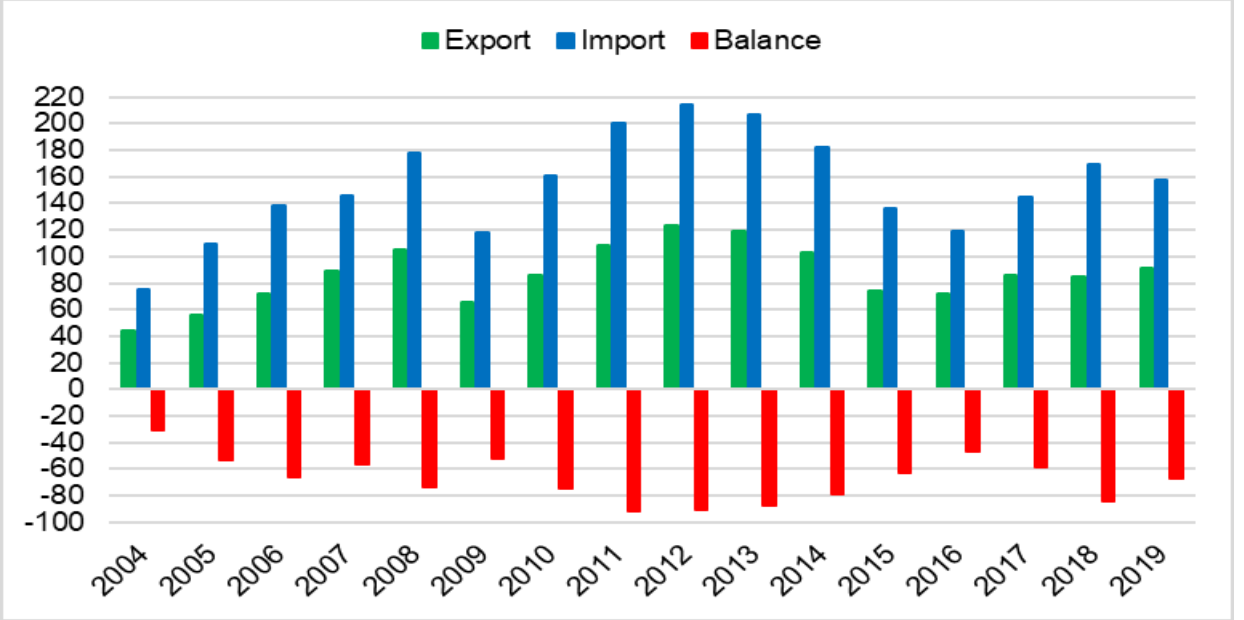

Figure 1: EU-Russia trade in goods, billion $€$ Source: Author's projection using Eurostat database (2021)

The statistical data showed a decrease in the volume of trade between the EU and the Russian Federation in the 2014-2018 period, compared to the 2010-2014 period (see Figure 1). The same trend can be noticed in regard to trade between CEECs and Russia (see Figure 2). Between 2014-2016, besides the restrictive measures adopted by the EU against Russian Federation and the countersanctions adopted by Russia, the evolution of bilateral trade flows was also influenced by the reduction of oil prices, which, in turn, caused the depreciation of the Russian rouble. Though such circumstances cannot be ignored, the aim of the paper is not to separate the effects of sanctions and counter-sanctions from the consequences of other factors, but to analyse the evolution of imports and exports 
of goods during the period 2014-2019, the time interval during which the restrictive measures were applied.

Poland, followed by Lithuania and Czech Republic are the states with the highest exports to Russia. On the other side, the top importers are Poland, Lithuania and Hungary.

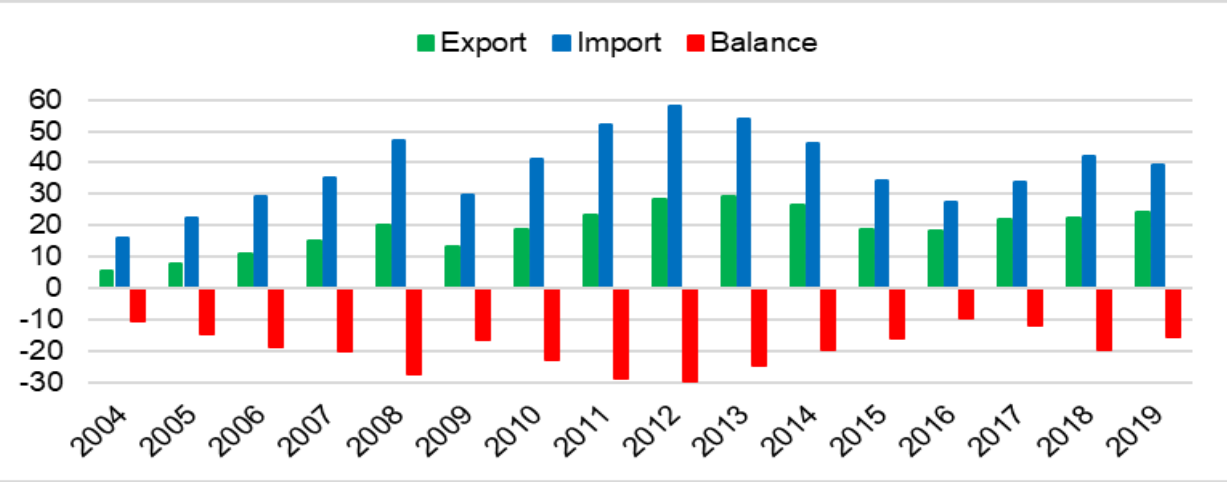

Figure 2: Trade between CEECs and Russia, billion $€$ Source: Author's projection using Eurostat database (2021)

\section{Impact on bilateral trade}

\section{Poland}

In 2013 Poland had $6,80 \%$ of EU exports to Russia and $27,91 \%$ of the CEECs' exports. In 2016, these shares had increased to $7,19 \%$ and $28,55 \%$, but Poland's export to Russia had decreased by EUR 2,91 billion in 2016, compared to 2013. Since 2017 the Polish export to the Russian Federation has begun to gradually recover, reaching EUR 7,43 billion (EUR 0,68 billion less than in 2013) (see Figure 3).

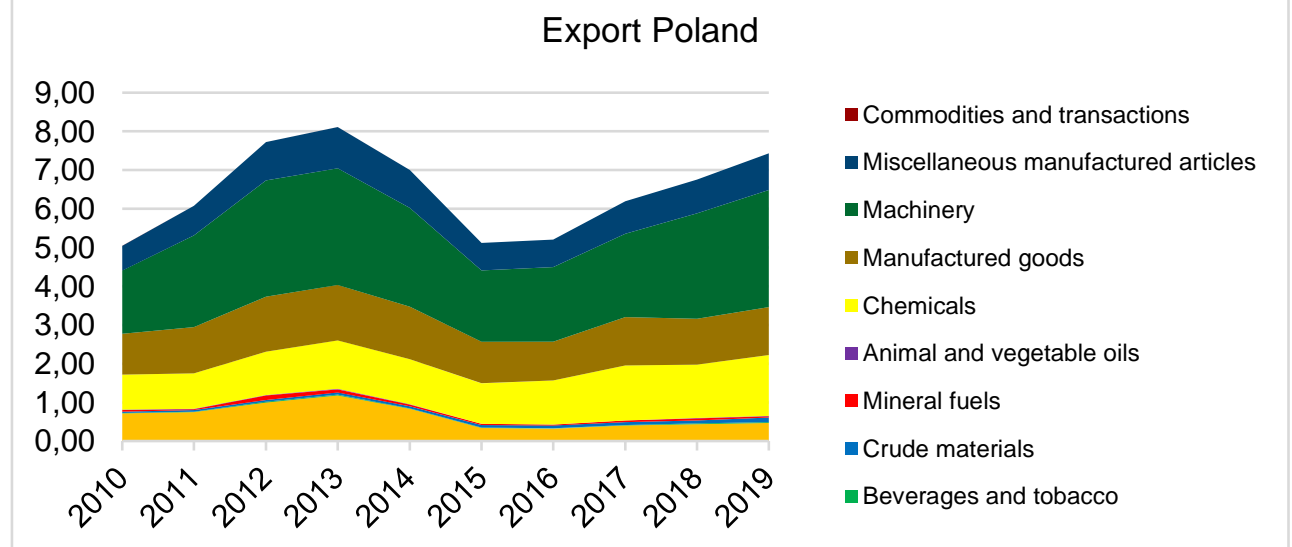

Figure 3: Poland's export to Russia, billion $€$

Source: Author's projection using Eurostat database (2021)

In 2013 Russian exports to Poland corresponded to 9,04\% of total EU imports from the Russian Federation and $34,68 \%$ of the CEECs' total imports from Russia. In the period 2014-2019, the shares were pretty much the same, but in nominal 
terms, Polish imports from the Russian Federation decreased (see Figure 4). In 2016, Russia imported from Poland goods amounted to EUR 10,28 billion, while in 2019, they amounted to EUR 14,23 billion (with EUR 5,76 billion, respectively EUR 4,43 billion less than in 2013, respectively). It is worth mentioning that Poland is the largest food exporter to Russia from Central and Eastern European Countries.

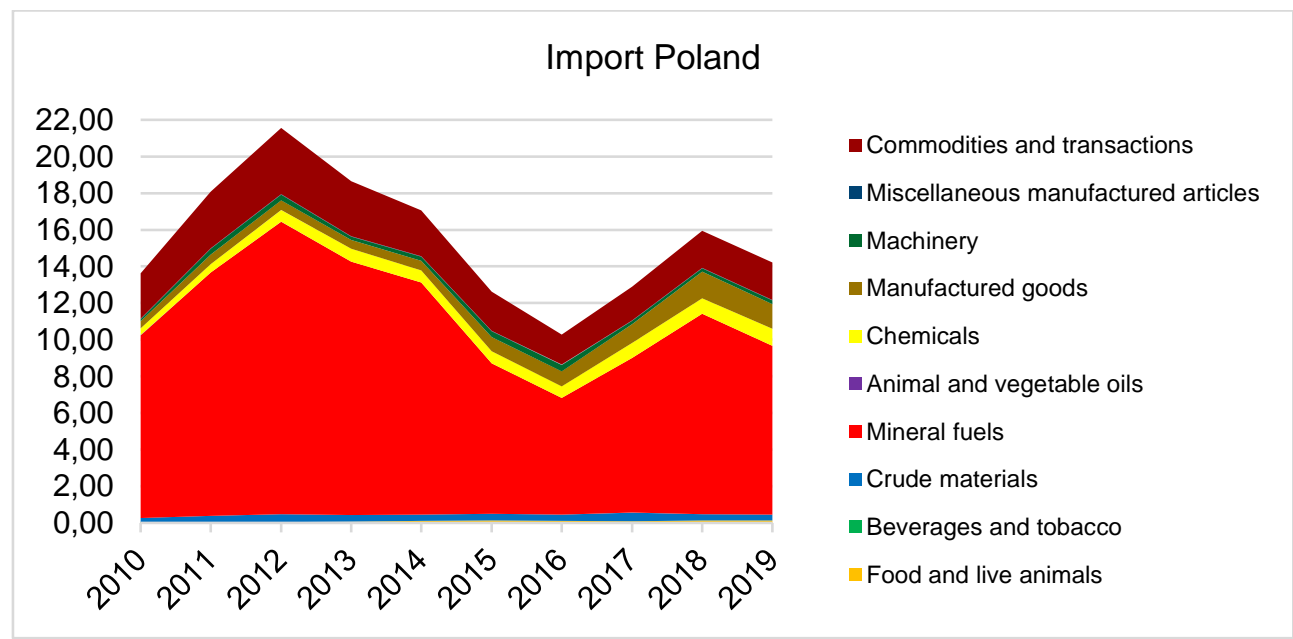

Figure 4: Poland's import from Russia, billion $€$

Source: Author's projection using Eurostat database (2021)

In the period 2013-2019, the export of foods declined by $60 \%$, reaching the lowest value in 2015. Also, exports of animal and vegetable oils decreased by $60,8 \%$ in 2019 compared to 2013. Machinery exports recorded the lowest value in 2015 (EUR 1,84 billion), but gradually recovered, and in 2019 they reached the level of 2013 (EUR 3 billion). Exports of chemicals did not decrease significantly in 20142016. Starting with 2017 they have increased and even exceeded the 2013 value.

\section{Lithuania}

In 2013 Lithuanian export to the Russian Federation corresponded to $4,08 \%$ of total EU export to Russia and $16,75 \%$ of the CEECs' total export to Russia. In 2019 , the respective figures were slightly higher, $4,56 \%$ and $17,24 \%$. Lithuania and Romania were the only states from Central and Eastern European Countries that had an increase in the volume of exports in 2014 compared to 2013. In the case of Lithuania, the increase in that year can be explained by a rise in exports of machinery. Machinery is Lithuania's biggest export product. Export of machinery declined in 2015, but it recovered in 2017. However, in the next two years (2015 and 2016), total exports from Lithuania to Russia experienced a deep decline. Like other CEECs Lithuania has suffered from a sharp decline in its food export that fell by $85 \%$ in 2014-2019. Lithuania has experienced increases of export of crude materials, chemicals and in the last two years (2018 and 2019) of beverages (see Figure 5). 


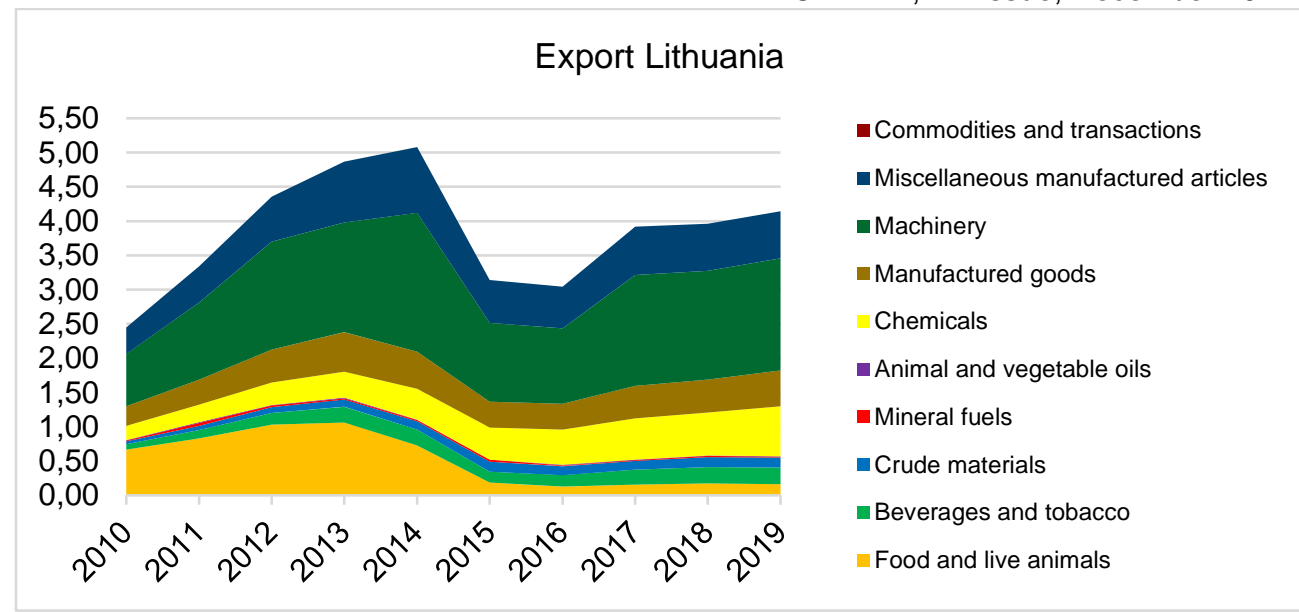

Figure 5: Lithuania's export to Russia, billion $€$ Source: Author's projection using Eurostat database (2021)

In the period 2014-2019, the total exports from Lithuania to the Russian Federation and the imports from Russia both decreased. Mineral fuels, lubricants and related materials are the most important goods that Lithuania imports from Russia and their value decreased dramatically during the analyzed period. Beverages and tobacco imports remained relatively constant. Imports of food, crude materials and manufactured goods have increased significantly since 2015 (see Figure 6).

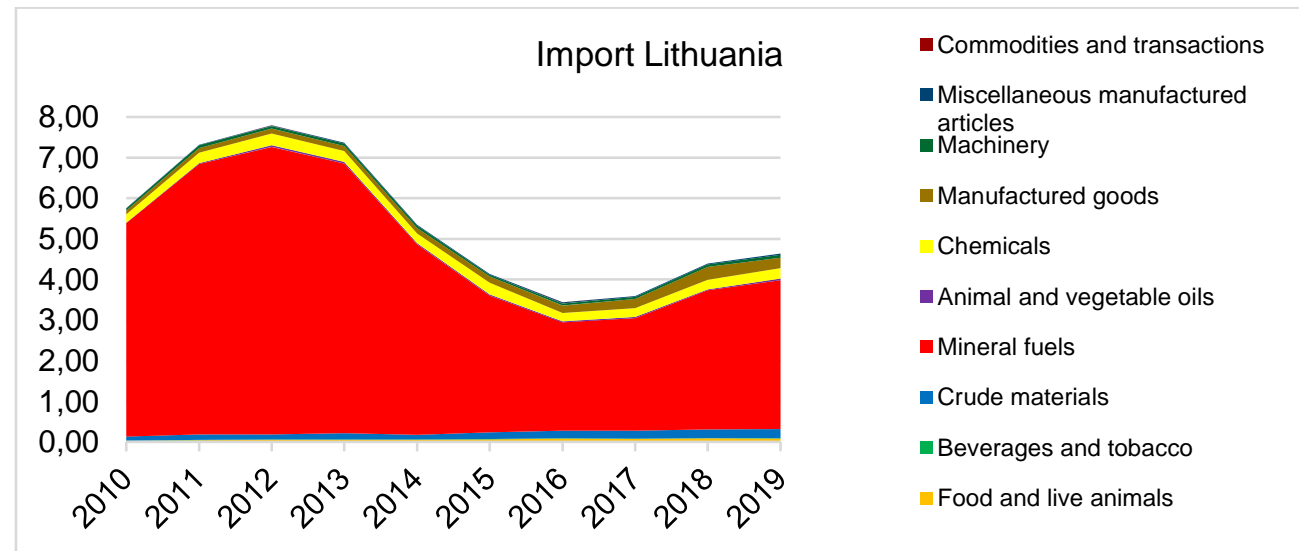

Figure 6: Lithuania's import from Russia, billion $€$ Source: Author's projection using Eurostat database (2021)

\section{Czech Republic}

The Czech Republic's share of export in the EU's total export to Russia was relatively constant between 2013 and 2019, varying between 3,75\% and 4,18\%. The same trend can be noticed in regard to its share of the CEECs' export to Russia (around 15\%). Even so, in the period mentioned above, Czech Republic's total export to Russia has declined. Its largest export was in machinery, which 
declined by $20 \%$. Export of food, beverages and miscellaneous manufactured articles kept their value relatively constant and registered increases in the last years of the analyzed period (see Figure 7). Also, total Czech imports from Russia have gradually fallen from EUR 5,38 billion in 2013 to EUR 2,94 billion in 2019. In 2013 the Czech Republic had 2,60\% of EU imports from Russia and 10,00\% of the CEECs' imports. After six years, the country had $1,86 \%$ of EU imports from Russia and 7,43\% respectively. In 2014-2019, imports of beverages and machinery from Russia to the Czech Republic have increased, while imports of crude materials and mineral fuels have recorded declines (see Figure 8).

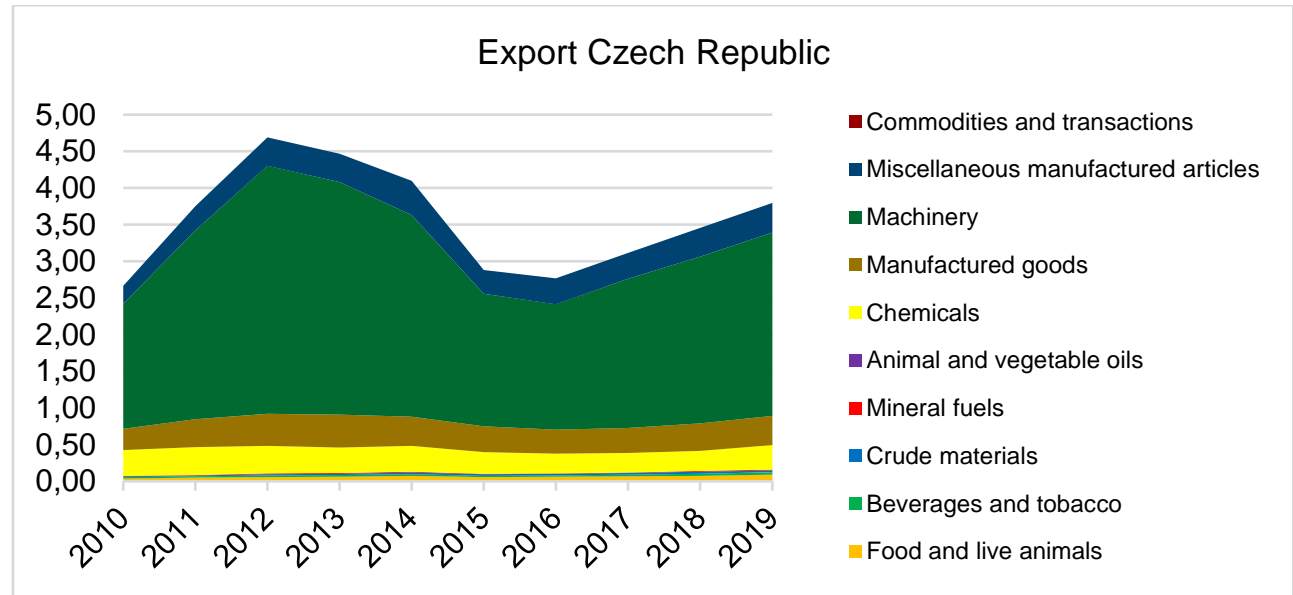

Figure 7: Czech Republic's export to Russia, billion $€$ Source: Author's projection using Eurostat database (2021)

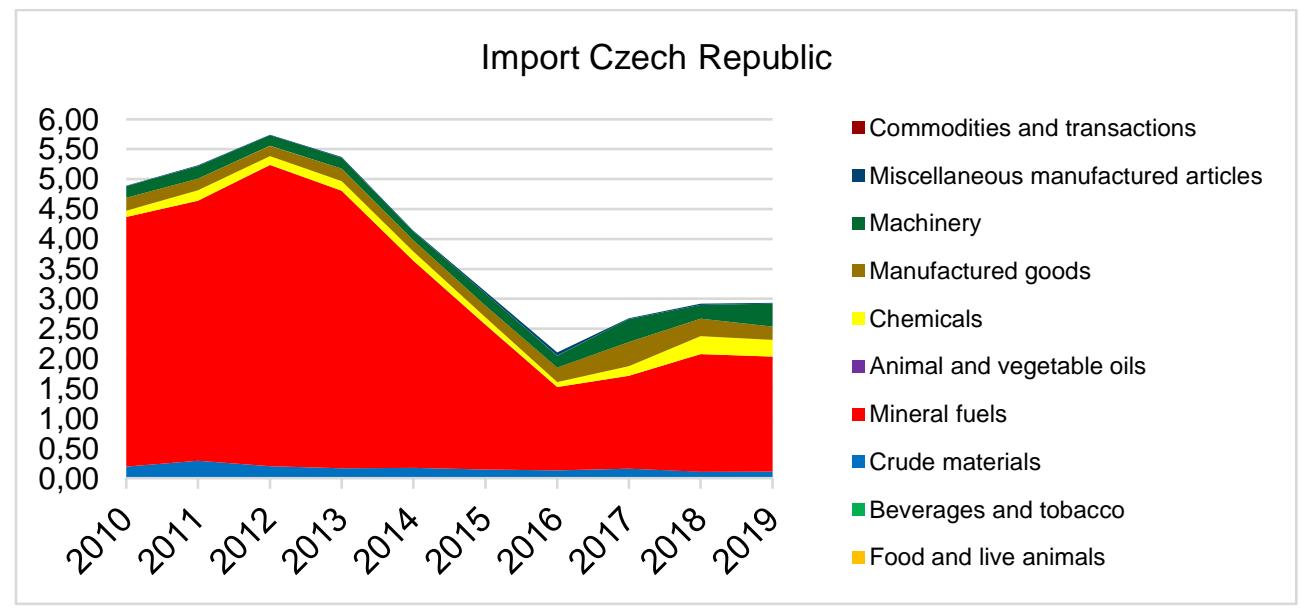

Figure 8: Czech Republic's import from Russia, billion $€$

Source: Author's projection using Eurostat database (2021)

\section{Latvia}

Latvia suffered a significant decline in 2015 and 2016, but it managed to recover its former export level and even outperformed it in 2018. Latvia had 1,47\% per cent of 
EU total export to Russia in 2013 and 6,05\% of the CEECs' export. In 2019 these shares had risen slightly to $2,18 \%$ and $8,24 \%$. Most important Latvia's export goods to Russia are beverages and machinery. Export of these categories of goods registered a decrease in the years 2014-2016, after which in the period 2017-2019 the imported values increased. Food export declined significantly and it has not recovered. Export of chemicals rose by EUR 0,05 billion and of miscellaneous goods by EUR 0,11 billion (year 2019 compared to 2013). Export of mineral fuels and animal and vegetable oils have also declined (see Figure 9).

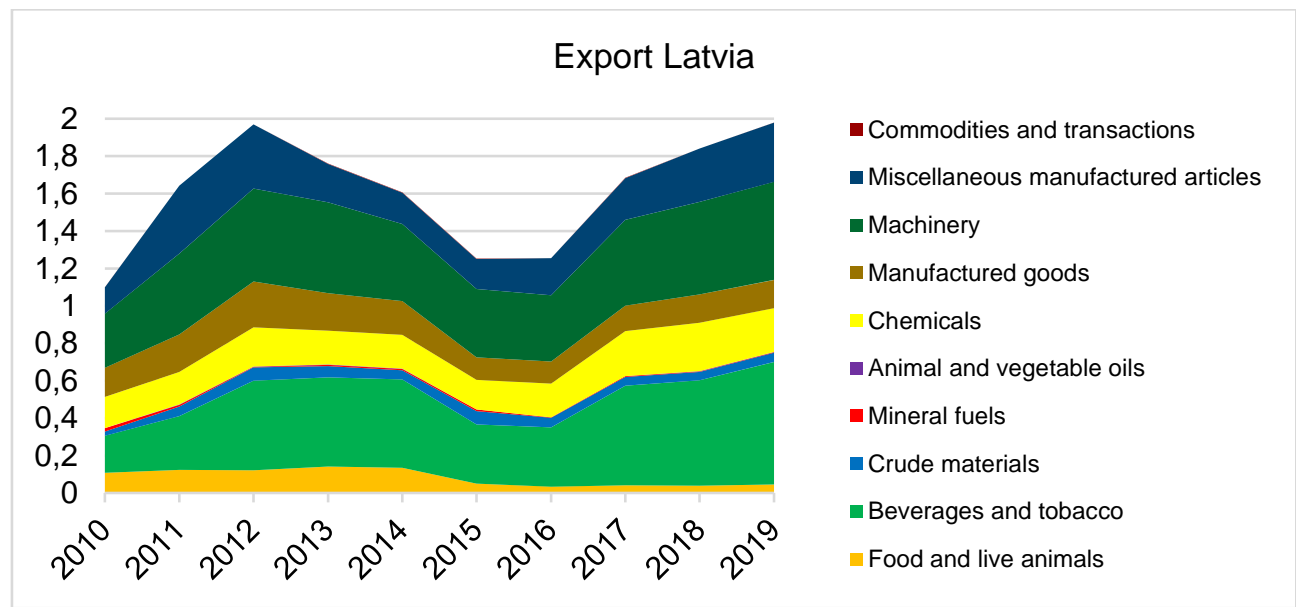

Figure 9: Latvia's export to Russia, billion $€$ Source: Author's projection using Eurostat database (2021)

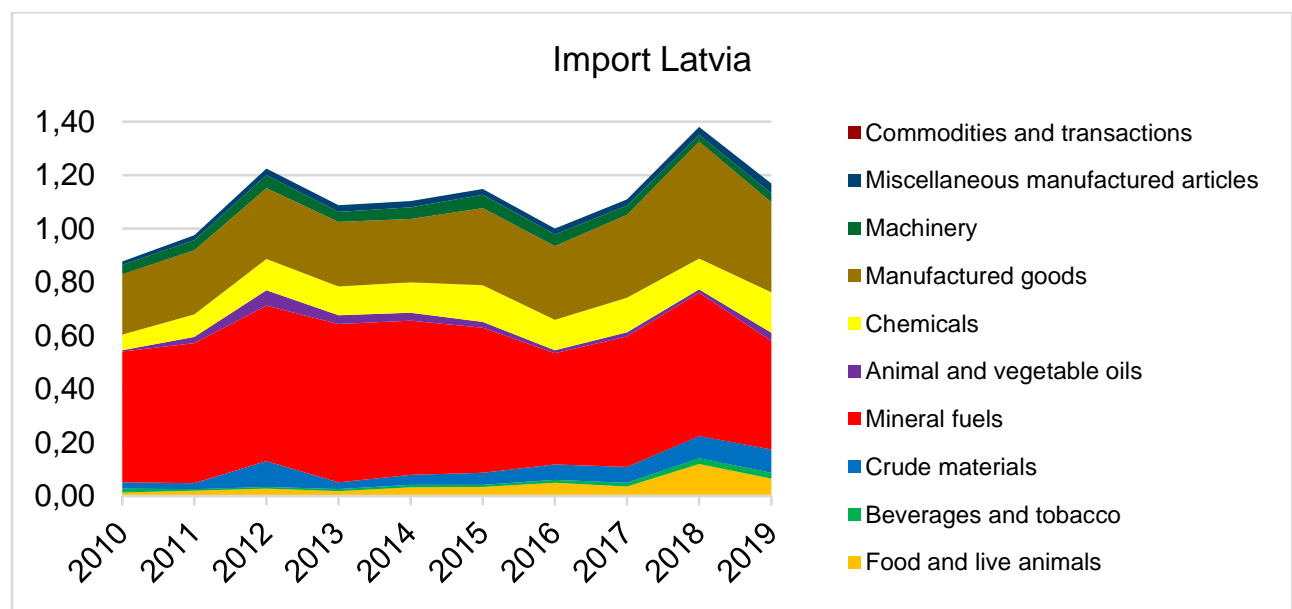

Figure 10: Latvia's import from Russia, billion $€$ Source: Author's projection using Eurostat database (2021)

Latvia's imports from Russia between 2013 and 2019 have been constant (around EUR one billion). Its share in total EU imports to Russia increased from $0,53 \%$ in 2013 to $0,74 \%$ in 2019 and that of the CEECs' imports from 2,02\% to 2,96\%. The 
main goods imported from Russia by Latvia are, as in the case of the other Central and Eastern European Countries, mineral fuels. In the period 2014-2019, the import of this type of goods decreased. At the same time, imports of food, beverages and tobacco and crude materials increased considerably. Imports of chemicals and manufactured goods also increased (see Figure 10).

\section{Romania}

In 2013 Romania had $1,16 \%$ of total EU export to Russia and $4,76 \%$ of the CEECs' total export. Romania's export to Russia consists primarily of machinery, chemicals and manufactured goods. In 2014, two of these three categories, namely machinery and chemicals registered an increase, after which in 2015 there was a sharp decline. Overall, these three types of export goods have declined between 2013 and 2019. Food exports increased in 2014 compared to 2013, after which they gradually decreased, and in 2019 they reached the lowest value during the period 2013-2019. However, there are several types of goods that have increased during the same period, for example: beverages and crude materials. Export of these goods is smaller by value but the increase compensates to some degree for the losses in the primary export goods (see Figure 11).

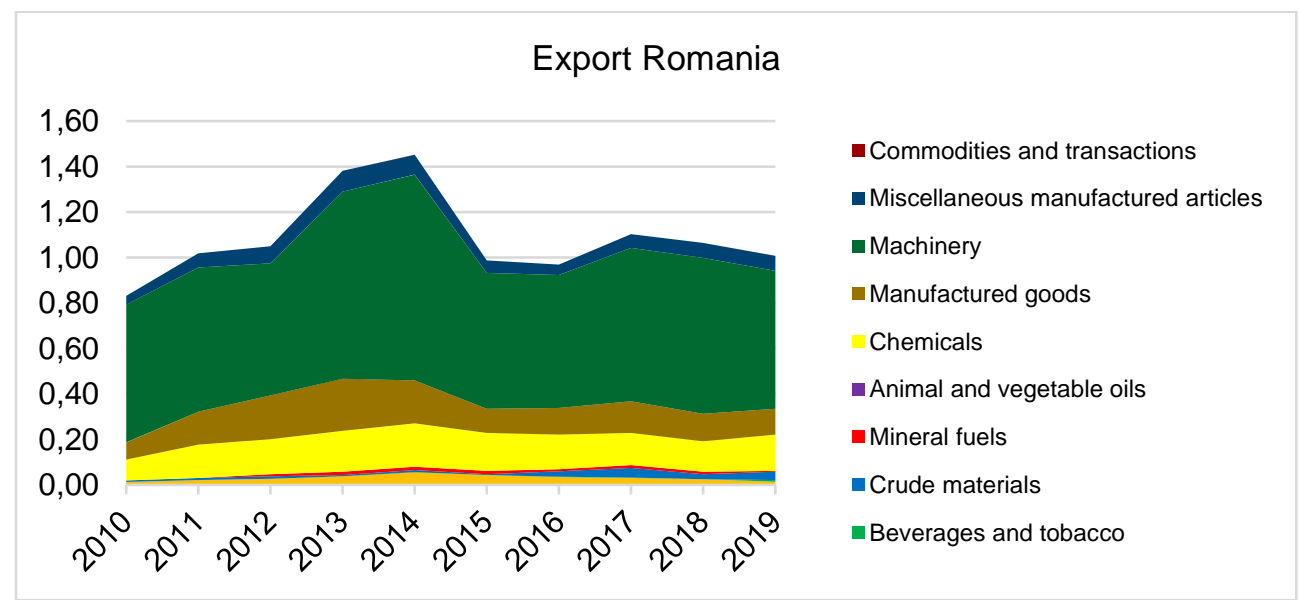

Figure 11: Romania's export to Russia, billion $€$

Source: Author's projection using Eurostat database (2021)

During these 6 years, the total value of imports from Russia to Romania has fluctuated (EUR 2,36 billion in 2013 and EUR 3,09 billion in 2019). From 2013 to 2016, total imports declined, after which they began to increase. In 2013 Romanian imports from the Russian Federation corresponded to 1,14\% of total EU imports from the Russian Federation and 4,39\% of the CEECs' total imports from Russia. In 2019, the respective figures were slightly higher, $1,96 \%$ and $7,84 \%$, respectively. Food imports decreased in 2014 and 2015, after which they recovered and even exceeded the values recorded in 2013. Beverage imports increased significantly from EUR 0,24 billion in 2013 to EUR 4,53 billion in 2019. Imports of chemicals decreased in the period 2014-2016, after which they recovered starting with 2017, and in 2019 the value registered in 2013 almost doubled. Also, during the analyzed period, the imports of manufactured goods and machinery increased considerably (see Figure 12). 


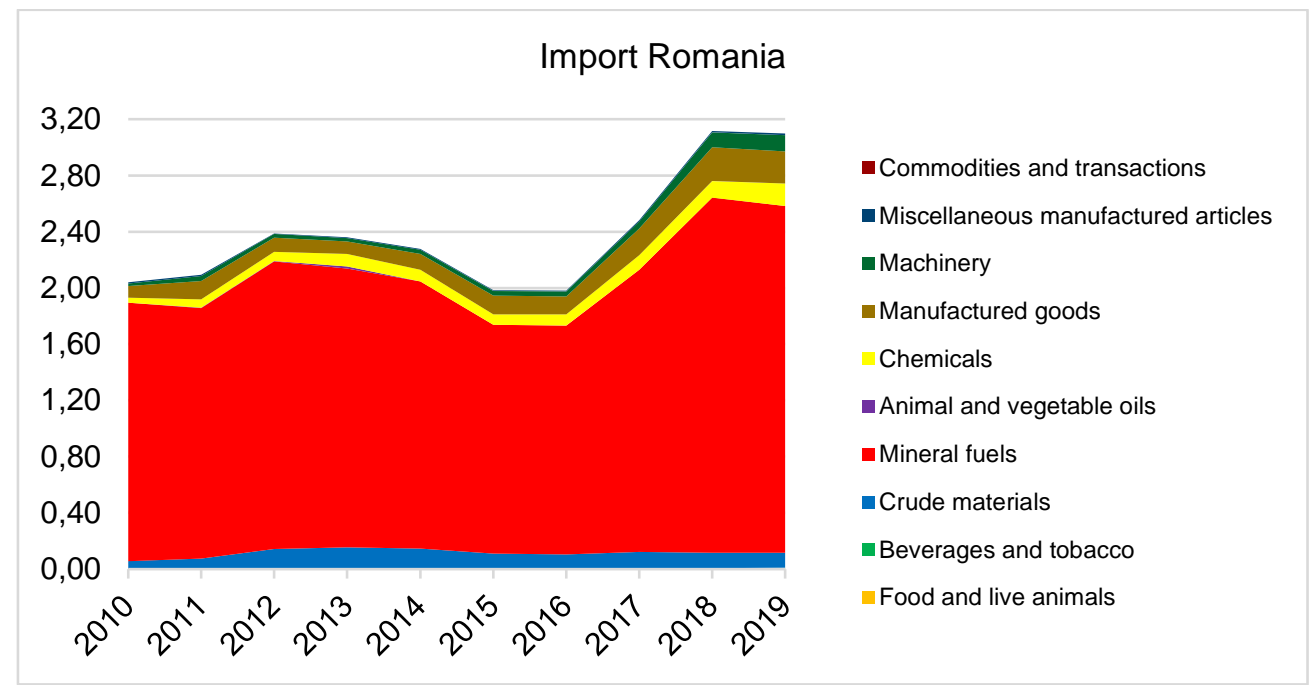

Figure 12: Romania's import from Russia, billion $€$ Source: Author's projection using Eurostat database (2021)

\section{Factors explaining the differences between the Central and Eastern European Countries}

The analysis of the historical data contributed to the discovery of some factors that can explain why the sanctions and counter-sanctions had a different impact on trade in goods between Central and Eastern European Countries and the Russian Federation. To begin with, some Member States have suffered more due to their geographical location. Being geographically close to the Russian Federation had led to a more intense bilateral trade. Following the sanctions, those countries incurred higher losses. Another finding of this research is related to how each country applied the restrictive measures against Russia. In addition, the categories of goods that dominate the imports and exports determine the existence of differences. The CEECs' exports to Russia are led by machinery and transport equipment, and Member States with a high share of machinery in their exports have experienced substantial losses. Countries, in the export structure of which, the products affected by sanctions and counter-sanctions, such as dual-use technology and agricultural products, had a higher share, suffered higher losses. CEECs that had a high share of food in their exports were affected significantly because of the food import ban imposed by the Russian Federation. Countries with relatively high levels of chemicals, raw materials and beverages in their exports suffered lower losses since these types of products were not directly affected by either the EU's economic sanctions or Russia's embargo on food products imported from European Union countries. 


\section{Conclusions}

TOM XXX, $2^{\text {nd }}$ Issue, December 2021

The research finds that in the years following the adoption of the restrictive measures, all eleven Central and Eastern European Countries saw a decline in their exports to the Russian Federation, but some states were more affected than others. CEECs' total imports from Russia also declined. Although bilateral trade has begun to recover since 2017, exports and imports still haven't managed to reach the values recorded in 2013.

Quantitative analysis of the historical data highlighted several factors that can explain why the restrictive measures had an uneven impact on trade in goods between Russia and the Member States. The differences are determined by the geographical proximity, the structure of each country's exports and the way in which the national authorities interpreted and applied the sanctions. Another finding is that Russia's principal trading partners among Central and Eastern European Countries suffered the largest losses in nominal terms. Poland, Lithuania and the Czech Republic are the states with the highest exports to Russia, which means these countries were the most affected by the decreasing exports to the Russian Federation.

Some categories of products were more severely affected than others. Thus, the structure of exports and imports of each country played a decisive role in establishing the level of sensitivity to restrictive measures. Also, the structure of exports and imports influenced the evolution of bilateral trade in the next period and determined the ability to recover trade between Russia and each of the eleven Central and Eastern European Countries.

\section{References}

1. Bali, M. (2018). "The Impact of Economic Sanctions on Russia and its Six Greatest European Trade Partners: a Country SVAR Analysis", Finance \& Business, 14 (2), pp.45-67.

2. Bond I., Odendahl C., Rankin J. (2015) Frozen: The politics and economics of sanctions against Russia. CER, London, [Online], Available: https://www.cer.eu/publications/archive/policy-brief/2015/frozen-politics-andeconomics-sanctions-against-russia [19 October 2021].

3. DG EPPD (2017) Russia's sanctions: economic and trade effects, compliance and the way forward, Directorate General for Externa Policies Department, paper produced on request of the European Parliament's Committee on International Trade [Online], Available: http://www.europarl.europa.eu/RegData/etudes/ STUD/2017/603847/EXPO_STU(2017)603847_EN.pdf [20 September 2021].

4. Dolidze T. (2015) EU Sanctions Policy towards Russia: The SanctionerSanctionee's Game of Thrones, CEPS Working Document No. 402, Bruxelles. [Online], Available: https://www.ceps.eu/ceps-publications/eu-sanctions-policytowards-russia-sanctioner-sanctionees-game-thrones/ [19 October 2021].

5. European Council, EU restrictive measures in response to the crisis in Ukraine, [Online], Available: https://www.consilium.europa.eu/en/policies/sanctions/ ukrainecrisis/) [19 October 2021].

6. Eurostat, EU trade since 1988 by HS2,4,6 and CN8, [Online], Available: https://appsso.eurostat.ec.europa.eu/nui/show.do?dataset=DS-645593\&lang=en [29 November 2021]. 
7. Giumelli, F (2017) "The Redistributive Impact of Restrictive Measures on EU Members: Winners and Losers from Imposing Sanctions on Russia", Journal of Common Market Studies (JCMS), vol. 55 no. 5, pp. $1062-1080$.

8. Gurvich, E., Prilepskiy, I. (2015) "The impact of financial sanctions on the Russian economy ", Russian Journal of Economics, Elsevier, vol. 1(4), pp 359-385. 9. Havlik, P. (2019) EU-Russia sanctions exchange has had important economic and political consequences, [Online], Available: https://wiiw.ac.at/eu-russiasanctions-exchange-has-had-important-economic-and-political-consequences-n365.html [15 November 2021].

10. Ilina E. (2015) "Effect of Sanctions on Russian economy", The Review of Economy, the Law and Sociology, pp. 34-37.

11. Oxenstierna, S. (2015) The sanctions against Russia. Are there winners and losers around the Baltic Sea? Some recommendations for the policy-makers, BSR Policy Briefing 9/2018, Centrum Balticum Foundation [Online], Available: http://www.centrumbalticum.org/files/4090/BSR_Policy_Briefing_10_2018.pdf [19 October 2021].

12. Russell, M. (2018) Sanctions over Ukraine Impact on Russia, European Parliamentary Research Service, [Online], Available: https://www.europarl.europa.eu/RegData/etudes/BRIE/2018/614665/EPRS_BRI(20 18) 614665_EN.pdf [19 October 2021]. 


\title{
OPTIMISER LE TRAVAIL D'EQUIPE GRACE A LA MAITRISE DES LANGUES ETRANGERES / OPTIMIZING TEAMWORK BY KNOWLEDGE OF FOREIGN LANGUAGES
}

\author{
Rodica BOGDAN \\ Department of International Business, Faculty of Economic Science, University of \\ Oradea, Oradea, România \\ robogdan17@gmail.com
}

\begin{abstract}
In the context of globalization and labour mobility, it has become a habit for teams to be made up of members from different countries, speaking different languages and having an inhomogeneous cultural background. For a basic communication to achieve professional goals, a common code is usually established. However, we find that the efficiency of communication and implicitly of the work results involves the knowledge of several foreign languages. In this paper we aim to emphasise how important it is for economics students to learn different foreign languages, to assimilate and master business language. Thus, they will be able to communicate easily in a professional environment and to develop at a brisk pace in order to reach the top of the company. The ability to interact with a teammate in the language s/he has mastered since childhood leads to increased trust and better group homogeneity, which results in the optimization of teamwork.
\end{abstract}

Keywords: teamwork; foreign language; communication; labour market; mobility; globalization

\section{JEL Classification: $Y 8$}

\section{Introduction}

Afin de renforcer leur formation professionnelle à l'heure de la mondialisation, les étudiants en économie sont de plus en plus convaincus que la maîtrise d'une ou de plusieurs langues étrangères est un atout indéniable. Outre leur satisfaction personnelle d'avoir accru le capital de connaissances et de compétences diverses, ils se rendent compte qu'ils peuvent plus facilement s'intégrer dans des équipes internationales et multiethniques, dans lesquelles ils devront mettre en valeur les compétences acquises.

On parle de mondialisation depuis des décennies, et parfois le concept est trop généralisé. L'accent est mis sur les côtés économique et culturel de la mondialisation. Mais il faut aussi considérer les dimensions sociologique et anthropologique.

La mobilité de la main-d'œuvre entraîne des changements dans les comportements individuels et collectifs - la façon dont les gens interagissent dans les nouveaux contextes de travail et de proximité. Ils sont influencés même dans leurs choix vestimentaires, et leurs habitudes alimentaires, de transport et de loisirs. 
Si le premier réflexe est de penser économiquement la mondialisation, la dimension politique ne peut être sous-estimée - "La dynamique de la mondialisation est contrôlée par des forces économiques, mais ses conséquences les plus importantes sont politiques" (Klaus Müller). Les décisions sur les crises économiques, les pandémies, les déplacements de personnes dans les zones UE et hors UE, la limitation des effets de la pollution, la prévention du réchauffement climatique, etc., toutes ces décisions sont prises au niveau politique, national, international et mondial.

L'éducation de la jeune génération, la formation professionnelle, les établissements d'enseignement de chaque pays sont intégrés dans un système cohérent, socioéconomique, politique et culturel. À l'ère de la mondialisation, ce système s'ouvre indéfiniment.

Les nouveaux défis liés à la formation et à l'orientation professionnelle des membres d'une communauté diversifiée ont un impact à long terme sur toute société. Les différences culturelles, de mentalité, d'orientation religieuse et de cohésion au sein des groupes sociaux entraînent des changements dans le comportement des consommateurs et se reflètent dans la dynamique du mécanisme de l'offre et de la demande sur le marché du travail.

Les grandes entreprises cherchent à optimiser leurs coûts de main-d'œuvre, ce qui conduit dans de nombreux cas à la formation d'équipes inhomogènes, mais qui doivent fonctionner efficacement et effectuer un travail de qualité.

II ne fait aucun doute que des professionnels bien formés dans tous les domaines sont nécessaires pour répondre aux demandes dans un contexte de mondialisation économique. Leur préparation se fait par étapes, depuis l'école primaire et secondaire, jusqu'à l'enseignement supérieur et postuniversitaire, ainsi que dans la formation professionnelle, où les connaissances théoriques sont mises en pratique, sont appliquées dans des situations concrètes.

\section{Développement des compétences linguistiques}

La mission de l'enseignement supérieur est de donner à chaque étudiant la chance de devenir compétitif dans sa formation professionnelle, et même de performer. II s'agit de développer des compétences en communication orale et écrite dans une ou plusieurs langues étrangères. Nous appelons génériquement la langue d'un individu LM (langue maternelle), et pour la langue de communication dans l'environnement professionnel nous utiliserons LP. Plus les compétences linguistiques d'un professionnel sont riches (LP1, LP2, LP3, LP4, etc.), plus il sera promu rapidement et accédera aux niveaux hiérarchiques les plus élevés de l'entreprise pour laquelle il travaille.

C'est pourquoi l'éducation dans notre pays met l'accent sur l'importance de la connaissance des langues étrangères de circulation internationale et sur l'acquisition de compétences linguistiques multiples. Les étudiants ont également la possibilité d'apprendre une langue spécialisée (LS). Dans le cas des étudiants en économie, il s'agit du langage des affaires. Acquérir la capacité de s'exprimer de manière cohérente et efficace dans une langue de circulation internationale augmente les chances d'intégration dans le domaine du travail à des postes mieux 
rémunérés, dans des entreprises qui se sont développées et opèrent dans le monde entier.

\section{Langue maternelle vs. langue professionnelle}

Suite à un questionnaire sur la nécessité de maîtriser une langue étrangère pour trouver un emploi dans notre pays, nous avons reçu plusieurs réponses, dont nous allons lister deux, pertinentes pour notre étude.

Les réponses données ont mis en évidence le fait qu'au travail les gens s'adaptent pour parler une langue étrangère à des fins professionnelles (LP), mais quand il s'agit de la famille et des proches, de la communication extra-professionnelle, la plupart optent pour l'utilisation de la langue maternelle (LM). Lorsqu'il y a deux membres ou plus dans une équipe qui parlent la même LM, ils s'entraident pour rendre la communication plus efficace dans la LP.

Les questions proposées aux personnes travaillant dans des équipes multiculturelles et multilingues étaient les suivantes : 1) Dans quelle mesure est-il nécessaire de connaître une ou plusieurs langues étrangères dans le milieu professionnel ? 2) En supposant que vous utilisiez la LP au travail, si vous avez un membre de l'équipe avec qui vous parlez la même langue maternelle, préférezvous le dialogue en LM ou LP ? 3) Connaissant une ou plusieurs langues étrangères, avez-vous de meilleures chances de vous intégrer sur le marché du travail roumain?

Voici deux réponses pertinentes:

1. A.M. - Travailler pour un produit SaaS avec plus de 6 millions de clients dans le monde signifie que toute la communication doit se faire en anglais. Lorsque $Z$. a rejoint notre équipe de marketing de contenu, j'étais ravi car avoir une personne anglophone dans mon équipe serait un atout majeur pour notre activité. Le fait que tout le monde dans l'équipe de contenu, mais surtout, tout le service marketing parle couramment l'anglais, m'a vraiment aidé à intégrer Z. Pour moi, c'était un défi car nous devions basculer toute notre communication du roumain vers l'anglais, ce qui signifiait que toutes nos réunions seraient en anglais. Au début, les membres de mon équipe étaient probablement plus réticents à communiquer avec $Z$. en raison de la barrière de la langue. Pourtant, après quelques mois de collaboration, je constate que chaque membre de l'équipe est plus à l'aise de parler une autre langue au bureau. Sans oublier que la capacité de tout le monde à parler anglais s'est considérablement améliorée (Working for a SaaS product with over 6 million clients worldwide means that all the communication must be done in English. When Z. joined our content marketing team, I was thrilled because having a native English-speaking person on my team would be a major plus for our activity. The fact that everyone in the content team, but most importantly, the entire marketing department is fluent in English, really helped me integrate Z. For me, it was a challenge because we had to switch all our communication from Romanian to English, which meant that all our meetings would be in English. At first, people in my team were probably more reticent to communicate with $Z$. due to the language barrier. Still, after a few months of working together, I can see that every team member is more comfortable speaking another language at the office. Not to mention that everyone's English speaking ability improved drastically). 
2. L.T. - Je considère qu'il est hautement nécessaire de parler au moins une langue étrangère au travail, en particulier dans les domaines de l'informatique, du marketing ou des affaires, où vous pouvez avoir des collègues de différents pays avec lesquels vous devez collaborer. Pour la deuxième question, la bonne réponse serait que je mélange les deux langues. Logiquement, il est toujours plus facile d'utiliser sa langue maternelle, mais les années d'écriture et de réflexion dans la langue étrangère requises par votre entreprise laissent vraiment des traces dans votre cerveau. Parfois, même sans m'en rendre compte, je commence mes conversations avec des mots anglais, au lieu du roumain, qui est ma langue maternelle. À la troisième question, ma réponse est définitivement oui! Étant donné que de plus en plus d'investisseurs étrangers créent des entreprises ici en Roumanie, il est crucial de parler au moins une langue étrangère (anglais, allemand ou français, par exemple). Comme je l'ai déjà dit, vous devrez collaborer avec des collègues de différents pays, et nous savons tous à quel point la communication est importante. De mon point de vue, le manque de parler des langues étrangères peut vous limiter beaucoup (I consider it highly necessary to speak at least one foreign language at work, especially in the IT, marketing, or business fields, where you might have colleagues from different countries with whom you must collaborate. The correct answer would be that I'm mixing both languages. Logically speaking, it's always easier to use your mother tongue, but the years of writing and thinking in the foreign language required by your company really do leave marks on your brain. Sometimes, even without realizing, I start my conversations with English words, instead of Romanian, which is my mother tongue. Definitely, yes! Since more and more foreign investors are starting businesses here in Romania, it's crucial to speak at least one foreign language (English, German or French, for instance). Like l've said before, you'll need to collaborate with colleagues from different countries, and we all know how important communication is. From my point of view, the lack of speaking foreign languages can limit yourself very much).

\section{Optimiser le travail d'équipe}

Surtout dans les moyennes et grandes entreprises, l'optimisation du travail en équipe a pour point de départ une communication optimale entre ses membres. Une équipe multiethnique et multilingue communiquera sur la base d'un code commun (LP), un langage dans lequel les membres de l'équipe pourront s'exprimer, promouvoir leurs idées et exercer leurs compétences linguistiques.

La cohésion de l'équipe passe avant tout par le dépassement des obstacles posés par les différences culturelles, nationales ou religieuses de ses membres. Les forces et les faiblesses de chacun doivent être maintenues en équilibre, en poursuivant l'unité de but afin d'atteindre les objectifs professionnels.

En même temps, venant d'horizons différents, les membres de l'équipe peuvent apporter une touche de créativité et d'innovation en raison des différences culturelles qui les ont marqués au cours de leur éducation et de leur formation.

Toute équipe multilingue et multiethnique déclenchera des mécanismes de compétition. Ainsi, ses membres seront constamment motivés pour se surpasser et atteindre la performance.

La communication professionnelle est efficace lorsque chaque membre de l'équipe comprend ce qu'il a à faire, quelle tâche il a, et pour cela il doit très bien connaître 
le code commun, la langue parlée dans le milieu professionnel (LP). La méconnaissance des tâches fixées par le leader, résultant d'une connaissance insuffisante de la langue utilisée sur le lieu de travail peut conduire à des conflits spontanés. Les résoudre en temps opportun et continuer le travail dans de bonnes conditions nécessite l'intervention du leader, et un bon manager d'équipe doit avoir la capacité de surmonter de tels conflits. II doit poursuivre l'objectif commun à l'avenir et minimiser les lacunes des différences culturelles et la compréhension de la langue des membres de l'équipe.

\section{Conclusion}

Travailler dans une équipe multiethnique et multiculturelle est un défi pour la jeune génération à l'ère de la mondialisation. Connaître et maîtriser une ou plusieurs langues étrangères aide les étudiants en économie à s'intégrer plus facilement sur le marché du travail et à décrocher des emplois mieux rémunérés.

Dans l'enseignement supérieur de notre pays on met le point sur la nécessité de développer les compétences linguistiques des étudiants. De la part de ceux qui travaillent déjà dans des équipes internationales, le feedback est en faveur de l'apprentissage des langues étrangères et du développement des compétences linguistiques et communicatives. Ainsi, les futurs collaborateurs seront mieux préparés à accroître la cohésion d'équipe et à atteindre les objectifs de performance professionnelle. Même si la plupart des gens préfèrent parler leur langue maternelle (LM) dans un environnement non professionnel, de plus en plus de jeunes s'adaptent bien à la communication en langue étrangère (LP) dans un environnement professionnel.

\section{References}

1. Meyer, E., The Culture Map: Breaking Through the Invisible Boundaries of Global Business, Public Affairs, 2016

2. Mucchielli, R., Le travail en équipe. Clés pour une meilleure efficacité collective, ESF Editeur, 2016

3. Müller, Klaus, Globalisierung, Campus Verlag, Frankfurt/Main, 2002

4. Thomas-Bion, F., Le système éducatif français, Rue des écoles, Agora Education, Paris, 2010

5. https://www.europarl.europa.eu/news/en/headlines/economy/20190712STO5 6968/globalisation-s-impact-on-employment-and-the-eu

6. https://asana.com/fr/resources/ways-improve-team-efficiency-work

7. https://www.fond.co/blog/9-ways-multicultural-team/

8. https://www.synchroteam.fr/blog/2016/01/05/gerer-equipe-multilinguemulticulturelle/.

9. https://www.weforum.org/agenda/2018/04/fix-the-roof-now-three-prioritiesfor-the-global-economy/ 


\title{
THE IDIOMATIC VOCABULARY OF THE PANDEMIC
}

\author{
Monica-Ariana SIM, Anamaria Mirabela POP \\ Department of International Business, Faculty of Economic Science, University of \\ Oradea, Oradea, România \\ arianamona@yahoo.com \\ mipop@uoradea.ro
}

\begin{abstract}
A pandemic was declared last year, and it has changed our lives forever. It has resulted in many unusual but necessary actions and measures and Coronavirus has led to an explosion of new words and phrases, both in English and in other languages. Language is meant for communication. Communication can have literal and figurative meanings. Idioms are a type of figurative language. They do not always and necessarily make sense literally. Learning idioms is fun, especially when you compare English idioms to the idioms in one's native language. English is a language particularly rich in idioms and they were extremely used in the present health circumstances as this new vocabulary helps us make sense of the changes that have suddenly become part of our everyday lives. Linguists are analysing these idioms and metaphors with a special attention paid to how effective they really are in encouraging compliance with public health advice, as well as issues of translation, and access to healthcare. The paper intends to present some of the most frequent expressions, idioms and perhaps metaphors that piled up in the very recent vocabulary.
\end{abstract}

Keywords: COVID-19, idioms; pandemic; vocabulary; language, dictionaries.

JEL classification: Y60

\section{Introduction}

As a widespread international phenomenon, the COVID-19 pandemic benefits from the vocabulary of globalization. The language we speak is always changing. There are several factors that drive change, among them the influence of other languages and major events that imprint our lives. Should new events happen, and circumstances change, we need new words to describe them. Currently humanity is facing one of the greatest challenges of this century: the COVID 19. People are going through a period of fearful insecurity and stress causing many problems and mental health, some of them probably hard to remediate. Nevertheless, people are adjusting to the new way of living: some countries of the world are still on lockdown, permitted to leave home only for such reasons as food and medicine shopping, others have managed better and are striving to come to normality. The fact is most people are faced with the sudden changes to lifestyles and that might be challenging. COVID-19 has had a major impact on people around the world, but how is the pandemic changing our language and the way we communicate? 
Besides politics and sports, health, disease, and medical breakthroughs are topics of interest generally, but with so many people impacted by the COVID-19 pandemic, there are even more media stories on these topics than usual. The new vocabulary talking about this issue helps people articulate their worries, share feelings about the biggest health crisis in generations. Despite the negative aspects which are numerous, it is interesting to observe that the pandemic brings people together around a set of collective cultural reference points working as a kind of social connector. Social distancing means the absence of the regular social contact; thus, shared talk is an important part of helping people feel connected to one another.

\section{Figurative meaning - Idioms}

"Creativity is not a capacity of special people but a special capacity of all people. It shows speakers as language makers and not simply as language users" (Carter, 2004) It is perfect beginning for the subchapter on figurative meaning, a choice of each end every individual.

Communication can have literal and figurative meanings. One can only rely on the literal meaning making direct reference to words or sentences to objects, others may also employ the figurative sense to give an imaginative description or a special effect. English is a language particularly rich in idioms; without them it would lose much of its variety and humour both in speech and writing. Louisa Bukingham (2006) remarks that "Idioms are widely recognized to be a stumbling block in the acquisition of a foreign language; it is often maintained that their 'arbitrary', language-specific nature makes them difficult for learners to understand and acquire, and resistant to translation."

Idioms are a form of a language that is spoken in a particular area and that uses some of its own words, grammar, and pronunciations; a style or form of expression that is characteristic of a particular person, type of art, etc. (http://www.merriam-webster.com/dictionary/idiom). Idioms which are pure samples of prefabricated speech may also be defined as "complex bits of frozen syntax, whose meanings are more than simply the sum of their individual parts" (Nattinger and De Carrico, 1992:32).

Briefly, an idiom is a combination of words that has some features:

- The meaning of the idiom is different from the meanings of the individual words themselves; it is thus a phrase which defies the regular grammatical rules and meanings. An idiom can have a literal meaning in one situation and a different

- The meaning of an idiom can be replaced by a single word. For example, "kick the bucket" is an idiomatic expression which means "die".

- In idiomatic expressions the words are used metaphorically. Therefore, the surface structure helps only a little in understanding the meaning of the whole expression: "to bury the hatchet", meaning to become friendly again after a disagreement, the meanings of the words 'to bury' and. 'the hatchet' are different from the meaning of the whole expression. 
- The word order of the idiom cannot be changed, they "tend to be frozen in form and meaning and do not allow change in structure and meaning". (Liu, Zhengyuan, 2012). For example, the idiom "let the cat out of the bag" cannot be reordered to "the cat got left out of the bag".

Further in the article there are examples of idioms that very frequently used during this period of the health crisis.

\subsection{Enriched vocabulary due to COVID 19 crisis}

In the global pandemic context of the last two years, the need for communication and specialists in the art and science of communication has been more evident than ever. Expressions, phrases or terms specific to crisis communication, which before the pandemic were part of the specialized vocabulary used by students, teachers or specialists in media and communication in classes, case studies, or to communicate isolated situations, have reached very short time to be widely used, thus entering the basic vocabulary of all languages.

Coronavirus has plundered towns, cities, and communities; thus, people face the challenge of figuring out how to talk about the impact the virus is having on everyday lives. The new medical crisis has led to an explosion of new words and phrases, both in English and in other languages for in times of significant change, linguistic creativity not only reflects the major preoccupations of the time, but also shows how people gather to talk about new challenges and contexts. In his book on linguistic creativity Ronald Carter (2004) considers that "verbal play is often undertaken for humorous purposes, serving in part to bring people closer together", as well as challenging the "normal" view of things. Carter goes on to argue that inventive language is not just ornamental, but practical. The unusual trend of the period refers to the fact that even though these new words or phrases are used by or written for the public they often contain terms that are usually only used by health professionals and other types of researchers.

Every three months the Oxford English Dictionary adds new words and phrases as "creativity shows speakers as language makers not simply language users" (Carter, 2004); still, due to the coronavirus crisis, more new words and meaning are being coined than ever before, and in an amazingly fast manner so they needed an early update. This new vocabulary helps us make sense of the changes that have suddenly become part of our everyday lives. Nevertheless, specialists claim that the only truly new word produced by the health crisis is the acronym COVID-19.

Most of the other coronavirus-related words or expressions -specialists claim- are older, more obscure words and phrases being drawn into common usage, such as reproduction number and social distancing.

All in all, established terms like self-isolating, pandemic, quarantine, lockdown, and key workers have increased in use, while coronavirus/COVID-19 neologisms such as covidiot, covideo party, covexit, are being registered by dictionaries faster and easier than ever. 
We will further on focus on words, phrases, and idioms around the theme of dealing with difficult situations. Idioms are descriptive and poetic, but unfortunately the literal and dictionary meanings of the words have little to do with the idioms' meanings. Idioms come from life experience. They are rich with meaning. The following enumeration of the most frequent expressions, idioms and perhaps metaphors that piled up in the very recent vocabulary with come according to the grammatical category.

\subsubsection{The noun grouping category}

Community transmission is also a syntagm that has gained ground as of all the ways in which Covid-19 can spread itself, being among the most worrying for health professionals. Community transmission means nobody knows how somebody got the disease. As opposed to this transmission with no clear origin, close contact of someone with Covid-19 is a person you have spent more than 15 minutes of face-to-face contact within two meters of someone who has Covid-19, indoors or outdoors and thus, contact tracing is identification and monitoring of people who may have had contact with an infectious person.

Exponential growth is one of phrases that have been misused in relation to the pandemic of 2020. The word exponential means having an exponent or to the power of; thus, if two people have Covid-19 today and four have it tomorrow and eight the following day, we face an actual exponential growth, but it does work for low numbers only - 100 cases today and 200 tomorrow, it would need 10,000 cases to make the growth exponential.

\subsubsection{Verb groups of coronavirus expressions}

Flattening the curve is a verbal construction that reflects the change of the steep upward curve on a graph of new disease cases to a flatter, shallower upward curve over a longer time through measures such as social distancing. The US Control of Disease Centre (CDC) defines the curve as a "visual display of the onset of illness among cases associated with an outbreak" and starting with 2020 we all have become obsessed about the daily figures and the trends that followed as we all felt somehow responsible for flattening the curve. Nevertheless, writer Karen Russell has found the term 'flatten the curve' to be reassuring - a reminder of the importance of both individual and collective action.

To test negative/ to test positive means that if someone takes a test for an infection and $\mathrm{s} /$ he tests negative, that means they do not have the infection, whereas if they test positive, that means they have the infection.

Cocooning is a term first coined in the 1980s for those with apocalyptic inclinations who were stocking their basements with VCRs, tins of beans and bottled water while awaiting the nuclear holocaust. It was brought back to attention in 2020 when people were told to "cocoon" so as to avoid other people, to remain indoors, have their shopping delivered and not venture out. 


\subsubsection{Adjective groups}

Non-essential is an adjective that is worth mentioning as it has been rising in frequency and that has enriched its original meaning from "something that is not necessary" to expressions like non-essential travel, employees, or businesses where the latter aims at the meaning related to recreational and leisure time like theaters, museums, restaurants.

Asymptomatic is also interesting as it is so very frequently used these days by non-specialists about showing no symptoms of a particular disease.

\subsubsection{Acronyms of coronavirus expressions}

Previously, other health crises also generated new acronyms and terminology: AIDS and HIV entered the language almost 40 years ago. There are new acronyms of the current crisis, that came along to populate our vocabulary.

COVID-19 is an acronym, a word combination already added by the dictionaries as "an acute respiratory illness in humans caused by coronavirus" where the latter term referring to the large category of coronaviruses that include the flue virus, MERS and SARS, for example. Thus, COVID-19 is the strain of coronaviruses we are facing today, consequently, it is a more specific term, the shortened word for the syntagm coronavirus disease 2019. One of the most used, searched for word of the recent period. Novel coronavirus is sometimes the name under which the newly identified coronavirus strain is often called.

But should it be written as COVID-19 or as Covid-19? The Oxford English Dictionary published it under the headword Covid-19.

$\mathrm{WFH}$ - another acronym describing the new working reality stands for working from home.

$R$-rate: $\mathrm{R}$ stands for reproduction. This is the rate at which the virus reproduces itself.

$P P E$-personal protective equipment like masks and gloves that are required.

$P C R$ test detects viral particles in blood or other body fluids. (PCR $=$ polymerase chain reaction) - the PCR test is one of the tools that doctors use to diagnose certain coronavirus diseases

\subsection{Words and expressions that shifted their meaning}

The social relations, the way people connect with one another produced numerous new words and phrases registered by dictionaries or caused changes in meaning. Some of these words can be confusing, even they have been encountered before. Here is a list of COVID-19 useful words and phrases.

Elbow bump is such an idiom referring to greeting one another when shaking hands is not a desirable option. The expression changed its meaning, as not long ago it was the equivalent of high five, a sort of celebration. 
Related to the same social interaction, new habits occurred and claimed for new words to render them, or new meanings of old words. Such an example is selfisolation. Previously, the named structure referred to political or economic aspects of countries that kept themselves separate. Historically, some countries have had an isolationist foreign policy, with no foreign trade and difficulty for other countries to enter them. Presently, self-isolation means something different - i.e., if someone has or thinks s/he has the coronavirus, they self-isolate and keep themselves apart from their family. They must stay physically apart and clean and disinfect the common areas.

Self-quarantine is another idiom made up of two words one of which is the Cambridge Dictionary's Word of Year 2020 -quarantine as a period in which people are kept apart, are not allowed to leave their homes or travel freely so that they do not spread or catch a disease. Presently, people are self-quarantining not to infect their families, so they must stay isolated, a tough thing to do.

Social distancing is a phrase very often heard written or seen. In the past it meant not wanting to get engaged socially with other people. Now it is less about feelings and attitudes or personal choices, and more about physical distance, i.e., to stay six feet apart.

Lockdown refers to an official order given in dangerous situations, controlling the free movement of people and vehicles. Originally, prisoners in jail might have been placed on lockdown if they showed violence. It is very strict, and it suggests danger. Currently, people refer to lockdown when staying home and they really wished to go out. In America it is called a stay at home order and is sounds less restrictive, or shelter in place. The last term used to be linked to gun violence or a tornado and it means stay and do not move whereas now it means do not go out meaning a prolonged period of social isolation.

Air bridge is an agreement in which two countries agree that people can fly directly between them, without some of the rules and controls that affect travellers from other countries.

New normal is a nowadays phrase describing the new existence we have lived in for the last twenty months: online education, working from home, Zoom calls, social distance, shuttered pubs and restaurants all became part of the "new normal".

Circuit breaker - the phrase is linked to a headline in a New York Times newspaper, "Markets Spiral as a Globe Shudders Over Virus." referring to the way the economy has suffered due to the pandemic.

Contact tracing - method of monitoring the spread of the virus.

Frontline workers designated the front-line medical staff, doctors and all the medical staff who sacrifice themselves every day.

Unprecedented - a word often heard in our political speeches - is an unprecedented situation.

Virtual happy hour - with the implementation of quarantine, people have thought of ways to get together, to interact, so they thought of the idea of "virtual happy hour" where people meet on an online platform and discuss. 


\subsection{New inventions}

TOM XXX. 2nd Issue. December 2021

The COVID-19 pandemic has produced new terms that are combinations of other words, being used for the fun of colourful communication. Nevertheless, Fiona McPherson (2020), the senior editor of the Oxford English Dictionary (OED) notes that the only actual new word added to the dictionary is "Covid-19", whereas the others are pre-existing terms that have gained new meaning at a time when many people are subject to a "stay-at-home order" (US), "movement control order" (Malaysia) or "enhanced community quarantine" (Philippines), "restricted traffic/movement" (Romania).

They include among others the following:

"maskne," an acne outbreak caused by facial coverings;

"zoombombing," that is an intrusion of uninvited on video conferences;

"quarantini," a cocktail consumed in isolation, even "quaranteams" which are online teams created during lockdown;

"covidiot," depicting someone who ignores public safety recommendations;

"doomscrolling," or "consuming a large amount of information that can affect you emotionally, without you being able to stop doing it." The expression reflects the reality experienced by many of us, who daily watched more and more tragic news.;

"vax" stands for vaccine, vaccination along with its derivative "vaxer", "anti-vaxer"/ anti-vaxxer referring to a person opposed to vaccines and vaccination on principle. "coronababies" are the children born or conceived during the pandemic and the word is obtained by prefixation.

The beauty of the language relies also on the metaphors people use when talking about our response to Coronavirus, making use of war metaphors invoking "battles', "enemies", and "front-lines" that are being widely applied to the pandemic, all these being already analysed by linguists. The psychological explanation of this reliance on emergency vocabulary could be explained by the need of building unity and mobilising swiftly. On the other hand, the perpetuation of this way of thinking and verbal expression might become dangerous by generating anxiety and distorting things about the pandemic.

\subsection{Idioms of the pandemic}

Toe the line meaning to conform to a rule or standard, to do what you are expected to do without causing trouble for anyone or to stand poised at the starting line in a footrace. e.g. Biden toes the line on Covid-19 vaccine messaging.

Break loose is an idiom that stands for suddenly stop being attached to something, get away from someone or something by using force or effort. e.g. A Novel Coronavirus is Breaking Loose.

Go to the wall means to fail, to be destroyed e.g. Lots of companies went to the wall during the pandemic.

Pull oneself together is recovering after emotions or painful, unpleasant actions. e.g. As a travel agency owner, she was terrified by the effects of the pandemic, but she pulled herself together. 
Show promise refers to indicate a likely success. e.g. The vaccine research against Covid-19 infection has been showing promise.

Taking a toll means causing harm over time. e.g. Corona virus is taking its toll on people's lives.

At the crossroads is at a point where an important decision needs to be made. e.g. These days Romania stands at a crossroads in its fight against the COVID-19 pandemic.

\section{The vocabulary of pandemic in Romanian - English influences}

The Romanian Academy organized, on the occasion of the Romanian Language Day, a debate in which Prof. Gabriela Pană Dindelegan, drew attention on the ever-increasing use of some terms related to the pandemic of coronavirus in Romanian.

"Asymptomatic versus symptomatic; quarantine, quarantining, quarantined, quantization; comorbidity, comorbidities; confirmed; contacts; contaminated, contamination; covid; sanitized; infection, infected; isolation, isolated; mask; plateau; positive, positivized, repositioned; relaxation with strictly referring to complying the rules; testing, tested and others ", were among the words enumerated by prof. Dindelegan (2021).

The current Romanian language behaves exactly like all the other languages, proving an impressive linguistic dynamic as the recent and rich vocabulary of the pandemic prides with newly created terms, new meanings, extensions, and deviations of meaning, some forming real families.

Nevertheless, linguists call these new words barbarisms, more precisely terms borrowed from a foreign language without being necessary and unassimilated or slang words (language specific to certain social or professional categories). They are usually terms improperly translated from the international press. These terms have been rolled out in official press releases and have often been taken up in public discourse without being explained. Still, language is a living organism, which transforms, evolves. It is possible that these newly entered terms in our vocabulary will disappear as quickly as they appeared.

They also began to be used out of the need to save words: we say " to quarantine" instead of "to set to quarantine"; or the verb "to impact" which has not been used before, whereas the noun "covid" as a short form of COVID 19 was turned into a verb proving once again the immense flexibility and versatility of Romanian language or, as pointed out prof. Gabriela Pană Dindelegan (2021), this phenomenon highlights the "vigor, richness and creative force" of the Romanian language.

\subsection{Examples of Romanian use of the vocabulary of the pandemic}


Some terms were just modeled according to foreign patterns, that is mainly English as it the most important source of information for Romanians, consequently new terms are being imported with identical form, others adapted, others simply translated. Here is a list of the most present one in the everyday discourse of non-specialists and media.

- distantare sociala (<engl.social distance) -"... pentru radicalii carora distantarea socială e o utopie, sau apropierea de infern".(https://www.dw.com/ro/lumea-de-dupa-corona/a-53064317)

- carantina - Metodologie pentru ieșirea din carantină in a 10 a zi cu efectuarea testului pentru SARS-COV-2 în a 8 a zi de carantină (https://dspb.ro/dspb-uploads/2021/08/IMG 0001.pdf).

- Lockdown (<engl.lockdown) -Frica de lockdown întârzie măsurile care ar putea salva vieți.

- certificat digital (<engl.digital certificate) (https://romania.europalibera.org/a/romania-lockdown/). Certificatele digitale COVID-19 pentru călătoriile în UE se pot descărca din portalul https://certificat-covid.gov.ro/.

- $\quad$ auto-izolare (<engl.self-isolation) - Care este diferența dintre autoizolarea la domiciliu și carantină? (https://www.unicef.org)

- Asimptomtic, asimptomatica, asipmtopmatici, asimptomatice (<engl. asymptomatic) - Prevederi importante în cazul celor asimptomatici (https://www.digi24.ro/stiri/actualitate).

- Campanie de vaccinare (<engl.vaccination campaign) - Campanie de vaccinare da roade, 80.627 de români s-au vaccinat în ultimele 24 de ore. (https://www.digi24.ro/stiri/actualitate).

- Rata de vaccinare (<engl. vaccination rate) - Țările cu rate mari de vaccinare din Europa iau măsuri din ce în ce mai dure. (https://alephnews.ro).

- noua normalitate (<engl.new normal)- Munca de acasa e noua normalitate pentru români. (https://www.mediafax.ro/social)

- munca de acasă/ munca remote (<working from home) - Munca remote îi afectează și pe noii angajați deoarece aceștia nu se integrează în echipă (https://www.mediafax.ro/social).

- Lucrători în prima linie (<engl.front line workers) - Protejarea tuturor lucrătorilor din prima linie este importantă, ei fiind cei mai vulnerabili la riscurile pentru sănătate (https://www.unicef.org/moldova/).

- Prima doza/a doua doza (< first dose) - Pentru doza a doua au mers 44.348 de români, în timp ce 17.978 au făcut a treia doza (https://www.digi24.ro/stiri/actualitate).

Primul val/ al doilea val )<first wave) - Focarul initial din Wuhan a fost primul val al pandemiei (https://www.dw.com/ro).

- Școala on-line (<online school) - când elevii de la stat reiau cursurile după ...să se intre în școală online (https://www.hotnews.ro/stiri-educatie25135647-cimpeanu-exista-sanse-din-8-noiembrie-scoala-inceapaonline.htm). 
Metaphors for COVID-19 are also taken from the war terminology as in English:

- război - Acest razboi a silit tarile sa-si inchida granitele si sa-si opreasca exporturile, $\quad \ldots \quad$ (https://www.dw.com/ro/lumea-de-dupa-corona/a53064317)

- criza prezentă - Sper că ne vom aduce aminte de asta nu doar pe durata crizei prezente, ci şi după ce aceasta se va fi încheiat. https://www.dw.com/ro/yuval-noah-harari-cel-mai-mare-pericol-nu-estevirusul-\%C3\%AEn-sine/a-53224160

- situația epidemiologică - În cazul în care situaţia epidemiologică nu se îmbunătăţeşte, elevii nu se vor întoarce fizic la şcoală după vacanţa de două săptămâni. https://www.romaniatv.net/scoli-inchise-si-dupa-8noiembrie-elevii-vor-face-cursuri-online-dupa-vacanta 5930148.html

Abbreviations that became words themselves copying the English model: PCR test, ATI, DSP, with the derivative DSP-ist, DSU.

- COVID itself was initially taken as an acronym, hence the writing of each component in capital letters, but has lost its acronymic meaning over time.

- $\quad$ test $P C R$ - Dacă o persoană a trecut prin boală și deține certificat digital mai are nevoie de test RT-PCR negativ pentru a călători? (http://www.mae.ro/node/51759)

- $\quad D S P$ - Datele $D S P$ de duminică dimineață confirmă trendul de scădere (https://www.bihon.ro/stirile-judetului-bihor/bihorul-cea-mai-mareincidenta-covid-din-tara-trei-orase-din-bihor-ocupa-primele-trei-locuri3853391).

In this process, Professor Dindelegan (2021) noted that not only the simple terms, invaded the vocabulary, but also the derivatives themselves", such as "izoletă", after the model bicicletă, motocicletă, "anticovid", "noncovid", derivatives with negative prefixes.

Romanian speakers convert 'COVID' into a verb- Câți s-au covidat zilele acestea? Therea are compounds with proper prefixes and those with prefixoids or suffixoids, such as coronavirus, coronasceptic, pandemic, thermoscanning, vaccinosceptic..

\section{Conclusions}

In this paper, we have provided information on aspects regarding the neologisms of the pandemic vocabulary and the attitudes and energy it causes in a language. Some of these words, phrases, idioms looked upon gravitate around the theme of dealing with difficult situations. Linguists believe that many of the terms currently in use will not endure. The ones with a stronger chance of remaining and maybe being included in dictionaries are those that describe lasting behavioural changes. Creativity is the key word of the present vocabulary, and it reflects the role of language as a means of coping mechanism. These innovative usages, enable people to name even the unnameable; and once you can name whatever is difficult, for instance, the practices, it just gives people power and a sense of belonging through shared vocabulary and of belonging, of not being alone. Ingenuity with vocabulary communicate as well that the current difficult situations will not last forever. As always, language serves its purpose. 


\section{References}

1. Bukingham, L (2006), A multilingual didactic approach to idioms using a conceptual framework, Retrieved May 8, 2021. [online] http://elies.rediris.es/Language Design/LD8/2-Louisa-multilingual-LD8.pdf

2. Carter, Ronald (2004), Language and Creativity: The Art of Common Talk, Routledge11 New Fetter Lane, London

3. Pana-Dindelegan, G. (2021) Statutul actual al limbii române, Retrieved May 10, 2021, https://acad.ro/com2021

4. Nattinger, J.R. \& De Carrico, J.S. (1992-2009). Lexical Phrases and Language Teaching, Oxford: OUP. Oxford Dictionary of Idioms (2000) Oxford: Oxford University Press, Print

5. Nilsen, A.P. \& Nilsen, D.L.F. (2003). A new spin on teaching vocabulary: A source-based approach. The Reading Teacher, 56, 436-439. (Analysis of Idiom Variation in the Framework of Linguistic Subjectivity ACADEMIC JOURNAL ARTICLE By Liu, Zhengyuan English Language Teaching, Vol. 5, No. 6 , June 2012, Retrieved April 17, 2021. [online] https://www.questia.com/library/journal/1P3-2691373711/analysis-of-idiomvariation-inthe-framework-of-linguistic)

6. Joseph, N. (2020), How COVID-19 is changing the English language, The Conversation, Retrieved March12, 2021. [online] https://theconversation.com/how-covid-19-is-changing-the-englishlanguage-146171

7. Popiolek, Kim (2020) Researchers study how COVID pandemic is affecting language change, Retrieved March12, 2021. [online] https://msutoday.msu.edu/news/2020/researchers-study-how-COVIDpandemic-is-affecting-language-change

8. Ben Sassi, Rakia (2021) 30 Idioms From Pandemic News to Sound Like Native English Speaker, Retrieved March17, 2021. [online] https://rakiabensassi.medium.com/english-idioms-from-pandemic-news-f0f167af650c

9. Ro, Christine (2020) Why we've created new language for coronavirus, Retrieved March12, $2021 . \quad$ [online] https://www.bbc.com/worklife/article/20200522-why-weve-created-newlanguage-for-coronavirus

10. https://www.dw.com/en/german-idioms-in-challenging-times/a-52921901

11. https://www.arc.unsw.edu.au/volunteering/culture-cafe/5-english-idioms

12. https://www.nps.org.au/glossary

13. https://www.linkedin.com/pulse/social-english-5-idioms-expressions-talkcovid-19-louise-pirie/

14. https://theconversation.com/coronavirus-has-led-to-an-explosion-of-newwords-and-phrases-and-that-helps-us-cope-136909

15. https://www.irishtimes.com/news/ireland/irish-news/covid-19-cocooningnew-normal-10-phrases-that-defined-2020-1.4448012

16. https://dictionaryblog.cambridge.org/2020/04/01/making-the-best-of-itdealing-with-life-during-the-coronavirus-pandemic/

17. https://www.cdc.gov/

18. https://eslflow.com/21743.html 
19. https://www.romaniatv.net/scoli-inchise-si-dupa-8-noiembrie-elevii-vorface-cursuri-online-dupa-vacanta 5930148.html

20. https://www.dw.com/ro/yuval-noah-harari-cel-mai-mare-pericol-nu-estevirusul-\%C3\%AEn-sine/a-53224160

21. https://www.dw.com/ro/lumea-de-dupa-corona/a-53064317

22. https://certificat-covid.gov.ro

23. https://www.bihon.ro/stirile-judetului-bihor/bihorul-cea-mai-mare-incidentacovid-din-tara-trei-orase-din-bihor-ocupa-primele-trei-locuri-3853391/

24. http://www.mae.ro/node/51759

25. https://www.hotnews.ro/stiri-educatie-25135647-cimpeanu-exista-sansedin-8-noiembrie-scoala-inceapa-online.htm

26. https://www.dw.com/ro

27. https://dspb.ro/dspb-uploads/2021/08/IMG 0001.pdf

28. https://romania.europalibera.org/a/romania-lockdown/

29. https://www.digi24.ro/stiri/actualitate

30. https://www.mediafax.ro/social

31. https://www.unicef.org/moldova/

32. https://www.unicef.org/

33. https://alephnews.ro 


\title{
THE PERKS AND DOWNSIDES OF TEACHING ENGLISH ONLINE
}

\section{Cristina-Laura ABRUDAN, loana-Claudia HOREA}

Faculty of Economic Sciences, University of Oradea, Oradea, Romania cabrudan2003@yhaoo.com

ihorea@gmail.com

\begin{abstract}
In the 1990s, the rise of the Internet throughout the world helped significantly the job of the English language teachers, in ways of having access to vast information and access to new methods of teaching foreign languages. We think that, back then, nobody thought of what technology and access to Internet would mean to us one day. But since the beginning of 2020, the world has been going through an unprecedented crisis. The pandemic has changed everything: family behaviour, schools, businesses, environment, and so on and so forth. The world has been divided into two: the businesses and companies that have been stopped and the sector of the jobs that continued working. Since many countries have faced lockdowns, subsequently many schools have closed their doors. The teachers have faced the situation of delivering courses using virtual classrooms, not matter how tech-shy they have been. Of course, online teaching English has both advantages and disadvantages. The question is simple: do the perks outweigh the downsides of teaching English online? The answer is difficult. It depends on every teacher. The present paper is trying to throw some light on this question.
\end{abstract}

Keywords: teaching English; innovation; on-line technologies; education research.

JEL Classification: J60

'The next big killer on the Internet will be education. Online education will be so great that it will make email use seem like a rough mistake.' Cisco Systems CEO, John T. Chambers stated in 1999. And so, it happened.

\section{Introduction}

In March 2020, our lives began to look different. Even though, none of us understood what was going on, we still had to face the reality of a lockdown regarding all aspects of our lives. Consequently, the lockdown movement had a great impact on schools, on our teaching methods and on our way of using technology. Thus, for teachers, using virtual classrooms and providing online selfstudy materials for students have become the new way of delivering the act of education. The 'new normal' in education has triggered new ways of learning. Today, digital learning has emerged as a necessary resource for students and schools all over the world, whether we like it or not; and for certain types of learners, there are incredible benefits. Still, many teachers nowadays are reluctant to teaching online since it lacks face-to face contact with the students, it can be focused more on grading than on teaching, and the technological expertise for undergoing this task is often limited, lacking pedagogical skills. Critical thinking, problem-solving and communication represent some of the key factors that 
influence learning. If the students are successful in controlling these factors, the success of distance learning is fulfilled. As with most teaching methods, online learning also has its own set of perks and downsides. Decoding and understanding these positives and negatives will help teachers create strategies for being more efficient in the act of delivering the lessons, thus ensuring an uninterrupted learning journey for students. This is the topic of the present paper, having the aim to highlight the advantages and disadvantages of online learning.

\subsection{The concept and definition of E-learning}

Since the great appearance of the Internet that has radically changed our lives, the international network has gained the recognition of one of the vital ways of making resources and information available, both for research and learning, for teachers and students, in order to acquire and share information. Online learning, also known as e-learning, is actually the acquisition of knowledge which takes place virtually, by means of media and electronic technologies, encompassing the use of the Internet in order to produce materials for learning, covering a large range of applications, learning methods and processes. There has been large debate on the topic of a common definition for the term online learning, or e-learning and researchers don't seem to have found a common point. Thus, it is difficult to find a definition that has been commonly accepted. According to Rossi (2009), Hawkins (2008) and Dublin (2003), there is no common definition for the term. Hawkins (2008) noted that 'e-Learning has transformed from a fully-online course to using technology to deliver part or all of a course independent of permanent time and place'. Also, in 2001, the European Commission describes e-learning as 'the use of new multimedia technologies and the Internet to increase learning quality by easing access to facilities and services as well as distant exchanges and collaboration'. Abbad et al (2009) regard as e-learning, any type of learning activity that is undergone by means of electronic equipment, thus, narrowing somehow the definition of online learning to learning that is empowered by the use of the Internet, actually by the use of digital technologies. According to OECD (2005) elearning is defined as the use of information and communication technologies in diverse processes of education to support and enhance learning in institutions of higher education and includes the usage of information and communication technology as a complement to traditional classrooms, online learning or mixing the two modes.' Another point of view is expressed by Wentling et al in 2000, when the term e-learning is used to express the attainment and use of knowledge that are mainly distributed and facilitated by electronic means. In some definitions, elearning refers to using the computer and the communication technologies that enable the access to the internet while in some others, the term e-learning refers to the attainment and use of knowledge that are mainly distributed and facilitated by electronic devices. Some other researchers consider that e-learning is a revolutionary approach of studying which enables the students the access to an interactive system, that is customizable, repetitious, and self-paced.

But all these definitions have certain common points that must be mentioned: elearning summarizes a revolutionary approach centred on the learner that can customize his/her process of learning, giving the students the possibility of individualized support; it proposes a multimedia environment that gives freedom to 
its students; the multimedia constructs have changed the process of learning into a more active and enjoyable one. Thus, the practices of e-learning require a deep evaluation before being implemented in the process of learning. The consideration of gains and losses of using particular education technologies, methodologies represent an important part of this evaluation.

\subsection{The history of E-learning}

Francis Bacon, a British philosopher, stated in the 1600s that Knowledge is power. Thus, the one who has knowledge has also power in all the domains of our lives: power over nature, power over people, power over thoughts, power over everything that surrounds us. Moreover, knowledge is given by education, whether it is elearning or traditional, education has a vital role in the world today.

The first official recognition of education through correspondence took place in 1883, the University of Wisconsin and the University of Chicago establishing major correspondence programs. In the 1960s and 1970s, due to the development of new media technologies, significant changes occurred in long distance learning. The success of satellite communication, in 1965, brought about an increased level of experimentation with educational programs via satellites. The tools that were at hand, such as television, telephone, and videotapes gave free way to the more complicated and sophisticated educational programs. This is the way in which, in the 1990s, long distance education was developing at an unprecedented pace. The Internet and the digital applications added a whole new dimension to the term of distance learner, bringing along educational opportunities to the nontraditio0nal learner. Along with the appearance of these, the term e-learning started to take shape. According to Laurillard (2004) 'e-learning describes the interaction in which students use different types of ICTs in their learning process.' Both for the students and for the teachers, the ICTs and e-learning are extremely important. They create more flexible solutions for both parties involved in the educational process. In 2009 , the courses which were held online reached $65 \%$. The number has been steadily increasing ever since.

\subsection{Types of E-learning}

According to Aparicio, Bacao \& Oliveira 'The e-learning systems' theoretical framework contains the three main components of information systems. These components are people, technologies, and services. People interact with e-learning systems. E-learning technologies enable the direct or indirect interaction of the different groups of users. Technologies provide support to integrate content, enable communication, and provide collaboration tools. E-learning services integrate all the activities corresponding to pedagogical models and to instructional strategies. The complex interaction combination is the direct or indirect action with e-learning systems. At the same time, systems provide services according to the specified strategies for activities. In other words, service specifications are elearning activities aligned with the e-learning pedagogical models and the instructional strategies'.

There are several ways of classifying the e-learning types, according to: the learning tools, the extent of the engagement in education and the timing of the 
interaction. Scientist have identified the following categories: computer assisted instruction (CAI), computer assisted learning (CAL), computer-based education (CBE), learning management systems (LMS), and massive open online courses (MOOC). The two common aspects of these concepts are: learning and computers. In the case of computer-based learning, there is a full range of hardware and software that comprises it and each component can be used in either of two ways: computer managed instruction and computer assisted learning. In the first category, the computer replaces the traditional methods, providing the interactive software as a support tool during the classes. It operates with through information databases. However, the computers have the role of storing and retrieving information, helping in the management of education, containing the information that the student has to learn. On the other hand, the internet-based learning represents a step forward in the computer assisted learning, having links and knowledge sources that can be used by learners at any time and in any place. Interactivity is the primary value of this type of learning, allowing students to become interactive learners not just passive ones.

Some other scientists make a difference between synchronous online learning and asynchronous online learning. When talking about learning, synchronous learning refers to an event in which all the participants are engaged in the process of learning at the same time. There are several advantages of this type of learning, among which we mention: the participants can interact, the teacher can give realtime feedback to the students, the schedule is fixed, and the participants can share their knowledge and experience. On the other hand, asynchronous learning refers exactly to the opposite. There is no real-time interaction between the participants, the teacher isn't engaged in the process at the same time with the students, and there isn't a fixed schedule. Of course, this type of e-learning has its own advantages too: the participants can learn according to their own schedule, automated tasks reduce the repetitive work, the work of the teacher is somehow reduced as the pre-recorded videos, audio files, and webinar recordings can be used several times. Among other types of e-learning we mention fixed e-learning, adaptive e-learning, linear e-learning, interactive e-learning, individual online learning and collaborative online learning. Fixed e-learning refers to the fact that the material used does not change from its original variant and all the students receive the information in the same way, without any changes from group one grout to another, being predetermined and without being adapted to the students; preferences. On the other hand, the adaptive e-learning is a relatively new and adaptive type of e-learning which can be adapted and redesigned for each group of students, allowing the process of learning to be more student-centred and more individualized. The interactive e-learning permits the two parties implied in the process to switch roles thus the sender becomes the receiver and vice-versa. But what does this actually mean? It means that, from the messages that have been sent and received the students can change their learning methods and the teachers can change their teaching methods. The Internet has an enormous potential for rapid dissemination of information and knowledge and these are just a few examples of e-learning types.

Elliott Masie, a New-York-based training think tank's president estimated that $92 \%$ of large organisations worldwide will use one form or another of online learning. 
The designing, the developing and the delivering online teaching has several distinct advantages and disadvantages.

\section{Advantages and disadvantages}

The traditional way of teaching/learning has encountered a wide range of issues, beginning with the management of the classes, scheduling, assessing, ending with communicating and balancing the face-to-face classes. In view of these issues, the concept of online teaching has started to be more and more present in the field of English Language Teaching. On the other hand, the online mode of teaching/learning has endowed a new set of advantages and disadvantages, as there is no perfect way of teaching/learning.

\subsection{Advantages}

\section{1) EFFICIENCY}

Online teaching offers a number of tools such as videos, PDFs, podcasts, and teachers can use these tools as part of their lessons. By extending the lesson plan beyond the traditional textbooks, teachers are able to become more efficient educators since the young generation's life, as a whole, depends on gadgets.

\section{2)SUITABILITY, EXTENDIBILITY AND ACCESIBILITY}

The most obvious advantage of online learning is that it allows people to learn in their own way, at their own pace, absorbing as much information as they can. The fact that students can attend classes from any location of their choice is another advantage, allowing universities to reach out to a more extensive network of students without being restricted by geographical boundaries. Moreover, if some students need more time on a certain topic, they can go through it over and over again, as slowly as they can and as many times as they wish. Also, the fact that they can listen to the material or read the original material can facilitate knowledge retention.

\section{3) REDUCED COSTS}

This is one of the most obvious advantages of online learning since researchers have stated that half-day of traditional training is equivalent to a one-hour elearning course. The reduced financial cost transforms online education in a more affordable one as compared to physical learning since there are no more accommodation costs, transportation costs, meals for students, and so on and so forth. Expenses regarding students' travel, training facilities, in-house training development and equipment do not represent an issue anymore.

\section{4) COLLABORATIVE AND EXPLORATORY LEARNING ENVIRONMENTS}

The entire process of learning is based on exploration, as students explore the content of a course, on their own, building a solid knowledge base, cooperating and collaborating in order to uncover information, share the findings and solve exercises and problems together. The online teaching/learning system allows the learners to approach problems in different ways, according to relevance, adopted strategies and learning mechanisms.

\section{5) EASE OF CONTENT UPDATE}

In today's world, information and knowledge change faster than ever. With printed materials, the whole process of sharing information for teachers is a complex one, being also costly and sometimes time-demanding. On the other hand, on-line courses can be adapted easily and the changes undergone by the teacher can 
instantaneously be available to the students. Moreover, the fact that students can have access to the changes of the course on the spot, as their teacher is undergoing them, is definitely an advantage, being a friendly way to transmit the information adapted to the needs of the students.

\section{6) CONTROLLED ACCES AND IMPROVED STUDENT'S ATTENDANCE}

From the teacher's point of view, one of the main advantages of online teaching is that you can direct and monitor exactly who receives the training. Moreover, you the teacher can collect a lot of information regarding the students' activity: when the students access the discipline's page, how many times, how they organise their work and also you have full access to their work, including homework, projects, and so on and so forth. On the other hand, since online classes can be taken from home or location of choice, there are fewer chances of students missing out on lessons.

\subsection{Disadvantages}

Besides the advantages mentioned in the lines above, the teaching/learning activity encounters a lot of disadvantages too, which can be seen as challenges that both teachers and students must overcome. In this respect, we will try to give also some hints how to overcome these challenges.

\section{1) Difficulty in adaptability}

Both the students and the teachers who have always been studying in the traditional way find it difficult to adapt to the online environment, to focus on the online platform at once, and also to meet today's educational demand. The era of globalisation has brought about the era of information economy and the era of technology and therefore teachers must continuously update their knowledge and skills. The slower the adaptability process is, the slower the results of the teaching/ learning results appear. And we all know that the quality of the human capital comes from a quality education process.

\section{2) Online learning/teaching requires self-discipline}

The fact that online learning creates a sense of isolation is known to everyone. Students physically attending classes increases accountability and the sense of proper guidance. If these lack and the students have the feeling of not being part of a community, they may not have enough self-discipline and they may not have enough discipline to fully engage in the lessons themselves. In order to keep the students engaged, teachers have to use tools like real-time classes instead of just online classes, live quizzes, giving the students a greater sense of accountability. The current generation of students may be more satisfied with the online methods but the teachers must bring to their attention that self-discipline is crucial in achieving results.

\section{3) Additional training for teachers}

In order to create successful online classes, teachers must make extra effort to increase their knowledge, continuously developing their expertness to implement innovative way of teaching strategies. The results of the courses depend mostly on the positive learning relationships between the students and the teachers and also 
on the effective learning environment that can be created through online method of handling English language teaching. Online classes have a lot of advantages. Thus, the teachers need to have a deeper understanding of the different approaches to teaching and learning, making the most of the tools that online teaching has to offer. This is, of course, a time-demanding activity and for the ones who are more accustomed to the traditional way of teaching/learning, this could represent a disadvantage. On the other hand, teachers need proper training regarding the use of the technical equipment, otherwise they do not know how to offer the most of the benefits that technology offers us. For the teachers, proper training means new skills that represent a steep learning curve, but thoughtful investment in proper training will pay off both for the institution, where teachers work, and for the teachers.

\section{4) Technical issues}

Everybody knows that technology is complex and its complexity makes online classes be prone to technical issues. Connection issues that disrupt online classes are extremely unpleasant both for the teacher and for the students. In the past, students were required to install cumbersome apps that would deliver information that sometimes was inconsistent. Nowadays, things have changed, and we are as far as a click from online classes, without having the need of installing anything. Not only the Internet worldwide has increased dramatically but also the students' devices have improved significantly.

\section{5) More screen-time}

The raise of the Internet, the appearance of the technology, the digitalisation throughout the world have all led to a frightening amount of time spent by everyone in front of screens. Sadly, online classes contribute a great deal to this problem. Excessive screen-time can lead to all sorts of problems, including health problems like headaches and poor posture but also psychological problems that can root from the sense of isolation that we all have during this process. Students can also have problems regarding focusing, since the Internet can distract us with social media and entertainment that is just a click away. Good online platforms and software have all kinds of features and tools that can help students stay engaged in the complex process of learning.

\section{Conclusions}

In the present paper we have tried to put forward the idea that along with the idea of globalisation, the Internet and the development of technology, the spread of online teaching/learning have posed new challenges to teachers in general, not only to language teachers. The recent boom in the development of the mobile technologies and of the Internet has given way to the present-day students and teachers to an unrestricted access to information, knowledge and learning, which led to the re-conceptualization of the meaning of communication and the purpose of our teaching. New learning and education patterns have emerged due to the rapid transfer in the field of technology. In order to meet today's educational demands today's teacher needs to focus on 'professional development'. As Hargreaves and Fullan say 'the teacher is the ultimate key to educational change 
and school improvement'. Especially language teachers can use their own practice for developing attractive and challenging strategies in the online mode by exploring the opportunity to easily share information and collaborating on a wide range of topics and projects. Of course, there are advantages and disadvantages since no learning/teaching method is flawless. Generally speaking, it is always advisable to take into consideration the fact that online learning/teaching can be accessed from anywhere and anytime, being cost-effective providing consistent and standardized training every time. The experience is the same for all the students, each having unique preferences and goal. Online learning has the possibility of catering to individual needs, giving us the possibility of having another look at what we have been doing in our classrooms in terms of methods, strategies and outcomes. As we have stated in the lines above, online teaching and learning have a wide range of advantages, posing some challenges, too. The role of the teachers is to monitor the engagement of the students in classes, to teach, to provide advice for students and also to help in coping with the abrupt crises that can often occur, therefor being crucial to understand both the perception of the teachers and of the students concerning online classes.

\section{References}

1.Abbad, M. M., Morris, D., \& de Nahlik, C., Looking under the Bonnet: Factors Affecting Student Adoption of E-Learning Systems in Jordan. The International Review of Research in Open and Distance Learning, 2009

2. Casey M., Shaw E., Online Teaching, Rowman\&Littlefield Press, 2017

3. Ellis, A., Goodyear, P., Students' Experience of E-learning in Higher Education. New York: Routledge, 2009

4. Fee, K., Delivering E-learning: A Complete Strategy for Design, Application and Assessment. London: Kogan Page, 2009

5. Hargreaves A., Fullan M, The Power of Professional Capital, http://www.michaelfullan.ca/wp-content/uploads/2013/08/JSD-Power-of-

Professional-Capital.pdf

6. Hargreaves A., Fullan M, Professional Capital: Transforming Teaching in Every School, Teachers College Press, 2019

7.https://www.fastcompany.com/1093654/how-ciscos-ceo-john-chambers-turningtech-giant-socialist

8. Jfenthaler D., Sampson D., Online Teaching and Learning in Higher Education, Springer International Publishing, 2020

9. Major C., Teaching Online, Johm Hopkins University Press, 2019

10. Meskill C., Online Teaching and Learning, Bloomsbury Publishing House, 2019

11. Murphy D., Online Learning and Teaching with Technology, Taylor\&Francis Ltd. Publishing Hourse, 2018

12. OECD, E-learning in tertiary education [Online]. Available at http://www.cumex.org. (Accessed 27 /02/ 2014), 2005 


\title{
TEACHING BUSINESS ENGLISH ONLINE. ASSIGNMENT ACTIVITIES AND TESTS IN MOODLE
}

\author{
loana Claudia HOREA ${ }^{1}$, Cristina Laura ABRUDAN ${ }^{2}$ \\ 1,2 Department of International Business, Faculty of Economics, University of \\ Oradea, Oradea, Romania \\ 1 ioanahorea@gmail.com \\ 2cabrudan2003@yahoo.com
}

\begin{abstract}
In many universities around the world, the current pandemic situation confined the academic process to online interactions alone, with no physical presence in a class, the 'face-to-face' classes being held by means of applications or programs that provide video conferences facilities. Besides these tools for live communication, most universities - among which ours, as well - have started to make extensive use of the e-learning Moodle platform. Especially designed for the distance learning form of education, the Moodle platform has previously been used in our university mostly by the teachers involved in the distance learning form, particularly for the purpose of providing the distance learning students with study materials and other resources of interest for the subject - through the resources uploaded on the pages of the discipline -, for communication - by means of forums and chat rooms -, and for enabling a few tests and assignments along the semester. Now, with everything going online, the vast range of facilities this application offers has come to be discovered by all academics involved in the instruction process. In both synchronous and asynchronous activities organised by means of the platform, the user will find useful a series of facilities offered by the platform. Among these, the current study will refer to several diverse possibilities of using the activities of Assignment and Test for the classes of English for Business, with a series of examples of exercises that were created by means of these Moodle tools. The regular file upload assignment in which the student were instructed what to prepare, compose or solve, and upload at the specific button has now, with experience, 'grown' obsolete, more interesting online text types of assignment being preferred, such as video or audio records, texts written directly online in the applications or others types following templates and using materials posted. As for the tests, besides the basic types - more straightforward and easy to create - such as: multiple choice drills, matching, true / false, short answers, or drag and drop, there will be exemplifications of the embedded answers (cloze) type, which requires audacity and willingness from the teacher to put in more effort to prepare and self-instruct on how to use and enter special codes in order to create complex exercises. Needs teach us and eventually the results prove indeed rewarding and worth the effort.
\end{abstract}

Keywords: Business English, online teaching, Moodle platform, assignment activity, tests.

JEL classification: Z13, Y80, 121 


\section{Preliminary observations}

\subsection{Previous preoccupations}

Moodle is a well known platform for distance learning that has been implemented and used with universities around the world for several years now. The preoccupation for teaching languages through Moodle has been a concern of several researchers in the field.

As soon as the year 2009, a book with online language-learning activities using Moodle platform is published by Jeff Stanford, bringing a series of examples on "how to use Moodle 1.9 to create complete, usable activities." (Stanford, 2009)

In 2010, Moodle has already become a fashion, and teachers and researchers, as Phil Bird, began to share creative ideas, tools and techniques, used with their learners. (Bird, 2010)

In 2011, Warth-Sontheimer presented in details, with concrete examples, five Moodle activities - Forums, Chat, Wiki, Assignment, Glossary and Games - that will "take you very far", focusing on "using the individual activities for language teaching in particular." (Warth-Sontheimer, 2011, p.11)

Others see Moodle an advantage in itself, a step towards progress in language teaching and learning: "The multi-functionality of Learning-Management System (LMS) such as Moodle is integrated in English language classrooms to enhance students' learning." (Suksan; Nutprapha, 2010)

Some years later, Moodle had taken ground and more and more researchers started to dig into its utility and benefits. Reviewing an electronic language courses they developed and implemented at higher education level, Aikina and her fellow researchers come to the conclusion that "electronic courses designed by means of the e-learning platform Moodle are ideally suitable for the efficient blended learning implementation." (Aikina et all, 2015)

Learners, as always open to the new, to technology and innovative systems seem to find these courses and the activities they provide much more appealing than the classical lectures and seminars "Most students reported greater satisfaction from, engagement in and motivation for learning." (Gluchmanova, 2016, p.497)

There are, nevertheless, opinions to the contrary, as the research of Khabbaz and Najjar shows: "The findings imply that learning language through Moodle-based teaching materials impede the process of being autonomous language learners." (Khabbaz, Najjar, 2015)

\subsection{Current concerns}

Year 2020 comes with unforeseen challenges in education, as well as in most domains of human activity. The current circumstances, of Covid 19 pandemics, have brought about a great deal of new demands in the process of teaching and learning. In many cases, the academic process was confined to online interactions alone, with no physical presence in a class, the 'face-to-face' classes being held by means of applications or programs that allow "video conference", such as: Zoom, Google Meet, Microsoft Teams. Besides these tools for direct, live communication, most universities - among which our university - have used, intensively and extensively, the e-learning platform Moodle. 


\section{Assignment activities}

TOM XXX, $2^{\text {nd }}$ Issue, December 2021

\subsection{Regular assignments}

The uploaded files assignment type has been the most commonly used in previous years for projects, articles, even exercise solving, as homework or along the scheduled classes, as individual or group activity. But this previously so commonly used type of assignment consisting of posting requirements and then checking the uploaded files with the students' work on the exercises, articles or projects has kind of fallen into disuse or at least ordinariness.

Moodle nevertheless provides the possibility to have more attractive as well as straightforward types of assignment. These not only can offer diversity and neuroplasticity to the users but are also more user friendly. They can be less time consuming and more appropriate to the use during classes, due to the direct, online work they imply.

\subsection{Online activities}

Thus, more interesting online text types of assignment seem to be favoured, even spicing up the individual class activity, with video or audio records, texts written directly online in the applications or others types following templates and using materials posted.

Some of these can be seen in the figures that follow. They represent actual activities that were done with a class of first year students during their practical course classes. Names, contacts, video records of respondent students have been blurred for data protection reasons.

Figure 1 shows the pages representing the requirement in the assignment of audio recording, respectively, two answers registered for this assignment. The instructor hears the audio recordings posted, by clicking the play button directly from the view and grading page.

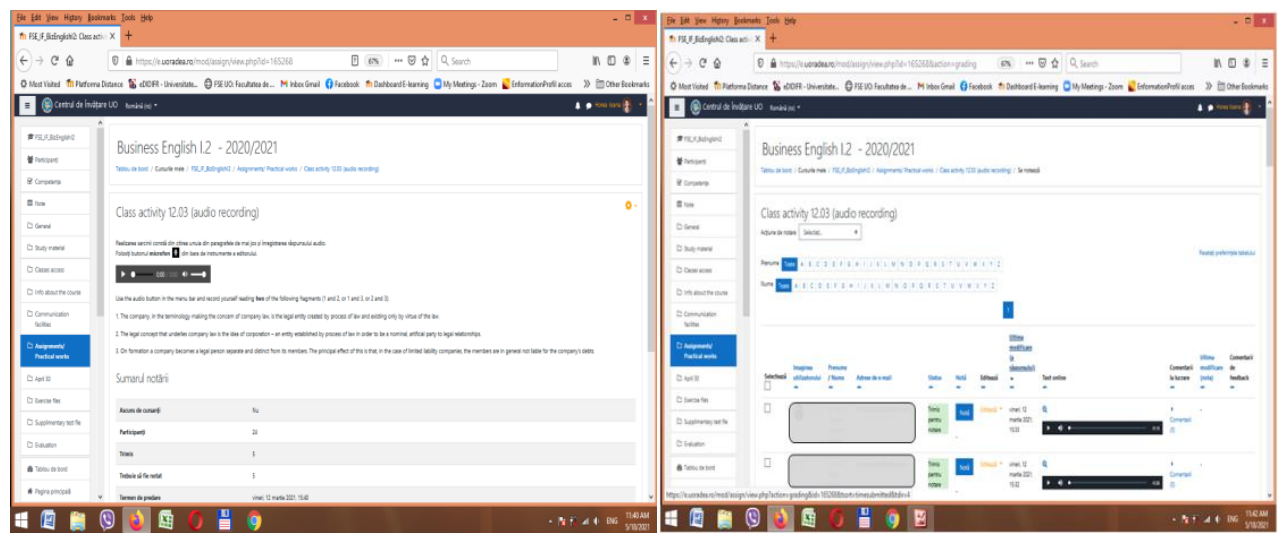

Figure 1. Online audio recording - assignment task page and response page

Figure 2 represents the task page and the response page for the assignment consisting in filling in a template file. As seen in the first picture, the template file is a word document attached to the assignment instruction page. This means that it 
becomes visible together with the assignment, i.e., if the case, at the moment the assignment's restrictions are over, conditions are met and it becomes available.

While figure 3 presents the page with instructions on a video recording assignment and then the view page with students registered activities, figure 4 shows instruction and results pages for online text assignment. The last example in the subtitle, figure 5 , brings about the design page of a questionnaire activity and that of its response page. It is quite obvious that at least two of these types of assignments can be very important for the course at stake: The video and audio recording facilities are of much value for language classes especially. They provide the teacher with records of the students' pronunciation, intonation and ability to render a text in a natural and proper way. Records can be later revisited, analysed and addressed, as well as they can stay as landmarks and proofs for improvement and progress.

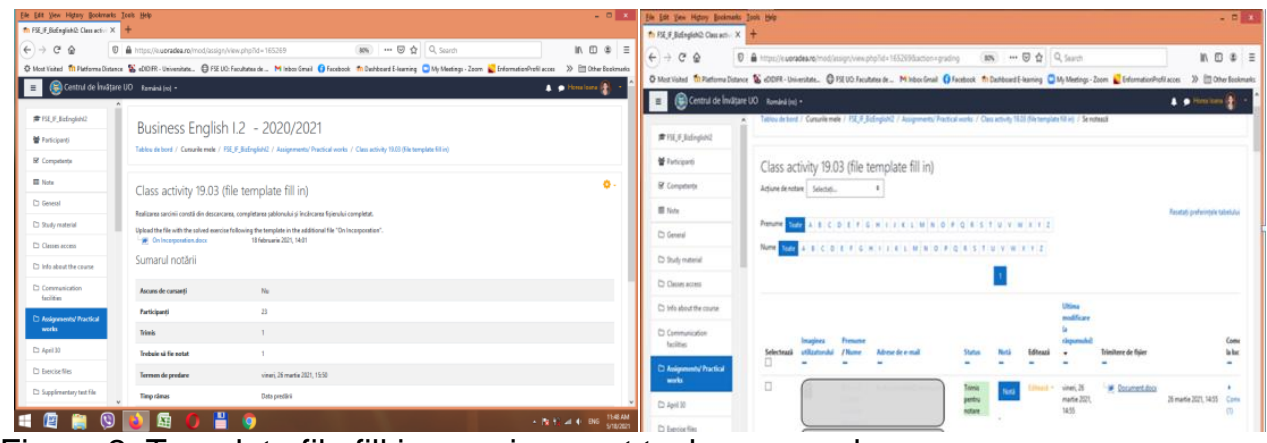

Figure 2. Template file fill in - assignment task page and response page

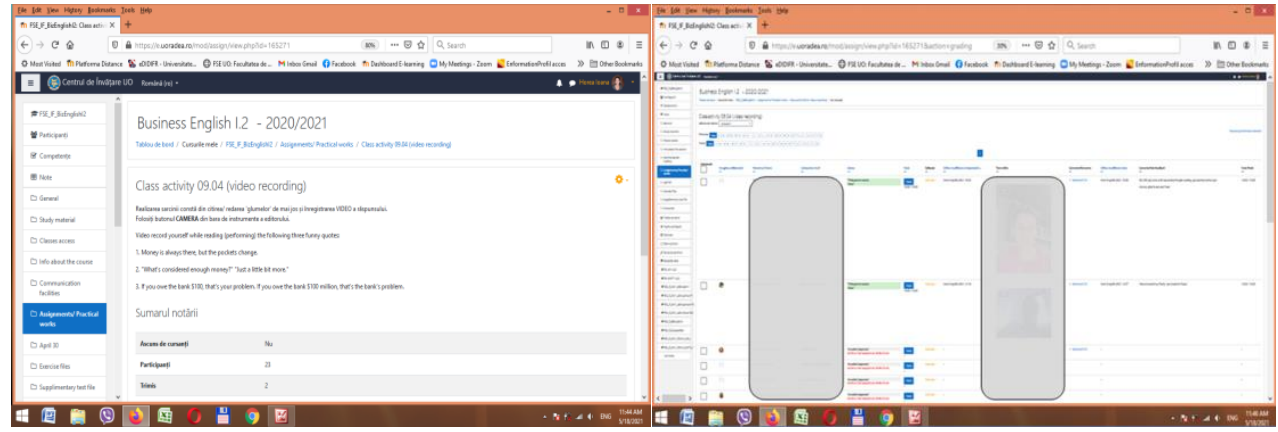

Figure 3. Online video recording - assignment task page and response page 


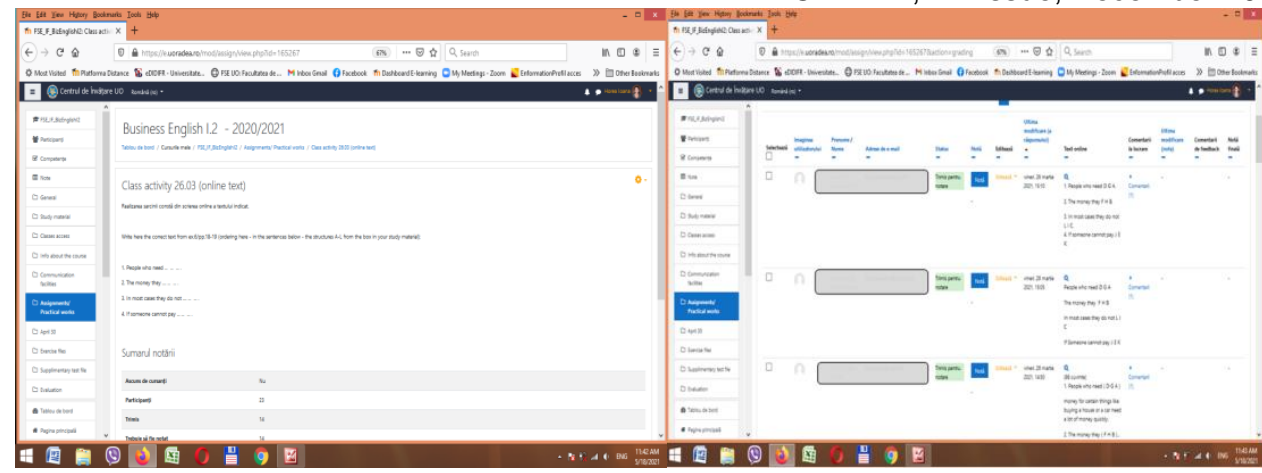

Figure 4. Online text writing - assignment task page and response page

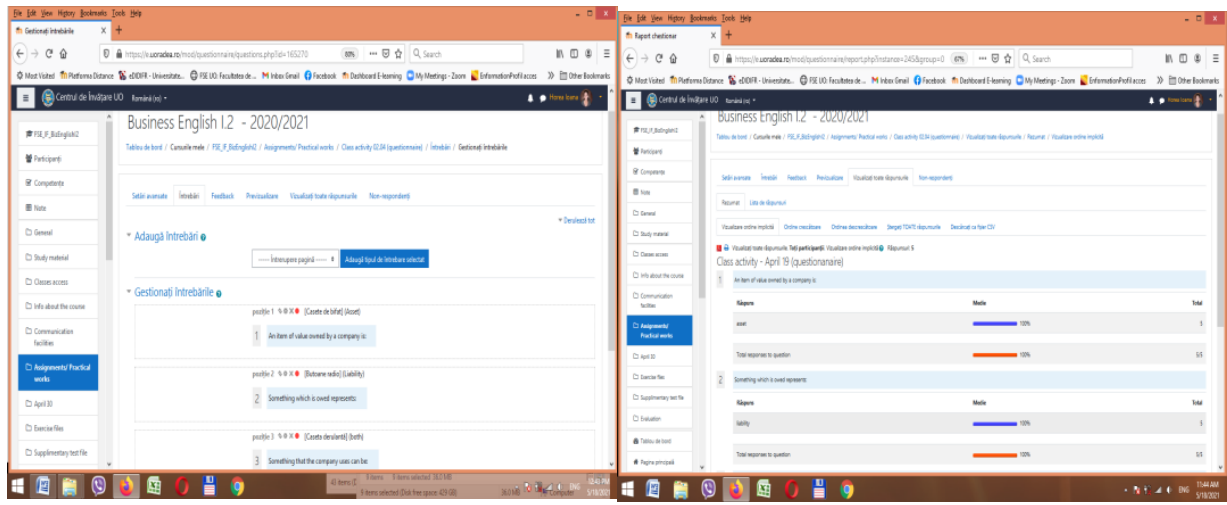

Figure 5. Online Questionnaire - questions editing page and response page

\section{Testing}

\subsection{Ready-made vs. complex test types}

The online test with multiple choice drills has been one of the first activities used with Moodle classes and evaluations and its usefulness and advantages are undoubtedly recognised. It has always been and will probably remain one of the best applications for rapid testing both during classes and for evaluations.

Various exercises such as matching, short answers, numeric answers, filling in gapped texts, drag and drop exercises, arranging fragments in texts, cloze text multiple choice from variants button, true/false, yes/no, diagram description, as well as combinations of these types make tests not only more complex and realistic but also more appealing and appropriate.

For matching, true/false, yes/no exercises, Moodle offers question types especially designed and the use of these is quite straightforward.

An example of matching type exercise and its configuration is in figure 6 . 


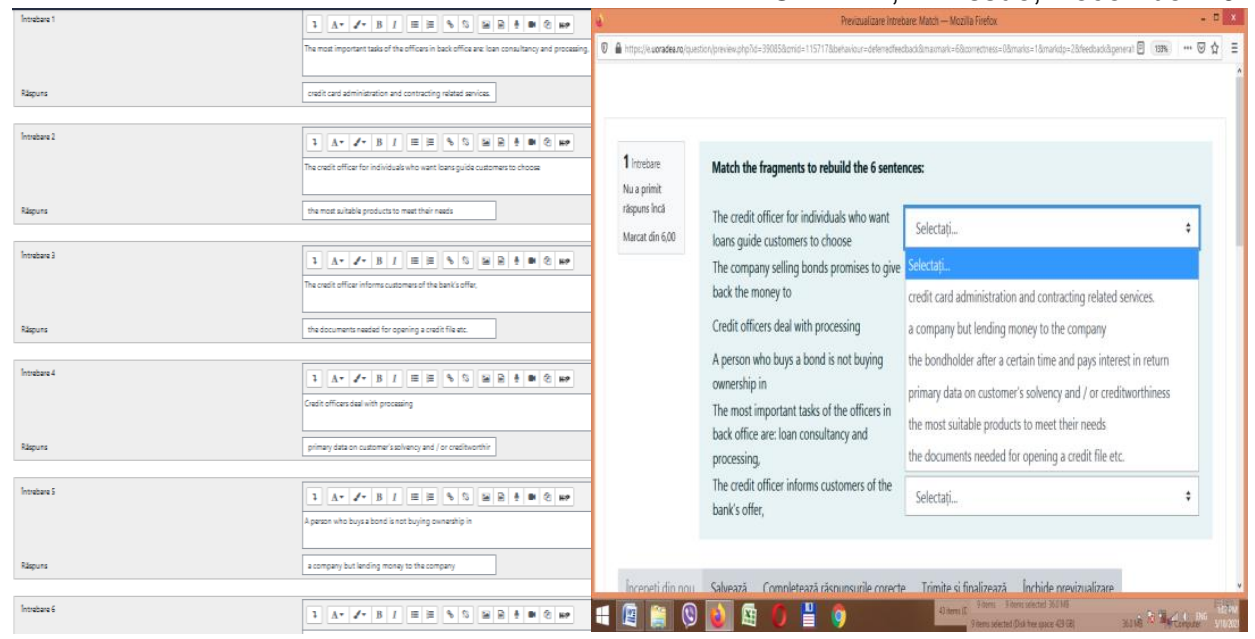

Figure 6. Creation and result for a matching exercise type

\subsection{Designing complex tests}

The creation of the other complex types aforementioned require more work as the embedded answers (cloze) question type has to be used (Figure 7a).

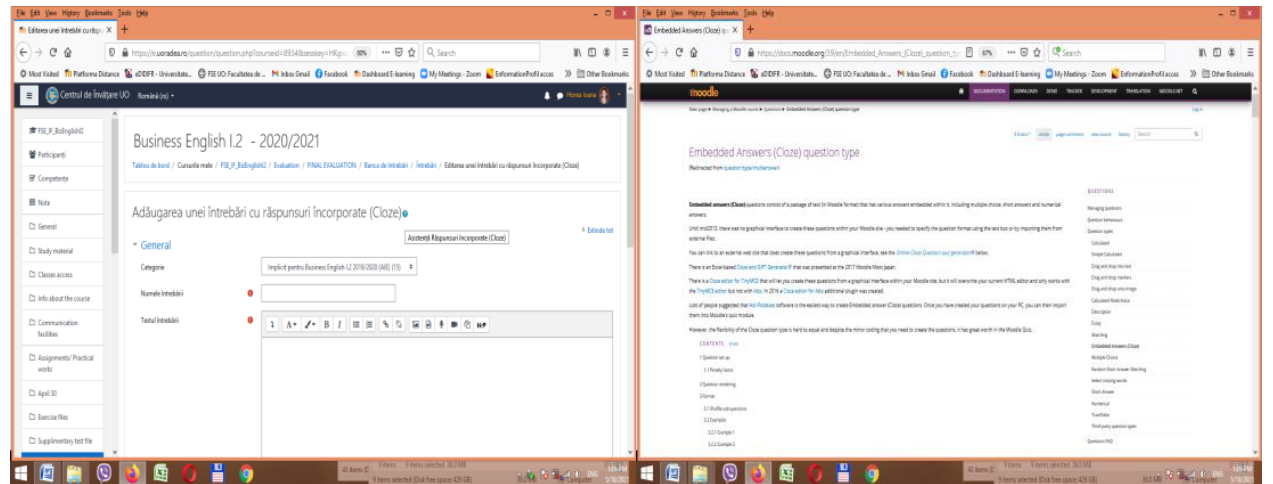

Figure 7a-b. Embedded answers (cloze) question type and design-instruction help-page

There are several formatting instructions that need to be strictly and attentively followed by the instructor in order to programme the application correctly and get the desired result.

Further assistance is needed so that the help section (Figure $7 \mathrm{~b}$ ) will surely be used, and the page with formatting instructions will have to be analysed.

\subsection{Examples of coding and final aspects of complex tests}

When editing the questions, the instructor has to accurately use the codes, to instruct the soft "talking" its language, so as the application can decrypt it properly and render the desired result. The exercises resulting from such encryptions used in their instructions will look like any normal exercises that are regularly used in printed format materials. 
Some examples can be seen in the figures of the subsections that follow.

\subsubsection{Giving short numerical answers}

The end result will be similarly looking exercises with gapped text in which numbers of the correct answers from those listed should be introduced by the respondent from the keyboard. The design, though, can be produces either by using the 'shortanswer' instruction and identifying the right one among all numbers listed, by the sign of equality placed in front of it, or simply by using the 'numerical' instruction followed only by the right number after the sign of equality. The latter variant is more appropriate in this situation, the former being more useful with longer answers to be typed. Such longer answers may be words or groups of words, either to choose from a given list or to just fill in according to specific requirements. For instance, as seen in the last subtitle here, 3.1.8., words derived from the ones given are required to be typed, checking knowledge of affixation and word formation.

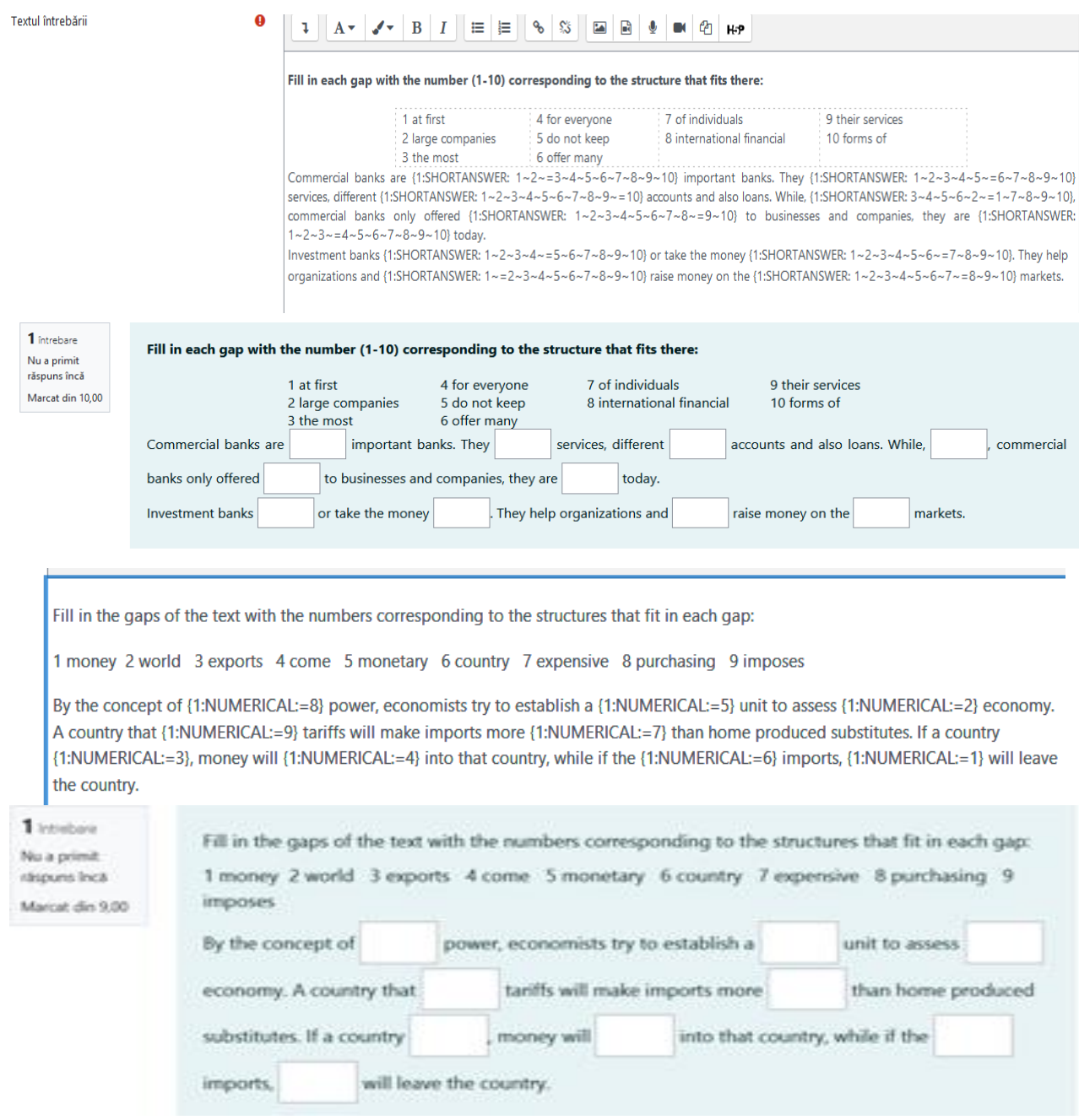


Figure 8 Coding and result for short numerical answers

\subsubsection{Image-text correlation}

Again using the 'numerical' instruction, the students can be asked to identify structures describing pictures, images, or drawings they are presented. The image in uploaded in the text of the question and then the descriptions are given and identified as correct by introducing the right number in the 'numerical' instructions. Further exercises are very pertinent in this situation. Thus, having in the first part several numbered speech bubbles and direct speech enunciations to choose from and match, a next part can be easily created. That latter part can be designed for checking knowledge of indirect speech. This can be done as in the example in figure 9 , by multiple choice questions having several variants from which to choose the correct transformation of the given enunciations into indirect speech. The variants will be introduced by the 'multichoice' instruction, or one of its variants, 'mch' - for horizontal design - or ' $m c v$ ' - for vertical design, as in the example below.

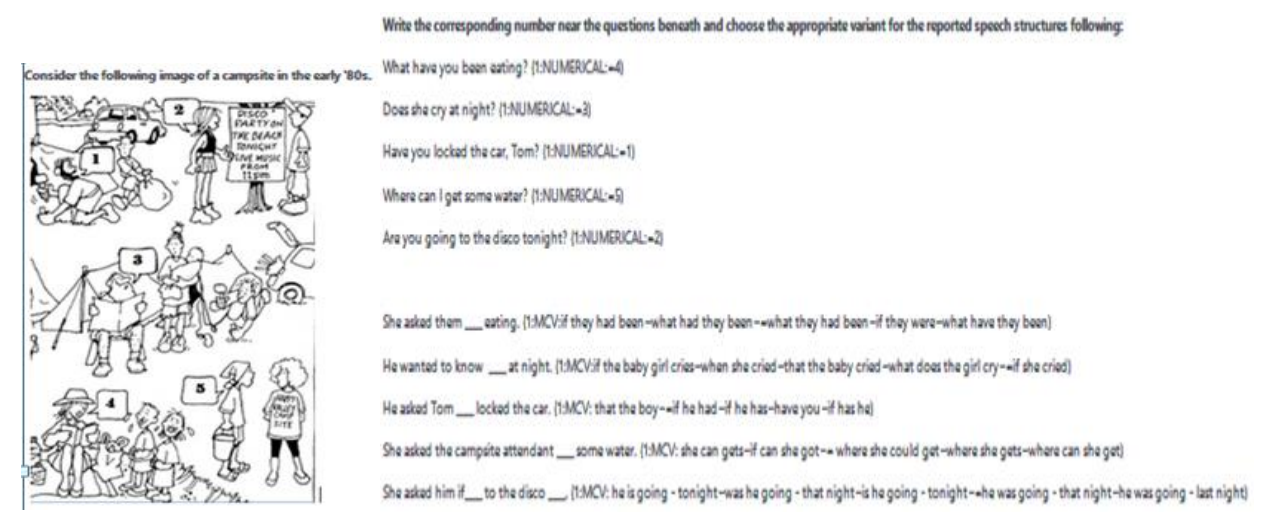



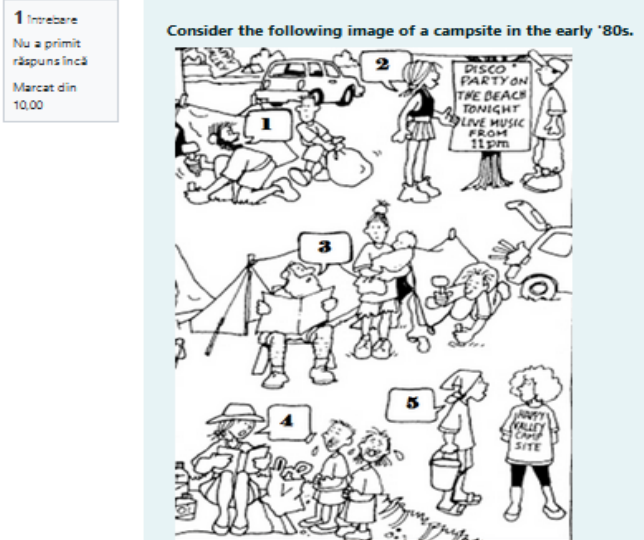

Write the corresponding number near the questions beneath and choose the appropriate variant for the reported speech structures following: What have you been eating? $\square$
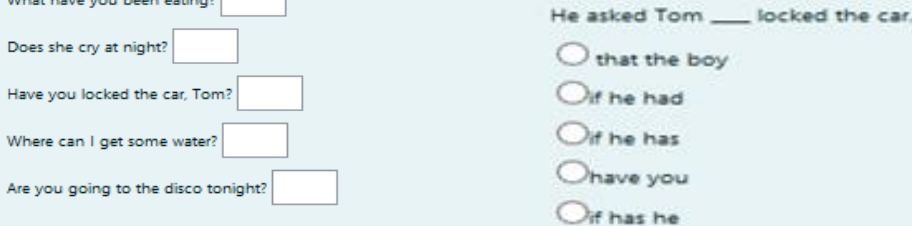

She asked them _ eating.

She asked the campsite attendant some water.

if they had been

She can gets

Owhat had they been

Oif can she got

Wwat they had been

Owhere she could get

Oif they were

Wwere she gets

Dwhat have they been

Owhere can she get

He wanted to know ___ at night.

She asked him if __ to the disco

Oif the baby girl cries

Ohe is going - tonight

Owhen she cried

Phat the baby cried

Owhat does the girl cry

Oif she cried

Owas he going - that night

Ois he going - tonight

Ohe was going - that night

Ohe was going - last night

Figure 9. Coding and result for image discussion (and reported speech)

\subsubsection{Diagram/graph description}

Inserting graphs or diagrams such as in the example below ("Describing charts" British Council, 2020), the encoded text can then be added to the text of the exercise in the creation page.
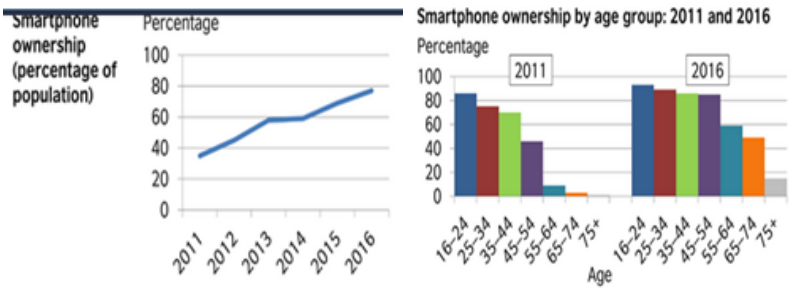


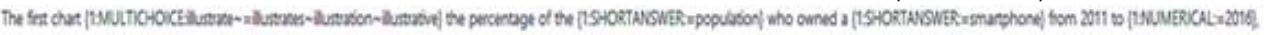

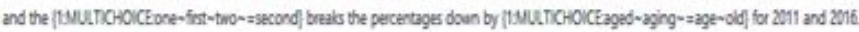

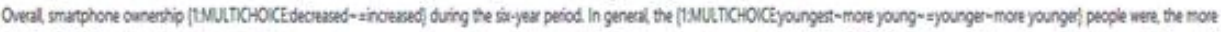

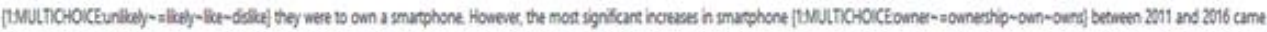

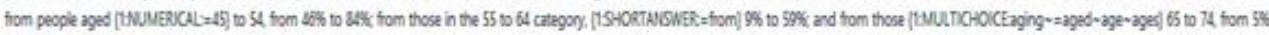

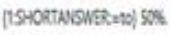

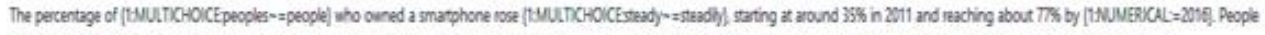

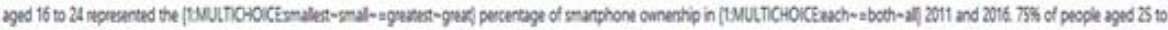

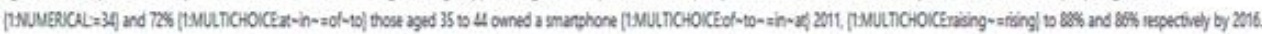

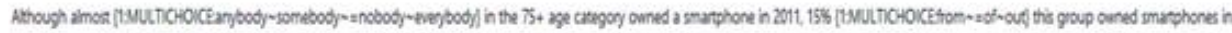
[1MULTOHOKE:2013-2014-2015-2016,

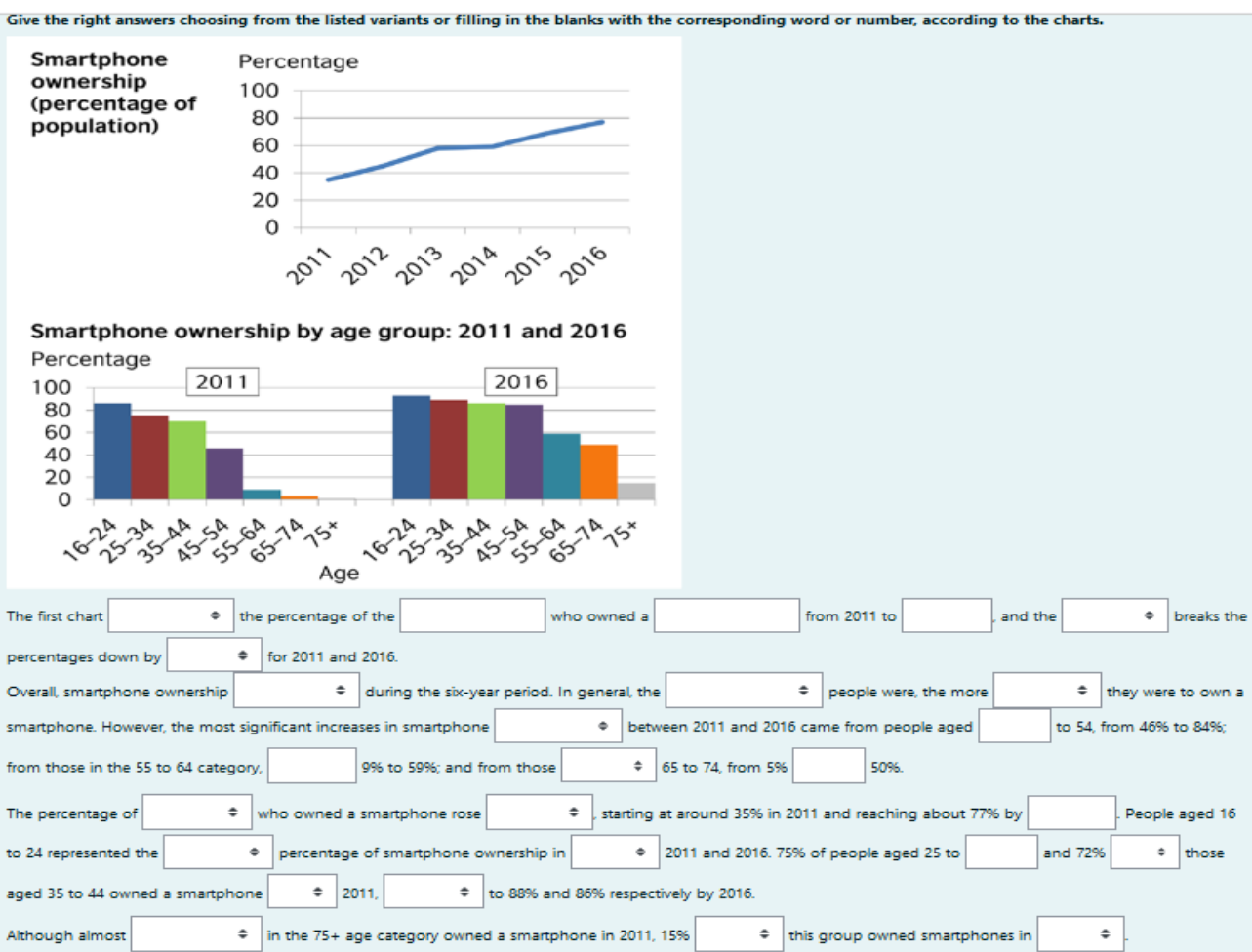

Figure 10. Coding and result for diagram discussion

This will result in a really professional looking outcome, an attractive exercise of graph description, such as seen in figure 10.

For encoding, all three instructions previously presented have been used, 'numerical', 'shortanswer' and 'multichoice'. This selection was resorted to for a combined and complex design of the end result. Thus, the final drill contains gaps to fill in with short words or numbers and selection arrow buttons to choose one variant from the ones displayed when clicking the arrows.

\subsubsection{Filling in with the right structure}

Exercises with words or structures to be placed in the right position in a text can be also created by using the drag and drop tool. This is encoded by inserting in 
the text numbers between double square brackets and then indicating the right answer for each numbered option. To have them presented in an identical design, the same group is selected for all words introduced, as seen here, in figure11, where group $A$ is chosen for all words.

The result will be an exercise consisting of a gapped text and the words/structures listed below it. The latter appear in boxes that can each be selected and dragged with the left button of the mouse kept pressed and then released to drop the content in the correspondent gap in the text. The shuffle button situated at the beginning of the options introduction fields has to be selected in order to have the structures displayed in the resulted exercise in a randomised order. Else, they are going to be listed exactly in the right order, which will reduce the exercise to a simple dexterity one, of exercising the mouse handling skill of dragging and dropping.

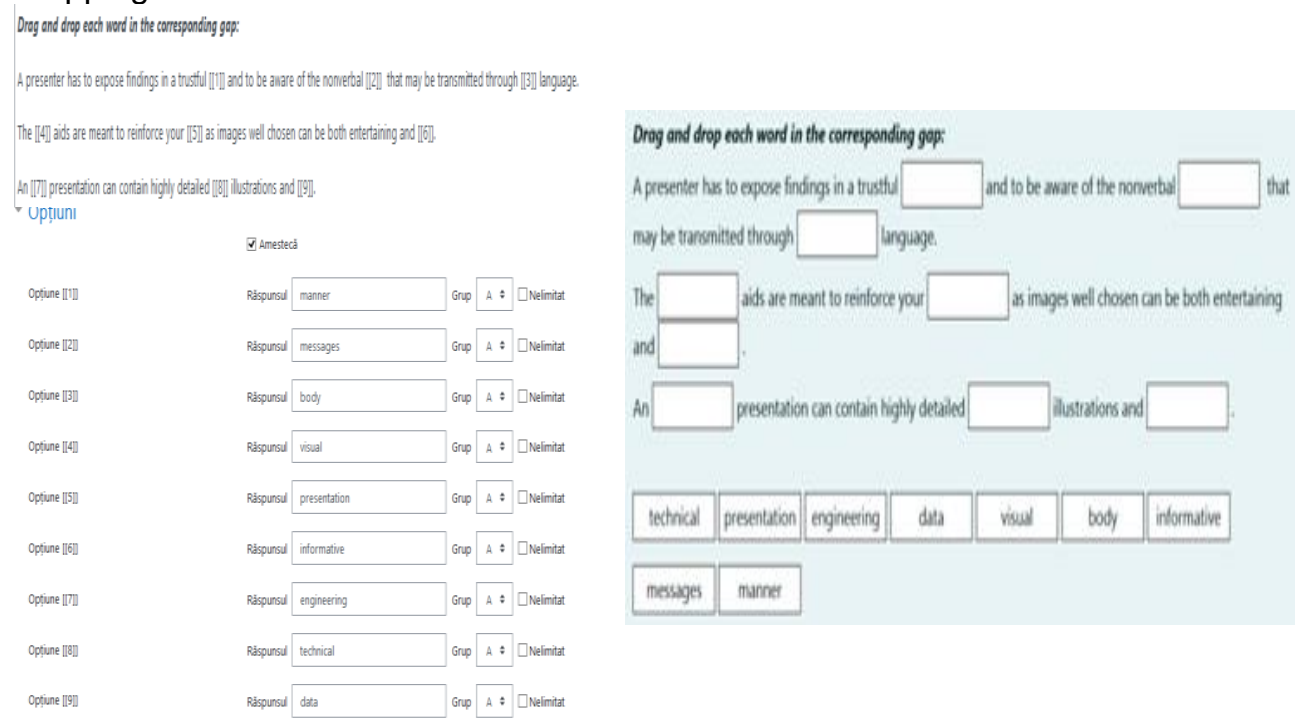

Figure 11. Coding and result for filling in a gapped text

\subsubsection{Arranging fragments in the right order}

Placing fragments in the correct order to get sentences is another type of exercise that can result from using the drag and drop tool. This time the structures that are to form distinct sentences can be identified, featuring different designs - colour and shape of the boxes, as seen in the last part of figure 12 - the image of the end result, the exercise created. This design is produced by selecting different groups for them, as seen in the middle part, which shows the way options are introduced: group $A$ for the structures 1-6 belonging to the first sentence, group B for the structures 7-10 that belong to the second sentence, and group $C$ for the last 5 structures that are to form the third sentence. 
To work shifts means [[1]] [[2]] [[3]] [[4]] [[5]] [[6]]. SME [[7]] [[8]] [[9]] [[10]].

The diagram [[11]] [[12]] [[13]] [[14]] [[15]].
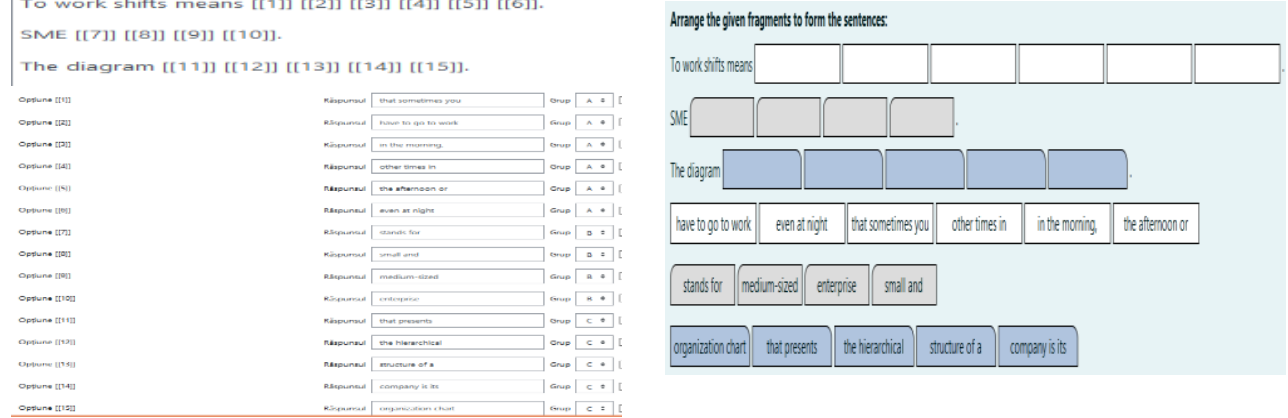

Figure 12. Coding and result for arranging fragments in order

\subsubsection{Combined answer types}

The following model features a combination of several instructions; the students will have to fill in with right words, choose from variants, find and write synonyms etc. For this, coding instructions for short answer, numeric answer and multichoice answer types will be used, combined as desired, the coding page and the resulting exercise being presented in figure 13.

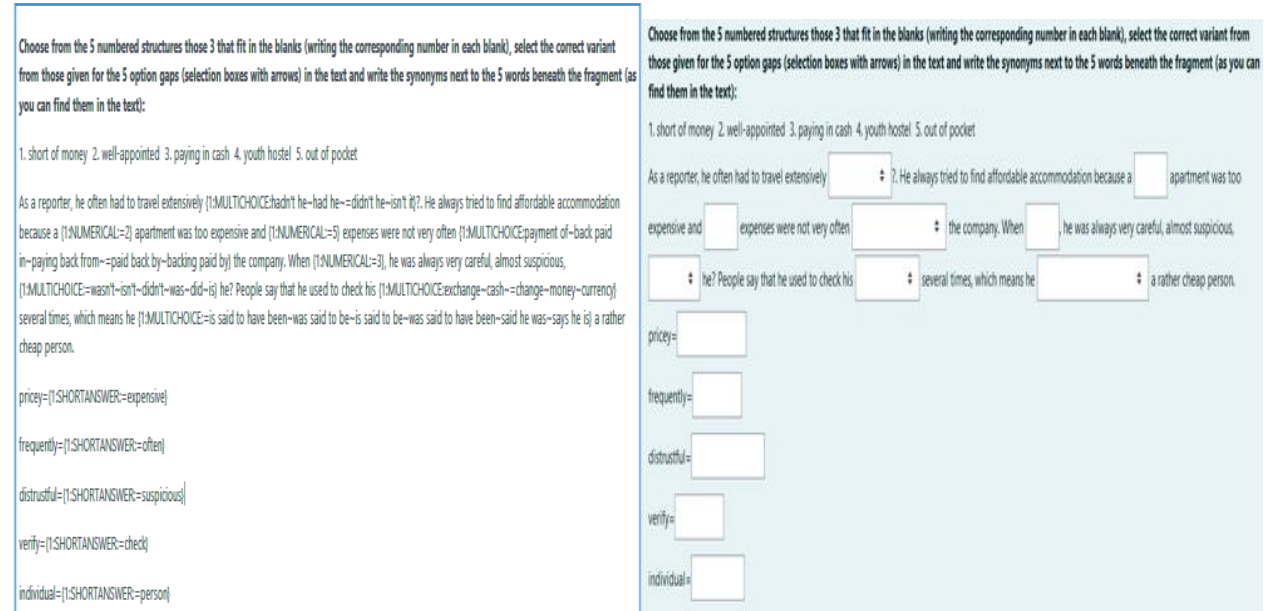

Figure 13. Coding and result for combined short, numeric and multiple choice answer

\subsubsection{Multiple choice}

Besides the general type of multiple choice drills, with one sentence at a time, tests containing more sentences in one exercise can be drawn up, as we briefly mentioned in a previous subtitle. The variants can be arranged either horizontally or vertically, or within the text and accessible from the selection arrow buttons, or after each sentence/ fragment or at the end a.s.o.

A. with variants displayed at selection arrow buttons within the text 
Choose the right structures:

Banks [1:MULTCHOICE: providing = provide provision) their customers with a [1:MULTCHOICE: numerous numbered $n=$ number] of services. With a checking (1:MULTCHOICE: count accountant $\sim$ =account) you can (1:MULTCHOCE: play pray $\sim$ =pay\} your bills, A check is a slip of paper \{1:MULTICHOCE: this = that whe\} tells the bank (1:MULTCHOICE: how many $w=$ how much so much) money it should withdraw \{1:MULTCHOICE; for you = from your from you\} acCount and (IIMULTICHOCE: pays at $\sim=$ =pay to paid for) someone else. Today, more and (1:MULTCHOICE: more peoples most peoplew=more people\} use the internet banking service, to paj [1:MULTCHOCCE: there bill whey bills $=$ their bills\}, Banks \{1:MULTICHOICE: give, too $=$ al5O give as well giventheir customers plastic cards (1:MULTICHOICE: which with w = with which which is) they can (1:MULTCCHOICE: get moneys = get money be got money) from their account everywhere (1:MULTCHOICE: ant $\sim$ end $\sim$ and) whenever they want.

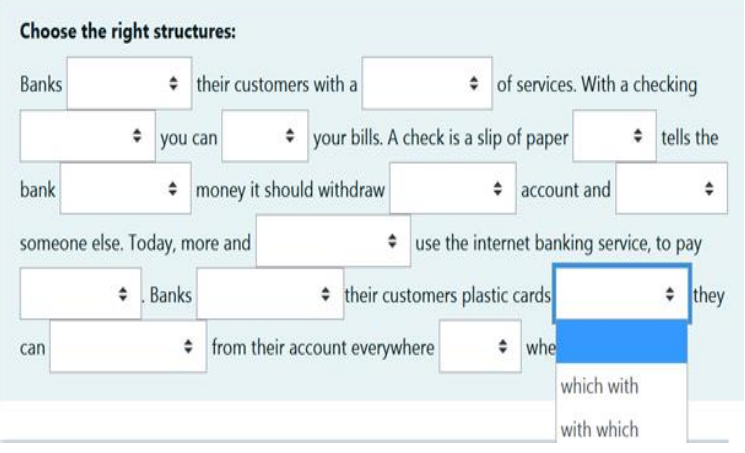

\section{B. horizontally, displayed after the text}

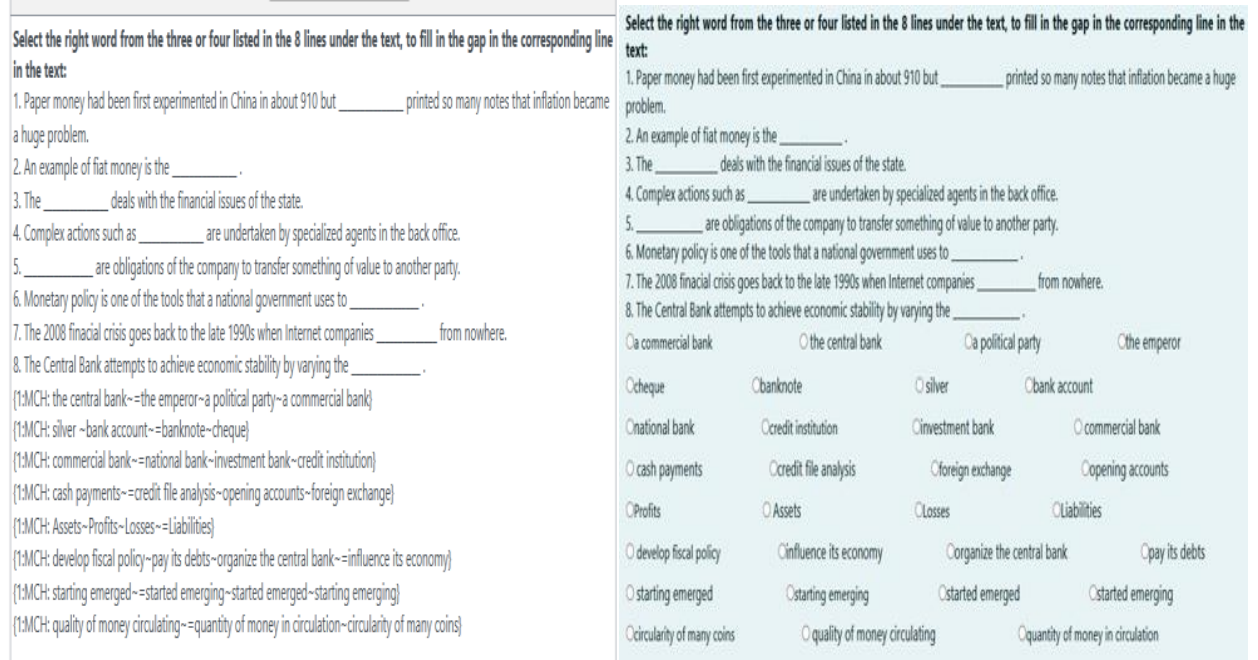

\section{C. horizontally, displayed after each sentence}
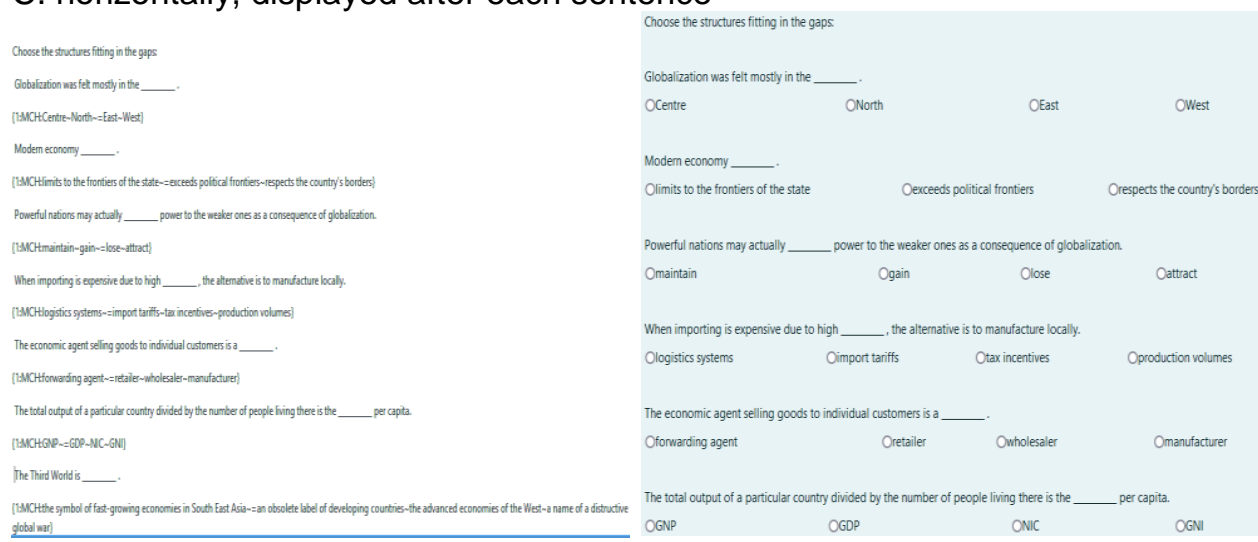

D. vertically, displayed after each sentence 
The Annals of the University of Oradea. Economic Sciences TOM XXX, $2^{\text {nd }}$ Issue, December 2021
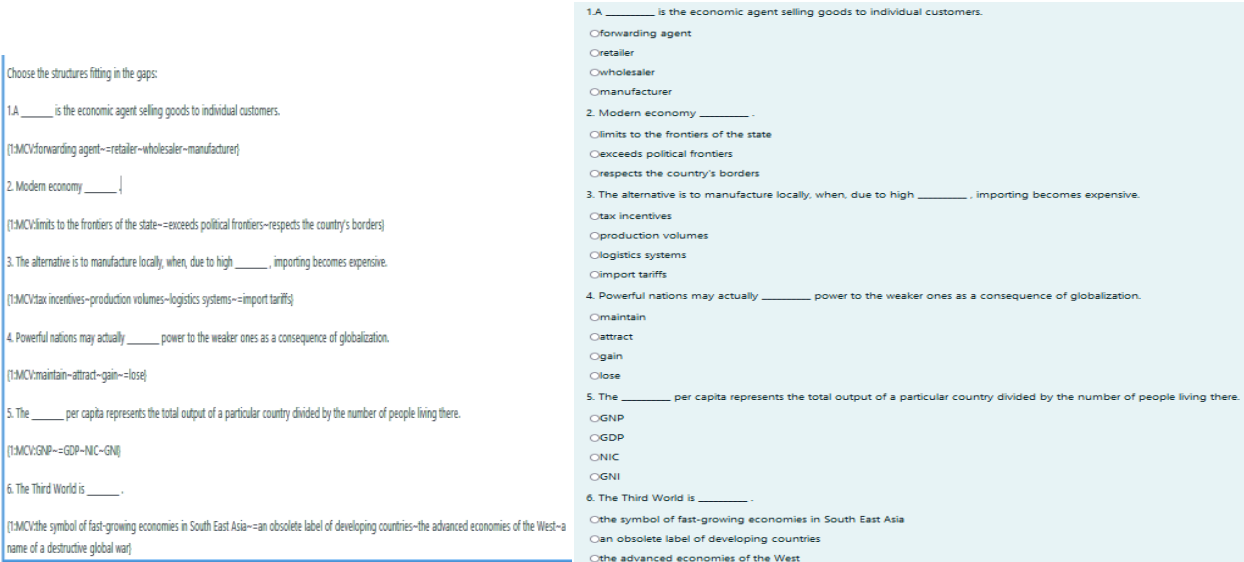

Figure 14 A-D Coding and result pages with various displays for multiple choice drills in one single exercise

Four examples can be seen in the images constituting figure 14 (A-D), and having design explanations before each, as seen above.

The instructions used were 'multichoice' (for A), 'mch' (for B and C) and 'mcv' (for D). Mch and mcv have to be positioned according to the display desired for the final exercise: either after each sentence or below the whole text, the end result following the same structure.

\subsubsection{Word formation}

As incidentally mentioned in the first subtitle, the 'shortanswer' instruction is best used with words that are to be written by the students from the keyboard, as following diverse indications. Some of the most common refer to changing the grammar value of given words so as to fit in the text, namely word formation by derivation and affixation. Others may refer to simply writing the missing words according to the requirements given by close vocabulary elements, lexical structures, idiomatic expressions, collocations or grammar rules. Figure 15 shows the production and the end result of an exercise based on suffixation.

\footnotetext{
Fill in each line with the corresponding word (IN CAPITALS) derived from the following words given in the right order: INSTITUTE, LIABLE, NEGATE, COMMERCE, INCREASE, CORPORATE, OWN, MEET, DIRECT An $\{1:$ SHORTANSWER: $=$ INSTITUTION $\}$ may fail because it becomes insolvent; that is its assets fall below its (1:SHORTANSWER $~=$ LLABILTIES\}) and its net worth capita becomes [1:SHORTANSWER: = NEGATIVE),

A $[1:$ SHORTANSWER: $\sim=$ COMMERCIAL $]$ bank can become insolvent because of loan defaults, $\{1:$ :SHORTANSWER; $\sim=$ INCREASED $\}$ interest rates, and other events, Most \{1:\$HORTANSWER: $=$ CORPORATIONS\} offer two kinds of stock. \{1:SHORTANSWER: $\sim=$ OWNERS\} of common stock can go to the annual $\{1: S H O R T A N S W E R ; ~ \sim=M E E T I N G S \sim=$ MEETING $\}$ of the stockholders, present their ideas and vote for the board of $\{1 ;$ SHORTANSWER; $s=$ DIRECTORS\}.
}

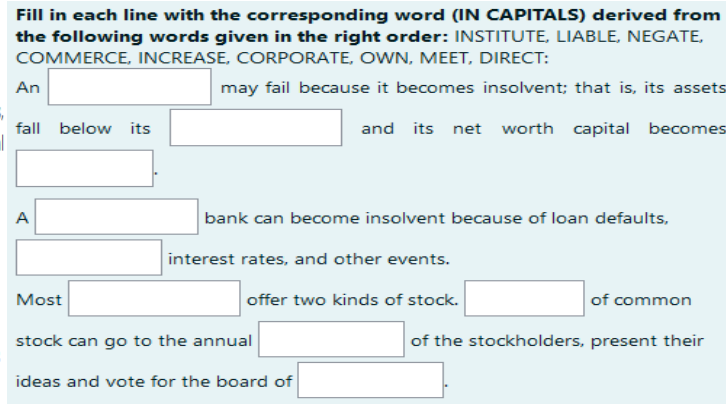

Figure 15. Coding and result for derived words 


\section{Conclusion}

TOM XXX, $2^{\text {nd }}$ Issue, December 2021

This article presented only some examples of the multitude of online exercises, activities and tests, produced on the Moodle platform for the classes of Business English taught by the authors during the academic year 2020-2021. It was a challenging year both for students and for academic staff.

Rewarding as it is to see the appealing, effective and innovative exercises, as the results of the designing Moodle activities, assignments and tests prove to be for Business English classes, the amount of work behind them is also to be taken into consideration. It is indeed a sensitive topic for teachers and language instructors and an important factor in assessing worthiness of the entire process. However, one aspect is very relevant in evaluating the advantages: once created, these activities are easily importable from one page of the platform to another page managed by the same teacher. Thus, they can be useful resources for many classes, series of students, several years forward, or can, if needed, become the starting point for further developed exercises, with small changes brought to the already designed material.

Hard times ask for extra effort in all aspects, but, with proper management of resources and willingness to later integrate the acquired innovative approaches into the system that will one day reach normality again, the entire endeavour put into the production of the educational, language practice and testing resources can surely pay off. It is one big strive in these pandemic times that has the potential of becoming a true asset for the institutions that are open to implementing hybrid- and e-learning. If best used, properly assessed and later integrated in a revolutionary system willing to keep what is good from these times, these educational resources can only bring development and progress to the teaching and learning process and to the institution itself.

\section{References}

1. Aikina, Tatiana Yurievna; Sumtsova, Olga Vitalievna; Pavlov, Dmitriy Igorevich "Implementing Electronic Courses Based on Moodle for Foreign Language Teaching at Russian Technical Universities", International Journal of Emerging Technologies in Learning (iJET), Vol 10, No 3 (2015), [Online], Available: https://online-journals.org/index.php/ijet/article/view/4501, [June 19, 2021].

2. Bird, Phil "Creative Ideas for Language Learning with Moodle", Oxford University Press ELT, English Language Teaching Global Blog, June 1, 2010, [Online], Available: https://oupeltglobalblog.com/2010/06/01/creative-ideas-for-languagelearning-with-moodle/, [June 19, 2021].

3. "Describing charts. Writing - intermediate B1", Bristish Council, Learn English, Online], Available: https://www.google.com/imgres?imgurl=https\%3A\%2F\%2Flearnenglish.bri tishcouncil.org\%2Fsites\%2Fpodcasts\%2Ffiles\%2FWriting-B1-Describingcharts-

3.png\&imgrefurl=https\%3A\%2F\%2Flearnenglish.britishcouncil.org\%2Fskill s\%2Fwriting\%2Fintermediate-b1\%2Fdescribing- 
charts\%3Fpage\%3D1\&tbnid=I-

UMuqAspDKeQM\&vet=12ahUKEwjBvtaot6TxAhVLwqQKHZrzANQQMyg AegUIARCvAQ..i\&docid=MeheZyfjJIVvOM\&w=3000\& $=3000 \& q=s m a r t p h$ one\%20graph\%20description\%20english\&client=firefox-b-

d\&ved=2ahUKEwjBvtaot6TxAhVLwqQKHZrzANQQMygAegUIARCvAQ, [October, 2020].

4. Gluchmanova, Marta "Using the Moodle Platform in English Teaching", TEM Journal. Volume 5, Issue 4, Pages 492-497, ISSN 2217-8309, DOI: 10.18421/TEM54-13, November 2016, [Online], Available: https://www.google.com/search?q=moodle+in+teaching+languages\&client $=$ firefox- $b-$

d\&sxsrf=ALeKk03QEI64ypLL5zqFZ4M2lySoVUZF5A\%3A1624116645735 \&ei=pQ3OYMikLKL-

7_UP8OKeiAs\&oq=moodle+in+teaching+languages\&gs_lcp=Cgdnd3Mtd2 I6EAM6BwgAEEcQsANQsENYIF1g2mVoAXABeACAAdMBiAGrA5IBBTA uMi4xmAEAoAEBqgEHZ3dzLXdpesgBCMABAQ\&sclient=gws-

wiz\&ved=0ahUKEwili_jgaTXAhUi_7sIHXCxB7EQ4dUDCA0\&uact=5, [June 17, 2021].

5. Khabbaz, Majid; Najjar, Rasool "Moodle-based Distance Language Learning Strategies: An Evaluation of Technology in Language Classroom", International Journal of Applied Linguistics and English Literature IJALEL, Vol 4, No 4 (2015), [Online], Available: https://www.journals.aiac.org.au/index.php/IJALEL/article/view/1451, [June 21, 2021].

6. Stanford, Jeff Moodle 1.9 for Second Language Teaching, Packt, 2009, [Online], Available: https://www.packtpub.com/product/moodle-1-9-forsecond-language-teaching/9781847196248, [June 18, 2021].

7. Suksan, Suppasetseree; Nutprapha, K. Dennis "The Use of Moodle for Teaching and Learning English at Tertiary Level in Thailand", January 2010, International Journal of the Humanities 8(6):29-46, [Online], Available:

https://www.researchgate.net/publication/291281931_The_Use_of_Moodl e_for_Teaching_and_Learning_English_at_Tertiary_Level_in_Thailand, [June 17, 2021].

8. Warth-Sontheimer, Claudia "Using Moodle for Language Teaching. A Guide to Moodle Activities for the Language Classroom", Comenius Network Wide Minds (WiMi), University of Tübingen, 2011, [Online], Available:

https://www.academia.edu/620127/Using Moodle for Language Teachin g_A_Guide_to_Moodle_Activities_for_the_Language_Classroom, [June $21,2021]$. 